\title{
Caddo Pottery Vessels and Pipes from Sites in the Middle and Upper Sabine and Upper Neches River Basins, Smith and Wood Counties, Texas
}

Timothy K. Perttula

Heritage Research Center, Stephen F. Austin State University

Mark Walters

Heritage Research Center, Stephen F. Austin State University

Shawn Marceaux

Bo Nelson

Heritage Research Center, Stephen F. Austin State University

Follow this and additional works at: https://scholarworks.sfasu.edu/ita

Part of the American Material Culture Commons, Archaeological Anthropology Commons, Environmental Studies Commons, Other American Studies Commons, Other Arts and Humanities Commons, Other History of Art, Architecture, and Archaeology Commons, and the United States History Commons

Tell us how this article helped you.

This Article is brought to you for free and open access by the Center for Regional Heritage Research at SFA ScholarWorks. It has been accepted for inclusion in Index of Texas Archaeology: Open Access Gray Literature from the Lone Star State by an authorized editor of SFA ScholarWorks. For more information, please contact cdsscholarworks@sfasu.edu. 
Caddo Pottery Vessels and Pipes from Sites in the Middle and Upper Sabine and Upper Neches River Basins, Smith and Wood Counties, Texas

\section{Creative Commons License}

(c) (1) (8)

This work is licensed under a Creative Commons Attribution-NonCommercial 4.0 International License 


\title{
Caddo Pottery Vessels and Pipes from Sites in the Middle and Upper Sabine and Upper Neches River Basins, Smith and Wood Counties, Texas
}

\author{
Timothy K. Perttula, Mark Walters,
} Shawn Marceaux, and Bo Nelson

Special Publication No. 7

Friends of Northeast Texas Archaeology 


\section{Table of Contents}

List of Figures $\quad$ iv

List of Tables $\quad$ xvii

Acknowledgments $\quad$ xviii

$\begin{array}{ll}\text { Introduction } & 1\end{array}$

Documentation Efforts $\quad 2$

Methods of Vessel Analysis 3

$\begin{array}{ll}\text { Archeological Context of the Sites } & 6\end{array}$

41SM73, Joe Meyers Place 6

41SM193, Redwine 6

41SM197, Langford $\quad 7$

41SM198, Pardee $\quad 8$

41SM246, John Ellis site $\quad 9$

41SM290 9

41WD109, Spoonbill 9

41WD586, Turquoise site 10

41WD589 11

Joe Meyers Place (41SM73) Vessel 11

Redwine Site (41SM193) Vessels 12

$\begin{array}{ll}\text { Langford (41SM197) Vessels } & 40\end{array}$

Pardee Site (41SM198) Vessels 46

41SM223 Vessels 52

John Ellis (41SM246) Site Vessels

41SM247 Vessels 57

41SM248 Vessels 61

41SM249 Vessels $\quad 65$

41SM262 Vessels 74 
Table of Contents, cont.

41SM268 Vessels 76

41SM282 Vessels 77

$\begin{array}{ll}\text { 41SM290 Vessels } & 80\end{array}$

Spoonbill Site (41WD109) Vessels 96

$\begin{array}{ll}\text { 41WD354 Vessels } & 128\end{array}$

Turquoise Site (41WD586) Vessels 133

$\begin{array}{ll}\text { 41WD589 Vessels } & 138\end{array}$

Caney Creek Vessels, Wood County, Texas 140

Pottery Vessel Comparisons and Ceramic Traditions 195

$\begin{array}{ll}\text { Vessel Forms } & 195\end{array}$

Rim and Lip Form 197

$\begin{array}{lr}\text { Temper and Paste } & 199\end{array}$

$\begin{array}{ll}\text { Firing Conditions } & 200\end{array}$

$\begin{array}{ll}\text { Decorative Methods } & 201\end{array}$

Lip Notching $\quad 206$

$\begin{array}{ll}\text { Pigments } & 206\end{array}$

$\begin{array}{ll}\text { Pottery Pipes } & 208\end{array}$

41SM193 208

41SM247 208

41SM290 209

Caney Creek, Wood County 209

$\begin{array}{ll}\text { Unknown Sites } & 210\end{array}$

$\begin{array}{ll}\text { Conclusions } & 213\end{array}$

$\begin{array}{ll}\text { Notes } & 214\end{array}$

$\begin{array}{ll}\text { References Cited } & 215\end{array}$

Appendix 1, Sam Kaufman (41RR16) Vessels 222

Appendix 2, Ceramic Vessels from Unknown Caddo Sites in Walters 228

Collection from Smith or Wood Counties, Texas 


\section{List of Figures}

Figure 1. Location of sites and collection areas in the Sabine and Neches River basins of East Texas.

Figure 2. Map of 41SM198, showing the location of the burial with vessels, as well as Houses 1-3, and a midden deposit.

Figure 3. Plan of the Late Caddo cemetery excavated by J. A. Walters at the Spoonbill site. The location of Burial 4 is not known.

Figure 4. Plan of the burial excavations at 41WD589.

Figure 5. Poynor Engraved, var. Cook carinated bowl from the Joe Meyers Place (41SM73).

Figure 6. Reavely Brushed-Incised Jar from the Redwine site.

Figure 7. Handy Engraved jar from the Redwine site.

Figure 8. Crockett Curvilinear Incised carinated bowl from the Redwine site.

Figure 9. Haley Engraved bottle from the Redwine site.

Figure 10. Engraved beaker from the Redwine site.

Figure 11. A second engraved beaker from the Redwine site, Burial 3.

Figure 12. Engraved bottle from Burial 3 at the Redwine site.

Figure 13. Killough Pinched jar.

Figure 14. Killough Pinched jar from Burial 2 at the Redwine site.

Figure 15. Incised-punctated jar from Burial 2 at the Redwine site.

Figure 16. Plain carinated bowl from Burial 4 at the Redwine site.

Figure 17. Plain bowl from Burial 3 at the Redwine site.

Figure 18. Plain bowl from the Redwine site.

Figure 19. Engraved carinated bowl from Burial 1 at the Redwine site. 


\section{List of Figures, cont.}

Figure 20. Washington Square Paneled carinated bowl from Burial 1 at the Redwine site.

Figure 21. Plain carinated bowl from Burial 4 at the Redwine site.

Figure 22. Handy Engraved carinated bowl from Burial 3 at the Redwine site.

Figure 23. Engraved bowl from Burial 1 at the Redwine site.

Figure 24. Hood Engraved effigy bowl from Burial 3 at the Redwine site.

Figure 25. Engraved carinated bowl from Burial 3 at the Redwine site.

Figure 26. Engraved carinated bowl from the Redwine site, Burial 2.

Figure 27. Early variety of Poynor Engraved, or Mode A, carinated bowl from Burial 4 at the Redwine site.

Figure 28. Plain carinated bowl from the Redwine site.

Figure 29. Punctated bottle from the Redwine site, Burial 2

Figure 30. Lip notched carinated bowl from Burial 3 at the Redwine site.

Figure 31. Plain bowl, possible pigment pot, from Burial 3 at the Redwine site.

Figure 32. cf. Washington Square Paneled carinated bowl from Burial 1 at the Redwine site.

Figure 33. Red-slipped bowl from the Redwine site.

Figure 34. Red-slipped jar from the Redwine site.

Figure 35. Plain carinated bowl from the Redwine site.

Figure 36. cf. Washington Square Paneled jar from Burial 2 at the Langford site.

Figure 37. Engraved beaker with rattlesnake motif, Burial 3 at the Langford site.

Figure 38. Plain deep bowl from the Langford site, Burial 8.

Figure 39. Engraved bottle from Burial 9 at the Langford site.

Figure 40. Plain bottle from the Langford site, Burial 7. 


\section{List of Figures, cont.}

Figure 41. Brushed-punctated jar from the Langford site, Burial 8.

Figure 42. Engraved carinated bottle from Burial 1 at the Pardee site.

Figure 43. Engraved bottle from the Pardee site, Burial 1.

Figure 44. Plain bowl from the Pardee site, Burial 1.

Figure 45. Plain compound bowl from the Pardee site, Burial 1.

Figure 46. Plain bowl from Burial 1 at the Pardee site.

Figure 47. Washington Square Paneled carinated bowl from Burial 1 at the Pardee site.

Figure 48. cf. Dunkin Incised carinated bowl from the Pardee site.

Figure 49. cf. Washington Square Paneled carinated bowl from 41SM223.

Figure 50. Engraved compound bowl from 41SM223.

Figure 51. Punctated jar from Burial 1 at the John Ellis site.

Figure 52. Plain bowl from Burial 1 at the John Ellis site.

Figure 53. Incised jar from 41SM247.

Figure 54. Canton Incised or Dunkin Incised jar from 41SM247.

Figure 55. Canton Incised or Maydelle Incised jar from 41SM247.

Figure 56. Plain deep bowl from 41SM247.

Figure 57. Roughened jar from 41SM248.

Figure 58. cf. Maydelle Incised jar from 41SM248.

Figure 59. cf. Maydelle Incised jar from 41SM248.

Figure 60. Brushed-punctated-appliqued jar from 41SM248.

Figure 61. Plain shallow bowl from 41SM249.

Figure 62. Bullard Brushed jar from 41SM249, Burial 1. 


\section{List of Figures, cont.}

Figure 63. Poynor Engraved, var. Blackburn carinated bowl from Burial 1 at 41SM249.

Figure 64. Plain carinated bowl from 41SM249.

Figure 65. Poynor Engraved bottle from 41SM249.

Figure 66. Brushed-punctated jar from Burial 2 at 41SM249.

Figure 67. Plain bowl from 41SM249, Burial 3.

Figure 68. Punctated bottle from Burial 1 at 41SM249.

Figure 69. Hood Engraved, var. Hood effigy bowl, 41SM249, Burial 3.

Figure 70. Plain bottle from Burial 3 at 41SM249.

Figure 71. Plain deep bowl from 41SM262.

Figure 72. Canton Incised deep bowl from 41SM262.

Figure 73. Hickory Engraved bottle from 41SM268.

Figure 74. Plain deep bowl or bowls from 41SM282, showing Vessel 257-1 (left) and Vessel 257-2 (right).

Figure 75. Incised-punctated bowl or carinated bowl from 41SM282.

Figure 76. Engraved jar from 41SM290.

Figure 77. Hume Engraved, var. unspecified cylindrical bottle from 41SM290.

Figure 78. Plain jar from 41SM290.

Figure 79. Plain carinated bowl from 41SM290.

Figure 80. Poynor Engraved, var. A carinated bowl from 41SM290.

Figure 81. cf. Hume Engraved cylindrical bottle from 41SM290.

Figure 82. Shallow and plain bowl from 41SM290.

Figure 83. Poynor Engraved, var. Blackburn carinated bowl from 41SM290.

Figure 84. Poynor Engraved, var. $N$ or $P$ bottle from 41SM290. 


\section{List of Figures, cont.}

Figure 85. Hood Engraved, var. unspecified bowl from 41SM290.

Figure 86. Poynor Engraved, var. Lang carinated bowl from 41SM290.

Figure 87. Engraved bottle from 41SM290.

Figure 88. Poynor Engraved, var. Hood carinated bowl from 41SM290.

Figure 89. Poynor Engraved, var. Cook carinated bowl from 41SM290.

Figure 90. Hood Engraved, var. Cook effigy bowl from 41SM290.

Figure 91. Poynor Engraved, var. Lang carinated bowl from 41SM290.

Figure 92. Engraved carinated bowl from 41SM290.

Figure 93. La Rue Neck Banded jar from 41SM290.

Figure 94. Keno Trailed bottle from the Spoonbill site, Burial 10.

Figure 95. Hudson Engraved bottle from Burial 9 at the Spoonbill site.

Figure 96. Hudson Engraved bottle from Burial 10 at the Spoonbill site.

Figure 97. Taylor Engraved spool-necked bottle from the Spoonbill site, Burial 10.

Figure 98. Hodges Engraved bottle, Burial 6 at the Spoonbill site.

Figure 99. Maxey Noded Redware bottle, Burial 5 at the Spoonbill site.

Figure 100. Engraved bowl from the Spoonbill site.

Figure 101. Ripley Engraved carinated bowl from the Spoonbill site.

Figure 102. Incised-punctated and slipped bowl from Burial 11 at the Spoonbill site.

Figure 103. Engraved bowl from the Spoonbill site.

Figure 104. Simms Engraved, var. Darco carinated bowl from Burial 6 at the Spoonbill site.

Figure 105. Punctated bowl from Burial 8 at the Spoonbill site.

Figure 106. Taylor Engraved bottle from Burial 8 at the Spoonbill site. 


\section{List of Figures, cont.}

Figure 107. McKinney Plain jar from the Spoonbill site, Burial 8.

Figure 108. cf. Mockingbird Punctated jar from the Spoonbill site.

Figure 109. McKinney Plain jar from the Spoonbill site.

Figure 110. McKinney Plain (roughened-appliqued) jar from the Spoonbill site.

Figure 111. Mockingbird Punctated jar from Burial 6 at the Spoonbill site.

Figure 112. cf. La Rue Neck Banded jar from Burial 10 at the Spoonbill site.

Figure 113. Simms Engraved carinated bowl from Burial 10 at the Spoonbill site.

Figure 114. Spoonbill Engraved bowl from Burial 11 at the Spoonbill site.

Figure 115. Second Spoonbill Engraved bowl from Burial 11 at the Spoonbill site.

Figure 116. Taylor Engraved carinated bowl from Burial 15 at the Spoonbill site.

Figure 117. Keno Trailed, var. Phillips bowl from Burial 8 at the Spoonbill site.

Figure 118. Simms Engraved carinated bowl from the Spoonbill site.

Figure 119. Taylor Engraved carinated bowl from the Spoonbill site.

Figure 120. Lip punctated carinated bowl from the Spoonbill site, Burial 5.

Figure 121. Sanders Engraved carinated bowl from Burial 11 at the Spoonbill site.

Figure 122. Sanders Engraved carinated bowl from the Spoonbill site, Burial 11.

Figure 123. Red-slipped cf. Taylor Engraved or late form of Ripley Engraved carinated bowl from the Spoonbill site.

Figure 124. Red-slipped Taylor Engraved carinated bowl from the Spoonbill site.

Figure 125. Red-slipped Taylor Engraved or cf. Womack Engraved carinated bowl from the Spoonbill site.

Figure 126. Red-slipped Taylor Engraved carinated bowl from the Spoonbill site.

Figure 127. Incised jar from Burial 5 or 11 at the Spoonbill site. [NEED PHOTO] 


\section{List of Figures, cont.}

Figure 128. La Rue Neck Banded jar from Burial 2 at 41WD354.

Figure 129. Engraved and red-slipped compound bowl from Burial 1 at 41WD354.

Figure 130. Engraved compound bowl from Burial 2 at 41WD354.

Figure 131. Engraved bottle from 41WD354, Burial 1.

Figure 132. Moore Noded bowl from Burial 2 at 41WD354.

Figure 133. cf. Mockingbird Punctated jar from the Turquoise site.

Figure 134. Incised jar from Burial 6 at the Turquoise site.

Figure 135. Simms Engraved, var. Darco carinated bowl from Burial 2 at the Turquoise site.

Figure 136. cf. Womack Engraved carinated bowl from Burial 6 at the Turquoise site.

Figure 137. Red-slipped Ripley Engraved carinated bowl from the Turquoise site.

Figure 138. Engraved compound bowl from Burial 5 at 41WD589.

Figure 139. Ripley Engraved carinated bowl from 41WD589, Burial 6.

Figure 140. McKinney Plain jar from the Caney Creek area.

Figure 141. cf. McKinney Plain or La Rue Neck Banded jar from the Caney Creek area.

Figure 142. Ripley Engraved carinated bowl from the Caney Creek area.

Figure 143. Engraved compound bottle from the Caney Creek area.

Figure 144. Ripley Engraved carinated bowl, continuous scroll motif, from the Caney Creek area.

Figure 145. Ripley Engraved compound bowl from the Caney Creek area.

Figure 146. Ripley Engraved carinated bowl, scroll and circle motif, Caney Creek area.

Figure 147. Ripley Engraved carinated bowl, continuous scroll motif, from the Caney Creek area.

Figure 148. Engraved bowl from the Caney Creek area. 


\section{List of Figures, cont.}

Figure 149. Red-slipped Simms Engraved, var. Darco bowl from the Caney Creek area.

Figure 150. Miniature Ripley Engraved carinated bowl from the Caney Creek area.

Figure 151. Plain miniature jar from the Caney Creek area.

Figure 152. Ripley Engraved carinated bowl from the Caney Creek area.

Figure 153. cf. Ripley Engraved carinated bowl from the Caney Creek area.

Figure 154. Ripley Engraved carinated bowl, scroll motif, from the Caney Creek area.

Figure 155. Ripley Engraved carinated bowl, continuous scroll motif, from the Caney Creek area.

Figure 156. Engraved carinated bowl from the Caney Creek area.

Figure 157. cf. Ripley Engraved carinated bowl from the Caney Creek area.

Figure 158. Ripley Engraved carinated bowl, continuous scroll motif, from the Caney Creek area.

Figure 159. cf. Womack Engraved carinated bowl from the Caney Creek area.

Figure 160. Ripley Engraved carinated bowl, scroll and circle motif, from the Caney Creek area.

Figure 161. Ripley Engraved carinated bowl, continuous scroll motif, from the Caney Creek area.

Figure 162. cf. Ripley Engraved carinated bowl from the Caney Creek area.

Figure 163. Taylor Engraved carinated bowl from the Caney Creek area.

Figure 164. Ripley Engraved carinated bowl from the Caney Creek area.

Figure 165. cf. Ripley Engraved carinated bowl, or an early variety of Simms Engraved, from the Caney Creek area.

Figure 166. cf. Simms Engraved, var. unspecified carinated bowl from the Caney Creek area.

Figure 167. Ripley Engraved carinated bowl from the Caney Creek area. 


\section{List of Figures, cont.}

Figure 168. Taylor Engraved carinated bowl from the Caney Creek area.

Figure 169. Taylor Engraved carinated bowl from the Caney Creek area.

Figure 170. cf. Ripley Engraved carinated bowl from the Caney Creek area.

Figure 171. La Rue Neck Banded jar from the Caney Creek area.

Figure 172. Wilder Engraved bottle from the Caney Creek area.

Figure 173. Plain jar from the Caney Creek area.

Figure 174. Tool punctated carinated bowl from the Caney Creek area.

Figure 175. McKinney Plain jar from the Caney Creek area.

Figure 176. cf. Simms Engraved carinated bowl from the Caney Creek area.

Figure 177. Ripley Engraved carinated bowl, scroll and simple circle motif, from the Caney Creek area.

Figure 178. Taylor Engraved carinated bowl from the Caney Creek area.

Figure 179. Taylor Engraved bowl from the Caney Creek area.

Figure 180. Taylor Engraved carinated bowl from the Caney Creek area.

Figure 181. cf. Maxey Noded Redware bottle from the Caney Creek area.

Figure 182. Taylor Engraved bottle from the Caney Creek area.

Figure 183. Ripley Engraved carinated bowl, engraved scroll motif, from the Caney Creek area.

Figure 184. Taylor Engraved carinated bowl from the Caney Creek area.

Figure 185. cf. Hudson Engraved spool-necked bottle from the Caney Creek area.

Figure 186. Taylor Engraved spool-necked bottle from the Caney Creek area.

Figure 187. Ripley Engraved carinated bowl with a scroll and circle motif, Caney Creek area.

Figure 188. La Rue Neck Banded jar from the Caney Creek area. 


\section{List of Figures, cont.}

Figure 189. cf. Hudson Engraved spool-necked bottle from the Caney Creek area.

Figure 190. Ripley Engraved carinated bowl from the Caney Creek area.

Figure 191. Simms Engraved carinated bowl from the Caney Creek area, Wood County, Texas.

Figure 192. Simms Engraved hubcap-form carinated bowl, Caney Creek area, Wood County, Texas.

Figure 193. La Rue Neck Banded jar from the Caney Creek area, Wood County, Texas.

Figure 194. Ripley Engraved carinated bowl fragment from the Caney Creek area, Wood County, Texas.

Figure 195. Engraved bottle of undetermined type from the Caney Creek area, Wood County, Texas.

Figure 196. Plain elbow pipe from the Redwine site.

Figure 197. Pipe sherds from 41SM247; a (left to right), plain L-shaped elbow pipe; b, Red River pipe, probably Graves Chapel variety; c, Red River pipe stem, Haley variety; d, butt end of Red River pipe, Graves Chapel variety.

Figure 198. Plain elbow pipes from 41SM290.

Figure 199. Titus phase engraved elbow pipe from the Caney Creek area, Wood County, Texas.

Figure 200. Pipes from unknown sites in the Walters collection from Wood or Smith counties, Texas: a (left to right), Red River pipe bowl, Graves Chapel variety; b, small platform pipe; c, engraved elbow pipe.

Figure 201. Upper Neches River basin engraved elbow pipe (\#192) from the Walters collection.

Figure 202. Engraved elbow pipes from the Walters collection: a, \#189; b, \#188.

Figure 203. Plain elbow pipes from the Walters collection: a, \#186; b, \#187; c, \#190; d, \#193.

Figure 204. Incised-punctated jar from the Sam Kaufman site.

Figure 205. Engraved jar from the Sam Kaufman site. 


\section{List of Figures, cont.}

Figure 206. Simms Engraved, var. Darco carinated bowl from the Sam Kaufman site.

Figure 207. Simms Engraved, var. Darco carinated bowl from the Sam Kaufman site.

Figure 208. Plain bottle from the Walters collection, unknown provenience.

Figure 209. Unique engraved bottle from the Walters collection: a, panels; b, engraved human face?; c, quadruped?

Figure 210. Plain bowl from the Walters collection, unknown provenience.

Figure 211. Plain carinated bowl from the Walters collection.

Figure 212. cf. La Rue Neck Banded jar from the Walters collection, unknown provenience.

Figure 213. Miniature brushed bowl from the Walters collection, unknown provenience.

Figure 214. Engraved bowl from the Walters collection, unknown provenience.

Figure 215. La Rue Neck Banded jar from the Walters collection, unknown provenience.

Figure 216. Punctated jar from the Walters collection, unknown provenience.

Figure 217. Engraved bottle from the Walters collection, unknown provenience.

Figure 218. Wilder Engraved bottle from the Walters collection, unknown provenience.

Figure 219. Engraved bottle from the Walters collection, unknown provenience.

Figure 220. Engraved bottle from the Walters collection, Smith County, Texas.

Figure 221. Plain carinated bowl, Walters collection, unknown provenience.

Figure 222. Incised-appliqued jar from the Walters collection, unknown provenience.

Figure 223. Tool punctated carinated bowl from the Walters collection, unknown provenience.

Figure 224. Engraved bowl from the Walters collection, unknown provenience.

Figure 225. Incised-punctated carinated bowl from the Walters collection, unknown provenience. 


\section{List of Figures, cont.}

Figure 226. Punctated jar from the Walters collection, unknown provenience.

Figure 227. Poynor Engraved, var. Cook carinated bowl, possibly from the Lake Palestine area.

Figure 228. Ripley Engraved carinated bowl from the Walters collection.

Figure 229. Hood Engraved, var. Cook effigy bowl from the Walters collection, unknown provenience.

Figure 230. Poynor Engraved, var. Hood carinated bowl from the Walters collection, unknown provenience.

Figure 231. cf. Holly Fine Engraved carinated bowl from the Walters collection, provenience unknown.

Figure 232. cf. Holly Fine Engraved bowl from the Walters collection, unknown provenience.

Figure 233. Punctated-appliqued jar from the Walters collection, unknown provenience.

Figure 234. Cross-hatched engraved carinated bowl from the Walters collection, unknown provenience.

Figure 235. Lip-notched carinated bowl from the Walters collection, unknown provenience.

Figure 236. Incised deep bowl from the Walters collection, unknown provenience.

Figure 237. Engraved carinated bowl from the Walters collection, unknown provenience.

Figure 238. Engraved-punctated carinated bowl from the Walters collection, unknown provenience.

Figure 239. La Rue Neck Banded jar from the Walters collection, unknown provenience.

Figure 240. Dunkin Incised carinated bowl, Walters collection, unknown provenience.

Figure 241. cf. McKinney Plain jar, Walters collection, unknown provenience.

Figure 242. McKinney Plain jar, Walters collection, unknown provenience.

Figure 243. Taylor Engraved carinated bowl, Walters collection, unknown provenience. 


\section{List of Figures, cont.}

Figure 244. Spoonbill Plain bowl, Walters collection, unknown provenience.

Figure 245. Incised-appliqued jar, Walters collection, unknown provenience.

Figure 246. cf. Canton Incised jar from the Walters collection, unknown provenience. 


\section{List of Tables}

Table 1. Burials from the Redwine site.

Table 2. Burials from the Langford site.

Table 3. Burials from the Turquoise site.

Table 4. Vessel Forms.

Table 5. Rim and lip forms.

Table 6. Use of different tempers and sandy pastes.

Table 7. Firing conditions.

Table 8. Identified Pottery Types in the Collections.

Table 9. Decorative Methods represented in the Vessel collections.

Table 10. Lip notched vessels.

Table 11. Use of pigments.

Table 12. Pipes from 41SM290.

Table 13. Pipes from unknown sites in Smith and Wood counties, Texas. 


\section{Acknowledgments}

Bernie Ward graciously allowed us to interrupt his business day to document the vessels and pipes from 41SM290. We thank Bryan Boyd for taking the excellent

photographs of the J. A. Walters collection vessels and pipes; Bo Nelson took the photographs of the Bernie Ward collections from 41SM290. Sandra Hannum prepared Figure 1-4. 


\section{Introduction}

This report documents two collections of Caddo ceramic vessels and pipes from sites of prehistoric to early historic age in Smith and Wood counties, Texas, in the upper Sabine and upper Neches river basins in East Texas (Figure 1). Most of these Caddo artifacts are from the J. A. Walters collection, with the remainder being from the Bernie Ward collection.

Figure 1. Location of sites and collection areas in the Sabine and Neches River basins of East Texas.

Mr. J. A. Walters was a lifetime resident of Smith County, Texas, who amassed a large collection of Caddo artifacts. He was a commercial rose grower, a part of a local nursery industry that began in Smith County in the late 1800s. He was an active church member and respected family man, the father of three children, the eldest (Mark Walters) being one of the authors of this paper.

J. A. Walters became interested in archeology in the late 1950s through the influence of his brother-in-law Sam Whiteside, an active avocational archeologist who recorded numerous important Caddo sites in Smith County and surrounding counties (Walters 2005). Mr. Walters became a longtime member of the Texas Archeological Society and the Arkansas Archeological Society and enjoyed attending several of the Arkansas Archeological Society annual meetings.

Unfortunately, Mr. Walters had an unpleasant experience with a member of the Texas professional archeological community early in his amateur archeological career. Often professional archeologists are guilty of failing to recognize the contributions of amateur archeologists or place themselves in elevated positions. One consequence of this unpleasant encounter was that Mr. Walters never fully embraced the principles of professional archeology as far as record-keeping activities went. Fortunately, he did acquire numerous 7.5' topographic quadrangle maps and he made good records of his site locations; there were numerous as Mr. Walters exhibited a real zeal for his acquired hobby. He also made sketch maps (although often fairly crude by professional standards) showing features he encountered during his site excavations. Through these records, it is possible to obtain a fairly accurate description of his artifacts and their locations at sites, and within features on those sites.

During the late 1950s and early 1960s Mr. Walters mostly worked in Smith County. He located sites by visual observations and uncontrolled shovel testing. He would often then place hand-excavated test trenches across the site looking for features. At several sites he noted Caddo houses, middens, and burials; these occurred either as single interments or, in a few cases, as interments in small cemeteries. South of the 
Sabine River in Smith County, these family cemeteries often are small in size (containing less than 10 individuals), unlike the larger prehistoric and early historic Caddo cemeteries north of the Sabine River that Mr. Walters encountered later in Wood County, Texas.

In the mid-1960s, Mr. Walters made acquaintances with several large landowners in Wood County, mostly along Caney Creek in the Lake Fork Creek drainage basin. It was during this period that he discovered and excavated portions of several large Titus phase cemeteries, including a cemetery area at the Spoonbill (41WD109) site (Perttula and Middlebrook 2007; Walters 2007; Bruseth and Perttula 1981). Mr. Walters continued his work in this area of Wood County (see Perttula 2005:Figure 11-6) until the mid-1970s, when his health began to fail.

Mr. Bernie Ward is a prominent geologist in Tyler, Texas. He has been a longtime member of the Texas Archeological Society and a collector of Native American art. Around 1985, Mr. Ward, along with Bubba and Donny Jones of Arp, Texas, excavated a Frankston Phase Caddo cemetery at 41SM290 in what is now an exclusive residential area in Tyler. Mr. Ward has a portion of the recovered artifacts from the burial features, along with additional Caddo artifacts, including several ceramic vessels and pipes that he collected over the years from the area. Mr. Ward graciously allowed us to photograph and document those portions of his collection that had a measure of site provenience.

\section{Documentation Efforts}

In the early 1990s Mark Walters became active in Texas archeology and realized the need to document the archeological record of his father's collections as well as his Uncle Sam Whiteside's work. He has to date filed hundreds of archeological site forms with the state of Texas recording new site locations, including sites first found by his father, and written numerous reports documenting that work. Documenting in details the collections of J. A. Walters was a logical next step in the study of these archeological materials.

In late January and early February 2009, around the time of the East Texas Archeological Conference held in Tyler, Texas, the J. A. Walters collection and Bernie Ward collections were fully documented. Involved in this effort was Timothy K. Perttula, Mark Walters, Shawn Marceaux, and Bo Nelson, with the last minute assistance of James Harrison III. As discussed below, a detailed description of each ceramic vessel or ceramic pipe was made for documentation purposes, accompanied by drawings, where needed, of ceramic vessel decorative motifs or pipe morphology to supplement the artifact descriptions. Mark Walters and Bryan Boyd, a member of the Texas Archeological Stewardship Network, had photographed the J. A. Walters collection at an earlier date, and Bo Nelson took the photographs of the Bernie Ward collection that we documented.

At the present time, it is not certain to which avenue this collection effort (and

others that remain to be completed) will lead. It is our intent to make this important 
information on Caddo collections from East Texas Caddo sites a part of the public record. We believe that there is substantial information to be gained as a result of this effort that will be of considerable benefit in increasing knowledge of Caddo archeology. Private collections are very vulnerable to the possibility of being sold, or broken up, and there are few options for the holders of these collections to ensure that they remain together and also be available for future study. Because the publication of this documentation effort involves a sizable expense for report formatting and printing, and the funding for these publication efforts remain uncertain at this time, it is not clear how this report-or others contemplated-will be distributed. We contemplate putting this report and accompanying figures and photographs on a $\mathrm{CD}$ for distribution, as well as on a Caddo archeology website under development.

\section{Methods of Vessel Analysis}

The large number of ceramic vessels that we proposed to study in the Walters and Ward collections are from generally contemporaneous prehistoric Caddo sites in the middle Sabine and upper Neches River basins. Therefore, we established a documentation protocol to assist in the analysis of each of the vessels from the different sites. Each of the ceramic vessels in the collections is described and analyzed utilizing a consistent set of morphological, functional, and stylistic attributes modeled after the presentations in Cast et al. (2006); Gadus and Fields (1996); Gonzalez et al. (2005), Perttula et al. (1998, 2008), Perttula (2009), and Perttula (2005, ed.). The purpose of the documentation is to thoroughly characterize the character of each of the ceramic vessels in the different Caddo collections. The sections that follow provide the completed vessel recordation forms from 16 prehistoric Caddo sites in these two river basins in East Texas (see Figure 1), as well as accompanying vessel photographic illustrations.

The following attributes were employed in the ceramic vessel study:

Non-plastics: Deliberate and indeterminate materials in the paste (Rice 1987:411), including a variety of tempers (grog or crushed sherds, bone, hematite, shell, quartz sands, etc.) and "particulate matter of some size." The grog, bone, and hematite non-plastics appear to have been deliberately added to the paste as tempers. The bone used for temper had been burned and calcined, then crushed, before it was added to the paste.

Vessel Form: The principal vessel form categories include open containers (bowls, carinated bowls, and compound bowls) and restricted containers, including jars and bottles of several shapes and sizes. As restricted containers, jars allow access by hand, but bottles do not (Brown 1996:335). Another important vessel form, at least in burial contexts, is the effigy bowl with a modeled head (usually a bird or duck head) and a tab tail. Occasionally, an effigy vessel will have a broader tab tail that supported an anthropomorphic or zoomorphic tail rider (see Suhm and Jelks 1962:Plate 24k). 
Additional form attributes that were recorded on each of the vessels (depending upon their completeness) include the rim profile (outflaring or everted, vertical or standing, and inverted), lip profile (rolled to the exterior, rounded, flat, or thinned), and base shape (flat or rounded).

Core Colors: Observations on ceramic cross-section colors permit consideration of oxidation patterns (Teltser 1993:Figure 2A-H; Perttula 2005, ed.), and thus the conditions under which the vessel was fired and then cooled after firing. Comments are included for these attributes on the presence and location of fireclouding, sooting or smudging from cooking use (Skibo 1992), and the preservation and location of charred organic remains.

Wall Thickness: Thickness was recorded in millimeters, using a vernier caliper, at the lip, along the rim, at several points along the body, and at the base when possible (only for the vessels that were not complete).

Interior and Exterior Surface Treatment: The primary methods of finishing the surface of the vessel include smoothing, burnishing, and polishing (Rice 1987:138). Brushing is a popular method of roughening the surface (particularly the body) of large and small Middle Caddo (ca. A.D. 1200-1400) and Late Caddo (ca. A.D. 1400-1680) period cooking jars and other utility wares. Here it is considered a decorative treatment rather than solely a functional surface treatment (cf. Rice 1987:138), although not all Caddo ceramic analysts treat brushing as a decorative treatment (cf. Gadus et al. 2006:31). In certain fine ware vessels, brushed bodies accompanied engraved rim panels. Smoothing creates "a finer and more regular surface... [and] has a matte rather than a lustrous finish" (Rice 1987:138). Burnishing, on the other hand, creates an irregular lustrous finish marked by parallel facets left by the burnishing tool (perhaps a pebble or bone). A polished surface treatment is marked by a uniform and highly lustrous surface finish, done when the vessel is dry, but without "the pronounced parallel facets produced by burnishing leather-hard clay" (Rice 1987:138).

The application of a hematite-rich clay slip (Ferring and Perttula 1987), either red or black after firing in an oxidizing or reducing (i.e., low-oxygen) environment, is another form of surface treatment noted in these vessel assemblages, albeit very rarely. The clay slip is more frequently applied on the vessel exterior than on the interior surface, and then was either burnished or polished after it was leather-hard or dry.

Height and Orifice Diameter: These attributes, measured in centimeters, were recorded with a ruler.

Diameter at Bottom of Rim and Base Diameter: Also recorded in millimeters using a ruler, these attributes permit characterization of the overall contour and shape of the vessel. 
Volume: Vessel volume in liters was determined by filling (to within $1 \mathrm{~mm}$ of the lip) the vessel with lentil seeds, then dumping the lentil seeds in containers of known volume. In estimating the volume of vessels with holes, the vessel was first filled with a cloth that conformed to vessel contours, then the lentil seeds were poured into the depression in the cloth to within $1 \mathrm{~mm}$ of the top of the lip. Then they were dumped into containers of known volume. In cases where the vessels were not (or could not) be reconstructed, but measurements of height and orifice diameter were be obtained, volumes were estimated by comparison with known vessel volumes of specific forms (i.e., carinated bowl, jar, bottle, compound bowl, and bowl) in other documented Caddo vessel assemblages.

Decoration: Decorative techniques present in the vessel collections from sites in the middle Sabine and upper Neches River basins of East Texas include engraving and excising, incising, punctating, pinching, lip notching, brushing, neck banding, and appliquéing. On certain vessels, combinations of decorative techniques (i.e., brushed-punctated) created the decorative elements and motifs. Engraving and lip notching was done with a sharp tool when the vessel was either leather-hard, or after it was fired, while the other decorative techniques were executed with tools (incising and punctation), by adding strips of clay to the wet body (appliqué), by crimping the coils (neck banding), using frayed sticks or grass stems (brushing) dragged across the body surface, or fingernails (certain forms of punctations and pinching), when the vessel was wet or still plastic. Excising is considered a form of engraved decoration, where the clay is deliberately and closely marked/scraped and carved away with a sharp tool, usually to create triangular elements (the pendant triangle or small tick marks) or crescent-shaped elements that separate or serve to define scrolls (Suhm and Jelks 1962:Plate 64a-b, f).

A red clay film or wash was added to the surface of some vessels as a slip before they were fired. Another form of vessel decoration is the use of red (hematite or ochre) or white (kaolin clay) clay pigments that have been smeared, impressed, or rubbed into the engraved lines of certain vessels.

Type: The kinds of named ceramic types in these collections from the middle Sabine and upper Neches River basins follow primarily the work of Suhm and Jelks (1962), Kleinschmidt (1982), and Hart (1982), as well as new types (Hood Engraved) and varieties of Poynor Engraved defined by Perttula (2008, 2009).

In the sections that follow, we first discuss the archeological character of the vessels found in mortuary contexts at the various prehistoric Caddo sites represented in the J. A. Walters and Bernie Ward collections. Then, this vessel data is employed to make comparisons of the kinds of decorative motifs and elements found on the different kinds of vessel forms, followed by assemblage-level considerations of vessel form, vessel size, use of temper, and firing conditions, as well as the use of pigments, from mortuary vessels of different ages and ceramic traditions in both the upper and middle reaches of the Sabine River and the upper Neches River basins. Following this is a discussion of the pottery pipes in the J. A. Walters collection. This report also includes two appendices: 
Appendix 1, the documentation of a small number of vessels from the well-known Sam Kaufman site (41RR16; also known as the Roitsch site) in the Red River basin, and Appendix 2, the documentation of vessels from unknown sites in both Smith and Wood counties, Texas.

\section{Archeological Context of the Sites}

Where available from existing field notes, plan maps, and published articles, the archeological context of the prehistoric Caddo ceramic vessels and pipes in the J. A. Walters and Bernie Ward collections are discussed on a site by site basis. Those sites not discussed below unfortunately have no available information on the archeological context of the ceramic vessels and/or pipes in the J. A. Walters collection.

\section{SM73, Joe Meyers Place}

The one ceramic vessel from the Joe Meyers Place, on Saline Creek in the Neches River basin (see Figure 1), discussed in this report is in the Bernie Ward collection. According to Johnson (1961:219-221), the Joe Meyers Place is primarily an Early Caddo habitation site (with a midden deposit) and cemetery, and at least seven burial features (Anderson 1972:139). However, Late Caddo Frankston phase ceramics and one whole vessel of Poynor Engraved were found by the East Texas Archeological Society in 1957 and indicate some use of the site by the Caddo after ca. A.D. 1400.

\section{SM193, Redwine}

The Redwine site is a small Middle Caddo mound and habitation center in the Auburn Creek valley, a small tributary to Harris Creek, in the middle reaches of the Sabine River (see Figure 1). The ceramic vessels and pipes were excavated in the early 1960 s by Sam Whiteside, who conducted investigations in a substructural mound (Walters et al. 1998:22-25), and also excavated four prehistoric Caddo burials; the location of the burials at the site are not known. Later 1990s archeological investigations reported by Walters et al. (1998:1) identified Middle Caddo period midden deposits on the crest of the landform. The one calibrated radiocarbon date from a midden feature is AD 1304-1434 (2 sigma) (Walters et al. 1998:35); the calibrated mid-point is AD 1401 (Reimer et al. 2004).

The burials at the Redwine site were placed in fairly deep (ca. $1 \mathrm{~m} \mathrm{bs}$ ) pits, and were laid on their backs in an extended supine position; their orientation or direction is not known (Walters et al. 1998:25). The burials contain ceramic vessels, ceramic pipes, and arrow points as funerary offerings (Table 1). In total, there are 28 ceramic vessels ( 7.0 vessels per burial), three ceramic pipes ( 0.75 pipes per burial), and 24 arrow points (6.0 arrow points per burial). 
Table 1. Burials from the Redwine site.

\begin{tabular}{llll}
\hline Burial No. & $\begin{array}{l}\text { No. of ceramic } \\
\text { vessels }\end{array}$ & No. of pipes & $\begin{array}{l}\text { No. of arrow } \\
\text { points }\end{array}$ \\
\hline 1 & 11 & 2 & 18 \\
2 & 4 & - & - \\
3 & 9 & 1 & 6 \\
4 & 4 & - & - \\
\hline Totals & 28 & 3 & 24 \\
\hline
\end{tabular}

The ceramic vessels from the Redwine site burials are discussed in more detail below. Shafer (2008:55-61) analyzed the arrow points from Burials 1 and 3. He identified Perdiz $(n=6)$, Perdiz-Bonham $(n=2)$, and Bonham-Alba $(n=1)$ points from Burial 1, along with a number of arrow points with a stylistic resemblance to point clusters from several shaft tomb features at the George C. Davis site (Shafer 2008:58). The Burial 3 arrow points include two Bonham-Alba and four that are untyped (Shafer 2008:60-61).

\section{SM197, Langford}

The Langford site was excavated by J. A. Walters in 1960 (Walters 1997). The site is located on an alluvial terrace overlooking the Sabine River, not far downstream from the confluence of Harris Creek with the river (see Figure 1).

During that work, a Caddo house and several midden deposits were investigated, along with nine Middle Caddo period burials; Walters (1997:38-39) provides a description of Burials 1-7. The nine burials contain only 16 vessels (1.78 vessels per burial), among them a beaker with engraved rattlesnakes (Walters 1997:Figure 2), and a platform pipe (Table 2). One of the points is a dart point in the fill of Burial 8, but the other is a small stemmed arrow point embedded in bone in the groin area of Burial 1.

\section{Table 2. Burials from the Langford site.}

\begin{tabular}{llllc} 
Burial No. & $\begin{array}{l}\text { Burial depth } \\
(\mathrm{cm} \text { bs })\end{array}$ & $\begin{array}{c}\text { No. of ceramic } \\
\text { vessels }\end{array}$ & No. of pipes & $\begin{array}{c}\text { No. of arrow/dart } \\
\text { points }\end{array}$ \\
\hline 1 & 61 & 1 & - & $1 *$ \\
2 & 61 & 2 & - & - \\
3 & 97 & 3 & - & - \\
4 & 97 & 3 & - & -
\end{tabular}


Table 2. Burials from the Langford site, cont.

\begin{tabular}{lllll} 
Burial No. & $\begin{array}{l}\text { Burial depth } \\
\text { (cm bs) }\end{array}$ & $\begin{array}{l}\text { No. of ceramic } \\
\text { vessels }\end{array}$ & No. of pipes & $\begin{array}{c}\text { No. of arrow/dart } \\
\text { points }\end{array}$ \\
\hline 5 & 102 & 2 & - & - \\
6 & N/A & - & - & - \\
7 & N/A & 1 & - & - \\
8 & N/A & 3 & 1 & - \\
9 & N/A & 1 & - & - \\
\hline
\end{tabular}

\begin{tabular}{llll} 
Totals & 16 & 1 & 2 \\
\hline
\end{tabular}

*arrow point embedded in the groin area

\section{SM198, Pardee}

The Pardee site is situated on a sandy alluvial rise on the east side of Sunstroke Creek, in the Harris Creek drainage basin (see Figure 1). The rise is approximately $2.4 \mathrm{~m}$ above the creek floodplain, and there is a naturally-formed lagoon along the south side of the landform (Figure 2).

Figure 2. Map of 41SM198, showing the location of the burial with vessels, as well as Houses 1-3, and a midden deposit.

J. A. Walters conducted excavations at the Pardee site in the late 1950s. During that work, he excavated three circular Caddo houses, a burial (Feature 4), and portions of a midden deposit (see Figure 2). House 1-3 ranged from $5.5 \mathrm{~m}$ in diameter (Houses 1 and 2, both with central hearths) to $6.1 \mathrm{~m}$ in diameter (House 3, also with a hearth, but its location within the house was not specified in the field notes). There were numerous mussel shells found in Houses 1 and 2, along with many animal bones, four Bonham arrow points, and numerous large plain and decorated grog-and bone-tempered ceramic sherds. Decorated sherds included examples from Dunkin Incised, Crockett Curvilinear Incised, and Canton Incised types, and there were a few red-slipped sherds as well as a small amount of brushed pottery. There were engraved sherds in the ceramic assemblage, primarily from bottles.

The one burial from the Pardee site is approximately $10 \mathrm{~m}$ west of House 1 (see Figure 2). No burial pit was noted, but the individual was laid out in an extended supine position, with its head at the eastern end of the grave, and the body oriented in an westnorthwesterly position. Nine ceramic vessels were placed in the grave as funerary offerings, three (Vessels 1-3) by the right side of the head and right shoulders, and the other six (Vessels 1-9) on the right side of the body near the waist. Five of the vessels (Vessels 4-5, 7-9) are plain, and the others are engraved bottles (Vessels 1 and 6), a Canton Incised jar (Vessel 3), and an incised carinated bowl (Vessel 2) (see below). 


\section{SM246, John Ellis site}

The John Ellis site is about 0.5 miles south of the Middle Caddo Jamestown Mound site (41SM54), a large site with seven known earthen mounds as well as midden and habitation deposits (Perttula 1989; Perttula and Walker 2008:Figure 1). The John Ellis site has a single mound, approximately $9.5 \mathrm{~m}$ in diameter, and Mr. J. A. Walters identified two Caddo house structures just to the south and the northeast of the mound. A single burial (Feature 2) was discovered and excavated about $1.8 \mathrm{~m}$ west of the southern end of the mound. This burial, in a $2.1 \times 2.0 \mathrm{~m}$ pit, contained three ceramic vessels and a polished clay pipe stem.

\section{SM290}

41SM290 is in the West Mud Creek drainage basin, in the southern part of the City of Tyler proper (see Figure 1). It is a prehistoric Frankston phase cemetery with seven burials, along with an associated $20 \times 20 \mathrm{~m}$ habitation area based on the surface scatter of artifacts. The cemetery was dug by Bubba and Donny Jones in ca. 1985, and the vessels documented from the cemetery (in the Bernie Ward collection) represent only a portion of the funerary objects found with the burials.

\section{WD109, Spoonbill}

The Spoonbill site, primarily a Late Caddo Titus phase cemetery, in the Caney Creek valley of the Lake Fork Creek drainage basin (see Figure 1), was excavated by J. A. Walters in 1967 (Walters 1998:46). He excavated a cemetery with 15 burials, in an area covering ca. $16 \times 21 \mathrm{~m}$, on a portion of terrace landform that overlooks the Caney Creek floodplain to the north (Figure 3). These burials are in several east-west rows, presumably with the individuals laid out in an extended supine position in the graves, with their heads facing west.

Figure 3. Plan of the Late Caddo cemetery excavated by J. A. Walters at the Spoonbill site. The location of Burial 4 is not known.

Two of the burials in the cemetery-Burials 5 and 11 - excavated by J. A. Walters apparently date to the Middle Caddo period, based on the decorated vessels placed with the deceased individuals. The range of vessels known to have been recovered from the various Titus phase graves at the Spoonbill site, including Taylor Engraved, Simms Engraved, Womack Engraved, and Keno Trailed, var. Phillips, suggest that this cemetery dates to the late $17^{\text {th }}$ century (Walters 1998,2007 ).

The exact location of the Titus phase cemetery excavated by J. A. Walters at the Spoonbill site is not known, unfortunately. Later archeological investigations at the site (Bruseth and Perttula 1981:40-48 and Figure 3-39) identified two more Middle Caddo period burials and a post-A.D. 1600 Titus phase burial in a cluster at the southern end of the site. That work also identified two temporally sequent Early to Middle Caddo period clusters of pit features and a circular structure. Calibrated radiocarbon dates from the 
Early Caddo component range from AD 967-1160, with midpoints at AD 1020 and 1040, while dates from the Middle Caddo period component range from AD 1228-1395 (Perttula 1997:Table 1), with calibrated mid-points of AD 1279 and 1285 (Reimer et al. 2004, IntCal04.14c).

\section{WD586, Turquoise site}

According to Walters (2006a:84-85), J. A. Walters excavated a Titus phase cemetery in the mid-1960s at the Turquoise site in the Caney Creek valley (see Figure 1). The nine burials were arranged east-west in several rows with the heads of the deceased facing west and the bodies in extended supine position. The grave offerings:

were composed of ceramic vessels (located from the shoulder to the knee and mostly on the right side), clusters of arrow points (both stemmed and triangular forms) around the left side of the knee areas, clay pipes (elbow style) located around the shoulder and the left side of the knee areas, and a turquoise pendant which was located in the neck area (Walters 2006a:84).

Information about each of the burials is provided in Table 3. There were a total of 56 separate funerary offerings in these burials, primarily ceramic vessels $(68 \%$, and 4.2 vessels per burial), as well as stemmed and triangular arrow points (27\%, and 1.67 points per burial), and elbow pipes (5.4\%, 0.3 pipes per burial).

Table 3. Burials from the Turquoise site.

\begin{tabular}{lllll} 
Burial No. & $\begin{array}{l}\text { Burial depth } \\
(\mathrm{cm} \text { bs })\end{array}$ & $\begin{array}{l}\text { No. of ceramic } \\
\text { vessels }\end{array}$ & No. of pipes & No. of arrow points \\
\hline $1^{*}$ & 46 & 5 & - & - \\
2 & 76 & 7 & - & - \\
3 & 66 & 6 & 1 & 3 \\
4 & 61 & 6 & 1 & 8 \\
5 & 61 & 3 & - & - \\
6 & N/A & 4 & - & 2 \\
7 & N/A & 4 & 1 & - \\
8 & N/A & 2 & - & - \\
9 & N/A & 1 & - & 15 \\
& & & 3 & \\
Totals & & 38 & 3 & \\
\hline
\end{tabular}

*also contained a turquoise pendant at the neck

The range of decorated ceramic vessels from the site-including red-slipped Taylor Engraved bowls and Simms Engraved bowls - along with the presence of both 
stemmed and triangular (Maud type) arrow points suggests that the cemetery dates to the latter part of the Titus phase, perhaps between ca. A.D. 1500-1600, or even later.

\section{WD589}

Excavations by J. A. Walters at 41WD589 encountered six burials (Burials 1-6) and a pit feature that bisected Burial 1 (Figure 4). There are two instances of burials overlapping one another (Burial 4 bisecting Burial 6 and Burial 2 bisecting Burial 3) in the cemetery, indicating several periods of cemetery use during the Late Caddo Titus phase. Four of the burial pits are oriented generally east-west, with the head of the deceased at the eastern end of the pit, facing west, and grave goods placed around the head and body of the deceased. Two burial pits were oriented in different directions: Burial 1 west-northwest, with the head facing northwest; and Burial 2, northeastsouthwest, with the head facing southwest (see Figure 4).

Figure 4. Plan of the burial excavations at 41WD589.

Burial 1 had three vessels, Burials $2 / 3$ had 11 vessels and three arrow points (1 Bassett and 2 Maud type), Burial 4 also had 11 vessels, Burial 5 had at least three vessels, and Burial 6 had three vessels. The average number of vessels per burial pit is $5.0(n=30)$.

\section{Joe Meyers Place (41SM73) Vessel}

One ceramic vessel in the Bernie Ward collection is from the Joe Meyers Place in the upper Neches River basin, not far from 41SM249 (see Figure 1). This is a Late Caddo, Frankston phase, Poynor Engraved, var. Cook carinated bowl.

SITE NAME OR SITE NUMBER: Joe Meyers (41SM73)

VESSEL NO.: BW-1

NON-PLASTICS: grog and hematite

VESSEL FORM: Carinated bowl

RIM AND LIP FORM: inverted rim and rounded lip

CORE COLOR: $\mathrm{F}$ (fired in a reducing environment and cooled in the open air)

INTERIOR SURFACE COLOR: yellowish-brown (10YR 5/4)

EXTERIOR SURFACE COLOR: light yellowish-brown (10YR 6/4)

WALL THICKNESS (RIM, BODY, AND BASE IN MM): 9.5 mm, rim

INTERIOR SURFACE TREATMENT: smoothed on the rim 
EXTERIOR SURFACE TREATMENT: smoothed on the rim and body

HEIGHT (IN CM): 16.0

ORIFICE DIAMETER (IN CM): 26.3

DIAMETER AT BOTTOM OF RIM OR NECK (IN CM): 27.3

BASE DIAMETER (IN CM): 9.5

ESTIMATED VOLUME (IN LITERS): 3.78 liters

DECORATION: The engraved panel on the rim has a series of ovals with near-vertical arches between the large ovals; horizontal brushed body (Figure 5).

Figure 5. Poynor Engraved, var. Cook carinated bowl from the Joe Meyers Place (41SM73).

TYPE: Poynor Engraved, var. Cook

\section{Redwine Site (41SM193) Vessels}

There are 30 Caddo ceramic vessels in the J. A. Walters collection from the Redwine site, a Middle Caddo habitation and mound center in the Harris Creek drainage basin in the middle Sabine River basin (see Figure 1). The vessels include a Reavely Brushed-Incised jar, a Handy Engraved jar and a carinated bowl, a Crockett Curvilinear Incised carinated bowl, a possible Haley Engraved bottle, two engraved beakers, a "brick-wall" engraved carinated bowl, two other engraved carinated bowls (with resemblances to engraved vessels at the Washington Square Mound site, see Hart 1982), an engraved bowl with a Middle Caddo style Redwine Mode lip (see Walters n.d.), an engraved effigy bowl, an early form of Poynor Engraved carinated bowl, a Washington Square Paneled bowl and carinated bowl, an engraved bottle, a punctated-pinched jar, a Killough Pinched jar, an incised-punctated jar, a tool punctated bottle, plain carinated bowls $(n=5)$, plain bowls $(n=2)$, two red-slipped bowls, and a red-slipped jar.

SITE NAME OR SITE NUMBER: Redwine (41SM193), Burial 1

VESSEL NO.: 1

NON-PLASTICS: grog

VESSEL FORM: Jar with opposed strap handles and four rim peaks 
RIM AND LIP FORM: Everted rim and a rounded lip

CORE COLOR: $\mathrm{F}$ (fired in a reducing environment and cooled in the open air)

INTERIOR SURFACE COLOR: pale brown (10YR 6/3)

EXTERIOR SURFACE COLOR: pale brown (10YR 6/3); fire clouds on the rim and body

WALL THICKNESS (RIM, BODY, AND BASE IN MM): 6.2 mm, rim

INTERIOR SURFACE TREATMENT: smoothed on the rim

EXTERIOR SURFACE TREATMENT: none

HEIGHT (IN CM): 13.5

ORIFICE DIAMETER (IN CM): 15.3

DIAMETER AT BOTTOM OF RIM OR NECK (IN CM): 13.9

BASE DIAMETER (IN CM): 9.1

ESTIMATED VOLUME (IN LITERS): 1.23 liters

DECORATION: The rim has three rows of tool punctations that alternate with two zones of horizontal brushing marks; the lowermost row of tool punctations is at the rim-body juncture (Figure 6). The vessel body has five vertical panels defined by vertical appliqued fillets. Within the panels are either diagonal and vertical brushing marks and adjacent diagonal or vertical rows of tool punctations; in the vertical brushed panels, there is a single row of punctations, but there are two diagonal rows of punctations in the diagonal brushed panels. Around the body by direction, the panels have diagonal brushedpunctated elements; vertical brushed-punctated; diagonal brushed-punctated (but pitched in the opposite direction); another vertical brushed-punctated panel; and a diagonal brushed-punctated panel pitched in the opposite direction from the preceding panel.

Figure 6. Reavely Brushed-Incised Jar from the Redwine site.

The two strap handles are also decorated. They have a central appliqued node with tiny tool punctations on it, and diagonal and curvilinear rows of tool punctations and diagonal and curvilinear brushed zones surrounding the appliqued node.

TYPE: cf. Reavely Brushed-Incised (see Hart 1982; Walters et al. 1998:Figure 11g)

SITE NAME OR SITE NUMBER: Redwine (41SM193), Burial 1 
VESSEL NO.: 2

NON-PLASTICS: none apparent

VESSEL FORM: Jar with opposed strap handles and four body peaks

RIM AND LIP FORM: Direct rim with a rounded and exterior folded lip; Redwine mode lip (Walters n.d.)

CORE COLOR: B (fired and cooled in a reducing environment)

INTERIOR SURFACE COLOR: black (10YR 2/1)

EXTERIOR SURFACE COLOR: black (10YR 2/1)

WALL THICKNESS (RIM, BODY, AND BASE IN MM): $7.1 \mathrm{~mm}$, rim

INTERIOR SURFACE TREATMENT: Burnished

EXTERIOR SURFACE TREATMENT: Burnished

HEIGHT (IN CM): 7.2

ORIFICE DIAMETER (IN CM): 8.0

DIAMETER AT BOTTOM OF RIM OR NECK (IN CM): 6.5

BASE DIAMETER (IN CM): 6.0

ESTIMATED VOLUME (IN LITERS): 0.34 liters

DECORATION: The rim has four sets of a punctated motif, consisting of upper and lower (at the rim-body juncture) tool punctated rows interlocked with punctated brackets (Figure 7). The area between the interlocking punctated rows is filled with horizontal brushing. The body has four repeating sets of engraved concentric circles and scroll lines, with the innermost circle also having small excised rays. The connecting engraved scroll line has small excised spurs. Above and below each concentric circle are sets of a single curvilinear engraved line around excised pendant triangles.

Figure 7. Handy Engraved jar from the Redwine site.

The strap handles have an engraved panel with a concentric circle motif, the center of which is a small hatched circle. The panel is defined by excised vertical brackets. 
TYPE: cf. Handy Engraved (see Walters et al. 1998:Figure 11c)

SITE NAME OR SITE NUMBER: Redwine (41SM193), Burial 1

VESSEL NO.: 3

NON-PLASTICS: grog

VESSEL FORM: Carinated bowl

RIM AND LIP FORM: Direct rim and a rounded lip

CORE COLOR: $\mathrm{F}$ (fired in a reducing environment and cooled in the open air)

INTERIOR SURFACE COLOR: brown (10YR 5/3); fire cloud on base

EXTERIOR SURFACE COLOR: brown (10YR 5/3); fire cloud on base

WALL THICKNESS (RIM, BODY, AND BASE IN MM): 9.5 mm, rim

INTERIOR SURFACE TREATMENT: smoothed on the rim

EXTERIOR SURFACE TREATMENT: smoothed on the rim

HEIGHT (IN CM): 12.2

ORIFICE DIAMETER (IN CM): 31.7

DIAMETER AT BOTTOM OF RIM OR NECK (IN CM): 27.6

BASE DIAMETER (IN CM): 11.0

ESTIMATED VOLUME (IN LITERS): 2.32 liters

DECORATION: The rim panel has five repeating incised-punctated scrolls around the vessel. The central and embedded element in the scroll is a tool punctated-filled circle. The upper and lower scroll fill zones are filled with tool punctates (Figure 8).

Figure 8. Crockett Curvilinear Incised carinated bowl from the Redwine site. TYPE: cf. Crockett Curvilinear Incised (see Walters et al. 1998:Figure 13d) 
SITE NAME OR SITE NUMBER: Redwine (41SM193), Burial 1

VESSEL NO.: 7

NON-PLASTICS: grog, hematite, and bone

VESSEL FORM: Bottle with a collared neck

RIM AND LIP FORM: Direct rim and a rounded lip

CORE COLOR: $\mathrm{F}$ (fired in a reducing environment and cooled in the open air)

INTERIOR SURFACE COLOR: strong brown (7.5YR 4/6)

EXTERIOR SURFACE COLOR: strong brown (7.5YR 4/6)

WALL THICKNESS (RIM, BODY, AND BASE IN MM): 6.6 mm, neck

INTERIOR SURFACE TREATMENT: smoothed on the upper neck

EXTERIOR SURFACE TREATMENT: smoothed

HEIGHT (IN CM): $20.0 \mathrm{~cm}$; bottle neck is $8.0 \mathrm{~cm}$ in height

ORIFICE DIAMETER (IN CM): 4.9

DIAMETER AT BOTTOM OF RIM OR NECK (IN CM): 5.0; $12.2 \mathrm{~cm}$ at the widest point on the body

BASE DIAMETER (IN CM): 8.5

ESTIMATED VOLUME (IN LITERS): 0.68 liters

DECORATION: The bottle body has a vertical excised scroll motif with a central embedded circle; the motif is repeated four times around the body. The central circle has a small excised dot in it. Each of the vertical scrolls have vertical excised curvilinear and triangular dividers (Figure 9).

Figure 9. Haley Engraved bottle from the Redwine site.

TYPE: cf. Haley Engraved (see Walters et al. 1998:Figure 11b)

SITE NAME OR SITE NUMBER: Redwine (41SM193)

VESSEL NO.: 8 
NON-PLASTICS: grog

VESSEL FORM: Beaker

RIM AND LIP FORM: Direct rim and a flat lip

CORE COLOR: $\mathrm{F}$ (fired in a reducing environment and cooled in the open air)

INTERIOR SURFACE COLOR: dark brown (7.5YR 3/4)

EXTERIOR SURFACE COLOR: brown (7.5YR 4/4)

WALL THICKNESS (RIM, BODY, AND BASE IN MM): 6.2 mm, rim

INTERIOR SURFACE TREATMENT: burnished on the upper rim

EXTERIOR SURFACE TREATMENT: smoothed to burnished

HEIGHT (IN CM): 15.0

ORIFICE DIAMETER (IN CM): 5.8

DIAMETER AT BOTTOM OF RIM OR NECK (IN CM): N/A

BASE DIAMETER (IN CM): 7.6

ESTIMATED VOLUME (IN LITERS): 0.70 liters

DECORATION: The beaker has a single horizontal engraved line around the rim. There are five vertical cross-hatched engraved ladders that extend from the rim to the vessel base. Each cross-hatched ladder has three sets of semi-circular engraved lines pendant from the ladder (Figure 10). These semi-circular elements are comprised of a diagonal hatched zone between two lines, as well as a third outer semi-circular line. In one instance, one of the sets of semi-circular engraved lines does not have a hatched zone. A red clay pigment has been rubbed in the engraved lines.

Figure 10. Engraved beaker from the Redwine site.

TYPE: Undetermined fine ware (see Walters et al. 1998:Figure 11a)

SITE NAME OR SITE NUMBER: Redwine (41SM193), Burial 3

VESSEL NO.: 9 
NON-PLASTICS: grog and hematite

VESSEL FORM: Beaker

RIM AND LIP FORM: Direct rim and a flat lip

CORE COLOR: B (fired and cooled in a low oxygen environment)

INTERIOR SURFACE COLOR: very dark gray (10YR 3/1)

EXTERIOR SURFACE COLOR: very dark gray (10YR 3/1)

WALL THICKNESS (RIM, BODY, AND BASE IN MM): 6.0 mm, rim

INTERIOR SURFACE TREATMENT: burnished only under the lip

EXTERIOR SURFACE TREATMENT: burnished

HEIGHT (IN CM): 16.9

ORIFICE DIAMETER (IN CM): 7.3

DIAMETER AT BOTTOM OF RIM OR NECK (IN CM): N/A

BASE DIAMETER (IN CM): 7.1

ESTIMATED VOLUME (IN LITERS): 0.98 liters

DECORATION: The vessel body and rim has three tiers of swastika-in-circle elements, two swastika-in-circle elements per tier, that are connected by curvilinear cross-hatched engraved zones or scrolls that run between each of the tiers (Figure 11). There are also cross-hatched rectangular to curvilinear engraved panels pendant from the top and bottom of the beaker. A red clay pigment has been rubbed in the engraved lines.

Figure 11. A second engraved beaker from the Redwine site, Burial 3.

TYPE: Undetermined fine ware (see Walters et al. 1998:Figure 13b)

SITE NAME OR SITE NUMBER: Redwine (41SM193), Burial 3

VESSEL NO.: 10

NON-PLASTICS: grog and hematite

VESSEL FORM: Bottle with a collared and straight neck 
RIM AND LIP FORM: Direct rim and a rounded lip

CORE COLOR: $\mathrm{G}$ (fired in a reducing environment and cooled in the open air)

INTERIOR SURFACE COLOR: N/A

EXTERIOR SURFACE COLOR: light yellowish-brown (10YR 6/4)

WALL THICKNESS (RIM, BODY, AND BASE IN MM): 7.9 mm, neck

INTERIOR SURFACE TREATMENT: none

EXTERIOR SURFACE TREATMENT: burnished

HEIGHT (IN CM): 14.9

ORIFICE DIAMETER (IN CM): 4.0

DIAMETER AT BOTTOM OF RIM OR NECK (IN CM): 6.1 (on collar); $13.4 \mathrm{~cm}$ wide at the widest part of the body

BASE DIAMETER (IN CM): 8.2

ESTIMATED VOLUME (IN LITERS): 0.49 liters

DECORATION: The bottle body has been divided into three panels by narrow and partially excised or cross-hatched vertical bands. Two of the panels have interlocking scrolls with lower rectangular or oval zones, while the third has a partially excised and cross-hatched scroll with a central embedded circle (Figure 12). At the bottom of this panel is a partially excised rectangle as well as a small circle and a partial hooked arm element, both pendant from a vertical engraved zone. A red clay pigment has been rubbed in the engraved lines.

Figure 12. Engraved bottle from Burial 3 at the Redwine site.

TYPE: Undetermined fine ware (see Walters et al. 1998:Figure 13c)

SITE NAME OR SITE NUMBER: Redwine (41SM193), Burial 1

VESSEL NO.: 11

NON-PLASTICS: grog

VESSEL FORM: Jar 
RIM AND LIP FORM: Everted rim and a rounded lip

CORE COLOR: $\mathrm{F}$ (fired in a reducing environment and cooled in the open air)

INTERIOR SURFACE COLOR: reddish-brown (5YR 4/4); fire clouding on the base and rim

EXTERIOR SURFACE COLOR: reddish-brown (2.5YR 4/4); fire clouding on the base and body

WALL THICKNESS (RIM, BODY, AND BASE IN MM): 6.2 mm, rim

INTERIOR SURFACE TREATMENT: smoothed on the rim

EXTERIOR SURFACE TREATMENT: none

HEIGHT (IN CM): 7.1

ORIFICE DIAMETER (IN CM): 8.5

DIAMETER AT BOTTOM OF RIM OR NECK (IN CM): 6.8

BASE DIAMETER (IN CM): 7.0

ESTIMATED VOLUME (IN LITERS): 0.36 liters

DECORATION: There is a single tool punctated row on the central part of the rim. The vessel body has six equally-spaced sets of three vertical pinched ridges that extend from the rim-body juncture to the vessel base. Between each of these sets of pinched ridges are six or seven horizontal rows of tool punctates at the upper part of the vessel body (Figure $13)$.

Figure 13. Killough Pinched jar.

TYPE: cf. Killough Pinched (see Walters et al. 1998:Figure 11h)

SITE NAME OR SITE NUMBER: Redwine (41SM193), Burial 2

VESSEL NO.: 12

NON-PLASTICS: grog

VESSEL FORM: Jar; the vessel has been cut down and recycled as a bowl 
RIM AND LIP FORM: Direct cut down rim and rounded lip

CORE COLOR: $\mathrm{F}$ (fired in a reducing environment and cooled in the open air)

INTERIOR SURFACE COLOR: strong brown (7.5YR 4/6)

EXTERIOR SURFACE COLOR: strong brown (7.5YR 5/6)

WALL THICKNESS (RIM, BODY, AND BASE IN MM): 6.5 mm, rim

INTERIOR SURFACE TREATMENT: smoothed

EXTERIOR SURFACE TREATMENT: none

HEIGHT (IN CM): 5.4

ORIFICE DIAMETER (IN CM): 13.0

DIAMETER AT BOTTOM OF RIM OR NECK (IN CM): N/A

BASE DIAMETER (IN CM): 10.0

ESTIMATED VOLUME (IN LITERS): 0.42 liters

DECORATION: The entire vessel surface is covered with closely-spaced vertical pinched ridges (Figure 14).

Figure 14. Killough Pinched jar from Burial 2 at the Redwine site.

TYPE: Killough Pinched (see Walters et al. 1998:Figure 12d)

SITE NAME OR SITE NUMBER: Redwine (41SM193), Burial 2

VESSEL NO.: 13

NON-PLASTICS: grog

VESSEL FORM: Jar

RIM AND LIP FORM: Everted rim and a rounded lip

CORE COLOR: $\mathrm{F}$ (fired in a reducing environment and cooled in the open air)

INTERIOR SURFACE COLOR: reddish-yellow (7.5YR 6/6) 
EXTERIOR SURFACE COLOR: light brown (7.5YR 6/4); fire clouding on base and body

WALL THICKNESS (RIM, BODY, AND BASE IN MM): 6.3 mm, rim

INTERIOR SURFACE TREATMENT: smoothed

EXTERIOR SURFACE TREATMENT: none

HEIGHT (IN CM): 9.9

ORIFICE DIAMETER (IN CM): 10.4

DIAMETER AT BOTTOM OF RIM OR NECK (IN CM): 7.6

BASE DIAMETER (IN CM): 5.2

ESTIMATED VOLUME (IN LITERS): 0.62 liters

DECORATION: There is a row of tool punctations under the lip and two additional rows of tool punctations at the rim-body juncture. Between the punctated rows are a series of vertical and intersecting diagonal to horizontal incised lines (Figure 15).

Figure 15. Incised-punctated jar from Burial 2 at the Redwine site.

TYPE: Undetermined utility ware (see Walters et al. 1998:Figure 12c)

SITE NAME OR SITE NUMBER: Redwine (41SM193), Burial 4

VESSEL NO.: 14

NON-PLASTICS: grog

VESSEL FORM: Carinated bowl

RIM AND LIP FORM: Direct rim with a rounded and exterior folded lip

CORE COLOR: $F$ (fired in a reducing environment and cooled in the open air)

INTERIOR SURFACE COLOR: strong brown (7.5YR 4/6)

EXTERIOR SURFACE COLOR: strong brown (7.5YR 5/6); fire cloud on base

WALL THICKNESS (RIM, BODY, AND BASE IN MM): 5.9 mm, rim 
INTERIOR SURFACE TREATMENT: smoothed on the rim

EXTERIOR SURFACE TREATMENT: burnished on the rim and body

HEIGHT (IN CM): 8.3

ORIFICE DIAMETER (IN CM): 14.9

DIAMETER AT BOTTOM OF RIM OR NECK (IN CM): 12.5

BASE DIAMETER (IN CM): 7.0

ESTIMATED VOLUME (IN LITERS): 0.74 liters

DECORATION: Plain (Figure 16)

Figure 16. Plain carinated bowl from Burial 4 at the Redwine site.

TYPE: Undetermined plain ware vessel (see Walters et al. 1998:Figure 14b)

SITE NAME OR SITE NUMBER: Redwine (41SM193), Burial 3

VESSEL NO.: 15

NON-PLASTICS: grog

VESSEL FORM: Bowl

RIM AND LIP FORM: Direct rim and a rounded lip

CORE COLOR: $\mathrm{H}$ (fired in a reducing environment and cooled in the open air)

INTERIOR SURFACE COLOR: brown (10YR 5/3)

EXTERIOR SURFACE COLOR: very dark gray (10YR 3/1)

WALL THICKNESS (RIM, BODY, AND BASE IN MM): 7.7 mm, rim

INTERIOR SURFACE TREATMENT: none

EXTERIOR SURFACE TREATMENT: smoothed; organic residue on the rim and body

HEIGHT (IN CM): 10.0

ORIFICE DIAMETER (IN CM): 13.8 
DIAMETER AT BOTTOM OF RIM OR NECK (IN CM): N/A

BASE DIAMETER (IN CM): 9.4

ESTIMATED VOLUME (IN LITERS): 0.55 liters

DECORATION: Plain (Figure 17)

TYPE: Undetermined plain ware vessel (see Walters et al. 1998:Figure 13g)

Figure 17. Plain bowl from Burial 3 at the Redwine site.

SITE NAME OR SITE NUMBER: Redwine (41SM193)

VESSEL NO.: 16

NON-PLASTICS: grog

VESSEL FORM: Bowl

RIM AND LIP FORM: Direct rim and a rounded lip

CORE COLOR: A (fired and cooled in a high oxidizing environment)

INTERIOR SURFACE COLOR: yellowish-red (5YR 5/6)

EXTERIOR SURFACE COLOR: yellowish-red (5YR 5/6)

WALL THICKNESS (RIM, BODY, AND BASE IN MM): 6.3 mm, rim

INTERIOR SURFACE TREATMENT: smoothed on the rim

EXTERIOR SURFACE TREATMENT: burnished on the body and rim

HEIGHT (IN CM): 7.0

ORIFICE DIAMETER (IN CM): 15.0

DIAMETER AT BOTTOM OF RIM OR NECK (IN CM): N/A

BASE DIAMETER (IN CM): 15.0

ESTIMATED VOLUME (IN LITERS): 0.42 liters 
DECORATION: Plain; possible red slip or red clay wash on both interior and exterior vessel surfaces (Figure 18)

TYPE: Undetermined plain ware vessel

Figure 18. Plain bowl from the Redwine site.

SITE NAME OR SITE NUMBER: Redwine (41SM193), Burial 1

VESSEL NO.: 17

NON-PLASTICS: grog and temper voids (bone?)

VESSEL FORM: Carinated bowl

RIM AND LIP FORM: Direct rim and a rounded lip

CORE COLOR: A (Fired and cooled in a high oxygen environment)

INTERIOR SURFACE COLOR: brown (7.5YR 4/4)

EXTERIOR SURFACE COLOR: brown (7.5YR 4/4)

WALL THICKNESS (RIM, BODY, AND BASE IN MM): 6.2 mm, rim

INTERIOR SURFACE TREATMENT: smoothed

EXTERIOR SURFACE TREATMENT: burnished

HEIGHT (IN CM): 6.5

ORIFICE DIAMETER (IN CM): 16.0

DIAMETER AT BOTTOM OF RIM OR NECK (IN CM): 12.5

BASE DIAMETER (IN CM): 8.8

ESTIMATED VOLUME (IN LITERS): 0.62 liters

DECORATION: The rim panel is comprised of three sets of closely-spaced vertical and horizontal intersecting engraved lines, creating a "brick wall" design (Walters et al. 1998:26), and three sets of semi-circular engraved lines (Figure 19). In one instance, the set of curvilinear engraved lines has intersecting horizontal lines cutting across them. 
TYPE: Undetermined fine ware (see Walters et al. 1998:Figure 11d)

Figure 19. Engraved carinated bowl from Burial 1 at the Redwine site.

SITE NAME OR SITE NUMBER: Redwine (41SM193), Burial 1

VESSEL NO.: 18

NON-PLASTICS: grog

VESSEL FORM: Bowl

RIM AND LIP FORM: Direct rim and a rounded lip

CORE COLOR: $\mathrm{F}$ (fired in a reducing environment and cooled in the open air)

INTERIOR SURFACE COLOR: brown (7.5YR 4/4)

EXTERIOR SURFACE COLOR: brown (7.5YR 4/4)

WALL THICKNESS (RIM, BODY, AND BASE IN MM): 4.6 mm, rim

INTERIOR SURFACE TREATMENT: burnished on rim

EXTERIOR SURFACE TREATMENT: burnished

HEIGHT (IN CM): 4.5

ORIFICE DIAMETER (IN CM): 12.0

DIAMETER AT BOTTOM OF RIM OR NECK (IN CM): N/A

BASE DIAMETER (IN CM): 11.0

ESTIMATED VOLUME (IN LITERS): 0.22 liters

DECORATION: The rim panel has horizontal interlocking panels executed with horizontal and vertical rows of tool punctations (Figure 20).

TYPE: Washington Square Paneled (see Hart 1982:Figure 3-12b; see also Walters et al. 1998:Figure 11f)

Figure 20. Washington Square Paneled carinated bowl from Burial 1 at the Redwine site. 
SITE NAME OR SITE NUMBER: Redwine (41SM193), Burial 4

VESSEL NO.: 19

NON-PLASTICS: finely crushed grog and hematite

VESSEL FORM: Carinated bowl with two opposed small rim peaks (Figure 21)

RIM AND LIP FORM: Direct rim and a flat lip

CORE COLOR: A (fired and cooled in an oxidizing environment)

INTERIOR SURFACE COLOR: reddish-brown (5YR 4/4)

EXTERIOR SURFACE COLOR: reddish-brown (5YR 5/4)

WALL THICKNESS (RIM, BODY, AND BASE IN MM): 6.5 mm, rim

INTERIOR SURFACE TREATMENT: smoothed on the rim

EXTERIOR SURFACE TREATMENT: smoothed

HEIGHT (IN CM): 5.0

ORIFICE DIAMETER (IN CM): 10.4

DIAMETER AT BOTTOM OF RIM OR NECK (IN CM): 10.6

BASE DIAMETER (IN CM): 6.6

ESTIMATED VOLUME (IN LITERS): 0.31 liters

DECORATION: Plain

TYPE: Undetermined plain ware (see Walters et al. 1998:Figure 14c)

Figure 21. Plain carinated bowl from Burial 4 at the Redwine site.

SITE NAME OR SITE NUMBER: Redwine (41SM193), Burial 3

VESSEL NO.: 20

NON-PLASTICS: grog

VESSEL FORM: Carinated bowl 
RIM AND LIP FORM: Direct rim and a rounded lip; sprocket mode lip (see Miller 1986)

CORE COLOR: $\mathrm{F}$ (fired in a reducing environment and cooled in the open air)

INTERIOR SURFACE COLOR: grayish-brown (10YR 5/2); fire clouding on rim, body, and base

EXTERIOR SURFACE COLOR: dark grayish-brown (10YR 4/2); fire clouding on the rim, body, and base

WALL THICKNESS (RIM, BODY, AND BASE IN MM): 4.5 mm, rim

INTERIOR SURFACE TREATMENT: burnished on the rim

EXTERIOR SURFACE TREATMENT: burnished

HEIGHT (IN CM): 5.5

ORIFICE DIAMETER (IN CM): 20.0

DIAMETER AT BOTTOM OF RIM OR NECK (IN CM): 17.0

BASE DIAMETER (IN CM): 18.0

ESTIMATED VOLUME (IN LITERS): 0.66 liters

DECORATION: The rim panel has a continuous incised scroll band filled with tool punctations that is repeated five time around the vessel. There are embedded circles in each scroll; sometimes that circle has a central dot. The upper and lower scroll fill zones consist of concentric semi-circles and circles as well as cross-hatched corners (Figure 22). A white kaolin clay pigment has been rubbed in the engraved and incised-punctated elements.

TYPE: cf. Handy Engraved (see Walters et al. 1998:Figure 13e)

Figure 22. Handy Engraved carinated bowl from Burial 3 at the Redwine site.

SITE NAME OR SITE NUMBER: Redwine (41SM193), Burial 1

VESSEL NO.: 21

NON-PLASTICS: very fine grog

VESSEL FORM: Bowl 
RIM AND LIP FORM: Direct rim and a rounded lip; Redwine mode lip

CORE COLOR: $\mathrm{F}$ (fired in a reducing environment, and cooled in the open air)

INTERIOR SURFACE COLOR: strong brown (7.5YR 4/6)

EXTERIOR SURFACE COLOR: strong brown (7.5YR 4/6)

WALL THICKNESS (RIM, BODY, AND BASE IN MM): $8.6 \mathrm{~mm}$, lip; $4.0 \mathrm{~mm}$, body

INTERIOR SURFACE TREATMENT: burnished

EXTERIOR SURFACE TREATMENT: burnished; brown slip

HEIGHT (IN CM): 8.0

ORIFICE DIAMETER (IN CM): 21.2

DIAMETER AT BOTTOM OF RIM OR NECK (IN CM): 19.5

BASE DIAMETER (IN CM): 9.0

ESTIMATED VOLUME (IN LITERS): 0.68 liters

DECORATION: There are 17 hatched engraved pendant triangles on each scalloped part of the Redwine mode lip. A single engraved line encircles the inner edge of the lip, while the apex of the hatched triangles point away from the lip (Figure 23).

TYPE: Undetermined fine ware (see Walters et al. 1998:Figure 11i)

Figure 23. Engraved bowl from Burial 1 at the Redwine site.

SITE NAME OR SITE NUMBER: Redwine (41SM193), Burial 3

VESSEL NO.: 22

NON-PLASTICS: grog

VESSEL FORM: Effigy bowl with effigy head and opposed tail tab

RIM AND LIP FORM: Direct rim and a rounded lip

CORE COLOR: $\mathrm{F}$ (fired in a reducing environment and cooled in the open air) 
INTERIOR SURFACE COLOR: grayish-brown (10YR 5/2); fire clouding on body and base

EXTERIOR SURFACE COLOR: grayish-brown (10YR 5/2); fire clouding on body, base, and tab tail

WALL THICKNESS (RIM, BODY, AND BASE IN MM): 7.4 mm, rim

INTERIOR SURFACE TREATMENT: smoothed

EXTERIOR SURFACE TREATMENT: burnished

HEIGHT (IN CM): 8.5

ORIFICE DIAMETER (IN CM): 19.6

DIAMETER AT BOTTOM OF RIM OR NECK (IN CM): N/A

BASE DIAMETER (IN CM): 9.0

ESTIMATED VOLUME (IN LITERS): 0.67 liters

DECORATION: The rim has three horizontal engraved lines around the vessel; each of these lines dips underneath both the bird effigy and the tab tail. The bird effigy head has an excised mouth and engraved eyes; each eye has a central excised dot (Figure 24). The tail tab is lip notched; it also has two concentric engraved circles, the innermost filled with cross-hatched engraved lines.

TYPE: Hood Engraved, var. unspecified (see Walters et al. 1998:Figure 13f)

Figure 24. Hood Engraved effigy bowl from Burial 3 at the Redwine site.

SITE NAME OR SITE NUMBER: Redwine (41SM193), Burial 3

VESSEL NO.: 23

NON-PLASTICS: finely crushed grog and bone

VESSEL FORM: Carinated bowl

RIM AND LIP FORM: Direct rim and a rounded and exterior folded lip

CORE COLOR: $\mathrm{F}$ (fired in a reducing environment but cooled in the open air)

INTERIOR SURFACE COLOR: red (10R 4/6); fire cloud on the base 
EXTERIOR SURFACE COLOR: red (10R 4/6); fire clouding on the body and base

WALL THICKNESS (RIM, BODY, AND BASE IN MM): $6.5 \mathrm{~mm}$, rim

INTERIOR SURFACE TREATMENT: smoothed on the rim

EXTERIOR SURFACE TREATMENT: burnished on the rim and body

HEIGHT (IN CM): 10.0

ORIFICE DIAMETER (IN CM): 22.2

DIAMETER AT BOTTOM OF RIM OR NECK (IN CM): 21.4

BASE DIAMETER (IN CM): 8.7

ESTIMATED VOLUME (IN LITERS): 1.33 liters

DECORATION: The rim has engraved continuous scrolls with cross-hatched embedded circles and sets of semi-circular lines in the scroll fill zone. The scrolls are repeated four times around the vessel (Figure 25).

TYPE: Undetermined fine ware, but similar to Nacogdoches Engraved (see Hart 1982:Figure 3-6d; see also Walters et al. 1998:Figure 13a)

Figure 25. Engraved carinated bowl from Burial 3 at the Redwine site.

SITE NAME OR SITE NUMBER: Redwine (41SM193), Burial 2

VESSEL NO.: 24

NON-PLASTICS: grog

VESSEL FORM: Carinated bowl

RIM AND LIP FORM: Direct rim and a rounded lip

CORE COLOR: F (fired in a reducing environment and cooled in the open air)

INTERIOR SURFACE COLOR: strong brown (7.5YR 5/6)

EXTERIOR SURFACE COLOR: strong brown (7.5YR 5/6)

WALL THICKNESS (RIM, BODY, AND BASE IN MM): 7.9 mm, rim 
INTERIOR SURFACE TREATMENT: smoothed

EXTERIOR SURFACE TREATMENT: burnished

HEIGHT (IN CM): 8.6

ORIFICE DIAMETER (IN CM): 26.5

DIAMETER AT BOTTOM OF RIM OR NECK (IN CM): 24.0

BASE DIAMETER (IN CM): 10.5

ESTIMATED VOLUME (IN LITERS): 1.37 liters

DECORATION: The rim panel has an idiosyncratic engraved motif that consists of a series of excised and cross-hatched elements that are pendant from the carination that resemble the outlines of Caddo wood "beehive-shaped structures." Interspersed amongst these excised and cross-hatched elements are five engraved semi-circles with smaller excised elements pendant from the outer semi-circular line (Figure 26). The inner part of the semi-circles have oval-shaped excised zones.

TYPE: Undetermined fine ware (see Walters et al. 1998:Figure 12a)

Figure 26. Engraved carinated bowl from the Redwine site, Burial 2.

SITE NAME OR SITE NUMBER: Redwine (41SM193), Burial 4

VESSEL NO.: 25

NON-PLASTICS: grog, bone, and hematite

VESSEL FORM: Carinated bowl

RIM AND LIP FORM: Direct rim and a rounded, scalloped lip

CORE COLOR: $\mathrm{F}$ (fired in a reducing environment and cooled in the open air)

INTERIOR SURFACE COLOR: yellowish-red (5YR 5/6)

EXTERIOR SURFACE COLOR: yellowish-red (5YR 5/6)

WALL THICKNESS (RIM, BODY, AND BASE IN MM): 9.0 mm, rim

INTERIOR SURFACE TREATMENT: smoothed 
EXTERIOR SURFACE TREATMENT: burnished

HEIGHT (IN CM): 12.0

ORIFICE DIAMETER (IN CM): 28.8

DIAMETER AT BOTTOM OF RIM OR NECK (IN CM): 25.0

BASE DIAMETER (IN CM): 9.0

ESTIMATED VOLUME (IN LITERS): 2.07 liters

DECORATION: This vessel has a rectangular rim panel motif with cross-hatched engraved triangles at each corner of the eight panels, and an engraved swastika-in-circle at the center of the panel (Figure 27).

TYPE: cf. Poynor Engraved, early variety (see Perttula 2009; Walters et al. 1998:Figure 14a); Hart (1982:Figure 13-b) refers to this as Mode A in certain vessels from the Washington Square Mound site (41NA49).

Figure 27. Early variety of Poynor Engraved, or Mode A, carinated bowl from Burial 4 at the Redwine site.

SITE NAME OR SITE NUMBER: Redwine (41SM193)

VESSEL NO.: 26

NON-PLASTICS: grog

VESSEL FORM: Carinated bowl

RIM AND LIP FORM: Direct rim and a rounded lip

CORE COLOR: A (fired and cooled in a high oxygen environment)

INTERIOR SURFACE COLOR: weak red (10R 4/4)

EXTERIOR SURFACE COLOR: red (10R 5/6)

WALL THICKNESS (RIM, BODY, AND BASE IN MM): 7.4 mm, rim

INTERIOR SURFACE TREATMENT: none

EXTERIOR SURFACE TREATMENT: smoothed 
HEIGHT (IN CM): 5.1

ORIFICE DIAMETER (IN CM): 9.2

DIAMETER AT BOTTOM OF RIM OR NECK (IN CM): 8.2

BASE DIAMETER (IN CM): 6.0

ESTIMATED VOLUME (IN LITERS): 0.19 liters

DECORATION: Plain (Figure 28)

TYPE: Undetermined plain ware

Figure 28. Plain carinated bowl from the Redwine site.

SITE NAME OR SITE NUMBER: Redwine (41SM193), Burial 2

VESSEL NO.: 27

NON-PLASTICS: grog

VESSEL FORM: Miniature bottle

RIM AND LIP FORM: Direct rim and a rounded lip

CORE COLOR: $\mathrm{F}$ (fired in a reducing environment and cooled in the open air)

INTERIOR SURFACE COLOR: brown (7.5YR 5/4)

EXTERIOR SURFACE COLOR: brown (7.5YR 5/4); fire clouding on the body

WALL THICKNESS (RIM, BODY, AND BASE IN MM):

INTERIOR SURFACE TREATMENT: none

EXTERIOR SURFACE TREATMENT: none

HEIGHT (IN CM): 4.7

ORIFICE DIAMETER (IN CM): 2.0

DIAMETER AT BOTTOM OF RIM OR NECK (IN CM): 2.5 
BASE DIAMETER (IN CM): 3.0

ESTIMATED VOLUME (IN LITERS): 0.06 liters

DECORATION: The vessel body has horizontal and diagonal tool punctated rows; the neck is plain (Figure 29).

TYPE: Undetermined utility ware (see Walters et al. 1998:Figure 12b)

Figure 29. Punctated bottle from the Redwine site, Burial 2

SITE NAME OR SITE NUMBER: Redwine (41SM193), Burial 3

VESSEL NO.: 28; Vessel 29 (see below) was found nested inside this vessel

NON-PLASTICS: grog

VESSEL FORM: Carinated bowl

RIM AND LIP FORM: Direct rim and a flat lip

CORE COLOR: A (fired and cooled in a high oxygen environment)

INTERIOR SURFACE COLOR: reddish-yellow (7.5YR 6/6); fire clouding on the base

EXTERIOR SURFACE COLOR: reddish-yellow (7.5YR 6/6); fire clouding on base

WALL THICKNESS (RIM, BODY, AND BASE IN MM): 3.8 mm, rim

INTERIOR SURFACE TREATMENT: smoothed

EXTERIOR SURFACE TREATMENT: burnished

HEIGHT (IN CM): 4.0

ORIFICE DIAMETER (IN CM): 9.0

DIAMETER AT BOTTOM OF RIM OR NECK (IN CM): 8.8

BASE DIAMETER (IN CM): 5.0

ESTIMATED VOLUME (IN LITERS): 0.22 liters

DECORATION: Lip notched only (Figure 30) 
TYPE: Undetermined lip notched ware (see Walters et al. 1998:Figure 13h)

Figure 30. Lip notched carinated bowl from Burial 3 at the Redwine site.

SITE NAME OR SITE NUMBER: Redwine (41SM193), Burial 3

VESSEL NO.: 29

NON-PLASTICS: none

VESSEL FORM: Bowl, probably a pigment vessel (glauconite chunks found inside the vessel) (Figure 31)

RIM AND LIP FORM: Direct rim and a rounded lip

CORE COLOR: $\mathrm{F}$ (fired in a reducing environment and cooled in the open air)

INTERIOR SURFACE COLOR: reddish-yellow (5YR 5/6)

EXTERIOR SURFACE COLOR: reddish-yellow (5YR 5/6)

WALL THICKNESS (RIM, BODY, AND BASE IN MM): $4.0 \mathrm{~mm}$, rim

INTERIOR SURFACE TREATMENT: none

EXTERIOR SURFACE TREATMENT: none

HEIGHT (IN CM): 2.2

ORIFICE DIAMETER (IN CM): 6.5

DIAMETER AT BOTTOM OF RIM OR NECK (IN CM): N/A

BASE DIAMETER (IN CM): 4.5

ESTIMATED VOLUME (IN LITERS): 0.06 liters

DECORATION: Plain

TYPE: Undetermined plain ware (see Walters et al. 1998:Figure 13i)

Figure 31. Plain bowl, possible pigment pot, from Burial 3 at the Redwine site. 
SITE NAME OR SITE NUMBER: Redwine (41SM193), Burial 1

VESSEL NO.: 33

NON-PLASTICS: grog

VESSEL FORM: Carinated bowl

RIM AND LIP FORM: Direct rim and a flat lip; sprocket mode lip (see Miller 1986)

CORE COLOR: $\mathrm{F}$ (fired in a reducing environment and cooled in the open air)

INTERIOR SURFACE COLOR: dark gray (7.5YR 4/1)

EXTERIOR SURFACE COLOR: brown (7.5YR 5/3)

WALL THICKNESS (RIM, BODY, AND BASE IN MM): 10.0 mm, rim; $7.6 \mathrm{~mm}$, body; $9.0 \mathrm{~mm}$, base

INTERIOR SURFACE TREATMENT: burnished

EXTERIOR SURFACE TREATMENT: smoothed

HEIGHT (IN CM): 10.3

ORIFICE DIAMETER (IN CM): 32.0

DIAMETER AT BOTTOM OF RIM OR NECK (IN CM): 28.0

BASE DIAMETER (IN CM): 13.5

ESTIMATED VOLUME (IN LITERS): 1.98 liters

DECORATION: The rim panel has five separate and narrow scrolls of incised lines filled with punctations. There are single rows of tool punctations under the vessel lip and at the carination (Figure 32).

TYPE: cf. Washington Square Paneled (see Walters et al. 1998:Figure 11e)

Figure 32. cf. Washington Square Paneled carinated bowl from Burial 1 at the Redwine site.

SITE NAME OR SITE NUMBER: Redwine (41SM193)

VESSEL NO.: 107 
NON-PLASTICS: grog

VESSEL FORM: Bowl

RIM AND LIP FORM: Direct rim and a rounded lip

CORE COLOR: $\mathrm{F}$ (fired in a reducing environment and cooled in the open air)

INTERIOR SURFACE COLOR: dark red (10R 3/6)

EXTERIOR SURFACE COLOR: red (10R 4/6); fire clouding on the rim

WALL THICKNESS (RIM, BODY, AND BASE IN MM): $5.5 \mathrm{~mm}$, rim and body

INTERIOR SURFACE TREATMENT: smoothed

EXTERIOR SURFACE TREATMENT: smoothed

HEIGHT (IN CM): 4.0

ORIFICE DIAMETER (IN CM): 8.0

DIAMETER AT BOTTOM OF RIM OR NECK (IN CM): N/A

BASE DIAMETER (IN CM): 5.3

ESTIMATED VOLUME (IN LITERS): 0.13 liters

DECORATION: interior and exterior red-slipped (Figure 33)

TYPE: Undetermined slipped ware

Figure 33. Red-slipped bowl from the Redwine site.

SITE NAME OR SITE NUMBER: Redwine (41SM193)

VESSEL NO.: 145

NON-PLASTICS: grog

VESSEL FORM: Jar

RIM AND LIP FORM: Everted rim and a rounded lip 
CORE COLOR: $\mathrm{F}$ (fired in a reducing environment and cooled in a high oxygen environment)

INTERIOR SURFACE COLOR: red (2.5YR 4/6)

EXTERIOR SURFACE COLOR: red (2.5YR 4/6)

WALL THICKNESS (RIM, BODY, AND BASE IN MM): $5.5 \mathrm{~mm}$, rim; $6.3 \mathrm{~mm}$, body

INTERIOR SURFACE TREATMENT: none

EXTERIOR SURFACE TREATMENT: smoothed

HEIGHT (IN CM): 8.0

ORIFICE DIAMETER (IN CM): 8.8

DIAMETER AT BOTTOM OF RIM OR NECK (IN CM): 7.8

BASE DIAMETER (IN CM): 4.5

ESTIMATED VOLUME (IN LITERS): 0.42 liters

DECORATION: interior and exterior red-slipped (Figure 34)

TYPE: Undetermined red-slipped ware

Figure 34. Red-slipped jar from the Redwine site.

SITE NAME OR SITE NUMBER: Redwine (41SM193)

VESSEL NO.: 147

NON-PLASTICS: grog and hematite

VESSEL FORM: Carinated bowl (Figure 35)

RIM AND LIP FORM: Direct rim and a rounded lip

CORE COLOR: A (fired and cooled in a high oxygen environment)

INTERIOR SURFACE COLOR: strong brown (7.5YR 5/6)

EXTERIOR SURFACE COLOR: yellowish-red (5YR 5/6); fire clouding on the base 
WALL THICKNESS (RIM, BODY, AND BASE IN MM): 4.5 mm, rim

INTERIOR SURFACE TREATMENT: none

EXTERIOR SURFACE TREATMENT: smoothed on the rim

HEIGHT (IN CM): 3.7

ORIFICE DIAMETER (IN CM): 8.9

DIAMETER AT BOTTOM OF RIM OR NECK (IN CM): 8.8

BASE DIAMETER (IN CM): 4.4

ESTIMATED VOLUME (IN LITERS): 0.2 liters

DECORATION: Plain

TYPE: Undetermined plain ware

Figure 35. Plain carinated bowl from the Redwine site.

\section{Langford (41SM197) Vessels}

The Langford site is a Middle Caddo settlement and cemetery on the Sabine River, just downstream from its confluence with Harris Creek (see Figure 1). There are six vessels in the J. A. Walters collection that can be attributed to the Langford site burial features, although the available records indicate 16 vessels were recovered from the nine burials in the cemetery (see Table 2). The vessels in the collection include one brushedpunctated-pinched jar, a brushed-punctated jar, an engraved beaker (with a rattlesnake motif), a plain bowl, a plain bottle, and an engraved bottle.

SITE NAME OR SITE NUMBER: Langford (41SM197), Burial 2

VESSEL NO.: 39

NON-PLASTICS: grog

VESSEL FORM: Jar with a tall rim

RIM AND LIP FORM: Everted rim and a rounded lip

CORE COLOR: B (fired and cooled in a low oxygen environment)

INTERIOR SURFACE COLOR: very dark gray (10YR 3/1) 
EXTERIOR SURFACE COLOR: very dark gray (10YR 3/1)

WALL THICKNESS (RIM, BODY, AND BASE IN MM): 7.6 mm, rim

INTERIOR SURFACE TREATMENT: smoothed on the rim

EXTERIOR SURFACE TREATMENT: none

HEIGHT (IN CM): 10.8

ORIFICE DIAMETER (IN CM): 10.7

DIAMETER AT BOTTOM OF RIM OR NECK (IN CM): 8.1

BASE DIAMETER (IN CM): 7.3

ESTIMATED VOLUME (IN LITERS): 0.69 liters

DECORATION: The rim area has three stacked sets of horizontal interlocking panels defined by tool punctations; each of the panels is filled with either horizontal or curvilinear brushed marks. The remainder of the vessel body, extending to just above the base, has four pinched concentric circles, each set with four pinched circles (Figure 36).

TYPE: cf. Washington Square Paneled; Walters (1997:38-39) suggests the vessel may be an early and undefined variety of Foster Trailed Incised.

Figure 36. cf. Washington Square Paneled jar from Burial 2 at the Langford site.

SITE NAME OR SITE NUMBER: Langford (41SM197), Burial 3

VESSEL NO.: 41

NON-PLASTICS: grog

VESSEL FORM: Beaker

RIM AND LIP FORM: Direct rim and a rounded lip

CORE COLOR: B (fired and cooled in a low oxygen environment)

INTERIOR SURFACE COLOR: black (10YR 2/1)

EXTERIOR SURFACE COLOR: black (10YR 2/1) 
WALL THICKNESS (RIM, BODY, AND BASE IN MM): 5.5 mm, rim

INTERIOR SURFACE TREATMENT: none

EXTERIOR SURFACE TREATMENT: burnished

HEIGHT (IN CM): 14.4

ORIFICE DIAMETER (IN CM): 7.9

DIAMETER AT BOTTOM OF RIM OR NECK (IN CM): N/A

BASE DIAMETER (IN CM): 6.8

ESTIMATED VOLUME (IN LITERS): 0.91 liters

DECORATION: The beaker has two engraved panels defined by two horizontal engraved lines at the top of the beaker and a single horizontal engraved line near the bottom of the beaker; a red clay pigment has been rubbed in these engraved lines as well as the engraved motifs in both panels (Figure 37).

The first panel has three vertical bands divided into either nine or 10 small rectangles. The rectangles in two of the bands have a single small centrally-placed excised dot; the other band has no such excised dots. The second panel has two opposed and segmented and cross-hatched engraved rattlesnakes (Walters 2006b:Figure 18), with forked tongues and dots for eyes. Above or below each of the engraved rattlesnakes are concentric semi-circles, one with a cross-hatched semi-circular band, another with a central excised dot, a third with excised rays emanating from the semi-circles, and the fourth with cross-hatched rays (see Figure 37).

TYPE: Undetermined fine ware

Figure 37. Engraved beaker with rattlesnake motif, Burial 3 at the Langford site.

SITE NAME OR SITE NUMBER: Langford (41SM197), Burial 8

VESSEL NO.: 47

NON-PLASTICS: grog

VESSEL FORM: Deep bowl (Figure 38); mass of kaolin clay in the bottom of the vessel

RIM AND LIP FORM: Direct rim and a rounded lip

CORE COLOR: $\mathrm{G}$ (fired in a reducing environment and cooled in the open air) 
INTERIOR SURFACE COLOR: very dark grayish-brown (10YR 3/2)

EXTERIOR SURFACE COLOR: yellowish-brown (10YR 5/4)

WALL THICKNESS (RIM, BODY, AND BASE IN MM): 6.2 mm, rim

INTERIOR SURFACE TREATMENT: none

EXTERIOR SURFACE TREATMENT: smoothed

HEIGHT (IN CM): 13.5

ORIFICE DIAMETER (IN CM): 14.2

DIAMETER AT BOTTOM OF RIM OR NECK (IN CM): N/A

BASE DIAMETER (IN CM): 7.4

ESTIMATED VOLUME (IN LITERS): 1.53 liters

DECORATION: Plain

TYPE: Undetermined plain ware

Figure 38. Plain deep bowl from the Langford site, Burial 8.

SITE NAME OR SITE NUMBER: Langford (41SM197), Burial 9

VESSEL NO.: 155

NON-PLASTICS: grog

VESSEL FORM: Short-necked bottle (Figure 39)

RIM AND LIP FORM: Direct lip and a rounded lip

CORE COLOR: $\mathrm{F}$ (fired in a reducing environment and cooled in the open air)

INTERIOR SURFACE COLOR: brown (10YR 5/3)

EXTERIOR SURFACE COLOR: brown (10YR 5/3)

WALL THICKNESS (RIM, BODY, AND BASE IN MM): 5.2 mm, neck 
INTERIOR SURFACE TREATMENT: smoothed on the neck

EXTERIOR SURFACE TREATMENT: burnished

HEIGHT (IN CM): 10.7

ORIFICE DIAMETER (IN CM): 5.0

DIAMETER AT BOTTOM OF RIM OR NECK (IN CM): $5.1 ; 7.3 \mathrm{~cm}$ at its maximum body width

BASE DIAMETER (IN CM): 5.0

ESTIMATED VOLUME (IN LITERS): 0.21 liters

DECORATION: The body of the vessel has three nearly vertical negative engraved scrolls defined by excised areas. Between each of the negative scrolls is an engraved circle with a small central swastika-in-circle element (see Figure 39). The swastika-incircle is an element and a motif that is associated with the Beneath World or Underwater Realm (Reilly 2004:129-130). A red pigment has been rubbed in the engraved lines.

TYPE: Undetermined fine ware

Figure 39. Engraved bottle from Burial 9 at the Langford site.

SITE NAME OR SITE NUMBER: Langford (41SM197), Burial 7

VESSEL NO.: 240

NON-PLASTICS: grog

VESSEL FORM: Bottle with a flaring neck (Figure 40)

RIM AND LIP FORM: Direct rim and a rounded lip

CORE COLOR: A (fired and cooled in a high oxygen environment)

INTERIOR SURFACE COLOR: dark reddish-brown (5YR 3/3)

EXTERIOR SURFACE COLOR: dark reddish-brown (5YR 3/3)

WALL THICKNESS (RIM, BODY, AND BASE IN MM): 6.0 mm, rim

INTERIOR SURFACE TREATMENT: none 
EXTERIOR SURFACE TREATMENT: burnished

HEIGHT (IN CM): 8.8

ORIFICE DIAMETER (IN CM): 4.4

DIAMETER AT BOTTOM OF RIM OR NECK (IN CM): 3.5; $6.4 \mathrm{~cm}$ at its widest part of the body

BASE DIAMETER (IN CM): 4.0

ESTIMATED VOLUME (IN LITERS): 0.14 liters

DECORATION: Plain

TYPE: Undetermined plain ware

Figure 40. Plain bottle from the Langford site, Burial 7.

SITE NAME OR SITE NUMBER: Langford (41SM197), Burial 8

VESSEL NO.: 242

NON-PLASTICS: grog

VESSEL FORM: Jar with four rim peaks (Figure 41)

RIM AND LIP FORM: Everted rim and a rounded lip

CORE COLOR: B (fired and cooled in a low oxygen environment)

INTERIOR SURFACE COLOR: very dark gray (10YR 3/1)

EXTERIOR SURFACE COLOR: very dark gray (10YR 3/1)

WALL THICKNESS (RIM, BODY, AND BASE IN MM): 6.7 mm, rim

INTERIOR SURFACE TREATMENT: smoothed

EXTERIOR SURFACE TREATMENT: none

HEIGHT (IN CM): 18.6

ORIFICE DIAMETER (IN CM): 13.9 


\section{DIAMETER AT BOTTOM OF RIM OR NECK (IN CM): 11.8}

BASE DIAMETER (IN CM): 9.3

ESTIMATED VOLUME (IN LITERS): 2.32 liters

DECORATION: The rim is horizontally brushed, and there are single rows of tool punctations under the lip and at the rim-body juncture. The vessel body has four panels defined by zones of vertical brushing; each panel is filled with horizontal brushing marks (see Figure 41).

TYPE: undetermined utility ware, cf. Pease Brushed-Incised

Figure 41. Brushed-punctated jar from the Langford site, Burial 8.

\section{Pardee Site (41SM198) Vessels}

A total of seven vessels are in the J. A. Walters collection from Burial 1 at the Pardee site. This Middle Caddo period habitation and mound center is on Harris Creek in the middle reaches of the Sabine River basin (see Figure 1). The vessels include two engraved bottles of an undetermined type, plain bowls $(n=2)$, a plain compound bowl, a Washington Square Paneled carinated bowl, and a Dunkin Incised carinated bowl.

SITE NAME OR SITE NUMBER: Pardee (41SM198), Burial 1

VESSEL NO.: 37

NON-PLASTICS: grog; sandy paste

VESSEL FORM: Bottle with a straight neck and a carinated body (Figure 42)

RIM AND LIP FORM: Direct rim and a rounded lip

CORE COLOR: $\mathrm{G}$ (fired in a reducing environment and cooled in the open air)

INTERIOR SURFACE COLOR: very dark gray (10YR 3/1)

EXTERIOR SURFACE COLOR: dark yellowish-brown (10YR 4/4)

WALL THICKNESS (RIM, BODY, AND BASE IN MM): 9.2 mm, neck

INTERIOR SURFACE TREATMENT: none

EXTERIOR SURFACE TREATMENT: smoothed 
HEIGHT (IN CM): 21.8

ORIFICE DIAMETER (IN CM): 4.3

DIAMETER AT BOTTOM OF RIM OR NECK (IN CM): 6.2; $14.4 \mathrm{~cm}$ at the widest part of the body

BASE DIAMETER (IN CM): 11.2

ESTIMATED VOLUME (IN LITERS): 0.98 liters

DECORATION: The body of the bottle has 16 vertical engraved lines, as well as a single horizontal engraved line below the base of the bottle neck. Each of the vertical engraved lines has a series of engraved pendant triangles and ovals (see Figure 42), including four such pendant elements on one line; five elements on two lines; six elements on nine lines; and seven elements on four vertical engraved lines.

TYPE: Undetermined fine ware

Figure 42. Engraved carinated bottle from Burial 1 at the Pardee site.

SITE NAME OR SITE NUMBER: Pardee (41SM198), Burial 1

VESSEL NO.: 38

NON-PLASTICS: grog

VESSEL FORM: Bottle with a straight neck and a carinated body (Figure 43)

RIM AND LIP FORM: Direct rim and a flat lip

CORE COLOR: A (fired and cooled in an oxidizing environment)

INTERIOR SURFACE COLOR: strong brown (7.5YR 4/6)

EXTERIOR SURFACE COLOR: strong brown (7.5YR 4/6)

WALL THICKNESS (RIM, BODY, AND BASE IN MM): 6.7 mm, neck

INTERIOR SURFACE TREATMENT: none

EXTERIOR SURFACE TREATMENT: burnished

HEIGHT (IN CM): 13.4 
ORIFICE DIAMETER (IN CM): 4.0

DIAMETER AT BOTTOM OF RIM OR NECK (IN CM): $4.5 ; 9.5 \mathrm{~cm}$ at the widest part of the body

BASE DIAMETER (IN CM): 9.4

ESTIMATED VOLUME (IN LITERS): 0.50 liters

DECORATION: There are three horizontal engraved lines at the top of the bottle neck, reminiscent of Hickory Engraved and Holly Fine Engraved bottles (see Suhm and Jelks 1962:Plates 36h and 40e). There is also a single horizontal engraved line at the top of the vessel body, and there are seven sets of small semi-circles (each with three semi-circles) pendant from that horizontal engraved line (see Figure 43).

TYPE: Undetermined fine ware

Figure 43. Engraved bottle from the Pardee site, Burial 1.

SITE NAME OR SITE NUMBER: Pardee (41SM198), Burial 1

VESSEL NO.: 146

NON-PLASTICS: grog and hematite

VESSEL FORM: Bowl

RIM AND LIP FORM: Direct rim and a rounded lip

CORE COLOR: A (fired and cooled in an oxidizing environment)

INTERIOR SURFACE COLOR: strong brown (7.5YR 5/6); fire clouding on the base

EXTERIOR SURFACE COLOR: strong brown (7.5YR 5/6)

WALL THICKNESS (RIM, BODY, AND BASE IN MM): 6.4 mm, rim

INTERIOR SURFACE TREATMENT: none

EXTERIOR SURFACE TREATMENT: smoothed

HEIGHT (IN CM): 3.0

ORIFICE DIAMETER (IN CM): 9.4 


\section{DIAMETER AT BOTTOM OF RIM OR NECK (IN CM): N/A}

BASE DIAMETER (IN CM): 5.7

ESTIMATED VOLUME (IN LITERS): 0.11 liters

DECORATION: Plain (Figure 44)

TYPE: Undetermined plain ware

Figure 44. Plain bowl from the Pardee site, Burial 1.

SITE NAME OR SITE NUMBER: Pardee (41SM198), Burial 1

VESSEL NO.: 149

NON-PLASTICS: grog and hematite

VESSEL FORM: Compound Bowl (Figure 45)

RIM AND LIP FORM: Direct rim and a rounded lip

CORE COLOR: A (fired and cooled in a high oxygen environment)

INTERIOR SURFACE COLOR: reddish-yellow (7.5YR 7/6)

EXTERIOR SURFACE COLOR: reddish-yellow (7.5YR 7/6); fire clouding on the body and rim

WALL THICKNESS (RIM, BODY, AND BASE IN MM): $4.1 \mathrm{~mm}$, rim

INTERIOR SURFACE TREATMENT: none

EXTERIOR SURFACE TREATMENT: smoothed

HEIGHT (IN CM): 5.9

ORIFICE DIAMETER (IN CM): 5.7

DIAMETER AT BOTTOM OF RIM OR NECK (IN CM): 5.8

BASE DIAMETER (IN CM): 4.7

ESTIMATED VOLUME (IN LITERS): 0.27 liters 
DECORATION: Plain

TYPE: Undetermined plain ware

Figure 45. Plain compound bowl from the Pardee site, Burial 1.

SITE NAME OR SITE NUMBER: Pardee (41SM198), Burial 1

VESSEL NO.: 154

NON-PLASTICS: grog; sandy paste

VESSEL FORM: Bowl (Figure 46)

RIM AND LIP FORM: Direct rim and a rounded lip

CORE COLOR: A (fired and cooled in a high oxygen environment)

INTERIOR SURFACE COLOR: strong brown (7.5YR 4/6)

EXTERIOR SURFACE COLOR: strong brown (7.5YR 5/6)

WALL THICKNESS (RIM, BODY, AND BASE IN MM): $7.2 \mathrm{~mm}$, rim

INTERIOR SURFACE TREATMENT: smoothed

EXTERIOR SURFACE TREATMENT: smoothed

HEIGHT (IN CM): 5.4

ORIFICE DIAMETER (IN CM): 11.6

DIAMETER AT BOTTOM OF RIM OR NECK (IN CM): N/A

BASE DIAMETER (IN CM): 5.5

ESTIMATED VOLUME (IN LITERS): 0.25 liters

DECORATION: Plain

TYPE: Undetermined plain ware

Figure 46. Plain bowl from Burial 1 at the Pardee site. 
SITE NAME OR SITE NUMBER: Pardee (41SM198), Burial 1

VESSEL NO.: 225

NON-PLASTICS: grog

VESSEL FORM: Carinated bowl

RIM AND LIP FORM: Direct rim and a rounded lip; Redwine mode lip (Figure 47)

CORE COLOR: A (fired and cooled in a high oxygen environment)

INTERIOR SURFACE COLOR: strong brown (7.5YR 5/6)

EXTERIOR SURFACE COLOR: strong brown (7.5YR 5/6)

WALL THICKNESS (RIM, BODY, AND BASE IN MM): 5.7 mm, rim

INTERIOR SURFACE TREATMENT: smoothed

EXTERIOR SURFACE TREATMENT: smoothed

HEIGHT (IN CM): 8.6

ORIFICE DIAMETER (IN CM): 19.0

DIAMETER AT BOTTOM OF RIM OR NECK (IN CM): 16.5

BASE DIAMETER (IN CM): 8.6

ESTIMATED VOLUME (IN LITERS): 0.98 liters

DECORATION: The rim has two sets of horizontal interlocking incised panels; each of the interlocking panels and the dividing curvilinear brackets are filled with tool punctations. The panels are delimited by a single horizontal incised line at the vessel carination as well as a horizontal incised band under the lip that is filled with short diagonal incised dashes (see Figure 47).

TYPE: Washington Square Paneled

Figure 47. Washington Square Paneled carinated bowl from Burial 1 at the Pardee site.

SITE NAME OR SITE NUMBER: Pardee (41SM198), Burial 1

VESSEL NO.: 232 
NON-PLASTICS: grog

VESSEL FORM: Carinated bowl

RIM AND LIP FORM: Direct rim and a flat lip

CORE COLOR: $\mathrm{G}$ (fired in a reducing environment and cooled in the open air)

INTERIOR SURFACE COLOR: dark gray (10YR 4/1)

EXTERIOR SURFACE COLOR: brownish-yellow (10YR 6/8)

WALL THICKNESS (RIM, BODY, AND BASE IN MM): 5.7 mm, rim

INTERIOR SURFACE TREATMENT: smoothed on the rim

EXTERIOR SURFACE TREATMENT: smoothed on the body

HEIGHT (IN CM): 12.5

ORIFICE DIAMETER (IN CM): 22.9

DIAMETER AT BOTTOM OF RIM OR NECK (IN CM): 22.7

BASE DIAMETER (IN CM): 7.8

ESTIMATED VOLUME (IN LITERS): 1.72 liters

DECORATION: The upper half of the rim panel has cross-hatched incised lines on it (Figure 48).

TYPE: cf. Dunkin Incised

Figure 48. cf. Dunkin Incised carinated bowl from the Pardee site.

\section{SM223 Vessels}

The J. A. Walters collection has two Middle Caddo ceramic vessels from 41SM223. This site is in the Harris Creek drainage basin (see Figure 1), downstream from the Redwine site, and upstream from the Pardee site. One of the vessels is a Washington Square Paneled carinated bowl, and the other is a compound vessel with strap handles and an engraved scroll motif. 
SITE NAME OR SITE NUMBER: 41SM223

VESSEL NO.: 35

NON-PLASTICS: coarse and heavily bone-tempered

VESSEL FORM: Carinated bowl

RIM AND LIP FORM: Direct rim with a flat and exterior folded lip; Redwine lip mode (Figure 49)

CORE COLOR: $\mathrm{H}$ (fired in a reducing environment and cooled in an oxidizing environment)

INTERIOR SURFACE COLOR: brown (7.5YR 4/3)

EXTERIOR SURFACE COLOR: reddish-yellow (7.5YR 6/6)

WALL THICKNESS (RIM, BODY, AND BASE IN MM): 5.7 mm, rim; 5.0 mm, body

INTERIOR SURFACE TREATMENT: none

EXTERIOR SURFACE TREATMENT: none

HEIGHT (IN CM): 10.0

ORIFICE DIAMETER (IN CM): 16.5

DIAMETER AT BOTTOM OF RIM OR NECK (IN CM): 13.8

BASE DIAMETER (IN CM): 6.5

ESTIMATED VOLUME (IN LITERS): 0.99 liters

DECORATION: The rim of the vessel has horizontal interlocking panels comprised of broad tool punctated elements (see Figure 49).

TYPE: cf. Washington Square Paneled

Figure 49. cf. Washington Square Paneled carinated bowl from 41SM223.

SITE NAME OR SITE NUMBER: 41SM223

VESSEL NO.: 36 
NON-PLASTICS: grog

VESSEL FORM: Compound bowl with opposed strap handles

RIM AND LIP FORM: Direct rim and a flat lip; Redwine mode lip (Figure 50)

CORE COLOR: B (fired and cooled in a reducing environment)

INTERIOR SURFACE COLOR: very dark gray (10YR 3/1)

EXTERIOR SURFACE COLOR: very dark gray (10YR 3/1)

WALL THICKNESS (RIM, BODY, AND BASE IN MM): N/A

INTERIOR SURFACE TREATMENT: burnished on the rim; smoothed on the body

EXTERIOR SURFACE TREATMENT: burnished

HEIGHT (IN CM): 5.5

ORIFICE DIAMETER (IN CM): 11.0

DIAMETER AT BOTTOM OF RIM OR NECK (IN CM): 9.9

BASE DIAMETER (IN CM): 4.6

ESTIMATED VOLUME (IN LITERS): 0.48 liters

DECORATION: The upper rim panel has a single centrally-placed horizontal engraved line. The lower rim panel has two sets of two engraved scrolls outlined by excised areas (see Figure 50). The strap handles are also decorated with engraved lines, namely with a central circle and cross. Each arm of the cross has between 1-3 short horizontal or vertical engraved lines.

TYPE: Undetermined fine ware

Figure 50. Engraved compound bowl from 41SM223.

\section{John Ellis (41SM246) Site Vessels}

Three vessels are in the J. A. Walters collection from Burial 1 (Feature 2) at the John Ellis site. This site is on Village Creek in the middle reaches of the Sabine River basin (see Figure 1). One of the vessels is plain, another is a punctated jar, and a third 
vessel is brushed-punctated. A fourth vessel-an engraved bottle-reported from Burial 1 (see above) could not be identified in the collection.

SITE NAME OR SITE NUMBER: John Ellis (41SM246), Burial 1

VESSEL NO.: 134

NON-PLASTICS: grog

VESSEL FORM: Jar

RIM AND LIP FORM: Everted rim and a flat lip

CORE COLOR: F (fired in a reducing environment and cooled in the open air)

INTERIOR SURFACE COLOR: light gray (10YR 7/2)

EXTERIOR SURFACE COLOR: light gray (10YR 7/2)

WALL THICKNESS (RIM, BODY, AND BASE IN MM): 5.6 mm, rim

INTERIOR SURFACE TREATMENT: none; organic residue on the body

EXTERIOR SURFACE TREATMENT: smoothed on the body; organic residue on the body

HEIGHT (IN CM): 17.5

ORIFICE DIAMETER (IN CM): 16.9

DIAMETER AT BOTTOM OF RIM OR NECK (IN CM): 15.8

BASE DIAMETER (IN CM): 8.3

ESTIMATED VOLUME (IN LITERS): 2.66 liters

DECORATION: Five rows of linear punctations on the vessel rim and upper body (Figure 51)

TYPE: Undetermined utility ware

Figure 51. Punctated jar from Burial 1 at the John Ellis site. 
SITE NAME OR SITE NUMBER: John Ellis (41SM246), Burial 1

VESSEL NO.: 158

NON-PLASTICS: grog

VESSEL FORM: Bowl (Figure 52)

RIM AND LIP FORM: Direct rim and a rounded lip

CORE COLOR: $\mathrm{F}$ (fired in a reducing environment and cooled in the open air)

INTERIOR SURFACE COLOR: dark grayish-brown (10YR 4/2)

EXTERIOR SURFACE COLOR: dark grayish-brown (10YR 4/2)

WALL THICKNESS (RIM, BODY, AND BASE IN MM): $6.0 \mathrm{~mm}$, rim

INTERIOR SURFACE TREATMENT: smoothed

EXTERIOR SURFACE TREATMENT: burnished

HEIGHT (IN CM): 5.1

ORIFICE DIAMETER (IN CM): 11.7

DIAMETER AT BOTTOM OF RIM OR NECK (IN CM): N/A

BASE DIAMETER (IN CM): 5.8

ESTIMATED VOLUME (IN LITERS): 0.24 liters

DECORATION: Plain

TYPE: Undetermined plain ware

Figure 52. Plain bowl from Burial 1 at the John Ellis site.

SITE NAME OR SITE NUMBER: John Ellis (41SM246), Burial 1

VESSEL NO.: 273

NON-PLASTICS: grog

VESSEL FORM: Jar 
RIM AND LIP FORM: Direct rim and a rounded, exterior folded lip

CORE COLOR: $\mathrm{G}$ (fired in a reducing environment and cooled in the open air)

INTERIOR SURFACE COLOR: dark grayish-brown (10YR 4/2)

EXTERIOR SURFACE COLOR: grayish-brown

WALL THICKNESS (RIM, BODY, AND BASE IN MM): 7.7 mm, rim; 5.8 mm, body

INTERIOR SURFACE TREATMENT: smoothed

EXTERIOR SURFACE TREATMENT: none

HEIGHT (IN CM): 32.0+

ORIFICE DIAMETER (IN CM): N/A

DIAMETER AT BOTTOM OF RIM OR NECK (IN CM): N/A

BASE DIAMETER (IN CM): N/A

ESTIMATED VOLUME (IN LITERS): N/A

DECORATION: The rim is horizontally brushed with teardrop-shaped tool punctates pushed through the brushing. The vessel body is vertically brushed, with teardrop-shaped tool punctates pushed through the brushing.

TYPE: Brushed-punctated utility ware

\section{SM247 Vessels}

There are four ceramic vessels from 41SM247 on Prairie Creek in northern Smith County, Texas (see Figure 1). The vessels include a plain bowl, two incised jars, and an incised-punctated jar.

SITE NAME OR SITE NUMBER: 41SM247

VESSEL NO.: 46

NON-PLASTICS: grog

VESSEL FORM: Jar 
RIM AND LIP FORM: Everted rim and a rounded lip

CORE COLOR: $\mathrm{G}$ (fired in a reducing environment and cooled in a high oxygen environment)

INTERIOR SURFACE COLOR: dark grayish-brown (10YR 4/2)

EXTERIOR SURFACE COLOR: brownish-yellow (10YR 6/6)

WALL THICKNESS (RIM, BODY, AND BASE IN MM): 6.6 mm, rim

INTERIOR SURFACE TREATMENT: none

EXTERIOR SURFACE TREATMENT: smoothed on the body

HEIGHT (IN CM): 13.5

ORIFICE DIAMETER (IN CM): 10.2

DIAMETER AT BOTTOM OF RIM OR NECK (IN CM): 9.6

BASE DIAMETER (IN CM): 6.9

ESTIMATED VOLUME (IN LITERS): 0.83 liters

DECORATION: Randomly placed and very widely-spaced diagonal and diagonal opposed incised lines on the rim (Figure 53).

TYPE: Undetermined utility ware

Figure 53. Incised jar from 41SM247.

SITE NAME OR SITE NUMBER: 41SM247

VESSEL NO.: 48

NON-PLASTICS: grog

VESSEL FORM: Jar

RIM AND LIP FORM: Direct rim and a flat lip

CORE COLOR: B (fired and cooled in a reducing environment)

INTERIOR SURFACE COLOR: very dark gray (10YR 3/1) 
EXTERIOR SURFACE COLOR: very dark gray (10YR 3/1)

WALL THICKNESS (RIM, BODY, AND BASE IN MM): 7.3 mm, body

INTERIOR SURFACE TREATMENT: smoothed

EXTERIOR SURFACE TREATMENT: none

HEIGHT (IN CM): 12.5

ORIFICE DIAMETER (IN CM): 12.6

DIAMETER AT BOTTOM OF RIM OR NECK (IN CM): 12.5

BASE DIAMETER (IN CM): 8.6

ESTIMATED VOLUME (IN LITERS): 0.94 liters

DECORATION: Cross-hatched incised-filled panel around the vessel rim (Figure 54)

TYPE: Undetermined utility ware, cf. Canton Incised or Dunkin Incised

Figure 54. Canton Incised or Dunkin Incised jar from 41SM247.

SITE NAME OR SITE NUMBER: 41SM247

VESSEL NO.: 49

NON-PLASTICS: bone and grog

VESSEL FORM: Jar

RIM AND LIP FORM: Everted rim and a rounded lip

CORE COLOR: $\mathrm{H}$ (fired in a reducing environment and cooled in the open air)

INTERIOR SURFACE COLOR: reddish-brown (5YR 4/4); fire clouding on the rim EXTERIOR SURFACE COLOR: black (10YR 2/1)

WALL THICKNESS (RIM, BODY, AND BASE IN MM): $6.0 \mathrm{~mm}$, rim; $6.3 \mathrm{~mm}$, body; $6.7 \mathrm{~mm}$, base

INTERIOR SURFACE TREATMENT: smoothed 
EXTERIOR SURFACE TREATMENT: smoothed; organic residue

HEIGHT (IN CM): 15.0

ORIFICE DIAMETER (IN CM): 11.0

DIAMETER AT BOTTOM OF RIM OR NECK (IN CM): 12.0

BASE DIAMETER (IN CM): N/A

ESTIMATED VOLUME (IN LITERS): 0.99 liters

DECORATION: The rim has diagonal incised lines pitched in opposite directions, forming triangular areas between the incised lines. These triangular areas are filled with tool punctations (Figure 55).

TYPE: Canton Incised or Maydelle Incised; the everted rim (see Suhm and Jelks 1962:103) suggests that Maydelle Incised is the more likely typological identification.

Figure 55. Canton Incised or Maydelle Incised jar from 41SM247.

SITE NAME OR SITE NUMBER: 41SM247

VESSEL NO.: 50

NON-PLASTICS: grog; sandy paste

VESSEL FORM: Deep bowl (Figure 56)

RIM AND LIP FORM: rim and lip missing

CORE COLOR: B (fired and cooled in a reducing environment)

INTERIOR SURFACE COLOR: very dark grayish-brown (10YR 3/2)

EXTERIOR SURFACE COLOR: very dark gray (10YR 3/1)

WALL THICKNESS (RIM, BODY, AND BASE IN MM): 5.4 mm, body

INTERIOR SURFACE TREATMENT: smoothed

EXTERIOR SURFACE TREATMENT: smoothed to burnished

HEIGHT (IN CM): N/A 
ORIFICE DIAMETER (IN CM): 10.3

DIAMETER AT BOTTOM OF RIM OR NECK (IN CM): N/A

BASE DIAMETER (IN CM): 7.4

ESTIMATED VOLUME (IN LITERS): N/A

DECORATION: Plain

TYPE: Undetermined plain ware

Figure 56. Plain deep bowl from 41SM247.

\section{SM248 Vessels}

This Prairie Creek site has four Middle Caddo period ceramic vessels from an unknown number of burials. The vessels include four jars, one with a roughened rim, two with incised-punctated decorations, and a fourth with a brushed-punctated-appliqued decoration.

SITE NAME OR SITE NUMBER: 41SM248

VESSEL NO.: 42

NON-PLASTICS: grog

VESSEL FORM: Jar

RIM AND LIP FORM: Everted rim and rounded lip

CORE COLOR: $\mathrm{G}$ (fired in a reducing environment and cooled in the open air)

INTERIOR SURFACE COLOR: very dark gray (10YR 3/1)

EXTERIOR SURFACE COLOR: light yellowish-brown (10YR 6/4)

WALL THICKNESS (RIM, BODY, AND BASE IN MM): 7.0 mm, rim

INTERIOR SURFACE TREATMENT: smoothed on the rim; organic residue on the rim and body

EXTERIOR SURFACE TREATMENT: smoothed on the body 
HEIGHT (IN CM): 16.5

ORIFICE DIAMETER (IN CM): 18.8

DIAMETER AT BOTTOM OF RIM OR NECK (IN CM): 18.1

BASE DIAMETER (IN CM): 8.0

ESTIMATED VOLUME (IN LITERS): 2.79 liters

DECORATION: roughened rim (Figure 57)

TYPE: Undetermined utility ware

Figure 57. Roughened jar from 41SM248.

SITE NAME OR SITE NUMBER: 41SM248

VESSEL NO.: 43

NON-PLASTICS: grog

VESSEL FORM: Jar

RIM AND LIP FORM: Everted rim and a rounded lip

CORE COLOR: B (fired and cooled in a low oxygen environment)

INTERIOR SURFACE COLOR: dark grayish-brown (10YR 4/2)

EXTERIOR SURFACE COLOR: brown (10YR 4/3)

WALL THICKNESS (RIM, BODY, AND BASE IN MM): 7.3 mm, rim

INTERIOR SURFACE TREATMENT: smoothed

EXTERIOR SURFACE TREATMENT: smoothed on the body

HEIGHT (IN CM): 16.0

ORIFICE DIAMETER (IN CM): 15.8

DIAMETER AT BOTTOM OF RIM OR NECK (IN CM): 14.8 
BASE DIAMETER (IN CM): 8.3

ESTIMATED VOLUME (IN LITERS): 2.27 liters

DECORATION: The rim has eight sets of incised triangles filled with tool punctations; these incised-punctated triangles extend past the rim-body juncture, an unusual characteristic not commonly noted in Caddo decorated jars (Figure 58). In several instances, the incised-punctated triangles are separated by diagonal incised zones filled with tool punctations.

TYPE: cf. Maydelle Incised

Figure 58. cf. Maydelle Incised jar from 41SM248.

SITE NAME OR SITE NUMBER: 41SM248

VESSEL NO.: 44

NON-PLASTICS: grog

VESSEL FORM: Jar

RIM AND LIP FORM: Everted rim and a rounded lip

CORE COLOR: B (fired and cooled in a low oxygen environment)

INTERIOR SURFACE COLOR: very dark gray (10YR 3/1)

EXTERIOR SURFACE COLOR: very dark gray (10YR 3/1)

WALL THICKNESS (RIM, BODY, AND BASE IN MM): 6.2 mm, rim

INTERIOR SURFACE TREATMENT: smoothed on the rim

EXTERIOR SURFACE TREATMENT: smoothed on the body

HEIGHT (IN CM): 16.0

ORIFICE DIAMETER (IN CM): 16.9

DIAMETER AT BOTTOM OF RIM OR NECK (IN CM): 16.5

BASE DIAMETER (IN CM): 8.2

ESTIMATED VOLUME (IN LITERS): 2.43 liters 
DECORATION: The rim has diagonal and diagonal opposed incised lines as well as diagonal incised scrolls, repeated eight times around the vessel (Figure 59). Most of the diagonal opposed and diagonal incised scrolls have a small central circle, semi-circle, or rectangle filled with small tool punctates; one of the incised scrolls only has two centrally-placed tool punctates.

TYPE: cf. Maydelle Incised

Figure 59. cf. Maydelle Incised jar from 41SM248.

SITE NAME OR SITE NUMBER: 41SM248

VESSEL NO.: 45

NON-PLASTICS: grog; sandy paste

VESSEL FORM: Jar

RIM AND LIP FORM: Everted rim and a rounded lip

CORE COLOR: G (fired in a reducing environment and cooled in the open air)

INTERIOR SURFACE COLOR: very dark gray (10YR 3/1)

EXTERIOR SURFACE COLOR: yellowish-brown (10YR 5/4)

WALL THICKNESS (RIM, BODY, AND BASE IN MM): 6.4 mm, rim

INTERIOR SURFACE TREATMENT: smoothed on the rim; organic residue on the body

EXTERIOR SURFACE TREATMENT: none

HEIGHT (IN CM): 12.5

ORIFICE DIAMETER (IN CM): 10.0

DIAMETER AT BOTTOM OF RIM OR NECK (IN CM): 10.3

BASE DIAMETER (IN CM): 7.9

ESTIMATED VOLUME (IN LITERS): 0.75 liters 
DECORATION: The rim has horizontal brushing marks, and there is a single row of tool punctates at the rim-body juncture. The body is divided into four panels by vertical appliqued fillets. Each of the panels is filled with vertical brushing (Figure 60).

TYPE: Undetermined utility ware, cf. Pease Brushed-Incised

Figure 60. Brushed-punctated-appliqued jar from 41SM248.

\section{SM249 Vessels}

There are 10 vessels from three Late Caddo period, Frankston phase (ca. A.D. 1400-1650), burials at 41SM249. This site is located in the upper Neches River basin, near Saline and County Line creeks in the Lake Palestine area (see Figure 1). The vessels include plain bowls $(\mathrm{n}=2)$, bottles $(\mathrm{n}=1)$, and carinated bowls $(\mathrm{n}=1)$, Bullard Brushed $(\mathrm{n}=1)$, a brushed-punctated jar $(\mathrm{n}=1)$, Poynor Engraved, var. Blackburn $(\mathrm{n}=1)$, Poynor Engraved, var. unspecified $(\mathrm{n}=1)$, a Hood Engraved, var. Hood effigy vessel $(\mathrm{n}=1)$, and a unique punctated bottle $(n=1)$.

SITE NAME OR SITE NUMBER: 41SM249

VESSEL NO.: 104

NON-PLASTICS: grog; sandy paste

VESSEL FORM: Shallow bowl (Figure 61)

RIM AND LIP FORM: Everted rim and a rounded lip

CORE COLOR: $\mathrm{G}$ (fired in a reducing environment and cooled in the open air)

INTERIOR SURFACE COLOR: brown (7.5YR 4/2)

EXTERIOR SURFACE COLOR: reddish-yellow (5YR 6/6); fire clouds on the base

WALL THICKNESS (RIM, BODY, AND BASE IN MM): 5.2 mm, rim

INTERIOR SURFACE TREATMENT: smoothed

EXTERIOR SURFACE TREATMENT: smoothed

HEIGHT (IN CM): 3.5

ORIFICE DIAMETER (IN CM): 11.6 
DIAMETER AT BOTTOM OF RIM OR NECK (IN CM): N/A

BASE DIAMETER (IN CM): 4.0

ESTIMATED VOLUME (IN LITERS): 0.16 liters

DECORATION: Plain

TYPE: Undetermined plain ware

Figure 61. Plain shallow bowl from 41SM249.

SITE NAME OR SITE NUMBER: 41SM249, Burial 1

VESSEL NO.: 136

NON-PLASTICS: grog

VESSEL FORM: Jar with two opposing rim lugs (Figure 62)

RIM AND LIP FORM: Everted rim and a rounded lip

CORE COLOR: $\mathrm{G}$ (fired in a reducing environment and cooled in the open air)

INTERIOR SURFACE COLOR: very dark grayish-brown (10YR 3/2)

EXTERIOR SURFACE COLOR: dark yellowish-brown (10YR 4/4)

WALL THICKNESS (RIM, BODY, AND BASE IN MM): 7.0 mm, rim

INTERIOR SURFACE TREATMENT: smoothed

EXTERIOR SURFACE TREATMENT: none

HEIGHT (IN CM): 20.5

ORIFICE DIAMETER (IN CM): 16.8

DIAMETER AT BOTTOM OF RIM OR NECK (IN CM): 14.2

BASE DIAMETER (IN CM): 7.0

ESTIMATED VOLUME (IN LITERS): 3.1 liters 
DECORATION: Diagonal to vertical brushing on the rim and vessel body, stopping just above the base of the vessel (see Figure 62).

TYPE: Bullard Brushed

Figure 62. Bullard Brushed jar from 41SM249, Burial 1.

SITE NAME OR SITE NUMBER: 41SM249, Burial 1

VESSEL NO.: 137

NON-PLASTICS: grog

VESSEL FORM: Globular carinated bowl

RIM AND LIP FORM: Direct rim and a flat lip

CORE COLOR: A (oxidized during firing and cooling)

INTERIOR SURFACE COLOR: brownish-yellow (10YR 6/6)

EXTERIOR SURFACE COLOR: yellowish-red (5YR 5/8)

WALL THICKNESS (RIM, BODY, AND BASE IN MM): 4.5 mm, rim; 5.2 mm, body

INTERIOR SURFACE TREATMENT: smoothed

EXTERIOR SURFACE TREATMENT: smoothed

HEIGHT (IN CM): 9.8

ORIFICE DIAMETER (IN CM): 15.0

DIAMETER AT BOTTOM OF RIM OR NECK (IN CM): 13.0

BASE DIAMETER (IN CM): 5.0

ESTIMATED VOLUME (IN LITERS): 0.88 liters

DECORATION: The rim has 14 rectangular engraved panels defined by sets of vertical engraved lines at either end of the panel. Each panel also contains a single large excised pendant triangle, with their apex alternating between pointing towards the rim or pointing towards the carination/base (Figure 63).

TYPE: cf. Poynor Engraved, var. Blackburn 
Figure 63. Poynor Engraved, var. Blackburn carinated bowl from Burial 1 at 41SM249.

SITE NAME OR SITE NUMBER: 41SM249

VESSEL NO.: 138

NON-PLASTICS: grog and hematite

VESSEL FORM: Carinated bowl

RIM AND LIP FORM: Direct rim and a rounded lip

CORE COLOR: C (incompletely oxidized during firing)

INTERIOR SURFACE COLOR: brownish-yellow (7.5YR 6/5)

EXTERIOR SURFACE COLOR: brownish-yellow (7.5YR 6/5)

WALL THICKNESS (RIM, BODY, AND BASE IN MM): 6.7 mm, rim

INTERIOR SURFACE TREATMENT: smoothed

EXTERIOR SURFACE TREATMENT: smoothed

HEIGHT (IN CM): 11.4

ORIFICE DIAMETER (IN CM): 20.4

DIAMETER AT BOTTOM OF RIM OR NECK (IN CM): 21.0

BASE DIAMETER (IN CM): 8.5

ESTIMATED VOLUME (IN LITERS): 1.39 liters

DECORATION: Plain (Figure 64)

TYPE: Undetermined plain ware

Figure 64. Plain carinated bowl from 41SM249.

SITE NAME OR SITE NUMBER: 41SM249, Burial 2

VESSEL NO.: 141 
NON-PLASTICS: grog

VESSEL FORM: Bottle with a straight neck

RIM AND LIP FORM: Direct rim and a rounded lip

CORE COLOR: $\mathrm{F}$ (fired in a reducing environment and cooled in the open air)

INTERIOR SURFACE COLOR: grayish-brown (10YR 5/2)

EXTERIOR SURFACE COLOR: grayish-brown (10YR 5/2)

WALL THICKNESS (RIM, BODY, AND BASE IN MM): 5.4 mm, rim

INTERIOR SURFACE TREATMENT: none

EXTERIOR SURFACE TREATMENT: smoothed

HEIGHT (IN CM): 20.0

ORIFICE DIAMETER (IN CM): 4.6

DIAMETER AT BOTTOM OF RIM OR NECK (IN CM): 5.7; $16.0 \mathrm{~cm}$ at the widest part of the body

BASE DIAMETER (IN CM): 8.0

ESTIMATED VOLUME (IN LITERS): 0.64 liters

DECORATION: The rim panel has four swastika-in-circle motifs within negative circles formed by cross-hatched brackets and upper and lower fill zones. There are four smaller negative circles within the cross-hatched brackets (Figure 65). As previously mentioned, the swastika-in-circle is a motif that is associated with the Beneath World or Underwater Realm (Reilly 2004:129-130).

TYPE: cf. Poynor Engraved, var. unspecified

Figure 65. Poynor Engraved bottle from 41SM249.

SITE NAME OR SITE NUMBER: 41SM249, Burial 2

VESSEL NO.: 142

NON-PLASTICS: grog and bone; sandy paste 
VESSEL FORM: Jar

RIM AND LIP FORM: Everted rim and a rounded lip

CORE COLOR: $\mathrm{G}$ (fired in a reducing environment and cooled in the open air)

INTERIOR SURFACE COLOR: very dark gray (10YR 3/1)

EXTERIOR SURFACE COLOR: yellowish-brown (10YR 5/4)

WALL THICKNESS (RIM, BODY, AND BASE IN MM): 9.2 mm, rim

INTERIOR SURFACE TREATMENT: smoothed

EXTERIOR SURFACE TREATMENT: none

HEIGHT (IN CM): 13.0

ORIFICE DIAMETER (IN CM): 10.5

DIAMETER AT BOTTOM OF RIM OR NECK (IN CM): 9.3

BASE DIAMETER (IN CM): 7.8

ESTIMATED VOLUME (IN LITERS): 0.82 liters

DECORATION: The rim has three widely-spaced rows of tool punctations. The body, except near the base, has overlapping brushing marks (Figure 66).

TYPE: Undetermined utility ware

Figure 66. Brushed-punctated jar from Burial 2 at 41SM249.

SITE NAME OR SITE NUMBER: 41SM249, Burial 3

VESSEL NO.: 150

NON-PLASTICS: grog

VESSEL FORM: Bowl (Figure 67)

RIM AND LIP FORM: Direct rim and a rounded lip

CORE COLOR: A (fired and cooled in a high oxygen environment) 
INTERIOR SURFACE COLOR: light yellowish-brown (10YR 6/4)

EXTERIOR SURFACE COLOR: light yellowish-brown (10YR 6/4)

WALL THICKNESS (RIM, BODY, AND BASE IN MM): 4.2 mm, rim

INTERIOR SURFACE TREATMENT: none

EXTERIOR SURFACE TREATMENT: smoothed

HEIGHT (IN CM): 6.8

ORIFICE DIAMETER (IN CM): 7.7

DIAMETER AT BOTTOM OF RIM OR NECK (IN CM): N/A

BASE DIAMETER (IN CM): 5.9

ESTIMATED VOLUME (IN LITERS): 0.21 liters

DECORATION: Plain

TYPE: Undetermined plain ware

Figure 67. Plain bowl from 41SM249, Burial 3.

SITE NAME OR SITE NUMBER: 41SM249, Burial 1

VESSEL NO.: 224

NON-PLASTICS: grog

VESSEL FORM: Cylindrical bottle

RIM AND LIP FORM: Direct rim and a flat lip

CORE COLOR: A (fired and cooled in a high oxygen environments)

INTERIOR SURFACE COLOR: brownish-yellow (10YR 6/8)

EXTERIOR SURFACE COLOR: brownish-yellow (10YR 6/8)

WALL THICKNESS (RIM, BODY, AND BASE IN MM): 8.6 mm, rim 
INTERIOR SURFACE TREATMENT: none

EXTERIOR SURFACE TREATMENT: burnished

HEIGHT (IN CM): 26.4

ORIFICE DIAMETER (IN CM): 4.6

DIAMETER AT BOTTOM OF RIM OR NECK (IN CM): N/A

BASE DIAMETER (IN CM): 9.9

ESTIMATED VOLUME (IN LITERS): 1.05 liters

DECORATION: There is a single tool punctated row at the juncture of the bottle neck and the body. The body has three vertical sets of punctations, one with six closely-spaced vertical rows; one with seven vertical rows of closely-spaced punctations; and the third with eight vertical rows of tool punctations (Figure 68).

TYPE: Undetermined fine ware; the vessel form is consistent with certain Poynor Engraved bottles (see Suhm and Jelks 1962:Plate 63f)

Figure 68. Punctated bottle from Burial 1 at 41SM249.

SITE NAME OR SITE NUMBER: 41SM249, Burial 3

VESSEL NO.: 226

NON-PLASTICS: grog

VESSEL FORM: Bowl with a bird effigy head $(4.0 \mathrm{~cm}$ in height and width) and tab tail (3.5 cm wide and $1.5 \mathrm{~cm}$ in length) (Figure 69)

RIM AND LIP FORM: Direct rim and a flat lip

CORE COLOR: F (fired in a low oxygen environment and cooled in the open air)

INTERIOR SURFACE COLOR: dark grayish-brown (10YR 4/2)

EXTERIOR SURFACE COLOR: dark yellowish-brown (10YR 4/4)

WALL THICKNESS (RIM, BODY, AND BASE IN MM): 6.7 mm, rim

INTERIOR SURFACE TREATMENT: smoothed on the rim 
EXTERIOR SURFACE TREATMENT: burnished

HEIGHT (IN CM): 8.6

ORIFICE DIAMETER (IN CM): 14.4

DIAMETER AT BOTTOM OF RIM OR NECK (IN CM): N/A

BASE DIAMETER (IN CM): 7.0

ESTIMATED VOLUME (IN LITERS): 0.50 liters

DECORATION: There are three broad horizontal engraved lines encircling the vessel rim; the lines are not continuous, but are divided by raised ridges underneath the effigy head and the tab tail (see Figure 69).

TYPE: Hood Engraved, var. Hood

Figure 69. Hood Engraved, var. Hood effigy bowl, 41SM249, Burial 3.

SITE NAME OR SITE NUMBER: 41SM249, Burial 3

VESSEL NO.: 237

NON-PLASTICS: grog

VESSEL FORM: Bottle with a straight neck and a carinated body (Figure 70)

RIM AND LIP FORM: Direct rim and a rounded lip

CORE COLOR: F (fired in a low oxygen environment and cooled in the open air)

INTERIOR SURFACE COLOR: reddish-yellow (7.5YR 5/6)

EXTERIOR SURFACE COLOR: reddish-yellow (7.5YR 5/6); fire clouding on the body, neck, and base

WALL THICKNESS (RIM, BODY, AND BASE IN MM): 5.7 mm, rim

INTERIOR SURFACE TREATMENT: none

EXTERIOR SURFACE TREATMENT: smoothed

HEIGHT (IN CM): 13.5; the neck is $6.0 \mathrm{~cm}$ in length 
ORIFICE DIAMETER (IN CM): 3.3

DIAMETER AT BOTTOM OF RIM OR NECK (IN CM): 4.5; maximum width is 9.4 $\mathrm{cm}$

BASE DIAMETER (IN CM): 5.5

ESTIMATED VOLUME (IN LITERS): 0.30 liters

DECORATION: Plain

TYPE: Undetermined plain ware

Figure 70. Plain bottle from Burial 3 at 41SM249.

\section{SM262 Vessels}

There are two Caddo ceramic vessels of likely Early to Middle Caddo period age from 41SM262 in the J. A. Walters collection; the site is on Village Creek (see Figure 1). One is a plain deep bowl and the other is an incised-punctated Canton Incised deep bowl.

SITE NAME OR SITE NUMBER: 41SM262

VESSEL NO.: 51

NON-PLASTICS: grog

VESSEL FORM: Deep bowl (Figure 71)

RIM AND LIP FORM: Direct rim and a flat lip

CORE COLOR: $\mathrm{F}$ (fired in a reducing environment and cooled in the open air)

INTERIOR SURFACE COLOR: yellowish-brown (10YR 5/4)

EXTERIOR SURFACE COLOR: yellowish-brown (10YR 5/4)

WALL THICKNESS (RIM, BODY, AND BASE IN MM): $4.5 \mathrm{~mm}$, rim

INTERIOR SURFACE TREATMENT: smoothed

EXTERIOR SURFACE TREATMENT: smoothed; organic residue on the body

HEIGHT (IN CM): 14.5 
ORIFICE DIAMETER (IN CM): 14.8

DIAMETER AT BOTTOM OF RIM OR NECK (IN CM): N/A

BASE DIAMETER (IN CM): 7.9

ESTIMATED VOLUME (IN LITERS): 1.72 liters

DECORATION: Plain

TYPE: Undetermined plain ware

Figure 71. Plain deep bowl from 41SM262.

SITE NAME OR SITE NUMBER: 41SM262

VESSEL NO.: 52

NON-PLASTICS: grog

VESSEL FORM: Deep bowl

RIM AND LIP FORM: Direct rim and a flat lip

CORE COLOR: $\mathrm{F}$ (fired in a reducing environment and cooled in the open air)

INTERIOR SURFACE COLOR: brownish-yellow (10YR 6/6)

EXTERIOR SURFACE COLOR: brownish-yellow (10YR 6/6)

WALL THICKNESS (RIM, BODY, AND BASE IN MM): 5.7 mm, rim

INTERIOR SURFACE TREATMENT: smoothed on the rim

EXTERIOR SURFACE TREATMENT: smoothed on the body

HEIGHT (IN CM): 18.5

ORIFICE DIAMETER (IN CM): 14.6

DIAMETER AT BOTTOM OF RIM OR NECK (IN CM): N/A

BASE DIAMETER (IN CM): 9.6 
ESTIMATED VOLUME (IN LITERS): 2.16 liters

DECORATION: The rim has eight incised triangles that are filled with tool punctations. The apex of the triangles points towards the vessel base (Figure 72).

TYPE: Canton Incised

Figure 72. Canton Incised deep bowl from 41SM262.

\section{SM268 Vessels}

The one vessel in the J. A. Walters collection from 41SM268, on Village Creek in the Sabine River basin, is a Hickory Engraved bottle. This bottle suggests a prehistoric Caddo occupation at the site that dates between ca. A.D. 850-1300 (see Story 2000).

SITE NAME OR SITE NUMBER: 41SM268

VESSEL NO.: 267

NON-PLASTICS: bone and grog

VESSEL FORM: Bottle with a straight neck

RIM AND LIP FORM: Direct rim; the lip is missing

CORE COLOR: $\mathrm{G}$ (fired in a reducing environment and cooled in the open air)

INTERIOR SURFACE COLOR: very dark gray (10YR 3/1)

EXTERIOR SURFACE COLOR: light gray (10YR 7/2)

WALL THICKNESS (RIM, BODY, AND BASE IN MM): $5.3 \mathrm{~mm}$, rim; 6.4 mm, body

INTERIOR SURFACE TREATMENT: none

EXTERIOR SURFACE TREATMENT: smoothed

HEIGHT (IN CM): 15.0

ORIFICE DIAMETER (IN CM): 4.8

DIAMETER AT BOTTOM OF RIM OR NECK (IN CM): 5.7

BASE DIAMETER (IN CM): missing 


\section{ESTIMATED VOLUME (IN LITERS): N/A}

DECORATION: Three horizontal engraved lines encircling the upper part of the vessel body (Figure 73).

TYPE: Hickory Fine Engraved

Figure 73. Hickory Engraved bottle from 41SM268.

\section{SM282 Vessels}

There are three apparent vessels in the collection from 41SM282 on Harris Creek, a tributary to the Sabine River, in northern Smith County, Texas. Two of them are plain grog-tempered deep bowls that may represent sections of the same bowl (though the vessel sections do not conjoin), and the third vessel (either a bowl or carinated bowl) has an incised-punctated rim decoration.

SITE NAME OR SITE NUMBER: 41SM282

VESSEL NO.: 257-1

NON-PLASTICS: grog

VESSEL FORM: Deep bowl (Figure 74)

RIM AND LIP FORM: Direct rim and a flat lip

CORE COLOR: $\mathrm{F}$ (fired in a reducing environment and cooled in the open air)

INTERIOR SURFACE COLOR: dark grayish-brown (10YR 4/2) to brown (10YR 5/3)

EXTERIOR SURFACE COLOR: dark grayish-brown (10YR 4/2) to brown (10YR 5/3)

WALL THICKNESS (RIM, BODY, AND BASE IN MM): $8.3 \mathrm{~mm}$, rim; $11.0 \mathrm{~mm}$, base

INTERIOR SURFACE TREATMENT: smoothed; organic residue on the body

EXTERIOR SURFACE TREATMENT: smoothed

HEIGHT (IN CM): N/A

ORIFICE DIAMETER (IN CM): 28.0 
DIAMETER AT BOTTOM OF RIM OR NECK (IN CM): N/A

BASE DIAMETER (IN CM): N/A

ESTIMATED VOLUME (IN LITERS): N/A

DECORATION: Plain

TYPE: Undetermined plain ware

Figure 74. Plain deep bowl or bowls from 41SM282, showing Vessel 257-1 (left) and Vessel 257-2 (right).

SITE NAME OR SITE NUMBER: 41SM282

VESSEL NO.: 257-2

NON-PLASTICS: grog

VESSEL FORM: Deep bowl (see Figure 74, right)

RIM AND LIP FORM: N/A

CORE COLOR: $\mathrm{G}$ (fired in a reducing environment and cooled in the open air)

INTERIOR SURFACE COLOR: very dark gray (10YR 3/1)

EXTERIOR SURFACE COLOR: brown (10YR 5/3); fire clouding on the base

WALL THICKNESS (RIM, BODY, AND BASE IN MM): 7.9 mm, body; $9.8 \mathrm{~mm}$, base

INTERIOR SURFACE TREATMENT: smoothed

EXTERIOR SURFACE TREATMENT: smoothed

HEIGHT (IN CM): N/A

ORIFICE DIAMETER (IN CM): N/A

DIAMETER AT BOTTOM OF RIM OR NECK (IN CM): N/A

BASE DIAMETER (IN CM): 8.8

ESTIMATED VOLUME (IN LITERS): N/A 


\section{DECORATION: Plain}

TYPE: Undetermined plain ware; it is possible that Vessel 257-1 and Vessel 257-2 are part of the same deep bowl.

SITE NAME OR SITE NUMBER: 41SM282

VESSEL NO.: 257-3

NON-PLASTICS: grog and bone

VESSEL FORM: Bowl or carinated bowl

RIM AND LIP FORM: Direct rim and a flat lip

CORE COLOR: $\mathrm{G}$ (fired in a reducing environment and cooled in the open air)

INTERIOR SURFACE COLOR: dark gray (10YR 4/1) to light yellowish-brown (10YR $6 / 4)$

EXTERIOR SURFACE COLOR: light yellowish-brown (10YR 6/4)

WALL THICKNESS (RIM, BODY, AND BASE IN MM): $8.1 \mathrm{~mm}$, rim

INTERIOR SURFACE TREATMENT: smoothed

EXTERIOR SURFACE TREATMENT: none

HEIGHT (IN CM): N/A

ORIFICE DIAMETER (IN CM): 18.0

DIAMETER AT BOTTOM OF RIM OR NECK (IN CM): N/A

BASE DIAMETER (IN CM): N/A

ESTIMATED VOLUME (IN LITERS): N.A.

DECORATION: The rim design consists of a series of alternating sets of concentric semi-circles surrounded by zones of tool punctates. One of the sets of concentric semicircles has a single semi-circle filled in with tool punctates (Figure 75).

TYPE: Undetermined utility ware

Figure 75. Incised-punctated bowl or carinated bowl from 41SM282. 


\section{SM290 Vessels}

There are 18 vessels in the Bernie Ward collection from 41SM290. They include Poynor Engraved, var. Cook $(\mathrm{n}=2)$, Poynor Engraved, var. Blackburn/Cook $(\mathrm{n}=1)$, Poynor Engraved, var. Lang (n=2), Poynor Engraved, var. Hood $(\mathrm{n}=1)$, Poynor Engraved, var. $A(\mathrm{n}=1)$, Poynor Engraved, var. $N$ or $P(\mathrm{n}=1)$, cf. Hume Engraved $(\mathrm{n}=2)$, Hood Engraved, var. Cook $(\mathrm{n}=1)$, Hood Engraved, var. unspecified $(\mathrm{n}=1)$, undetermined fine ware $(n=3)$, La Rue Neck Banded $(n=1)$, plain jars $(n=1)$, plain carinated bowls $(n=1)$, and plain bowls $(n=1)$. Based on the range of varieties represented in the Poynor Engraved vessels in this collection, it is likely that they come from Caddo burials that date to the middle part of the Frankston phase, ca. A.D. 1480-1560 (Perttula 2009:Table 6-37).

SITE NAME OR SITE NUMBER: 41SM290, Burial 2, \#2

VESSEL NO.: BW-2

NON-PLASTICS: grog

VESSEL FORM: Jar with two opposed strap handles and four rim peaks (Figure 76)

RIM AND LIP FORM: direct rim and a rounded lip

CORE COLOR: B (fired in a reducing environment)

INTERIOR SURFACE COLOR: gray (10YR 5/1)

EXTERIOR SURFACE COLOR: dark gray (10YR 4/1)

WALL THICKNESS (RIM, BODY, AND BASE IN MM): 5.2 mm, rim

INTERIOR SURFACE TREATMENT: smoothed

EXTERIOR SURFACE TREATMENT: burnished

HEIGHT (IN CM): 9.6

ORIFICE DIAMETER (IN CM): 12.5

DIAMETER AT BOTTOM OF RIM OR NECK (IN CM): 12.0

BASE DIAMETER (IN CM): 8.0

ESTIMATED VOLUME (IN LITERS): 0.72 liters 
DECORATION: The upper part of the jar has a diagonal engraved scroll motif repeated six times around the vessel. This diagonal scroll includes a central hooked arm element, as well as cross-hatched brackets and triangles that form negative ovals (see Figure 76); the vessel is also lip notched.

TYPE: Undetermined fine ware

Figure 76. Engraved jar from 41SM290.

SITE NAME OR SITE NUMBER: 41SM290

VESSEL NO.: BW-3

NON-PLASTICS: grog and hematite

VESSEL FORM: Cylindrical bottle with a short neck (Figure 77)

RIM AND LIP FORM: Direct rim and a rounded lip

CORE COLOR: A (fired and cooled in an oxidizing environment)

INTERIOR SURFACE COLOR: red (2.5YR 5/6)

EXTERIOR SURFACE COLOR: red (2.5YR 5/6)

WALL THICKNESS (RIM, BODY, AND BASE IN MM): 5.7 mm, rim

INTERIOR SURFACE TREATMENT: none

EXTERIOR SURFACE TREATMENT: burnished

HEIGHT (IN CM): 23.9

ORIFICE DIAMETER (IN CM): 5.9

DIAMETER AT BOTTOM OF RIM OR NECK (IN CM): $10.0 \mathrm{~cm}$ in diameter near the vessel base

BASE DIAMETER (IN CM): 7.8

ESTIMATED VOLUME (IN LITERS): 0.75 liters

DECORATION: The rim is roughened. Each side of the body of the bottle has a single circular and semi-circular engraved element (consisting of three closely-spaced engraved lines) that extends from the rim to just above the base. These elements have a series of 
large hatched pendant triangles that extend out from the circular and semi-circular lines (see Figure 77).

TYPE: cf. Hume Engraved, var. unspecified

Figure 77. Hume Engraved, var. unspecified cylindrical bottle from 41SM290.

SITE NAME OR SITE NUMBER: 41SM290

VESSEL NO.: BW-4

NON-PLASTICS: grog and hematite

VESSEL FORM: Jar

RIM AND LIP FORM: Direct rim and a rounded lip

CORE COLOR: $\mathrm{F}$ (fired in a reducing environment and cooled in the open air)

INTERIOR SURFACE COLOR: light yellowish-brown (10YR 6/4); fire clouds on the base

EXTERIOR SURFACE COLOR: light yellowish-brown (10YR 6/4); fire clouds on the base

WALL THICKNESS (RIM, BODY, AND BASE IN MM): 6.4 mm, rim

INTERIOR SURFACE TREATMENT: smoothed on the rim

EXTERIOR SURFACE TREATMENT: smoothed on the rim; organic residue on the rim and the body

HEIGHT (IN CM): 17.0

ORIFICE DIAMETER (IN CM): 13.9

DIAMETER AT BOTTOM OF RIM OR NECK (IN CM): 13.7

BASE DIAMETER (IN CM): 7.0

ESTIMATED VOLUME (IN LITERS): 2.1 liters

DECORATION: Plain (Figure 78)

TYPE: Undetermined plain utility ware 
Figure 78. Plain jar from 41SM290.

SITE NAME OR SITE NUMBER: 41SM290

VESSEL NO.: BW-5

NON-PLASTICS: grog

VESSEL FORM: Carinated bowl (Figure 79)

RIM AND LIP FORM: Direct rim and a rounded lip

CORE COLOR: A (fired and cooled in the open air)

INTERIOR SURFACE COLOR: yellowish-brown (10YR 5/6); fire clouding on the base EXTERIOR SURFACE COLOR: yellowish-brown (10YR 5/6); fire clouding on the body and the base

WALL THICKNESS (RIM, BODY, AND BASE IN MM): 6.3 mm, rim

INTERIOR SURFACE TREATMENT: smoothed on the rim

EXTERIOR SURFACE TREATMENT: burnished

HEIGHT (IN CM): 6.2

ORIFICE DIAMETER (IN CM): 13.0

DIAMETER AT BOTTOM OF RIM OR NECK (IN CM): 12.9

BASE DIAMETER (IN CM): 5.8

ESTIMATED VOLUME (IN LITERS): 0.48 liters

DECORATION: Plain

TYPE: Undetermined plain ware

Figure 79. Plain carinated bowl from 41SM290.

SITE NAME OR SITE NUMBER: 41SM290

VESSEL NO.: BW-6 
NON-PLASTICS: grog

VESSEL FORM: Carinated bowl

RIM AND LIP FORM: Direct rim and a rounded lip

CORE COLOR: $\mathrm{F}$ (fired in a reducing environment and cooled in the open air)

INTERIOR SURFACE COLOR: brown (7.5YR 5/4)

EXTERIOR SURFACE COLOR: strong brown (7.5YR 4/6)

WALL THICKNESS (RIM, BODY, AND BASE IN MM): 4.5 mm, rim

INTERIOR SURFACE TREATMENT: smoothed

EXTERIOR SURFACE TREATMENT: burnished

HEIGHT (IN CM): 5.8

ORIFICE DIAMETER (IN CM): 8.2

DIAMETER AT BOTTOM OF RIM OR NECK (IN CM): 8.4

BASE DIAMETER (IN CM): 4.7

ESTIMATED VOLUME (IN LITERS): 0.29 liters

DECORATION: The rim panel has six engraved nested triangles (with hatched corners) divided by a single hooked arm element and two small hatched pendant triangles under and above the hooked arm element (Figure 80).

TYPE: Poynor Engraved, var. A (Perttula 2009:Figure 6-64)

Figure 80. Poynor Engraved, var. A carinated bowl from 41SM290.

SITE NAME OR SITE NUMBER: 41SM290

VESSEL NO.: BW-7

NON-PLASTICS: grog

VESSEL FORM: Cylindrical bottle with a short neck (Figure 81) 
RIM AND LIP FORM: Everted rim and a rounded lip

CORE COLOR: $\mathrm{F}$ (fired in a reducing environment and cooled in the open air)

INTERIOR SURFACE COLOR: Undetermined

EXTERIOR SURFACE COLOR: pale brown (10YR 6/3); fire clouds

WALL THICKNESS (RIM, BODY, AND BASE IN MM): 5.1 mm, neck

INTERIOR SURFACE TREATMENT: none

EXTERIOR SURFACE TREATMENT: burnished

HEIGHT (IN CM): 28.0

ORIFICE DIAMETER (IN CM): 4.2

DIAMETER AT BOTTOM OF RIM OR NECK (IN CM): 3.3; maximum width on the body is $8.5 \mathrm{~cm}$

BASE DIAMETER (IN CM): 8.2

ESTIMATED VOLUME (IN LITERS): 0.92 liters

DECORATION: There are four sets of three vertical engraved lines on the body of the bottle (see Figure 81 ). If the vertical engraved lines were cross-hatched, the design would be similar to Hume Engraved, var. Hume (Perttula 2008:Figure 2e).

TYPE: cf. Hume Engraved

Figure 81. cf. Hume Engraved cylindrical bottle from 41SM290.

SITE NAME OR SITE NUMBER: 41SM290, Burial 1

VESSEL NO.: BW-8

NON-PLASTICS: grog; sandy paste

VESSEL FORM: Shallow bowl (Figure 82)

RIM AND LIP FORM: Direct rim and a rounded lip

CORE COLOR: $\mathrm{F}$ (fired in a reducing environment and cooled in the open air) 
INTERIOR SURFACE COLOR: light yellowish-brown (10YR 6/4)

EXTERIOR SURFACE COLOR: light yellowish-brown (10YR 6/4)

WALL THICKNESS (RIM, BODY, AND BASE IN MM): 7.0 mm, rim

INTERIOR SURFACE TREATMENT: none

EXTERIOR SURFACE TREATMENT: none

HEIGHT (IN CM): 4.0

ORIFICE DIAMETER (IN CM): 18.9

DIAMETER AT BOTTOM OF RIM OR NECK (IN CM): N/A

BASE DIAMETER (IN CM): 9.5

ESTIMATED VOLUME (IN LITERS): 0.30 liters

DECORATION: Plain

TYPE: Undetermined plain ware

Figure 82. Shallow and plain bowl from 41SM290.

SITE NAME OR SITE NUMBER: 41SM290

VESSEL NO.: BW-9

NON-PLASTICS: grog

VESSEL FORM: Carinated bowl

RIM AND LIP FORM: Direct rim, with a rounded and exterior folded lip

CORE COLOR: $\mathrm{F}$ (fired in a reducing environment and cooled in the open air)

INTERIOR SURFACE COLOR: light yellowish-brown (10YR 6/4)

EXTERIOR SURFACE COLOR: light yellowish-brown (10YR 6/4); fire clouding on the rim

WALL THICKNESS (RIM, BODY, AND BASE IN MM): 6.7 mm, rim 
INTERIOR SURFACE TREATMENT: smoothed

EXTERIOR SURFACE TREATMENT: smoothed

HEIGHT (IN CM): 10.2

ORIFICE DIAMETER (IN CM): 19.8

DIAMETER AT BOTTOM OF RIM OR NECK (IN CM): 17.5

BASE DIAMETER (IN CM): 9.0

ESTIMATED VOLUME (IN LITERS): 1.2 liters

DECORATION: The rim has a series of 17 vertical engraved lines forming rectangular panels (Figure 83). Between two of the vertical engraved lines is a single engraved oval defined by an arc of lines (cf. consistent with Poynor Engraved, var. Cook, see Perttula [2009:Figure 6-63c).

TYPE: Poynor Engraved, var. Blackburn

Figure 83. Poynor Engraved, var. Blackburn carinated bowl from 41SM290.

SITE NAME OR SITE NUMBER: 41SM290

VESSEL NO.: BW-10

NON-PLASTICS: grog

VESSEL FORM: Bottle with a short neck (Figure 84)

RIM AND LIP FORM: Direct rim and a rounded lip

CORE COLOR: A (fired and cooled in a high oxygen environment)

INTERIOR SURFACE COLOR: very pale brown (10YR 7/4)

EXTERIOR SURFACE COLOR: very pale brown (10YR 7/4); fire clouds on the vessel body

WALL THICKNESS (RIM, BODY, AND BASE IN MM): 4.9 mm, rim

INTERIOR SURFACE TREATMENT: none 
EXTERIOR SURFACE TREATMENT: burnished

HEIGHT (IN CM): 13.4

ORIFICE DIAMETER (IN CM): 5.0

DIAMETER AT BOTTOM OF RIM OR NECK (IN CM): 6.0

BASE DIAMETER (IN CM): 5.7

ESTIMATED VOLUME (IN LITERS): 0.31 liters

DECORATION: The neck of this vessel has three hooked arm elements, separated from another by a single curvilinear line (see Figure 84 ).

TYPE: Poynor Engraved, var. $N$ or $P$ (Perttula 2009:Figure 6-64n, p)

Figure 84. Poynor Engraved, var. $N$ or $P$ bottle from 41SM290.

SITE NAME OR SITE NUMBER: 41SM290

VESSEL NO.: BW-11

NON-PLASTICS: grog

VESSEL FORM: Bowl

RIM AND LIP FORM: Direct rim with a flat lip

CORE COLOR: A (fired and cooled in a high oxygen environment)

INTERIOR SURFACE COLOR: light yellowish-brown (10YR 6/4); fire cloud on base

EXTERIOR SURFACE COLOR: light yellowish-brown (10YR 6/4)

WALL THICKNESS (RIM, BODY, AND BASE IN MM): N/A

INTERIOR SURFACE TREATMENT: smoothed

EXTERIOR SURFACE TREATMENT: burnished

HEIGHT (IN CM): 9.0

ORIFICE DIAMETER (IN CM): 14.8 


\section{DIAMETER AT BOTTOM OF RIM OR NECK (IN CM): N/A}

BASE DIAMETER (IN CM): 8.4

ESTIMATED VOLUME (IN LITERS): 0.53 liters

DECORATION: The rim has three broad horizontal engraved lines on it, as do Hood Engraved vessels (Perttula 2009:6-203), but there is no indication that this vessel had effigy head and tab tail attachments. The horizontal engraved lines are divided by four sets of two vertical appliqued ridges that extend from the top to the bottom of the engraved lines at the rim (Figure 85).

TYPE: cf. Hood Engraved, var. unspecified

Figure 85. Hood Engraved, var. unspecified bowl from 41SM290.

SITE NAME OR SITE NUMBER: 41SM290

VESSEL NO.: BW-12

NON-PLASTICS: grog

VESSEL FORM: globular carinated bowl

RIM AND LIP FORM: Direct rim and a rounded lip

CORE COLOR: A (fired and cooled in a high oxygen environment)

INTERIOR SURFACE COLOR: red (2.5YR 4/6)

EXTERIOR SURFACE COLOR: red (2.5YR 4/6)

WALL THICKNESS (RIM, BODY, AND BASE IN MM): 4.8 mm, rim

INTERIOR SURFACE TREATMENT: smoothed

EXTERIOR SURFACE TREATMENT: burnished

HEIGHT (IN CM): 12.5

ORIFICE DIAMETER (IN CM): 11.6

DIAMETER AT BOTTOM OF RIM OR NECK (IN CM): 11.5 
BASE DIAMETER (IN CM): 8.0

ESTIMATED VOLUME (IN LITERS): 0.87 liters

DECORATION: The lower part of the rim has a series of four engraved panels with inner and outer circular elements. Each panel is separated from the other by two near-vertical engraved brackets (Figure 86).

TYPE: Poynor Engraved, var. Lang (Perttula 2009:Figure 6-63g)

Figure 86. Poynor Engraved, var. Lang carinated bowl from 41SM290.

SITE NAME OR SITE NUMBER: 41SM290, Burial 6

VESSEL NO.: BW-13

NON-PLASTICS: grog

VESSEL FORM: Bottle

RIM AND LIP FORM: Direct rim and a rounded lip

CORE COLOR: $\mathrm{F}$ (fired in a reducing environment and cooled in the open air)

INTERIOR SURFACE COLOR: N/A

EXTERIOR SURFACE COLOR: brown (10YR 5/3); fire clouds

WALL THICKNESS (RIM, BODY, AND BASE IN MM): 6.3 mm, neck

INTERIOR SURFACE TREATMENT: none

EXTERIOR SURFACE TREATMENT: burnished

HEIGHT (IN CM): 22.0; the neck is $10.0 \mathrm{~cm}$ in height

ORIFICE DIAMETER (IN CM): 4.1

DIAMETER AT BOTTOM OF RIM OR NECK (IN CM): 6.2; maximum width on the body is $15.4 \mathrm{~cm}$

BASE DIAMETER (IN CM): 8.0

ESTIMATED VOLUME (IN LITERS): 0.70 liters 
DECORATION: The body of the bottle has four engraved circle and swastika elements surrounded by hatched dividers and fill areas. Within each hatched divider and fill area are four negative circles, two above and two below the central circle and swastika (Figure 87).

TYPE: Undetermined fine ware

Figure 87. Engraved bottle from 41SM290.

SITE NAME OR SITE NUMBER: 41SM290

VESSEL NO.: BW-14

NON-PLASTICS: grog

VESSEL FORM: globular carinated bowl

RIM AND LIP FORM: Direct rim with a rounded and exterior folded lip

CORE COLOR: A (fired and cooled in a high oxygen environment)

INTERIOR SURFACE COLOR: yellowish-brown (10YR 5/4)

EXTERIOR SURFACE COLOR: yellowish-brown (10YR 5/4)

WALL THICKNESS (RIM, BODY, AND BASE IN MM): 5.4 mm, rim

INTERIOR SURFACE TREATMENT: smoothed

EXTERIOR SURFACE TREATMENT: burnished; organic residue on the rim and the body

HEIGHT (IN CM): 11.6

ORIFICE DIAMETER (IN CM): 11.0

DIAMETER AT BOTTOM OF RIM OR NECK (IN CM): 11.5

BASE DIAMETER (IN CM): 6.6

ESTIMATED VOLUME (IN LITERS): 0.77 liters

DECORATION: The rim has five negative engraved ovals on the rim panel, defined by cross-hatched vertical brackets (Figure 88). 
TYPE: Poynor Engraved, var. Hood (Perttula 2009:Figure 6-63e)

Figure 88. Poynor Engraved, var. Hood carinated bowl from 41SM290.

SITE NAME OR SITE NUMBER: 41SM290

VESSEL NO.: BW-15

NON-PLASTICS: grog

VESSEL FORM: globular carinated bowl

RIM AND LIP FORM: Direct rim and a rounded lip

CORE COLOR: C (incompletely oxidized during firing)

INTERIOR SURFACE COLOR: very dark gray (10YR 3/1)

EXTERIOR SURFACE COLOR: very dark gray (10YR 3/1); fire clouds on the vessel body

WALL THICKNESS (RIM, BODY, AND BASE IN MM): N/A

INTERIOR SURFACE TREATMENT: burnished

EXTERIOR SURFACE TREATMENT: burnished

HEIGHT (IN CM): 10.0

ORIFICE DIAMETER (IN CM): 13.1

DIAMETER AT BOTTOM OF RIM OR NECK (IN CM): 12.9

BASE DIAMETER (IN CM): 7.0

ESTIMATED VOLUME (IN LITERS): 0.79 liters

DECORATION: The rim has 27 engraved panels defined by ovals, near-vertical arcs, hatched dividers, and ovals with upper and lower hatched pendant triangles (Figure 89).

TYPE: Poynor Engraved, var. Cook (Perttula 2009:Figure 6-63d)

Figure 89. Poynor Engraved, var. Cook carinated bowl from 41SM290. 
SITE NAME OR SITE NUMBER: 41SM290

VESSEL NO.: BW-16

NON-PLASTICS: grog

VESSEL FORM: Effigy bowl with a tab tail and an effigy head (Figure 90), partially broken away

RIM AND LIP FORM: Direct rim with a rounded and exterior folded lip

CORE COLOR: $\mathrm{F}$ (fired in a reducing environment and cooled in the open air)

INTERIOR SURFACE COLOR: grayish-brown (10YR 5/2)

EXTERIOR SURFACE COLOR: grayish-brown (10YR 5/2); fire clouds

WALL THICKNESS (RIM, BODY, AND BASE IN MM): 5.7 mm, body

INTERIOR SURFACE TREATMENT: smoothed

EXTERIOR SURFACE TREATMENT: smoothed

HEIGHT (IN CM): 8.2

ORIFICE DIAMETER (IN CM): 12.0

DIAMETER AT BOTTOM OF RIM OR NECK (IN CM): N/A

BASE DIAMETER (IN CM): 7.5

ESTIMATED VOLUME (IN LITERS): 0.39 liters

DECORATION: This vessel has an effigy head and a tab tail, as well as an engraved decoration. This consists of a set of three broad horizontal engraved lines and hatched pendant triangles only on either side of the effigy head attachment (see Figure 90).

TYPE: Hood Engraved, var. Cook

Figure 90. Hood Engraved, var. Cook effigy bowl from 41SM290.

SITE NAME OR SITE NUMBER: 41SM290

VESSEL NO.: BW-17 
NON-PLASTICS: grog and hematite

VESSEL FORM: Globular carinated bowl with four rim peaks (Figure 91)

RIM AND LIP FORM: Inverted rim and a rounded lip

CORE COLOR: A (fired and cooled in a high oxygen environment)

INTERIOR SURFACE COLOR: yellowish-brown (10YR 5/6)

EXTERIOR SURFACE COLOR: yellowish-brown (10YR 5/6); fire cloud on base

WALL THICKNESS (RIM, BODY, AND BASE IN MM): 4.5 mm, rim

INTERIOR SURFACE TREATMENT: smoothed

EXTERIOR SURFACE TREATMENT: burnished

HEIGHT (IN CM): 8.0

ORIFICE DIAMETER (IN CM): 13.5

DIAMETER AT BOTTOM OF RIM OR NECK (IN CM): 14.0

BASE DIAMETER (IN CM): 8.0

ESTIMATED VOLUME (IN LITERS): 0.65 liters

DECORATION: The rim is divided into eight oval panels defined by near-vertical arcs of engraved lines with upper and lower hatched pendant triangles. At the center of each oval panel is half of a hooked arm element (see Figure 91).

TYPE: Poynor Engraved, var. Lang (Perttula 2009:Figure 6-63g')

Figure 91. Poynor Engraved, var. Lang carinated bowl from 41SM290.

SITE NAME OR SITE NUMBER: 41SM290

VESSEL NO.: BW-18

NON-PLASTICS: grog and hematite

VESSEL FORM: Globular carinated bowl

RIM AND LIP FORM: Direct rim and a rounded and scalloped lip (Figure 92) 
CORE COLOR: A (fired and cooled in a high oxygen environment)

INTERIOR SURFACE COLOR: brownish-yellow (10YR 6/6)

EXTERIOR SURFACE COLOR: brownish-yellow (10YR 6/6); fire cloud on base

WALL THICKNESS (RIM, BODY, AND BASE IN MM): 6.5 mm, rim

INTERIOR SURFACE TREATMENT: smoothed

EXTERIOR SURFACE TREATMENT: burnished

HEIGHT (IN CM): 11.4

ORIFICE DIAMETER (IN CM): 12.5

DIAMETER AT BOTTOM OF RIM OR NECK (IN CM): 12.2

BASE DIAMETER (IN CM): 7.5

ESTIMATED VOLUME (IN LITERS): 0.85 liters

DECORATION: The upper panel on the vessel is plain, while the lower panel has a semicircular engraved motif that is repeated three times around the rim (see Figure 92). The motif includes a central circle and cross, surrounded by two sets of semi-circular engraved lines. These semi-circular engraved lines have large hatched pendant triangles on them whose apex points toward the central circle and cross.

TYPE: Undetermined fine ware

Figure 92. Engraved carinated bowl from 41SM290.

SITE NAME OR SITE NUMBER: 41SM290

VESSEL NO.: BW-19

NON-PLASTICS: grog

VESSEL FORM: Jar

RIM AND LIP FORM: Everted rim with a rounded and exterior folded lip

CORE COLOR: B (fired and cooled in a reducing environment) 
INTERIOR SURFACE COLOR: black (10YR 2/1)

EXTERIOR SURFACE COLOR: dark grayish-brown (10YR 3/2); fire clouding

WALL THICKNESS (RIM, BODY, AND BASE IN MM): 6.4 mm, body

INTERIOR SURFACE TREATMENT: smoothed

EXTERIOR SURFACE TREATMENT: smoothed on the body

HEIGHT (IN CM): 25.5

ORIFICE DIAMETER (IN CM): 20.5

DIAMETER AT BOTTOM OF RIM OR NECK (IN CM): 18.0

BASE DIAMETER (IN CM): 8.5

ESTIMATED VOLUME (IN LITERS): 6.79 liters

DECORATION: There are four rows of neck bands on the rim of the vessel; the body is plain (Figure 93).

TYPE: La Rue Neck Banded

Figure 93. La Rue Neck Banded jar from 41SM290.

\section{Spoonbill Site (41WD109) Vessels}

There are 34 Caddo ceramic vessels in the J. A. Walters collection from the Spoonbill site, an important multi-component Caddo settlement and cemetery on Caney Creek in the Lake Fork Creek drainage basin (see Figure 1). The vessels are from both Middle Caddo and Late Caddo period burials found in the same cemetery.

The Middle Caddo period ceramic vessels include a red-slipped and punctated bottle (cf. Maxey Noded Redware) from Burial 5 (see Figure 3), an interior and exterior engraved bowl, a red-slipped incised-punctated bowl from Burial 11, an incised jar from either Burial 5 or Burial 11, two Spoonbill Engraved bowls from Burial 11, and two Sanders Engraved carinated bowls from Burial 11. The Titus phase graves include vessels of the following identified ceramic types: Hodges Engraved, Hudson Engraved, Keno Trailed, var. Phillips, La Rue Neck Banded, McKinney Plain (perhaps better named McKinney Appliqued?), Mockingbird Punctated, Ripley Engraved, Simms Engraved, var. Darco, and Taylor Engraved. 
SITE NAME OR SITE NUMBER: Spoonbill (41WD109), Burial 10

VESSEL NO.: 53

NON-PLASTICS: grog

VESSEL FORM: Bottle with a slight spool neck (Figure 94)

RIM AND LIP FORM: Direct rim and a rounded, exterior folded lip

CORE COLOR: B (fired and cooled in a low oxygen environment)

INTERIOR SURFACE COLOR: very dark grayish-brown (10YR 3/2)

EXTERIOR SURFACE COLOR: very dark grayish-brown (10YR 3/2)

WALL THICKNESS (RIM, BODY, AND BASE IN MM): 6.3 mm, neck

INTERIOR SURFACE TREATMENT: smoothed on upper neck

EXTERIOR SURFACE TREATMENT: burnished

HEIGHT (IN CM): 14.0

ORIFICE DIAMETER (IN CM): 4.6

DIAMETER AT BOTTOM OF RIM OR NECK (IN CM): 4.6; $11.8 \mathrm{~cm}$ at the widest part of the body

BASE DIAMETER (IN CM): 5.0

ESTIMATED VOLUME (IN LITERS): 0.28

DECORATION: The bottle has three or four horizontal trailed lines at the top and the bottom of the vessel body. The body is covered with five sets of stacked interlocking scrolls of trailed lines (see Figure 94). A red pigment has been rubbed in the trailed lines; the vessel is also lip notched.

TYPE: Keno Trailed

Figure 94. Keno Trailed bottle from the Spoonbill site, Burial 10.

SITE NAME OR SITE NUMBER: Spoonbill (41WD109), Burial 9

VESSEL NO.: 54 
NON-PLASTICS: grog

VESSEL FORM: Bottle with a spool neck (Figure 95)

RIM AND LIP FORM: Everted rim and a rounded lip

CORE COLOR: $\mathrm{G}$ (fired in a reducing environment and cooled in the open air)

INTERIOR SURFACE COLOR: N/A

EXTERIOR SURFACE COLOR: yellowish-brown (10YR 5/4)

WALL THICKNESS (RIM, BODY, AND BASE IN MM): 6.4 mm, rim

INTERIOR SURFACE TREATMENT: smoothed on the neck

EXTERIOR SURFACE TREATMENT: smoothed

HEIGHT (IN CM): 17.5

ORIFICE DIAMETER (IN CM): 4.6

DIAMETER AT BOTTOM OF RIM OR NECK (IN CM): 5.4; $16.5 \mathrm{~cm}$ at the widest part of the body

BASE DIAMETER (IN CM): 6.5

ESTIMATED VOLUME (IN LITERS): 0.45 liters

DECORATION: The vessel body has four sets of narrow engraved scrolls with interlocking arms at the top and bottom of the vessel. Each scroll is composed of a narrow band filled with short dashed lines (see Figure 95). A red hematite-rich clay pigment has been rubbed in the engraved lines. The vessel is also lip notched.

TYPE: Hudson Engraved

Figure 95. Hudson Engraved bottle from Burial 9 at the Spoonbill site.

SITE NAME OR SITE NUMBER: Spoonbill (41WD109), Burial 10

VESSEL NO.: 55

NON-PLASTICS: grog 
VESSEL FORM: Bottle with a spool neck (Figure 96)

RIM AND LIP FORM: Direct rim and a rounded, exterior folded lip

CORE COLOR: $\mathrm{G}$ (fired in a low oxygen environment and cooled in the open air)

INTERIOR SURFACE COLOR: dark gray (10YR 4/1)

EXTERIOR SURFACE COLOR: light yellowish-brown (10YR 6/4)

WALL THICKNESS (RIM, BODY, AND BASE IN MM): 6.3 mm, neck

INTERIOR SURFACE TREATMENT: smoothed on the upper neck

EXTERIOR SURFACE TREATMENT: burnished

HEIGHT (IN CM): 13.0

ORIFICE DIAMETER (IN CM): 4.5

DIAMETER AT BOTTOM OF RIM OR NECK (IN CM): 4.2; $12.0 \mathrm{~cm}$ at the widest part of the body

BASE DIAMETER (IN CM): 6.5

ESTIMATED VOLUME (IN LITERS): 0.34 liters

DECORATION: There are four upper and lower sets of hatched and excised hooked arm scrolls and zones; each zone of scrolls contains four hooked arms, as well as five negative circles within the hatched and excised scrolls and zones (see Figure 96). A red pigment has been rubbed in the engraved lines. The vessel is also lip notched.

TYPE: Hudson Engraved

Figure 96. Hudson Engraved bottle from Burial 10 at the Spoonbill site.

SITE NAME OR SITE NUMBER: Spoonbill (41WD109), Burial 10

VESSEL NO.: 56

NON-PLASTICS: grog

VESSEL FORM: Bottle with a spool neck

RIM AND LIP FORM: Direct rim and a rounded lip (Figure 97) 
CORE COLOR: $\mathrm{G}$ (fired in a reducing environment and cooled in the open air)

INTERIOR SURFACE COLOR: dark yellowish-brown (10YR 4/4)

EXTERIOR SURFACE COLOR: dark yellowish-brown (10YR 4/4)

WALL THICKNESS (RIM, BODY, AND BASE IN MM): $7.3 \mathrm{~mm}$, neck; $5.5 \mathrm{~mm}$, body

INTERIOR SURFACE TREATMENT: smoothed on the upper neck

EXTERIOR SURFACE TREATMENT: burnished

HEIGHT (IN CM): 13.7

ORIFICE DIAMETER (IN CM): 4.9

DIAMETER AT BOTTOM OF RIM OR NECK (IN CM): $5.1 ; 12.0 \mathrm{~cm}$ at the widest part of the body

BASE DIAMETER (IN CM): 5.3

ESTIMATED VOLUME (IN LITERS): 0.29 liters

DECORATION: There are upper and lower sets of hooked arm engraved scrolls on the vessel body. The vessel base is also outlined by two sets of rectangular engraved lines, with the lower set of hooked arm scrolls beginning with the outer rectangular line around the base (see Figure 97).

TYPE: Taylor Engraved

Figure 97. Taylor Engraved spool-necked bottle from the Spoonbill site, Burial 10.

SITE NAME OR SITE NUMBER: Spoonbill (41WD109), Burial 6

VESSEL NO.: 58

NON-PLASTICS: grog, hematite, and charred organics

VESSEL FORM: Bottle with a spool neck and four legs $(3.6 \mathrm{~cm}$ in height and $3.0 \mathrm{~cm}$ in diameter) (Figure 98)

RIM AND LIP FORM: Direct rim and a flat, exterior folded lip

CORE COLOR: $\mathrm{F}$ (fired in a reducing environment and cooled in the open air) 
INTERIOR SURFACE COLOR: light yellowish-brown (10YR 6/4)

EXTERIOR SURFACE COLOR: light yellowish-brown (10YR 6/4); fire clouding on the rim, body, and base

WALL THICKNESS (RIM, BODY, AND BASE IN MM): 4.3 mm, rim

INTERIOR SURFACE TREATMENT: none

EXTERIOR SURFACE TREATMENT: burnished

HEIGHT (IN CM): 14.7

ORIFICE DIAMETER (IN CM): 5.0

DIAMETER AT BOTTOM OF RIM OR NECK (IN CM): 4.6

BASE DIAMETER (IN CM): 9.0

ESTIMATED VOLUME (IN LITERS): 0.53 liters

DECORATION: The vessel body has a continuous curvilinear negative scroll element that also has small triangular tick marks on the central scroll engraved line. The negative scroll is outlined by cross-hatched scroll filler zones with five repeating sets of two hooked arms. Within each of the cross-hatched zones, there is a negative oval, with a cross-hatched band within it, below one of the hooked arms and one smaller negative oval below one of the other hooked arms; there are 10 negative ovals across the vessel body (see Figure 98). A white clay pigment has been rubbed in the engraved lines.

TYPE: Hodges Engraved

Figure 98. Hodges Engraved bottle, Burial 6 at the Spoonbill site.

SITE NAME OR SITE NUMBER: Spoonbill (41WD109), Burial 5

VESSEL NO.: 61

NON-PLASTICS: grog

VESSEL FORM: Bottle with a straight neck and a carinated body

RIM AND LIP FORM: Direct rim and a rounded lip

CORE COLOR: $\mathrm{F}$ (fired in a reducing environment and cooled in the open air) 
INTERIOR SURFACE COLOR: red (10R 4/6) on the upper neck

EXTERIOR SURFACE COLOR: red (10R 4/6)

WALL THICKNESS (RIM, BODY, AND BASE IN MM): 4.6 mm, neck

INTERIOR SURFACE TREATMENT: smoothed on the upper neck

EXTERIOR SURFACE TREATMENT: burnished

HEIGHT (IN CM): 20.8

ORIFICE DIAMETER (IN CM): 5.0

DIAMETER AT BOTTOM OF RIM OR NECK (IN CM): 5.7; $16.3 \mathrm{~cm}$ at the widest part of the body

BASE DIAMETER (IN CM): 7.7

ESTIMATED VOLUME (IN LITERS): 0.64 liters

DECORATION: The vessel is red-slipped on its exterior surface, with the exception of two (triangular and rectangular-shaped) negative areas on the central part of the vessel body that are not red-slipped. There is a single row of tool punctations immediately under the base of the bottle neck (Figure 99).

TYPE: cf. Maxey Noded Redware

Figure 99. Maxey Noded Redware bottle, Burial 5 at the Spoonbill site.

SITE NAME OR SITE NUMBER: Spoonbill (41WD109)

VESSEL NO.: 63

NON-PLASTICS: grog and bone

VESSEL FORM: Bowl

RIM AND LIP FORM: Direct rim and a rounded lip

CORE COLOR: $\mathrm{F}$ (fired in a reducing environment and cooled in the open air)

INTERIOR SURFACE COLOR: red (10R 4/6) 
EXTERIOR SURFACE COLOR: red (10R 4/6)

WALL THICKNESS (RIM, BODY, AND BASE IN MM): 6.6 mm, rim

INTERIOR SURFACE TREATMENT: burnished

EXTERIOR SURFACE TREATMENT: burnished

HEIGHT (IN CM): 9.6

ORIFICE DIAMETER (IN CM): 20.0

DIAMETER AT BOTTOM OF RIM OR NECK (IN CM): N/A

BASE DIAMETER (IN CM): 8.5

ESTIMATED VOLUME (IN LITERS): 0.77 liters

DECORATION: The bowl is red-slipped on interior and exterior vessel surfaces. There is a single horizontal engraved line on the vessel interior, midway (ca. $30 \mathrm{~mm}$ ) down the vessel rim. The exterior vessel surface has a rectangular engraved motif only on one section of the vessel rim (Figure 100). This motif consists of a joined set of three vertical and horizontal engraved lines, forming three rectangular zones, two of different sizes that are oriented horizontally and a third, even smaller in size, that is oriented vertically.

TYPE: Undetermined fine ware, related to Spoonbill Engraved

Figure 100. Engraved bowl from the Spoonbill site.

SITE NAME OR SITE NUMBER: Spoonbill (41WD109)

VESSEL NO.: 64

NON-PLASTICS: grog

VESSEL FORM: Carinated bowl

RIM AND LIP FORM: Direct rim and a rounded lip

CORE COLOR: $\mathrm{F}$ (fired in a reducing environment and cooled in the open air)

INTERIOR SURFACE COLOR: red (10YR 5/6)

EXTERIOR SURFACE COLOR: red (10YR 5/6) 
WALL THICKNESS (RIM, BODY, AND BASE IN MM): 6.7 mm, rim

INTERIOR SURFACE TREATMENT: burnished

EXTERIOR SURFACE TREATMENT: burnished

HEIGHT (IN CM): 7.0

ORIFICE DIAMETER (IN CM): 16.5

DIAMETER AT BOTTOM OF RIM OR NECK (IN CM): 16.5

BASE DIAMETER (IN CM): 7.7

ESTIMATED VOLUME (IN LITERS): 0.69 liters

DECORATION: The vessel rim panel has an engraved scroll motif (Thurmond 1990:Figure 6b), with negative S-shaped vertical dividers, that is repeated only two times around the rim. The scroll fill zones have small excised tick marks (Figure 101). The vessel is also red-slipped on both interior and exterior vessel surfaces.

TYPE: Ripley Engraved

Figure 101. Ripley Engraved carinated bowl from the Spoonbill site.

SITE NAME OR SITE NUMBER: Spoonbill (41WD109), Burial 11

VESSEL NO.: 65

NON-PLASTICS: grog

VESSEL FORM: Bowl with a tall rim (Figure 102)

RIM AND LIP FORM: Everted rim and a flat lip

CORE COLOR: $\mathrm{F}$ (fired in a reducing environment and cooled in the open air)

INTERIOR SURFACE COLOR: red (10R 4/6)

EXTERIOR SURFACE COLOR: red (10R 4/6)

WALL THICKNESS (RIM, BODY, AND BASE IN MM): $4.1 \mathrm{~mm}$, rim

INTERIOR SURFACE TREATMENT: smoothed 
EXTERIOR SURFACE TREATMENT: smoothed

HEIGHT (IN CM): 8.8

ORIFICE DIAMETER (IN CM): 9.9

DIAMETER AT BOTTOM OF RIM OR NECK (IN CM): 8.3

BASE DIAMETER (IN CM): 5.2

ESTIMATED VOLUME (IN LITERS): 0.35 liters

DECORATION: The vessel has a red slip on both interior and exterior vessel surfaces. On the exterior vessel rim there are eight opposed incised triangles (formed by two sets of four diagonal incised lines) filled with tool punctations (see Figure 102). In one instance, there is an incised triangle that is bisected by four nearly vertical incised lines, with tool punctations on either side of the vertical lines.

TYPE: Undetermined fine ware

Figure 102. Incised-punctated and slipped bowl from Burial 11 at the Spoonbill site.

SITE NAME OR SITE NUMBER: Spoonbill (41WD109)

VESSEL NO.: 66

NON-PLASTICS: bone, grog, and hematite; sandy paste

VESSEL FORM: Bowl

RIM AND LIP FORM: Direct rim and a rounded lip

CORE COLOR: A (fired and cooled in a high oxygen environment)

INTERIOR SURFACE COLOR: brown (7.5YR 5/4); fire clouding on the body and base

EXTERIOR SURFACE COLOR: brown (7.5YR 5/4); fire clouding on the body and base

WALL THICKNESS (RIM, BODY, AND BASE IN MM): 6.7 mm, rim

INTERIOR SURFACE TREATMENT: none

EXTERIOR SURFACE TREATMENT: none

HEIGHT (IN CM): 10.0 
ORIFICE DIAMETER (IN CM): 15.4

DIAMETER AT BOTTOM OF RIM OR NECK (IN CM): N/A

BASE DIAMETER (IN CM): 7.5

ESTIMATED VOLUME (IN LITERS): 0.62 liters

DECORATION: The vessel has a single horizontal engraved line under the rim, along with 12 sets of equally-spaced and short vertical engraved lines. Each of the 12 sets has three closely-spaced vertical engraved lines (Figure 103).

TYPE: Undetermined fine ware

Figure 103. Engraved bowl from the Spoonbill site.

SITE NAME OR SITE NUMBER: Spoonbill (41WD109), Burial 6

VESSEL NO.: 67

NON-PLASTICS: fine grog

VESSEL FORM: Carinated bowl

RIM AND LIP FORM: Inverted rim and a rounded lip

CORE COLOR: $\mathrm{G}$ (fired in a reducing environment and cooled in the open air)

INTERIOR SURFACE COLOR: very dark gray (7.5YR 3/1); fire clouding on the body and base

EXTERIOR SURFACE COLOR: brown (7.5YR 5/4); fire clouding on the body and base

WALL THICKNESS (RIM, BODY, AND BASE IN MM): 4.2 mm, rim

INTERIOR SURFACE TREATMENT: burnished

EXTERIOR SURFACE TREATMENT: burnished

HEIGHT (IN CM): 6.4

ORIFICE DIAMETER (IN CM): 8.6

DIAMETER AT BOTTOM OF RIM OR NECK (IN CM): 9.3 
BASE DIAMETER (IN CM): 4.8

ESTIMATED VOLUME (IN LITERS): 0.33 liters

DECORATION: The rim panel has four sets of discontinuous diagonal engraved scrolls with tick marks. Each set has two discontinuous ticked scrolls that originate either at the rim or at the carination; the upper scroll has tick marks that point up to the rim, while the lower scroll has tick marks that point towards the vessel carination. Each set of engraved scrolls is divided by sets of three vertical engraved lines that extend from the rim to the carination, one set on either side of each set of discontinuous engraved scrolls (Figure 104).

TYPE: Simms Engraved, var. Darco

Figure 104. Simms Engraved, var. Darco carinated bowl from Burial 6 at the Spoonbill site.

SITE NAME OR SITE NUMBER: Spoonbill (41WD109), Burial 8

VESSEL NO.: 69

NON-PLASTICS: grog and hematite

VESSEL FORM: Bowl with an exterior thickened rim (Figure 105)

RIM AND LIP FORM: Direct rim and a rounded lip

CORE COLOR: A (fired and cooled in a high oxygen environment)

INTERIOR SURFACE COLOR: strong brown (7.5YR 5/6)

EXTERIOR SURFACE COLOR: strong brown (7.5YR 5/6)

WALL THICKNESS (RIM, BODY, AND BASE IN MM): 5.7 mm, rim

INTERIOR SURFACE TREATMENT: none

EXTERIOR SURFACE TREATMENT: smoothed

HEIGHT (IN CM): 7.3

ORIFICE DIAMETER (IN CM): 12.0

DIAMETER AT BOTTOM OF RIM OR NECK (IN CM): N/A 
BASE DIAMETER (IN CM): 5.0

ESTIMATED VOLUME (IN LITERS): 0.35 liters

DECORATION: There are two rows of tool punctates on the exterior thickened rim, simulating neck banding (see Figure 105).

TYPE: Undetermined utility ware

Figure 105. Punctated bowl from Burial 8 at the Spoonbill site.

SITE NAME OR SITE NUMBER: Spoonbill (41WD109), Burial 8

VESSEL NO.: 70

NON-PLASTICS: grog

VESSEL FORM: Bottle with a straight to slightly flaring neck

RIM AND LIP FORM: Direct rim with a rounded and exterior folded lip

CORE COLOR: B (fired and cooled in a reducing environment)

INTERIOR SURFACE COLOR: dark grayish-brown (10YR 4/2)

EXTERIOR SURFACE COLOR: dark grayish-brown (10YR 4/2); fire clouding

WALL THICKNESS (RIM, BODY, AND BASE IN MM): 4.1 mm, neck; 4.4 mm, body; $4.5 \mathrm{~mm}$, base

INTERIOR SURFACE TREATMENT: none

EXTERIOR SURFACE TREATMENT: smoothed

HEIGHT (IN CM): 10.0

ORIFICE DIAMETER (IN CM): 3.6

DIAMETER AT BOTTOM OF RIM OR NECK (IN CM): 3.8; maximum body width is $8.9 \mathrm{~cm}$

BASE DIAMETER (IN CM): N/A

ESTIMATED VOLUME (IN LITERS): ca. 0.15 liters 
DECORATION: There are three repeating sets of vertical to curvilinear hooked arm engraved scrolls on the vessel body. Each scroll is composed of four engraved lines (Figure 106).

TYPE: Taylor Engraved

Figure 106. Taylor Engraved bottle from Burial 8 at the Spoonbill site.

SITE NAME OR SITE NUMBER: Spoonbill (41WD109), Burial 8

VESSEL NO.: 71

NON-PLASTICS: grog

VESSEL FORM: Jar

RIM AND LIP FORM: Everted rim and a rounded lip

CORE COLOR: $\mathrm{G}$ (fired in a reducing environment and cooled in the open air)

INTERIOR SURFACE COLOR: very dark gray (10YR 3/1)

EXTERIOR SURFACE COLOR: light yellowish-brown (10YR 6/4)

WALL THICKNESS (RIM, BODY, AND BASE IN MM): 6.0 mm, rim

INTERIOR SURFACE TREATMENT: smoothed on the rim

EXTERIOR SURFACE TREATMENT: smoothed on the body

HEIGHT (IN CM): 12.3

ORIFICE DIAMETER (IN CM): 13.3

DIAMETER AT BOTTOM OF RIM OR NECK (IN CM): 11.0

BASE DIAMETER (IN CM): 4.8

ESTIMATED VOLUME (IN LITERS): 0.98 liters

DECORATION: The vessel has a roughened rim and appliqued elements on the body. These consist of three vertical appliqued ridges spaced around the vessel that extend from near the rim-body juncture to the base. At the top of each appliqued ridge, and just under the rim-body juncture, is an appliqued node (Figure 107). 
TYPE: McKinney Plain

Figure 107. McKinney Plain jar from the Spoonbill site, Burial 8.

SITE NAME OR SITE NUMBER: Spoonbill (41WD109)

VESSEL NO.: 74

NON-PLASTICS: grog

VESSEL FORM: Jar

RIM AND LIP FORM: Everted rim with a rounded and exterior folded lip

CORE COLOR: F (fired in a reducing environment and cooled in the open air)

INTERIOR SURFACE COLOR: black (10YR 2/1)

EXTERIOR SURFACE COLOR: light yellowish-brown (10YR 6/4); fire clouding on the rim and body

WALL THICKNESS (RIM, BODY, AND BASE IN MM): 6.8 mm, body

INTERIOR SURFACE TREATMENT: smoothed

EXTERIOR SURFACE TREATMENT: smoothed; organic residue on the rim and body

HEIGHT (IN CM): 16.5

ORIFICE DIAMETER (IN CM): 15.8

DIAMETER AT BOTTOM OF RIM OR NECK (IN CM): 14.5

BASE DIAMETER (IN CM): 10.0

ESTIMATED VOLUME (IN LITERS): 2.34 liters

DECORATION: A single horizontal row of linear tool punctates at the rim-body juncture (Figure 108).

TYPE: cf. Mockingbird Punctated

Figure 108. cf. Mockingbird Punctated jar from the Spoonbill site. 
SITE NAME OR SITE NUMBER: Spoonbill (41WD109)

VESSEL NO.: 75

NON-PLASTICS: grog

VESSEL FORM: Jar

RIM AND LIP FORM: Everted rim and a rounded lip

CORE COLOR: $\mathrm{F}$ (fired in a reducing environment and cooled in the open air)

INTERIOR SURFACE COLOR: brownish-yellow (10YR 6/6)

EXTERIOR SURFACE COLOR: brownish-yellow (10YR 6/6); fire clouding on the body and base

WALL THICKNESS (RIM, BODY, AND BASE IN MM): 5.9 mm, rim; 5.4 mm, body

INTERIOR SURFACE TREATMENT: smoothed

EXTERIOR SURFACE TREATMENT: smoothed on the body

HEIGHT (IN CM): 16.0

ORIFICE DIAMETER (IN CM): 18.8

DIAMETER AT BOTTOM OF RIM OR NECK (IN CM): 16.1

BASE DIAMETER (IN CM): 7.5

ESTIMATED VOLUME (IN LITERS): 2.7 liters

DECORATION: The vessel has a roughened rim and a series of three appliqued triangles or chevrons (each triangle or chevron is filled with three diagonal appliqued ridges of different length) that are pendant from the rim-body juncture (Figure 109).

TYPE: McKinney Plain

Figure 109. McKinney Plain jar from the Spoonbill site.

SITE NAME OR SITE NUMBER: Spoonbill (41WD109)

VESSEL NO.: 77 
NON-PLASTICS: grog

VESSEL FORM: Jar

RIM AND LIP FORM: Everted rim and a rounded lip

CORE COLOR: $\mathrm{F}$ (fired in a reducing environment and cooled in the open air)

INTERIOR SURFACE COLOR: yellow (10YR 7/6); fire clouding on the rim

EXTERIOR SURFACE COLOR: yellow (10YR 7/6)

WALL THICKNESS (RIM, BODY, AND BASE IN MM): N/A

INTERIOR SURFACE TREATMENT: smoothed

EXTERIOR SURFACE TREATMENT: smoothed on the body; organic residue on the body

HEIGHT (IN CM): 18.0

ORIFICE DIAMETER (IN CM): 14.5

DIAMETER AT BOTTOM OF RIM OR NECK (IN CM): 12.5

BASE DIAMETER (IN CM): 7.0

ESTIMATED VOLUME (IN LITERS): 2.34 liters

DECORATION: The vessel has a roughened rim and four repeating sets of semi-circular appliqued ridges that are pendant from the rim-body juncture (Figure 110).

TYPE: cf. McKinney Plain

Figure 110. McKinney Plain (roughened-appliqued) jar from the Spoonbill site.

SITE NAME OR SITE NUMBER: Spoonbill (41WD109), Burial 6

VESSEL NO.: 78

NON-PLASTICS: grog

VESSEL FORM: Jar

RIM AND LIP FORM: Everted rim and a rounded lip 
CORE COLOR: $\mathrm{F}$ (fired in a reducing environment and cooled in the open air)

INTERIOR SURFACE COLOR: reddish-yellow (7.5YR 6/6)

EXTERIOR SURFACE COLOR: reddish-yellow (7.5YR 6/6); fire clouding on the body

WALL THICKNESS (RIM, BODY, AND BASE IN MM): 7.9 mm, rim; 7.9 mm, body

INTERIOR SURFACE TREATMENT: smoothed on the rim

EXTERIOR SURFACE TREATMENT: smoothed on the body; sooting on the body

HEIGHT (IN CM): 19.0

ORIFICE DIAMETER (IN CM): 18.5

DIAMETER AT BOTTOM OF RIM OR NECK (IN CM): 14.5

BASE DIAMETER (IN CM): 7.0

ESTIMATED VOLUME (IN LITERS): 3.16 liters

DECORATION: There are four rows of fingernail punctates on the rim and four small appliqued nodes on the upper body; these are placed immediately below the rim-body juncture (Figure 111).

TYPE: cf. Mockingbird Punctated

Figure 111. Mockingbird Punctated jar from Burial 6 at the Spoonbill site.

SITE NAME OR SITE NUMBER: Spoonbill (41WD109), Burial 10

VESSEL NO.: 79

NON-PLASTICS: grog

VESSEL FORM: Jar

RIM AND LIP FORM: Everted rim and rounded lip

CORE COLOR: B (fired and cooled in a reducing environment)

INTERIOR SURFACE COLOR: dark grayish-brown (10YR 4/2) 
EXTERIOR SURFACE COLOR: dark grayish-brown (10YR 4/2)

WALL THICKNESS (RIM, BODY, AND BASE IN MM): $7.1 \mathrm{~mm}$, rim

INTERIOR SURFACE TREATMENT: smoothed on the rim

EXTERIOR SURFACE TREATMENT: smoothed on the body

HEIGHT (IN CM): 14.6

ORIFICE DIAMETER (IN CM): 15.0

DIAMETER AT BOTTOM OF RIM OR NECK (IN CM): 9.8

BASE DIAMETER (IN CM): 6.0

ESTIMATED VOLUME (IN LITERS): 1.31 liters

DECORATION: The vessel has a roughened rim, and a horizontal row of tool punctates at the rim-body juncture (Figure 112).

TYPE: cf. La Rue Neck Banded

Figure 112. cf. La Rue Neck Banded jar from Burial 10 at the Spoonbill site.

SITE NAME OR SITE NUMBER: Spoonbill (41WD109), Burial 10

VESSEL NO.: 88

NON-PLASTICS: grog

VESSEL FORM: Carinated bowl with two rim panels (Figure 113)

RIM AND LIP FORM: Upper rim panel is direct in profile with a rounded lip; lower rim panel is inverted in profile

CORE COLOR: B (fired and cooled in a low oxygen environment)

INTERIOR SURFACE COLOR: gray (10YR 5/1); fire clouding on the rim and base

EXTERIOR SURFACE COLOR: dark grayish-brown (10YR 4/2); fire clouding on the base

WALL THICKNESS (RIM, BODY, AND BASE IN MM): 4.4 mm, rim 
INTERIOR SURFACE TREATMENT: smoothed

EXTERIOR SURFACE TREATMENT: smoothed

HEIGHT (IN CM): 8.0

ORIFICE DIAMETER (IN CM): 15.5

DIAMETER AT BOTTOM OF RIM OR NECK (IN CM): 16.0

BASE DIAMETER (IN CM): 5.4

ESTIMATED VOLUME (IN LITERS): 0.74 liters

DECORATION: The upper rim panel is plain. The lower rim panel has an engraved motif with a red clay pigment rubbed in the engraved lines. The motif consists of eight equally-spaced sets of three vertical engraved lines, with continuous rows of triangular tick marks at the top and bottom of the rim panel (see Figure 113). The apex of the upper row of tick marks points toward the vessel carination, while the apex of the lower row of tick marks points towards the vessel rim.

TYPE: Simms Engraved

Figure 113. Simms Engraved carinated bowl from Burial 10 at the Spoonbill site.

SITE NAME OR SITE NUMBER: Spoonbill (41WD109), Burial 11

VESSEL NO.: 89

NON-PLASTICS: grog

VESSEL FORM: Bowl

RIM AND LIP FORM: Direct and interior thickened rim and a rounded lip

CORE COLOR: $\mathrm{F}$ (fired in a reducing environment but cooled in a high oxygen environment)

INTERIOR SURFACE COLOR: brown (7.5YR 5/3)

EXTERIOR SURFACE COLOR: reddish-brown (5YR 5/4)

WALL THICKNESS (RIM, BODY, AND BASE IN MM): $5.7 \mathrm{~mm}$, rim

INTERIOR SURFACE TREATMENT: smoothed on the rim 
EXTERIOR SURFACE TREATMENT: smoothed

HEIGHT (IN CM): 8.0

ORIFICE DIAMETER (IN CM): 18.3

DIAMETER AT BOTTOM OF RIM OR NECK (IN CM): N/A

BASE DIAMETER (IN CM): 6.8

ESTIMATED VOLUME (IN LITERS): 0.59 liters

DECORATION: The interior thickened rim has upper and lower rows of 19 sets of hatched (3-4 hatched lines) engraved triangles. The apex of the upper and lower rows of triangles touch (Figure 114).

TYPE: Spoonbill Engraved (see Perttula et al. 2007:19-20 and Figure 12a)

Figure 114. Spoonbill Engraved bowl from Burial 11 at the Spoonbill site.

SITE NAME OR SITE NUMBER: Spoonbill (41WD109), Burial 11

VESSEL NO.: 90

NON-PLASTICS: grog

VESSEL FORM: Bowl

RIM AND LIP FORM: Direct and interior thickened rim (Figure 115), and a rounded lip CORE COLOR: $\mathrm{F}$ (fired in a reducing environment but cooled in the open air)

INTERIOR SURFACE COLOR: brown (7.5YR 5/3)

EXTERIOR SURFACE COLOR: strong brown (7.5YR 5/6)

WALL THICKNESS (RIM, BODY, AND BASE IN MM): 7.6 mm, rim; 6.9 mm, body

INTERIOR SURFACE TREATMENT: smoothed on the rim

EXTERIOR SURFACE TREATMENT: burnished

HEIGHT (IN CM): 8.0 
ORIFICE DIAMETER (IN CM): 17.8

DIAMETER AT BOTTOM OF RIM OR NECK (IN CM): N/A

BASE DIAMETER (IN CM): 6.6

ESTIMATED VOLUME (IN LITERS): 0.57 liters

DECORATION: The interior thickened rim has upper and lower rows of 17 sets of hatched (three hatched lines) engraved triangles (see Figure 115). The apex of the upper and lower rows of triangles touch.

TYPE: Spoonbill Engraved (see Perttula et al. 2007:Figure 12b)

Figure 115. Second Spoonbill Engraved bowl from Burial 11 at the Spoonbill site.

SITE NAME OR SITE NUMBER: Spoonbill (41WD109), Burial 15

VESSEL NO.: 95

NON-PLASTICS: grog

VESSEL FORM: Carinated bowl

RIM AND LIP FORM: Inverted rim and a rounded lip

CORE COLOR: $\mathrm{F}$ (fired in a reducing environment and cooled in the open air)

INTERIOR SURFACE COLOR: dark grayish-brown (10YR 4/2)

EXTERIOR SURFACE COLOR: dark grayish-brown (10YR 4/2)

WALL THICKNESS (RIM, BODY, AND BASE IN MM): 7.9 mm, rim

INTERIOR SURFACE TREATMENT: burnished on the rim and smoothed on the body

EXTERIOR SURFACE TREATMENT: burnished

HEIGHT (IN CM): 8.8

ORIFICE DIAMETER (IN CM): 11.9

DIAMETER AT BOTTOM OF RIM OR NECK (IN CM): 13.6

BASE DIAMETER (IN CM): 4.3 
ESTIMATED VOLUME (IN LITERS): 0.63 liters

DECORATION: The rim panel, defined by upper and lower horizontal engraved lines, has 10 repeating sets of tightly interlocked vertical scrolls with a central hooked arm (Figure 116). A red clay pigment has been rubbed in the engraved lines.

TYPE: Taylor Engraved

Figure 116. Taylor Engraved carinated bowl from Burial 15 at the Spoonbill site.

SITE NAME OR SITE NUMBER: Spoonbill (41WD109), Burial 8

VESSEL NO.: 109

NON-PLASTICS: grog

VESSEL FORM: Bowl

RIM AND LIP FORM: Direct rim and a rounded lip

CORE COLOR: $\mathrm{G}$ (fired in a reducing environment and cooled in the open air)

INTERIOR SURFACE COLOR: very dusky red (2.5YR 2.5/2)

EXTERIOR SURFACE COLOR: dark reddish-brown (2.5YR 3/3)

WALL THICKNESS (RIM, BODY, AND BASE IN MM): 2.8 mm, rim; $4.2 \mathrm{~mm}$, body

INTERIOR SURFACE TREATMENT: smoothed

EXTERIOR SURFACE TREATMENT: smoothed

HEIGHT (IN CM): 9.1

ORIFICE DIAMETER (IN CM): 15.0

DIAMETER AT BOTTOM OF RIM OR NECK (IN CM): 14.5

BASE DIAMETER (IN CM): 8.5

ESTIMATED VOLUME (IN LITERS): 0.55 liters 
DECORATION: The vessel body has four sets of trailed vertical interlocking scrolls. Each set of scrolls is comprised of opposed sets of 12 closely-spaced trailed lines. The vessel is also lip notched (Figure 117).

TYPE: Keno Trailed, var. Phillips (Schambach and Miller 1984:123 and Figures 11-14a and 11-17a)

Figure 117. Keno Trailed, var. Phillips bowl from Burial 8 at the Spoonbill site.

SITE NAME OR SITE NUMBER: Spoonbill (41WD109)

VESSEL NO.: 115

NON-PLASTICS: grog

VESSEL FORM: Carinated bowl

RIM AND LIP FORM: Inverted rim and a rounded, exterior folded lip

CORE COLOR: $\mathrm{F}$ (fired in a reducing environment and cooled in the open air)

INTERIOR SURFACE COLOR: light brown (7.5YR 6/3)

EXTERIOR SURFACE COLOR: light brown (7.5YR 6/4)

WALL THICKNESS (RIM, BODY, AND BASE IN MM): 4.9 mm, rim; $6.1 \mathrm{~mm}$, body; $12.1 \mathrm{~mm}$, base

INTERIOR SURFACE TREATMENT: smoothed

EXTERIOR SURFACE TREATMENT: burnished

HEIGHT (IN CM): 14.0

ORIFICE DIAMETER (IN CM): 23.0

DIAMETER AT BOTTOM OF RIM OR NECK (IN CM): 25.5

BASE DIAMETER (IN CM): 8.0

ESTIMATED VOLUME (IN LITERS): 2.9 liters

DECORATION: The rim panel, defined by upper and lower horizontal engraved lines, has three sets of curvilinear scrolls with linear tick marks. The scrolls are divided by two 
sets of vertical excised and spurred lines. Within each of these sets is a single vertical Sshaped engraved line (Figure 118).

TYPE: cf. Simms Engraved

Figure 118. Simms Engraved carinated bowl from the Spoonbill site.

SITE NAME OR SITE NUMBER: Spoonbill (41WD109)

VESSEL NO.: 117

NON-PLASTICS: grog

VESSEL FORM: Carinated bowl

RIM AND LIP FORM: Inverted rim and a rounded lip

CORE COLOR: $\mathrm{F}$ (fired in a reducing environment and cooled in the open air)

INTERIOR SURFACE COLOR: pale brown (10YR 6/3)

EXTERIOR SURFACE COLOR: light yellowish-brown (10YR 6/4)

WALL THICKNESS (RIM, BODY, AND BASE IN MM): 8.2 mm, rim; 9.6 mm, body

INTERIOR SURFACE TREATMENT: smoothed

EXTERIOR SURFACE TREATMENT: smoothed

HEIGHT (IN CM): 19.3

ORIFICE DIAMETER (IN CM): 26.0

DIAMETER AT BOTTOM OF RIM OR NECK (IN CM): 29.0

BASE DIAMETER (IN CM): 9.8

ESTIMATED VOLUME (IN LITERS): 4.5 liters

DECORATION: The rim panel has eight gracefully sweeping curvilinear scrolls that end in hooked arms. The upper and lower scroll fill zones each have two hatched vertical brackets that connect the scroll to the rim or the vessel carination (Figure 119). The vessel is also lip notched.

TYPE: Taylor Engraved 
Figure 119. Taylor Engraved carinated bowl from the Spoonbill site.

SITE NAME OR SITE NUMBER: Spoonbill (41WD109), Burial 5

VESSEL NO.: 121

NON-PLASTICS: grog

VESSEL FORM: Carinated bowl

RIM AND LIP FORM: Direct rim and a flat lip

CORE COLOR: A (fired and cooled in a high oxygen environment)

INTERIOR SURFACE COLOR: brown (7.5YR 5/4); fire clouding on the base and lower body

EXTERIOR SURFACE COLOR: strong brown (7.5YR 5/6)

WALL THICKNESS (RIM, BODY, AND BASE IN MM): 7.7 mm, rim

INTERIOR SURFACE TREATMENT: smoothed

EXTERIOR SURFACE TREATMENT: burnished

HEIGHT (IN CM): 17.0

ORIFICE DIAMETER (IN CM): 29.5

DIAMETER AT BOTTOM OF RIM OR NECK (IN CM): 28.5

BASE DIAMETER (IN CM): 10.5

ESTIMATED VOLUME (IN LITERS): 4.5 liters

DECORATION: There is a single row of tool punctates at the lip of this very large vessel (Figure 120), simulating lip crimping (cf. Perttula 2005:Figure 6-32b).

TYPE: Undetermined utility ware

Figure 120. Lip punctated carinated bowl from the Spoonbill site, Burial 5. 
SITE NAME OR SITE NUMBER: Spoonbill (41WD109), Burial 11

VESSEL NO.: 140

NON-PLASTICS: grog

VESSEL FORM: Carinated bowl

RIM AND LIP FORM: Direct rim and a flat lip

CORE COLOR: C (incompletely oxidized during firing)

INTERIOR SURFACE COLOR: reddish-yellow (7.5YR 7/6)

EXTERIOR SURFACE COLOR: yellowish-red (5YR 5/6)

WALL THICKNESS (RIM, BODY, AND BASE IN MM): $4.6 \mathrm{~mm}$, rim; $5.4 \mathrm{~mm}$, body

INTERIOR SURFACE TREATMENT: smoothed

EXTERIOR SURFACE TREATMENT: smoothed

HEIGHT (IN CM): 9.0

ORIFICE DIAMETER (IN CM): 18.9

DIAMETER AT BOTTOM OF RIM OR NECK (IN CM): 18.8

BASE DIAMETER (IN CM): 8.5

ESTIMATED VOLUME (IN LITERS): 1.02 liters

DECORATION: There is a single horizontal engraved line directly below the lip, with 29 hatched pendant engraved triangles that extend midway down the rim towards the vessel carination. Each triangle has between 2-4 hatched lines within it (Figure 121). A red clay pigment has been rubbed in the engraved lines.

TYPE: Sanders Engraved, var. unspecified (see Perttula et al. 2007:Figures 9 and 10)

Figure 121. Sanders Engraved carinated bowl from Burial 11 at the Spoonbill site.

SITE NAME OR SITE NUMBER: Spoonbill (41WD109), Burial 11

VESSEL NO.: 168 
NON-PLASTICS: grog and hematite

VESSEL FORM: Carinated bowl

RIM AND LIP FORM: Direct rim and a flat lip

CORE COLOR: $\mathrm{F}$ (fired in a reducing environment and cooled in the open air)

INTERIOR SURFACE COLOR: reddish-yellow (7.5YR 6/6)

EXTERIOR SURFACE COLOR: brown (7.5YR 5/4)

WALL THICKNESS (RIM, BODY, AND BASE IN MM): 5.3 mm, rim

INTERIOR SURFACE TREATMENT: none

EXTERIOR SURFACE TREATMENT: smoothed

HEIGHT (IN CM): 10.2

ORIFICE DIAMETER (IN CM): 21.4

DIAMETER AT BOTTOM OF RIM OR NECK (IN CM): 20.6

BASE DIAMETER (IN CM): 9.5

ESTIMATED VOLUME (IN LITERS): 1.31 liters

DECORATION: The rim panel has two sets of vertical and diagonal engraved lines around the vessel. The central part of the geometric motif is a zone with 16 vertical engraved lines. To either side of the vertical engraved lines are sets of 14 diagonal engraved lines pitched in opposite directions (Figure 122). The vessel is also lip notched.

TYPE: Sanders Engraved

Figure 122. Sanders Engraved carinated bowl from the Spoonbill site, Burial 11.

SITE NAME OR SITE NUMBER: Spoonbill (41WD109)

VESSEL NO.: 182

NON-PLASTICS: grog

VESSEL FORM: Carinated bowl 
RIM AND LIP FORM: Inverted rim and a flat lip

CORE COLOR: $\mathrm{F}$ (fired in a reducing environment and cooled in the open air)

INTERIOR SURFACE COLOR: dark yellowish-brown (10YR 4/6)

EXTERIOR SURFACE COLOR: dark yellowish-brown (10YR 4/6)

WALL THICKNESS (RIM, BODY, AND BASE IN MM): 7.0 mm, rim

INTERIOR SURFACE TREATMENT: burnished

EXTERIOR SURFACE TREATMENT: burnished

HEIGHT (IN CM): 14.4

ORIFICE DIAMETER (IN CM): 23.4

DIAMETER AT BOTTOM OF RIM OR NECK (IN CM): 25.4

BASE DIAMETER (IN CM): 10.0

ESTIMATED VOLUME (IN LITERS): 3.03 liters

DECORATION: The rim panel has a continuous scroll motif that is repeated four times around the vessel. The divider between the scrolls is a vertical bracket with two engraved spurs. The upper and lower scroll fill zones each have three to four small vertical hooked arm scrolls within them (Figure 123). The vessel is red-slipped on both interior and exterior vessel surfaces.

TYPE: cf. Taylor Engraved or a late form of Ripley Engraved

Figure 123. Red-slipped cf. Taylor Engraved or late form of Ripley Engraved carinated bowl from the Spoonbill site.

SITE NAME OR SITE NUMBER: Spoonbill (41WD109)

VESSEL NO.: 183

NON-PLASTICS: grog

VESSEL FORM: Carinated bowl

RIM AND LIP FORM: Inverted rim and rounded lip 
CORE COLOR: $\mathrm{F}$ (fired in a reducing environment and cooled in the open air)

INTERIOR SURFACE COLOR: dark yellowish-brown (10YR 4/6)

EXTERIOR SURFACE COLOR: dark yellowish-brown (10YR 4/6)

WALL THICKNESS (RIM, BODY, AND BASE IN MM): 6.6 mm, rim

INTERIOR SURFACE TREATMENT: smoothed

EXTERIOR SURFACE TREATMENT: burnished

HEIGHT (IN CM): 15.0

ORIFICE DIAMETER (IN CM): 23.4

DIAMETER AT BOTTOM OF RIM OR NECK (IN CM): 25.0

BASE DIAMETER (IN CM): 7.5

ESTIMATED VOLUME (IN LITERS): 3.16 liters

DECORATION: The rim has a continuous engraved scroll with interlocking or hooked arms that is repeated four times around the vessel (Figure 124). The upper and lower scroll fill zones each have two excised triangles and brackets, as well as a single curvilinear engraved line. The vessel is red-slipped on both interior and exterior vessel surfaces.

TYPE: Taylor Engraved

Figure 124. Red-slipped Taylor Engraved carinated bowl from the Spoonbill site.

SITE NAME OR SITE NUMBER: Spoonbill (41WD109)

VESSEL NO.: 184

NON-PLASTICS: grog

VESSEL FORM: Carinated bowl

RIM AND LIP FORM: Inverted rim and a rounded lip

CORE COLOR: $\mathrm{F}$ (fired in a reducing environment and cooled in the open air)

INTERIOR SURFACE COLOR: red (10R 4/6) 
EXTERIOR SURFACE COLOR: red (10R 4/6)

WALL THICKNESS (RIM, BODY, AND BASE IN MM): 7.7 mm, rim

INTERIOR SURFACE TREATMENT: smoothed

EXTERIOR SURFACE TREATMENT: smoothed

HEIGHT (IN CM): 17.8

ORIFICE DIAMETER (IN CM): 22.2

DIAMETER AT BOTTOM OF RIM OR NECK (IN CM): 26.7

BASE DIAMETER (IN CM): 10.0

ESTIMATED VOLUME (IN LITERS): 3.55 liters

DECORATION: The upper and lower parts of the rim panel have narrow horizontal engraved bands that are filled with short vertical engraved lines. On the panel itself, there are three sets of two alternating engraved semi-circles (each with three lines), and the semi-circles have triangular tick marks either pointing towards the vessel rim or the carination (Figure 125). The vessel also has a red slip on interior and exterior vessel surfaces.

TYPE: Taylor Engraved (Perttula 2007a:141 and Figure 3a-b) or cf. Womack Engraved (Perttula and Nelson 2007:Figure 2)

Figure 125. Red-slipped Taylor Engraved or cf. Womack Engraved carinated bowl from the Spoonbill site.

SITE NAME OR SITE NUMBER: Spoonbill (41WD109)

VESSEL NO.: 185

NON-PLASTICS: grog

VESSEL FORM: Carinated bowl

RIM AND LIP FORM: Inverted rim and rounded lip

CORE COLOR: $\mathrm{F}$ (fired in a reducing environment and cooled in the open air)

INTERIOR SURFACE COLOR: dark yellowish-brown (10YR 4/6) 
EXTERIOR SURFACE COLOR: dark yellowish-brown (10YR 4/6)

WALL THICKNESS (RIM, BODY, AND BASE IN MM): 6.7 mm, rim; 7.0 mm, body; $8.9 \mathrm{~mm}$, base

INTERIOR SURFACE TREATMENT: smoothed on the rim

EXTERIOR SURFACE TREATMENT: burnished

HEIGHT (IN CM): 15.5+

ORIFICE DIAMETER (IN CM): 22.5

DIAMETER AT BOTTOM OF RIM OR NECK (IN CM): 23.2

BASE DIAMETER (IN CM): N/A

ESTIMATED VOLUME (IN LITERS): 3.13 liters+

DECORATION: The upper and lower parts of the rim panel have narrow but discontinuous horizontal engraved bands that are filled with short vertical engraved lines. These bands are broken by three sets of upper and lower engraved semi-circles that are filled with two sets of short vertical engraved lines on either side of a hooked arm scroll element. Above or below each of these engraved semi-circles is a single engraved semicircle with triangular tick marks either pointing towards the vessel rim or the carination (Figure 126). The vessel has been red-slipped on the exterior and interior surfaces.

TYPE: cf. Taylor Engraved (see Perttula 2007a:Figure 3a)

Figure 126. Red-slipped Taylor Engraved carinated bowl from the Spoonbill site.

SITE NAME OR SITE NUMBER: Spoonbill (41WD109), Burial 5 or 11

VESSEL NO.: 234

NON-PLASTICS: grog

VESSEL FORM: Jar with a tall rim

RIM AND LIP FORM: Direct rim and a flat lip

CORE COLOR: B (fired and cooled in a reducing environment)

INTERIOR SURFACE COLOR: dark gray (10YR 4/1) 
EXTERIOR SURFACE COLOR: dark gray (10YR 4/1)

WALL THICKNESS (RIM, BODY, AND BASE IN MM):

INTERIOR SURFACE TREATMENT: smoothed

EXTERIOR SURFACE TREATMENT: smoothed; organic residue on rim and body

HEIGHT (IN CM): 13.9

ORIFICE DIAMETER (IN CM): 11.6

DIAMETER AT BOTTOM OF RIM OR NECK (IN CM): 9.9

BASE DIAMETER (IN CM): 7.8

ESTIMATED VOLUME (IN LITERS): 0.97 liters

DECORATION: The rim has three sets of incised triangles or chevrons that extend from the rim to the rim-body juncture. The motif is composed of opposed sets of three diagonal incised lines that extend down the rim, but only one of the sets of diagonal incised lines actually meet (Figure 127).

TYPE: Undetermined utility ware

Figure 127. Incised jar from Burial 5 or 11 at the Spoonbill site.

\section{WD354 Vessels}

Five ceramic vessels in the J. A. Walters collection are from 41WD354, a Titus phase habitation and cemetery in the Caney Creek valley in the Lake Fork Creek drainage basin (see Figure 1). The five vessels are from two burials excavated at the site. They include a La Rue Neck Banded jar, an engraved and red-slipped compound bowl, another engraved compound bowl, an engraved bottle, and a Moore Noded bowl.

SITE NAME OR SITE NUMBER: 41WD354, Burial 2

VESSEL NO.: 81

NON-PLASTICS: grog

VESSEL FORM: Jar 
RIM AND LIP FORM: Everted rim and rounded lip

CORE COLOR: $\mathrm{G}$ (fired in a reducing environment and cooled in the open air)

INTERIOR SURFACE COLOR: very dark grayish-brown (10YR 3/2)

EXTERIOR SURFACE COLOR: yellowish-brown (10YR 5/4)

WALL THICKNESS (RIM, BODY, AND BASE IN MM): 7.9 mm, rim

INTERIOR SURFACE TREATMENT: smoothed

EXTERIOR SURFACE TREATMENT: smoothed only on the body

HEIGHT (IN CM): 12.0

ORIFICE DIAMETER (IN CM): 12.5

DIAMETER AT BOTTOM OF RIM OR NECK (IN CM): 10.6

BASE DIAMETER (IN CM): 6.5

ESTIMATED VOLUME (IN LITERS): 0.90 liters

DECORATION: Two horizontal rows of neck banding on the rim, as well as four vertical appliqued ridges on the vessel body (Figure 128).

TYPE: La Rue Neck Banded

Figure 128. La Rue Neck Banded jar from Burial 2 at 41WD354.

SITE NAME OR SITE NUMBER: 41WD354, Burial 1

VESSEL NO.: 84

NON-PLASTICS: grog

VESSEL FORM: Compound bowl; there are two suspension holes on the rim panel (Figure 129)

RIM AND LIP FORM: Direct rim and a rounded lip

CORE COLOR: $\mathrm{F}$ (fired in a reducing environment and cooled in the open air)

INTERIOR SURFACE COLOR: brown (10YR 5/3) 
EXTERIOR SURFACE COLOR: brown (10YR 5/3) to yellowish-brown (10YR 5/6), with a lower red slip

WALL THICKNESS (RIM, BODY, AND BASE IN MM): 6.0 mm, rim

INTERIOR SURFACE TREATMENT: smoothed on the rim

EXTERIOR SURFACE TREATMENT: burnished

HEIGHT (IN CM): 10.5

ORIFICE DIAMETER (IN CM): 9.5

DIAMETER AT BOTTOM OF RIM OR NECK (IN CM): 7.6

BASE DIAMETER (IN CM): 5.4

ESTIMATED VOLUME (IN LITERS): 0.80 liters

DECORATION: The rim panel has an engraved design. This design consists of three rectangular panels, defined by two sets of vertical engraved lines, with a cross-hatched scroll and upper and lower cross-hatched rectangular fill zones. A red clay pigment has been rubbed into the engraved lines. The body of the vessel has an exterior red slip (see Figure 129). The vessel is also lip notched.

TYPE: Undetermined fine ware

Figure 129. Engraved and red-slipped compound bowl from Burial 1 at 41WD354.

SITE NAME OR SITE NUMBER: 41WD354, Burial 2

VESSEL NO.: 85

NON-PLASTICS: grog

VESSEL FORM: Compound bowl

RIM AND LIP FORM: Direct rim and a rounded lip

CORE COLOR: $\mathrm{G}$ (fired in a reducing environment and cooled in the open air)

INTERIOR SURFACE COLOR: dark gray (7.5YR 4/1)

EXTERIOR SURFACE COLOR: brown (10YR 5/3) 
WALL THICKNESS (RIM, BODY, AND BASE IN MM): 6.6 mm, rim

INTERIOR SURFACE TREATMENT: burnished on the rim and smoothed on the body

EXTERIOR SURFACE TREATMENT: burnished

HEIGHT (IN CM): 8.8

ORIFICE DIAMETER (IN CM): 14.3

DIAMETER AT BOTTOM OF RIM OR NECK (IN CM): 13.6

BASE DIAMETER (IN CM): 6.9

ESTIMATED VOLUME (IN LITERS): 1.0 liters

DECORATION: The vessel has two rim panels. The upper rim panel has three equallyspaced horizontal engraved lines. The lower rim panel includes an engraved motif repeated four times around the rim. This motif consists of two sets of alternating excised triangles - separated by a single diagonal engraved line - on either side of a single vertical engraved line (Figure 130); in one instance, the vertical engraved element at the center of each motif has two engraved lines instead of one.

TYPE: Undetermined fine ware

Figure 130. Engraved compound bowl from Burial 2 at 41WD354.

SITE NAME OR SITE NUMBER: 41WD354, Burial 1

VESSEL NO.: 93

NON-PLASTICS: grog and bone

VESSEL FORM: Bottle with a straight neck

RIM AND LIP FORM: Direct rim and a rounded lip

CORE COLOR: $\mathrm{G}$ (fired in a reducing environment and cooled in the open air)

INTERIOR SURFACE COLOR: reddish-brown (2.5YR 5/4)

EXTERIOR SURFACE COLOR: red (2.5YR 4/6)

WALL THICKNESS (RIM, BODY, AND BASE IN MM): 6.5 mm, rim 
INTERIOR SURFACE TREATMENT: none

EXTERIOR SURFACE TREATMENT: burnished

HEIGHT (IN CM): 10.0

ORIFICE DIAMETER (IN CM): 3.8

DIAMETER AT BOTTOM OF RIM OR NECK (IN CM): 3.8; $7.3 \mathrm{~cm}$ at the widest part of the body

BASE DIAMETER (IN CM): 5.2

ESTIMATED VOLUME (IN LITERS): 0.2 liters

DECORATION: The body of the bottle has two widely-spaced engraved lines under the bottle neck, and a third horizontal engraved line near the vessel base, creating body panels. The uppermost horizontal engraved line has six small engraved pendant triangles. Two of the body panels each have three concentric and increasingly smaller engraved circles. The other two body panels have four semi-circular or circular engraved lines, two of which are connected in a hatched band. At the center of the motif is a small circle with four hatched pendant triangles or rays (Figure 131).

TYPE: Undetermined fine ware

Figure 131. Engraved bottle from 41WD354, Burial 1.

SITE NAME OR SITE NUMBER: 41WD354, Burial 2

VESSEL NO.: 151

NON-PLASTICS: grog and hematite

VESSEL FORM: Bowl

RIM AND LIP FORM: Direct rim and a rounded lip

CORE COLOR: F (fired in a reducing environment and cooled in the open air)

INTERIOR SURFACE COLOR: dark grayish-brown (10YR 4/2)

EXTERIOR SURFACE COLOR: grayish-brown (10YR 5/2) 
WALL THICKNESS (RIM, BODY, AND BASE IN MM): 7.6 mm, rim

INTERIOR SURFACE TREATMENT: smoothed on the rim

EXTERIOR SURFACE TREATMENT: smoothed on the body

HEIGHT (IN CM): 5.8

ORIFICE DIAMETER (IN CM): 11.0

DIAMETER AT BOTTOM OF RIM OR NECK (IN CM): N/A

BASE DIAMETER (IN CM): 5.2

ESTIMATED VOLUME (IN LITERS): 0.25 liters

DECORATION: There are three rows of appliqued nodes on the vessel rim and four large and equally-spaced appliqued node appendages or rattles (Figure 132).

TYPE: Moore Noded (see Webb 1959)

Figure 132. Moore Noded bowl from Burial 2 at 41WD354.

\section{Turquoise Site (41WD586) Vessels}

The Turquoise site is a late Titus phase cemetery in the Caney Creek valley in the Lake Fork Creek drainage basin (see Figure 1). Only five vessels in the J. A. Walters collection can be confidently attributed to the Turquoise site, out of the 38 vessels reported from the nine excavated burials (see Table 3 ). These vessels include a punctatedappliqued jar, an incised jar, a Simms Engraved, var. Darco hubcap-shaped carinated bowl, a possible Womack Engraved carinated bowl, and a red-slipped Ripley Engraved carinated bowl.

SITE NAME OR SITE NUMBER: Turquoise (41WD586)

VESSEL NO.: 80

NON-PLASTICS: grog

VESSEL FORM: Jar

RIM AND LIP FORM: Everted rim and rounded lip

CORE COLOR: $\mathrm{G}$ (fired in a reducing environment and cooled in the open air) 
INTERIOR SURFACE COLOR: very dark gray (7.5YR 3/1)

EXTERIOR SURFACE COLOR: brown (7.5YR 5/4)

WALL THICKNESS (RIM, BODY, AND BASE IN MM): 6.4 mm, rim

INTERIOR SURFACE TREATMENT: smoothed on the rim

EXTERIOR SURFACE TREATMENT: organic residue on the rim and upper body

HEIGHT (IN CM): 9.5

ORIFICE DIAMETER (IN CM): 11.2

DIAMETER AT BOTTOM OF RIM OR NECK (IN CM): 9.4

BASE DIAMETER (IN CM): 5.0

ESTIMATED VOLUME (IN LITERS): 0.64 liters

DECORATION: Three rows of closely-spaced tool punctates on the rim (simulating neck banding) and four equally-spaced appliqued nodes on the upper part of the rim (Figure 133).

TYPE: Undetermined utility ware, cf. Mockingbird Punctated

Figure 133. cf. Mockingbird Punctated jar from the Turquoise site.

SITE NAME OR SITE NUMBER: Turquoise (41WD586), Burial 6

VESSEL NO.: 87

NON-PLASTICS: grog

VESSEL FORM: Jar

RIM AND LIP FORM: Everted rim and a rounded lip

CORE COLOR: $\mathrm{G}$ (fired in a reducing environment and cooled in the open air)

INTERIOR SURFACE COLOR: dark grayish-brown (10YR 4/2)

EXTERIOR SURFACE COLOR: yellowish-brown (10YR 5/4) 
WALL THICKNESS (RIM, BODY, AND BASE IN MM): 5.0 mm, rim

INTERIOR SURFACE TREATMENT: smoothed; organic residue on the body

EXTERIOR SURFACE TREATMENT: none

HEIGHT (IN CM): 8.4

ORIFICE DIAMETER (IN CM): 10.1

DIAMETER AT BOTTOM OF RIM OR NECK (IN CM): 8.6

BASE DIAMETER (IN CM): 4.0

ESTIMATED VOLUME (IN LITERS): 0.51 liters

DECORATION: The rim and body of this vessel is completely covered with panels of incised lines formed by deeply incised diagonal lines. The panels are filled with either horizontal, vertical, and diagonal incised lines pitched in different directions (Figure 134).

TYPE: undetermined utility ware (cf. late variety of Dunkin Incised?) (see Suhm and Jelks 1962:Plate 19a, e-g).

Figure 134. Incised jar from Burial 6 at the Turquoise site.

SITE NAME OR SITE NUMBER: Turquoise (41WD586), Burial 2

VESSEL NO.: 91

NON-PLASTICS: grog

VESSEL FORM: Carinated bowl, hubcap form with upper and lower rim panels (Figure 135)

RIM AND LIP FORM: Direct rim and a rounded lip

CORE COLOR: $\mathrm{G}$ (fired in a reducing environment and cooled in the open air)

INTERIOR SURFACE COLOR: dark grayish-brown (10YR 4/2)

EXTERIOR SURFACE COLOR: grayish-brown (10YR 5/2)

WALL THICKNESS (RIM, BODY, AND BASE IN MM): 5.0 mm, rim; 5.8 mm, body 
INTERIOR SURFACE TREATMENT: burnished

EXTERIOR SURFACE TREATMENT: burnished

HEIGHT (IN CM): 7.0

ORIFICE DIAMETER (IN CM): 16.5

DIAMETER AT BOTTOM OF RIM OR NECK (IN CM): 15.0

BASE DIAMETER (IN CM): N/A

ESTIMATED VOLUME (IN LITERS): 0.69 liters

DECORATION: The upper rim panel is plain, except for lip notching. The lower panel has 10 sets of two discontinuous diagonal scrolls with tick marks on each of the sets of scrolls; the apex of the tick marks point either towards the rim or the carination (see Figure 135).

TYPE: Simms Engraved, var. Darco

Figure 135. Simms Engraved, var. Darco carinated bowl from Burial 2 at the Turquoise site.

SITE NAME OR SITE NUMBER: Turquoise (41WD586), Burial 6

VESSEL NO.: 118

NON-PLASTICS: grog and hematite

VESSEL FORM: Carinated bowl

RIM AND LIP FORM: Inverted rim and a rounded/interior beveled lip

CORE COLOR: $\mathrm{F}$ (fired in a reducing environment and cooled in the open air)

INTERIOR SURFACE COLOR: yellowish-brown (10YR 5/4)

EXTERIOR SURFACE COLOR: brown (7.5YR 5/4)

WALL THICKNESS (RIM, BODY, AND BASE IN MM): $6.2 \mathrm{~mm}$, rim; $7.4 \mathrm{~mm}$, body; $10.8 \mathrm{~mm}$, base

INTERIOR SURFACE TREATMENT: smoothed 
EXTERIOR SURFACE TREATMENT: burnished

HEIGHT (IN CM): 15.0

ORIFICE DIAMETER (IN CM): 28.0

DIAMETER AT BOTTOM OF RIM OR NECK (IN CM): 29.5

BASE DIAMETER (IN CM): 9.0

ESTIMATED VOLUME (IN LITERS): 3.78 liters

DECORATION: This large vessel has upper and low rows of large cross-hatched pendant triangles, 11 in each row. The apex of the upper row of pendant triangles points to the vessel carination, while the lower row of pendant triangles points toward the vessel rim (Figure 136).

TYPE: cf. Womack Engraved, Design A (Harris et al. 1965:Figure 6a)

Figure 136. cf. Womack Engraved carinated bowl from Burial 6 at the Turquoise site.

SITE NAME OR SITE NUMBER: Turquoise (41WD586)

VESSEL NO.: 181

NON-PLASTICS: grog

VESSEL FORM: Carinated bowl

RIM AND LIP FORM: Direct rim with a rounded and exterior folded lip

CORE COLOR: $\mathrm{F}$ (fired in a reducing environment and cooled in the open air)

INTERIOR SURFACE COLOR: red (10R 4/6)

EXTERIOR SURFACE COLOR: red (10R 4/8)

WALL THICKNESS (RIM, BODY, AND BASE IN MM): $7.7 \mathrm{~mm}$, rim; $8.8 \mathrm{~mm}$, body; $9.8 \mathrm{~mm}$, base

INTERIOR SURFACE TREATMENT: smoothed

EXTERIOR SURFACE TREATMENT: burnished

HEIGHT (IN CM): 19.2 
ORIFICE DIAMETER (IN CM): 26.6

DIAMETER AT BOTTOM OF RIM OR NECK (IN CM): 25.7

BASE DIAMETER (IN CM): 12.0

ESTIMATED VOLUME (IN LITERS): 4.6 liters

DECORATION: The rim panel has a scroll motif (see Thurmond 1990:Figure 6b) that is repeated four times around the vessel; each scroll is separated from each other by a vertical engraved bracket with excised upper and lower corners (Figure 137). The interior and exterior vessel surfaces have a red slip.

TYPE: Ripley Engraved

Figure 137. Red-slipped Ripley Engraved carinated bowl from the Turquoise site.

\section{WD589 Vessels}

There are only two vessels in the J. A. Walters collection that can be confidently attributed to 41WD589, a Late Caddo Titus phase site and cemetery in the Caney Creek valley in the Lake Fork Creek basin (see Figure 1). The include an engraved compound bowl in Burial 5 and a Ripley Engraved carinated bowl with an interlocking scroll motif in Burial 6 (see Figure 4).

SITE NAME OR SITE NUMBER: 41WD589, Burial 5

VESSEL NO.: 83

NON-PLASTICS: grog

VESSEL FORM: Compound bowl with two suspension holes on the uppermost rim panel (Figure 138)

RIM AND LIP FORM: Everted rim and a rounded lip

CORE COLOR: C (incompletely oxidized during firing)

INTERIOR SURFACE COLOR: brown (10YR 4/3)

EXTERIOR SURFACE COLOR: brown (10YR 4/3)

WALL THICKNESS (RIM, BODY, AND BASE IN MM): $5.1 \mathrm{~mm}$, rim 
INTERIOR SURFACE TREATMENT: smoothed

EXTERIOR SURFACE TREATMENT: smoothed

HEIGHT (IN CM): 12.5

ORIFICE DIAMETER (IN CM): 14.0

DIAMETER AT BOTTOM OF RIM OR NECK (IN CM): 10.0

BASE DIAMETER (IN CM): 6.0

ESTIMATED VOLUME (IN LITERS): 1.4 liters

DECORATION: The upper two panels or sections of the compound bowl have diagonal hatched engraved ladders or narrow bands, apparently repeated six times on each panel. The six hatched ladders on the lower section also have sets of three or four hatched pendant triangles on one side of each engraved ladder; the lower portion of the engraved ladder and two of the pendant triangles extend onto the lowermost section of the vessel (see Figure 138).

TYPE: Undetermined fine ware

Figure 138. Engraved compound bowl from Burial 5 at 41WD589.

SITE NAME OR SITE NUMBER: 41WD589

VESSEL NO.: 96

NON-PLASTICS: grog

VESSEL FORM: Carinated bowl

RIM AND LIP FORM: Direct rim and a rounded lip

CORE COLOR: B (fired and cooled in a reducing environment)

INTERIOR SURFACE COLOR: dark gray (10YR 4/1)

EXTERIOR SURFACE COLOR: dark gray (10YR 4/1)

WALL THICKNESS (RIM, BODY, AND BASE IN MM): 6.5 mm, rim

INTERIOR SURFACE TREATMENT: smoothed on the rim 
EXTERIOR SURFACE TREATMENT: burnished

HEIGHT (IN CM): 7.0

ORIFICE DIAMETER (IN CM): 11.1

DIAMETER AT BOTTOM OF RIM OR NECK (IN CM): 10.3

BASE DIAMETER (IN CM): 5.5

ESTIMATED VOLUME (IN LITERS): 0.46 liters

DECORATION: The rim panel has an interlocking horizontal engraved scroll (Thurmond 1990:Figure 6g) that is repeated four times around the rim. Each scroll motif is divided by vertical hatched brackets (Figure 139).

TYPE: Ripley Engraved

Figure 139. Ripley Engraved carinated bowl from 41WD589, Burial 6.

\section{Caney Creek Vessels, Wood County, Texas}

There are 58 vessels in the J. A. Walters collection that can only be identified as coming from burials in the Caney Creek valley in the Lake Fork Creek basin (see Figure 1). Over the years, these vessels have lost their provenience, but they come from either the Spoonbill site, 41WD354, the Turquoise site, or 41WD589. With one exception (Vessel 223, see below), the vessels from Caddo sites in the Caney Creek valley are clearly from late (post ca. A.D. 1550) Titus phase burials. They include vessels belonging to the defined fine ware types Hudson Engraved,. Ripley Engraved, Simms Engraved, var. Darco and var. unspecified, Taylor Engraved, Wilder Engraved, and probably Womack Engraved, and several utility ware types: McKinney Plain and La Rue Neck Banded. There are also plain jars $(n=2)$ and a punctated carinated bowl $(n=1)$.

SITE NAME OR SITE NUMBER: Caney Creek

VESSEL NO.: 57

NON-PLASTICS: grog

VESSEL FORM: Bottle

RIM AND LIP FORM: Everted rim and a rounded lip

CORE COLOR: $\mathrm{G}$ (fired in a reducing environment and cooled in the open air) 
INTERIOR SURFACE COLOR: very dark gray (10YR 3/1)

EXTERIOR SURFACE COLOR: brown (10YR 5/3)

WALL THICKNESS (RIM, BODY, AND BASE IN MM): 4.5 mm, rim; $6.1 \mathrm{~mm}$, body; $9.1 \mathrm{~mm}$, base

INTERIOR SURFACE TREATMENT: none

EXTERIOR SURFACE TREATMENT: smoothed

HEIGHT (IN CM): N/A

ORIFICE DIAMETER (IN CM): 4.7

DIAMETER AT BOTTOM OF RIM OR NECK (IN CM): 4.8; $11.0 \mathrm{~cm}$ at the widest part of the body

BASE DIAMETER (IN CM): 6.2

ESTIMATED VOLUME (IN LITERS): N/A

DECORATION: The body of the vessel has an engraved hooked arm scroll motif that is repeated five times around the body.

TYPE: Taylor Engraved

SITE NAME OR SITE NUMBER: Caney Creek

VESSEL NO.: 72

NON-PLASTICS: grog

VESSEL FORM: Jar

RIM AND LIP FORM: missing

CORE COLOR: $\mathrm{F}$ (fired in a reducing environment and cooled in the open air)

INTERIOR SURFACE COLOR: light yellowish-brown (10YR 6/4)

EXTERIOR SURFACE COLOR: light yellowish-brown (10YR 6/4)

WALL THICKNESS (RIM, BODY, AND BASE IN MM): $7.2 \mathrm{~mm}$, body 
INTERIOR SURFACE TREATMENT: smoothed

EXTERIOR SURFACE TREATMENT: smoothed on the body

HEIGHT (IN CM): N/A

ORIFICE DIAMETER (IN CM): N/A

DIAMETER AT BOTTOM OF RIM OR NECK (IN CM): 11.5

BASE DIAMETER (IN CM): N/A

ESTIMATED VOLUME (IN LITERS): N/A

DECORATION: The body of the jar has four appliqued chevrons that begin at the rimbody juncture; each appliqued chevron is separated from each other by a single vertical appliqued strip (Figure 140).

TYPE: cf. McKinney Plain

Figure 140. McKinney Plain jar from the Caney Creek area.

SITE NAME OR SITE NUMBER: Caney Creek

VESSEL NO.: 73

NON-PLASTICS: grog

VESSEL FORM: Jar

RIM AND LIP FORM: missing

CORE COLOR: B (fired and cooled in a low oxygen environment)

INTERIOR SURFACE COLOR: dark grayish-brown (10YR 4/2)

EXTERIOR SURFACE COLOR: dark grayish-brown (10YR 4/2)

WALL THICKNESS (RIM, BODY, AND BASE IN MM): 5.9 mm, rim; $7.0 \mathrm{~mm}$, body; $8.0 \mathrm{~mm}$, base

INTERIOR SURFACE TREATMENT: smoothed

EXTERIOR SURFACE TREATMENT: smoothed on the body 
HEIGHT (IN CM): 11.0

ORIFICE DIAMETER (IN CM): 13.0

DIAMETER AT BOTTOM OF RIM OR NECK (IN CM): 12.5

BASE DIAMETER (IN CM): 8.5

ESTIMATED VOLUME (IN LITERS): 0.86 liters

DECORATION: The rim is roughened. The body has four sets of three vertical appliqued strips, joined at the top by a single horizontal appliqued strip. Each of these sets of appliqued strips are separated from each other by a single vertical appliqued strip (Figure 141).

TYPE: cf. McKinney Plain or La Rue Neck Banded

Figure 141. cf. McKinney Plain or La Rue Neck Banded jar from the Caney Creek area.

SITE NAME OR SITE NUMBER: Caney Creek

VESSEL NO.: 86

NON-PLASTICS: grog

VESSEL FORM: Carinated bowl

RIM AND LIP FORM: Direct rim and a rounded lip

CORE COLOR: G (fired in a low oxygen or reducing environment and cooled in the open air)

INTERIOR SURFACE COLOR: very dark grayish-brown (10YR 3/2)

EXTERIOR SURFACE COLOR: yellowish-brown (10YR 5/4)

WALL THICKNESS (RIM, BODY, AND BASE IN MM): 6.4 mm, rim; 7.0 mm, base

INTERIOR SURFACE TREATMENT: smoothed

EXTERIOR SURFACE TREATMENT: burnished

HEIGHT (IN CM): 7.5 
ORIFICE DIAMETER (IN CM): 16.0

DIAMETER AT BOTTOM OF RIM OR NECK (IN CM): 15.0

BASE DIAMETER (IN CM): 6.0

ESTIMATED VOLUME (IN LITERS): 0.72 liters

DECORATION: The rim panel has a continuous scroll engraved motif (Thurmond 1990:Figure 6f) repeated four times around the rim; a red clay pigment has been rubbed in the engraved lines. The engraved brackets that divide each scroll motif have small excised spurs (Figure 142).

TYPE: Ripley Engraved

Figure 142. Ripley Engraved carinated bowl from the Caney Creek area.

SITE NAME OR SITE NUMBER: Caney Creek

VESSEL NO.: 92

NON-PLASTICS: grog

VESSEL FORM: Compound bottle or stacked series of vessels (Figure 143)

RIM AND LIP FORM: Everted rim and a rounded lip

CORE COLOR: $\mathrm{F}$ (fired in a reducing environment and cooled in the open air)

INTERIOR SURFACE COLOR: brown (10YR 4/3)

EXTERIOR SURFACE COLOR: yellowish-brown (10YR 5/4)

WALL THICKNESS (RIM, BODY, AND BASE IN MM): 5.2 mm, rim

INTERIOR SURFACE TREATMENT: smoothed on the upper neck

EXTERIOR SURFACE TREATMENT: smoothed

HEIGHT (IN CM): 11.5

ORIFICE DIAMETER (IN CM): 4.5

DIAMETER AT BOTTOM OF RIM OR NECK (IN CM): 4.2; $7.8 \mathrm{~cm}$ at the widest part of the bottle 
BASE DIAMETER (IN CM): 4.5

ESTIMATED VOLUME (IN LITERS): 0.2 liters

DECORATION: The rim is plain The upper body panel has three oval-shaped engraved zones filled with short horizontal engraved lines. The lower body panel, defined by upper and lower horizontal engraved lines, has a series of opposed and alternating engraved triangles $(n=8)$ and semi-circles $(n=4)$, defined by both engraved lines, excised lines, or narrow hatched zones (see Figure 143).

TYPE: Undetermined fine ware

Figure 143. Engraved compound bottle from the Caney Creek area.

SITE NAME OR SITE NUMBER: Caney Creek

VESSEL NO.: 94

NON-PLASTICS: grog

VESSEL FORM: Carinated bowl

RIM AND LIP FORM: Direct rim and a rounded, exterior folded, lip

CORE COLOR: B (fired and cooled in a low oxygen environment)

INTERIOR SURFACE COLOR: very dark gray (10YR 3/1)

EXTERIOR SURFACE COLOR: very dark gray (10YR 3/1)

WALL THICKNESS (RIM, BODY, AND BASE IN MM): $5.6 \mathrm{~mm}$, rim; $7.0 \mathrm{~mm}$, body

INTERIOR SURFACE TREATMENT: smoothed

EXTERIOR SURFACE TREATMENT: burnished

HEIGHT (IN CM): 5.5

ORIFICE DIAMETER (IN CM): 11.4

DIAMETER AT BOTTOM OF RIM OR NECK (IN CM): 11.4

BASE DIAMETER (IN CM): 5.5 
ESTIMATED VOLUME (IN LITERS): 0.38 liters

DECORATION: The rim panel has a continuous scroll engraved motif (Thurmond 1990:Figure 6f) that is repeated four times around the vessel (Figure 144).

TYPE: Ripley Engraved

Figure 144. Ripley Engraved carinated bowl, continuous scroll motif, from the Caney Creek area.

SITE NAME OR SITE NUMBER: Caney Creek

VESSEL NO.: 97

NON-PLASTICS: grog

VESSEL FORM: Compound bowl

RIM AND LIP FORM: Direct rim and a rounded, exterior folded lip

CORE COLOR: $\mathrm{G}$ (fired in a reducing environment and cooled in the open air)

INTERIOR SURFACE COLOR: dark gray (10YR 4/1)

EXTERIOR SURFACE COLOR: brown (10YR 5/3)

WALL THICKNESS (RIM, BODY, AND BASE IN MM): 6.2 mm, rim

INTERIOR SURFACE TREATMENT: burnished

EXTERIOR SURFACE TREATMENT: burnished

HEIGHT (IN CM): 9.0

ORIFICE DIAMETER (IN CM): 11.0

DIAMETER AT BOTTOM OF RIM OR NECK (IN CM): 10.6

BASE DIAMETER (IN CM): 6.4

ESTIMATED VOLUME (IN LITERS): 0.79 liters

DECORATION: The upper rim panel has three broadly-spaced horizontal engraved lines. The lower rim panel has an engraved scroll motif (Thurmond 1990:Figure 6b) repeated 
three times around the vessel. The hatched brackets and scroll fill zones have small excised spurs on them (Figure 145).

TYPE: Ripley Engraved

Figure 145. Ripley Engraved compound bowl from the Caney Creek area.

SITE NAME OR SITE NUMBER: Caney Creek

VESSEL NO.: 98

NON-PLASTICS: grog

VESSEL FORM: Carinated bowl

RIM AND LIP FORM: Direct rim and a rounded lip

CORE COLOR: $\mathrm{F}$ (fired in a reducing environment and cooled in the open air)

INTERIOR SURFACE COLOR: brown (10YR 4/3)

EXTERIOR SURFACE COLOR: brown (10YR 4/3)

WALL THICKNESS (RIM, BODY, AND BASE IN MM): 4.5 mm, rim; 5.9 mm, body

INTERIOR SURFACE TREATMENT: smoothed on the rim

EXTERIOR SURFACE TREATMENT: burnished

HEIGHT (IN CM): 9.0

ORIFICE DIAMETER (IN CM): 14.5

DIAMETER AT BOTTOM OF RIM OR NECK (IN CM): 13.9

BASE DIAMETER (IN CM): 6.0

ESTIMATED VOLUME (IN LITERS): 0.78 liters

DECORATION: The rim panel has an engraved scroll and circle motif (Thurmond 1990:Figure 6c) that is repeated four times around the rim, with excised fillers above and below the scrolls and in the central circle element (Figure 146). A red clay pigment has been rubbed in the engraved lines. 
The engraved "circle" in the central part of the motif (see Figure 146) is probably not a circle at all, but a representation of a peyote button (see Tunnell 2000:Figure 1). It seems likely that the Titus phase Caddo peoples were familiar with peyote and probably with peyote ceremonialism by the $15^{\text {th }}$ century A.D (Perttula 2005:23-24). This is turn suggests that these Caddo, either through intermediaries or through pilgrimages of their own, had knowledge of or had journeyed to the peyote gardens of southern Texas (e.g. El-Seedi et al. 2005; Terry et al. 2006) long before they had the horse.

TYPE: Ripley Engraved

Figure 146. Ripley Engraved carinated bowl, scroll and circle motif, Caney Creek area.

SITE NAME OR SITE NUMBER: Caney Creek

VESSEL NO.: 99

NON-PLASTICS: grog and hematite

VESSEL FORM: Carinated bowl

RIM AND LIP FORM: Direct rim and a rounded, exterior folded, lip

CORE COLOR: $\mathrm{H}$ (fired in a reducing environment and cooled in the open air)

INTERIOR SURFACE COLOR: brown (10YR 4/3)

EXTERIOR SURFACE COLOR: dark grayish-brown (10YR 4/2)

WALL THICKNESS (RIM, BODY, AND BASE IN MM): 6.6 mm, rim

INTERIOR SURFACE TREATMENT: smoothed on the rim

EXTERIOR SURFACE TREATMENT: burnished

HEIGHT (IN CM): 8.1

ORIFICE DIAMETER (IN CM): 16.0

DIAMETER AT BOTTOM OF RIM OR NECK (IN CM): 13.7

BASE DIAMETER (IN CM): 6.0

ESTIMATED VOLUME (IN LITERS): 0.78 liters 
DECORATION: The rim panel has a continuous scroll engraved motif (Thurmond 1990:Figure 6f) repeated four times around the vessel (Figure 147). The dividers between each of the motifs are different from one another: one consists of two vertical sets of two closely-spaced engraved lines; a second consists of two sets of narrow hatched ladders; a third has two engraved arcing lines; and the final divider includes two sets of two closelyspaced vertical engraved lines, one line of each set having small tick marks on them.

TYPE: Ripley Engraved

Figure 147. Ripley Engraved carinated bowl, continuous scroll motif, from the Caney Creek area.

SITE NAME OR SITE NUMBER: Caney Creek

VESSEL NO.: 100

NON-PLASTICS: grog

VESSEL FORM: Bowl

RIM AND LIP FORM: Inverted rim and a rounded lip

CORE COLOR: B (fired and cooled in a low oxygen environment)

INTERIOR SURFACE COLOR: very dark grayish-brown (10YR 3/2)

EXTERIOR SURFACE COLOR: dark grayish-brown (10YR 4/2); fire clouding

WALL THICKNESS (RIM, BODY, AND BASE IN MM): 5.7 mm, rim

INTERIOR SURFACE TREATMENT: smoothed

EXTERIOR SURFACE TREATMENT: burnished

HEIGHT (IN CM): 5.5

ORIFICE DIAMETER (IN CM): 9.5

DIAMETER AT BOTTOM OF RIM OR NECK (IN CM): 10.5

BASE DIAMETER (IN CM): 4.0

ESTIMATED VOLUME (IN LITERS): 0.21 liters 
DECORATION: The rim panel consists of a geometric continuous scroll motif that is repeated three times around the vessel. Each scroll motif is outlined by hatched brackets (Figure 148). A red clay pigment has been rubbed in the engraved lines.

TYPE: Undetermined fine ware, cf. Ripley Engraved

Figure 148. Engraved bowl from the Caney Creek area.

SITE NAME OR SITE NUMBER: Caney Creek

VESSEL NO.: 101

NON-PLASTICS: grog

VESSEL FORM: Bowl

RIM AND LIP FORM: Inverted rim and a rounded lip

CORE COLOR: F (fired in a reducing environment and cooled in the open air)

INTERIOR SURFACE COLOR: red (2.5YR 5/8)

EXTERIOR SURFACE COLOR: red (10R 4/8)

WALL THICKNESS (RIM, BODY, AND BASE IN MM): 5.0 mm, rim; 5.0 mm, body

INTERIOR SURFACE TREATMENT: smoothed

EXTERIOR SURFACE TREATMENT: smoothed

HEIGHT (IN CM): 5.0

ORIFICE DIAMETER (IN CM): 8.8

DIAMETER AT BOTTOM OF RIM OR NECK (IN CM): 9.0

BASE DIAMETER (IN CM): N/A

ESTIMATED VOLUME (IN LITERS): 0.18 liters

DECORATION: The rim panel has five discontinuous curvilinear and horizontal ticked scrolls; the tick marks are linear in shape (Figure 149). The vessel is also lip notched, redslipped on both interior and exterior vessel surfaces, and has a white kaolin clay pigment rubbed in the engraved lines. 
TYPE: Simms Engraved, var. Darco

Figure 149. Red-slipped Simms Engraved, var. Darco bowl from the Caney Creek area.

SITE NAME OR SITE NUMBER: Caney Creek

VESSEL NO.: 102

NON-PLASTICS: grog

VESSEL FORM: Miniature carinated bowl (Figure 150), probably an accompaniment for the burial of a child

RIM AND LIP FORM: Direct rim and a rounded lip

CORE COLOR: B (fired and cooled in a low oxygen environment)

INTERIOR SURFACE COLOR: very dark grayish-brown (10YR 3/2)

EXTERIOR SURFACE COLOR: very dark grayish-brown (10YR 3/2)

WALL THICKNESS (RIM, BODY, AND BASE IN MM): 5.7 mm, rim

INTERIOR SURFACE TREATMENT: smoothed on the rim

EXTERIOR SURFACE TREATMENT: burnished

HEIGHT (IN CM): 3.4

ORIFICE DIAMETER (IN CM): 6.4

DIAMETER AT BOTTOM OF RIM OR NECK (IN CM): 6.2

BASE DIAMETER (IN CM): 3.2

ESTIMATED VOLUME (IN LITERS): 0.08 liters

DECORATION: The rim panel has a continuous scroll engraved motif (Thurmond 1990:Figure 6f) that is repeated four times around the vessel. At the beginning or ending of each scroll is a single small excised dot (see Figure 150).

TYPE: Ripley Engraved

Figure 150. Miniature Ripley Engraved carinated bowl from the Caney Creek area. 
SITE NAME OR SITE NUMBER: Caney Creek

VESSEL NO.: 103

NON-PLASTICS: grog and bone

VESSEL FORM: miniature jar

RIM AND LIP FORM: Direct rim and a rounded lip

CORE COLOR: A (fired and cooled in a high oxygen environment)

INTERIOR SURFACE COLOR: light yellowish-brown (10YR 6/4); fire clouding on the base

EXTERIOR SURFACE COLOR: light yellowish-brown (10YR 6/4)

WALL THICKNESS (RIM, BODY, AND BASE IN MM): N/A

INTERIOR SURFACE TREATMENT: none; coils visible

EXTERIOR SURFACE TREATMENT: none other than random and faint grass

impressions, probably from wiping the vessel surface when wet (Figure 151)

HEIGHT (IN CM): 4.1

ORIFICE DIAMETER (IN CM): 5.1

DIAMETER AT BOTTOM OF RIM OR NECK (IN CM): N/A

BASE DIAMETER (IN CM): 3.5

ESTIMATED VOLUME (IN LITERS): 0.13 liters

DECORATION: Plain

TYPE: Undetermined plain ware

Figure 151. Plain miniature jar from the Caney Creek area.

SITE NAME OR SITE NUMBER: Caney Creek

VESSEL NO.: 108 
NON-PLASTICS: grog

VESSEL FORM: Carinated bowl

RIM AND LIP FORM: Direct rim and a rounded, exterior folded, lip

CORE COLOR: B (fired and cooled in a low oxygen environment)

INTERIOR SURFACE COLOR: very dark grayish-brown (10YR 3/2)

EXTERIOR SURFACE COLOR: very dark grayish-brown (10YR 3/2)

WALL THICKNESS (RIM, BODY, AND BASE IN MM): N/A

INTERIOR SURFACE TREATMENT: burnished on the rim; smoothed on the body

EXTERIOR SURFACE TREATMENT: burnished

HEIGHT (IN CM): 10.7

ORIFICE DIAMETER (IN CM): 18.6

DIAMETER AT BOTTOM OF RIM OR NECK (IN CM): 18.3

BASE DIAMETER (IN CM): 5.8

ESTIMATED VOLUME (IN LITERS): 1.2 liters

DECORATION: The rim panel has an engraved-punctated interlocking horizontal scroll motif (Thurmond 1990:Figure 6g) that is repeated two times around the vessel. The punctated elements form the bottom and top lines of the rim panel, just above the carination and under the lip, as well as a central line of punctations forming part of the interlocking scrolls themselves. The scroll motifs are separated from each other by vertical and curvilinear excised dividers (Figure 152).

TYPE: Ripley Engraved

Figure 152. Ripley Engraved carinated bowl from the Caney Creek area.

SITE NAME OR SITE NUMBER: Caney Creek

VESSEL NO.: 110

NON-PLASTICS: grog 
VESSEL FORM: Carinated bowl

RIM AND LIP FORM: Inverted rim and a rounded, exterior folded lip

CORE COLOR: $\mathrm{F}$ (fired in a reducing environment and cooled in the open air)

INTERIOR SURFACE COLOR: strong brown (7.5YR 5/6)

EXTERIOR SURFACE COLOR: strong brown (7.5YR 5/6)

WALL THICKNESS (RIM, BODY, AND BASE IN MM): 7.7 mm, rim

INTERIOR SURFACE TREATMENT: smoothed

EXTERIOR SURFACE TREATMENT: smoothed

HEIGHT (IN CM): 13.0

ORIFICE DIAMETER (IN CM): 19.5

DIAMETER AT BOTTOM OF RIM OR NECK (IN CM): 21.0

BASE DIAMETER (IN CM): 6.0

ESTIMATED VOLUME (IN LITERS): 2.28 liters

DECORATION: The rim has four large engraved circles connected to one another by two horizontal engraved lines, perhaps a rudimentary attempt at a continuous scroll. Each circle has a small central hatched circle, as well as cross-hatched triangular zones at the top and bottom of the circles. A third horizontal engraved line connects the upper crosshatched zones. At the bottom of the motif, between the large engraved circles, is an ovalshaped engraved area with hatched corners (Figure 153).

TYPE: cf. Ripley Engraved

Figure 153. cf. Ripley Engraved carinated bowl from the Caney Creek area.

SITE NAME OR SITE NUMBER: Caney Creek

VESSEL NO.: 111

NON-PLASTICS: grog

VESSEL FORM: Carinated bowl 
RIM AND LIP FORM: Direct rim and a rounded lip

CORE COLOR: $\mathrm{G}$ (fired in a reducing environment and cooled in the open air)

INTERIOR SURFACE COLOR: dark grayish-brown (10YR 4/2)

EXTERIOR SURFACE COLOR: brown (10YR 5/3)

WALL THICKNESS (RIM, BODY, AND BASE IN MM): 6.8 mm, rim

INTERIOR SURFACE TREATMENT: smoothed

EXTERIOR SURFACE TREATMENT: smoothed

HEIGHT (IN CM): 15.3

ORIFICE DIAMETER (IN CM): 24.0

DIAMETER AT BOTTOM OF RIM OR NECK (IN CM): 21.2

BASE DIAMETER (IN CM): 8.9

ESTIMATED VOLUME (IN LITERS): 3.3 liters

DECORATION: The rim panel has an engraved scroll motif (cf. Thurmond 1990:Figure 6b) that is repeated four times around the vessel. Each motif is separated from the other by a vertical bracket with top and bottom excised corners (Figure 154).

TYPE: Ripley Engraved

Figure 154. Ripley Engraved carinated bowl, scroll motif, from the Caney Creek area.

SITE NAME OR SITE NUMBER: Caney Creek

VESSEL NO.: 112

NON-PLASTICS: grog and hematite

VESSEL FORM: Carinated bowl

RIM AND LIP FORM: Inverted rim and a rounded and exterior folded lip

CORE COLOR: $\mathrm{G}$ (fired in a reducing environment and cooled in a high oxygen environment) 
INTERIOR SURFACE COLOR: very dark grayish-brown (10YR 3/2)

EXTERIOR SURFACE COLOR: yellowish-brown (7.5YR 5/6)

WALL THICKNESS (RIM, BODY, AND BASE IN MM): 6.6 mm, rim

INTERIOR SURFACE TREATMENT: smoothed

EXTERIOR SURFACE TREATMENT: smoothed

HEIGHT (IN CM): 14.4

ORIFICE DIAMETER (IN CM): 20.5

DIAMETER AT BOTTOM OF RIM OR NECK (IN CM): 22.0

BASE DIAMETER (IN CM): 7.0

ESTIMATED VOLUME (IN LITERS): 2.65 liters

DECORATION: The rim panel has an engraved continuous scroll motif (Thurmond 1990:Figure 6f) that is repeated four times around the vessel (Figure 155).

TYPE: Ripley Engraved

Figure 155. Ripley Engraved carinated bowl, continuous scroll motif, from the Caney Creek area.

SITE NAME OR SITE NUMBER: Caney Creek

VESSEL NO.: 113

NON-PLASTICS: grog

VESSEL FORM: Carinated bowl

RIM AND LIP FORM: Inverted rim and a rounded, exterior folded lip

CORE COLOR: $\mathrm{F}$ (fired in a reducing environment and cooled in the open air)

INTERIOR SURFACE COLOR: brown (10YR 5/3)

EXTERIOR SURFACE COLOR: pale brown (10YR 6/3)

WALL THICKNESS (RIM, BODY, AND BASE IN MM): 6.3 mm, body 
INTERIOR SURFACE TREATMENT: smoothed

EXTERIOR SURFACE TREATMENT: smoothed

HEIGHT (IN CM): 15.0

ORIFICE DIAMETER (IN CM): 21.2

DIAMETER AT BOTTOM OF RIM OR NECK (IN CM): 23.0

BASE DIAMETER (IN CM): 9.5

ESTIMATED VOLUME (IN LITERS): 2.8 liters

DECORATION: The rim panel has nine sets of nested engraved concentric circles divided by sets of diagonal engraved lines (2-4 lines) that are pitched in opposite directions around the rim (Figure 156).

TYPE: Undetermined fine ware

Figure 156. Engraved carinated bowl from the Caney Creek area.

SITE NAME OR SITE NUMBER: Caney Creek

VESSEL NO.: 114

NON-PLASTICS: grog

VESSEL FORM: Carinated bowl

RIM AND LIP FORM: Inverted rim and a rounded lip

CORE COLOR: F (fired in a reducing environment and cooled in the open air)

INTERIOR SURFACE COLOR: light yellowish-brown (10YR 6/4)

EXTERIOR SURFACE COLOR: light yellowish-brown (10YR 6/4)

WALL THICKNESS (RIM, BODY, AND BASE IN MM): 6.9 mm, rim

INTERIOR SURFACE TREATMENT: smoothed

EXTERIOR SURFACE TREATMENT: burnished 
HEIGHT (IN CM): 18.8

ORIFICE DIAMETER (IN CM): 23.3

DIAMETER AT BOTTOM OF RIM OR NECK (IN CM): 28.0

BASE DIAMETER (IN CM): 10.5

ESTIMATED VOLUME (IN LITERS): 3.9 liters

DECORATION: The rim panel has an engraved scroll motif (see Thurmond 1990:Figure $6 b)$ that is repeated four times around the vessel (Figure 157).

TYPE: cf. Ripley Engraved

Figure 157. cf. Ripley Engraved carinated bowl from the Caney Creek area.

SITE NAME OR SITE NUMBER: Caney Creek

VESSEL NO.: 116

NON-PLASTICS: grog

VESSEL FORM: Carinated bowl

RIM AND LIP FORM: Direct rim and a rounded lip

CORE COLOR: $\mathrm{F}$ (fired in a reducing environment and cooled in the open air)

INTERIOR SURFACE COLOR: light yellowish-brown (10YR 6/4)

EXTERIOR SURFACE COLOR: light yellowish-brown (10YR 6/4)

WALL THICKNESS (RIM, BODY, AND BASE IN MM): 7.0 mm, rim

INTERIOR SURFACE TREATMENT: burnished

EXTERIOR SURFACE TREATMENT: burnished

HEIGHT (IN CM): 15.0

ORIFICE DIAMETER (IN CM): 25.2

DIAMETER AT BOTTOM OF RIM OR NECK (IN CM): 25.0 
BASE DIAMETER (IN CM): 8.0

ESTIMATED VOLUME (IN LITERS): 3.4 liters

DECORATION: The rim panel has an engraved continuous scroll motif (Thurmond 1990:Figure 6f) that is repeated four times around the vessel. The brackets that separate each of the repeating motifs has upper and lower small excised pendant triangles and central rectangular hatched or excised zones (Figure 158). A white kaolin clay has been rubbed in the engraved lines.

TYPE: Ripley Engraved

Figure 158. Ripley Engraved carinated bowl, continuous scroll motif, from the Caney Creek area.

SITE NAME OR SITE NUMBER: Caney Creek

VESSEL NO.: 119

NON-PLASTICS: grog

VESSEL FORM: Carinated bowl

RIM AND LIP FORM: Inverted rim with a rounded and exterior folded lip

CORE COLOR: $\mathrm{F}$ (fired in a reducing environment and cooled in the open air)

INTERIOR SURFACE COLOR: brown (7.5YR 5/3)

EXTERIOR SURFACE COLOR: brown (7.5YR 5/3); fire clouding on the body and base WALL THICKNESS (RIM, BODY, AND BASE IN MM): 7.5 mm, rim; $9.2 \mathrm{~mm}$, body

INTERIOR SURFACE TREATMENT: smoothed

EXTERIOR SURFACE TREATMENT: smoothed

HEIGHT (IN CM): 17.1

ORIFICE DIAMETER (IN CM): 23.8

DIAMETER AT BOTTOM OF RIM OR NECK (IN CM): 24.5

BASE DIAMETER (IN CM): 8.8 
ESTIMATED VOLUME (IN LITERS): 3.6 liters

DECORATION: The rim has a series of hatched triangular-shaped elements that are pendant from the rim and the vessel carination. There are nine hatched elements along the rim, with their apex pointing towards the carination, and 10 hatched elements at the vessel carination, with their apex pointing towards the rim (Figure 159).

TYPE: cf. Womack Engraved

Figure 159. cf. Womack Engraved carinated bowl from the Caney Creek area.

SITE NAME OR SITE NUMBER: Caney Creek

VESSEL NO.: 120

NON-PLASTICS: grog and hematite

VESSEL FORM: Carinated bowl

RIM AND LIP FORM: Direct rim and a flat lip

CORE COLOR: $\mathrm{G}$ (fired in a reducing environment and cooled in the open air)

INTERIOR SURFACE COLOR: very dark grayish-brown (10YR 3/2); fire clouding on the base

EXTERIOR SURFACE COLOR: dark grayish-brown (10YR 4/2)

WALL THICKNESS (RIM, BODY, AND BASE IN MM): $8.1 \mathrm{~mm}$, rim

INTERIOR SURFACE TREATMENT: smoothed on the rim

EXTERIOR SURFACE TREATMENT: burnished; organic residue on the body

HEIGHT (IN CM): 17.0

ORIFICE DIAMETER (IN CM): 26.0

DIAMETER AT BOTTOM OF RIM OR NECK (IN CM): 25.8

BASE DIAMETER (IN CM): 9.5

ESTIMATED VOLUME (IN LITERS): 4.0 liters 
DECORATION: The rim panel has an engraved scroll and circle motif (Thurmond 1990:Figure 6c) that is repeated four times around the vessel. At the center of each circle is a small excised dot (Figure 160).

TYPE: Ripley Engraved

Figure 160. Ripley Engraved carinated bowl, scroll and circle motif, from the Caney Creek area.

SITE NAME OR SITE NUMBER: Caney Creek

VESSEL NO.: 122

NON-PLASTICS: grog

VESSEL FORM: Carinated bowl

RIM AND LIP FORM: Direct rim and a rounded, exterior folded lip

CORE COLOR: $\mathrm{F}$ (fired in a reducing environment and cooled in the open air)

INTERIOR SURFACE COLOR: brown (10YR 4/3)

EXTERIOR SURFACE COLOR: brown (10YR 4/3)

WALL THICKNESS (RIM, BODY, AND BASE IN MM): 7.6 mm, rim; 7.7 mm, body

INTERIOR SURFACE TREATMENT: smoothed

EXTERIOR SURFACE TREATMENT: burnished

HEIGHT (IN CM): 14.5

ORIFICE DIAMETER (IN CM): 26.5

DIAMETER AT BOTTOM OF RIM OR NECK (IN CM): 24.0

BASE DIAMETER (IN CM): 7.5

ESTIMATED VOLUME (IN LITERS): 3.4 liters

DECORATION: The rim panel has a continuous scroll engraved motif (Thurmond 1990:Figure 6f) repeated four times around the vessels (Figure 161). The brackets dividing each individual motif has upper and lower small hatched pendant triangles 
within them, as well as a central and rectangular hatched zone (see also Vessel 116, Caney Creek area). A white kaolin clay pigment has been rubbed in the engraved lines.

TYPE: Ripley Engraved

Figure 161. Ripley Engraved carinated bowl, continuous scroll motif, from the Caney Creek area.

SITE NAME OR SITE NUMBER: Caney Creek

VESSEL NO.: 123

NON-PLASTICS: grog

VESSEL FORM: Carinated bowl

RIM AND LIP FORM: Inverted rim and a rounded lip

CORE COLOR: $\mathrm{G}$ (fired in a reducing environment and cooled in the open air)

INTERIOR SURFACE COLOR: dark grayish-brown (10YR 4/2)

EXTERIOR SURFACE COLOR: light yellowish-brown (10YR 6/4)

WALL THICKNESS (RIM, BODY, AND BASE IN MM): 7.2 mm, rim; 8.0 mm, body; $9.7 \mathrm{~mm}$, base

INTERIOR SURFACE TREATMENT: smoothed

EXTERIOR SURFACE TREATMENT: smoothed

HEIGHT (IN CM): 18.5

ORIFICE DIAMETER (IN CM): N/A

DIAMETER AT BOTTOM OF RIM OR NECK (IN CM): N/A

BASE DIAMETER (IN CM): N/A

ESTIMATED VOLUME (IN LITERS): N/A

DECORATION: The rim has large ovals that are repeated four times around the vessel. Within each of these ovals are two upper and two lower cross-hatched pendant triangles. Excised brackets separate each of the engraved ovals (Figure 162). A red hematite-rich clay pigment has been rubbed in the engraved lines. 
TYPE: cf. Ripley Engraved

Figure 162. cf. Ripley Engraved carinated bowl from the Caney Creek area.

SITE NAME OR SITE NUMBER: Caney Creek

VESSEL NO.: 124

NON-PLASTICS: grog

VESSEL FORM: Carinated bowl

RIM AND LIP FORM: Inverted rim and a rounded, exterior folded lip

CORE COLOR: $\mathrm{G}$ (fired in a reducing environment and cooled in the open air)

INTERIOR SURFACE COLOR: dark yellowish-brown (10YR 4/2)

EXTERIOR SURFACE COLOR: brown (10YR 5/3); fire clouding

WALL THICKNESS (RIM, BODY, AND BASE IN MM): $7.1 \mathrm{~mm}$, rim; $7.9 \mathrm{~mm}$, body

INTERIOR SURFACE TREATMENT: smoothed

EXTERIOR SURFACE TREATMENT: smoothed

HEIGHT (IN CM): 16.0

ORIFICE DIAMETER (IN CM): 23.5

DIAMETER AT BOTTOM OF RIM OR NECK (IN CM): 25.0

BASE DIAMETER (IN CM): 9.0

ESTIMATED VOLUME (IN LITERS): 3.4 liters

DECORATION: The rim has a poorly executed hooked arm scroll motif that is repeated four times around the vessel (Figure 163). A hematite-rich clay pigment has been rubbed in the engraved lines.

TYPE: Taylor Engraved

Figure 163. Taylor Engraved carinated bowl from the Caney Creek area. 
SITE NAME OR SITE NUMBER: Caney Creek

VESSEL NO.: 125

NON-PLASTICS: grog

VESSEL FORM: Carinated bowl

RIM AND LIP FORM: Inverted rim and a rounded lip

CORE COLOR: $\mathrm{G}$ (fired in a reducing environment and cooled in the open air)

INTERIOR SURFACE COLOR: dark grayish-brown (10YR 4/2)

EXTERIOR SURFACE COLOR: brown (10YR 4/3); fire clouding on the rim and body

WALL THICKNESS (RIM, BODY, AND BASE IN MM): $6.2 \mathrm{~mm}$, rim; $6.0 \mathrm{~mm}$, body; $10.1 \mathrm{~mm}$, base

INTERIOR SURFACE TREATMENT: smoothed; organic residue on the body and rim EXTERIOR SURFACE TREATMENT: smoothed; organic residue on the body and rim HEIGHT (IN CM): 15.5

ORIFICE DIAMETER (IN CM): 26.0

DIAMETER AT BOTTOM OF RIM OR NECK (IN CM): N/A

BASE DIAMETER (IN CM): 9.0

ESTIMATED VOLUME (IN LITERS): 3.6 liters

DECORATION: The rim panel has an engraved continuous scroll motif (Thurmond 1990:Figure 6f) that is repeated four times around the vessel (Figure 164).

TYPE: Ripley Engraved

Figure 164. Ripley Engraved carinated bowl from the Caney Creek area.

SITE NAME OR SITE NUMBER: Caney Creek

VESSEL NO.: 126

NON-PLASTICS: grog 
VESSEL FORM: Carinated bowl

RIM AND LIP FORM: Inverted rim and a rounded lip

CORE COLOR: $\mathrm{G}$ (fired in a reducing environment and cooled in the open air)

INTERIOR SURFACE COLOR: dark grayish-brown (10YR 4/2)

EXTERIOR SURFACE COLOR: brown (10YR 5/3)

WALL THICKNESS (RIM, BODY, AND BASE IN MM): 7.0 mm, rim

INTERIOR SURFACE TREATMENT: smoothed

EXTERIOR SURFACE TREATMENT: burnished

HEIGHT (IN CM): 13.3

ORIFICE DIAMETER (IN CM): 22.2

DIAMETER AT BOTTOM OF RIM OR NECK (IN CM): 24.5

BASE DIAMETER (IN CM): 8.0

ESTIMATED VOLUME (IN LITERS): 2.66 liters

DECORATION: The rim has a panel with four engraved ovals. There are excised diagonal slanted pendant triangles (two at the top of the oval and two at the bottom) on each engraved oval (Figure 165). The ovals are divided by vertical engraved brackets.

TYPE: cf. Ripley Engraved or an early variety of Simms Engraved

Figure 165. cf. Ripley Engraved carinated bowl, or an early variety of Simms Engraved, from the Caney Creek area.

SITE NAME OR SITE NUMBER: Caney Creek

VESSEL NO.: 127

NON-PLASTICS: grog

VESSEL FORM: Carinated bowl

RIM AND LIP FORM: Inverted rim and a rounded and exterior folded lip 
CORE COLOR: $\mathrm{G}$ (fired in a reducing environment and cooled in the open air)

INTERIOR SURFACE COLOR: very dark grayish-brown (10YR 3/2)

EXTERIOR SURFACE COLOR: yellowish-brown (10YR 5/4); fire clouding

WALL THICKNESS (RIM, BODY, AND BASE IN MM): $6.7 \mathrm{~mm}$, rim; $6.0 \mathrm{~mm}$, body;

$6.4 \mathrm{~mm}$, base

INTERIOR SURFACE TREATMENT: smoothed

EXTERIOR SURFACE TREATMENT: burnished

HEIGHT (IN CM): 17.0

ORIFICE DIAMETER (IN CM): 28.0

DIAMETER AT BOTTOM OF RIM OR NECK (IN CM): 29.0

BASE DIAMETER (IN CM): N/A

ESTIMATED VOLUME (IN LITERS): 4.3 liters

DECORATION: The rim has a hatched engraved zone with 22 associated vertical hatched areas that extend below the main hatched zone onto the vessel body (Figure 166).

TYPE: cf. Simms Engraved, var. unspecified

Figure 166. cf. Simms Engraved, var. unspecified carinated bowl from the Caney Creek area.

SITE NAME OR SITE NUMBER: Caney Creek

VESSEL NO.: 128

NON-PLASTICS: grog and hematite

VESSEL FORM: Carinated bowl

RIM AND LIP FORM: Direct rim and a rounded lip

CORE COLOR: $\mathrm{G}$ (fired in a reducing environment and cooled in the open air)

INTERIOR SURFACE COLOR: very dark grayish-brown (10YR 3/2) 
EXTERIOR SURFACE COLOR: yellowish-brown (10YR 5/4)

WALL THICKNESS (RIM, BODY, AND BASE IN MM): 6.9 mm, rim; $8.5 \mathrm{~mm}$, body

INTERIOR SURFACE TREATMENT: smoothed

EXTERIOR SURFACE TREATMENT: burnished

HEIGHT (IN CM): 14.0

ORIFICE DIAMETER (IN CM): 25.3

DIAMETER AT BOTTOM OF RIM OR NECK (IN CM): 25.1

BASE DIAMETER (IN CM): 9.7

ESTIMATED VOLUME (IN LITERS): 3.2 liters

DECORATION: The rim panel has an engraved scroll motif (Thurmond 1990:Figure 6b) that is repeated four times around the vessel (Figure 167). The scroll fill elements have excised spurs as do several other Caney Creek valley Titus phase vessels in the J. A. Walters collection.

TYPE: Ripley Engraved

Figure 167. Ripley Engraved carinated bowl from the Caney Creek area.

SITE NAME OR SITE NUMBER: Caney Creek

VESSEL NO.: 129

NON-PLASTICS: grog and hematite

VESSEL FORM: Carinated bowl

RIM AND LIP FORM: Inverted rim and a rounded lip

CORE COLOR: $\mathrm{G}$ (fired in a reducing environment and cooled in the open air)

INTERIOR SURFACE COLOR: very dark gray (10YR 3/1)

EXTERIOR SURFACE COLOR: brown (10YR 5/3)

WALL THICKNESS (RIM, BODY, AND BASE IN MM): $6.3 \mathrm{~mm}$, rim 
INTERIOR SURFACE TREATMENT: smoothed

EXTERIOR SURFACE TREATMENT: burnished

HEIGHT (IN CM): 13.5

ORIFICE DIAMETER (IN CM): 22.5

DIAMETER AT BOTTOM OF RIM OR NECK (IN CM): 24.9

BASE DIAMETER (IN CM): 9.7

ESTIMATED VOLUME (IN LITERS): 2.7 liters

DECORATION: Closely-spaced sets of curvilinear engraved lines that end in a hooked arm scroll. This motif is repeated seven times around the vessel (Figure 168).

TYPE: Taylor Engraved

Figure 168. Taylor Engraved carinated bowl from the Caney Creek area.

SITE NAME OR SITE NUMBER: Caney Creek

VESSEL NO.: 130

NON-PLASTICS: grog

VESSEL FORM: Carinated bowl

RIM AND LIP FORM: Inverted rim and a rounded lip

CORE COLOR: $\mathrm{F}$ (fired in a reducing environment and cooled in the open air)

INTERIOR SURFACE COLOR: brown (10YR 5/3)

EXTERIOR SURFACE COLOR: yellowish-brown (10YR 5/4)

WALL THICKNESS (RIM, BODY, AND BASE IN MM): 8.6 mm, rim

INTERIOR SURFACE TREATMENT: smoothed

EXTERIOR SURFACE TREATMENT: smoothed

HEIGHT (IN CM): 15.0 
ORIFICE DIAMETER (IN CM): 21.5

DIAMETER AT BOTTOM OF RIM OR NECK (IN CM): 22.7

BASE DIAMETER (IN CM): 8.0

ESTIMATED VOLUME (IN LITERS): 2.9 liters

DECORATION: The rim has a gracefully sweeping scroll and scroll fill motif that end in a hooked arm element (Figure 169). This motif is repeated nine times around the vessel.

TYPE: Taylor Engraved

Figure 169. Taylor Engraved carinated bowl from the Caney Creek area.

SITE NAME OR SITE NUMBER: Caney Creek

VESSEL NO.: 131

NON-PLASTICS: grog

VESSEL FORM: Carinated bowl

RIM AND LIP FORM: Inverted rim with a rounded and exterior folded lip

CORE COLOR: B (fired and cooled in a low oxygen environment)

INTERIOR SURFACE COLOR: dark grayish-brown (10YR 4/2)

EXTERIOR SURFACE COLOR: grayish-brown (10YR 5/2); fire clouding

WALL THICKNESS (RIM, BODY, AND BASE IN MM): 5.5 mm, rim; 6.7 mm, body

INTERIOR SURFACE TREATMENT: smoothed; visible tool marks around the carination point

EXTERIOR SURFACE TREATMENT: smoothed

HEIGHT (IN CM): 12.0

ORIFICE DIAMETER (IN CM): 19.5

DIAMETER AT BOTTOM OF RIM OR NECK (IN CM): 21.5 
BASE DIAMETER (IN CM): 5.5

ESTIMATED VOLUME (IN LITERS): 1.4 liters

DECORATION: The rim has a continuous geometric scroll motif that is repeated four times around the vessel (Figure 170). A red hematite-rich clay pigment has been rubbed into the engraved lines.

TYPE: cf. Ripley Engraved

Figure 170. cf. Ripley Engraved carinated bowl from the Caney Creek area.

SITE NAME OR SITE NUMBER: Caney Creek

VESSEL NO.: 132

NON-PLASTICS: grog

VESSEL FORM: Jar

RIM AND LIP FORM: Everted rim and a rounded lip

CORE COLOR: $\mathrm{G}$ (fired in a reducing environment and cooled in the open air)

INTERIOR SURFACE COLOR: black (10YR 2/1); sooting

EXTERIOR SURFACE COLOR: dark yellowish-brown (10YR 4/4); sooting

WALL THICKNESS (RIM, BODY, AND BASE IN MM): 5.8 mm, rim

INTERIOR SURFACE TREATMENT: smoothed; organic residue on the rim

EXTERIOR SURFACE TREATMENT: smoothed on the body

HEIGHT (IN CM): 15.7

ORIFICE DIAMETER (IN CM): 17.0

DIAMETER AT BOTTOM OF RIM OR NECK (IN CM): 13.0

BASE DIAMETER (IN CM): 7.0

ESTIMATED VOLUME (IN LITERS): 1.6 liters 
DECORATION: There are five rows of neck banded coils on the rim of the vessel (Figure 171).

TYPE: La Rue Neck Banded

Figure 171. La Rue Neck Banded jar from the Caney Creek area.

SITE NAME OR SITE NUMBER: Caney Creek

VESSEL NO.: 144

NON-PLASTICS: grog

VESSEL FORM: Bottle with an incurved neck and carinated body (Figure 172)

RIM AND LIP FORM: Direct rim and a rounded lip

CORE COLOR: A (fired and cooled in an oxidizing environment)

INTERIOR SURFACE COLOR: brown (7.5YR 5/4)

EXTERIOR SURFACE COLOR: brown (7.5YR 5/4)

WALL THICKNESS (RIM, BODY, AND BASE IN MM): 4.6 mm, neck

INTERIOR SURFACE TREATMENT: none

EXTERIOR SURFACE TREATMENT: burnished

HEIGHT (IN CM): 27.0

ORIFICE DIAMETER (IN CM): 5.5

DIAMETER AT BOTTOM OF RIM OR NECK (IN CM): 7.7; maximum body diameter is $19.0 \mathrm{~cm}$

BASE DIAMETER (IN CM): 9.0

ESTIMATED VOLUME (IN LITERS): 0.97 liters

DECORATION: There are two horizontal engraved lines on the upper body, and a third horizontal line above the base. The body has a near-vertical scroll with hooked arms, cross-hatched bands pendant to the arms, and a small central cross-hatched circle. The hooked arms of the scroll begin from the apex of upper and lower triangles with three cross-hatched engraved corners (see Figure 172). 
TYPE: Wilder Engraved

Figure 172. Wilder Engraved bottle from the Caney Creek area.

SITE NAME OR SITE NUMBER: Caney Creek

VESSEL NO.: 152

NON-PLASTICS: grog

VESSEL FORM: Jar

RIM AND LIP FORM: Everted rim and a rounded lip

CORE COLOR: A (fired and cooled in an oxidizing environment)

INTERIOR SURFACE COLOR: brown (7.5YR 5/4)

EXTERIOR SURFACE COLOR: brown (7.5YR 5/4)

WALL THICKNESS (RIM, BODY, AND BASE IN MM): 4.4 mm, rim

INTERIOR SURFACE TREATMENT: smoothed on the rim

EXTERIOR SURFACE TREATMENT: smoothed

HEIGHT (IN CM): 5.2

ORIFICE DIAMETER (IN CM): 5.5

DIAMETER AT BOTTOM OF RIM OR NECK (IN CM): 5.6

BASE DIAMETER (IN CM): 4.5

ESTIMATED VOLUME (IN LITERS): 0.17 liters

DECORATION: Plain (Figure 173)

TYPE: Undetermined plain ware

Figure 173. Plain jar from the Caney Creek area. 
SITE NAME OR SITE NUMBER: Caney Creek

VESSEL NO.: 153

NON-PLASTICS: grog

VESSEL FORM: Carinated bowl

RIM AND LIP FORM: Direct rim and a flat lip

CORE COLOR: $\mathrm{F}$ (fired in a reducing environment and cooled in the open air)

INTERIOR SURFACE COLOR: strong brown (7.5YR 5/8); fire clouding on the base

EXTERIOR SURFACE COLOR: brown (7.5YR 5/4); fire clouding on the base

WALL THICKNESS (RIM, BODY, AND BASE IN MM): 4.8 mm, rim

INTERIOR SURFACE TREATMENT: smoothed

EXTERIOR SURFACE TREATMENT: smoothed

HEIGHT (IN CM): 4.5

ORIFICE DIAMETER (IN CM): 8.0

DIAMETER AT BOTTOM OF RIM OR NECK (IN CM): 8.5

BASE DIAMETER (IN CM): 4.0

ESTIMATED VOLUME (IN LITERS): 0.22 liters

DECORATION: A singe row of tool punctates around the top of the vessel rim, possibly simulating the crimping of the rim and lip (Figure 174).

TYPE: Undetermined utility ware

Figure 174. Tool punctated carinated bowl from the Caney Creek area.

SITE NAME OR SITE NUMBER: Caney Creek

VESSEL NO.: 170

NON-PLASTICS: grog 
VESSEL FORM: Jar

RIM AND LIP FORM: missing

CORE COLOR: $\mathrm{G}$ (fired in a reducing environment and cooled in the open air)

INTERIOR SURFACE COLOR: very dark grayish-brown (10YR 3/2)

EXTERIOR SURFACE COLOR: yellow (10YR 7/6); fire clouding on the base

WALL THICKNESS (RIM, BODY, AND BASE IN MM): 6.4 mm, body

INTERIOR SURFACE TREATMENT: none; organic residue

EXTERIOR SURFACE TREATMENT: none

HEIGHT (IN CM): N/A

ORIFICE DIAMETER (IN CM): N/A

DIAMETER AT BOTTOM OF RIM OR NECK (IN CM): 20.2

BASE DIAMETER (IN CM): 6.8; dimple base

ESTIMATED VOLUME (IN LITERS): N/A

DECORATION: The rim is plain, except for a row of tool punctations at the rim-body juncture. The body has four appliqued semi-circles, divided from each other by vertical appliqued ridges that extend from the rim-body juncture to near the base (Figure 175).

TYPE: cf. McKinney Plain

Figure 175. McKinney Plain jar from the Caney Creek area.

SITE NAME OR SITE NUMBER: Caney Creek

VESSEL NO.: 172

NON-PLASTICS: grog

VESSEL FORM: Carinated bowl

RIM AND LIP FORM: Inverted rim and a rounded, exterior folded lip

CORE COLOR: $\mathrm{G}$ (fired in a reducing environment and cooled in the open air) 
INTERIOR SURFACE COLOR: dark grayish-brown (10YR 4/2); fire clouding on the body

EXTERIOR SURFACE COLOR: grayish-brown (10YR 5/2); fire clouding on the body and the rim

WALL THICKNESS (RIM, BODY, AND BASE IN MM): 6.2 mm, rim; 6.8 mm, body

INTERIOR SURFACE TREATMENT: smoothed

EXTERIOR SURFACE TREATMENT: burnished

HEIGHT (IN CM): 12.1

ORIFICE DIAMETER (IN CM): 20.4

DIAMETER AT BOTTOM OF RIM OR NECK (IN CM): 21.3

BASE DIAMETER (IN CM): 7.7

ESTIMATED VOLUME (IN LITERS): 1.48 liters

DECORATION: The rim panel has four engraved ovals divided by vertical brackets. Each of the oval panels has upper and lower diagonal linear tick marks or spurs; one of the ovals has an elongated diagonal hatched triangle pendant from the upper part of the panel (Figure 176).

TYPE: cf. Simms Engraved

Figure 176. cf. Simms Engraved carinated bowl from the Caney Creek area.

SITE NAME OR SITE NUMBER: Caney Creek

VESSEL NO.: 173

NON-PLASTICS: grog

VESSEL FORM: Carinated bowl

RIM AND LIP FORM: Inverted rim and a rounded lip

CORE COLOR: A (fired and cooled in an oxidizing environment)

INTERIOR SURFACE COLOR: brown (10YR 5/3); fire clouding on the base 
EXTERIOR SURFACE COLOR: brown (10YR 5/3); fire clouding on the base

WALL THICKNESS (RIM, BODY, AND BASE IN MM): $6.4 \mathrm{~mm}$, rim; $8.9 \mathrm{~mm}$, body; $10.2 \mathrm{~mm}$, base

INTERIOR SURFACE TREATMENT: smoothed

EXTERIOR SURFACE TREATMENT: burnished

HEIGHT (IN CM): 14.2

ORIFICE DIAMETER (IN CM): 24.0

DIAMETER AT BOTTOM OF RIM OR NECK (IN CM): 24.5

BASE DIAMETER (IN CM): 8.6

ESTIMATED VOLUME (IN LITERS): 3.1 liters

DECORATION: The rim panel has an engraved scroll and simple circle motif that is repeated four times around the vessel. The central circle consist of 1-2 very closelyspaced circular lines (Figure 177), not the circle and "cross" decorative element of the classic scroll and circle motif (cf. Thurmond 1990:Figure 6c).

TYPE: Ripley Engraved

Figure 177. Ripley Engraved carinated bowl, scroll and simple circle motif, from the Caney Creek area.

SITE NAME OR SITE NUMBER: Caney Creek

VESSEL NO.: 174

NON-PLASTICS: grog

VESSEL FORM: Carinated bowl

RIM AND LIP FORM: Inverted rim and a flat lip

CORE COLOR: $\mathrm{H}$ (fired in a reducing environment and cooled in the open air)

INTERIOR SURFACE COLOR: dark brown (7.5YR 3/3)

EXTERIOR SURFACE COLOR: brown (7.5YR 4/4); fire clouding on the base 
WALL THICKNESS (RIM, BODY, AND BASE IN MM): $6.1 \mathrm{~mm}$, rim

INTERIOR SURFACE TREATMENT: smoothed

EXTERIOR SURFACE TREATMENT: smoothed

HEIGHT (IN CM): 10.8

ORIFICE DIAMETER (IN CM): 15.0

DIAMETER AT BOTTOM OF RIM OR NECK (IN CM): 16.5

BASE DIAMETER (IN CM): 6.5

ESTIMATED VOLUME (IN LITERS): 0.97 liters

DECORATION: The rim panel has the hooked arm scroll motif repeated six times

around the vessel. A red clay pigment has been rubbed in the engraved lines (Figure 178).

TYPE: Taylor Engraved

Figure 178. Taylor Engraved carinated bowl from the Caney Creek area.

SITE NAME OR SITE NUMBER: Caney Creek

VESSEL NO.: 175

NON-PLASTICS: grog

VESSEL FORM: Carinated bowl

RIM AND LIP FORM: Inverted rim and a rounded, exterior folded lip

CORE COLOR: B (fired and cooled in a low oxygen environment)

INTERIOR SURFACE COLOR: very dark grayish-brown (10YR 3/2)

EXTERIOR SURFACE COLOR: very dark grayish-brown (10YR 3/2); fire clouding

WALL THICKNESS (RIM, BODY, AND BASE IN MM): $5.1 \mathrm{~mm}$, rim

INTERIOR SURFACE TREATMENT: smoothed

EXTERIOR SURFACE TREATMENT: burnished 
HEIGHT (IN CM): 8.0

ORIFICE DIAMETER (IN CM): 15.0

DIAMETER AT BOTTOM OF RIM OR NECK (IN CM): 17.0

BASE DIAMETER (IN CM): 6.5

ESTIMATED VOLUME (IN LITERS): 0.72 liters

DECORATION: The rim panel has the hooked arm scroll motif repeated six times around the vessel. There are two hatched brackets as part of each motif, the brackets anchoring the scroll to the rim and the vessel carination (Figure 179).

TYPE: Taylor Engraved

Figure 179. Taylor Engraved bowl from the Caney Creek area.

SITE NAME OR SITE NUMBER: Caney Creek

VESSEL NO.: 176

NON-PLASTICS: grog and hematite

VESSEL FORM: Carinated bowl

RIM AND LIP FORM: Inverted rim and a rounded, exterior folded, lip

CORE COLOR: $\mathrm{F}$ (fired in a reducing environment and cooled in the open air)

INTERIOR SURFACE COLOR: grayish-brown (10YR 5/2); fire clouding

EXTERIOR SURFACE COLOR: brown (7.5YR 5/3); fire clouding

WALL THICKNESS (RIM, BODY, AND BASE IN MM): 5.9 mm, rim

INTERIOR SURFACE TREATMENT: smoothed

EXTERIOR SURFACE TREATMENT: smoothed

HEIGHT (IN CM): 14.5

ORIFICE DIAMETER (IN CM): 20.0 
DIAMETER AT BOTTOM OF RIM OR NECK (IN CM): 22.5

BASE DIAMETER (IN CM): 8.5

ESTIMATED VOLUME (IN LITERS): 2.6 liters

DECORATION: The rim panel has the hooked arm scroll motif repeated six times around the vessel. There are three hatched brackets as part of each motif (Figure 180), the brackets serving to anchor the scroll to the rim and the vessel carination.

TYPE: Taylor Engraved

Figure 180. Taylor Engraved carinated bowl from the Caney Creek area.

SITE NAME OR SITE NUMBER: Caney Creek

VESSEL NO.: 223

NON-PLASTICS: grog

VESSEL FORM: Bottle with a short neck

RIM AND LIP FORM: Direct rim and a rounded lip

CORE COLOR: F (fired in a reducing environment and cooled in the open air)

INTERIOR SURFACE COLOR: pale brown (10YR 6/3)

EXTERIOR SURFACE COLOR: brown (10YR 5/3)

WALL THICKNESS (RIM, BODY, AND BASE IN MM): 5.6 mm, neck; 7.2 mm, body

INTERIOR SURFACE TREATMENT: none

EXTERIOR SURFACE TREATMENT: burnished

HEIGHT (IN CM): N/A

ORIFICE DIAMETER (IN CM): 6.0

DIAMETER AT BOTTOM OF RIM OR NECK (IN CM): 7.6

BASE DIAMETER (IN CM): N/A

ESTIMATED VOLUME (IN LITERS): N/A 
DECORATION: There are four rows of tool punctations on the vessel body, just below the bottle neck (Figure 181).

TYPE: cf. Maxey Noded Redware, except without the red slip on the exterior vessel surface (cf. Suhm and Jelks 1962:101)

Figure 181. cf. Maxey Noded Redware bottle from the Caney Creek area.

SITE NAME OR SITE NUMBER: Caney Creek

VESSEL NO.: 227

NON-PLASTICS: bone and grog

VESSEL FORM: Bottle

RIM AND LIP FORM: Direct rim; the lip is missing; there is a raised collar at the top of the vessel body

CORE COLOR: $\mathrm{G}$ (fired in a reducing environment and cooled in the open air)

INTERIOR SURFACE COLOR: dark grayish-brown (10YR 4/2)

EXTERIOR SURFACE COLOR: brown (7.5YR 4/4); fire clouding

WALL THICKNESS (RIM, BODY, AND BASE IN MM): 5.5 mm, neck

INTERIOR SURFACE TREATMENT: none

EXTERIOR SURFACE TREATMENT: burnished

HEIGHT (IN CM): 15.8

ORIFICE DIAMETER (IN CM): 4.2

DIAMETER AT BOTTOM OF RIM OR NECK (IN CM): 4.9; maximum width on the body is $13.0 \mathrm{~cm}$

BASE DIAMETER (IN CM): 6.5

ESTIMATED VOLUME (IN LITERS): 0.41 liters

DECORATION: The vessel body has a stacked series of engraved continuous scrolls, with a central engraved hooked arm scroll line beginning and ending with a small 
engraved circle at the end of one of the hooked arm. This complex motif is repeated five times around the vessel body (Figure 182). Above and below (i.e., from the top of the body and then near the base) the series of stacked scrolls are smaller hooked arm fill elements with areas of hatching and cross-hatching.

TYPE: Taylor Engraved

Figure 182. Taylor Engraved bottle from the Caney Creek area.

SITE NAME OR SITE NUMBER: Caney Creek

VESSEL NO.: 228

NON-PLASTICS: grog

VESSEL FORM: Carinated bowl

RIM AND LIP FORM: Direct rim and a rounded, exterior folded lip

CORE COLOR: B (fired and cooled in a reducing environment)

INTERIOR SURFACE COLOR: black (10YR 2/1)

EXTERIOR SURFACE COLOR: black (10YR 2/1)

WALL THICKNESS (RIM, BODY, AND BASE IN MM): 7.5 mm, rim

INTERIOR SURFACE TREATMENT: smoothed

EXTERIOR SURFACE TREATMENT: burnished

HEIGHT (IN CM): 11.7

ORIFICE DIAMETER (IN CM): 25.5

DIAMETER AT BOTTOM OF RIM OR NECK (IN CM): 25.2

BASE DIAMETER (IN CM): 6.4

ESTIMATED VOLUME (IN LITERS): 1.8 liters

DECORATION: The rim panel has an engraved scroll motif (Thurmond 1990:Figure 6b) repeated four times around the vessel. The central divider between the scrolls is a vertical negative S-shaped element formed by excising (Figure 183). The upper and lower scroll fill elements are cross-hatched brackets and excised triangular areas. 
TYPE: Ripley Engraved

Figure 183. Ripley Engraved carinated bowl, engraved scroll motif, from the Caney Creek area.

SITE NAME OR SITE NUMBER: Caney Creek

VESSEL NO.: 231

NON-PLASTICS: grog

VESSEL FORM: Carinated bowl

RIM AND LIP FORM: Inverted rim and a rounded, exterior folded lip

CORE COLOR: A (fired and cooled in a high oxygen environment)

INTERIOR SURFACE COLOR: reddish-yellow (7.5YR 6/6); fire clouding on the body and base

EXTERIOR SURFACE COLOR: reddish-yellow (7.5YR 6/6)

WALL THICKNESS (RIM, BODY, AND BASE IN MM): 7.6 mm, rim

INTERIOR SURFACE TREATMENT: smoothed

EXTERIOR SURFACE TREATMENT: smoothed; organic residue on the body

HEIGHT (IN CM): 12.5

ORIFICE DIAMETER (IN CM): 20.4

DIAMETER AT BOTTOM OF RIM OR NECK (IN CM): 22.0

BASE DIAMETER (IN CM): 8.2

ESTIMATED VOLUME (IN LITERS): 1.53 liters

DECORATION: The rim panel has the hooked arm scroll motif repeated 11 times around the vessel (Figure 184).

TYPE: Taylor Engraved

Figure 184. Taylor Engraved carinated bowl from the Caney Creek area. 
SITE NAME OR SITE NUMBER: Caney Creek

VESSEL NO.: 233

NON-PLASTICS: grog and hematite

VESSEL FORM: Bottle with a spool neck (Figure 185)

RIM AND LIP FORM: Everted rim and a rounded lip

CORE COLOR: A (fired and cooled in a high oxygen environment)

INTERIOR SURFACE COLOR: light yellowish-brown (10YR 6/4)

EXTERIOR SURFACE COLOR: light yellowish-brown (10YR 6/4); fire clouding on the body and base

WALL THICKNESS (RIM, BODY, AND BASE IN MM): 5.4 mm, rim

INTERIOR SURFACE TREATMENT: none

EXTERIOR SURFACE TREATMENT: burnished

HEIGHT (IN CM): 10.8

ORIFICE DIAMETER (IN CM): 3.9

DIAMETER AT BOTTOM OF RIM OR NECK (IN CM): $3.8 ; 10.0 \mathrm{~cm}$ at the widest part of the vessel body

BASE DIAMETER (IN CM): 4.0

ESTIMATED VOLUME (IN LITERS): 0.17 liters

DECORATION: The vessel body has a stacked series of narrow curvilinear engraved bands whose arms repeatedly hook around each other, similar to the hooked arm scroll motif on Taylor Engraved vessels. Within each band is a single curvilinear engraved line (see Figure 185). The stacked series of curvilinear engraved bands is repeated five times around the vessel body. The vessel is also lip notched.

TYPE: cf. Hudson Engraved, except it is not shell-tempered (see Suhm and Jelks 1962:81)

Figure 185. cf. Hudson Engraved spool-necked bottle from the Caney Creek area. 
SITE NAME OR SITE NUMBER: Caney Creek

VESSEL NO.: 235

NON-PLASTICS: grog

VESSEL FORM: Bottle with a probable spool neck

RIM AND LIP FORM: Direct; the lip is missing

CORE COLOR: B (fired and cooled in a reducing environment)

INTERIOR SURFACE COLOR: black (10YR 2/1)

EXTERIOR SURFACE COLOR: very dark grayish-brown (10YR 3/2); fire clouding

WALL THICKNESS (RIM, BODY, AND BASE IN MM): 5.8 mm, neck

INTERIOR SURFACE TREATMENT: none

EXTERIOR SURFACE TREATMENT: smoothed

HEIGHT (IN CM): 8.5

ORIFICE DIAMETER (IN CM): 3.6

DIAMETER AT BOTTOM OF RIM OR NECK (IN CM): 4.2; maximum width on the body is $10.5 \mathrm{~cm}$

BASE DIAMETER (IN CM): 5.5

ESTIMATED VOLUME (IN LITERS): 0.19 liters

DECORATION: The central motif is a series of curvilinear engraved scrolls (3-5 lines each) with hooked arms, and the arms hook around a small central engraved circle. This motif is repeated four times around the vessel body. The scroll motif is connected to the upper and lower vessel body by sets of three vertical engraved lines (Figure 186).

Underneath the bottle neck are four small rectangular engraved panels, with a single short horizontal line within each panel.

TYPE: Taylor Engraved

Figure 186. Taylor Engraved spool-necked bottle from the Caney Creek area. 
SITE NAME OR SITE NUMBER: Caney Creek

VESSEL NO.: 238

NON-PLASTICS: grog; sandy paste

VESSEL FORM: Carinated bowl

RIM AND LIP FORM: Direct rim with a rounded and exterior folded lip

CORE COLOR: B (fired and cooled in a low oxygen environment)

INTERIOR SURFACE COLOR: very dark gray (10YR 3/1)

EXTERIOR SURFACE COLOR: very dark gray (10YR 3/1)

WALL THICKNESS (RIM, BODY, AND BASE IN MM): 7.2 mm, rim

INTERIOR SURFACE TREATMENT: burnished on the rim, and smoothed on the body

EXTERIOR SURFACE TREATMENT: burnished

HEIGHT (IN CM): 7.6

ORIFICE DIAMETER (IN CM): 12.7

DIAMETER AT BOTTOM OF RIM OR NECK (IN CM): 12.8

BASE DIAMETER (IN CM): 5.8

ESTIMATED VOLUME (IN LITERS): 0.58 liters

DECORATION: The rim panel has an engraved scroll and circle motif (Thurmond 1990:Figure 6c) that is repeated four times around the vessel. The central circle in the motif is a swastika-in-circle (Figure 187). A white kaolin clay pigment has been rubbed in the engraved lines.

TYPE: Ripley Engraved

Figure 187. Ripley Engraved carinated bowl with a scroll and circle motif, Caney Creek area.

SITE NAME OR SITE NUMBER: Caney Creek

VESSEL NO.: 241 
NON-PLASTICS: grog

VESSEL FORM: Jar

RIM AND LIP FORM: Everted rim and a rounded lip

CORE COLOR: $\mathrm{F}$ (fired in a reducing environment and cooled in the open air)

INTERIOR SURFACE COLOR: brown (10YR 5/3)

EXTERIOR SURFACE COLOR: yellowish-brown (10YR 5/6)

WALL THICKNESS (RIM, BODY, AND BASE IN MM): 8.0 mm, rim

INTERIOR SURFACE TREATMENT: smoothed

EXTERIOR SURFACE TREATMENT: smoothed on the body

HEIGHT (IN CM): 12.2

ORIFICE DIAMETER (IN CM): 14.8

DIAMETER AT BOTTOM OF RIM OR NECK (IN CM): 11.5

BASE DIAMETER (IN CM): 5.7

ESTIMATED VOLUME (IN LITERS): 1.08 liters

DECORATION: There are two rows of horizontal neck bands on the vessel rim; the rest of the vessel is plain (Figure 188).

TYPE: La Rue Neck Banded

Figure 188. La Rue Neck Banded jar from the Caney Creek area.

SITE NAME OR SITE NUMBER: Caney Creek

VESSEL NO.: 244

NON-PLASTICS: grog

VESSEL FORM: Bottle with a spool neck

RIM AND LIP FORM: Everted rim and a rounded lip 
CORE COLOR: $\mathrm{F}$ (fired in a reducing environment and cooled in the open air)

INTERIOR SURFACE COLOR: yellowish-brown (10YR 5/4)

EXTERIOR SURFACE COLOR: yellowish-brown (10YR 5/4); fire clouding

WALL THICKNESS (RIM, BODY, AND BASE IN MM): 3.2 mm, rim; 7.4 mm, neck

INTERIOR SURFACE TREATMENT: none

EXTERIOR SURFACE TREATMENT: burnished

HEIGHT (IN CM): 13.0

ORIFICE DIAMETER (IN CM): 4.1

DIAMETER AT BOTTOM OF RIM OR NECK (IN CM): 4.4; maximum body width is $10.8 \mathrm{~cm}$

BASE DIAMETER (IN CM): $3.8 \mathrm{~cm}$

ESTIMATED VOLUME (IN LITERS): 0.2 liters

DECORATION: The vessel body has a series of five narrow spiral or curvilinear engraved bands whose arms hook around each other, similar to the hooked arm scroll motif on Taylor Engraved vessels (Figure 189). Within each band are a series of short dashed engraved lines (see Suhm and Jelks 1962:Plate 41b-d). The vessel is also lip notched.

TYPE: cf. Hudson Engraved, except it is not shell-tempered.

Figure 189. cf. Hudson Engraved spool-necked bottle from the Caney Creek area.

SITE NAME OR SITE NUMBER: Caney Creek

VESSEL NO.: 246

NON-PLASTICS: grog; sandy paste

VESSEL FORM: Carinated bowl

RIM AND LIP FORM: Direct rim and a rounded lip

CORE COLOR: $\mathrm{G}$ (fired in a reducing environment and cooled in the open air) 
INTERIOR SURFACE COLOR: dark gray (10YR 4/1)

EXTERIOR SURFACE COLOR: light yellowish-brown (10YR 6/4)

WALL THICKNESS (RIM, BODY, AND BASE IN MM): 5.9 mm, rim

INTERIOR SURFACE TREATMENT: smoothed on the rim; organic residue on the rim

EXTERIOR SURFACE TREATMENT: burnished

HEIGHT (IN CM): 12.9

ORIFICE DIAMETER (IN CM): 22.4

DIAMETER AT BOTTOM OF RIM OR NECK (IN CM): 22.7

BASE DIAMETER (IN CM): 9.0

ESTIMATED VOLUME (IN LITERS): 1.7 liters

DECORATION: The rim panel has an engraved continuous scroll motif (Thurmond 1990:Figure 6f) that is repeated four times around the vessel. The upper and lower scroll fill elements with each motif consist of four cross-hatched engraved brackets and two excised triangular zones (Figure 190).

TYPE: Ripley Engraved

Figure 190. Ripley Engraved carinated bowl from the Caney Creek area.

SITE NAME OR SITE NUMBER: Caney Creek

VESSEL NO.: 247

NON-PLASTICS: grog and hematite

VESSEL FORM: Jar

RIM AND LIP FORM: Everted rim and a rounded, exterior folded lip

CORE COLOR: $\mathrm{H}$ (fired in a reducing environment and cooled in the open air)

INTERIOR SURFACE COLOR: light yellowish-brown (10YR 6/4) 
EXTERIOR SURFACE COLOR: dark grayish-brown (10YR 4/2); fire clouding on the body

WALL THICKNESS (RIM, BODY, AND BASE IN MM): 4.9 mm, rim; $5.1 \mathrm{~mm}$, body

INTERIOR SURFACE TREATMENT: smoothed

EXTERIOR SURFACE TREATMENT: smoothed

HEIGHT (IN CM): 15.0

ORIFICE DIAMETER (IN CM): N/A

DIAMETER AT BOTTOM OF RIM OR NECK (IN CM): N/A

BASE DIAMETER (IN CM): 4.5

ESTIMATED VOLUME (IN LITERS): N/A

DECORATION: There are at least two sets (the vessel is broken, and it is not possible to ascertain the number of repetitions, although it is most likely four repetitions) of two appliqued nodes on the rim. Under each set of nodes, and beginning at the rim-body juncture, is a vertical appliqued ridge. Between the vertical appliqued ridges are appliqued chevrons, also formed from appliqued ridges.

TYPE: McKinney Plain

SITE NAME OR SITE NUMBER: Caney Creek

VESSEL NO.: 254

NON-PLASTICS: shell

VESSEL FORM: Carinated bowl, hubcap form (Figure 191)

RIM AND LIP FORM: Direct rim and a rounded lip, with upper and lower panels

CORE COLOR: N/A

INTERIOR SURFACE COLOR: dark grayish-brown (10YR 4/2, lower panel); red (2.5YR 4/6, upper panel)

EXTERIOR SURFACE COLOR: dark grayish-brown (10YR 4/2, lower panel); red (2.5YR 4/6, upper panel) 
WALL THICKNESS (RIM, BODY, AND BASE IN MM): 5.4 mm, rim; 5.3 mm, body

INTERIOR SURFACE TREATMENT: burnished

EXTERIOR SURFACE TREATMENT: burnished

HEIGHT (IN CM): 7.8

ORIFICE DIAMETER (IN CM): 14.7

DIAMETER AT BOTTOM OF RIM OR NECK (IN CM): 16.2

BASE DIAMETER (IN CM): N/A

ESTIMATED VOLUME (IN LITERS): 0.68 liters

DECORATION: The lower (and nearly horizontal) part of the upper rim panel has four widely-spaced sets of three short vertical engraved lines. The vessel is also lip notched (see Figure 191).

TYPE: Simms Engraved. The fact that this vessel is shell-tempered indicates that it was made outside of the Caney Creek valley, probably from a Caddo group living in the middle Red River (late McCurtain phase) basin (Cogswell et al. 2008).

Figure 191. Simms Engraved carinated bowl from the Caney Creek area, Wood County, Texas.

SITE NAME OR SITE NUMBER: Caney Creek

VESSEL NO.: 255

NON-PLASTICS: grog

VESSEL FORM: Carinated bowl, hubcap form, with upper and lower panels (Figure 192)

RIM AND LIP FORM: Direct rim and a rounded lip

CORE COLOR: B (fired and cooled in a low oxygen environment)

INTERIOR SURFACE COLOR: dark gray (7.5YR 4/1)

EXTERIOR SURFACE COLOR: dark gray (7.5YR 4/1) 
WALL THICKNESS (RIM, BODY, AND BASE IN MM): 5.9 mm, rim; 3.9 mm, body; $4.4 \mathrm{~mm}$, base

INTERIOR SURFACE TREATMENT: smoothed

EXTERIOR SURFACE TREATMENT: burnished

HEIGHT (IN CM): 8.0

ORIFICE DIAMETER (IN CM): 17.0

DIAMETER AT BOTTOM OF RIM OR NECK (IN CM): 18.0

BASE DIAMETER (IN CM): N/A

ESTIMATED VOLUME (IN LITERS): 0.82 liters

DECORATION: The upper rim panel is plain. The top (and nearly horizontal part) of the lower panel has a discontinuous diagonal scroll repeated four times around the vessel; these scrolls are separated by a single vertical engraved line at the beginning of each scroll. The scroll has small triangular tick marks whose apex point toward the vessel base. In addition to the diagonal discontinuous scroll motif, there is also an excised triangle at one end of the scroll itself. The vessel is also lip notched (see Figure 192).

TYPE: Simms Engraved

Figure 192. Simms Engraved hubcap-form carinated bowl, Caney Creek area, Wood County, Texas.

SITE NAME OR SITE NUMBER: Caney Creek

VESSEL NO.: 256

NON-PLASTICS: grog

VESSEL FORM: Jar

RIM AND LIP FORM: Everted rim and a rounded lip

CORE COLOR: G (fired in a reducing environment and cooled in the open air)

INTERIOR SURFACE COLOR: black (10YR 2/1)

EXTERIOR SURFACE COLOR: brown (7.5YR 5/4) 
WALL THICKNESS (RIM, BODY, AND BASE IN MM): 8.4 mm, rim; $6.1 \mathrm{~mm}$, body

INTERIOR SURFACE TREATMENT: smoothed

EXTERIOR SURFACE TREATMENT: smoothed on the body; organic residue

HEIGHT (IN CM): 16.0

ORIFICE DIAMETER (IN CM): 19.0

DIAMETER AT BOTTOM OF RIM OR NECK (IN CM): N/A

BASE DIAMETER (IN CM): N/A

ESTIMATED VOLUME (IN LITERS): 2.7 liters

DECORATION: Four rows of neck bands on the vessel rim. There are also four appliqued chevron ridges below the rim-body juncture (Figure 193).

TYPE: La Rue Neck Banded

Figure 193. La Rue Neck Banded jar from the Caney Creek area, Wood County, Texas.

SITE NAME OR SITE NUMBER: Caney Creek

VESSEL NO.: 259

NON-PLASTICS: bone and grog

VESSEL FORM: Carinated bowl

RIM AND LIP FORM: Direct rim and a rounded, exterior folded lip

CORE COLOR: $\mathrm{H}$ (fired in a reducing environment and cooled in the open air)

INTERIOR SURFACE COLOR: brown (10YR 5/3)

EXTERIOR SURFACE COLOR: dark brown (10YR 3/3)

WALL THICKNESS (RIM, BODY, AND BASE IN MM): 6.7 mm, rim; 6.4 mm, body

INTERIOR SURFACE TREATMENT: smoothed

EXTERIOR SURFACE TREATMENT: smoothed 
HEIGHT (IN CM): N/A

ORIFICE DIAMETER (IN CM): 28.0

DIAMETER AT BOTTOM OF RIM OR NECK (IN CM): N/A

BASE DIAMETER (IN CM): N/A

ESTIMATED VOLUME (IN LITERS): N/A

DECORATION: The rim panel has an engraved continuous scroll motif (Thurmond 1990:Figure 6f), probably repeated four times around the vessel (Figure 194).

TYPE: Ripley Engraved

Figure 194. Ripley Engraved carinated bowl fragment from the Caney Creek area, Wood County, Texas.

SITE NAME OR SITE NUMBER: Caney Creek

VESSEL NO.: 266

NON-PLASTICS: grog

VESSEL FORM: Bottle

RIM AND LIP FORM: Direct rim; the lip is missing

CORE COLOR: B (fired and cooled in a low oxygen environment)

INTERIOR SURFACE COLOR: dark grayish-brown (10YR 4/2)

EXTERIOR SURFACE COLOR: dark grayish-brown (10YR 4/2); fire clouding on the body

WALL THICKNESS (RIM, BODY, AND BASE IN MM): 5.1 mm, neck

INTERIOR SURFACE TREATMENT: none

EXTERIOR SURFACE TREATMENT: smoothed

HEIGHT (IN CM): 6.0

ORIFICE DIAMETER (IN CM): 3.5 
DIAMETER AT BOTTOM OF RIM OR NECK (IN CM): 4.3; maximum body width is $7.0 \mathrm{~cm}$

BASE DIAMETER (IN CM): 5.5

ESTIMATED VOLUME (IN LITERS): 0.13 liters

DECORATION: The vessel body has three engraved panels. Two of the panels have the same design: a central oval surrounded by a curvilinear line with attached hatched areas on one side of the line (Figure 195). The other panel has a semi-circular hatched zone separated from half of a semi-circular hatched zone by a single semi-circular engraved line. The top and bottom of the panels is delimited by two very closely-spaced horizontal engraved lines.

TYPE: Undetermined fine ware

Figure 195. Engraved bottle of undetermined type from the Caney Creek area, Wood County, Texas. 


\section{Pottery Vessel Comparisons and Ceramic Traditions}

The pottery vessels in the J. A. Walters and Bernie Ward collections are from Caddo sites that fall into a number of discrete geographical areas: the Caney Creek drainage in the upper Sabine River basin; from west to east, the Village Creek, Harris Creek, and Prairie Creek drainages in the middle Sabine River basin; the upper Neches River basin; and the upper Angelina River basin (see Figure 1). The sites from which the pottery vessels were obtained are not well dated through radiocarbon analysis - except perhaps for the Spoonbill site, based on archeological research carried out by Bruseth and Perttula 1981. Nevertheless, $\mathrm{n}$ the main, the burials at these sites that had whole pottery vessels placed in them as funerary offerings date to Middle Caddo (ca. A.D. 1200-1400) or Late Caddo (ca. A.D. 1400-1680) period times based on stylistic grounds. How do the Caddo pottery vessels from mortuary contexts from these different geographic areas and temporal periods compare with each other with respect to key attributes of vessel manufacture and decoration?

\section{Vessel Forms}

There are a wide range of vessel forms in the Caddo mortuary vessels from sites in the Caney Creek, upper Neches, upper Angelina, and Harris, Village, and Prairie Creek areas (Table 4). The principal vessel forms in each of the regions, regardless of the temporal context, are carinated bowls, jars, bottles, and bowls (including several different forms within each of the vessel categories), but there are also compound bowls, deep bowls, effigy bowls, and beakers.

Table 4. Vessel Forms.

\begin{tabular}{|c|c|c|c|c|c|c|c|}
\hline Vessel Forms & $\begin{array}{l}\text { Caney-Titus } \\
\text { phase }\end{array}$ & $\begin{array}{l}\text { Caney-Middle } \\
\text { Caddo }\end{array}$ & $\begin{array}{l}\text { Upper } \\
\text { Neches }\end{array}$ & $\begin{array}{l}\text { Upper } \\
\text { Ang. }\end{array}$ & $\begin{array}{l}\text { Harris } \\
\text { Creek }\end{array}$ & $\begin{array}{l}\text { Village } \\
\text { Creek }\end{array}$ & $\begin{array}{l}\text { Prairie } \\
\text { Creek }\end{array}$ \\
\hline $\begin{array}{l}\text { Bottle with } \\
\text { spool neck }\end{array}$ & $7.4^{*}$ & - & - & - & - & - & - \\
\hline $\begin{array}{l}\text { Bottle with } \\
\text { legs }\end{array}$ & 1.1 & - & - & - & - & - & - \\
\hline Bottle & 6.3 & 22.2 & 27.3 & - & 14.9 & 20.0 & - \\
\hline $\begin{array}{l}\text { Compound } \\
\text { bottle }\end{array}$ & 1.1 & - & - & - & - & - & - \\
\hline $\begin{array}{l}\text { Cylindrical } \\
\text { bottle }\end{array}$ & - & - & - & 22.2 & - & - & - \\
\hline Beaker & - & - & - & - & 6.4 & - & - \\
\hline $\begin{array}{l}\text { Carinated } \\
\text { bowl }\end{array}$ & 51.6 & 22.2 & 27.3 & 44.4 & 31.9 & - & - \\
\hline $\begin{array}{l}\text { Carinated } \\
\text { bowl, hubcap }\end{array}$ & 3.2 & - & - & - & - & - & - \\
\hline Bowl & 5.3 & 44.4 & 18.2 & 11.1 & 17.0 & 20.0 & - \\
\hline
\end{tabular}


Table 4. Vessel Forms, cont.

\begin{tabular}{|c|c|c|c|c|c|c|c|}
\hline Vessel Forms & $\begin{array}{l}\text { Caney-Titus } \\
\text { phase }\end{array}$ & $\begin{array}{l}\text { Caney-Middle } \\
\text { Caddo }\end{array}$ & $\begin{array}{l}\text { Upper } \\
\text { Neches }\end{array}$ & $\begin{array}{l}\text { Upper } \\
\text { Ang. }\end{array}$ & $\begin{array}{l}\text { Harris } \\
\text { Creek }\end{array}$ & $\begin{array}{l}\text { Village } \\
\text { Creek }\end{array}$ & $\begin{array}{l}\text { Prairie } \\
\text { Creek }\end{array}$ \\
\hline $\begin{array}{l}\text { Bowl with ext. } \\
\text { thickened rim }\end{array}$ & 1.1 & - & - & - & - & - & - \\
\hline Deep bowl & - & - & - & - & 6.4 & 40.0 & 12.5 \\
\hline Effigy bowl & - & - & 9.1 & 5.6 & 2.1 & - & - \\
\hline $\begin{array}{l}\text { Compound } \\
\text { bowl }\end{array}$ & 4.2 & - & - & - & 2.1 & - & - \\
\hline $\begin{array}{l}\text { Compound } \\
\text { bowl with } \\
\text { strap handles }\end{array}$ & - & - & - & - & 2.1 & - & - \\
\hline Jar & 18.9 & 11.1 & 9.1 & 11.1 & 12.8 & 20.0 & 87.5 \\
\hline $\begin{array}{l}\text { Jar with lugs } \\
\text { Jar with strap }\end{array}$ & - & - & 9.1 & - & - & - & - \\
\hline handles & - & - & - & 5.6 & 4.3 & - & - \\
\hline $\begin{array}{l}\text { Summary by } \\
\text { vessel form }\end{array}$ & & & & & & & \\
\hline Bottle & 15.8 & 22.2 & 27.3 & 22.2 & 14.9 & 20.0 & - \\
\hline Beaker & - & - & - & - & 6.4 & - & - \\
\hline Carinated bowl & 54.7 & 22.2 & 27.3 & 44.4 & 31.9 & - & - \\
\hline Bowl & 6.3 & 44.4 & 18.2 & 11.1 & 17.0 & 20.0 & - \\
\hline Deep bowl & - & - & - & - & 6.4 & 40.0 & 12.5 \\
\hline Effigy bowl & - & - & 9.1 & 5.6 & 2.1 & - & - \\
\hline Compound bowl & 4.2 & - & - & - & 4.3 & - & - \\
\hline Jar & 18.9 & 11.1 & 18.2 & 16.7 & 17.0 & 20.0 & 87.5 \\
\hline Totals & 95 & 9 & 11 & 18 & 47 & 5 & 8 \\
\hline
\end{tabular}

Bottles are an important part of Caddo pottery vessel assemblages, and it was typical that at least one bottle was placed as a funerary offering in each grave (except apparently not the case among the Prairie Creek burials); bottles account for 14.9-27.3\% of the vessels in each assemblage (see Table 4). The latest forms of the bottles include cylindrical bottles with short necks in the upper Angelina River site (both Hume Engraved and Poynor Engraved forms), spool neck bottles (in the Caney Creek area), and a Hodges Engraved bottle form with four hollow legs (cf. Suhm and Jelks 1962:Plate 37b). Earlier bottle forms tend to have globular bodies and long, relatively straight necks.

Beakers, including an example with engraved rattlesnake motifs, are present only in Middle Caddo period burials in the Harris Creek area (see Table 4). Similar decorated beakers have been found in other sites in the middle Sabine River basin as well as in the 
Angelina and Neches River basins, in contemporaneous Middle Caddo sites in Rusk and Panola counties (see Suhm and Jelks 1962:Plate 61c; Perttula and Nelson 2003:Figure 2.9; Rogers and Perttula 2004).

Carinated bowls are also well represented in these Caddo vessel assemblages. This is particularly the case in Late Caddo mortuary vessel assemblages from the upper Angelina (Frankston phase) and Caney Creek (Titus phase) areas (see Table 4), where they account for $44.4-54.7 \%$ of all the vessels. The preferential placement in burial features of carinated bowls that would have been used in life as serving vessels has been well documented in much larger Frankston and Titus phase vessel samples from East Texas (Perttula 2005, 2009). One distinctive form of carinated bowl present in the Caney Creek area in late Titus phase contexts is the hubcap form of certain Simms Engraved vessels (cf. Skinner et al. 1969; Perttula 1992:Table 11; Suhm and Jelks 1962:Plate 71bc), a vessel form apparently made and used between ca. A.D. 1500-1700. Compound bowls are present only in the Harris Creek (Middle Caddo period) and Caney Creek areas (see Table 4), the vessels in the latter area are found in association with other Late Caddo Titus phase mortuary vessels.

Bowls and deep bowls are relatively more abundant in mortuary contexts in Caddo burials of Middle Caddo period age in the Caney Creek, Harris Creek, Prairie Creek, and Village Creek areas than they are in Late Caddo contexts, irrespective of the geographic area. Together, between $23.4-60 \%$ of the vessels from the Caney Creek, Harris Creek, and Village Creek sites are bowls and deep bowls (see Table 4). Effigy bowls, on the other hand, are only represented in Frankston phase burials in the upper Neches and upper Angelina River basins as well as in the Harris Creek area in the middle Sabine River basin (see Table 4); this suggests that perhaps there was a cultural relationship between the Caddo peoples that lived in these areas.

Jars, used in life for cooking and storing food stuffs, consistently account for between $11.1-20 \%$ of the mortuary vessels from the different geographic areas, except in the small vessel sample from the Prairie Creek sites, where $87.5 \%$ of the vessels are jars (see Table 4). Jars with lugs or strap handles are noted only in the upper Neches, upper Angelina, and Harris Creek areas, where they occur on $25-50 \%$ of all the jars (see Table 4).

\section{Rim and Lip Form}

The rim profile of the vessels from the J. A. Walters and Bernie Ward collections include everted, direct or vertical, or inverted profiles. Most of the lips tend to be rounded, but there are also flat lips (Table 5). Everted rims are found most commonly on jars, but also on some bottle forms (especially near the lip), while direct and inverted rims are best seen on bowls and carinated bowls, as well as on some jars. Occasionally the lip of some of the vessels has been folded over towards the exterior vessel surface; other lips have distinctive Redwine or Sprocket lip modes (Miller 1986; Walters n.d.). Exterior folded lips occur in the Harris Creek area in Middle Caddo times, and in Titus phase and Frankston phase Late Caddo vessels in the Caney Creek and upper Angelina River areas. 
In the present sample, vessels with Redwine or Sprocket lip modes are present only in Middle Caddo sites in the Harris Creek area (Table 5).

Table 5. Rim and lip forms.

\begin{tabular}{|c|c|c|c|c|c|c|c|}
\hline $\begin{array}{l}\text { Rim and } \\
\text { lip form }\end{array}$ & $\begin{array}{l}\text { Caney-Titus } \\
\text { phase }\end{array}$ & $\begin{array}{l}\text { Caney-Middle } \\
\text { Caddo }\end{array}$ & $\begin{array}{l}\text { Upper } \\
\text { Neches }\end{array}$ & $\begin{array}{l}\text { Upper } \\
\text { Ang. }\end{array}$ & $\begin{array}{l}\text { Harris } \\
\text { Creek }\end{array}$ & $\begin{array}{l}\text { Village } \\
\text { Creek }\end{array}$ & $\begin{array}{l}\text { Prairie } \\
\text { Creek }\end{array}$ \\
\hline EV-RO & $18.5^{*}$ & - & 27.3 & 5.6 & 12.8 & - & 85.7 \\
\hline EV-FL & - & 11.1 & - & - & - & 20.0 & - \\
\hline $\begin{array}{l}\text { EV-RO, ext f } \\
\text { Subtotal, }\end{array}$ & 2.2 & - & - & 5.6 & - & - & - \\
\hline Everted rim & 20.7 & 11.1 & 27.3 & 11.2 & 12.8 & 20.0 & 85.7 \\
\hline D-RO & 26.1 & 33.3 & 36.4 & 61.1 & 48.9 & 20.0 & - \\
\hline D-FL & 3.3 & 33.3 & 27.3 & 5.6 & 17.0 & 40.0 & 14.3 \\
\hline $\mathrm{D}-\mathrm{RO}, \mathrm{Rm}$ & - & - & - & - & 4.3 & - & - \\
\hline $\mathrm{D}-\mathrm{FL}, \mathrm{Rm}$ & - & - & - & - & 2.1 & - & - \\
\hline $\mathrm{D}-\mathrm{RO}$, ext f & 12.0 & - & - & 16.7 & 4.3 & - & - \\
\hline D-FL, ext f & 1.1 & - & - & - & - & - & - \\
\hline $\mathrm{D}-\mathrm{RO}$, ext f, Rm & - & - & - & - & 2.1 & - & - \\
\hline D-FL, ext f, Rm & - & - & - & - & 2.1 & - & - \\
\hline D-RO, Spr & - & - & - & - & 2.1 & - & - \\
\hline D-FL, Spr & - & - & - & - & 2.1 & - & - \\
\hline D-RO, Scp & - & - & - & - & 2.1 & - & - \\
\hline D-RO, IntTh & - & 22.2 & - & - & - & - & - \\
\hline $\mathrm{D}-\ldots * *$ & 3.3 & - & - & - & - & 20.0 & - \\
\hline $\begin{array}{l}\text { Subtotal, } \\
\text { Direct rim }\end{array}$ & 45.8 & 88.8 & 63.7 & 83.4 & 87.2 & 80.0 & 14.3 \\
\hline INV-RO & 18.5 & - & 9.1 & 5.6 & - & - & - \\
\hline INV-RO, ext f & 12.0 & - & - & - & - & - & - \\
\hline INV-RO, IBv & 1.1 & - & - & - & - & - & - \\
\hline INV-FL & 2.2 & - & - & - & - & - & - \\
\hline $\begin{array}{l}\text { Subtotal, } \\
\text { Inverted rim }\end{array}$ & 32.8 & 0.0 & 9.1 & 5.6 & 0.0 & 0.0 & 0.0 \\
\hline$\frac{\text { Summary of: }}{\text { ext folded lip }}$ & 27.3 & 0.0 & 0.0 & 22.3 & 8.5 & 0.0 & 0.0 \\
\hline Redwine mode & 0.0 & 0.0 & 0.0 & 0.0 & 10.6 & 0.0 & 0.0 \\
\hline Sprocket mode & 0.0 & 0.0 & 0.0 & 0.0 & 4.2 & 0.0 & 0.0 \\
\hline Totals & 92 & 9 & 11 & 18 & 47 & 5 & 7 \\
\hline
\end{tabular}

*percentage; **lip is missing; $\mathrm{EV}=$ everted rim in profile; $\mathrm{D}=$ direct rim in profile; $\mathrm{INV}=$ inverted in profile; $\mathrm{RO}=$ rounded lip; $\mathrm{FL}=$ flat lip; ext $\mathrm{f}=$ =xterior folded; $\mathrm{Spr}=$ sprocket lip mode (see Miller 1986); $\mathrm{Rm}=\mathrm{Redwine}$ lip mode (Walters n.d.); $\mathrm{Scp}=$ scalloped lip; IBv=interior beveled; $\mathrm{IntTh}=$ interior thickened rim

Inverted rim vessels are present only in mortuary vessels from Late Caddo cemeteries in the Caney Creek, upper Neches, and upper Angelina drainage basins (see Table 5). These kinds of vessels are particularly abundant in post-A.D. 1550 Titus phase contexts (cf. Perttula 2007a) in the Caney Creek area, suggesting that this rim form has 
chronological significance. With the exception of the Prairie Creek area, the relative proportion of direct rim vessels is particularly common in Middle Caddo assemblages (80-88.8\% of the vessels) and in the upper Angelina River basin (83.4\%). The frequency of direct rim vessels in Late Caddo contexts in the upper Neches and Caney Creek areas ranges from $45.8-63.7 \%$ (see Table 5).

\section{Temper and Paste}

The Caddo vessels in the J. A. Walters and Bernie Ward collections, regardless of their geographic area or temporal context, are from grog-tempered pottery traditions (Table 6). Between 93.7-100\% of the vessels by area and cultural period have grog temper added to the paste, either as the sole temper inclusion $(62.5-80 \%)$, or in combination with hematite or bone. Hematite temper occurs in 9.1-22.2\% of the vessels from the different geographic areas, with the exception of the Prairie Creek and Village Creek areas, where it was not apparently used in vessel tempering. Bone temper is present in 5.3-20\% of the vessels that are not Frankston phase mortuary vessels from the upper Neches and upper Angelina River basin sites, but is absent in vessels from the latter two areas. The dearth of bone temper use in these areas is consistent with other ceramic analytical findings from the upper Neches, were the use of bone temper in vessels and domestic site sherd assemblages was typically less than 3-5\% in Late Caddo and Early Historic Caddo pottery assemblages (see Perttula 2009). The single shelltempered vessel from the Caney Creek area (Table 6) is considered an import from a manufacturing locale on the middle reaches of the Red River, in the area of the Sam Kaufman site (see Figure 1), where shell-tempered pottery was virtually the sole pottery manufactured there after ca. A.D. 1300.

Table 6. Use of different tempers and sandy pastes.

\begin{tabular}{|c|c|c|c|c|c|c|c|}
\hline $\begin{array}{l}\text { Tempers and } \\
\text { sandy paste }\end{array}$ & $\begin{array}{l}\text { Caney-Titus } \\
\text { phase }\end{array}$ & $\begin{array}{l}\text { Caney-Middle } \\
\text { Caddo }\end{array}$ & $\begin{array}{l}\text { Upper } \\
\text { Neches }\end{array}$ & $\begin{array}{l}\text { Upper } \\
\text { Ang. }\end{array}$ & $\begin{array}{l}\text { Harris } \\
\text { Creek }\end{array}$ & $\begin{array}{l}\text { Village } \\
\text { Creek }\end{array}$ & $\begin{array}{l}\text { Prairie } \\
\text { Creek }\end{array}$ \\
\hline $\begin{array}{l}\text { grog } \\
\text { grog/sandy }\end{array}$ & $77.8^{*}$ & 77.8 & 72.7 & 72.2 & 68.8 & 80.0 & 62.5 \\
\hline paste & 2.1 & - & 9.1 & 5.6 & 4.2 & - & 25.0 \\
\hline $\begin{array}{l}\text { grog-hematite } \\
\text { grog-hematite- }\end{array}$ & 11.6 & 11.1 & 9.1 & 22.2 & 12.5 & - & - \\
\hline $\begin{array}{l}\text { organics } \\
\text { grog-hematite- }\end{array}$ & 1.1 & - & - & - & - & - & - \\
\hline $\begin{array}{l}\text { bone } \\
\text { grog-hematite- } \\
\text { bone/sandy } \\
\text { naste }\end{array}$ & 11 & - & - & - & 4.2 & - & - \\
\hline $\begin{array}{l}\text { grog-bone } \\
\text { grog-bone/ }\end{array}$ & 4.2 & 11.1 & - & - & 4.2 & 20.0 & 12.5 \\
\hline sandy paste & - & - & 9.1 & - & - & - & - \\
\hline bone & - & - & - & - & 2.1 & - & - \\
\hline shell & 1.1 & - & - & - & - & - & - \\
\hline none & - & - & - & - & 4.2 & - & - \\
\hline
\end{tabular}


Table 6. Use of different tempers and sandy pastes, cont.

\begin{tabular}{|c|c|c|c|c|c|c|c|}
\hline $\begin{array}{l}\text { Tempers and } \\
\text { sandy paste }\end{array}$ & $\begin{array}{l}\text { Caney-Titus } \\
\text { phase }\end{array}$ & $\begin{array}{l}\text { Caney-Middle } \\
\text { Caddo }\end{array}$ & $\begin{array}{l}\text { Upper } \\
\text { Neches }\end{array}$ & $\begin{array}{l}\text { Upper } \\
\text { Ang. }\end{array}$ & $\begin{array}{l}\text { Harris } \\
\text { Creek }\end{array}$ & $\begin{array}{l}\text { Village } \\
\text { Creek }\end{array}$ & $\begin{array}{l}\text { Prairie } \\
\text { Creek }\end{array}$ \\
\hline \multicolumn{8}{|l|}{$\begin{array}{l}\text { summary of } \\
\text { temper/paste } \\
\text { in vessels }\end{array}$} \\
\hline $\begin{array}{l}\text { grog } \\
\text { hematite } \\
\text { bone } \\
\text { shell } \\
\text { sandy paste }\end{array}$ & $\begin{array}{l}98.9 \\
13.7 \\
5.3 \\
1.1 \\
3.2\end{array}$ & $\begin{array}{l}100.0 \\
11.1 \\
11.1 \\
- \\
-\end{array}$ & $\begin{array}{l}100.0 \\
9.1 \\
- \\
- \\
9.1\end{array}$ & $\begin{array}{l}100.0 \\
22.2 \\
- \\
- \\
5.6\end{array}$ & $\begin{array}{l}93.7 \\
16.7 \\
10.4 \\
- \\
4.2\end{array}$ & $\begin{array}{l}100.0 \\
- \\
20.0 \\
- \\
-\end{array}$ & $\begin{array}{l}100.0 \\
- \\
12.5 \\
- \\
25.0\end{array}$ \\
\hline Totals & 95 & 9 & 11 & 18 & 48 & 5 & 8 \\
\hline
\end{tabular}

*percentage

The vast majority of the vessels have either a clay or silty paste, and the clays for vessel manufacture were likely gathered from nearby alluvial settings, probably within a short (1-7 km away, at most) distance from each of the settlements. Depending upon the geographic area, about 3.2-25\% percent of the vessels have a fine sandy paste, suggesting that a naturally sandy clay was occasionally selected by Caddo potters, especially in the Prairie Creek, upper Neches, and upper Angelina River areas for use in making particular kinds of vessels. Those with a sandy paste may have facilitated resistance to thermal shock or mechanical breakage. The preferential occurrence of sand in the clay paste of Frankston phase vessels in the upper Neches and Angelina may, in fact, indicate a particular focus on the use of alluvial clays by local potters (at least after the $15^{\text {th }}$ century), rather than the harder to process bedrock clay. Another study of $15^{\text {th }}-17^{\text {th }}$ century vessels from the upper Neches documented that between 18-34\% of the vessels had a sandy paste (see Perttula 2009).

\section{Firing Conditions}

The Caddo pottery vessels in the J. A. Walters and Bernie Ward collections have been fired under several different conditions (Table 7). With the exception of the upper Angelina River vessels from 41SM290, the vast majority of the vessels have been fired in a low oxygen or reducing environment (75-100\%). In turn, most of these reduced-fired vessels were cooled in the open air (or exposed to an open fire) near the end of the firing process, leaving the vessel with a dark core and with either one or both vessel surfaces with a thin oxidized or lighter-colored band visible in cross-section. 
Table 7. Firing conditions.

\begin{tabular}{|c|c|c|c|c|c|c|c|}
\hline $\begin{array}{l}\text { Firing } \\
\text { Conditions }\end{array}$ & $\begin{array}{l}\text { Caney-Titus } \\
\text { phase }\end{array}$ & $\begin{array}{l}\text { Caney-Middle } \\
\text { Caddo }\end{array}$ & $\begin{array}{l}\text { Upper } \\
\text { Neches }\end{array}$ & $\begin{array}{l}\text { Upper } \\
\text { Ang. }\end{array}$ & $\begin{array}{l}\text { Harris } \\
\text { Creek }\end{array}$ & $\begin{array}{l}\text { Village } \\
\text { Creek }\end{array}$ & $\begin{array}{l}\text { Prairie } \\
\text { Creek }\end{array}$ \\
\hline Oxidizing & $9.5^{*}$ & - & 27.3 & 44.4 & 25.0 & - & - \\
\hline $\begin{array}{l}\text { Incompletely } \\
\text { oxidized }\end{array}$ & 1.1 & 11.1 & 9.1 & 5.6 & - & - & - \\
\hline Reducing & 18.9 & 11.1 & - & 11.1 & 12.5 & - & 50.0 \\
\hline $\begin{array}{l}\text { Reducing, } \\
\text { cooled in } \\
\text { open air }\end{array}$ & 70.6 & 77.8 & 63.6 & 38.9 & 62.5 & 100.0 & 50.0 \\
\hline Totals & 95 & 9 & 11 & 18 & 48 & 5 & 8 \\
\hline
\end{tabular}

By geographic area, the Caddo vessels included in Late Caddo period burials from the upper Neches and upper Angelina River areas, and from Middle Caddo period contexts at the Harris Creek sites, were most likely to have been fired in an oxidizing or high oxygen environment (see Table 7). Incompletely oxidized or low-fired pottery was also present in relatively low frequencies in the upper Neches and upper Angelina burial features, as it was in closely comparable amounts in Middle Caddo burial vessels from the Caney Creek valley in the upper Sabine River basin. The highest proportion of vessels fired in a reducing environment includes the Prairie Creek, Village Creek, and Caney Creek geographic areas (see Table 7)

\section{Decorative Methods}

Most of the mortuary vessels in Caddo pottery assemblages in the Sabine, Neches, and Angelina River basins are decorated. As will be discussed below, much of the decorated pottery is fine ware, with engraved or trailed designs, typically on carinated bowls and bottles, but a variety of vessel forms in these geographic areas have engraved designs. Utility wares have wet paste designs; that is, designs that were executed prior to a vessel being fired.

Eleven different utility ware ceramic types have been identified in the J. A. Walters and Bernie Ward collections from the different geographic areas, as well as 18 fine ware types (see Suhm and Jelks 1962; Hart 1982; Perttula 2009; Perttula et al. 1998, 2007; Webb 1959) (Table 8). The earlier utility ware types are present in the Village and Prairie Creek areas - including Canton Incised and Dunkin Incised - as well as the Harris Creek area, which has Dunkin Incised, Crockett Curvilinear Incised, Reavely BrushedIncised, and Killough Pinched. All of these types can be reasonably be expected to occur in ca. A.D. 1200-1400 contexts in Caddo sites in the middle Sabine River basin, as well as other parts of Northeast Texas. In the upper Neches, the sole utility ware identified in 
the J. W. Walters and Bernie Ward collections is Bullard Brushed, a Frankston phase cooking jar. Titus phase utility wares in the Caney Creek area include in order of frequency: McKinney Plain ( $\mathrm{n}=7$ ), La Rue Neck Banded ( $\mathrm{n}=5)$, Mockingbird Punctated $(\mathrm{n}=2)$, and Moore Noded $(\mathrm{n}=1)$. The absence of brushed utility wares is typical of western Titus phase ceramic traditions (Perttula 2005, ed.:401-405 and Table 11-10; Bruseth and Perttula 1981).

Table 8. Identified Pottery Types in the Collections.

\begin{tabular}{|c|c|c|c|c|c|c|c|}
\hline $\begin{array}{l}\text { Pottery } \\
\text { Types }\end{array}$ & $\begin{array}{l}\text { Caney-Titus } \\
\text { phase }\end{array}$ & $\begin{array}{l}\text { Caney-Middle } \\
\text { Caddo }\end{array}$ & $\begin{array}{l}\text { Upper } \\
\text { Neches }\end{array}$ & $\begin{array}{l}\text { Upper } \\
\text { Ang. }\end{array}$ & $\begin{array}{l}\text { Harris } \\
\text { Creek }\end{array}$ & $\begin{array}{l}\text { Village } \\
\text { Creek }\end{array}$ & $\begin{array}{l}\text { Prairie } \\
\text { Creek }\end{array}$ \\
\hline \multicolumn{8}{|l|}{ Utility Ware } \\
\hline $\begin{array}{l}\text { Canton Incised } \\
\text { Canton or } \\
\text { Maydelle I }\end{array}$ & & & & & & $\mathrm{X}$ & $\mathrm{X}$ \\
\hline $\begin{array}{l}\text { Dunkin Incised } \\
\text { Crockett C-I } \\
\text { Reavely B-I } \\
\text { Killough } \\
\text { Pinched }\end{array}$ & $X^{*}$ & & & & $\begin{array}{l}X \\
X \\
X \\
X\end{array}$ & & $\mathrm{X}$ \\
\hline $\begin{array}{l}\text { Bullard Brushed } \\
\text { McKinney Pl. } \\
\text { Mockingbird P } \\
\text { La Rue NB } \\
\text { Moore Noded }\end{array}$ & $\begin{array}{l}X \\
X \\
X \\
X\end{array}$ & & $\mathrm{X}$ & & & & \\
\hline \multicolumn{8}{|l|}{ Fine Ware } \\
\hline $\begin{array}{l}\text { Hickory Eng. } \\
\text { Maxey NR } \\
\text { Sanders Eng. } \\
\text { Spoonbill Eng. }\end{array}$ & & $\begin{array}{l}X \\
X \\
X\end{array}$ & & & & $\mathrm{X}$ & \\
\hline Handy Eng. & & & & & $\mathrm{X}$ & & \\
\hline $\begin{array}{l}\text { Haley Eng. } \\
\text { Washington SP }\end{array}$ & & & & & $\mathrm{X}$ & & \\
\hline $\begin{array}{l}\text { Washington SP } \\
\text { Poynor Eng. }\end{array}$ & & & $\mathrm{X}$ & & $\begin{array}{l}X \\
X\end{array}$ & & \\
\hline $\begin{array}{l}\text { Poynor Eng. } \\
\text { Hood Eng. }\end{array}$ & & & $\begin{array}{l}\Lambda \\
X\end{array}$ & $\begin{array}{l}\Lambda \\
X\end{array}$ & $\begin{array}{l}\Lambda \\
X\end{array}$ & & \\
\hline Hume Eng. & & & & $\mathrm{X}$ & & & \\
\hline Taylor Eng. & $\mathrm{X}$ & & & & & & \\
\hline Wilder Eng. & $\mathrm{X}$ & & & & & & \\
\hline Hodges Eng. & $\mathrm{X}$ & & & & & & \\
\hline Ripley Eng. & $\mathrm{X}$ & & & & & & \\
\hline Simms Eng. & $\mathrm{X}$ & & & & & & \\
\hline Hudson Eng. & $\mathrm{X}$ & & & & & & \\
\hline Womack Eng. & $\mathrm{X}$ & & & & & & \\
\hline Keno Tr. & $\mathrm{X}$ & & & & & & \\
\hline
\end{tabular}

$\mathrm{X}=$ presence; *late variety?; I=Incised; C-I=curvilinear incised; B-I=brushed-incised; Pl.=plain;

$\mathrm{P}=$ punctated; $\mathrm{NB}=$ neck banded; $\mathrm{NR}=$ noded redware; Eng.=engraved; $\mathrm{SP}=$ square paneled; $\mathrm{TR} .=$ trailed 
The earlier sets of engraved fine wares include Hickory Engraved in the Village Creek area; and Maxey Noded Redware, Sanders Engraved, and Spoonbill Engraved from the $13^{\text {th }}$ and $14^{\text {th }}$ century component at the Spoonbill site in the Caney Creek area. Bruseth and Perttula (1981:Table 5-10) identified four vessels from two burials in this component. ${ }^{1}$ They included two Monkstown Fingernail Impressed jars, a Sanders Engraved carinated bowl, and a plain bottle.

The fine wares Handy Engraved, Haley Engraved, and Washington Square Paneled have been identified from the Harris Creek area (see Table 8); these latter fine wares definitely point to social relationships and some shared ceramic stylistic practices between the Harris Creek Caddo and Caddo groups in the Angelina River basin (Hart 1982; Corbin and Hart 1998) as well as in the Red River, Haley phase, area of Caddo peoples in southwestern Arkansas. The Middle Caddo fine wares in the Harris Creek area, perhaps dating at the very end of the $14^{\text {th }}$ century A.D. at the Redwine site, also include examples of Poynor Engraved and Hood Engraved. These are more common fine wares in ca. A.D. 1400-1650 Frankston phase contexts - as seen in the upper Neches and Angelina River basins (see Table 8), along with Hume Engraved - but recent analyses of a large series of whole vessels in the upper Neches suggests that early varieties of Poynor Engraved are known that date from as early as ca. A.D. 1320-1400 (Perttula 2009).

The final set of engraved fine ware types are from the late Titus phase components at several sites in the Caney Creek area in the upper Sabine River basin (see Table 8); a number of these vessels (12.9\%) have a red slip as well as red or white pigments as decorative embellishments (see below). These include Taylor Engraved carinated bowls $(\mathrm{n}=13)$ and bottles $(\mathrm{n}=5)$, Wilder Engraved bottles $(\mathrm{n}=1)$, a Hodges Engraved bottle, Ripley Engraved carinated bowls $(\mathrm{n}=26)$ and compound bowls $(\mathrm{n}=1)$, Simms Engraved (including var. Darco) carinated bowls ( $\mathrm{n}=8$ ), Hudson Engraved bottles $(\mathrm{n}=4)$, Womack Engraved carinated bowls $(\mathrm{n}=2)$, and Keno Trailed bottles $(\mathrm{n}=1)$ and bowls $(\mathrm{n}=1$, var. Phillips). The Ripley Engraved rim motifs primarily include the continuous scroll $(n=11)$, the scroll $(n=7)$, the scroll and circle $(n=3)$, interlocking horizontal scroll $(\mathrm{n}=2)$, and the pendant triangle $(\mathrm{n}=1)$ (see Thurmond 1990:Figure 6a-c, $\mathrm{f}-\mathrm{g}$ ). These are popular western Titus phase rim engraved motifs (Perttula 2005:404). Bruseth and Perttula (1981:Table 5-10) recovered seven vessels from a late Titus phase burial at the Spoonbill site. They included a LaRue Neck Banded jar, a $16^{\text {th }}$ and $17^{\text {th }}$ century hubcap form Simms Engraved carinated bowl, a McKinney Plain (or appliqued) jar, and four Ripley Engraved carinated bowls. The engraved motifs on these Ripley Engraved vessels include the scroll $(\mathrm{n}=1)$, continuous scroll $(\mathrm{n}=2)$, and scroll and circle $(n=1)$.

Many of the engraved carinated bowls in the Caney Creek area have inverted rims (see below), and there are several spool-necked bottles; these are both pottery attributes characteristic of $16^{\text {th }}$ and $17^{\text {th }}$ century Titus phase vessel manufacture and style. Womack Engraved and Keno Trailed are likely evidence of post-A.D. 1650 mortuary use and vessel manufacture in the Caney Creek area. 
Dispensing with the typological categorizations, we can also examine and compare the different vessel assemblages with respect to the various decorative methods (i.e., brushing, incising, engraving), or combinations of decorative methods (i.e., brushedpunctated, engraved-brushed-punctated) represented on the decorated utility wares and fine wares. There are 15 combinations of utility ware decorative methods in these Caddo vessel collections, as well as nine fine ware decorative methods (Table 9).

Table 9. Decorative Methods represented in the Vessel collections.

\begin{tabular}{|c|c|c|c|c|c|c|c|}
\hline $\begin{array}{l}\text { Decorative } \\
\text { methods }\end{array}$ & $\begin{array}{l}\text { Caney-Titus } \\
\text { phase }\end{array}$ & $\begin{array}{l}\text { Caney-Middle } \\
\text { Caddo }\end{array}$ & $\begin{array}{l}\text { Upper } \\
\text { Neches }\end{array}$ & $\begin{array}{l}\text { Upper } \\
\text { Ang. }\end{array}$ & $\begin{array}{l}\text { Harris } \\
\text { Creek }\end{array}$ & $\begin{array}{l}\text { Village } \\
\text { Creek }\end{array}$ & $\begin{array}{l}\text { Prairie } \\
\text { Creek }\end{array}$ \\
\hline \multicolumn{8}{|l|}{ Utility ware } \\
\hline$\overline{\mathrm{I}}$ & 1.1 & 11.1 & - & - & 2.9 & - & 28.6 \\
\hline I-P & - & - & - & - & 14.7 & 50.0 & 42.9 \\
\hline $\mathrm{P}$ & 4.3 & 11.1 & 14.3 & - & 8.8 & 25.0 & - \\
\hline P-A & 3.2 & - & - & - & - & - & - \\
\hline P-Pi & - & - & - & - & 5.9 & - & - \\
\hline B & - & - & 14.3 & - & - & - & - \\
\hline B-P & - & - & 14.3 & - & 2.9 & - & - \\
\hline B-P-Pi & - & - & - & - & 2.9 & - & - \\
\hline B-A-P & - & - & - & - & 2.9 & - & 14.3 \\
\hline A & 3.2 & - & - & - & - & - & - \\
\hline NB & 3.2 & - & - & 6.7 & - & - & - \\
\hline NB-A & 2.2 & - & - & - & - & - & - \\
\hline $\mathrm{R}$ & - & - & - & - & - & - & 14.3 \\
\hline $\mathrm{R}-\mathrm{A}$ & 3.2 & - & - & - & - & - & - \\
\hline R-P & 1.1 & - & - & - & - & - & - \\
\hline $\begin{array}{l}\text { Subtotal, } \\
\text { Utility ware }\end{array}$ & 21.5 & 22.2 & 42.9 & 6.7 & 41.0 & 75.0 & 100.0 \\
\hline \multicolumn{8}{|l|}{ Fine ware } \\
\hline$\overline{\mathrm{E}}$ & 66.7 & 55.5 & 42.9 & 93.3 & 44.1 & 25.0 & - \\
\hline E-RS & 8.6 & - & - & - & - & - & - \\
\hline E-P & 1.1 & - & - & - & 2.9 & - & - \\
\hline E-B & - & - & 14.3 & - & - & - & - \\
\hline E-B-P & - & - & - & - & 2.9 & - & - \\
\hline TR & 2.2 & - & - & - & - & - & - \\
\hline RS & - & - & - & - & 8.8 & - & - \\
\hline RS-P & - & 11.1 & - & - & - & - & - \\
\hline RS-P-I & - & 11.1 & - & - & - & - & - \\
\hline $\begin{array}{l}\text { Subtotal, } \\
\text { Fine ware }\end{array}$ & 78.6 & 77.7 & 57.2 & 93.3 & 58.7 & 25.0 & 0.0 \\
\hline $\begin{array}{l}\% \text { Plain ware } \\
\text { in total } \\
\text { vessel assemblage }\end{array}$ & $e^{2.1}$ & 0.0 & 36.3 & 16.7 & 27.7 & 20.0 & 12.5 \\
\hline Totals & 93 & 9 & 7 & 15 & 34 & 4 & 7 \\
\hline
\end{tabular}

$\mathrm{I}=$ incised; $\mathrm{P}=$ =punctated; $\mathrm{A}=$ appliqued; $\mathrm{Pi}=$ pinched; $\mathrm{B}=$ brushed; $\mathrm{NB}=$ neck banded; $\mathrm{R}=$ roughened; $\mathrm{E}=$ engraved; $\mathrm{RS}=$ red-slipped; $\mathrm{TR}=$ trailed 
Utility wares are well represented in the mortuary vessels from the upper Neches, Harris Creek, Village Creek, and Prairie Creek areas, where they account for between 41$100 \%$ of the vessels found in burials (see Table 9). In the upper Neches, the utility wares are brushed, brushed-punctated, and punctated jars. In the area of the three creeks, the principal utility wares have incised-punctated, incised, and punctated designs. In the Harris Creek area, this unique assemblage also has brushed-punctated, brushedpunctated-pinched, and brushed-appliqued-punctated vessels, along with punctatedpinched vessels; they comprise approximately $35 \%$ of the utility wares (see Table 9 ).

In the upper Angelina and Caney Creek areas, utility ware vessels are apparently not common funerary offerings. They comprise only $6.7-22.2 \%$ of the mortuary vessels in these areas (see Table 9). The Middle Caddo utility wares from the Caney Creek area are incised and punctated, broadly similar in proportions to the Middle Caddo vessels from the Harris Creek area. The upper Angelina River utility ware is a neck banded vessel. Neck banded utility ware jars are also part of the Titus phase vessel assemblages from the Caney Creek area, where they account for $24 \%$ of the sample (see Table 9). Punctated and punctated-appliqued (35\%) and roughened-appliqued and roughenedpunctated $(20 \%)$ are also important decorative methods represented in the late Titus phase vessels from the Caney Creek area (see Table 9).

Vessels decorated solely with engraved lines are absent in the small sample of vessels from the Prairie Creek area. Otherwise, they are moderately common in the mortuary assemblages from the Village Creek, Harris Creek, and upper Neches areas (25$44.1 \%$ ), and very common in the other geographic areas (55.5-93.3\%) (see Table 9). By proportion, engraved fine wares account for between $72-100 \%$ of all the fine wares, with the highest proportions in the Village Creek and upper Angelina River areas.

In other Middle Caddo vessel assemblages, there are red-slipped fine wares $(15 \%$ of the fine wares in the Harris Creek area) as well as red-slipped-punctated fine wares (28\% of the Caney Creek Middle Caddo fine wares) (see Table 9). In the Harris Creek area, there are also engraved-punctated and engraved-brushed-punctated fine wares $(10 \%)$. The Late Caddo vessel assemblage in the upper Neches has an engraved-brushed vessel, which is a common decorative combination on large Poynor Engraved carinated bowls in Frankston phase mortuary assemblages (see Perttula 2009). In the Titus phase burials in the Caney Creek area, there are also engraved-red-slipped (11\%), trailed $(2.8 \%)$, and engraved-punctated (1.4\%) fine ware vessels (see Table 9); engraved-redslipped and trailed vessels are absent in the other geographic areas.

Another interesting difference in the composition of the mortuary vessels from these geographic areas is in the total percentage of plain vessels. In some areas, very few plain vessels were placed in graves, while in others (i.e., Middle Caddo sites in the middle Sabine River basin and Late Caddo sites in the upper Neches and Angelina River basins) plain vessels were a common funerary offering. In the Caney Creek area, for instance, only $2.1 \%$ of the vessels in the Titus phase burials are plain (in a larger sample of 2035 vessels from 17 Titus phase cemeteries, $7.7 \%$ of the vessels were plain [Perttula 2005:Table 11-10]); none of them are plain from the Middle Caddo period burials (see 
Table 9). By contrast, in Frankston phase burials from the upper Neches and upper Angelina, between 16.7-36.3\% of the vessels are plain (see Table 9). As a further comparison, in a larger sample of 630 vessels from 35 Frankston and Allen phase cemeteries in the upper Neches, $11.8 \%$ are plain vessels (Perttula 2009). Burials in the Harris, Village, and Prairie Creek areas have numerous plain ware vessel funerary offerings, ranging from 12.5-27.7\% from one area to another (see Table 9).

\section{Lip Notching}

Lip notching is an occasional and distinctive decorative treatment on certain Middle and Late Caddo vessels - almost exclusively seen on fine wares - in several different geographic areas (Table 10) in the upper and middle Sabine River basin and the upper Angelina River basin. It was most commonly employed as a decorative treatment in the Caney Creek drainage, in both Middle Caddo and Late Caddo, Titus phase, pottery vessels placed as funerary offerings.

\section{Table 10. Lip notched vessels.}

\begin{tabular}{|c|c|c|c|c|c|c|c|}
\hline Lip Notched & $\begin{array}{l}\text { Caney-Titus } \\
\text { phase }\end{array}$ & $\begin{array}{l}\text { Caney-Middle } \\
\text { Caddo }\end{array}$ & $\begin{array}{l}\text { Upper } \\
\text { Neches }\end{array}$ & $\begin{array}{l}\text { Upper } \\
\text { Ang. }\end{array}$ & $\begin{array}{l}\text { Harris } \\
\text { Creek }\end{array}$ & $\begin{array}{l}\text { Village } \\
\text { Creek }\end{array}$ & $\begin{array}{l}\text { Prairie } \\
\text { Creek }\end{array}$ \\
\hline Frequency & $8.4 \%$ & $11.1 \%$ & - & $5.6 \%$ & $2.1 \% *$ & - & - \\
\hline Total vessels & 95 & 9 & 11 & 18 & 48 & 5 & 8 \\
\hline \multicolumn{8}{|c|}{ *notched only on the tab tail of an effigy vessel } \\
\hline $\begin{array}{l}\text { The } \\
\text { late (post-ca } \\
(\mathrm{n}=2), \mathrm{a} \mathrm{Ke} \\
\text { Simms Eng } \\
\text { Engraved ca }\end{array}$ & $\begin{array}{l}\text { notched ve } \\
\text { A.D. } 1550-1 \\
\text { Engraved, } \\
\text { ved, var. Da } \\
\text { nated bowl. }\end{array}$ & $\begin{array}{l}\text { ls from the Ca } \\
\text { 0) ceramic typ } \\
\text { Phillips bowl } \\
\text { hubcap-shape }\end{array}$ & $\begin{array}{l}\text { ney Cre } \\
\text { s. Thes } \\
\text { one Ta } \\
\text { d carina }\end{array}$ & $\begin{array}{l}\text { ek area } \\
\text { e incluc } \\
\text { ylor Er } \\
\text { ted boy }\end{array}$ & $\begin{array}{l}\text { in Titus } \\
\text { e Hudss } \\
\text { graved } \\
\text { lls, and }\end{array}$ & $\begin{array}{l}\text { phase t } \\
\text { on Engr } \\
\text { carinate } \\
\text { a third }\end{array}$ & $\begin{array}{l}\text { times includes } \\
\text { aved bottles } \\
\text { d bowl, two } \\
\text { Simms }\end{array}$ \\
\hline
\end{tabular}

\section{Pigments}

Caddo potters made use of both red and white clay pigments as a decorative embellishment on certain fine ware vessels. The red hematite-rich clay and kaolin clay pigments were rubbed in the engraved lines "on vessels whose surface is of a shade that will show up the pigment to the best effect" (Campbell 1936:181).

In the present assemblage of pottery vessels, both red and white clay pigments were used for decorative purposes, although a red clay pigment was preferred on vessels by more than a 3:1 ratio in these geographic areas as a group (Table 11). It may be noteworthy that fine ware vessels in the present sample with pigments are absent in the upper Neches, upper Angelina, Village Creek, and Prairie Creek areas, or simply a 
product of small vessel sample sizes. Where vessels with pigments are present, they are found on between $11.1-15.8 \%$ of the vessels, very similar to the proportions documented by Campbell (1936:182) and Perttula (2009) in larger studies of East Texas Caddo pottery.

Table 11. Use of pigments.

\begin{tabular}{llllllll}
\hline Pigment & $\begin{array}{c}\text { Caney-Titus } \\
\text { phase }\end{array}$ & $\begin{array}{c}\text { Caney-Middle } \\
\text { Caddo }\end{array}$ & $\begin{array}{l}\text { Upper } \\
\text { Neches }\end{array}$ & $\begin{array}{l}\text { Upper } \\
\text { Ang. }\end{array}$ & $\begin{array}{l}\text { Harris } \\
\text { Creek }\end{array}$ & $\begin{array}{l}\text { Village } \\
\text { Creek }\end{array}$ & $\begin{array}{l}\text { Prairie } \\
\text { Creek }\end{array}$ \\
\hline Red pigment & $11.6 \%$ & $11.1 \%$ & - & - & $10.4 \%$ & - & - \\
White pigment & $4.2 \%$ & - & - & - & $2.1 \%$ & - & - \\
\hline Total vessels & 95 & 9 & 11 & 18 & 48 & 5 & 8 \\
\hline
\end{tabular}

By geographic area, pigment use is proportionally the highest, for both red and white pigments (in a 2.8:1 ratio), in Titus phase vessels from the Caney Creek area (see Table 11). The Middle Caddo period burials from the same area are dominated by vessels with a red clay pigment, while both red and white (in a 5:1 ratio) clay pigments have been used in mortuary vessels from the Harris Creek area in Middle Caddo period times. 


\section{Pottery Pipes}

\section{Redwine (41SM193)}

The one pottery pipe (No. 30) documented from the Redwine site is from Burial 3 (others are discussed in Walters et al. 1998). It is a plain untempered elbow pipe that is brownish-yellow (10YR 6/6) in color, with a rounded elbow, a distinct break or collar at the attachment of the bowl and stem, a rounded stem butt end, and a short bowl (24 $\mathrm{mm})$ with a rounded lip (Figure 196); the bowl rim is $3.8 \mathrm{~mm}$ thick. The pipe stem (with a flat lip) is $49 \mathrm{~mm}$ in length ad $8.9 \mathrm{~mm}$ in thickness. The orifice diameter of both the stem and bowl is $33 \mathrm{~mm}$.

Figure 196. Plain elbow pipe from the Redwine site.

\section{$41 S M 247$}

Fragments (\#195a-c) of three Red River style long-stemmed pipes (see Hoffman 1967) are in the collections from 41SM247. Two are grog-tempered and the third is tempered with bone. Two of these pipes were fired in a reducing environment and cooled in the open air (see Teltser 1993:Figure 2f-g) while the other was fired in an oxidizing environment (see Teltser 1993:Figure 2a).

The first pipe sherd (\#195a) is a burnished bowl fragment with a direct rim and a flat lip (Figure 197, $2^{\text {nd }}$ from left). The bowl height is $37.0 \mathrm{~mm}$, and the orifice diameter is $23.0 \mathrm{~mm}$. This is likely a Graves Chapel variety of the Red River pipe (Hoffman 1967:9), based on the size of the bowl. The second pipe sherd (\#195b) is the butt end of a bone-tempered Graves Chapel variety stem (Figure 197, $1^{\text {st }}$ from right). The stem diameter ranges from $3.0 \mathrm{~mm}$ (interior orifice) to $10.5 \mathrm{~mm}$ (exterior orifice). The third pipe stem sherd (\#195c) is a grog-tempered stem piece (direct rim and a flat lip) that had been broken at the bowl attachment (Figure 197, $2^{\text {nd }}$ from right). The interior and exterior stem hole diameters $(10.6 \mathrm{~mm}$ and $16.0 \mathrm{~mm})$ suggest this sherd is from a large Haley variety of the Red River long-stemmed pipe (see Hoffman 1967:10).

Figure 197. Pipe sherds from 41SM247; a (left to right), plain L-shaped elbow pipe; b, Red River pipe, probably Graves Chapel variety; c, Red River pipe stem, Haley variety; d, butt end of Red River pipe, Graves Chapel variety.

The fourth pipe sherd from 41SM247 (\#195d) is a large fragment from a plain Lshaped elbow pipe, probably the earliest form (ca. $14^{\text {th }}$ to early $15^{\text {th }}$ century) of elbow pipe in the middle reaches of the Sabine (Rogers and Perttula 2004) and upper Neches (Perttula 2009) river basins. The pipe is grog-tempered, made with a sandy clay, fired and cooled in a reducing environment, and then burnished (see Figure 197, $1^{\text {st }}$ from left). The pipe is approximately $46.3 \mathrm{~mm}$ in length, with an exterior stem diameter of $19.0 \mathrm{~mm}$; the stem hole diameter is $11.0 \mathrm{~mm}$. 


\section{SM290}

There are three undecorated elbow pipes in the Bernie Ward collection from 41SM290 (Figure 198a-c). They have generally the same bowl and stem size and length/height, with broad bowls and stem orifice diameters (Table 12). On the first two pipes the attachment of the bowl and stem is near a right angle, and the stem is perpendicular to the bowl, with the stem opening well removed from the bowl (Figure 198a-b). The third elbow pipe has a broad bowl and a sloping stem (Figure 198c).

Figure 198. Plain elbow pipes from 41SM290.

Table 12. Pipes from 41SM290.

\begin{tabular}{lllllll}
\hline Pipe \# Bowl & $\begin{array}{l}\text { Bowl } \\
(\mathrm{mm})\end{array}$ & $\begin{array}{l}\text { Orifice } \\
\text { Diameter } \\
(\mathrm{mm})\end{array}$ & $\begin{array}{l}\text { Stem } \\
(\mathrm{mm})\end{array}$ & $\begin{array}{l}\text { Stem } \\
\text { Ext. } \\
\text { Diam. } \\
(\mathrm{mm})\end{array}$ & $\begin{array}{l}\text { Int. } \\
\text { Dimm } \\
(\mathrm{mm})\end{array}$ & \\
\hline 1 & 39.0 & 32.0 & 45.0 & 20.0 & 11.2 & Direct Flat \\
2 & 32.0 & 28.0 & 49.0 & 17.0 & 10.3 & $\begin{array}{l}\text { Direct Rounded } \\
\text { Direct Flat }\end{array}$ \\
3 & 38.0 & 32.0 & 47.0 & 26.0 & 14.2 & \\
\hline
\end{tabular}

\section{Caney Creek, Wood County}

The Caney Creek pipe (\#248) is an engraved elbow pipe (with a white kaolin clay pigment rubbed in the engraved lines) and is likely to have come from a Titus phase burial, since pipes of this form and decorative style are relatively common in Titus phase contexts in both the upper Sabine and Cypress Creek drainage basins. This grogtempered pipe was fired in a reducing environment and cooled in the open air, has been polished, and is brown (10YR 5/3) in color.

The pipe is a maximum of $62.8 \mathrm{~mm}$ in length, with the bowl $47.3 \mathrm{~mm}$ in length, and with only a short stem $(15.5 \mathrm{~mm})$ extending past the bowl; the remainder of the stem sits under the bowl (Figure 199). The height of the pipe is $39.0 \mathrm{~mm}$. The exterior stem diameter is $27.3 \mathrm{~mm}$.

Figure 199. Titus phase engraved elbow pipe from the Caney Creek area, Wood County, Texas.

The stem has a single horizontal engraved line below the lip, as well as a crosshatched engraved band below the intersection of the stem and bowl. The bowl itself has semi-circular and cross-hatched engraved zones centered on either side of the bowl (see Figure 199). 


\section{Unknown Sites}

There is one small platform pipe (\#194c), grog-tempered, in the J. A. Walters collection. It is circular in shape, with the bowl at the top of the platform, and the edges of the platform have been carved to form a sprocket edge; there is a single broad horizontal engraved line below the stem hole but on the platform, as well as another engraved line that encircles the bowl (Figure 200b). The pipe is $46.0 \times 34.0$ in length and width, and the bowl orifice diameter is $20.2 \mathrm{~mm}$. The stem has an exterior stem diameter of $25.0 \mathrm{~mm}$, with a small $(5.6 \mathrm{~mm})$ stem hole diameter.

Figure 200. Pipes from unknown sites in the Walters collection from Wood or Smith counties, Texas: a (left to right), Red River pipe bowl, Graves Chapel variety; b, small platform pipe; c, engraved elbow pipe.

Another pipe sherd in the collection (\#194b) is a sherd from a grog-tempered (sandy paste) Red River pipe bowl, Graves Chapel variety, that has been broken at the stem attachment; the bottom of the bowl is flat (see Figure 200a). The bowl height is 29.0 $\mathrm{mm}$, and it has a $26.6 \mathrm{~mm}$ orifice diameter. The stem hole is $3.7 \mathrm{~mm}$ in diameter, and the exterior stem diameter is $11.0 \mathrm{~mm}$. There is also a larger pipe section (\#161), the bowl and part of the stem, from a Red River pipe, Haley variety. This pipe is grog-tempered, fired in an oxidizing environment (Teltser 1993:Figure 2a), and then burnished. The bowl is $33.0 \mathrm{~mm}$ in height, with a $23.5 \mathrm{~mm}$ orifice diameter; it is only $1.9 \mathrm{~mm}$ in thickness. The flat and direct stem has a $13.0 \mathrm{~mm}$ diameter; the stem hole is $8.1 \mathrm{~mm}$ in diameter.

One of the pipes (\#192) is an upper Neches River basin elbow pipe style, with an acute, almost flat, angle between the stem and the bowl. The pipe is engraved on both the stem and the bowl with circles and rectangular elements (Figure 201). The stem is 55.2 $\mathrm{mm}$ in length, with an exterior orifice diameter of $25.6 \mathrm{~mm}$; the bowl is $47.7 \mathrm{~mm}$ in height, with an exterior orifice diameter of $31.9 \mathrm{~mm}$.

Figure 201. Upper Neches River basin engraved elbow pipe (\#192) from the Walters collection.

There are eight other elbow pipes or pipe fragments in the J. A. Walters collection; three are decorated (Table 13) and two are L-shaped pipes. All of them are grog $(n=7)$ or grog-hematite $(n=1)$-tempered, and the majority of them $(75 \%)$ have been fired and cooled in an oxidizing environment, one (12.5\%) was fired and cooled in a reducing environment, and the other $(12.5 \%)$ was fired in a reducing environment but cooled in the open air. They are either burnished (37.5\%) or smoothed. Rims are direct with a flat lip. 
Table 13. Pipes from unknown sites in Smith and Wood counties, Texas.

\begin{tabular}{|c|c|c|c|c|c|c|c|}
\hline Pipe \# & $\begin{array}{l}\text { Bowl } \\
\text { Height } \\
(\mathrm{mm})\end{array}$ & $\begin{array}{l}\text { Bowl } \\
\text { Orifice } \\
\text { Diameter } \\
(\mathrm{mm})\end{array}$ & $\begin{array}{l}\text { Stem } \\
\text { Length } \\
(\mathrm{mm})\end{array}$ & $\begin{array}{l}\text { Stem } \\
\text { Ext. } \\
\text { Diam. } \\
(\mathrm{mm})\end{array}$ & $\begin{array}{l}\text { Stem } \\
\text { Int. } \\
\text { Diam. } \\
(\mathrm{mm})\end{array}$ & Rim & Lip \\
\hline \multicolumn{8}{|c|}{ Decorated elbow pipes } \\
\hline $188^{*}$ & 38.0 & 34.0 & 48.1 & 23.0 & 15.1 & Direct & Flat \\
\hline 189 & 31.0 & 39.0 & 50.1 & 28.3 & 16.0 & Direct & Flat \\
\hline $194 a$ & 36.3 & 31.9 & - & 23.5 & 11.0 & - & - \\
\hline \multicolumn{8}{|c|}{ Plain elbow pipes } \\
\hline $186^{*}$ & 46.0 & 27.0 & 59.0 & 24.2 & 15.0 & Direct & Flat \\
\hline 187 & 37.5 & 30.2 & 39.0 & 28.0 & 14.6 & Direct & Flat \\
\hline 190 & 27.0 & 28.8 & 24.0 & 23.8 & 14.2 & Direct & Flat \\
\hline 193 & 38.0 & 28.0 & 36.0 & 25.0 & 5.4 & - & - \\
\hline No no. & & - & - & 32.9 & 14.0 & Direct & Flat \\
\hline
\end{tabular}

*L-shaped

The first of the decorated elbow pipes (\#194a), with a rounded elbow form, has Titus phase engraved elements on the bowl. These consist of two horizontal engraved bands - one under the lip and one above the stem attachment - filled with short diagonal engraved lines (see Figure 200c). The other two decorated pipes may be from sites in the upper Neches River basin or the middle reaches of the Sabine River basin. One (\#189) has a rounded form and a very short stem that wraps under the bowl (similar to \#192, discussed above) and at its end is actually folded up against the bowl itself. The bowl is decorated with eight engraved triangles, four on either side of the bowl (Figure 202a). The other (\#188) is an L-shaped elbow pipe with four distinct engraved elements. The stem has two horizontal engraved lines under the lip, along with a single small pendant oval. The central portion of the under side of the stem has two sets of small hooked arm scrolls. The bowl, like \#189, has eight engraved triangles on the rim, four on each side of the bowl (Figure 202b).

Figure 202. Engraved elbow pipes from the Walters collection: a, \#189; b, \#188.

The plain elbow pipes range from an L-shaped form with a tall bowl and lengthy stem, as well as a large stem opening (Figure 203a), to three others with rounded elbow forms that have a shorter bowl and shorter stem (24-39 cm in total length) (Figure 203bd), and a fourth other with a broad stem. One of these rounded elbow pipe forms has a very small (5.4) stem hole diameter. Otherwise, internal stem hole diameters range from 11.0-16.0 $\mathrm{mm}$ (see Table 13). 
Figure 203. Plain elbow pipes from the Walters collection: a, \#186; b, \#187; c, \#190; d, \#193. 


\section{Conclusions}

This study of the Caddo vessels and pipes in the J. A. Walters and Bernie Ward collections from the upper and middle Sabine, upper Neches, and upper Angelina river basins in East Texas has documented a diversity of plain and decorated vessels, as well as several different kinds of pipes, from mortuary contexts at 16 known sites. These sites principally have mortuary features that date to Middle Caddo (i.e., Caney Creek, Village Creek, Harris Creek, and Prairie Creek) and Late Caddo (i.e., Caney Creek, Titus phase burials; upper Neches, and upper Angelina) period times, with the latest (estimated to date from the late $17^{\text {th }}$ to the early $18^{\text {th }}$ century) mortuary vessels having been found at the Spoonbill (41WD109) and Turquoise sites in the Caney Creek valley. Several of the vessels with unknown provenience (see Appendix 2), specifically of the Holly Fine Engraved type, may be indicative of Early Caddo period burials and settlements in this region, but unfortunately their site and mortuary contexts have been lost since they were collected many years ago.

While the findings of this study are subject to the vagaries of sample size and provenience issues, nevertheless they are important in documenting the wide range of ceramic practices employed by prehistoric and early historic Caddo potters in these regions of East Texas with respect to clay preferences, temper choices, methods of firing, and surface treatment, as well as in the kinds and sizes of vessels that were made and used. Just as significantly, the analysis of the stylistic designs and decorative methods employed in the decoration of utility wares and fine wares has demonstrated that each geographic area - regardless of the temporal context - has its own distinctive set of utility ware and fine ware styles. Pipes ranged from the long-stemmed Red River style (at 41SM247 in the Prairie Creek area), manufactured as late as the $14^{\text {th }}$ century A.D., to several varieties of plain and decorated elbow pipes, including the early L-shaped elbow pipe form, each distinctive to different geographic areas within this part of East Texas (e.g., Jackson 1933; Perttula 2009).

The upper Neches and upper Angelina River area mortuary vessels of Late Caddo, Frankston phase age, in the Walters and Ward collections (see Figure 1), and from many other studied sites, stand apart from each of the vessel assemblages from the Sabine River, and comprise part of distinctive Late Caddo grog-tempered ceramic tradition (Perttula 2009:Figure 6-70) dominated by a number of varieties of Poynor Engraved. In the upper Sabine River, in the Caney Creek area (see Figure 1), the majority of the vessels are from a larger western Titus phase ceramic tradition that also encompasses parts of the upper Big and Little Cypress Creek basins and the upper part of the White Oak Creek basin. The majority of these vessels are from a very late Titus phase occupation, extending into the early $18^{\text {th }}$ century, that has been recently recognized in this part of the western Titus phase area (see Perttula 2006, 2007a; Perttula et al. n.d.; Walters 2007). The character and stylistic variety of this late Titus phase ceramic assemblagedominated by Ripley Engraved, Taylor Engraved, and Simms Engraved fine wares and McKinney Plain/Appliqued and La Rue Neck Banded utility wares - is now much better understood at the local level. 
The Middle Caddo mortuary vessels from the Caney, Village, Harris, and Prairie Creek areas have a local stylistic and technological character, although they belong to the broad regional grog-tempered pottery tradition that characterizes much of the upper and middle Sabine River basin. That local character is particularly evident in the differences in pottery vessel decoration (as well as the proportion of plain wares in each assemblage), as the Caney Creek Middle Caddo ceramics resemble pottery found together as far north as the Red River (in Sanders phase contexts) and across the upper Sabine River basin (cf. Krieger 2000; Bruseth and Perttula 1981). The Village and Prairie Creek areas are the least well understood in stylistic character, but they are more similar to each other in the dominance of incised, incised-punctated, and punctated utility wares than they are in vessel assemblage character to either the Caney Creek or Harris Creek areas. More investigations of Caddo sites, and documentation of collections from both domestic and mortuary contexts, are warranted in the Village and Prairie Creek areas to bring these local ceramic traditions to a full light.

The Harris Creek area Middle Caddo mortuary vessels, especially those from the Redwine site (41SM193) have a character all their own, with unique vessel forms (i.e., beakers, engraved jars with strap handles) and vessel lip modes (the Redwine and sprocket modes, Walters n.d.) as well as a panoply of utility ware and fine ware decorative styles that are not seen elsewhere in this part of the middle Sabine River basin. However, vessels with similar form and stylistic attributes have been documented in the Angelina River basin and in parts of southwestern Arkansas. The Caddo peoples living in the Harris Creek area between ca. A.D. 1200-1400 most likely had extensive contact and social interaction with a diverse range of Caddo groups and potters, and were far from parochial.

We are pleased to be able to put the J. A. Walters and Bernie Ward collections of Caddo pottery vessels and pipes on record, and to have this information available from a number of different sites for present and future studies of the native history of the Caddo in parts of East Texas. Hopefully our study will encourage Caddo archeologists and others interested in the prehistory and history of the Caddo peoples to undertake the study of other important collections - especially those with accurate provenience data - of Caddo material remains (including chipped and ground stone tools) from East Texas.

\section{Notes}

1. None of the vessels described by Bruseth and Perttula (1981:Table 5-10) are illustrated, so the typological identifications proffered there must rely on the vessel attribute observations provided in Table 5-10 of that report. 


\section{References Cited}

Anderson, Keith M.

1972 Prehistoric Settlement of the Upper Neches River. Bulletin of the Texas Archeological Society 43:121-197.

Brown, James A.

1996 The Spiro Ceremonial Center: The Archaeology of Arkansas Valley Caddoan Culture in Eastern Oklahoma. 2 Vols. Memoirs No. 29. Museum of Anthropology, University of Michigan, Ann Arbor.

Bruseth, James E. and Timothy K. Perttula

1981 Prehistoric Settlement Patterns at Lake Fork Reservoir. Texas Antiquities Permit Series No. 2. Archaeology Research Program, Southern Methodist University, Dallas, and Texas Antiquities Committee, Austin.

Campbell, Thomas N.

1936 A Study of Ornamentation in the Pottery of Prehistoric East Texas, with Special Attention Given to Designs. Master of Arts thesis, Department of Anthropology, The University of Texas at Austin.

Cast, Robert, Timothy K. Perttula, Bobby Gonzalez, and Bo Nelson

2006 Documentation of Caddo Ceramic Vessels from 41WD60, Wood County, Texas. Historic Preservation Program, Caddo Nation of Oklahoma, Binger, Oklahoma.

Cogswell, James W., Hector Neff, and Michael D. Glascock

2008 Chemical Variation in Northeastern Texas Ceramics, including Analyses of Sherds from Four Red River County Sites. In "The Archeology of the Roitsch Site (41RR16), an Early to Historic Caddo Period Village on the Red River in Northeast Texas," edited by Timothy K. Perttula, pp. 402-413. Collected Papers from Past Texas Archeological Society Summer Field Schools. Special Publication No. 5. Texas Archeological Society, San Antonio.

Corbin, James E. and John P. Hart

1998 The Washington Square Mound Site: A Middle Caddo Mound Complex in South Central East Texas. Bulletin of the Texas Archeological Society 69:47-78.

El-Seedi, Hesham R., Peter A. G. M. De Smet, Olof Beck, Goran Possnert, and Jan G. Bruhn

2005 Prehistoric Peyote Use: Alkaloid Analysis and Radiocarbon Dating of Archaeological Specimens of Lophophora from Texas. Journal of Ethnopharmacology 101:238-242.

Ferring. C. Reid and Timothy K. Perttula

1987 Defining the Provenance of Red-Slipped Pottery from Texas and Oklahoma by Petrographic Methods. Journal of Archaeological Science 14:437-456. 
Gadus, Eloise F. and Ross C. Fields

1996 Ceramic Vessels from the Pleasure Point Site (41MR63), Marion County, Texas. Technical Report No. 22. Prewitt and Associates, Inc., Austin.

Gadus, Eloise F., Ross C. Fields, Jennifer K. McWilliams, John Dockall, and Michael C. Wilder

2006 National Register Testing of Seven Prehistoric Sites in the Sabine Mine's Area Q, Harrison County, Texas. Reports of Investigations No. 147. Prewitt \& Associates, Inc., Austin.

Gonzalez, Bobby, Robert Cast, Timothy K. Perttula, and Bo Nelson

2005 A Rediscovering of Caddo Heritage: The W. T. Scott Collection at the American Museum of Natural History and Other Caddo Collections from Arkansas and Louisiana. Historic Preservation Program, Caddo Nation of Oklahoma, Binger, Oklahoma.

Harris, R. K., Inus Marie Harris, Jay C. Blaine, and Jerrylee Blaine

1965 A Preliminary Archeological and Documentary Study of the Womack Site, Lamar County, Texas. Bulletin of the Texas Archeological Society 36:287-363.

Hart, John P.

1982 An Analysis of the Aboriginal Ceramics from the Washington Square Mound Site, Nacogdoches County, Texas. Master's thesis, Northeast Louisiana University, Monroe.

Hoffman, Michael P.

1967 Ceramic Pipe Style Chronology along the Red River Drainage in Southwestern Arkansas. The Arkansas Archeologist 8(1):4-14.

Jackson, A. T.

1933 Some pipes of East Texas. Bulletin of the Texas Archeological and Paleontological Society 5:69-86.

Johnson, Leroy, Jr.

1961 An Archeological Survey of Blackburn Crossing Reservoir on the Upper Neches River. Bulletin of the Texas Archeological Society 31:213-238.

Kleinschmidt, Ulrich K. W.

1982 Review and Analysis of the A. C. Saunders Site, 41AN19, Anderson County, Texas. Master's thesis, Department of Anthropology, The University of Texas at Austin. 
Krieger, Alex D.

2000 The Pottery of the Sanders Farm, Lamar County, Texas. In The 1931 Excavations at the Sanders Site, Lamar County, Texas: Notes on the Fieldwork, Human Osteology, and Ceramics, by A. T. Jackson, Marcus S. Goldstein, and Alex D. Krieger, pp. 131-144. Archival Series 2. Texas Archeological Research Laboratory, The University of Texas at Austin.

Miller, John E., III

1986 The Myers Mound: Salvage Excavations at a Caddo II Site in Southwest Arkansas. The Arkansas Archeologist 23/24:67-127.

Perttula, Timothy K.

1989 A Study of Mound Sites in the Sabine River basin, Northeast Texas and Northwest Louisiana. Institute of Applied Sciences, University of North Texas, Denton. Final report submitted to the Texas Historical Commission, Austin.

1992 “The Caddo Nation”: Archaeological \& Ethnohistoric Perspectives. University of Texas Press, Austin.

1997 A Compendium of Radiocarbon and Oxidizable Carbon Ratio Dates from Archaeological Sites in East Texas, with a Discussion of the Age and Dating of Select Components and Phases. Radiocarbon 39(3):305-341.

2005 The M. W. Burks Site (41WD52), A Late Caddo Hamlet in Wood County, Texas. Journal of Northeast Texas Archaeology 23:1-27.

2006 A Study of the Buddy Calvin Jones Collection from Northeast Texas Caddo Sites. Special Publication No. 6. Friends of Northeast Texas Archaeology, Pittsburg and Austin.

2007a Inverted Rim Engraved Vessels in Protohistoric and Early Historic Caddo Sites in Parts of Northeast Texas. Journal of Northeast Texas Archaeology 26:136-144.

2007b Kinsloe Focus Artifact Assemblages and Nadaco Caddo. Journal of Northeast Texas Archaeology 26:116-119.

2008 Trends and Varieties in Late Caddo and Historic Caddo Fine Ware Pottery Types in the Upper Neches River Basin. Journal of Northeast Texas Archaeology 28:5155.

2009 The Ceramic Artifacts from the Lang Pasture Site (41AN38) and the Place of the Site within an Upper Neches River Basin Caddo Ceramic Tradition. In Archeological Investigations at the Lang Pasture Site (41AN38) in the Upper Neches River Basin of East Texas, assembled and edited by Timothy K. Perttula and David B. Kelley. Coastal Environments, Inc., Baton Rouge. 
Perttula, Timothy K. (editor)

2005 Archeological Investigations at the Pilgrim's Pride Site (41CP304), a Titus

Phase Community in the Big Cypress Creek Basin. 2 Vols. Report of

Investigations No. 30. Archeological \& Environmental Consultants, LLC, Austin.

Perttula, Timothy K. and Tom Middlebrook

2007 Historic Caddo Archaeology: An Occasional Meeting of the East Texas Caddo

Research Group, December 2-3, 2006, in Nacogdoches, Texas. Journal of

Northeast Texas Archaeology 26:1-7.

Perttula, Timothy K. and Bo Nelson

2003 The Nawi haia ina Site (41RK170): Archeological Investigations in the City of Henderson's Southside Wastewater Treatment Plant, Rusk County, Texas. Report of Investigations No. 51. Archeological \& Environmental Consultants, LLC, Austin.

2007 The Gum Creek Cluster: Protohistoric Caddo Sites in the Little Cypress Creek Basin, ca. 1670-1720. Journal of Northeast Texas Archaeology 26:128-135.

Perttula, Timothy K. and Chester P. Walker

2008 The History of Archaeological Investigations and Geophysical Survey at the Jamestown Mound Site (41SM54), an Archaeological Conservancy Preserve in Smith County, Texas. Archeological \& Environmental Consultants, LLC and Archaeo-Geophysical Associates, LLC, Austin.

Perttula, Timothy K., Robert Cast, Bobby Gonzalez, and Bo Nelson

2008 Documentation of Unassociated and Culturally Unidentifiable Funerary Objects in the U.S. Army Corps of Engineers, Fort Worth District Collections Housed at the Texas Archeological Research Laboratory at The University of Texas at Austin. Historic Preservation Program, Caddo Nation of Oklahoma, Binger, Oklahoma.

Perttula, Timothy K., Mark Walters, Robert Cast, Bobby Gonzalez, and Bo Nelson 2007 Documentation of Funerary Offerings from a Prehistoric Caddo Burial at Site 41WD244, Wood County, Texas. Caddo Nation of Oklahoma, Binger, Oklahoma, and Archeological \& Environmental Consultants, LLC, Austin.

Perttula, Timothy K., Elsbeth Dowd, Lee Green, George Morgan, Bo Nelson, LeeAnna Schniebs, Beau Schriever, Jesse Todd, and Mark Walters

n.d. The Archaeology of the $16^{\text {th }}$ and $17^{\text {th }}$ Century Caddo in the Post Oak Savannah of Northeast Texas: The Tuinier Farm (41HP237), R. A. Watkins (41HP238), and Anglin (41HP240) Sites in the Stouts Creek basin, Hopkins County, Texas. Journal of Northeast Texas Archaeology 30, in press. 
Perttula, Timothy K., Melinda Tate, Hector Neff, James W. Cogswell, Michael D. Glascock, Elizabeth Skokan, Susan Mulholland, Robert Rogers, and Bo Nelson

1998 Analysis of the Titus Phase Mortuary Assemblage at the Mockingbird Site ("Kahbakayammaahin"), 41TT550. Document No. 970849. PBS\&J, Austin.

Reilly, F. Kent, III

2004 People of the Earth, People of the Sky: Visualizing the Sacred in Native American Art of the Mississippian Period. In Hero, Hawk, and Open Hand: American Indian Art of the Ancient Midwest and South, edited by Richard F. Townsend, pp. 125-137. The Art Institute of Chicago in association with Yale University Press, New Haven.

Reimer, Paula J., Mike G. L. Baillie, Edouard Bard, Alex Bayliss, J. Warren Beck, Chanda J. H. Bertrand, Paul G. Blackwell, Caitlin E. Buck, George S. Burr, Kirsten B. Cutler, Paul E. Damon, R. Lawrence Edwards, Richard G. Fairbanks, Michael Friedrich, Thomas P. Guilderson, Alan G. Hogg, Konrad A. Hughen, Bernd Kromer, Gerry McCormac, Sturt Manning, Christopher Bronk Ramsey, Ron W. Reimer, Sabine Remmele, John R. Southon, Minze Stuiver, Sahra Talamo, F. W. Taylor, Johannes van der Plicht, and Constanze E. Weyhenmeyer

2004 IntCal04 Terrestrial Radiocarbon Age Calibration, 0-26 cal kyr BP. Radiocarbon 46:10-29-1058.

Rice, Prudence M.

1987 Pottery Analysis: A Sourcebook. University of Chicago Press, Chicago.

Rogers, Robert and Timothy K. Perttula

2004 The Oak Hill Village (41RK214), Rusk County, Texas. Document No. 030083. PBS\&J, Austin.

Schambach, Frank F. and John E. Miller

1984 A Description and Analysis of the Ceramics. In Cedar Grove: An Interdisciplinary Investigation of a Late Caddo Farmstead in the Red River Valley, edited by Neal L. Trubowitz, pp. 109-170. Research Series No. 23. Arkansas Archeological Survey, Fayetteville.

Shafer, Harry J.

2008 A Study of Chipped Stone Artifacts from the Redwine Site (41SM193), Smith County, Texas. Journal of Northeast Texas Archaeology 27:49-75.

Skibo, James M.

1992 Pottery Function: A Use-Alteration Perspective. Plenum Press, New York.

Skinner, S. Alan, R. King Harris, and Keith M. Anderson (editors)

1969 Archaeological Investigations at the Sam Kaufman Site, Red River County, Texas. Contributions in Anthropology, Southern Methodist University, Dallas. 
Story, Dee Ann

2000 Introduction. In The George C. Davis Site, Cherokee County, Texas, by H. Perry Newell and Alex D. Krieger, pp. 1-31. $2^{\text {nd }}$ Edition. Society for American Archaeology, Washington, D.C.

Suhm, Dee Ann and Edward B. Jelks (editors)

1962 Handbook of Texas Archeology: Type Descriptions. Texas Archeological Society Special Publication 1 and Texas Memorial Museum Bulletin 4, The University of Texas at Austin.

Teltser, Patrice A.

1993 An Analytic Strategy for Studying Assemblage-Scale Ceramic Variation: A Case Study from Southeast Missouri. American Antiquity 58(3):530-543.

Terry, Martin, Karen L. Steelman, Tom Guilderson, Phil Dering, and Marvin W. Rowe 2006 Lower Pecos and Coahuila Peyote: New Radiocarbon Dates. Journal of Archaeological Science 33(7):1017-1021.

Thurmond, J. Peter

1990 Archeology of the Cypress Creek Drainage Basin, Northeastern Texas and Northwestern Louisiana. Studies in Archeology 5. Texas Archeological Research Laboratory, The University of Texas at Austin.

Tunnell, Curtis D.

2000 A Landmark Court Decision in Southern Texas on Peyote and the Native American Church. Special Publication No. 8. The Southern Texas Archaeological Association, San Antonio.

Walters, Mark

1997 The Langford Site (41SM197), Smith County, Texas. Journal of Northeast Texas Archaeology 9:38-41.

1998 A Keno Trailed Vessel from the Spoonbill Site in Wood County, Texas. Journal of Northeast Texas Archaeology 11:46-48.

2005 A Profile in East Texas Archeology. Bulletin of the Texas Archeological Society 75:119-120.

2006a Turquoise Pendant. Journal of Northeast Texas Archaeology 24:84-88.

2006b The Lake Clear (41SM243) Site and Crotalus horridus atricaudatus. Caddo Archeology Journal 15:5-39.

2007 Late Titus Phase Sites along Caney Creek in Northern Wood County, Texas. Journal of Northeast Texas Archaeology 26:145-149. 
n.d. (with the contributions of Tom Middlebrook and Timothy K. Perttula) Redwine or Pie-crust Lip Mode Forms in East Texas Caddo Ceramics and Comparisons with Sprocket Rims of Southwest Arkansas. MS in preparation.

Walters, Mark and Patti Haskins, with contributions by David H. Jurney, S. Eileen Goldborer, and Timothy K. Perttula

1998 Archaeological Investigations at the Redwine Site (41SM193), Smith County, Texas. Journal of Northeast Texas Archaeology 11:1-38.

Webb, Clarence H.

1959 The Belcher Mound: A Stratified Caddoan Site in Caddo Parish, Louisiana. Memoirs No. 16. Society for American Archaeology, Salt Lake City. 


\section{Appendix 1, Sam Kaufman (41RR16) Vessels}

There are several vessels from two different Caddo burials at the Sam Kaufman site (41RR16) in the Walters collection. The history of their acquisition is discussed in Perttula (2006:133). In general, these vessels are apparently from Late McCurtain phase (ca. A.D. 1500-1700) burials in the extensive village at the site.

SITE NAME OR SITE NUMBER: Sam Kaufman (41RR16), Burial 1 (1962)

VESSEL NO.: BCJ-2

NON-PLASTICS: shell

VESSEL FORM: Jar

RIM AND LIP FORM: Everted rim and a rounded lip

CORE COLOR: F (fired in a reducing environment and cooled in the open air)

INTERIOR SURFACE COLOR: light yellowish-brown (10YR 6/4)

EXTERIOR SURFACE COLOR: light yellowish-brown (10YR 6/4); fire clouding on the body

WALL THICKNESS (RIM, BODY, AND BASE IN MM): 5.2 mm, rim

INTERIOR SURFACE TREATMENT: none

EXTERIOR SURFACE TREATMENT: none

HEIGHT (IN CM): 20.7

ORIFICE DIAMETER (IN CM): 19.5

DIAMETER AT BOTTOM OF RIM OR NECK (IN CM): 18.6

BASE DIAMETER (IN CM): 8.2

ESTIMATED VOLUME (IN LITERS): 3.6 liters

DECORATION: The vessel has a roughened rim, a single line of linear tool punctations at the rim-body juncture, and four sets of triangular appliqued fillet elements that are pendant from the rim-body juncture

TYPE: cf. Nash Neck Banded 
SITE NAME OR SITE NUMBER: Sam Kaufman (41RR16), Burial 1

VESSEL NO.: BCJ 6-1

NON-PLASTICS: grog

VESSEL FORM: Jar

RIM AND LIP FORM: Direct rim and a rounded lip

CORE COLOR: B (fired and cooled in an low oxygen environment)

INTERIOR SURFACE COLOR: very dark gray (10YR 3/1)

EXTERIOR SURFACE COLOR: very dark gray (10YR 3/1)

WALL THICKNESS (RIM, BODY, AND BASE IN MM): $7.6 \mathrm{~mm}$, rim; $9.6 \mathrm{~mm}$, body

INTERIOR SURFACE TREATMENT: none

EXTERIOR SURFACE TREATMENT: none

HEIGHT (IN CM): 9.8

ORIFICE DIAMETER (IN CM): 10.5

DIAMETER AT BOTTOM OF RIM OR NECK (IN CM): 10.6

BASE DIAMETER (IN CM): N/A

ESTIMATED VOLUME (IN LITERS): 0.62 liters

DECORATION: The rim has cross-hatched incised lines. The body is divided into a series of panels by sets of four vertical incised lines; the panels themselves are filled either with rows of tool punctates, or rows of tool punctates around a set of short horizontal incised lines (Figure 204).

Figure 204. Incised-punctated jar from the Sam Kaufman site.

TYPE: Undetermined utility ware

SITE NAME OR SITE NUMBER: Sam Kaufman (41RR16), Burial 1

VESSEL NO.: BCJ 6-2 
NON-PLASTICS: shell

VESSEL FORM: Jar with four lug handles

RIM AND LIP FORM: Everted rim and a rounded lip

CORE COLOR: B (fired and cooled in a low oxygen environment)

INTERIOR SURFACE COLOR: black (10YR 2/1)

EXTERIOR SURFACE COLOR: black (10YR 2/1)

WALL THICKNESS (RIM, BODY, AND BASE IN MM): 4.9 mm, rim

INTERIOR SURFACE TREATMENT: smoothed on the rim

EXTERIOR SURFACE TREATMENT: smoothed

HEIGHT (IN CM): 10.0

ORIFICE DIAMETER (IN CM): 11.3

DIAMETER AT BOTTOM OF RIM OR NECK (IN CM): 8.4

BASE DIAMETER (IN CM): 6.0

ESTIMATED VOLUME (IN LITERS): 0.68 liters

DECORATION: The rim of the vessel is roughened or poorly smoothed. The body of the jar has a series of faint vertical engraved elements that begin at the rim-body juncture, including single vertical lines $(n=3)$ that alternate with vertical engraved lines with small pendant ovals $(\mathrm{n}=2)$, and two intersecting curvilinear lines (Figure 205).

TYPE: Undetermined engraved fine ware

Figure 205. Engraved jar from the Sam Kaufman site.

SITE NAME OR SITE NUMBER: Sam Kaufman (41RR16), Burial 1

VESSEL NO.: BCJ 6-3

NON-PLASTICS: shell

VESSEL FORM: Carinated bowl, hubcap form 
RIM AND LIP FORM: Direct rim and a flat lip

CORE COLOR: B (fired and cooled in a reducing environment)

INTERIOR SURFACE COLOR: very dark gray (10YR 3/1)

EXTERIOR SURFACE COLOR: black (10YR 2/1)

WALL THICKNESS (RIM, BODY, AND BASE IN MM): N/A

INTERIOR SURFACE TREATMENT: smoothed on the rim

EXTERIOR SURFACE TREATMENT: burnished

HEIGHT (IN CM): 8.0

ORIFICE DIAMETER (IN CM): 17.2

DIAMETER AT BOTTOM OF RIM OR NECK (IN CM): 17.4

BASE DIAMETER (IN CM): N/A

ESTIMATED VOLUME (IN LITERS): 0.83 liters

DECORATION: The upper panel of the vessel is plain, while the lower panel has four sets of discontinuous ticked scrolls; it is also lip notched (Figure 206).

TYPE: Simms Engraved, var. Darco (see Perttula and Nelson 2007; Perttula 2007b:118)

Figure 206. Simms Engraved, var. Darco carinated bowl from the Sam Kaufman site.

SITE NAME OR SITE NUMBER: Sam Kaufman (41RR16), Burial 1?

VESSEL NO.: BCJ 6-4

NON-PLASTICS: grog

VESSEL FORM: Carinated bowl

RIM AND LIP FORM: Direct rim and a rounded lip

CORE COLOR: A (fired and cooled in a high oxygen environment)

INTERIOR SURFACE COLOR: light brown (7.5YR 6/4) 
EXTERIOR SURFACE COLOR: reddish-yellow (7.5YR 6/6); fire clouding on the base WALL THICKNESS (RIM, BODY, AND BASE IN MM): 7.9 mm, rim INTERIOR SURFACE TREATMENT: none EXTERIOR SURFACE TREATMENT: smoothed HEIGHT (IN CM): 12.0

ORIFICE DIAMETER (IN CM): 24.0

DIAMETER AT BOTTOM OF RIM OR NECK (IN CM): 22.6

BASE DIAMETER (IN CM): 7.6

ESTIMATED VOLUME (IN LITERS): 1.73 liters

DECORATION: Plain

TYPE: Undetermined plain ware

SITE NAME OR SITE NUMBER: Sam Kaufman (41RR16), Burial 2

VESSEL NO.: BCJ-8

NON-PLASTICS: shell

VESSEL FORM: Carinated bowl

RIM AND LIP FORM: Direct rim and a flat lip

CORE COLOR: B (fired and cooled in a reducing environment)

INTERIOR SURFACE COLOR: black (10YR 2/1)

EXTERIOR SURFACE COLOR: black (10YR 2/1)

WALL THICKNESS (RIM, BODY, AND BASE IN MM): 4.5 mm, rim INTERIOR SURFACE TREATMENT: burnished

EXTERIOR SURFACE TREATMENT: burnished HEIGHT (IN CM): 10.0 
ORIFICE DIAMETER (IN CM): 17.5

DIAMETER AT BOTTOM OF RIM OR NECK (IN CM): 18.6

\section{BASE DIAMETER (IN CM): N/A}

ESTIMATED VOLUME (IN LITERS): 1.05 liters

DECORATION: The upper rim panel is plain, and the lower rim panel has four sets of two discontinuous ticked scrolls; each set is separated from the other by a single vertical engraved line at either end of the scroll (Figure 207). A red pigment has been rubbed in the engraved and ticked lines.

TYPE: Simms Engraved, var. Darco

Figure 207. Simms Engraved, var. Darco carinated bowl from the Sam Kaufman site. 


\section{Appendix 2, Ceramic Vessels from Unknown Caddo Sites in Walters Collection from Smith or Wood Counties, Texas}

There are 49 Caddo ceramic vessels in the J. A. Walters collection where site

provenience is not known, or has been lost. Nevertheless, it is known that they come from Caddo sites in either Smith or Wood counties, Texas, and thus provide further information on the broad character of prehistoric Caddo ceramic manufacture and stylistic treatment in this part of East Texas from Early Caddo to Late Caddo period times.

SITE NAME OR SITE NUMBER: Unknown

VESSEL NO.: 59

NON-PLASTICS: grog

VESSEL FORM: Bottle with a straight neck and a carinated body (Figure 208)

RIM AND LIP FORM: Direct rim and a flat lip

CORE COLOR: G (fired in a reducing environment and cooled in the open air)

INTERIOR SURFACE COLOR: dark gray (10YR 4/1)

EXTERIOR SURFACE COLOR: brown (10YR 4/3); fire clouding on the body and the neck

WALL THICKNESS (RIM, BODY, AND BASE IN MM): 7.0 mm, rim

INTERIOR SURFACE TREATMENT: none

EXTERIOR SURFACE TREATMENT: smoothed

HEIGHT (IN CM): 18.3

ORIFICE DIAMETER (IN CM): 4.5

DIAMETER AT BOTTOM OF RIM OR NECK (IN CM): $5.1 ; 14.3 \mathrm{~cm}$ at its maximum body width

BASE DIAMETER (IN CM): 8.2

ESTIMATED VOLUME (IN LITERS): 0.6 liters

DECORATION: Plain 
TYPE: Undetermined plain ware

Figure 208. Plain bottle from the Walters collection, unknown provenience.

SITE NAME OR SITE NUMBER: Unknown

VESSEL NO.: 60

NON-PLASTICS: grog

VESSEL FORM: Bottle with a straight neck

RIM AND LIP FORM: Direct rim with a flat, exterior folded, lip

CORE COLOR: N/A

INTERIOR SURFACE COLOR: N/A

EXTERIOR SURFACE COLOR: dark yellowish-brown (10YR 4/4)

WALL THICKNESS (RIM, BODY, AND BASE IN MM): 6.7 mm, neck

INTERIOR SURFACE TREATMENT: smoothed on the upper neck

EXTERIOR SURFACE TREATMENT: burnished

HEIGHT (IN CM): 18.0

ORIFICE DIAMETER (IN CM): 4.5

DIAMETER AT BOTTOM OF RIM OR NECK (IN CM): $5.3 ; 14.3 \mathrm{~cm}$ is the maximum body width

BASE DIAMETER (IN CM): 8.0

ESTIMATED VOLUME (IN LITERS): 0.58 liters

DECORATION: There are a series of engraved panels on the vessel body. Most of these panels ate filled with irregularly-spaced horizontal engraved lines (Figure 209a), although two panels are plain and a third has only a few short horizontal and diagonal engraved lines. In the central panels are motifs that resemble an engraved human face (Figure 209b) and the body of a quadruped (Figure 209c).

TYPE: Unknown engraved fine ware vessel 
Figure 209. Unique engraved bottle from the Walters collection: a, panels; b, engraved human face?; c, quadruped?

SITE NAME OR SITE NUMBER: Unknown

VESSEL NO.: 62

NON-PLASTICS: grog

VESSEL FORM: Globular bowl

RIM AND LIP FORM: Direct rim and a rounded lip

CORE COLOR: A (fired and cooled in a high oxygen environment)

INTERIOR SURFACE COLOR: brownish-yellow (10YR 6/4)

EXTERIOR SURFACE COLOR: brownish-yellow (10YR 6/4)

WALL THICKNESS (RIM, BODY, AND BASE IN MM): $6.2 \mathrm{~mm}$, rim

INTERIOR SURFACE TREATMENT: burnished on the rim and smoothed on the body

EXTERIOR SURFACE TREATMENT: burnished

HEIGHT (IN CM): 9.8

ORIFICE DIAMETER (IN CM): 12.1

DIAMETER AT BOTTOM OF RIM OR NECK (IN CM): 11.7

BASE DIAMETER (IN CM): 11.0

ESTIMATED VOLUME (IN LITERS): 0.48 liters

DECORATION: Plain (Figure 210)

TYPE: Undetermined plain ware

Figure 210. Plain bowl from the Walters collection, unknown provenience.

SITE NAME OR SITE NUMBER: Unknown (Smith County?)

VESSEL NO.: 68 
NON-PLASTICS: grog

VESSEL FORM: Carinated bowl

RIM AND LIP FORM: Inverted rim; the lip is missing

CORE COLOR: $\mathrm{F}$ (fired in a reducing environment and cooled in the open air)

INTERIOR SURFACE COLOR: pale brown (10YR 6/3)

EXTERIOR SURFACE COLOR: light yellowish-brown (10YR 6/4); fire clouding on the body

WALL THICKNESS (RIM, BODY, AND BASE IN MM): 6.7 mm, body

INTERIOR SURFACE TREATMENT: none

EXTERIOR SURFACE TREATMENT: smoothed

HEIGHT (IN CM): 7.3

ORIFICE DIAMETER (IN CM): 12.7

DIAMETER AT BOTTOM OF RIM OR NECK (IN CM): 13.8

BASE DIAMETER (IN CM): 7.5

ESTIMATED VOLUME (IN LITERS): 0.56 liters

DECORATION: Plain (Figure 211)

TYPE: Undetermined plain ware

Figure 211. Plain carinated bowl from the Walters collection.

SITE NAME OR SITE NUMBER: Unknown (Lake Palestine?, Smith County?)

VESSEL NO.: 76

NON-PLASTICS: grog

VESSEL FORM: Jar with a tall rim and 10 low rim peaks (Figure 212)

RIM AND LIP FORM: Everted rim and a rounded lip 
CORE COLOR: $\mathrm{G}$ (fired in a reducing environment and cooled in the open air)

INTERIOR SURFACE COLOR: very dark gray (10YR 3/1)

EXTERIOR SURFACE COLOR: light yellowish-brown (10YR 6/4)

WALL THICKNESS (RIM, BODY, AND BASE IN MM): 7.7 mm, rim

INTERIOR SURFACE TREATMENT: smoothed

EXTERIOR SURFACE TREATMENT: none

HEIGHT (IN CM): 19.3

ORIFICE DIAMETER (IN CM): 18.3

DIAMETER AT BOTTOM OF RIM OR NECK (IN CM): 16.0

BASE DIAMETER (IN CM): 8.0

ESTIMATED VOLUME (IN LITERS): 3.18 liters

DECORATION: The rim has eight horizontal rows of neck banding encircling the vessel. The body has a series of four pinched circles that extend from the rim-body juncture to just above the base; at the center of each pinched circle is a single appliqued node (see Figure 212).

TYPE: cf. La Rue Neck Banded

Figure 212. cf. La Rue Neck Banded jar from the Walters collection, unknown provenience.

SITE NAME OR SITE NUMBER: Unknown

VESSEL NO.: 105

NON-PLASTICS: grog and bone

VESSEL FORM: Miniature Bowl (Figure 213)

RIM AND LIP FORM: Direct rim and a rounded lip

CORE COLOR: B (fired and cooled in a reducing environment) 
INTERIOR SURFACE COLOR: dark gray (7.5YR 4/1)

EXTERIOR SURFACE COLOR: gray (7.5YR 5/1)

WALL THICKNESS (RIM, BODY, AND BASE IN MM): $6.0 \mathrm{~mm}$, rim

INTERIOR SURFACE TREATMENT: none

EXTERIOR SURFACE TREATMENT: none

HEIGHT (IN CM): 2.4

ORIFICE DIAMETER (IN CM): 3.4

DIAMETER AT BOTTOM OF RIM OR NECK (IN CM): N/A

BASE DIAMETER (IN CM): 2.6

ESTIMATED VOLUME (IN LITERS): 0.03 liters

DECORATION: Horizontal and diagonal brushing on the exterior vessel surface (see Figure 213)

TYPE: Undetermined utility ware

Figure 213. Miniature brushed bowl from the Walters collection, unknown provenience.

SITE NAME OR SITE NUMBER: Unknown

VESSEL NO.: 106

NON-PLASTICS: grog

VESSEL FORM: Bowl

RIM AND LIP FORM: Direct rim and a rounded lip

CORE COLOR: A (fired in an oxidizing environment)

INTERIOR SURFACE COLOR: strong brown (7.5YR 5/6)

EXTERIOR SURFACE COLOR: strong brown (7.5YR 5/6); fire clouding on the base

WALL THICKNESS (RIM, BODY, AND BASE IN MM): 6.2 mm, rim 
INTERIOR SURFACE TREATMENT: none

EXTERIOR SURFACE TREATMENT: smoothed

HEIGHT (IN CM): 4.0

ORIFICE DIAMETER (IN CM): 6.4

DIAMETER AT BOTTOM OF RIM OR NECK (IN CM): N/A

BASE DIAMETER (IN CM): 3.6

ESTIMATED VOLUME (IN LITERS): 0.1 liters

DECORATION: Below the rim is a single horizontal engraved line that has an alternating series of small engraved semi-circles $(n=3)$ or engraved triangles $(n=4)$ pendant from the horizontal line (Figure 214).

TYPE: Undetermined fine ware vessel

Figure 214. Engraved bowl from the Walters collection, unknown provenience.

SITE NAME OR SITE NUMBER: Unknown

VESSEL NO.: 133

NON-PLASTICS: grog

VESSEL FORM: Jar

RIM AND LIP FORM: Everted rim and a rounded lip

CORE COLOR: $\mathrm{F}$ (fired in a reducing environment and cooled in the open air)

INTERIOR SURFACE COLOR: very pale brown (10YR 7/4)

EXTERIOR SURFACE COLOR: yellowish-brown (10YR 5/4); fire clouding on the rim and body

WALL THICKNESS (RIM, BODY, AND BASE IN MM): N/A

INTERIOR SURFACE TREATMENT: smoothed; organic residue on the body

EXTERIOR SURFACE TREATMENT: smoothed on the body 
HEIGHT (IN CM): 24.6

ORIFICE DIAMETER (IN CM): 20.1

DIAMETER AT BOTTOM OF RIM OR NECK (IN CM): 17.3

BASE DIAMETER (IN CM): 7.0

ESTIMATED VOLUME (IN LITERS): 6.4 liters

DECORATION: The rim of this large vessel is roughened, with poorly preserved neck bands. There is also a single row of tool punctates at the rim-body juncture (Figure 215).

TYPE: La Rue Neck Banded

Figure 215. La Rue Neck Banded jar from the Walters collection, unknown provenience.

SITE NAME OR SITE NUMBER: Unknown

VESSEL NO.: 135

NON-PLASTICS: grog

VESSEL FORM: Jar with two opposed strap handles and two sets of two lip nodes

RIM AND LIP FORM: Everted rim and a rounded lip

CORE COLOR: B (fired and cooled in a reducing environment)

INTERIOR SURFACE COLOR: very dark gray (10YR 3/1)

EXTERIOR SURFACE COLOR: very dark gray (10YR 3/1)

WALL THICKNESS (RIM, BODY, AND BASE IN MM): $6.5 \mathrm{~mm}$, rim

INTERIOR SURFACE TREATMENT: smoothed on the rim

EXTERIOR SURFACE TREATMENT: smoothed only on the body

HEIGHT (IN CM): 13.5

ORIFICE DIAMETER (IN CM): 13.4

DIAMETER AT BOTTOM OF RIM OR NECK (IN CM): 10.8 
BASE DIAMETER (IN CM): 9.0

ESTIMATED VOLUME (IN LITERS): 1.08 liters

DECORATION: There are eight or more horizontal rows of small tool punctations covering the vessel rim. The strap handles and lip nodes are also decorated with small tool punctated rows (Figure 216).

TYPE: Undetermined utility ware

Figure 216. Punctated jar from the Walters collection, unknown provenience.

SITE NAME OR SITE NUMBER: Unknown

VESSEL NO.: 139

NON-PLASTICS: grog

VESSEL FORM: Bottle with a straight neck and a carinated body

RIM AND LIP FORM: Direct rim and a rounded lip

CORE COLOR: A (fired and cooled in an oxidizing environment)

INTERIOR SURFACE COLOR: reddish-yellow (10YR 6/6)

EXTERIOR SURFACE COLOR: reddish-yellow (10YR 6/6)

WALL THICKNESS (RIM, BODY, AND BASE IN MM): 7.2 mm, neck

INTERIOR SURFACE TREATMENT: none

EXTERIOR SURFACE TREATMENT: smoothed

HEIGHT (IN CM): 15.2

ORIFICE DIAMETER (IN CM): 3.5

DIAMETER AT BOTTOM OF RIM OR NECK (IN CM): 4.6; $11.9 \mathrm{~cm}$ at the widest part of the body

BASE DIAMETER (IN CM): 6.2

ESTIMATED VOLUME (IN LITERS): 0.38 liters 
DECORATION: There is a single narrow horizontal and hatched engraved panel below the bottle neck, and five widely-spaced vertical engraved lines that extend to the body carination. Each vertical engraved line has three small and alternating cross-hatched triangles or ovals that are pendant from, and on either side of, the vertical line (Figure 217).

TYPE: Undetermined fine ware vessel

Figure 217. Engraved bottle from the Walters collection, unknown provenience.

SITE NAME OR SITE NUMBER: Unknown

VESSEL NO.: 143

NON-PLASTICS: grog

VESSEL FORM: Bottle with an incurved neck

RIM AND LIP FORM: Everted rim and a rounded lip

CORE COLOR: B (fired and cooled in a low oxygen environment)

INTERIOR SURFACE COLOR: black (10YR 2/1)

EXTERIOR SURFACE COLOR: black (10YR 2/1)

WALL THICKNESS (RIM, BODY, AND BASE IN MM): 4.0 mm, neck; $4.1 \mathrm{~mm}$, body

INTERIOR SURFACE TREATMENT: smoothed on the upper neck

EXTERIOR SURFACE TREATMENT: smoothed

HEIGHT (IN CM): 24.0

ORIFICE DIAMETER (IN CM): 5.0

DIAMETER AT BOTTOM OF RIM OR NECK (IN CM): 8.0; maximum diameter on the body is $15.2 \mathrm{~cm}$

BASE DIAMETER (IN CM): 6.5

ESTIMATED VOLUME (IN LITERS): 0.62 liters

DECORATION: There are two horizontal engraved lines encircling the area immediately under the bottle neck. The body of the vessel has a hooked arm scroll motif repeated four 
times around the vessel (cf. Suhm and Jelks 1962:155); there are upper and lower horizontal engraved lines that delimit the motif. The two arms circle towards each other, but do not meet. There is a small excised circle between the two arms. Where the two engraved arms pass above and below the excised circle, they are widened by an area of cross-hatching. The very top and bottom of the hooked arms motif (i.e., near the bottle neck and the vessel base) have triangular elements with cross-hatched corners (Figure 218).

TYPE: Wilder Engraved

Figure 218. Wilder Engraved bottle from the Walters collection, unknown provenience.

SITE NAME OR SITE NUMBER: Unknown

VESSEL NO.: 156

NON-PLASTICS: bone and hematite

VESSEL FORM: Bottle with a straight neck and a carinated body

RIM AND LIP FORM: Direct rim and a flat lip

CORE COLOR: A (fired and cooled in a high oxygen environment)

INTERIOR SURFACE COLOR: reddish-yellow (7.5YR 6/6)

EXTERIOR SURFACE COLOR: reddish-yellow (7.5YR 6/6)

WALL THICKNESS (RIM, BODY, AND BASE IN MM): $5.5 \mathrm{~mm}$, rim

INTERIOR SURFACE TREATMENT: none

EXTERIOR SURFACE TREATMENT: smoothed on the body

HEIGHT (IN CM): 12.2

ORIFICE DIAMETER (IN CM): 3.6

DIAMETER AT BOTTOM OF RIM OR NECK (IN CM): 5.1; $9.6 \mathrm{~cm}$ at the widest part of the body

BASE DIAMETER (IN CM): 6.9

ESTIMATED VOLUME (IN LITERS): 0.34 liters 
DECORATION: The engraved lines on this vessel are poorly executed. The first motif, at the top of the vessel body, consists of a series of disconnected curvilinear and semicircular elements. The second motif is on the lower part of the body, below the body carination (Figure 219). This motif includes seven sets of closely-spaced vertical engraved lines, one set of vertical engraved lines with associated short horizontal engraved lines, and one set of circular and short scroll-like engraved lines.

TYPE: Undefined fine ware

Figure 219. Engraved bottle from the Walters collection, unknown provenience.

SITE NAME OR SITE NUMBER: Unknown (Smith County)

VESSEL NO.: 157

NON-PLASTICS: bone and grog

VESSEL FORM: Bottle with a straight neck and a carinated body

RIM AND LIP FORM: Direct rim and a rounded lip

CORE COLOR: A (fired and cooled in a high oxygen environment)

INTERIOR SURFACE COLOR: light brown (7.5YR 6/3)

EXTERIOR SURFACE COLOR: light brown (7.5YR 6/3); fire clouding on the body and base

WALL THICKNESS (RIM, BODY, AND BASE IN MM): $6.3 \mathrm{~mm}$, neck; $6.8 \mathrm{~mm}$, body; $8.5 \mathrm{~mm}$, base

INTERIOR SURFACE TREATMENT: none

EXTERIOR SURFACE TREATMENT: smoothed

HEIGHT (IN CM): 12.0 ; the bottle neck is $4.5 \mathrm{~cm}$ in height

ORIFICE DIAMETER (IN CM): 4.1

DIAMETER AT BOTTOM OF RIM OR NECK (IN CM): 4.6; maximum body width is $11.0 \mathrm{~cm}$

BASE DIAMETER (IN CM): 5.5

ESTIMATED VOLUME (IN LITERS): 0.26 liters 
DECORATION: There are 11 diagonal engraved panels on the vessel body (Figure 220), above a single horizontal engraved line encircling the vessel above the base. Nine of the panels have a uniquely oriented set of diagonally-placed lines (between four to eight lines per panel) within it, and one of these panels has a single semi-circular engraved line that intersects the diagonal engraved lines. Two of the panels have no diagonal engraved lines within them.

TYPE: Undetermined fine ware

Figure 220. Engraved bottle from the Walters collection, Smith County, Texas.

SITE NAME OR SITE NUMBER: Unknown

VESSEL NO.: 159

NON-PLASTICS: grog

VESSEL FORM: Carinated bowl

RIM AND LIP FORM: Everted rim and a rounded lip

CORE COLOR: $\mathrm{G}$ (fired in a reducing environment and cooled in the open air)

INTERIOR SURFACE COLOR: dark grayish-brown (10YR 4/2)

EXTERIOR SURFACE COLOR: brown (7.5YR 4/4)

WALL THICKNESS (RIM, BODY, AND BASE IN MM): 5.0 mm, rim

INTERIOR SURFACE TREATMENT: smoothed

EXTERIOR SURFACE TREATMENT: smoothed

HEIGHT (IN CM): 8.2

ORIFICE DIAMETER (IN CM): 15.5

DIAMETER AT BOTTOM OF RIM OR NECK (IN CM): 14.0

BASE DIAMETER (IN CM): 6.0

ESTIMATED VOLUME (IN LITERS): 0.76 liters

DECORATION: Plain (Figure 221) 
TYPE: Undetermined plain ware

Figure 221. Plain carinated bowl, Walters collection, unknown provenience.

SITE NAME OR SITE NUMBER: Unknown

VESSEL NO.: 160

NON-PLASTICS: grog

VESSEL FORM: Jar

RIM AND LIP FORM: Direct rim and a rounded, exterior folded, lip

CORE COLOR: C (incompletely oxidized during firing)

INTERIOR SURFACE COLOR: light yellowish-brown (10YR 6/4); fire clouding on the rim and body

EXTERIOR SURFACE COLOR: light yellowish-brown (10YR 6/4)

WALL THICKNESS (RIM, BODY, AND BASE IN MM): 5.6 mm, rim; $6.3 \mathrm{~mm}$, body

INTERIOR SURFACE TREATMENT: smoothed

EXTERIOR SURFACE TREATMENT: smoothed only on the body

HEIGHT (IN CM): 10.0

ORIFICE DIAMETER (IN CM): 10.0

DIAMETER AT BOTTOM OF RIM OR NECK (IN CM): 10.0

BASE DIAMETER (IN CM): 5.6

ESTIMATED VOLUME (IN LITERS): 0.6 liters

DECORATION: There are four vertical incised panels on the rim; each contains 13 closely-spaced vertical incised lines. There are also four sets of two appliqued nodes near the rim, either placed within or without the incised panels (Figure 222).

TYPE: Undetermined utility ware

Figure 222. Incised-appliqued jar from the Walters collection, unknown provenience. 
SITE NAME OR SITE NUMBER: Unknown

VESSEL NO.: 161

NON-PLASTICS: grog

VESSEL FORM: Carinated bowl

RIM AND LIP FORM: Direct rim and a flat lip

CORE COLOR: A (fired and cooled in a high oxygen environment)

INTERIOR SURFACE COLOR: strong brown (7.5YR 5/6)

EXTERIOR SURFACE COLOR: strong brown (7.5YR 5/6)

WALL THICKNESS (RIM, BODY, AND BASE IN MM): 5.8 mm, rim

INTERIOR SURFACE TREATMENT: none

EXTERIOR SURFACE TREATMENT: smoothed

HEIGHT (IN CM): 6.2

ORIFICE DIAMETER (IN CM): 12.0

DIAMETER AT BOTTOM OF RIM OR NECK (IN CM): 11.1

BASE DIAMETER (IN CM): 7.5

ESTIMATED VOLUME (IN LITERS): 0.46 liters

DECORATION: The vessel has a single tool punctated row at the lip/upper rim (Figure 223).

TYPE: Undetermined utility ware

Figure 223. Tool punctated carinated bowl from the Walters collection, unknown provenience.

SITE NAME OR SITE NUMBER: Unknown

VESSEL NO.: 162

NON-PLASTICS: grog 
VESSEL FORM: Bowl

RIM AND LIP FORM: Everted rim and a rounded lip

CORE COLOR: $\mathrm{G}$ (fired in a reducing environment and cooled in the open air)

INTERIOR SURFACE COLOR: reddish-yellow (7.5YR 6/6)

EXTERIOR SURFACE COLOR: reddish-yellow (7.5YR 6/6)

WALL THICKNESS (RIM, BODY, AND BASE IN MM): $5.0 \mathrm{~mm}$, rim and body

INTERIOR SURFACE TREATMENT: smoothed on the rim

EXTERIOR SURFACE TREATMENT: smoothed

HEIGHT (IN CM): 9.8

ORIFICE DIAMETER (IN CM): 13.7

DIAMETER AT BOTTOM OF RIM OR NECK (IN CM): N/A

BASE DIAMETER (IN CM): 9.0

ESTIMATED VOLUME (IN LITERS): 0.54 liters

DECORATION: The engraved decoration of this vessel consists of a series of stacked unconnected diagonal lines, diagonal opposed lines, sets of curvilinear lines, crosshatched areas, small triangles, and one engraved circle (Figure 224). One section of the lip is lip notched.

TYPE: Undetermined fine ware

Figure 224. Engraved bowl from the Walters collection, unknown provenience.

SITE NAME OR SITE NUMBER: Unknown

VESSEL NO.: 163

NON-PLASTICS: grog and hematite

VESSEL FORM: Carinated bowl

RIM AND LIP FORM: Everted rim and a flat lip; Redwine mode lip 
CORE COLOR: A (fired and cooled in a high oxygen environment)

INTERIOR SURFACE COLOR: yellow (10YR 7/6)

EXTERIOR SURFACE COLOR: yellow (10YR 7/6)

WALL THICKNESS (RIM, BODY, AND BASE IN MM): 7.9 mm, body

INTERIOR SURFACE TREATMENT: none

EXTERIOR SURFACE TREATMENT: none

HEIGHT (IN CM): 9.5

ORIFICE DIAMETER (IN CM): 20.8

DIAMETER AT BOTTOM OF RIM OR NECK (IN CM): 17.0

BASE DIAMETER (IN CM): 10.0

ESTIMATED VOLUME (IN LITERS): 1.18 liters

DECORATION: There are six incised ovals on the rim panel, and they are surrounded by areas filled with triangular to circular-shaped punctations (Figure 225).

TYPE: undetermined utility ware, possibly of Middle Caddo age, based on the Redwine mode lip

Figure 225. Incised-punctated carinated bowl from the Walters collection, unknown provenience.

SITE NAME OR SITE NUMBER: Unknown

VESSEL NO.: 164

NON-PLASTICS: grog and hematite

VESSEL FORM: Jar

RIM AND LIP FORM: Everted rim and a rounded, exterior folded lip

CORE COLOR: $\mathrm{F}$ (fired in an reducing environment and cooled in the open air)

INTERIOR SURFACE COLOR: light brown (7.5YR 6/4) 
EXTERIOR SURFACE COLOR: yellowish-red (5YR 5/6); fire clouding on the body and base

WALL THICKNESS (RIM, BODY, AND BASE IN MM): $5.5 \mathrm{~mm}$, rim

INTERIOR SURFACE TREATMENT: smoothed; organic residue on the body

EXTERIOR SURFACE TREATMENT: smoothed on the body; organic residue on the body

HEIGHT (IN CM): 14.0

ORIFICE DIAMETER (IN CM): 19.7

DIAMETER AT BOTTOM OF RIM OR NECK (IN CM): 14.5

BASE DIAMETER (IN CM): 5.5

ESTIMATED VOLUME (IN LITERS): 1.65 liters

DECORATION: The rim has two horizontal rows of linear punctations, one below the lip and the other at the rim-body juncture (Figure 226).

TYPE: Undetermined utility ware

Figure 226. Punctated jar from the Walters collection, unknown provenience.

SITE NAME OR SITE NUMBER: Unknown (Lake Palestine, Smith County?)

VESSEL NO.: 166

NON-PLASTICS: grog

VESSEL FORM: Carinated bowl

RIM AND LIP FORM: Inverted rim and a rounded lip

CORE COLOR: $\mathrm{F}$ (fired in a reducing environment and cooled in the open air)

INTERIOR SURFACE COLOR: light yellowish-brown (10YR 6/4)

EXTERIOR SURFACE COLOR: light yellowish-brown (10YR 6/4)

WALL THICKNESS (RIM, BODY, AND BASE IN MM): $7.1 \mathrm{~mm}$, rim 
INTERIOR SURFACE TREATMENT: smoothed

EXTERIOR SURFACE TREATMENT: smoothed

HEIGHT (IN CM): 16.0

ORIFICE DIAMETER (IN CM): 29.0

DIAMETER AT BOTTOM OF RIM OR NECK (IN CM): 32.0

BASE DIAMETER (IN CM): 10.5

ESTIMATED VOLUME (IN LITERS): 3.7 liters

DECORATION: The rim panel (defined by a single upper and lower horizontal engraved line) has 10 engraved ovals, half of them also with cross-hatched triangular elements at each upper and lower corner of the oval (Figure 227).

TYPE: Poynor Engraved, var. Cook (see Perttula 2008:Figure 1d)

Figure 227. Poynor Engraved, var. Cook carinated bowl, possibly from the Lake Palestine area.

SITE NAME OR SITE NUMBER: Unknown (Wood County?)

VESSEL NO.: 167

NON-PLASTICS: grog

VESSEL FORM: Carinated bowl

RIM AND LIP FORM: Direct rim and a rounded, exterior folded lip

CORE COLOR: B (fired and cooled in a low oxygen environment)

INTERIOR SURFACE COLOR: dark brown (7.5YR 3/2)

EXTERIOR SURFACE COLOR: very dark gray (7.5YR 3/1)

WALL THICKNESS (RIM, BODY, AND BASE IN MM): $6.3 \mathrm{~mm}$, rim; $6.6 \mathrm{~mm}$, body; $11.0 \mathrm{~mm}$, base

INTERIOR SURFACE TREATMENT: smoothed 
EXTERIOR SURFACE TREATMENT: burnished

HEIGHT (IN CM): 12.0

ORIFICE DIAMETER (IN CM): 24.0

DIAMETER AT BOTTOM OF RIM OR NECK (IN CM): 23.9

BASE DIAMETER (IN CM): 6.6

ESTIMATED VOLUME (IN LITERS): 1.73 liters

DECORATION: The rim panel has a scroll and semi-circle engraved motif repeated four times on the vessel. Each repeated motif is separated from the other by a single vertical engraved line with very small upper and lower excised triangles (Figure 228).

TYPE: Ripley Engraved

Figure 228. Ripley Engraved carinated bowl from the Walters collection.

SITE NAME OR SITE NUMBER: Unknown

VESSEL NO.: 169

NON-PLASTICS: grog

VESSEL FORM: Effigy (?) Bowl, with evidence of an attachment on the rim (missing) (Figure 229)

RIM AND LIP FORM: Direct rim and a rounded lip

CORE COLOR: $\mathrm{F}$ (fired in a reducing environment and cooled in the open air)

INTERIOR SURFACE COLOR: pale brown (10YR 6/3); fire clouding on the base

EXTERIOR SURFACE COLOR: brown (10YR 5/3); fire clouding on the lower body

WALL THICKNESS (RIM, BODY, AND BASE IN MM): $7.6 \mathrm{~mm}$, rim

INTERIOR SURFACE TREATMENT: none

EXTERIOR SURFACE TREATMENT: burnished

HEIGHT (IN CM): 10.8 
ORIFICE DIAMETER (IN CM): 20.8

DIAMETER AT BOTTOM OF RIM OR NECK (IN CM): N/A

BASE DIAMETER (IN CM): 12.6

ESTIMATED VOLUME (IN LITERS): 0.9 liters

DECORATION: There are three broad horizontal engraved lines on the upper part of the bowl, and these lines either end or dip underneath the area of the effigy attachment (Figure 229). There are also three sets of excised triangles pendant from each of the horizontal engraved lines.

TYPE: cf. Hood Engraved, var. Cook

Figure 229. Hood Engraved, var. Cook effigy bowl from the Walters collection, unknown provenience.

SITE NAME OR SITE NUMBER: Unknown (Smith County?)

VESSEL NO.: 171

NON-PLASTICS: grog

VESSEL FORM: Carinated bowl

RIM AND LIP FORM: Direct rim and a rounded, exterior folded lip

CORE COLOR: $\mathrm{F}$ (fired in a reducing environment and cooled in the open air)

INTERIOR SURFACE COLOR: brown (10YR 5/3)

EXTERIOR SURFACE COLOR: yellowish-brown (10YR 5/4)

WALL THICKNESS (RIM, BODY, AND BASE IN MM): $6.8 \mathrm{~mm}$, rim; $8.6 \mathrm{~mm}$, body

INTERIOR SURFACE TREATMENT: smoothed

EXTERIOR SURFACE TREATMENT: burnished

HEIGHT (IN CM): 14.5

ORIFICE DIAMETER (IN CM): 28.0

DIAMETER AT BOTTOM OF RIM OR NECK (IN CM): 27.0 
BASE DIAMETER (IN CM): 8.0

ESTIMATED VOLUME (IN LITERS): 3.6 liters

DECORATION: The rim panel has 12 negative engraved ovals separated by vertical excised brackets. A white kaolin clay pigment has been rubbed in the engraved lines (Figure 230).

TYPE: Poynor Engraved, var. Hood

Figure 230. Poynor Engraved, var. Hood carinated bowl from the Walters collection, unknown provenience.

SITE NAME OR SITE NUMBER: Unknown

VESSEL NO.: 177

NON-PLASTICS: grog

VESSEL FORM: Carinated bowl

RIM AND LIP FORM: Direct rim and a flat lip

CORE COLOR: F (fired in a reducing environment and cooled in the open air)

INTERIOR SURFACE COLOR: yellowish-brown (10YR 5/4)

EXTERIOR SURFACE COLOR: yellowish-brown (10YR 5/4)

WALL THICKNESS (RIM, BODY, AND BASE IN MM): 7.2 mm, rim

INTERIOR SURFACE TREATMENT: smoothed

EXTERIOR SURFACE TREATMENT: smoothed

HEIGHT (IN CM): 12.5

ORIFICE DIAMETER (IN CM): 29.5

DIAMETER AT BOTTOM OF RIM OR NECK (IN CM): 29.9

BASE DIAMETER (IN CM): N/A

ESTIMATED VOLUME (IN LITERS): 2.2 liters 
DECORATION: The upper part of the rim has four rows of cane punctations; a deeply grooved line separates the upper and lower parts of the rim panel. The lower part of the rim has opposed nearly vertical to diagonal sets of finely engraved lines with diagonal excised areas and upper excised triangles (Figure 231); there are also non-excised triangular-shaped areas on the upper portion of the engraved motif.

TYPE: cf. Holly Fine Engraved

Figure 231. cf. Holly Fine Engraved carinated bowl from the Walters collection, provenience unknown.

SITE NAME OR SITE NUMBER: Unknown

VESSEL NO.: 178

NON-PLASTICS: grog and hematite

VESSEL FORM: Bowl with two panels (Figure 232)

RIM AND LIP FORM: Direct rim, exterior thickened, and a rounded lip

CORE COLOR: $\mathrm{F}$ (fired in a reducing environment and cooled in the open air)

INTERIOR SURFACE COLOR: brownish-yellow (10YR 6/6)

EXTERIOR SURFACE COLOR: brownish-yellow (10YR 6/6)

WALL THICKNESS (RIM, BODY, AND BASE IN MM): $8.1 \mathrm{~mm}$, rim; 7.9 mm, body; $12.2 \mathrm{~mm}$, base

INTERIOR SURFACE TREATMENT: smoothed

EXTERIOR SURFACE TREATMENT: burnished

HEIGHT (IN CM): 8.4

ORIFICE DIAMETER (IN CM): 28.0

DIAMETER AT BOTTOM OF RIM OR NECK (IN CM): 28.0

BASE DIAMETER (IN CM): 12.0

ESTIMATED VOLUME (IN LITERS): 1.4 liters 
DECORATION: The upper panel is plain, and separated from the lower panel by a deep horizontal grooved line (as it also the case with Vessel 177, see above). The lower panel has finely engraved sets of near-vertical to diagonal lines, associated vertical to diagonal excised areas, as well as upper and lower sets of small excised triangles (see Figure 232).

TYPE: cf. Holly Fine Engraved

Figure 232. cf. Holly Fine Engraved bowl from the Walters collection, unknown provenience.

SITE NAME OR SITE NUMBER: Unknown

VESSEL NO.: 219

NON-PLASTICS: grog

VESSEL FORM: Jar

RIM AND LIP FORM: Everted rim and a rounded, exterior folded lip

CORE COLOR: B (fired and cooled in a low oxygen environment)

INTERIOR SURFACE COLOR: black (10YR 2/1)

EXTERIOR SURFACE COLOR: dark grayish-brown (10YR 4/2)

WALL THICKNESS (RIM, BODY, AND BASE IN MM): 9.7 mm, rim; 8.7 mm, body

INTERIOR SURFACE TREATMENT: smoothed

EXTERIOR SURFACE TREATMENT: none

HEIGHT (IN CM): 34.5

ORIFICE DIAMETER (IN CM): 34.5

DIAMETER AT BOTTOM OF RIM OR NECK (IN CM): 27.0

BASE DIAMETER (IN CM): 10.0

ESTIMATED VOLUME (IN LITERS): 15.5 liters

DECORATION: There are four sets of tool punctates on the rim, as well as three appliqued nodes under the lip. The body of the vessel has three narrow vertical appliqued strips (each strip placed under each of the appliqued nodes near the lip) that extend to just 
above the vessel base; the vertical appliqued strips begin at an appliqued node (Figure 233).

TYPE: Undetermined utility ware, cf. Mockingbird Punctated (Perttula et al. 1998) or McKinney Plain

Figure 233. Punctated-appliqued jar from the Walters collection, unknown provenience.

SITE NAME OR SITE NUMBER: Unknown

VESSEL NO.: 221

NON-PLASTICS: grog; sandy paste

VESSEL FORM: Jar

RIM AND LIP FORM: Direct rim and a rounded, crimped lip

CORE COLOR: A (fired and cooled in a high oxygen environment)

INTERIOR SURFACE COLOR: light yellowish-brown (10YR 6/4)

EXTERIOR SURFACE COLOR: light yellowish-brown (10YR 6/4)

WALL THICKNESS (RIM, BODY, AND BASE IN MM): 10.2 mm, rim; 9.3 mm, body

INTERIOR SURFACE TREATMENT: smoothed

EXTERIOR SURFACE TREATMENT: smoothed on the body

HEIGHT (IN CM): N/A

ORIFICE DIAMETER (IN CM): 35.0

DIAMETER AT BOTTOM OF RIM OR NECK (IN CM): 35.5

BASE DIAMETER (IN CM): N/A

ESTIMATED VOLUME (IN LITERS): N/A

DECORATION: Cross-hatched incised lines on the vessel rim

TYPE: Canton Incised 
SITE NAME OR SITE NUMBER: Unknown

VESSEL NO.: 229

NON-PLASTICS: grog

VESSEL FORM: Carinated bowl

RIM AND LIP FORM: Direct rim and a rounded lip

CORE COLOR: A (fired and cooled in a high oxygen environment)

INTERIOR SURFACE COLOR: brownish-yellow (10YR 6/6); fire clouding on the base EXTERIOR SURFACE COLOR: brownish-yellow (10YR 6/6); fire clouding on the base WALL THICKNESS (RIM, BODY, AND BASE IN MM): 5.9 mm, rim INTERIOR SURFACE TREATMENT: smoothed

EXTERIOR SURFACE TREATMENT: burnished

HEIGHT (IN CM): 8.5

ORIFICE DIAMETER (IN CM): 18.4

DIAMETER AT BOTTOM OF RIM OR NECK (IN CM): 15.0

BASE DIAMETER (IN CM): 7.0

ESTIMATED VOLUME (IN LITERS): 0.94 liters

DECORATION: Cross-hatched engraved lines on the rim (Figure 234)

TYPE: Undetermined fine ware, cf. Sanders Engraved

Figure 234. Cross-hatched engraved carinated bowl from the Walters collection, unknown provenience.

SITE NAME OR SITE NUMBER: Unknown

VESSEL NO.: 230

NON-PLASTICS: grog 
VESSEL FORM: Carinated bowl

RIM AND LIP FORM: Direct rim and a rounded lip

CORE COLOR: A (fired and cooled in a high oxygen environment)

INTERIOR SURFACE COLOR: yellowish-brown (10YR 5/4); fire clouding on the base EXTERIOR SURFACE COLOR: strong brown (7.5YR 4/6); fire clouding on the body and the base

WALL THICKNESS (RIM, BODY, AND BASE IN MM): 6.5 mm, rim

INTERIOR SURFACE TREATMENT: smoothed on the rim

EXTERIOR SURFACE TREATMENT: burnished

HEIGHT (IN CM): 7.6

ORIFICE DIAMETER (IN CM): 13.2

DIAMETER AT BOTTOM OF RIM OR NECK (IN CM): 13.3

BASE DIAMETER (IN CM): 7.2

ESTIMATED VOLUME (IN LITERS): 0.60 liters

DECORATION: Lip notched only (Figure 235).

TYPE: Undetermined fine ware

Figure 235. Lip-notched carinated bowl from the Walters collection, unknown provenience.

SITE NAME OR SITE NUMBER: Unknown

VESSEL NO.: 236

NON-PLASTICS: grog

VESSEL FORM: carinated bowl

RIM AND LIP FORM: Inverted rim and a rounded lip

CORE COLOR: F (fired in a reducing environment and cooled in the open air) 
INTERIOR SURFACE COLOR: reddish-yellow (7.5YR 6/6)

EXTERIOR SURFACE COLOR: reddish-yellow (7.5YR 6/6)

WALL THICKNESS (RIM, BODY, AND BASE IN MM): 4.8 mm, rim

INTERIOR SURFACE TREATMENT: smoothed on the rim

EXTERIOR SURFACE TREATMENT: burnished

HEIGHT (IN CM): 5.6

ORIFICE DIAMETER (IN CM): 8.3

DIAMETER AT BOTTOM OF RIM OR NECK (IN CM): 9.4

BASE DIAMETER (IN CM): 5.5

ESTIMATED VOLUME (IN LITERS): 0.19 liters

DECORATION: Plain

TYPE: Undetermined plain ware

SITE NAME OR SITE NUMBER: Unknown

VESSEL NO.: 239

NON-PLASTICS: grog

VESSEL FORM: Bowl

RIM AND LIP FORM: Direct rim and a rounded, exterior folded lip

CORE COLOR: $\mathrm{F}$ (fired in a reducing environment and cooled in the open air)

INTERIOR SURFACE COLOR: strong brown (7.5YR 5/6); fire clouding

EXTERIOR SURFACE COLOR: strong brown (7.5YR 5/6); fire clouding

WALL THICKNESS (RIM, BODY, AND BASE IN MM): $5.3 \mathrm{~mm}$, rim

INTERIOR SURFACE TREATMENT: smoothed 
EXTERIOR SURFACE TREATMENT: none

HEIGHT (IN CM): 6.0

ORIFICE DIAMETER (IN CM): 10.0

DIAMETER AT BOTTOM OF RIM OR NECK (IN CM): 10.0

BASE DIAMETER (IN CM): 6.4

ESTIMATED VOLUME (IN LITERS): 0.36 liters

DECORATION: The rim and body are covered with irregular sets of cross-hatched, vertical, and diagonal incised lines.

TYPE: Undetermined utility ware, cf. Canton Incised

SITE NAME OR SITE NUMBER: Unknown

VESSEL NO.: 243

NON-PLASTICS: grog

VESSEL FORM: Deep bowl

RIM AND LIP FORM: Direct rim and a flat lip

CORE COLOR: A (fired and cooled in a high oxygen environment)

INTERIOR SURFACE COLOR: light yellowish-brown (10YR 6/4)

EXTERIOR SURFACE COLOR: light yellowish-brown (10YR 6/4)

WALL THICKNESS (RIM, BODY, AND BASE IN MM): 6.8 mm, rim

INTERIOR SURFACE TREATMENT: none

EXTERIOR SURFACE TREATMENT: none

HEIGHT (IN CM): 9.0

ORIFICE DIAMETER (IN CM): 8.7

DIAMETER AT BOTTOM OF RIM OR NECK (IN CM): N/A 


\section{BASE DIAMETER (IN CM): 5.4}

ESTIMATED VOLUME (IN LITERS): 0.63 liters

DECORATION: There are 20 sets of diagonal opposed incised lines on the rim, and there is a single horizontal incised line underneath these sets. Pendant from this horizontal incised line are 25 small incised triangles; each triangle has one or two short incised lines within it (Figure 236).

TYPE: Undetermined utility ware

Figure 236. Incised deep bowl from the Walters collection, unknown provenience.

SITE NAME OR SITE NUMBER: Unknown

VESSEL NO.: 245

NON-PLASTICS: grog

VESSEL FORM: Carinated bowl

RIM AND LIP FORM: Direct rim and a rounded, exterior folded lip

CORE COLOR: B (fired and cooled in a low oxygen environment)

INTERIOR SURFACE COLOR: very dark gray (10YR 3/1)

EXTERIOR SURFACE COLOR: very dark gray (10YR 3/1)

WALL THICKNESS (RIM, BODY, AND BASE IN MM): $6.3 \mathrm{~mm}$, rim

INTERIOR SURFACE TREATMENT: smoothed

EXTERIOR SURFACE TREATMENT: burnished

HEIGHT (IN CM): 4.0

ORIFICE DIAMETER (IN CM): 7.2

DIAMETER AT BOTTOM OF RIM OR NECK (IN CM): 6.8

BASE DIAMETER (IN CM): 3.4

ESTIMATED VOLUME (IN LITERS): 0.17 liters 
DECORATION: The rim panel has two rows of six engraved semi-circles with punctated rays. The upper row of three semi-circles has rays that point to the vessel base, while the lower row of three semi-circles have punctated rays that point to the vessel rim (Figure 237). A red hematite clay pigment has been rubbed in the engraved lines.

TYPE: Undetermined fine ware

Figure 237. Engraved carinated bowl from the Walters collection, unknown provenience.

SITE NAME OR SITE NUMBER: Unknown (Smith County?)

VESSEL NO.: 249

NON-PLASTICS: grog

VESSEL FORM: Carinated bowl with two rim panels

RIM AND LIP FORM: Direct rim and a flat lip (upper panel)

CORE COLOR: $\mathrm{F}$ (fired in a reducing environment and cooled in the open air)

INTERIOR SURFACE COLOR: strong brown (7.5YR 5/6)

EXTERIOR SURFACE COLOR: strong brown (7.5YR 5/6)

WALL THICKNESS (RIM, BODY, AND BASE IN MM): 6.5 mm, rim

INTERIOR SURFACE TREATMENT: smoothed

EXTERIOR SURFACE TREATMENT: burnished on the lower rim panel

HEIGHT (IN CM): N/A

ORIFICE DIAMETER (IN CM): N/A

DIAMETER AT BOTTOM OF RIM OR NECK (IN CM): N/A

BASE DIAMETER (IN CM): N/A

ESTIMATED VOLUME (IN LITERS): N/A

DECORATION: The upper panel has five rows of cane punctations; a deep horizontal grooved line separates the upper and lower panels of decoration. The lower panel has at least four large engraved cross-hatched pendant triangles whose apex points towards the vessel base (Figure 238). 
TYPE: Undetermined fine ware; possibly related to cf. Holly Fine Engraved two paneled vessels 177 and 178 (see above)

Figure 238. Engraved-punctated carinated bowl from the Walters collection, unknown provenience.

SITE NAME OR SITE NUMBER: Unknown

VESSEL NO.: 250

NON-PLASTICS: grog

VESSEL FORM: Jar

RIM AND LIP FORM: Everted rim and a rounded lip

CORE COLOR: A (fired and cooled in a high oxygen environment)

INTERIOR SURFACE COLOR: brown (7.5YR 5/4)

EXTERIOR SURFACE COLOR: brown (7.5YR 5/4)

WALL THICKNESS (RIM, BODY, AND BASE IN MM): 7.9 mm, rim; 9.9 mm, body; $12.7 \mathrm{~mm}$, base

INTERIOR SURFACE TREATMENT: smoothed

EXTERIOR SURFACE TREATMENT: smoothed on the body

HEIGHT (IN CM): 12.6

ORIFICE DIAMETER (IN CM): 14.3

DIAMETER AT BOTTOM OF RIM OR NECK (IN CM): 11.0

BASE DIAMETER (IN CM): 7.0

ESTIMATED VOLUME (IN LITERS): 1.08 liters

DECORATION: Neck banded rows on the vessel rim (Figure 239)

TYPE: La Rue Neck Banded

Figure 239. La Rue Neck Banded jar from the Walters collection, unknown provenience. 
SITE NAME OR SITE NUMBER: Unknown

VESSEL NO.: 251

NON-PLASTICS: grog

VESSEL FORM: Carinated bowl

RIM AND LIP FORM: Inverted rim; the lip is missing

CORE COLOR: C (incompletely oxidized during firing)

INTERIOR SURFACE COLOR: strong brown (7.5YR 5/6)

EXTERIOR SURFACE COLOR: strong brown (7.5YR 5/6)

WALL THICKNESS (RIM, BODY, AND BASE IN MM): 5.6 mm, rim; 5.8 mm, body

INTERIOR SURFACE TREATMENT: smoothed

EXTERIOR SURFACE TREATMENT: smoothed

HEIGHT (IN CM): 15.5+

ORIFICE DIAMETER (IN CM): N/A

DIAMETER AT BOTTOM OF RIM OR NECK (IN CM): 23.0

BASE DIAMETER (IN CM): 9.0

ESTIMATED VOLUME (IN LITERS): N/A

DECORATION: The remaining portions of this vessel have engraved scroll elements, including cross-hatched triangular filled areas where the scroll terminates at the rim carination.

TYPE: cf. Ripley Engraved

SITE NAME OR SITE NUMBER: Unknown

VESSEL NO.: 253

NON-PLASTICS: grog

VESSEL FORM: Carinated bowl 
RIM AND LIP FORM: Direct rim and a rounded lip

CORE COLOR: A (fired and cooled in a high oxygen environment)

INTERIOR SURFACE COLOR: strong brown (7.5YR 5/8)

EXTERIOR SURFACE COLOR: brown (7.5YR 4/4)

WALL THICKNESS (RIM, BODY, AND BASE IN MM): $3.6 \mathrm{~mm}$, rim; $4.1 \mathrm{~mm}$, body; $6.5 \mathrm{~mm}$, base

INTERIOR SURFACE TREATMENT: smoothed on the rim

EXTERIOR SURFACE TREATMENT: smoothed on the body

HEIGHT (IN CM): 11.5

ORIFICE DIAMETER (IN CM): 21.0

DIAMETER AT BOTTOM OF RIM OR NECK (IN CM): 20.0

BASE DIAMETER (IN CM): 10.0

ESTIMATED VOLUME (IN LITERS): 1.4 liters

DECORATION: Cross-hatched incised lines within a rim panel defined by the lip and a lower horizontal incised line at the vessel carination (Figure 240).

TYPE: cf. Dunkin Incised (Suhm and Jelks 1962:Plate 19i)

Figure 240. Dunkin Incised carinated bowl, Walters collection, unknown provenience.

SITE NAME OR SITE NUMBER: Unknown (Smith County)

VESSEL NO.: 261

NON-PLASTICS: grog

VESSEL FORM: Jar

RIM AND LIP FORM: Everted rim and a rounded lip

CORE COLOR: $\mathrm{F}$ (fired in a reducing environment and cooled in the open air) 
INTERIOR SURFACE COLOR: reddish-brown (5YR 5/4)

EXTERIOR SURFACE COLOR: dark yellowish-brown (10YR 4/4); fire clouding

WALL THICKNESS (RIM, BODY, AND BASE IN MM): $7.3 \mathrm{~mm}$, rim; $6.8 \mathrm{~mm}$, body; $12.3 \mathrm{~mm}$, base

INTERIOR SURFACE TREATMENT: none

EXTERIOR SURFACE TREATMENT: none

HEIGHT (IN CM): 16.0

ORIFICE DIAMETER (IN CM): 17.0

DIAMETER AT BOTTOM OF RIM OR NECK (IN CM): N/A

BASE DIAMETER (IN CM): 6.0

ESTIMATED VOLUME (IN LITERS): 2.4 liters

DECORATION: The rim has diagonal incised lines. The vessel body is covered with an irregular pattern of cross-hatched incised lines that extend to the vessel base.

TYPE: Undetermined utility ware

SITE NAME OR SITE NUMBER: Unknown

VESSEL NO.: 262

NON-PLASTICS: grog

VESSEL FORM: Jar

RIM AND LIP FORM: Everted rim and a rounded lip

CORE COLOR: $\mathrm{F}$ (fired in a reducing environment and cooled in the open air)

INTERIOR SURFACE COLOR: light yellowish-brown (10YR 6/4)

EXTERIOR SURFACE COLOR: light yellowish-brown (10YR 6/4)

WALL THICKNESS (RIM, BODY, AND BASE IN MM): 8.4 mm, rim

INTERIOR SURFACE TREATMENT: smoothed 
EXTERIOR SURFACE TREATMENT: smoothed to burnished; organic residue on the body and rim

HEIGHT (IN CM): 34.6

ORIFICE DIAMETER (IN CM): 25.7

DIAMETER AT BOTTOM OF RIM OR NECK (IN CM): 23.7

BASE DIAMETER (IN CM): 11.0

ESTIMATED VOLUME (IN LITERS): 11.6 liters

DECORATION: The vessel rim is roughened (see Suhm and Jelks 1962:97) (Figure 241)

TYPE: cf. McKinney Plain

Figure 241. cf. McKinney Plain jar, Walters collection, unknown provenience.

SITE NAME OR SITE NUMBER: Unknown

VESSEL NO.: 263

NON-PLASTICS: grog and bone

VESSEL FORM: Carinated bowl

RIM AND LIP FORM: Direct rim and a rounded lip

CORE COLOR: $\mathrm{G}$ (fired in a low oxygen environment and cooled in the open air)

INTERIOR SURFACE COLOR: dark gray (10YR 4/1)

EXTERIOR SURFACE COLOR: yellowish-brown (10YR 5/4)

WALL THICKNESS (RIM, BODY, AND BASE IN MM): 7.8 mm, rim

INTERIOR SURFACE TREATMENT: smoothed

EXTERIOR SURFACE TREATMENT: smoothed

HEIGHT (IN CM): 9.8+

ORIFICE DIAMETER (IN CM): 19.4 
DIAMETER AT BOTTOM OF RIM OR NECK (IN CM): 19.2

BASE DIAMETER (IN CM): N/A

ESTIMATED VOLUME (IN LITERS): 1.14 liters+

DECORATION: The rim panel (defined by a single upper and lower horizontal engraved line) has six sets of engraved scrolls, divided by hatched brackets. There are hatched pendant triangles on the upper and lower horizontal engraved lines that define the rim panel.

TYPE: cf. Ripley Engraved

SITE NAME OR SITE NUMBER: Unknown

VESSEL NO.: 264

NON-PLASTICS: grog

VESSEL FORM: Jar

RIM AND LIP FORM: Missing

CORE COLOR: $\mathrm{F}$ (fired in a reducing environment and cooled in the open air)

INTERIOR SURFACE COLOR: strong brown (7.5YR 5/6)

EXTERIOR SURFACE COLOR: brown (7.5YR 4/3)

WALL THICKNESS (RIM, BODY, AND BASE IN MM): 7.6 mm, body

INTERIOR SURFACE TREATMENT: smoothed

EXTERIOR SURFACE TREATMENT: smoothed; organic residue on the body

HEIGHT (IN CM): 20.0+

ORIFICE DIAMETER (IN CM): 19.0

DIAMETER AT BOTTOM OF RIM OR NECK (IN CM): 20.5

BASE DIAMETER (IN CM): 10.5

ESTIMATED VOLUME (IN LITERS): 3.4+ liters 
DECORATION: Plain, but the rim is missing

TYPE: Undetermined utility ware

SITE NAME OR SITE NUMBER: Unknown

VESSEL NO.: 265

NON-PLASTICS: grog

VESSEL FORM: Jar

RIM AND LIP FORM: Everted rim and a rounded lip

CORE COLOR: $\mathrm{F}$ (fired in a reducing environment and cooled in the open air)

INTERIOR SURFACE COLOR: very pale brown (10YR 7/4)

EXTERIOR SURFACE COLOR: very pale brown (10YR 7/4)

WALL THICKNESS (RIM, BODY, AND BASE IN MM): 7.3 mm, rim; 7.4 mm, body; $10.5 \mathrm{~mm}$, base

INTERIOR SURFACE TREATMENT: smoothed

EXTERIOR SURFACE TREATMENT: smoothed on the body

HEIGHT (IN CM): 20.0

ORIFICE DIAMETER (IN CM): 18.0

DIAMETER AT BOTTOM OF RIM OR NECK (IN CM): 15.8

BASE DIAMETER (IN CM): N/A

ESTIMATED VOLUME (IN LITERS): 3.2 liters

DECORATION: The rim is roughened; there are also four sets of two small appliqued nodes on the rim. The upper part of the vessel body, beginning at the rim-body juncture, has four sets of appliqued chevrons (Figure 242).

TYPE: McKinney Plain

Figure 242. McKinney Plain jar, Walters collection, unknown provenience. 
SITE NAME OR SITE NUMBER: Unknown

VESSEL NO.: 268

NON-PLASTICS: grog

VESSEL FORM: Carinated bowl

RIM AND LIP FORM: Inverted rim with a flat and exterior folded lip

CORE COLOR: $\mathrm{G}$ (fired in a reducing environment and cooled in the open air)

INTERIOR SURFACE COLOR: black (10YR 2/1)

EXTERIOR SURFACE COLOR: yellowish-brown (10YR 5/4); fire clouding on the rim and the body

WALL THICKNESS (RIM, BODY, AND BASE IN MM): 8.8 mm, rim; 10.9 mm, body

INTERIOR SURFACE TREATMENT: smoothed

EXTERIOR SURFACE TREATMENT: burnished

HEIGHT (IN CM): 17.7

ORIFICE DIAMETER (IN CM): 25.4

DIAMETER AT BOTTOM OF RIM OR NECK (IN CM): 26.6

BASE DIAMETER (IN CM): 9.9

ESTIMATED VOLUME (IN LITERS): 4.0 liters

DECORATION: The rim panel has eight sets of hooked arm scrolls, with hatched upper and lower brackets that join the scrolls to the rim and the vessel carination (Figure 243).

TYPE: Taylor Engraved

Figure 243. Taylor Engraved carinated bowl, Walters collection, unknown provenience.

SITE NAME OR SITE NUMBER: Unknown

VESSEL NO.: 269 
NON-PLASTICS: grog and hematite

VESSEL FORM: Bowl

RIM AND LIP FORM: Direct and interior thickened (15 mm thick) rim and rounded and scalloped lip (Figure 244)

CORE COLOR: $\mathrm{G}$ (fired in a reducing environment and cooled in the open air)

INTERIOR SURFACE COLOR: dark gray (10YR 4/1)

EXTERIOR SURFACE COLOR: strong brown (7.5YR 5/6)

WALL THICKNESS (RIM, BODY, AND BASE IN MM): 8.4 mm, rim

INTERIOR SURFACE TREATMENT: smoothed

EXTERIOR SURFACE TREATMENT: smoothed

HEIGHT (IN CM): 8.0

ORIFICE DIAMETER (IN CM): 18.1

DIAMETER AT BOTTOM OF RIM OR NECK (IN CM): N/A

BASE DIAMETER (IN CM): 10.8

ESTIMATED VOLUME (IN LITERS): 0.58 liters

DECORATION: Plain, but with an interior thickened rim, as with Spoonbill Engraved (Perttula et al. 2007:19).

TYPE: Spoonbill Plain

Figure 244. Spoonbill Plain bowl, Walters collection, unknown provenience.

SITE NAME OR SITE NUMBER: Unknown

VESSEL NO.: 270

NON-PLASTICS: bone

VESSEL FORM: Jar

RIM AND LIP FORM: Everted rim and a rounded lip 
CORE COLOR: $\mathrm{H}$ (fired in a reducing environment and cooled in the open air)

INTERIOR SURFACE COLOR: yellowish-brown (10YR 5/4)

EXTERIOR SURFACE COLOR: very dark gray (10YR 3/1)

WALL THICKNESS (RIM, BODY, AND BASE IN MM): 6.4 mm, rim

INTERIOR SURFACE TREATMENT: none

EXTERIOR SURFACE TREATMENT: none

HEIGHT (IN CM): 14.9

ORIFICE DIAMETER (IN CM): 13.0

DIAMETER AT BOTTOM OF RIM OR NECK (IN CM): 11.4

BASE DIAMETER (IN CM): 6.8

ESTIMATED VOLUME (IN LITERS): 1.2 liters

DECORATION: Horizontal brushing marks on the rim, and overlapping brushing marks on the body. The brushing extends on the body to just above the base.

TYPE: Bullard Brushed

SITE NAME OR SITE NUMBER: Unknown

VESSEL NO.: 271

NON-PLASTICS: grog

VESSEL FORM: Jar with appliqued lug handles (Figure 245)

RIM AND LIP FORM: Everted rim and a rounded lip

CORE COLOR: $\mathrm{G}$ (fired in a reducing environment and cooled in the open air)

INTERIOR SURFACE COLOR: very dark gray (10YR 3/1)

EXTERIOR SURFACE COLOR: light yellowish-brown (10YR 6/4)

WALL THICKNESS (RIM, BODY, AND BASE IN MM): $7.2 \mathrm{~mm}$, rim 
INTERIOR SURFACE TREATMENT: smoothed

EXTERIOR SURFACE TREATMENT: smoothed on the body

HEIGHT (IN CM): 31.0

ORIFICE DIAMETER (IN CM): 25.5

DIAMETER AT BOTTOM OF RIM OR NECK (IN CM): 29.0

BASE DIAMETER (IN CM): 9.5

ESTIMATED VOLUME (IN LITERS): 10.3 liters

DECORATION: The rim has irregularly executed diagonal incised to overlapping incised lines around the lug handles. The rim is set apart from the vessel body by four sets of horizontal appliqued strips (either ridges or fillets); the appliqued strips are divided by a single appliqued node (see Figure 245). Below each of these four appliqued nodes, and extending down the body towards the vessel base, are four vertical appliqued fillets. There is a second node at the top of the appliqued fillet. The appliqued lug handle, the sets of nodes, and the vertical appliqued fillets are set on the same vertical axis.

TYPE: Undetermined utility ware

Figure 245. Incised-appliqued jar, Walters collection, unknown provenience.

SITE NAME OR SITE NUMBER: Unknown

VESSEL NO.: 272

NON-PLASTICS: grog

VESSEL FORM: Jar

RIM AND LIP FORM: Direct rim and a flat lip

CORE COLOR: B (fired and cooled in a low oxygen environment)

INTERIOR SURFACE COLOR: black (10YR 2/1)

EXTERIOR SURFACE COLOR: very dark gray (10YR 3/1)

WALL THICKNESS (RIM, BODY, AND BASE IN MM): $6.2 \mathrm{~mm}$, rim; $6.8 \mathrm{~mm}$, body 
INTERIOR SURFACE TREATMENT: none; organic residue on the rim and body

EXTERIOR SURFACE TREATMENT: none

HEIGHT (IN CM): N/A

ORIFICE DIAMETER (IN CM): 17.0

DIAMETER AT BOTTOM OF RIM OR NECK (IN CM): N/A

BASE DIAMETER (IN CM): N/A

ESTIMATED VOLUME (IN LITERS): N/A

DECORATION: The upper part of the vessel has an incised-punctated design. This consists of stacked sets of diagonal opposed triangles and triangular zones filled with tool punctations (Figure 246).

TYPE: cf. Canton Incised

Figure 246. cf. Canton Incised jar from the Walters collection, unknown provenience.

SITE NAME OR SITE NUMBER: Unknown

VESSEL NO.: No number (Vessel No. 147 set inside it)

NON-PLASTICS: grog and hematite

VESSEL FORM: Bowl

RIM AND LIP FORM: Everted rim and a rounded lip

CORE COLOR: A (fired and cooled in a high oxygen environment)

INTERIOR SURFACE COLOR: reddish-yellow (7.5YR 6/6)

EXTERIOR SURFACE COLOR: reddish-yellow (7.5YR 6/6)

WALL THICKNESS (RIM, BODY, AND BASE IN MM): 5.2 mm, rim

INTERIOR SURFACE TREATMENT: none

EXTERIOR SURFACE TREATMENT: smoothed

HEIGHT (IN CM): 4.8 
ORIFICE DIAMETER (IN CM): 10.5

DIAMETER AT BOTTOM OF RIM OR NECK (IN CM): N/A

BASE DIAMETER (IN CM): 7.5

ESTIMATED VOLUME (IN LITERS): 0.2 liters

DECORATION: Plain

TYPE: Undetermined plain ware

SITE NAME OR SITE NUMBER: Unknown

VESSEL NO.: No number

NON-PLASTICS: grog

VESSEL FORM: Carinated bowl

RIM AND LIP FORM: Inverted rim and a rounded lip

CORE COLOR: $\mathrm{G}$ (fired in a reducing environment and cooled in the open air)

INTERIOR SURFACE COLOR: dark gray (10YR 4/1); fire clouding on the base

EXTERIOR SURFACE COLOR: brown (10YR 5/3); fire clouding on the rim and body

WALL THICKNESS (RIM, BODY, AND BASE IN MM): 8.4 mm, rim; 7.4 mm, body; $9.4 \mathrm{~mm}$, base

INTERIOR SURFACE TREATMENT: smoothed

EXTERIOR SURFACE TREATMENT: burnished

HEIGHT (IN CM): 14.8

ORIFICE DIAMETER (IN CM): N/A

DIAMETER AT BOTTOM OF RIM OR NECK (IN CM): N/A

BASE DIAMETER (IN CM): 6.9

ESTIMATED VOLUME (IN LITERS): N/A 
DECORATION: The rim has a single horizontal engraved line under the lip and another at the carination. There is at least one set of two diagonal engraved lines in the engraved rim panel. A red pigment has been rubbed in the engraved lines.

TYPE: Undetermined fine ware 
General map

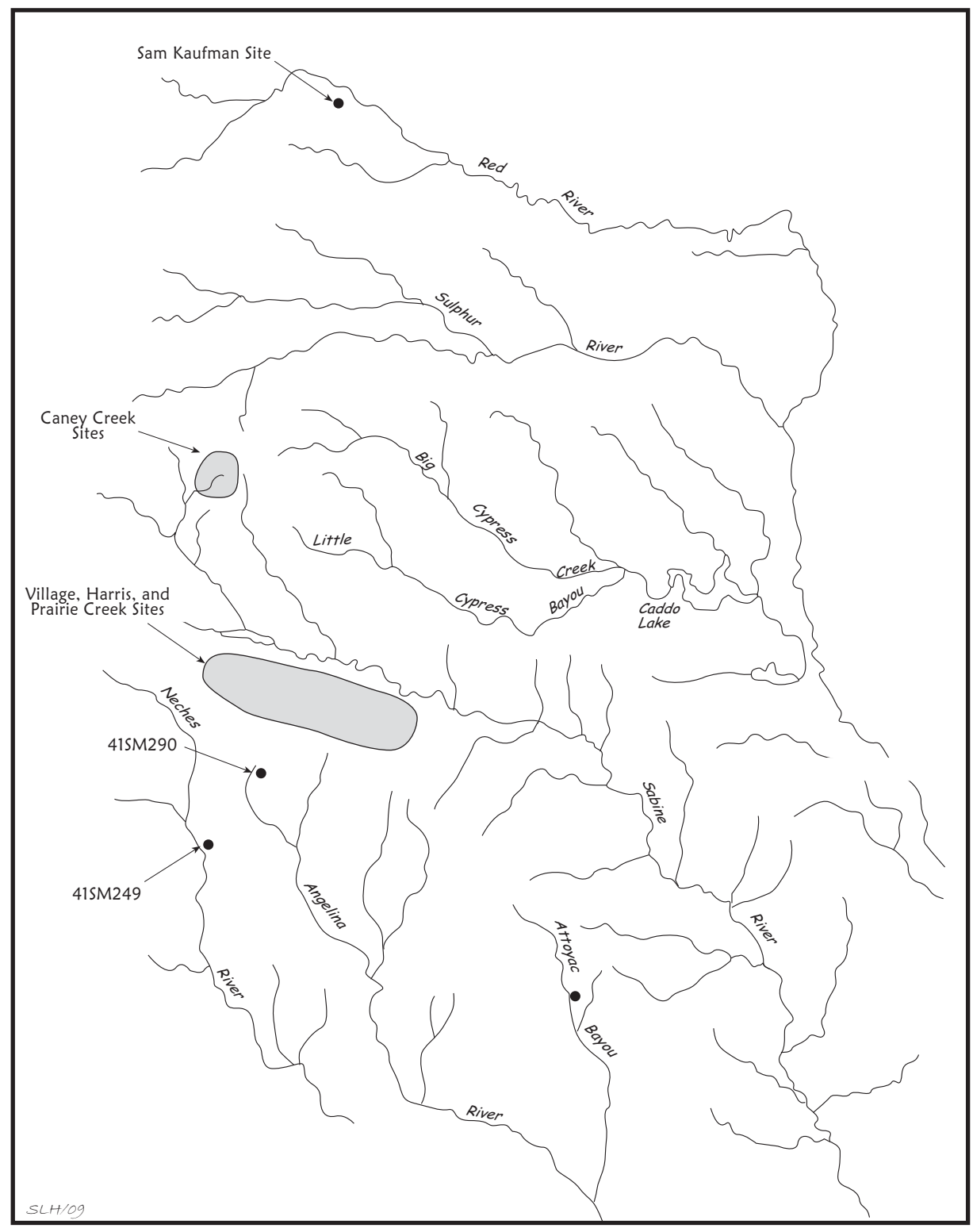

Figure 1 
Figure Houses

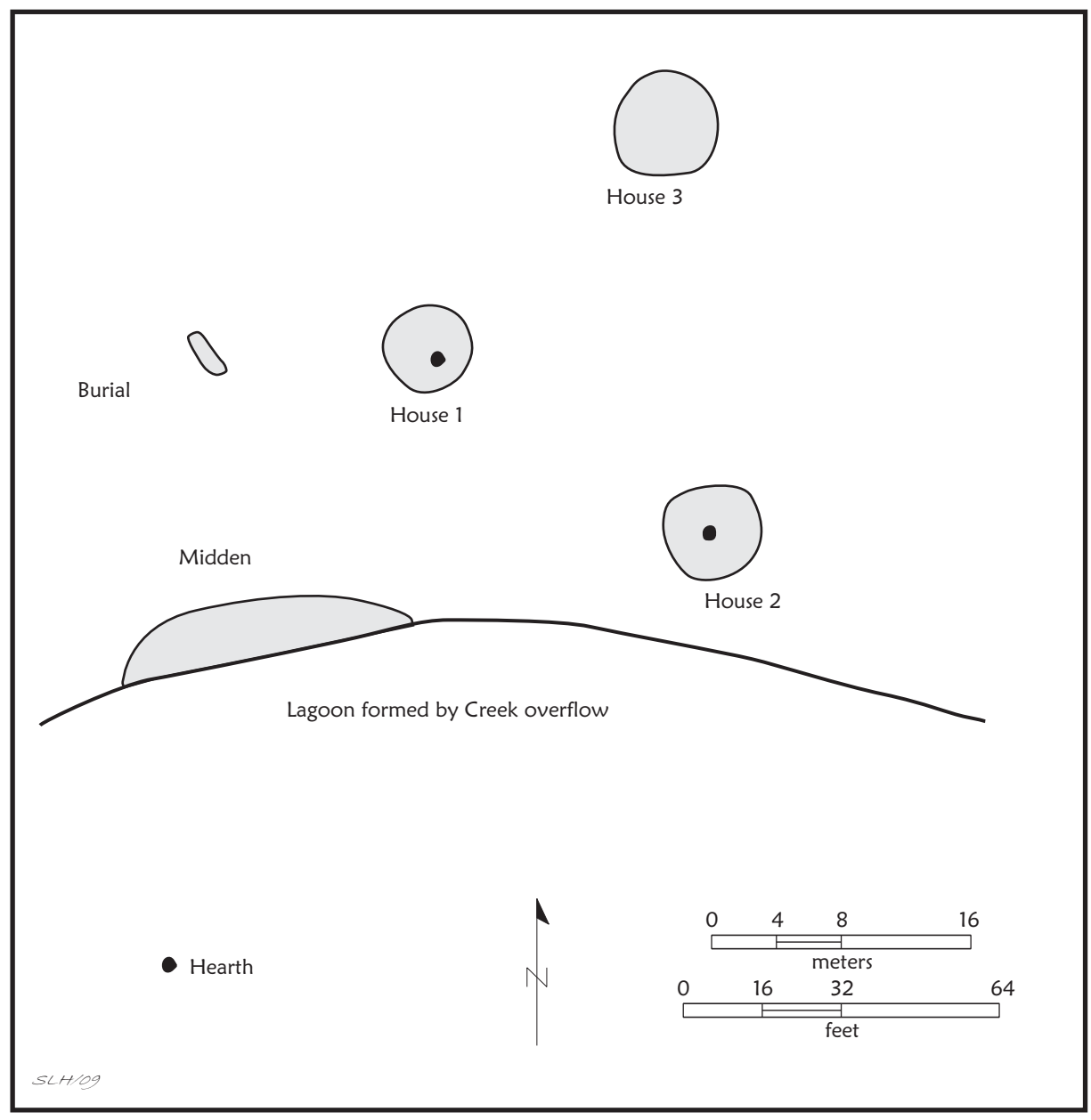

Figure 2 
Figure 41WD109

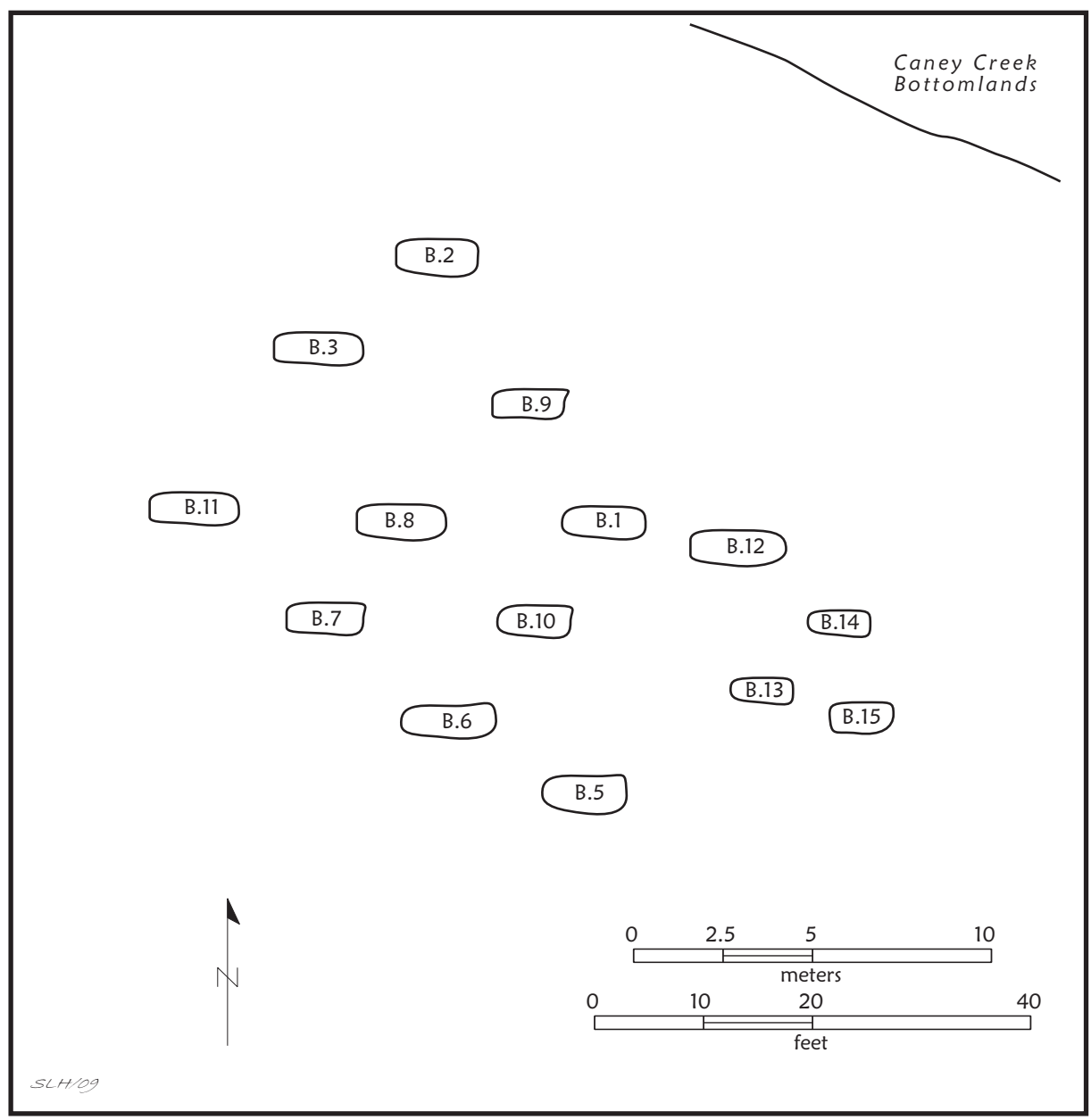

Figure 3 
Figure 41WD589

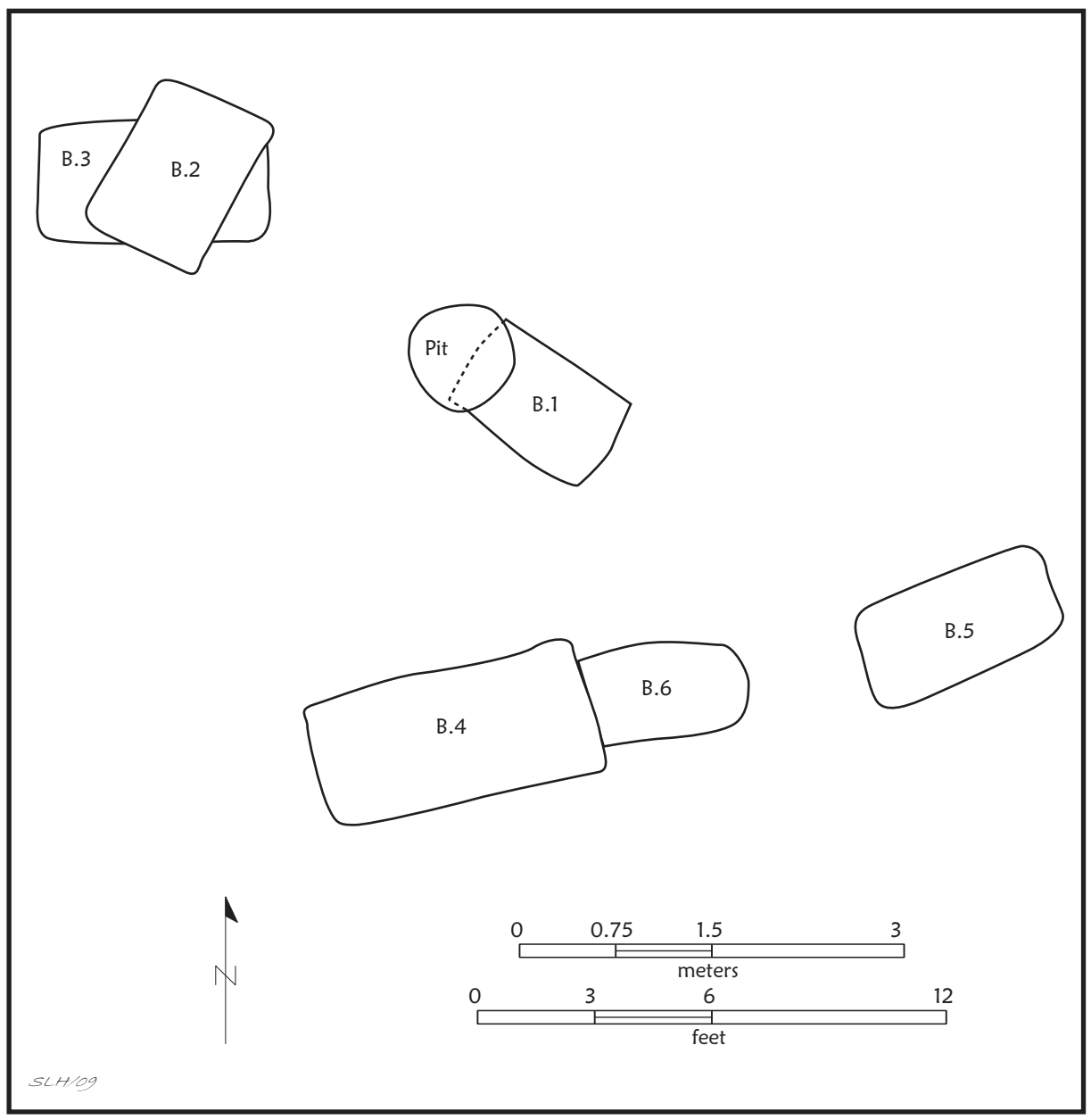

Figure 4 


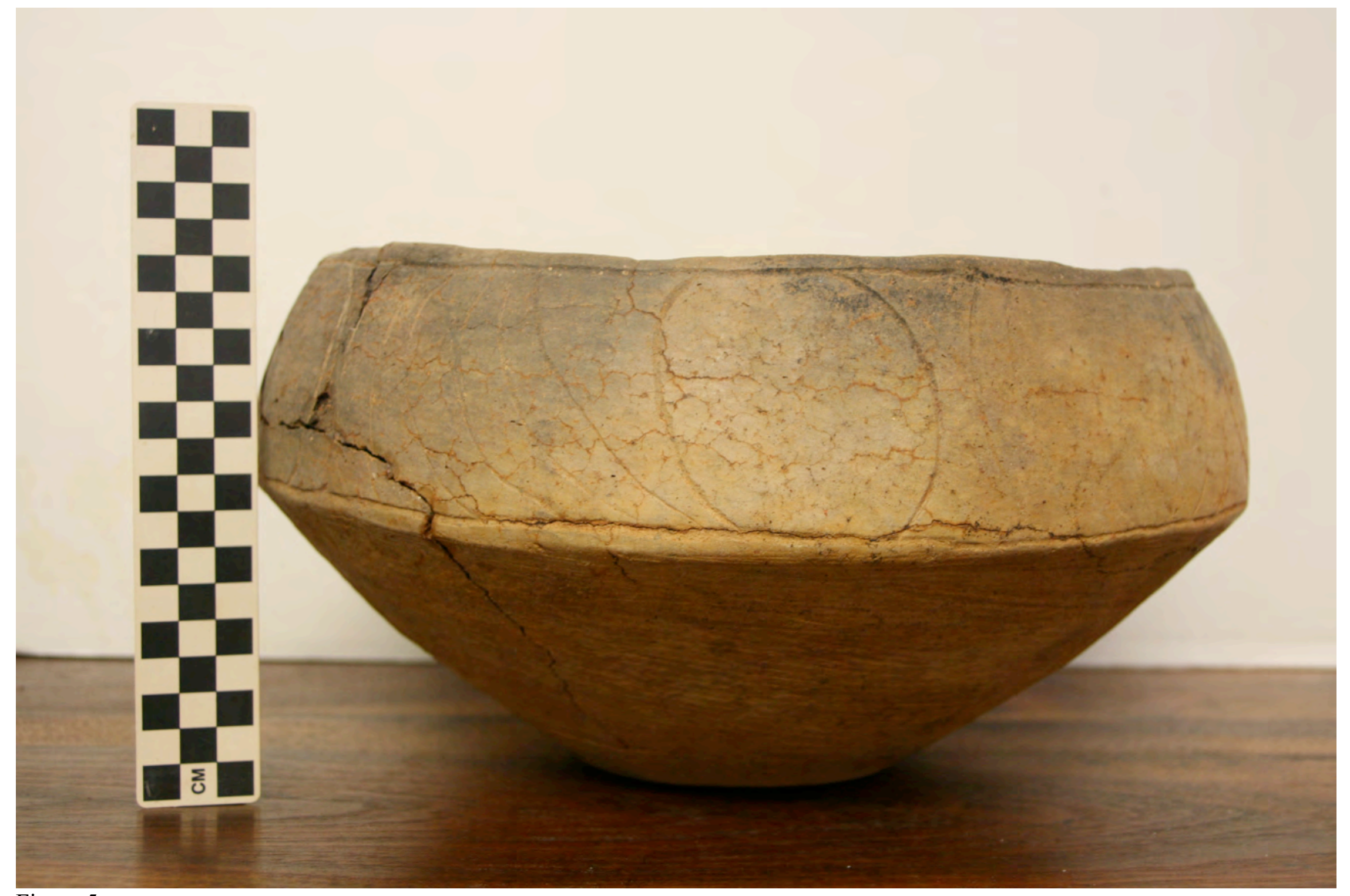

Figure 5 


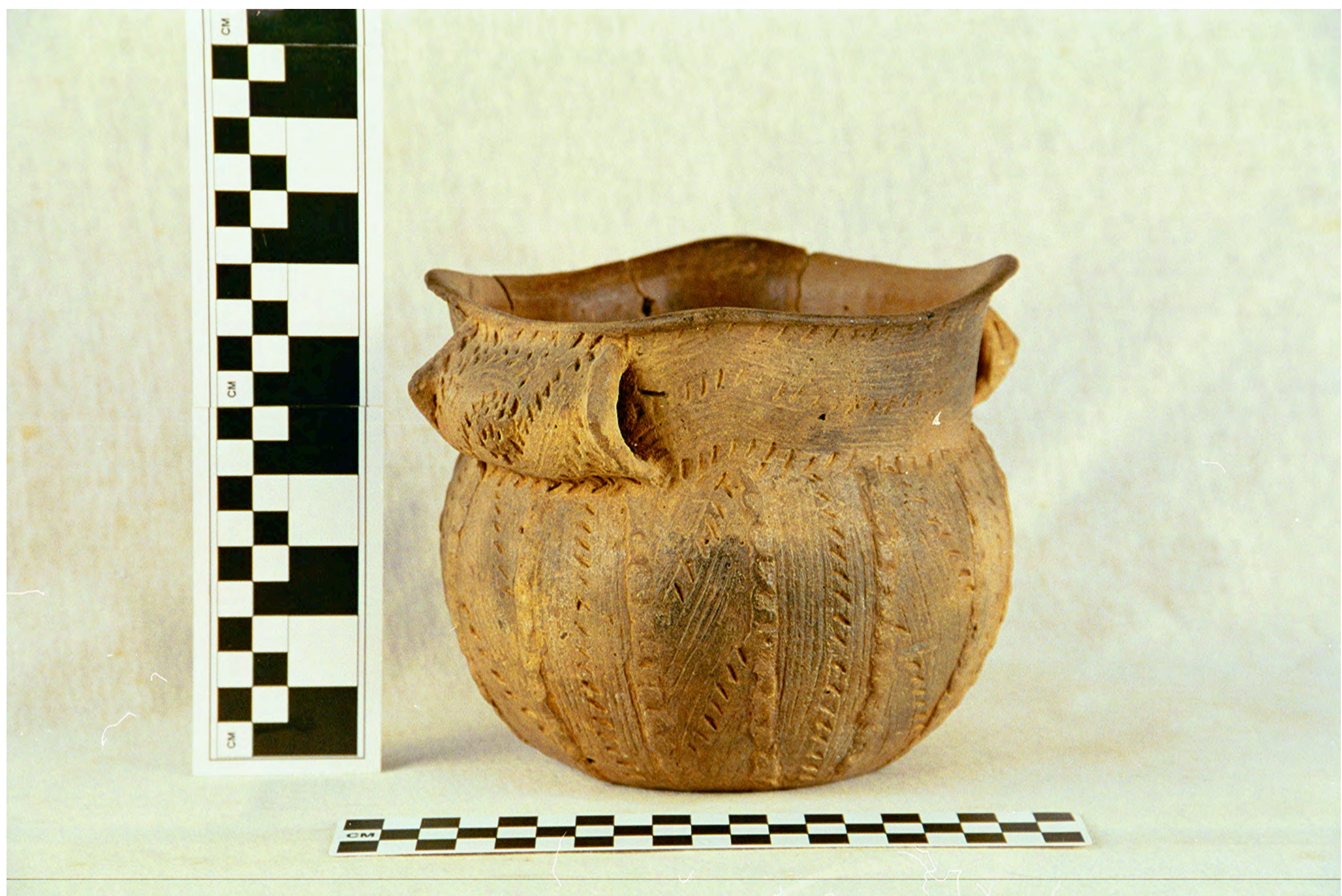

Figure 6 


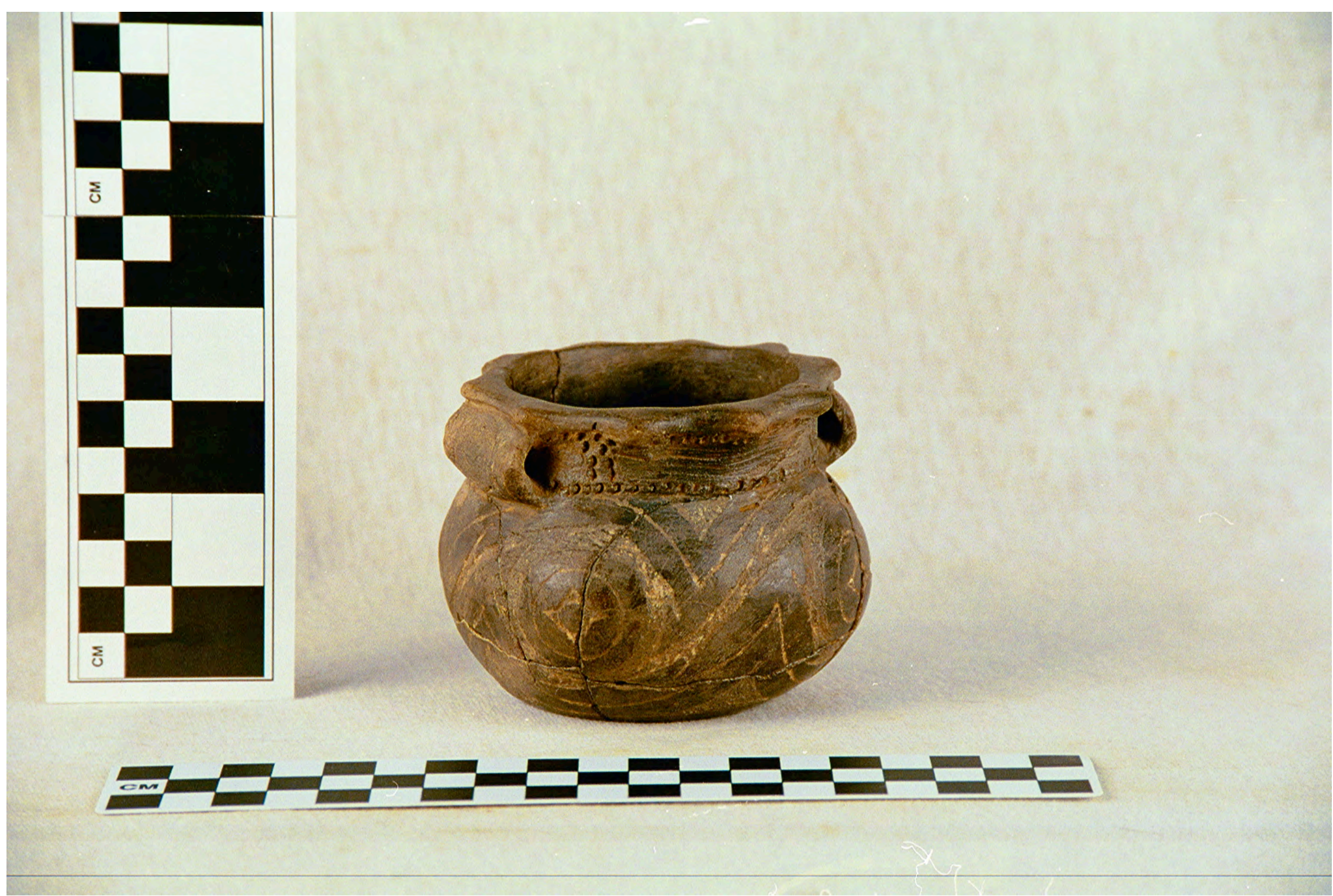

Figure 7 

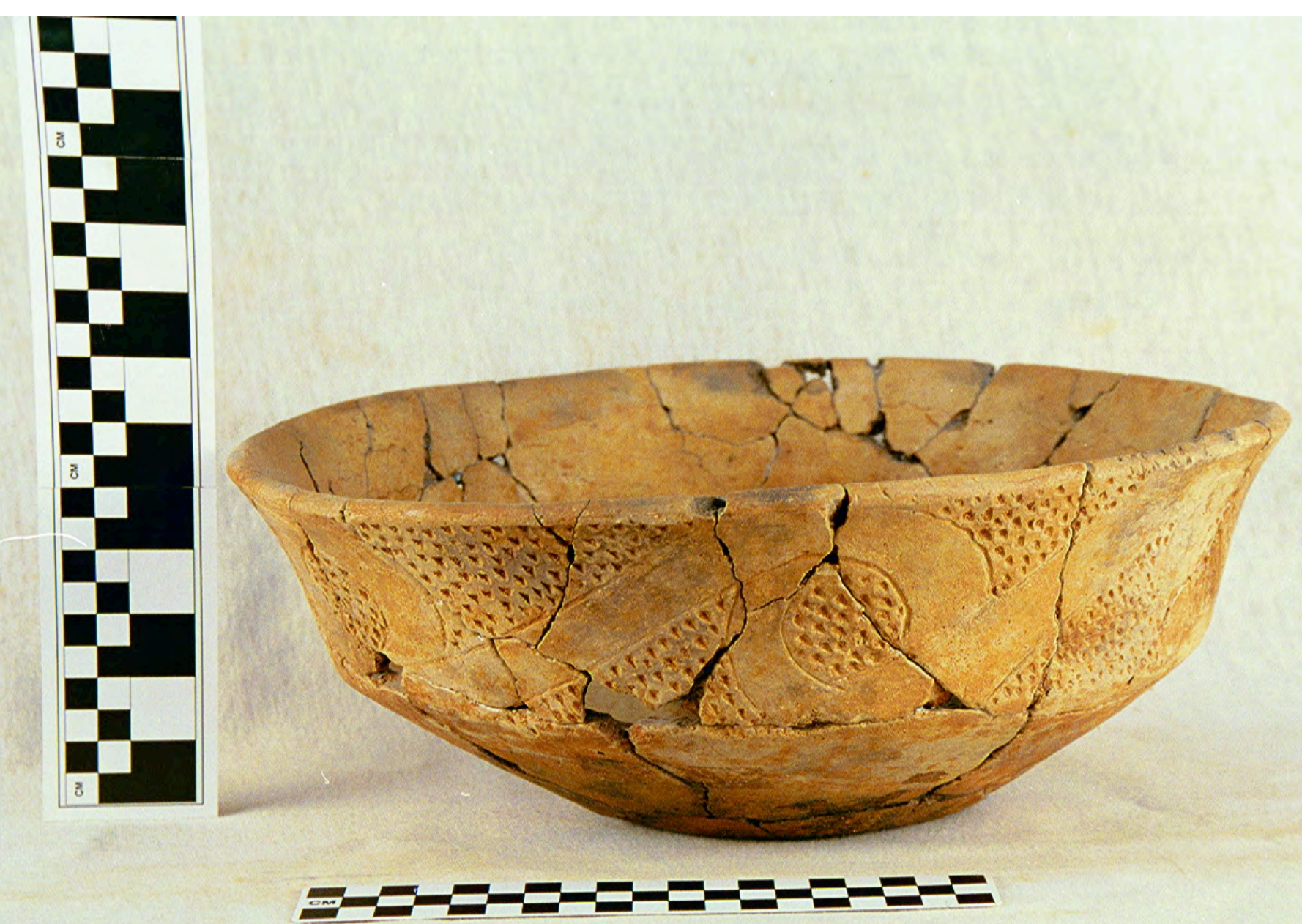

Figure 8 


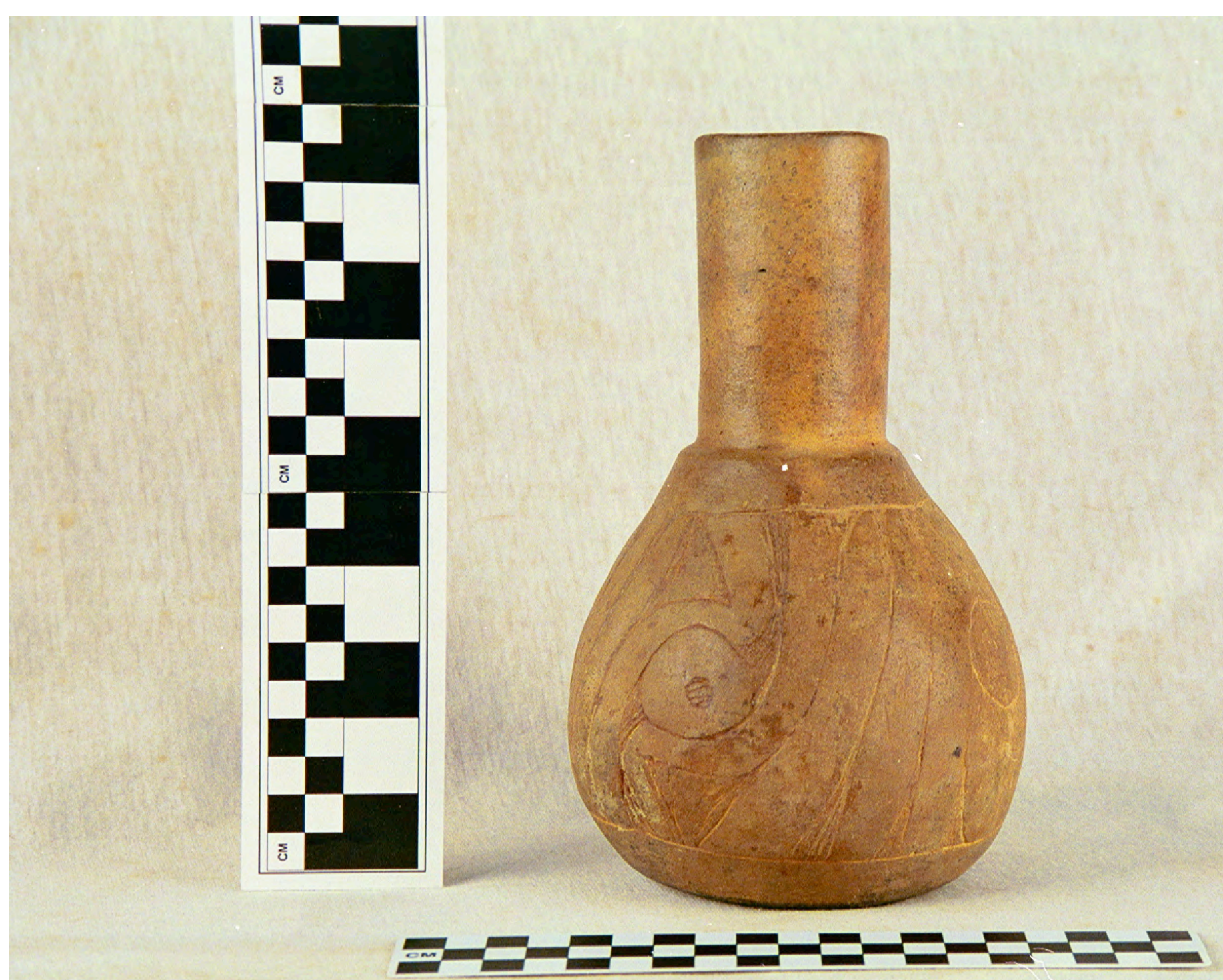

Figure 9 


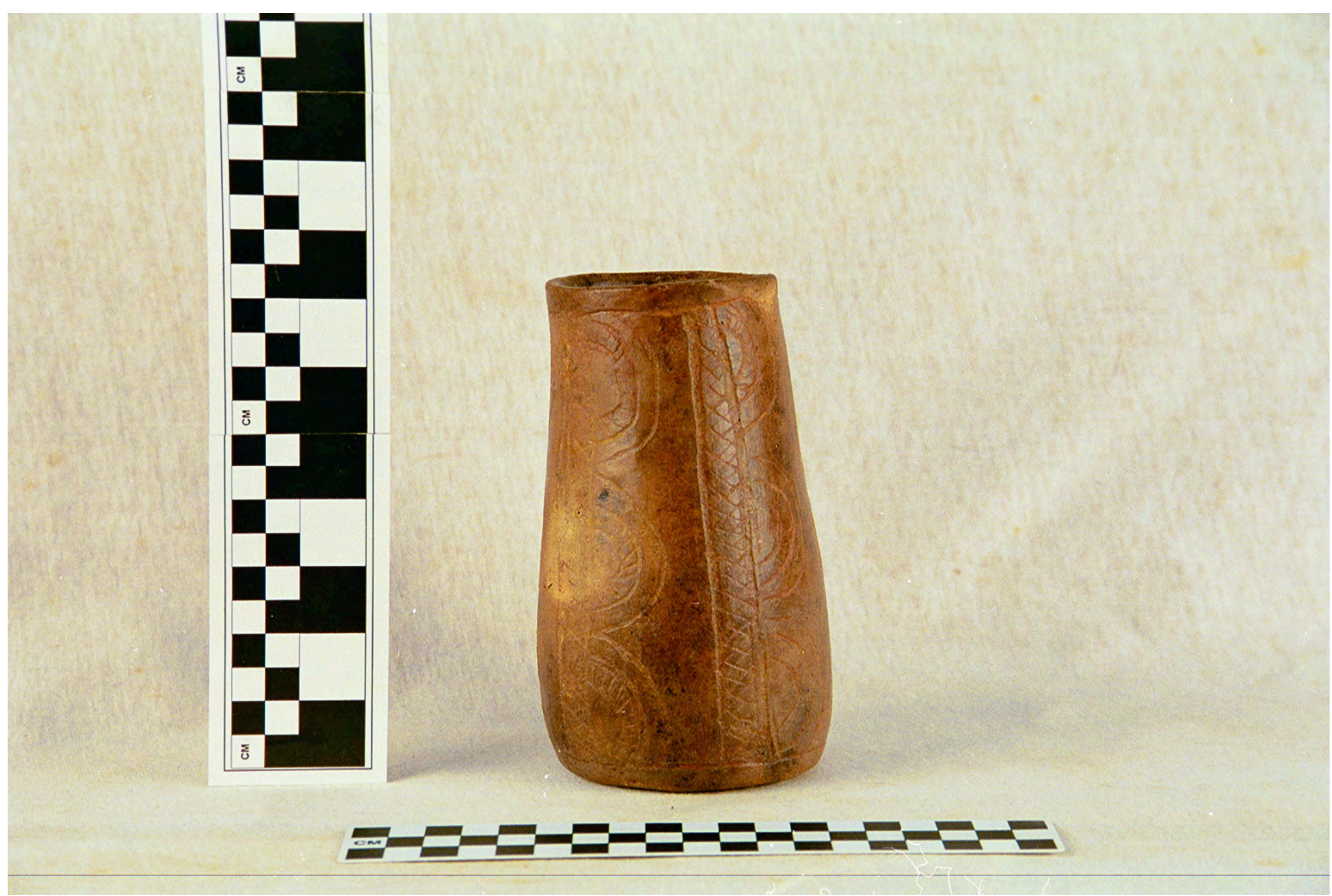

Figure 10 


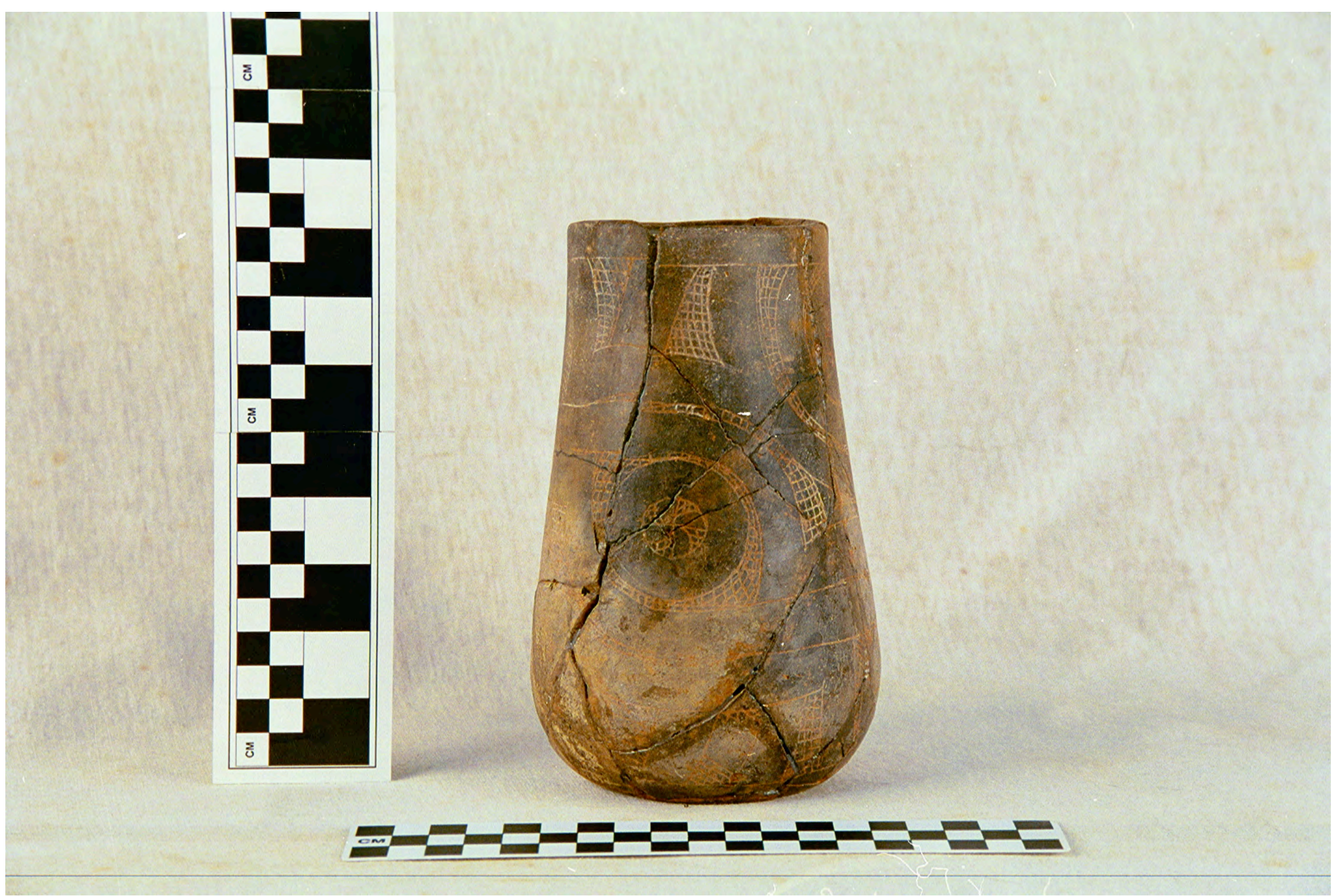

Figure 11 


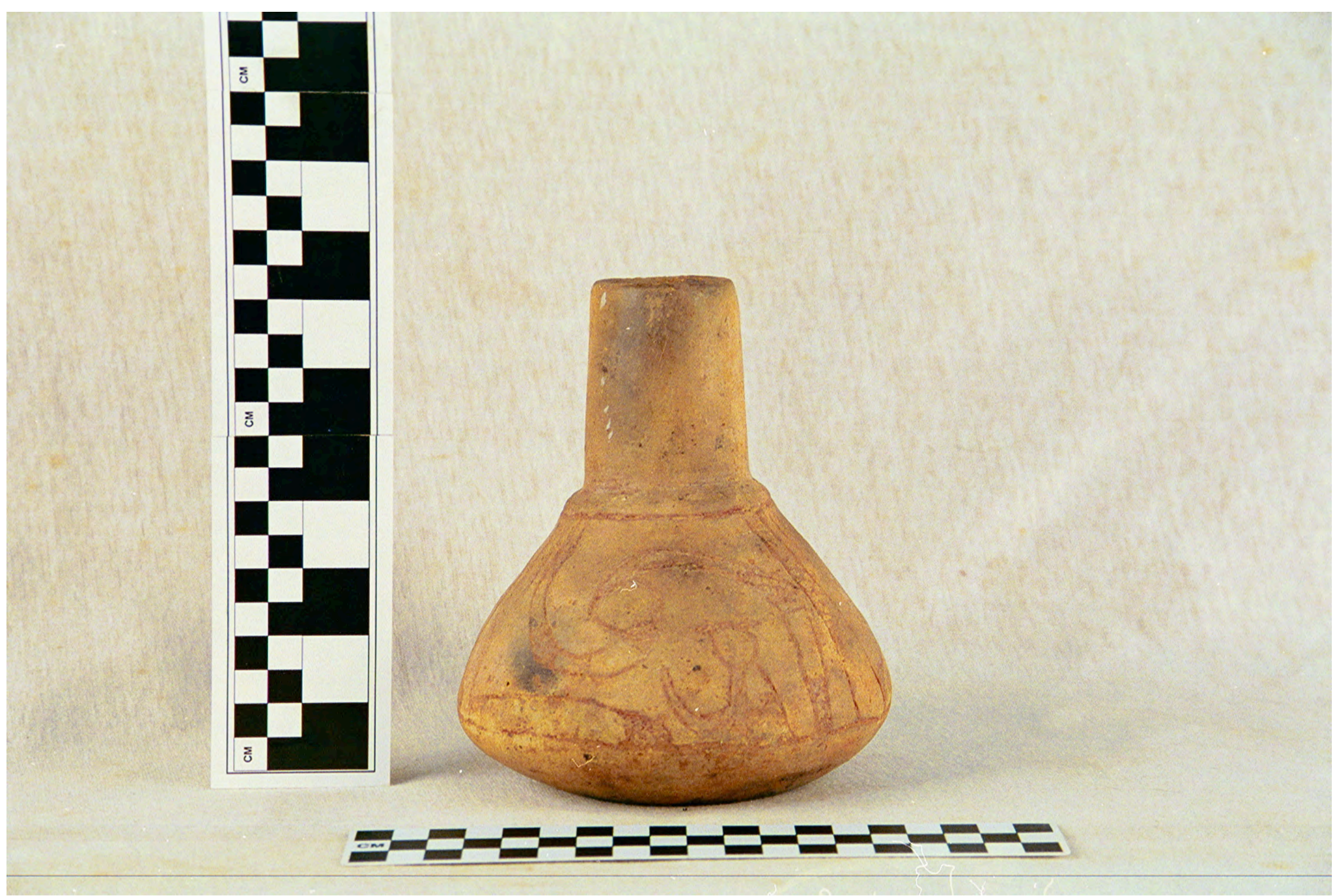

Figure 12 


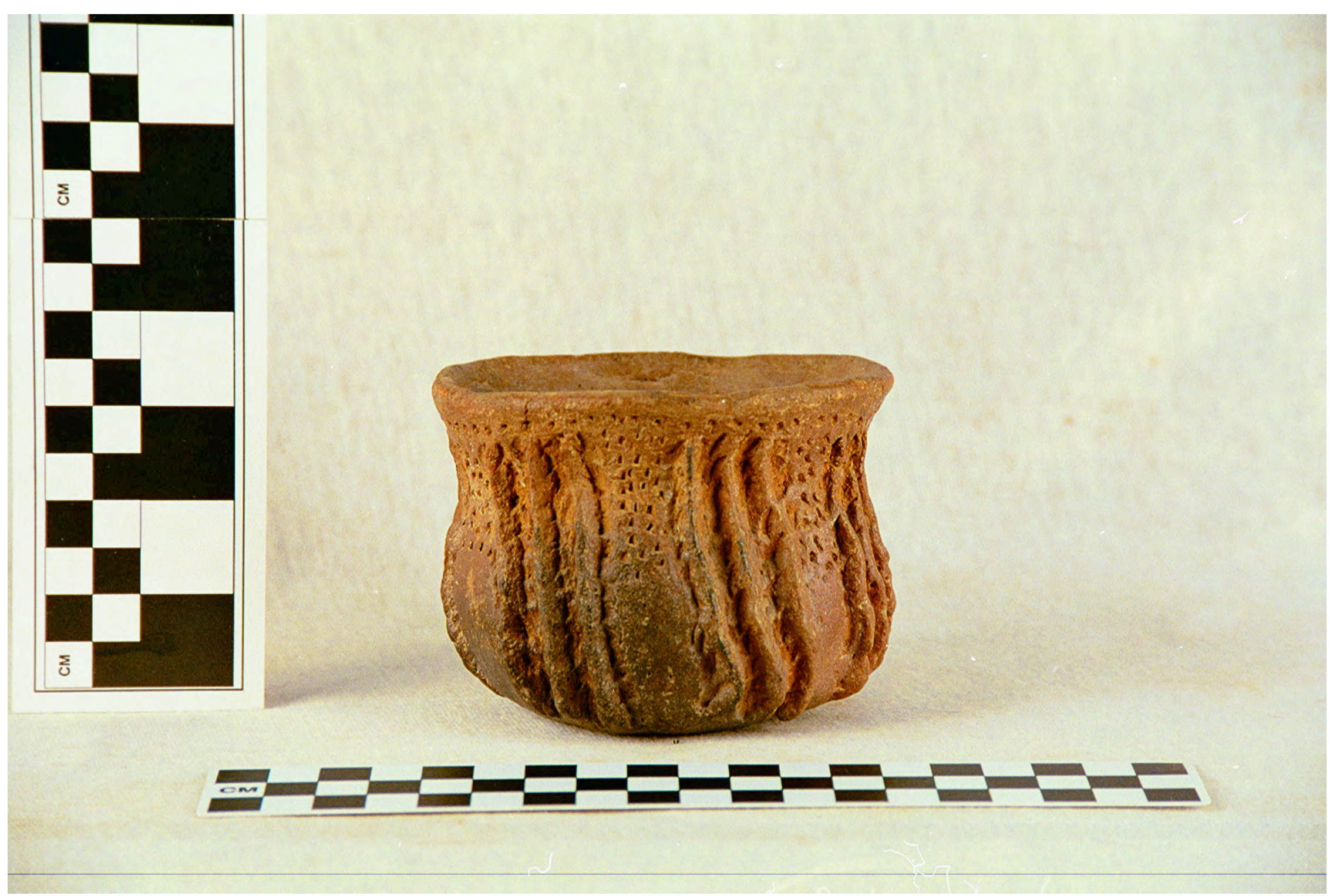

Figure 13 


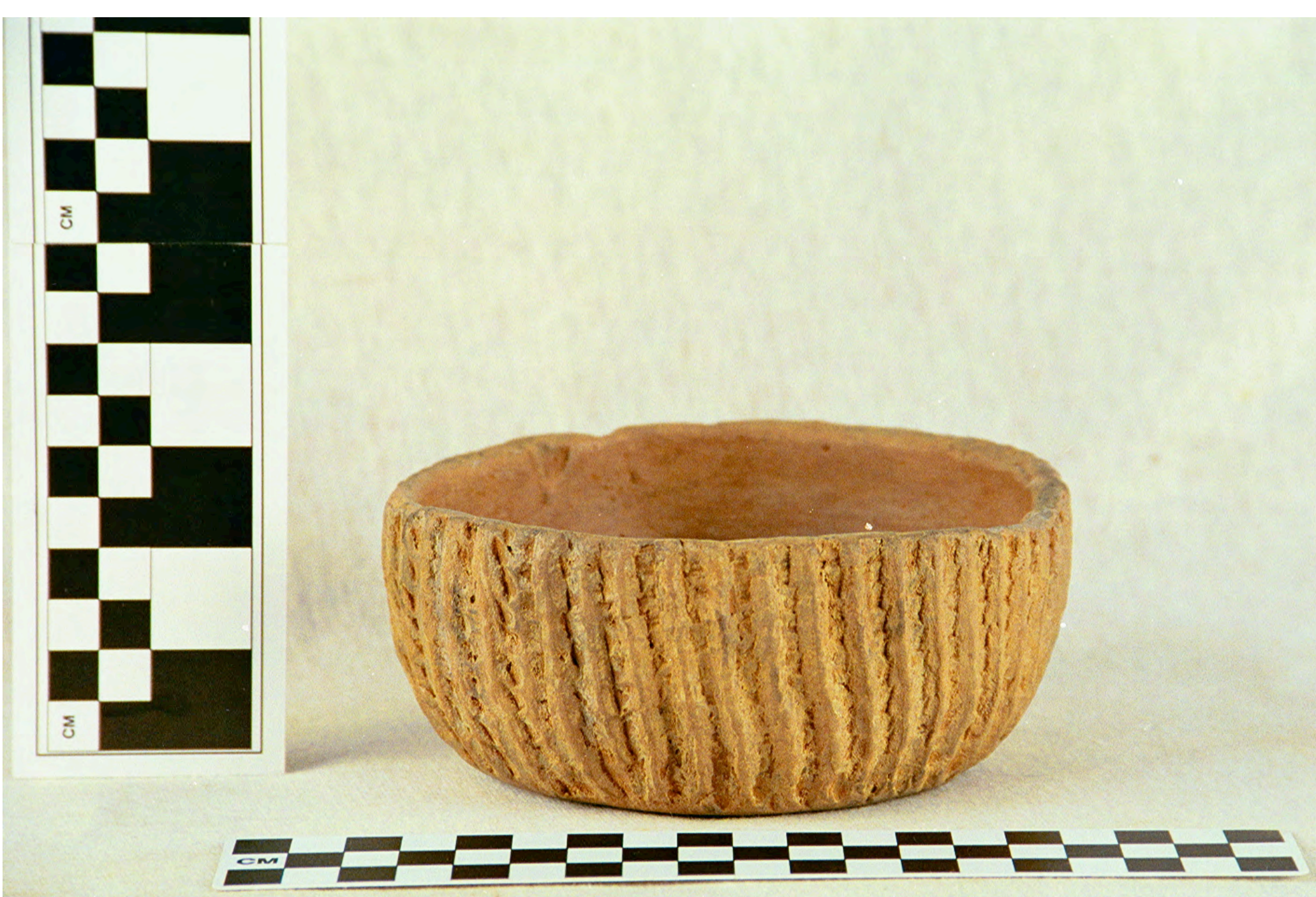

Figure 14 


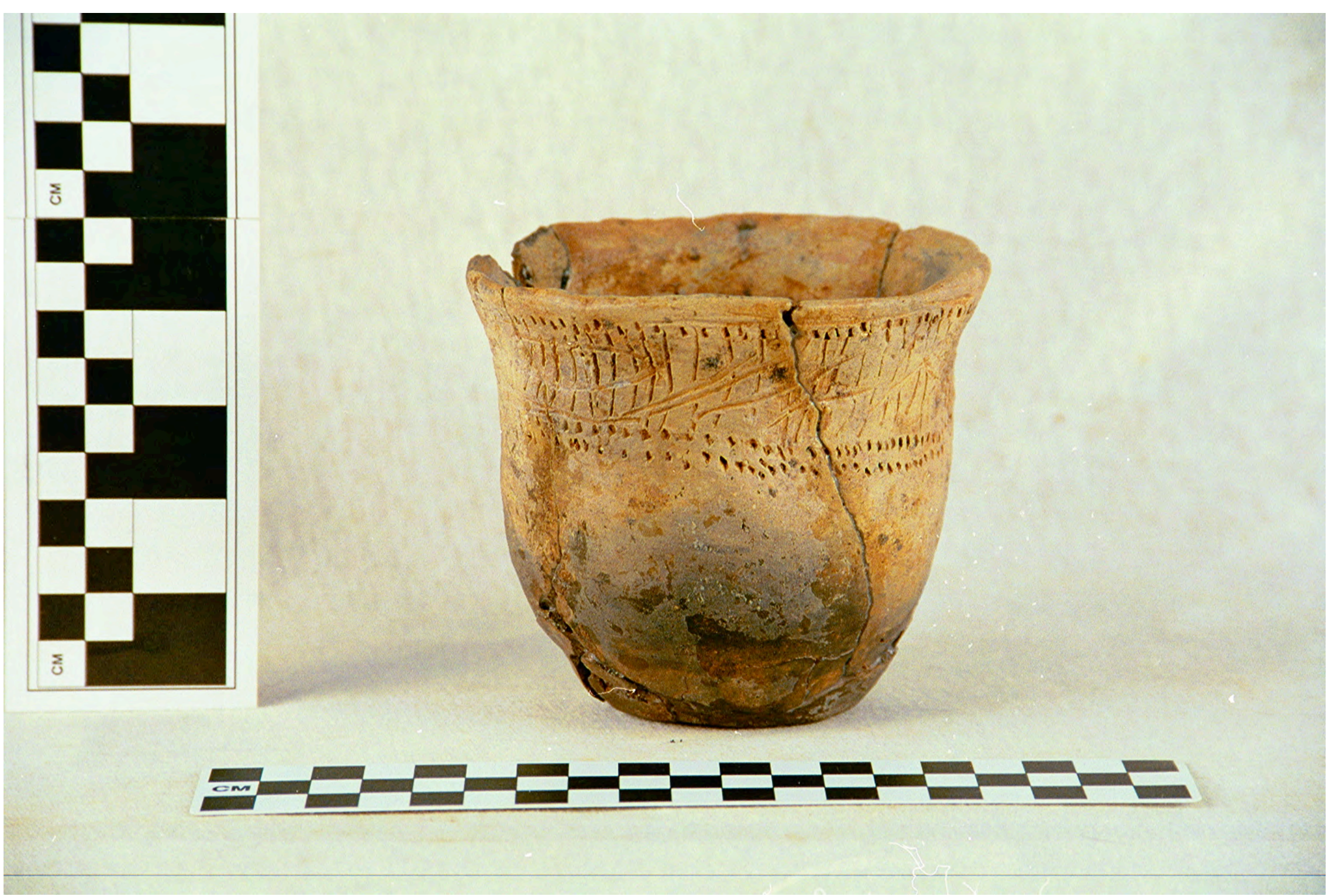

Figure 15 


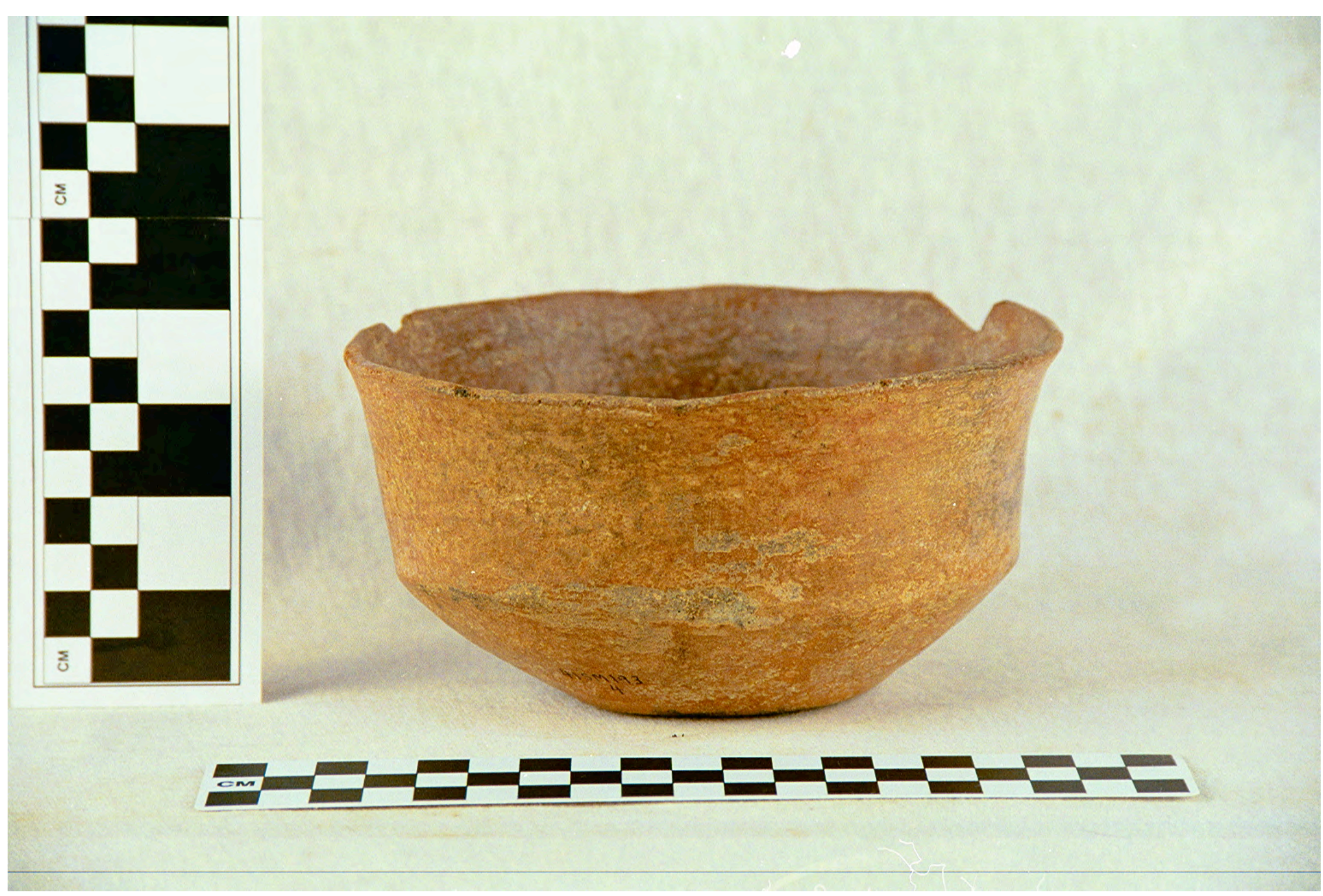

Figure 16 


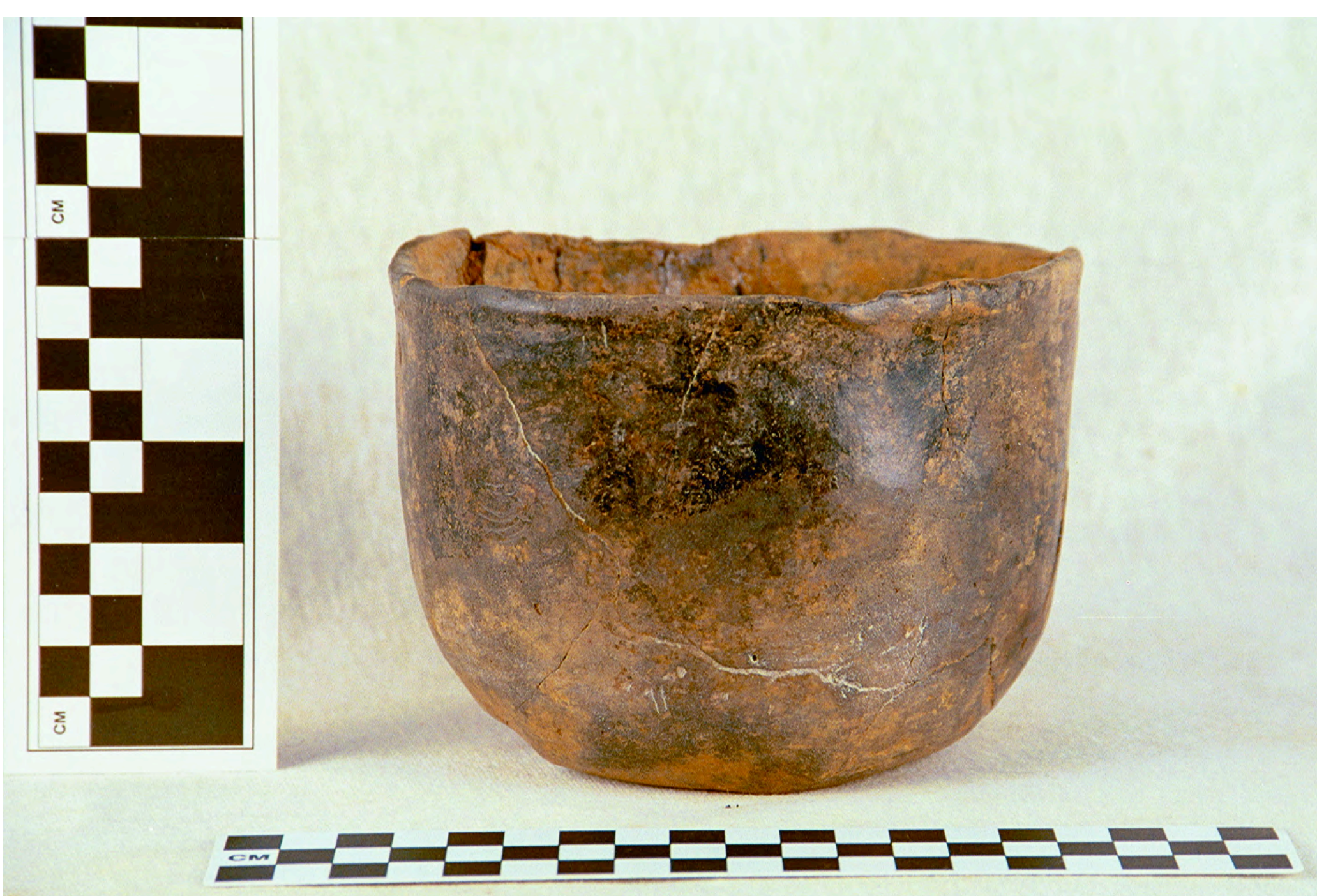

Figure 17 


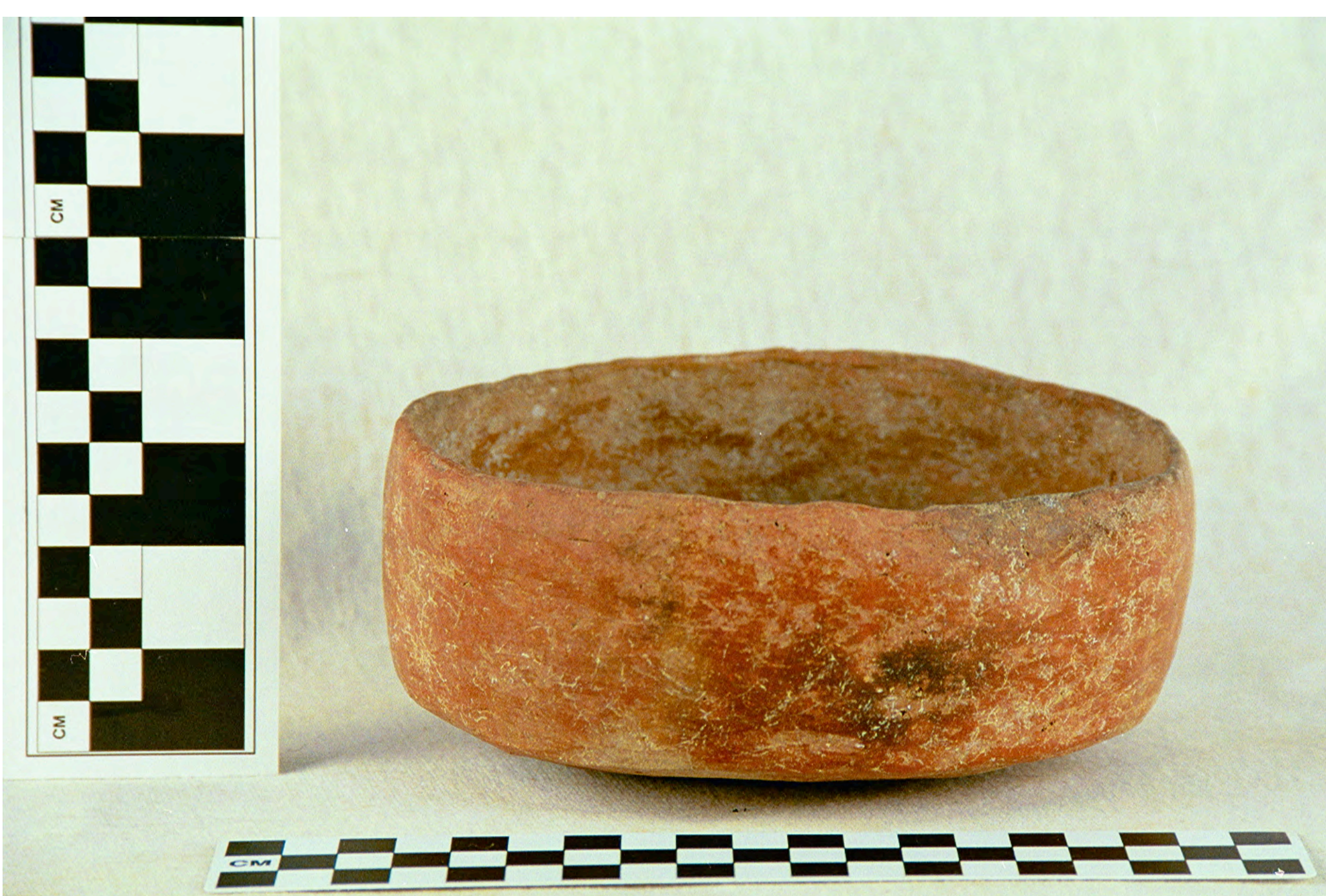

Figure 18 


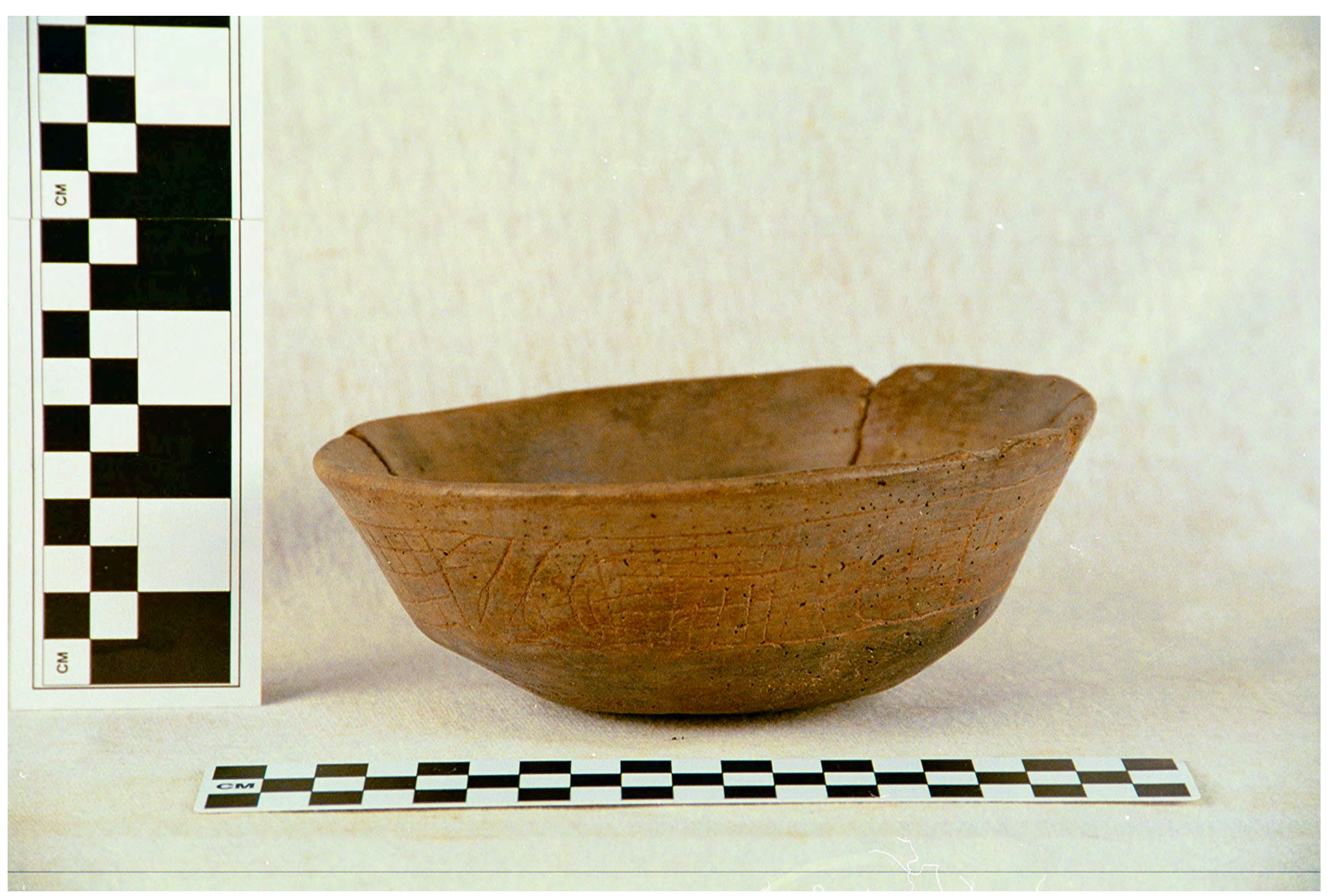

Figure 19 

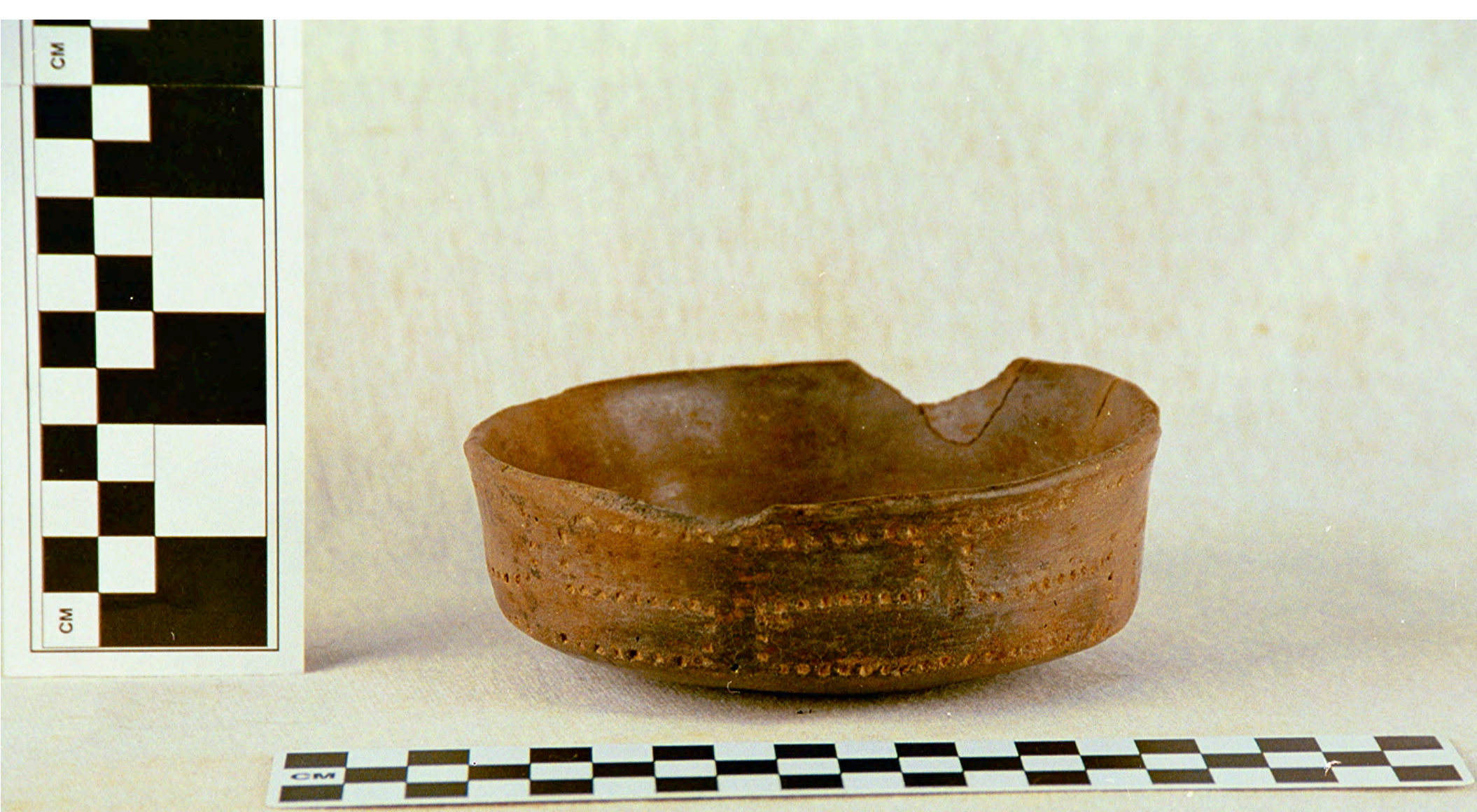

Figure 20 

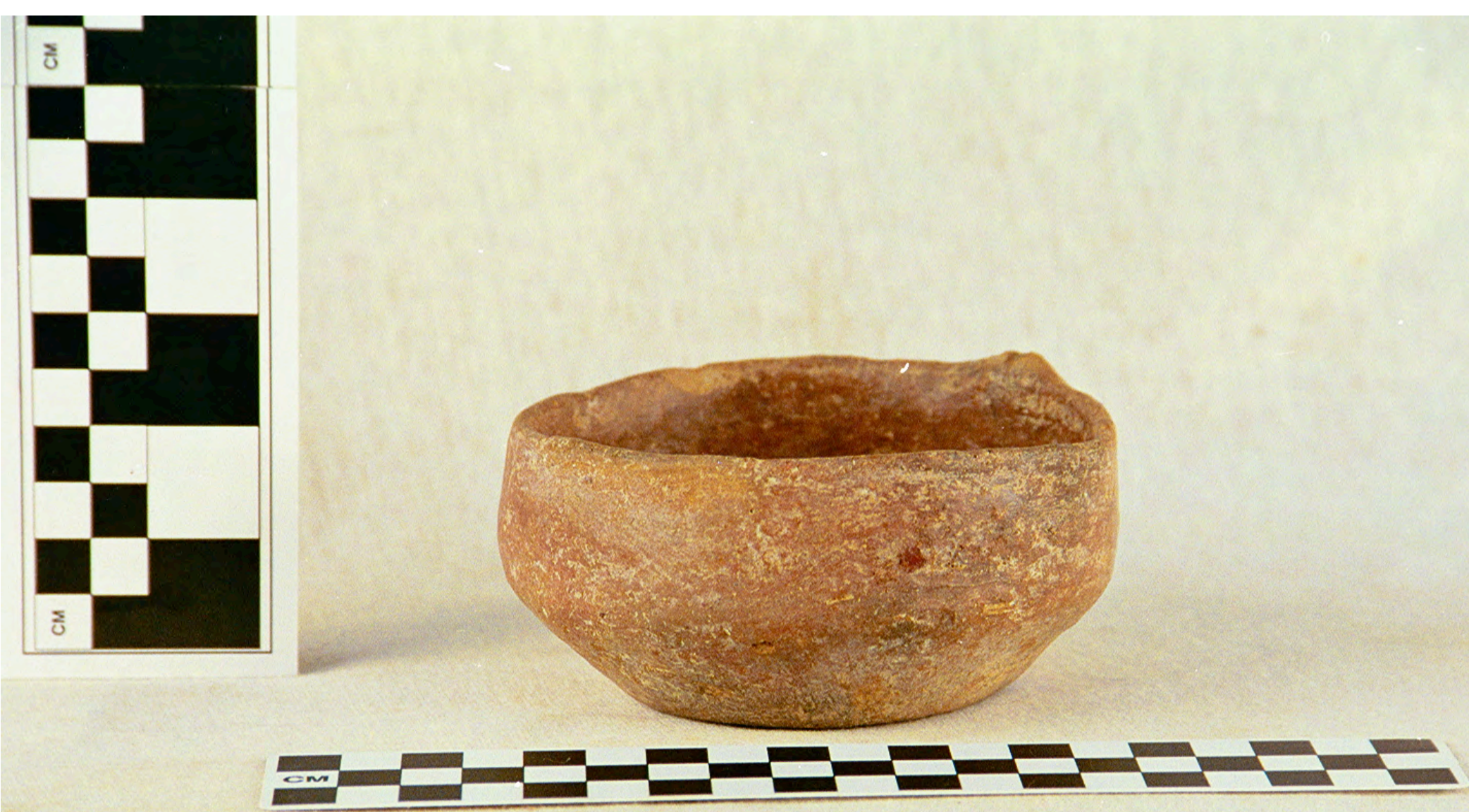

Figure 21 

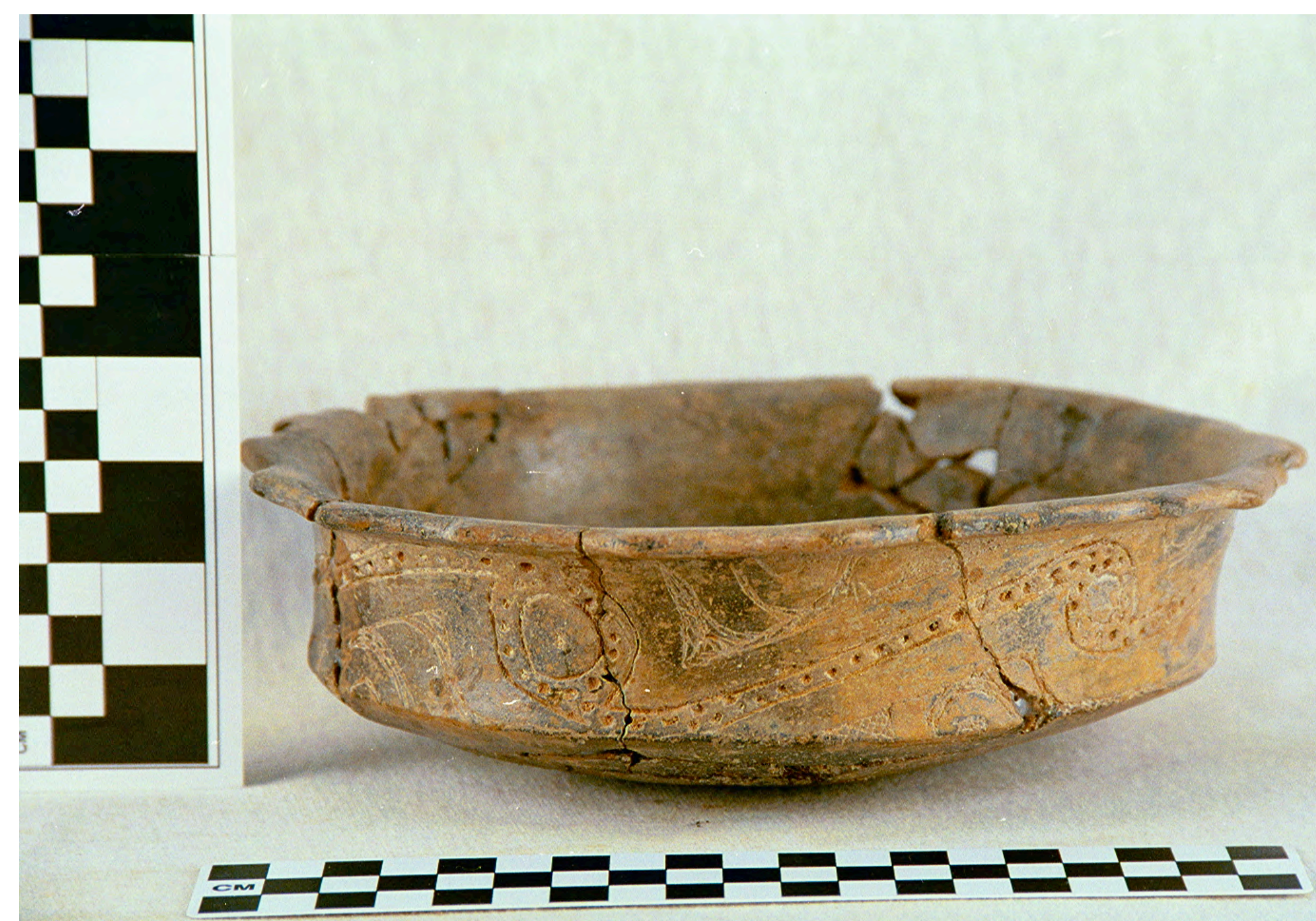

Figure 22 


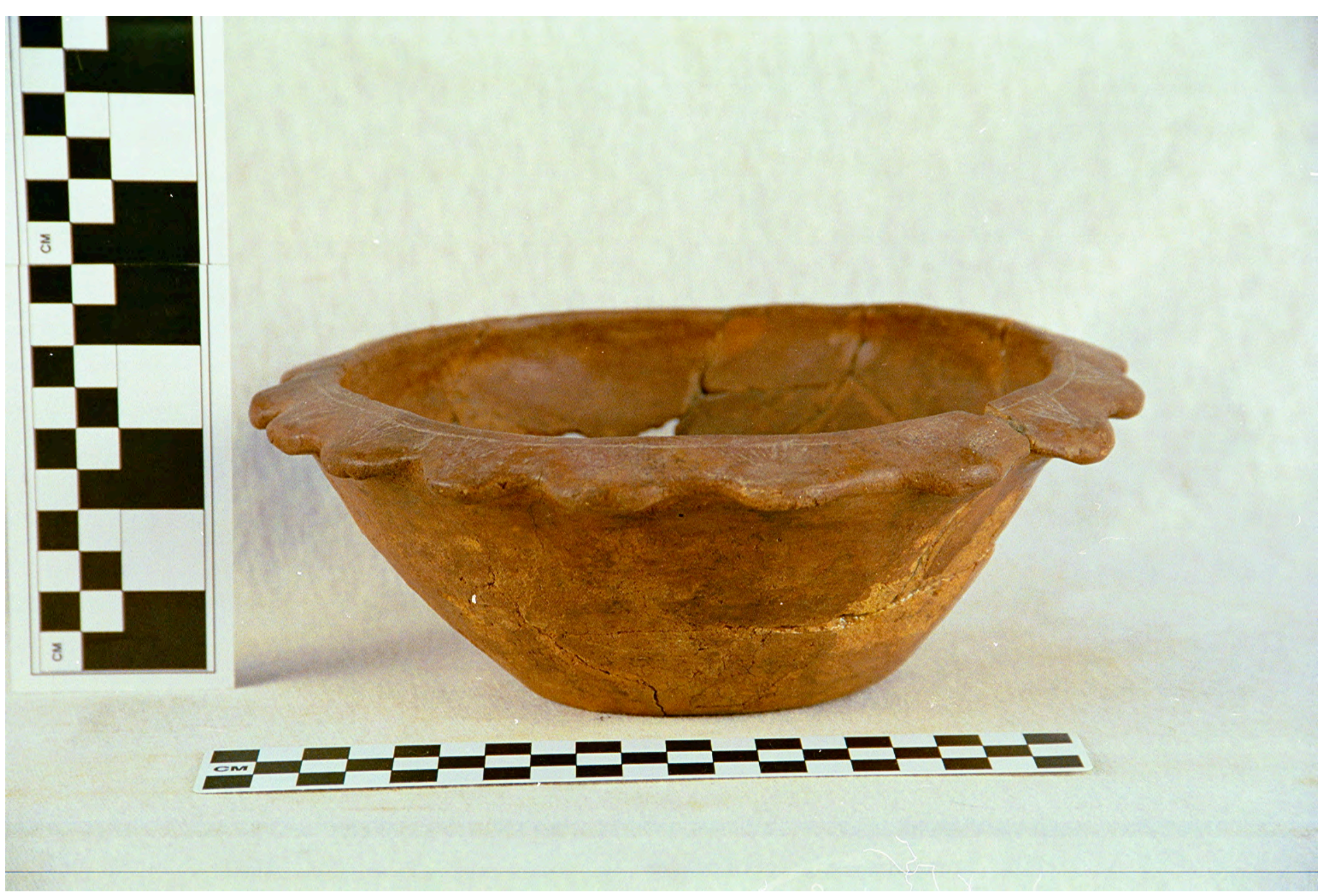

Figure 23 


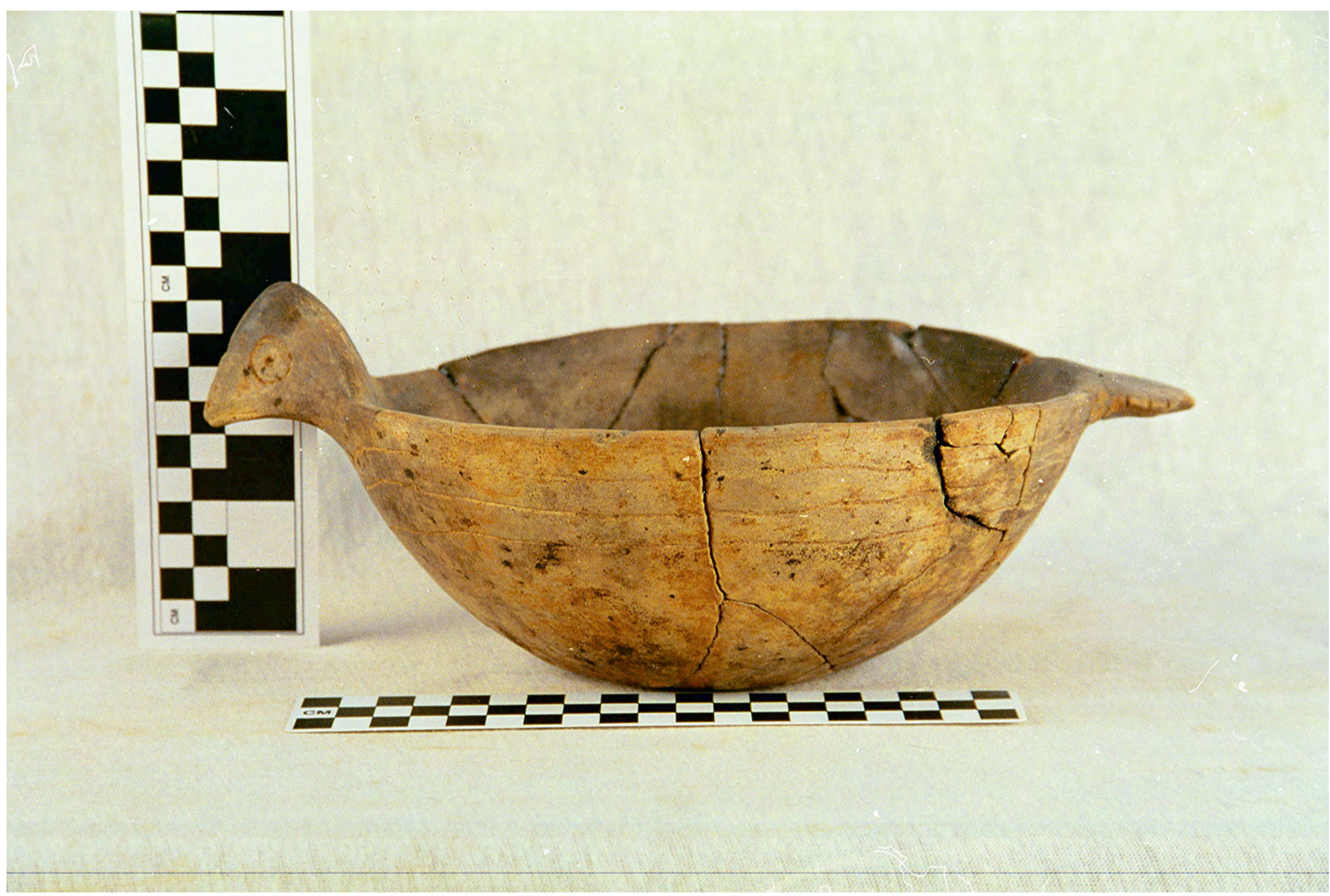

Figure 24 


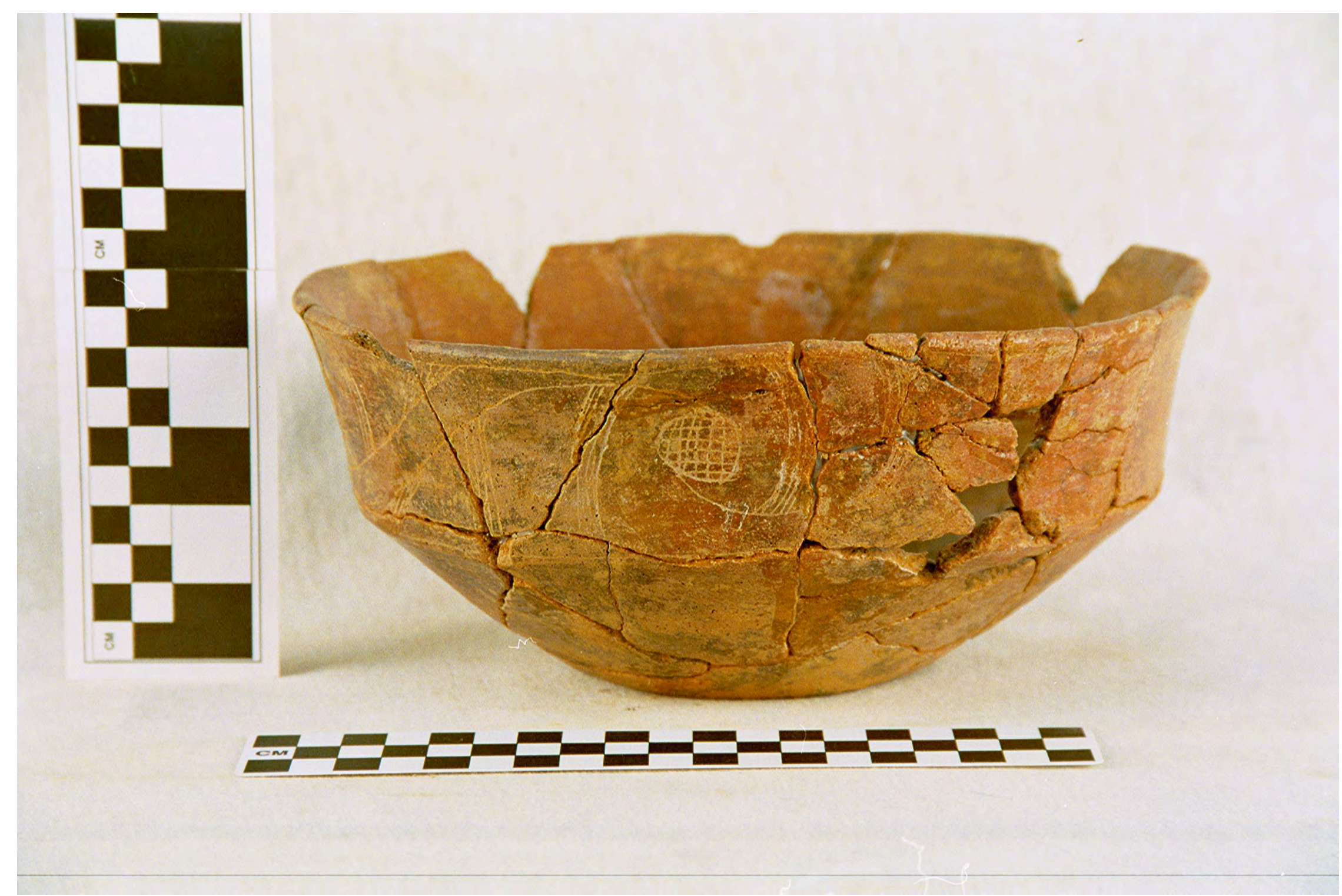

Figure 25 

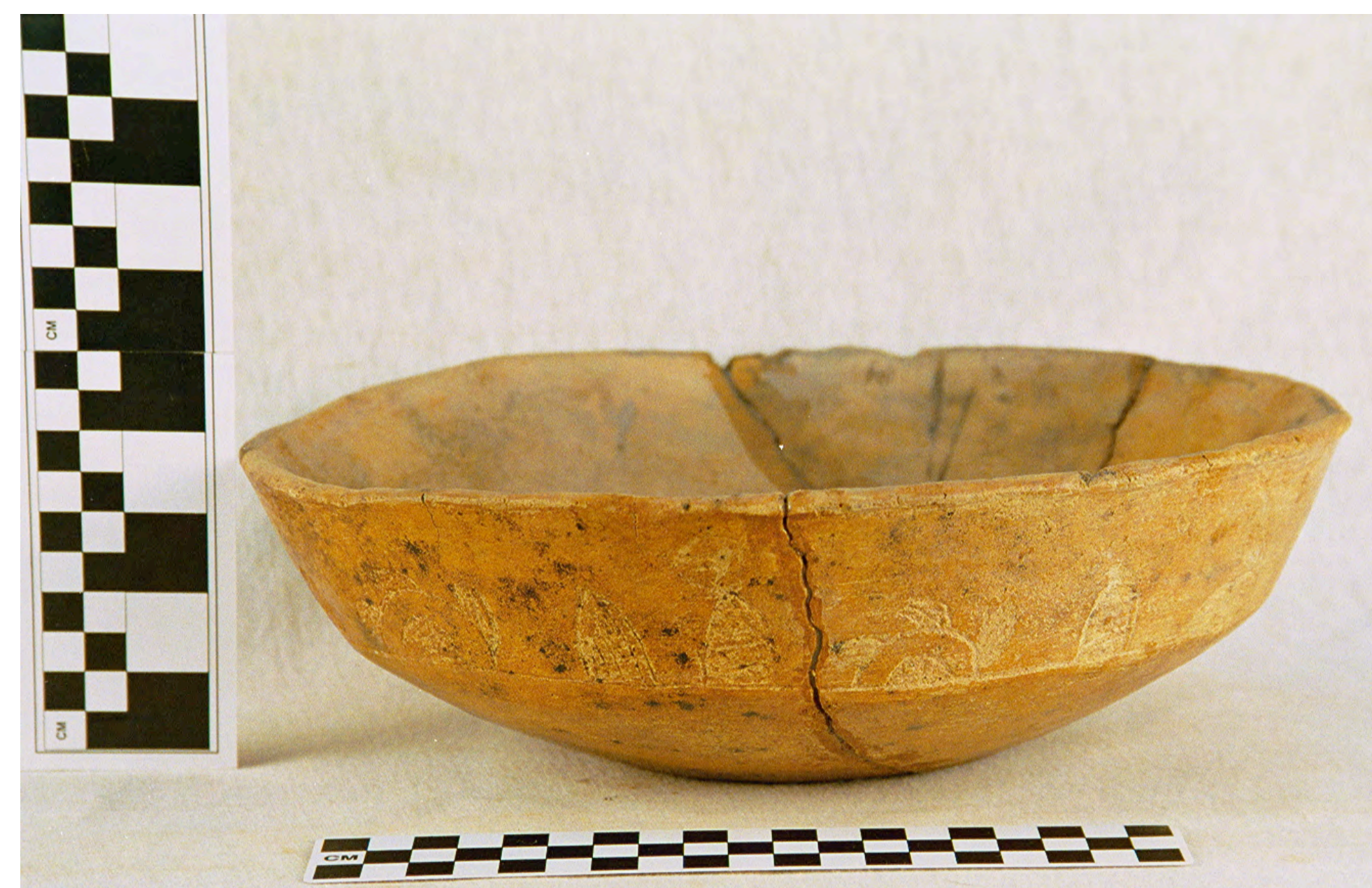

Figure 26 

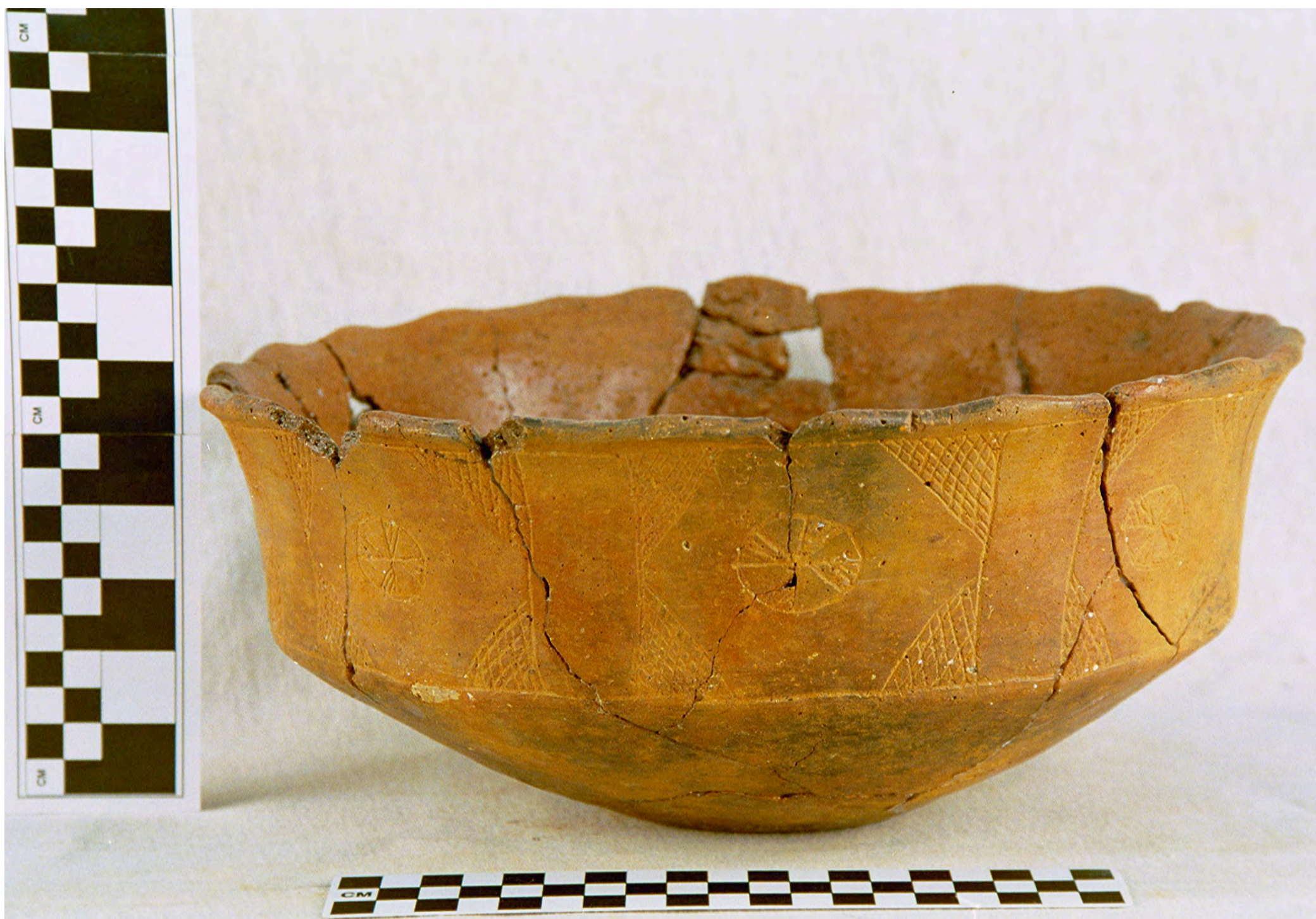

Figure 27 


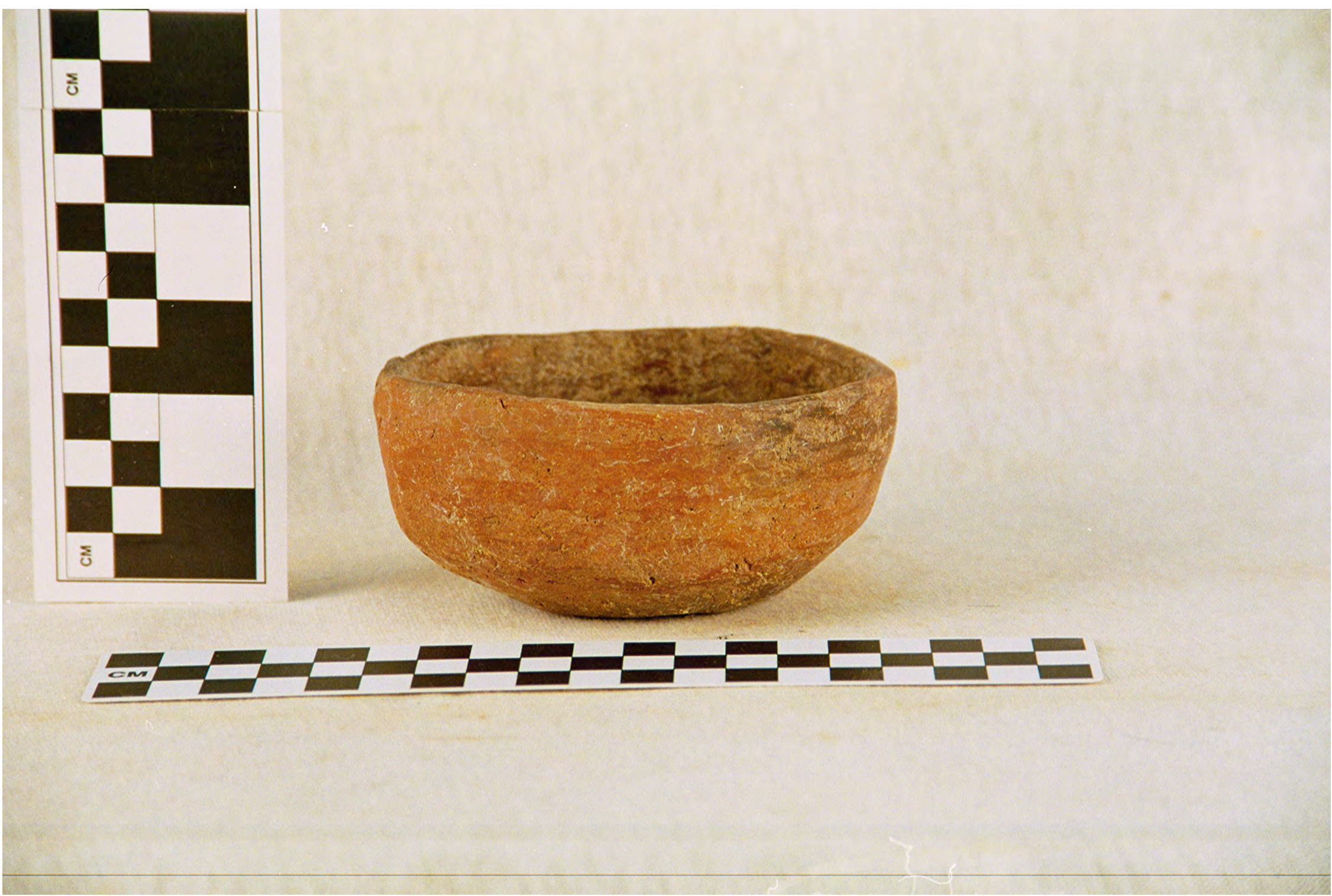

Figure 28 


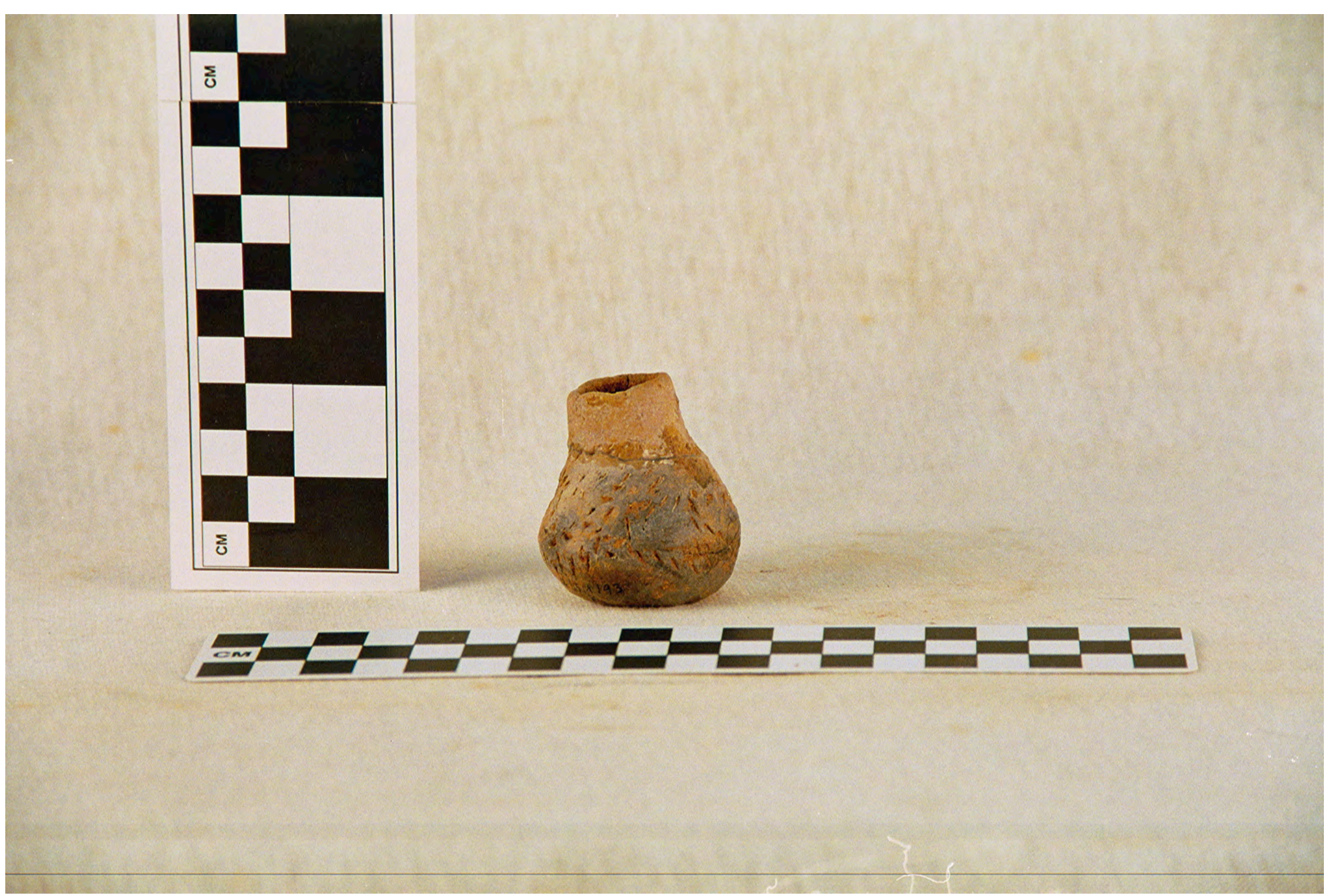

Figure 29 


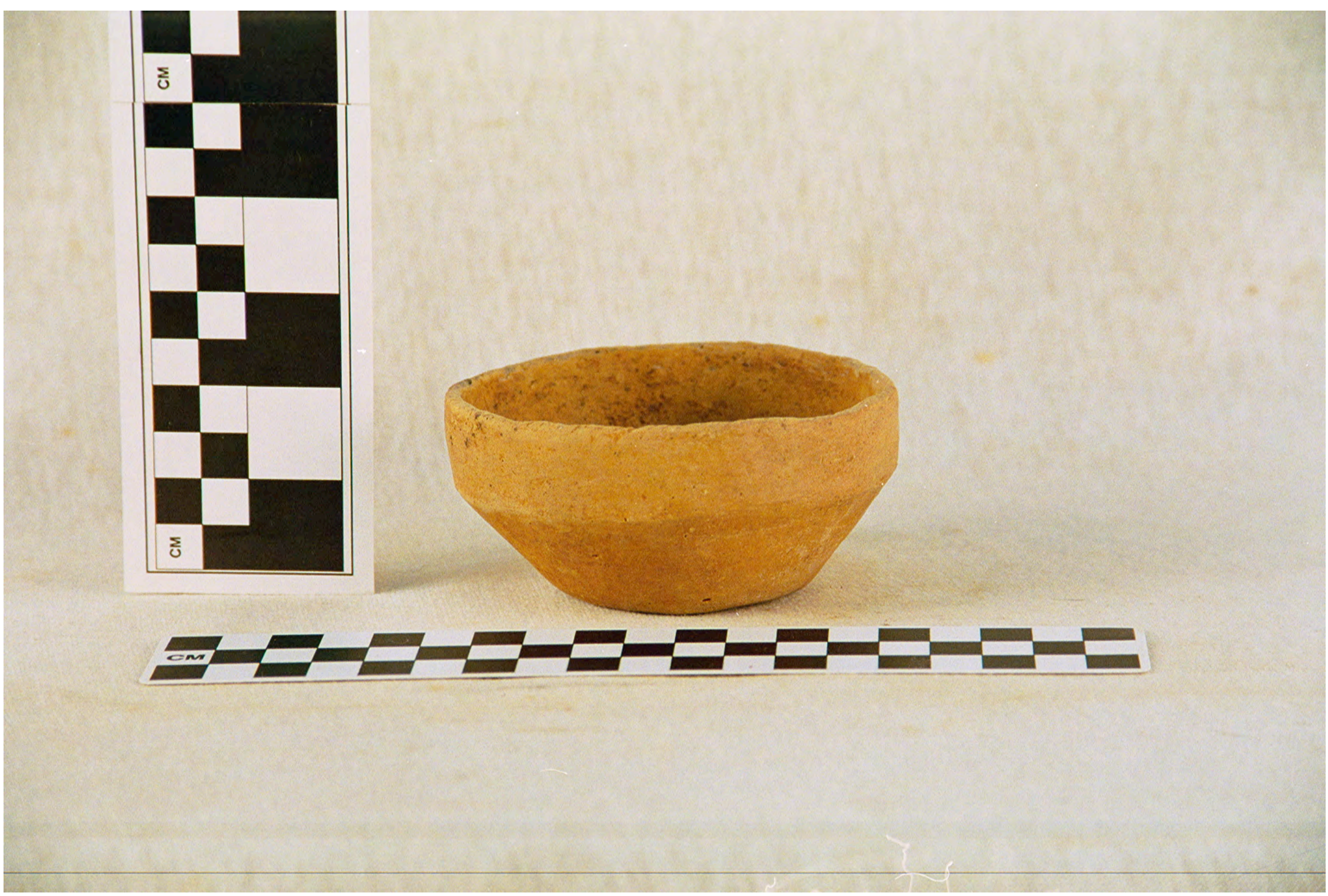

Figure 30 


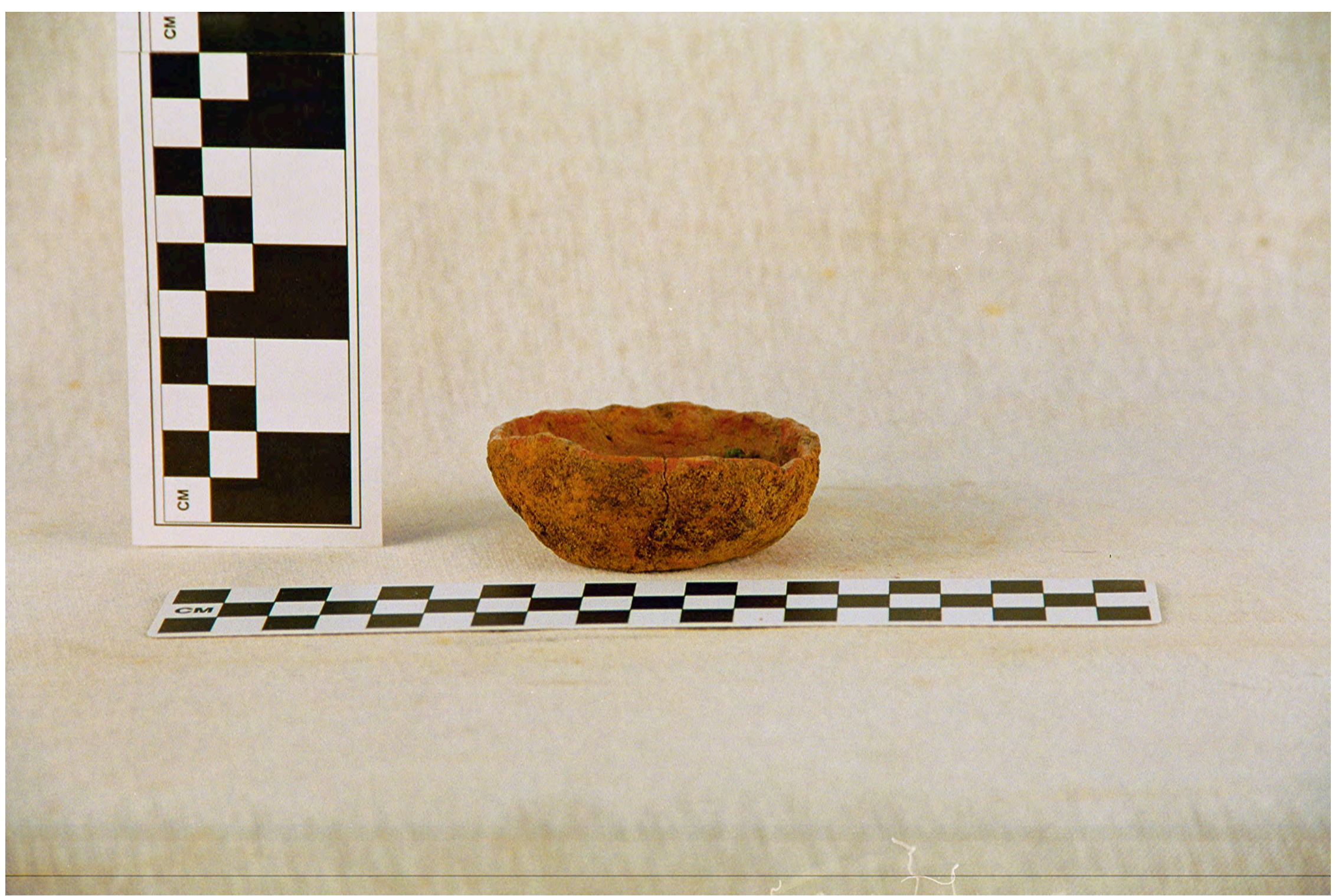

Figure 31 


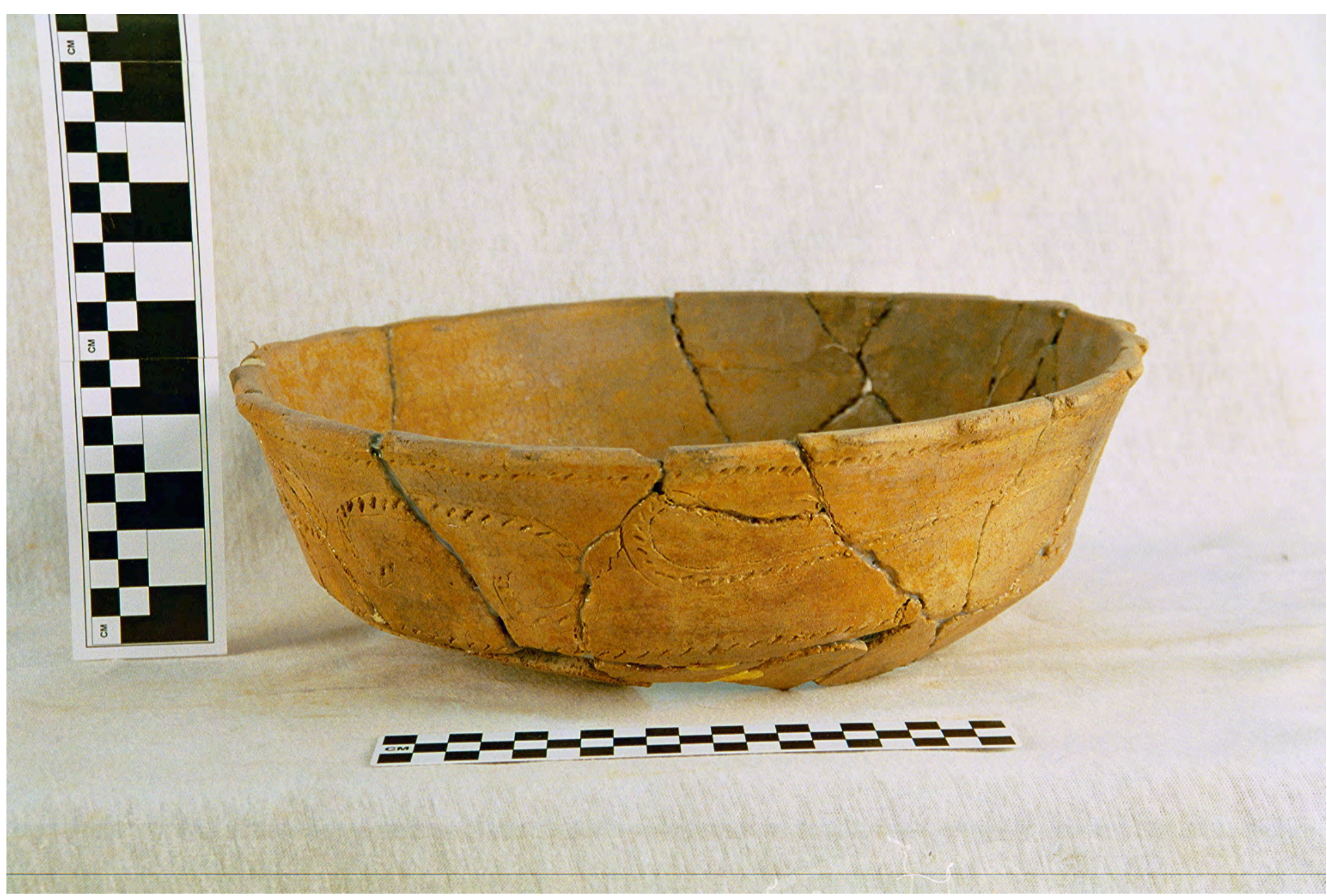

Figure 32 


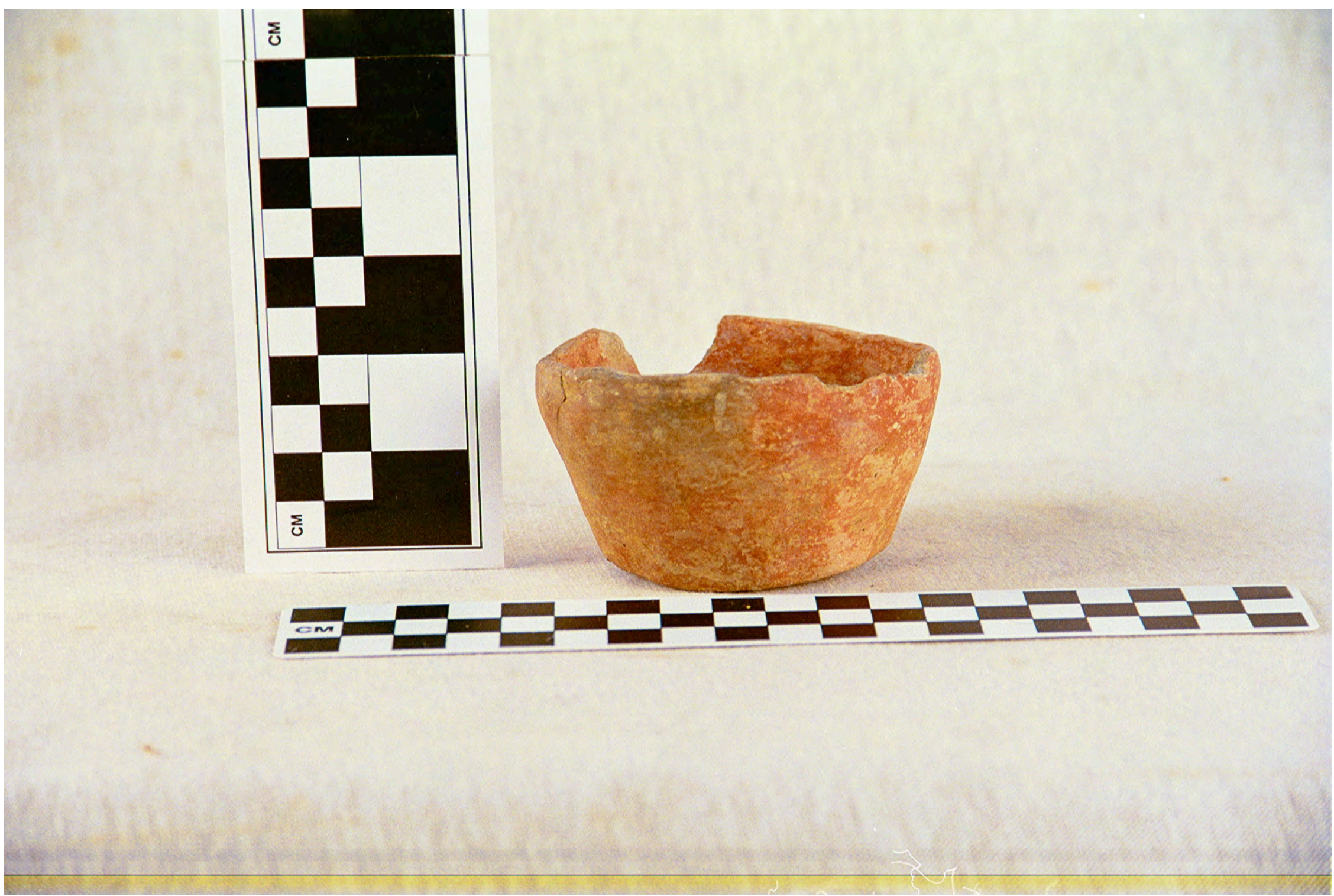

Figure 33 


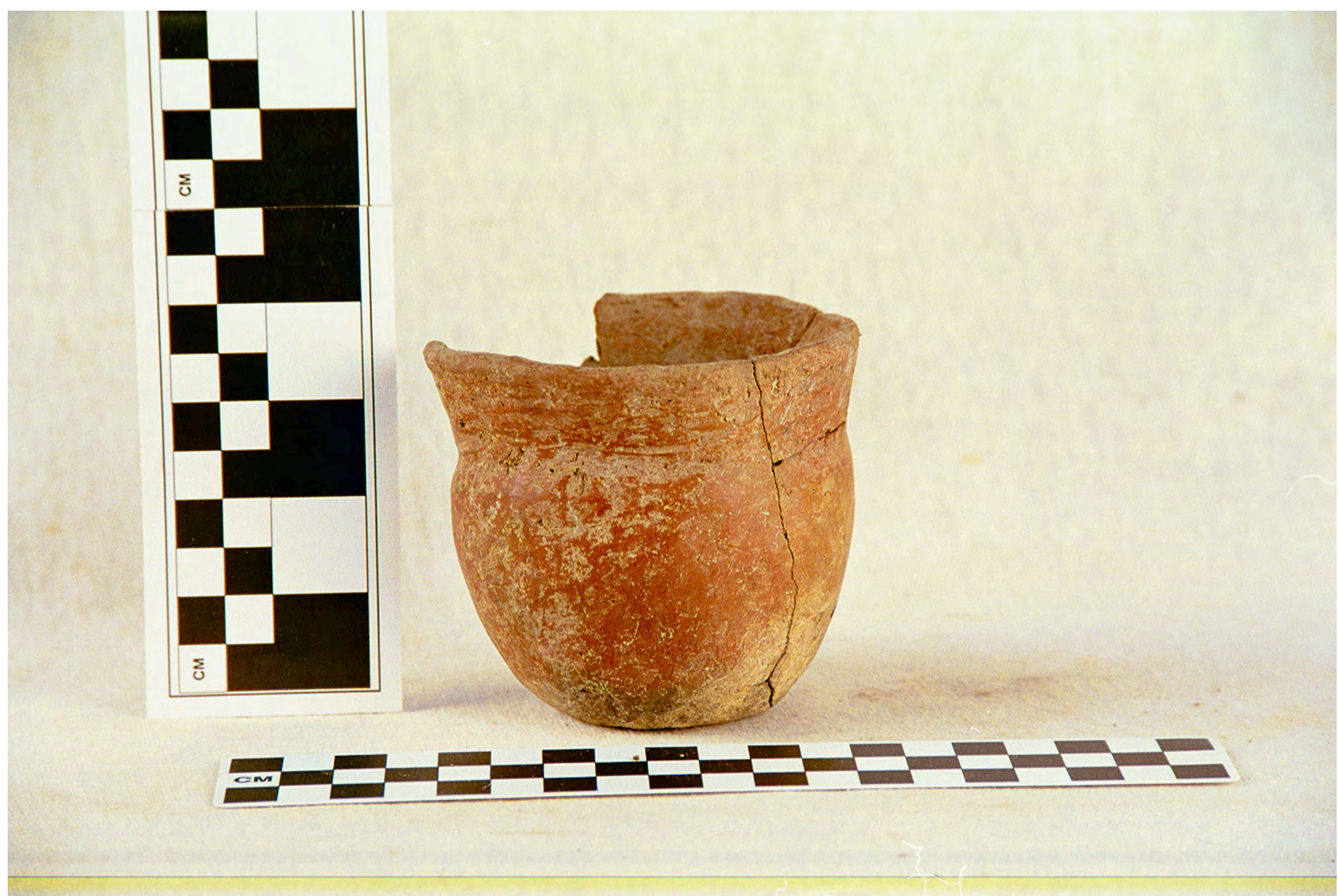

Figure 34 


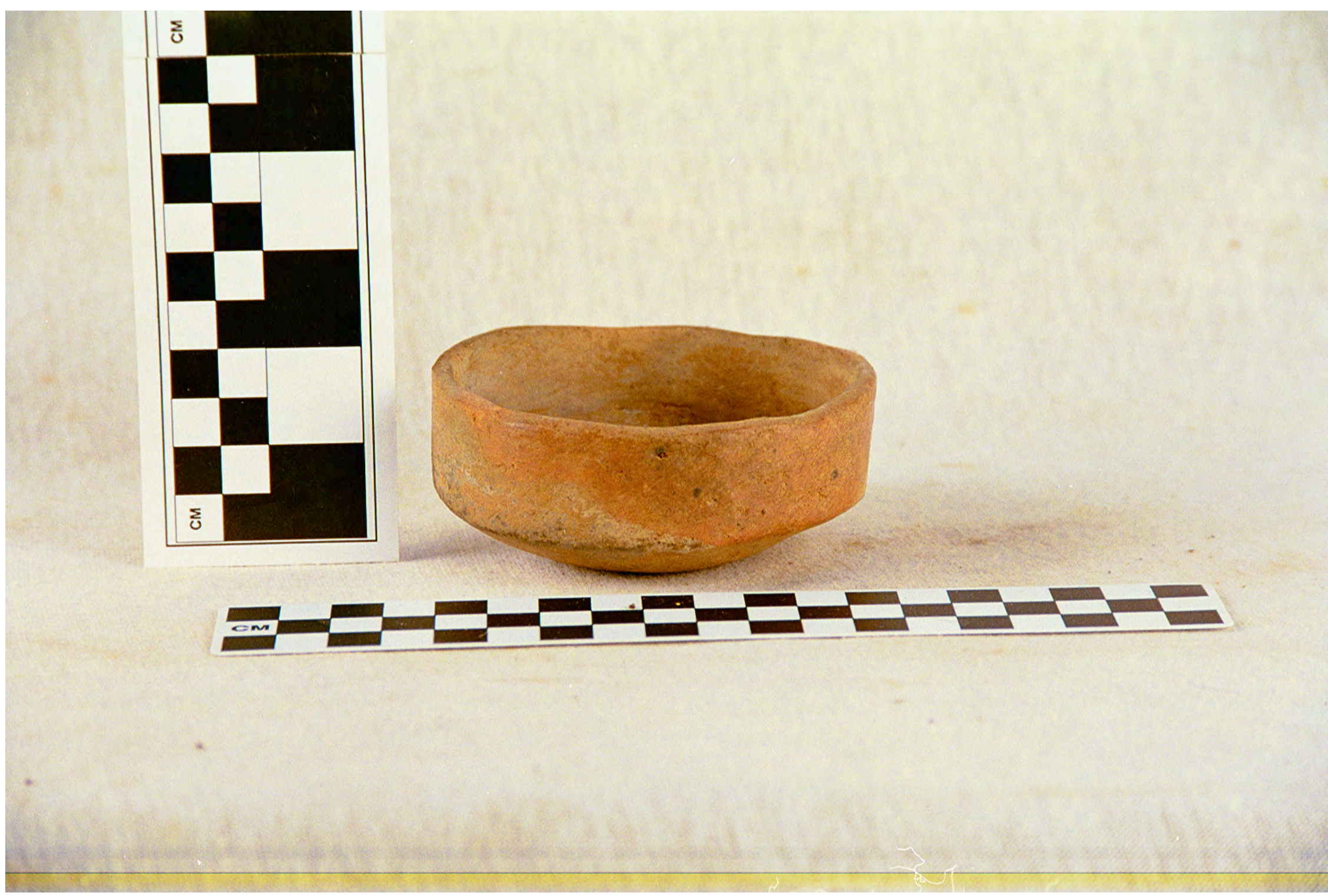

Figure 35 


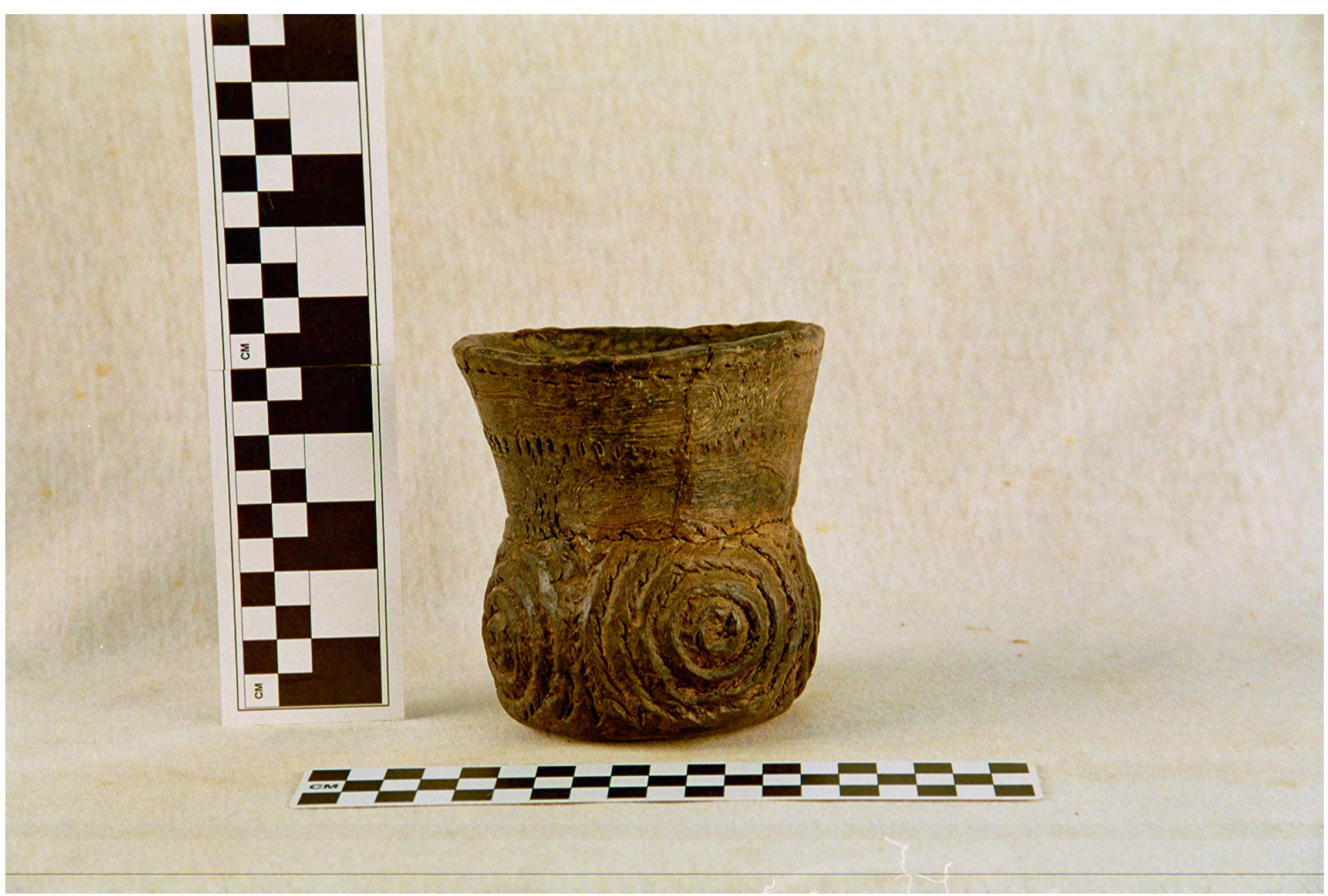

Figure 36 


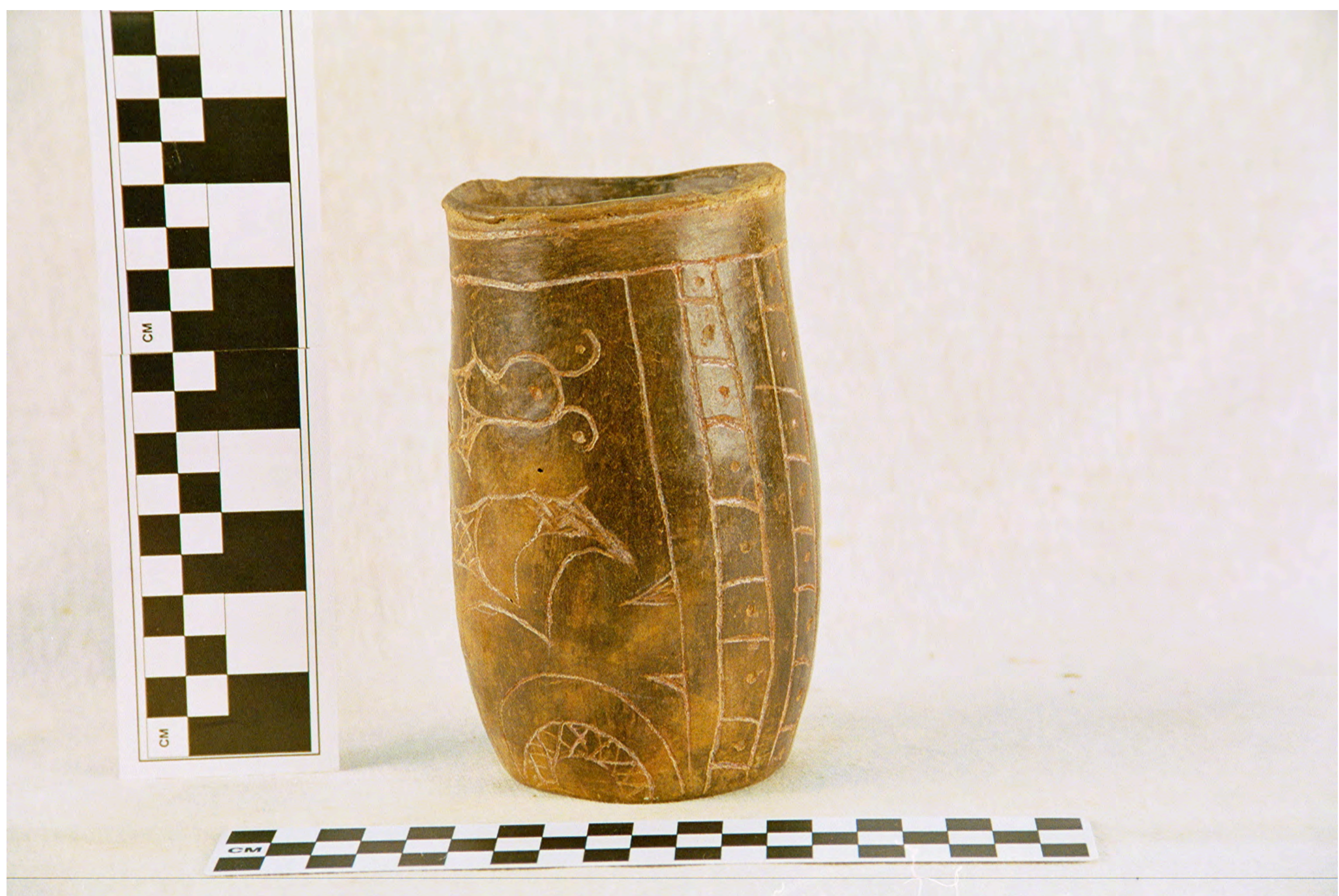

Figure 37 


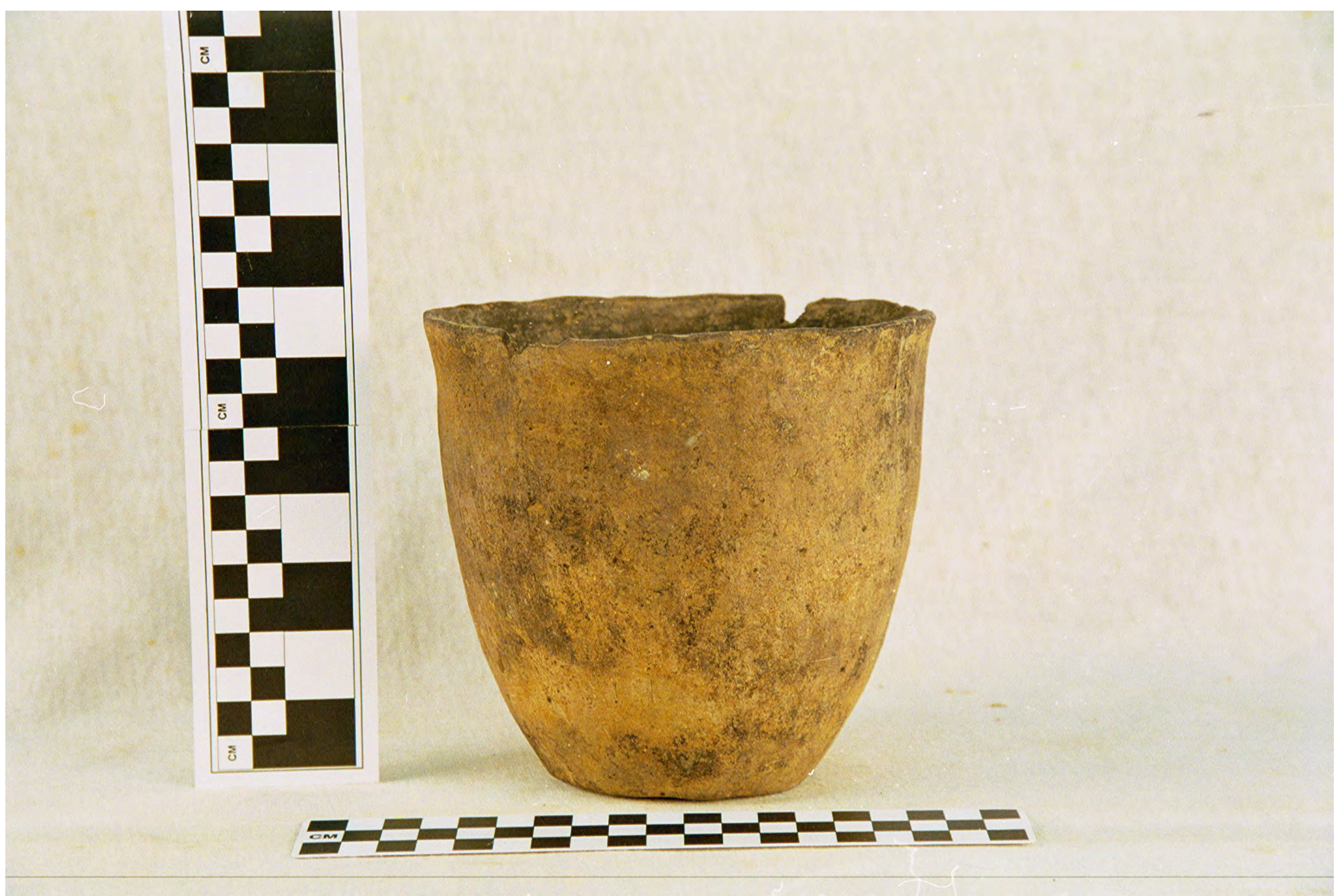

Figure 38 


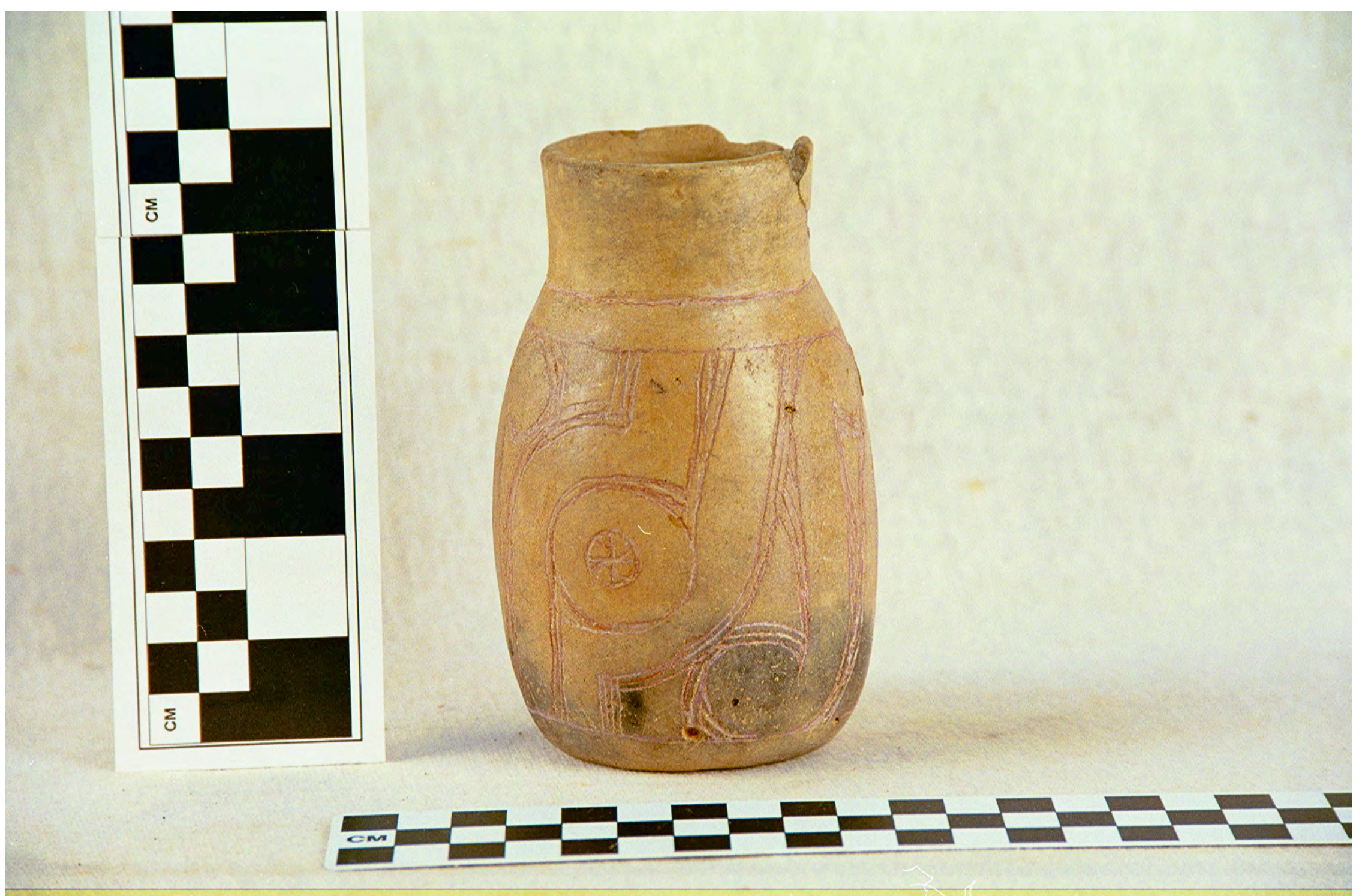

Figure 39 


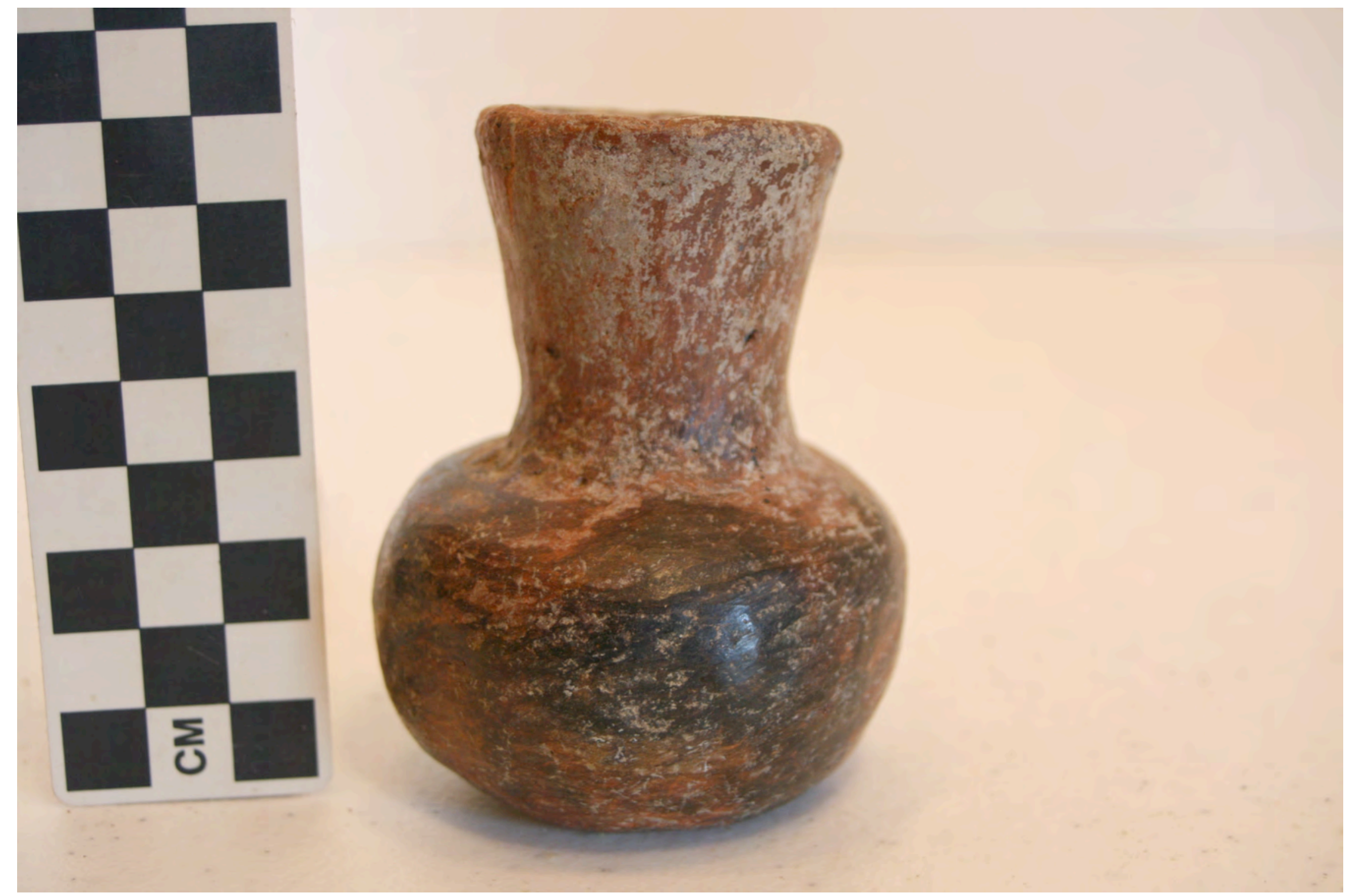

Figure 40 


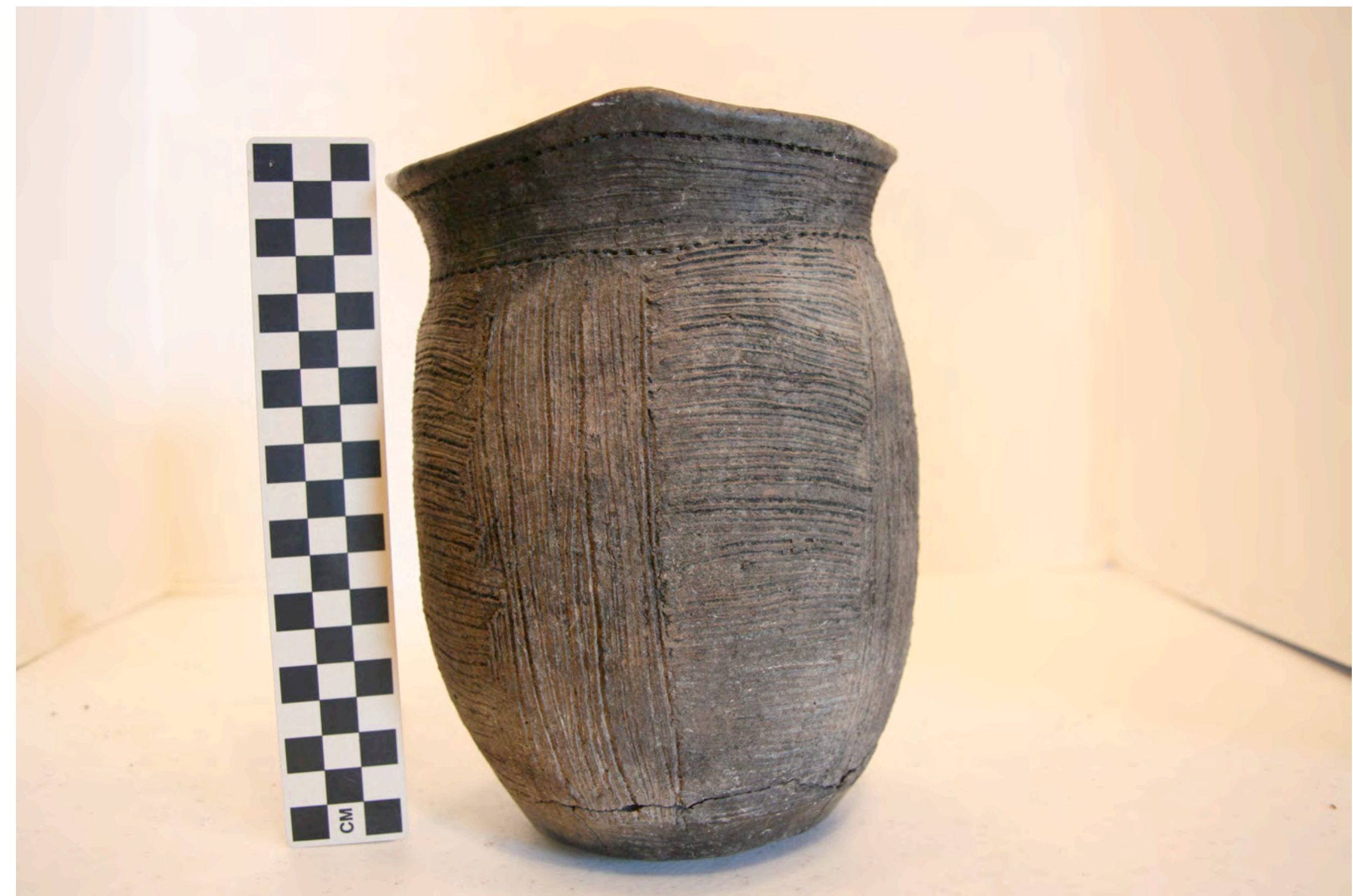

Figure 41 


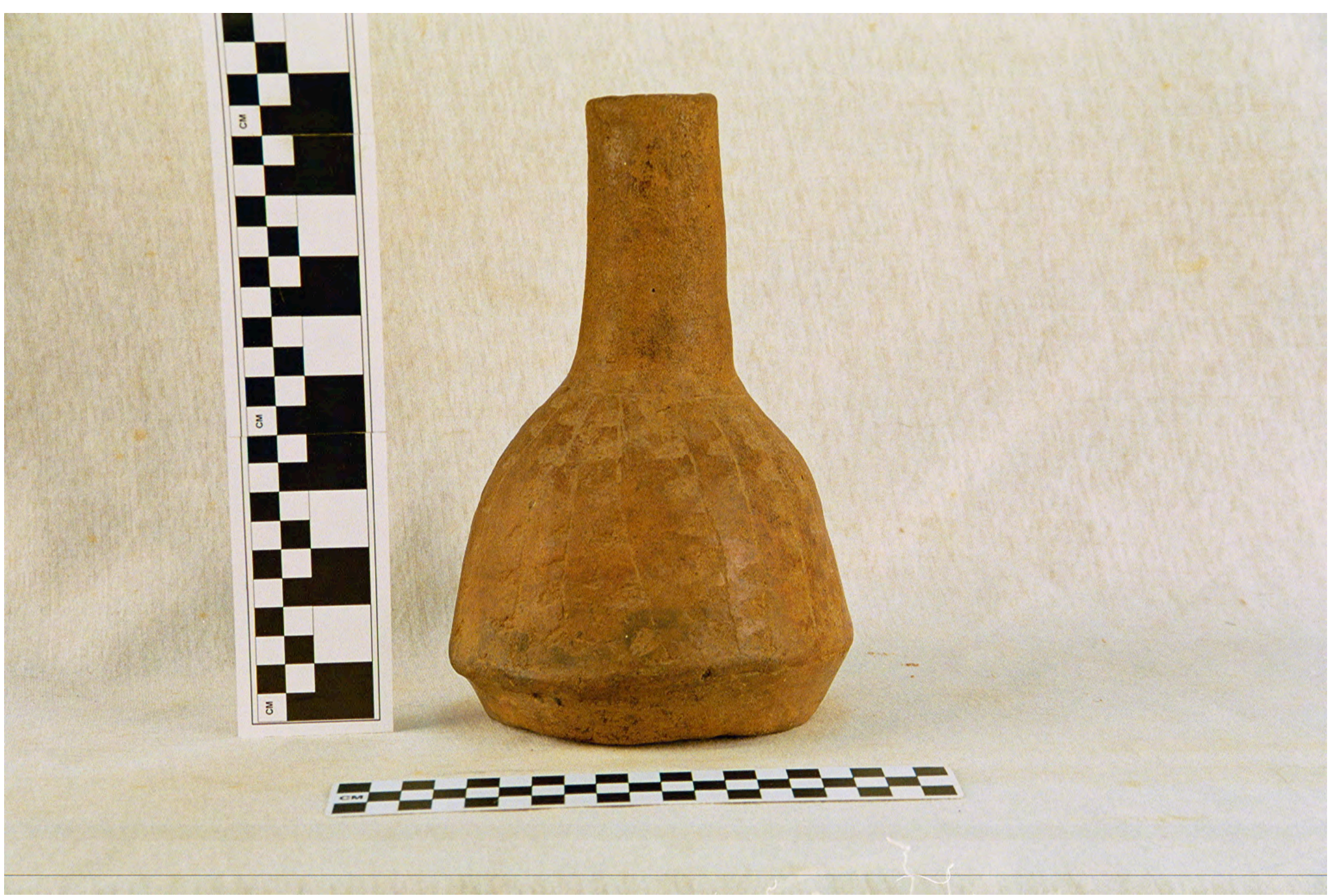

Figure 42 


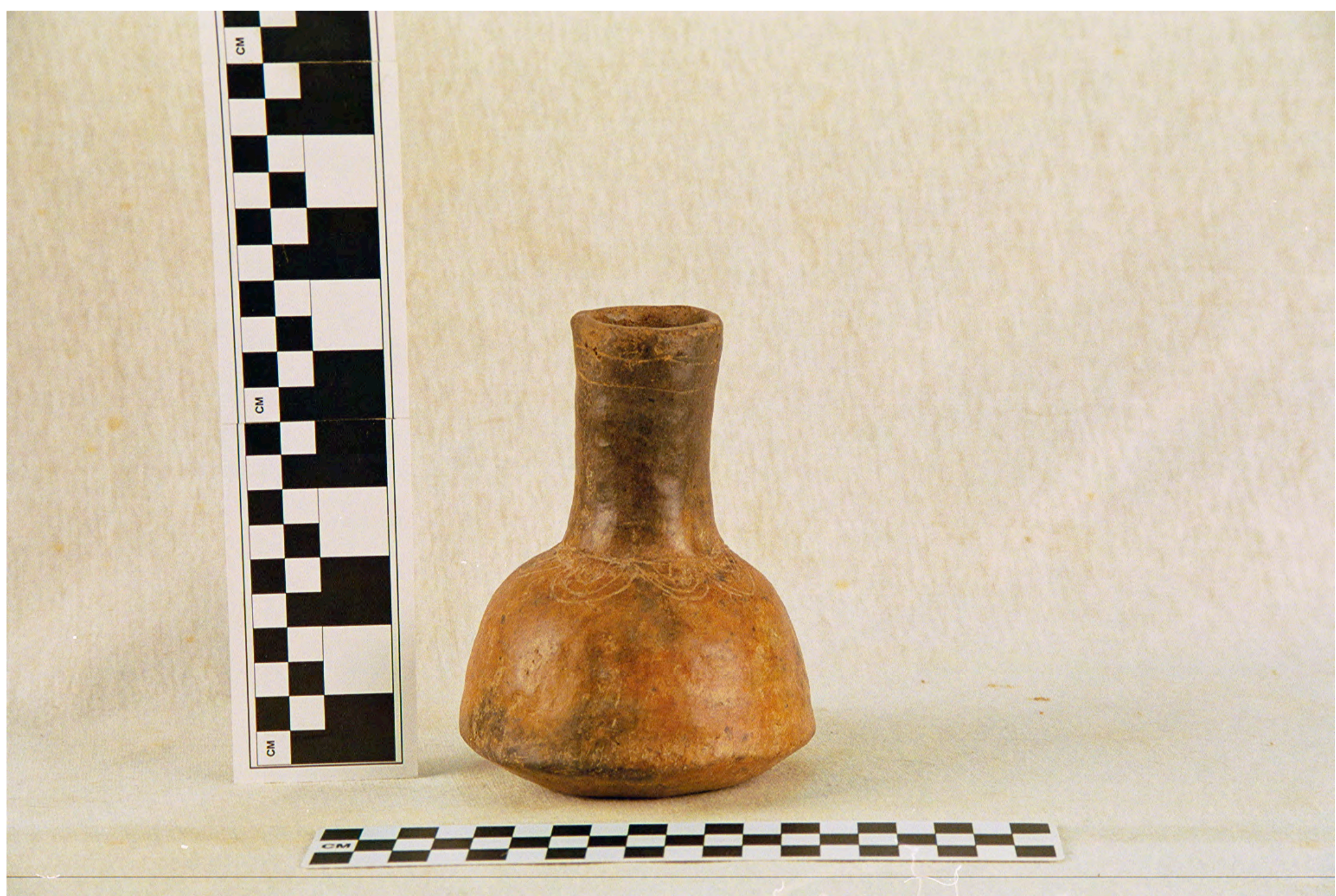

Figure 43 


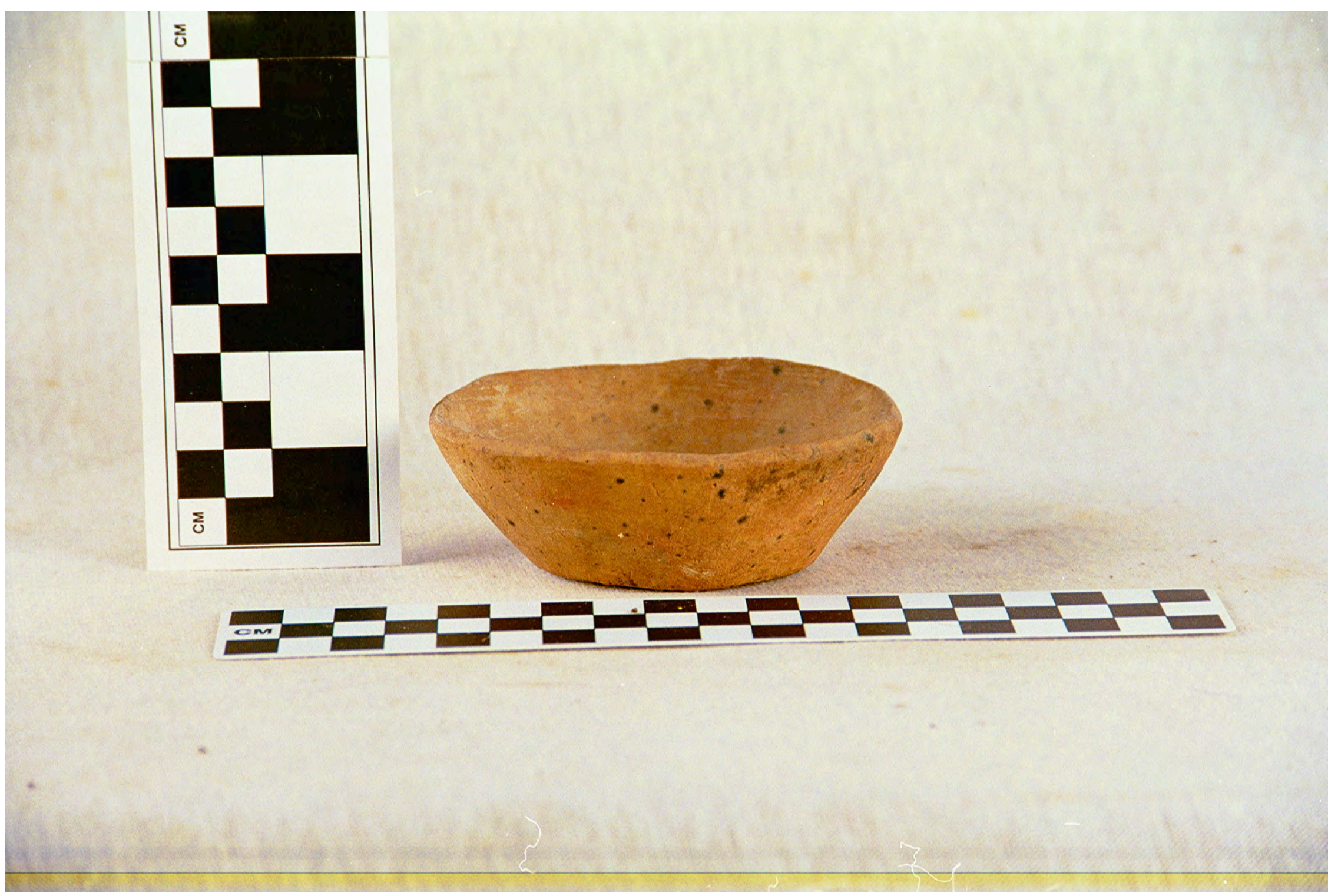

Figure 44 


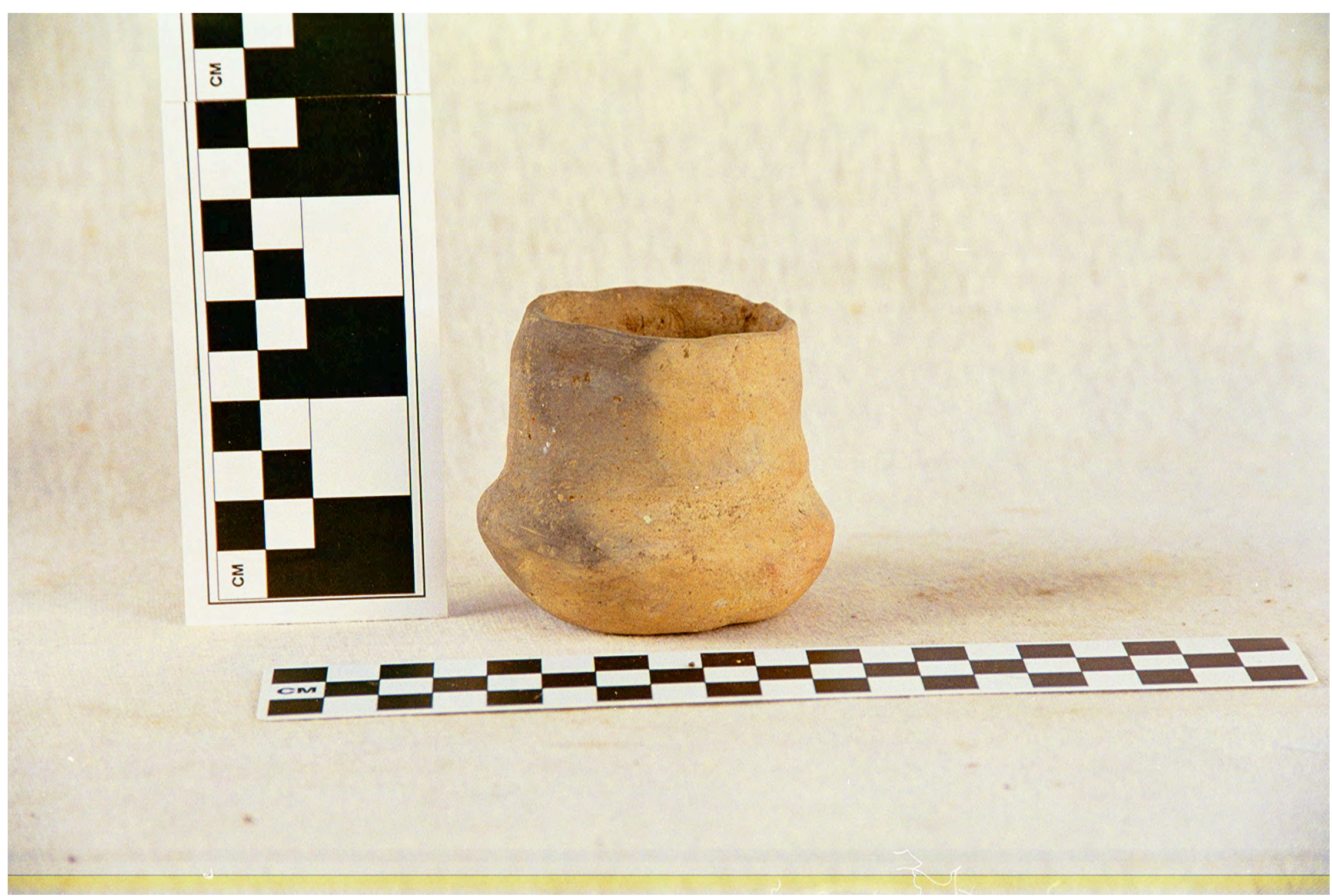

Figure 45 


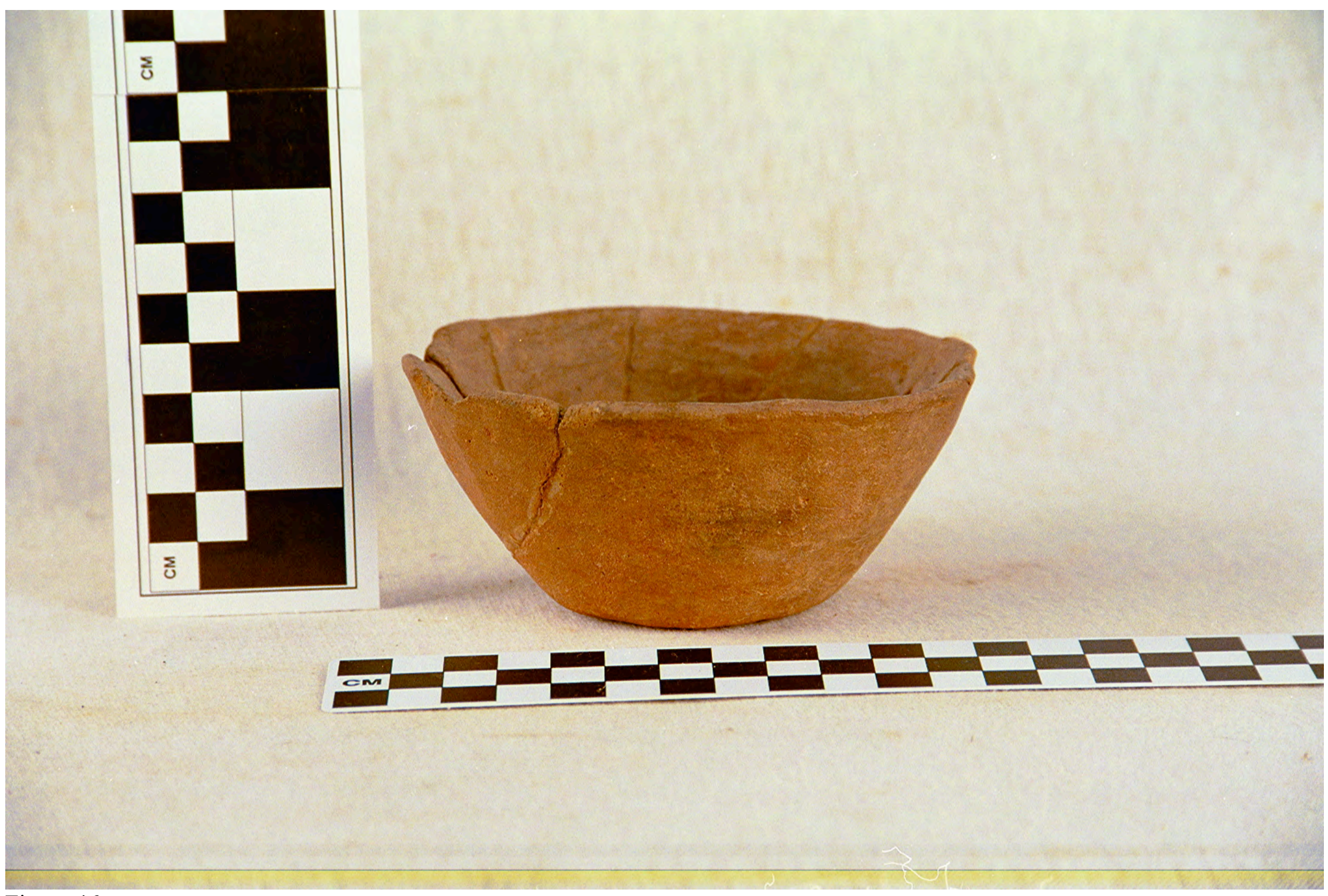

Figure 46 


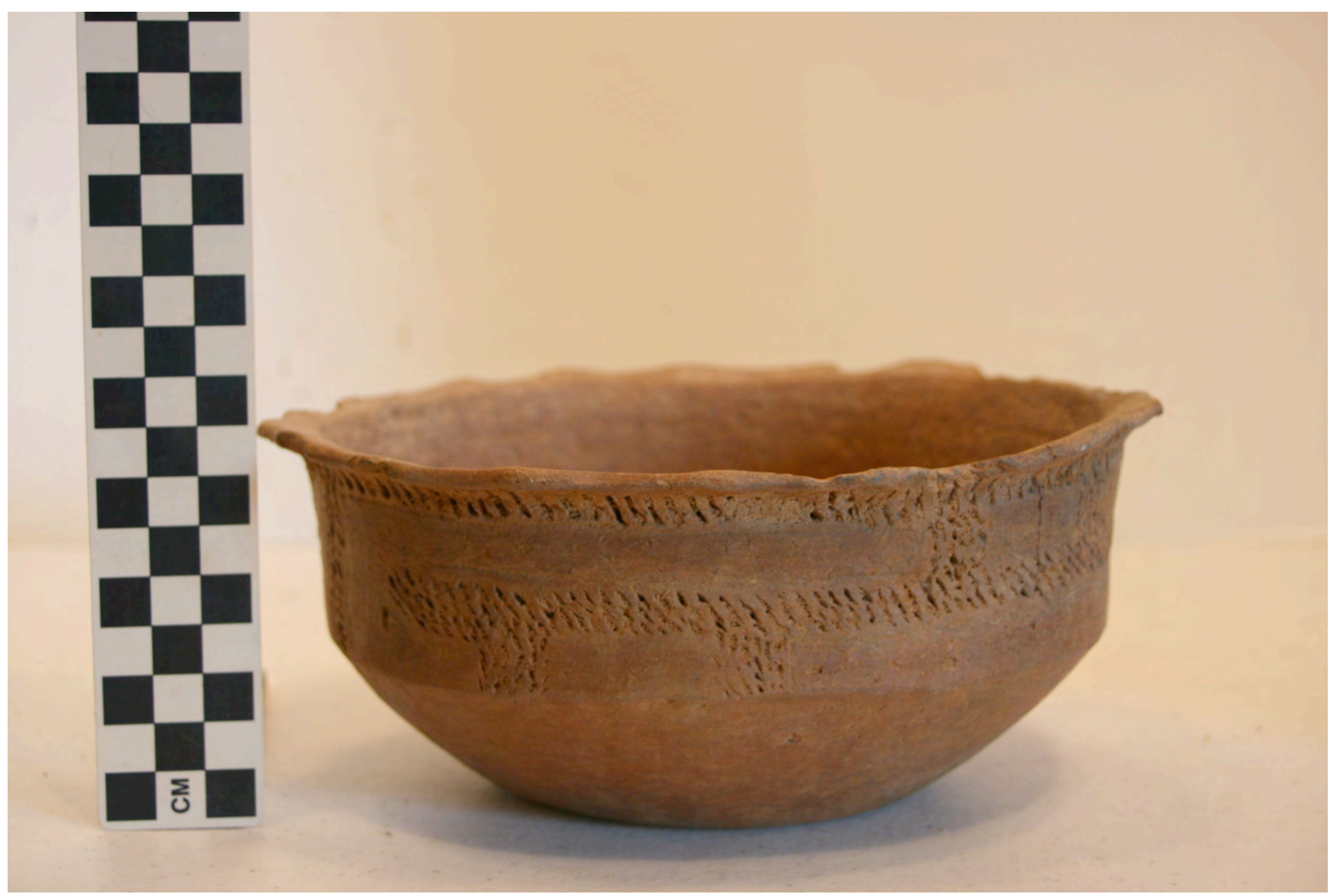

Figure 47 


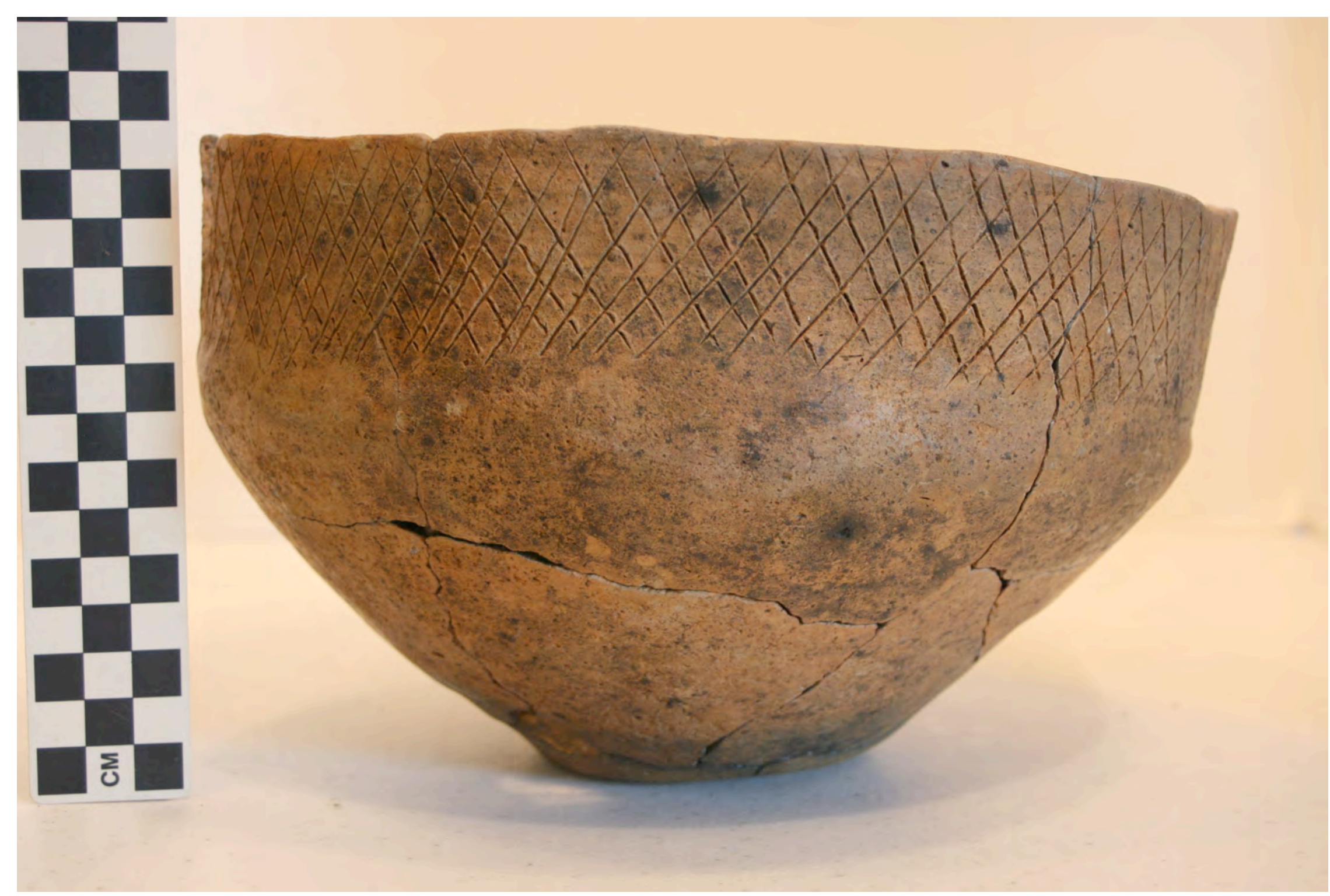

Figure 48 


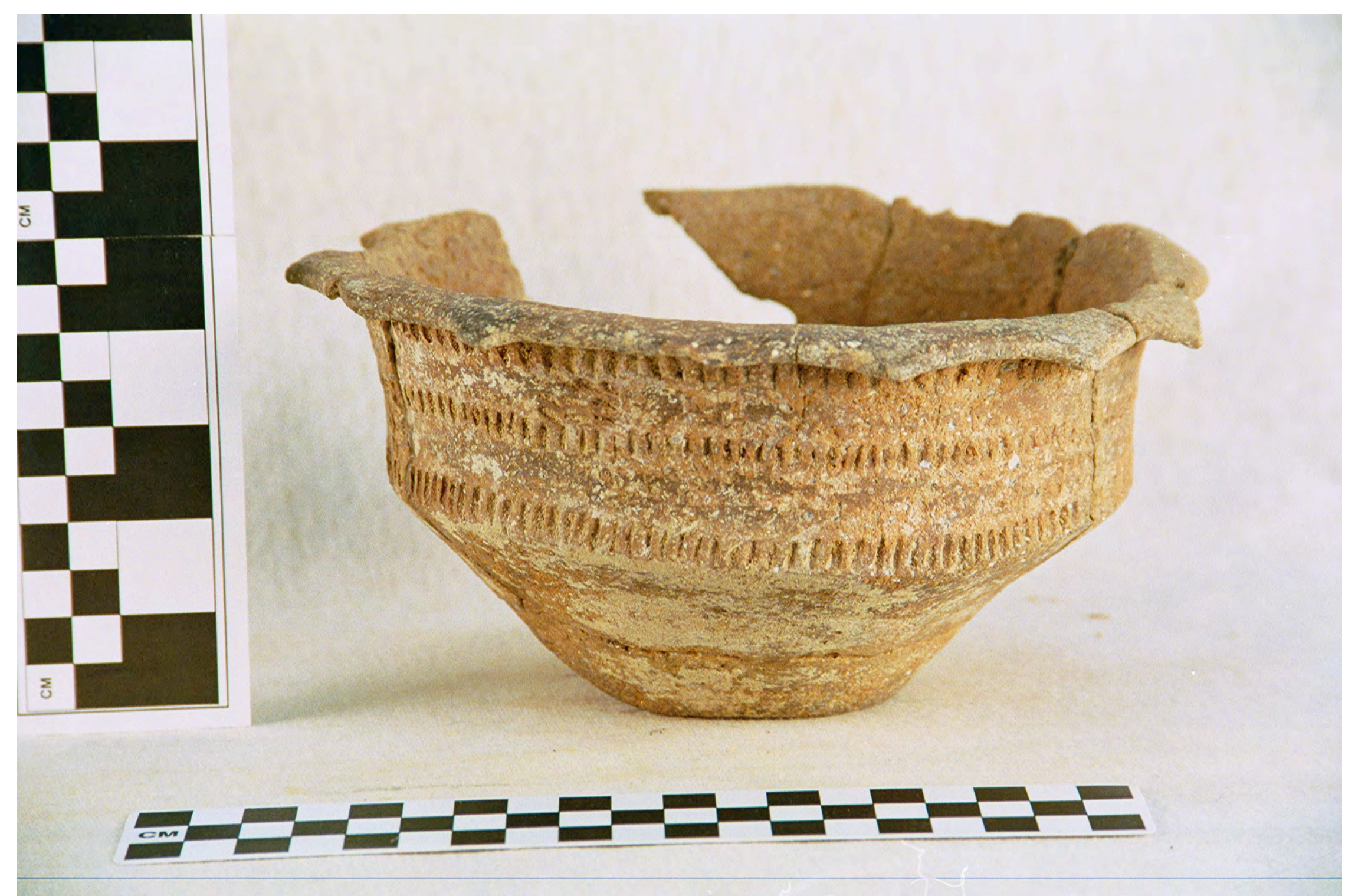

Figure 49 

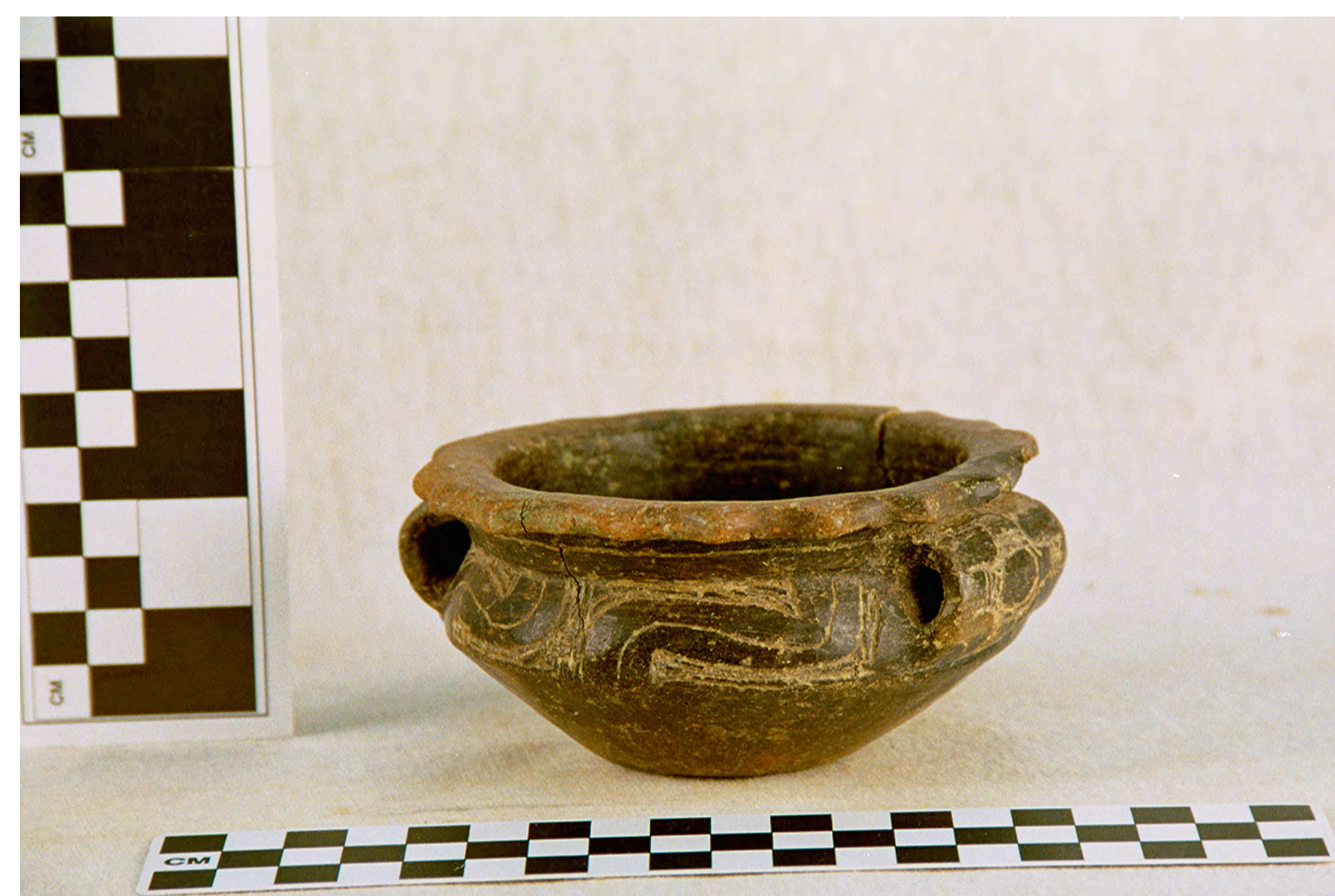

Figure 50 


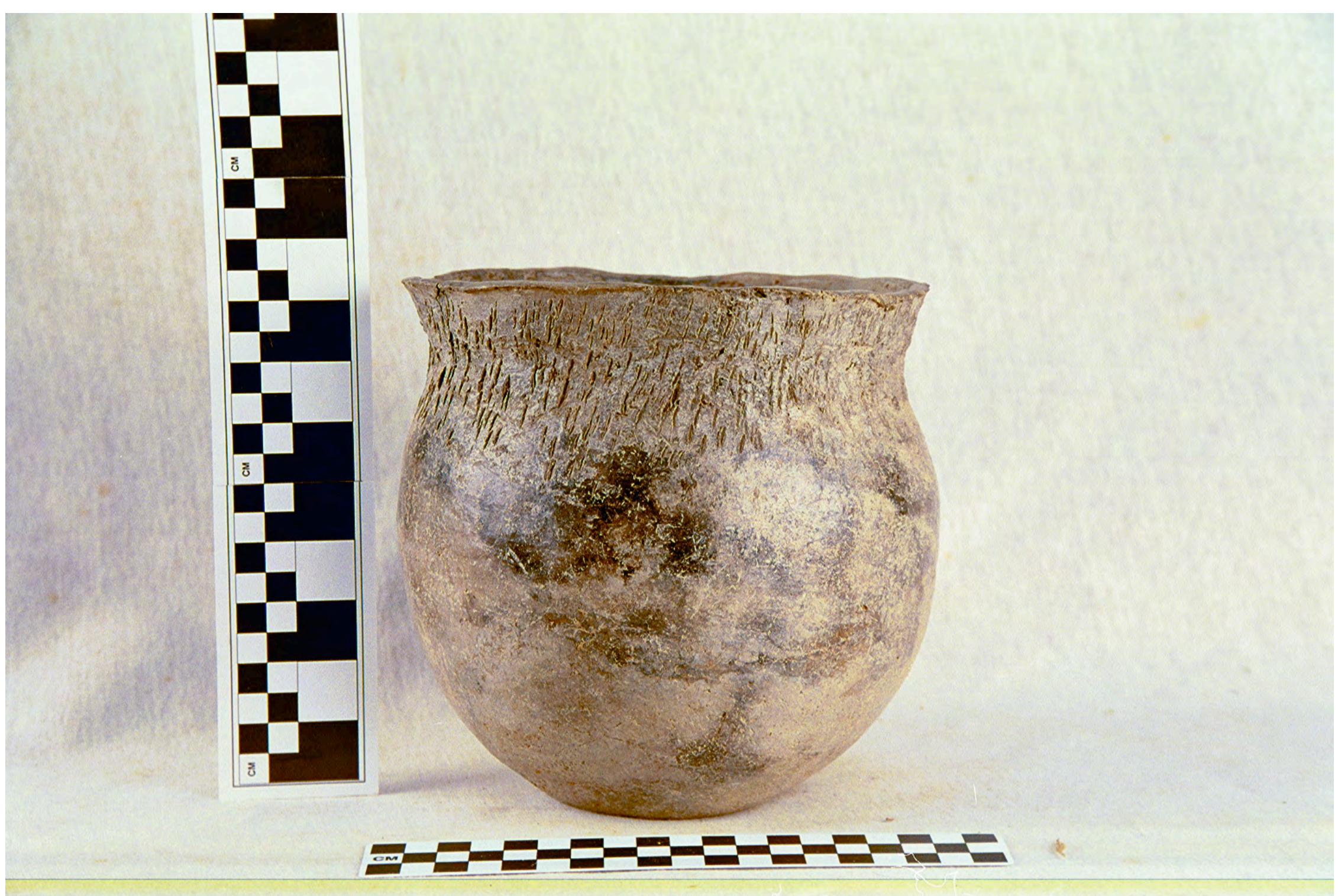

Figure 51 


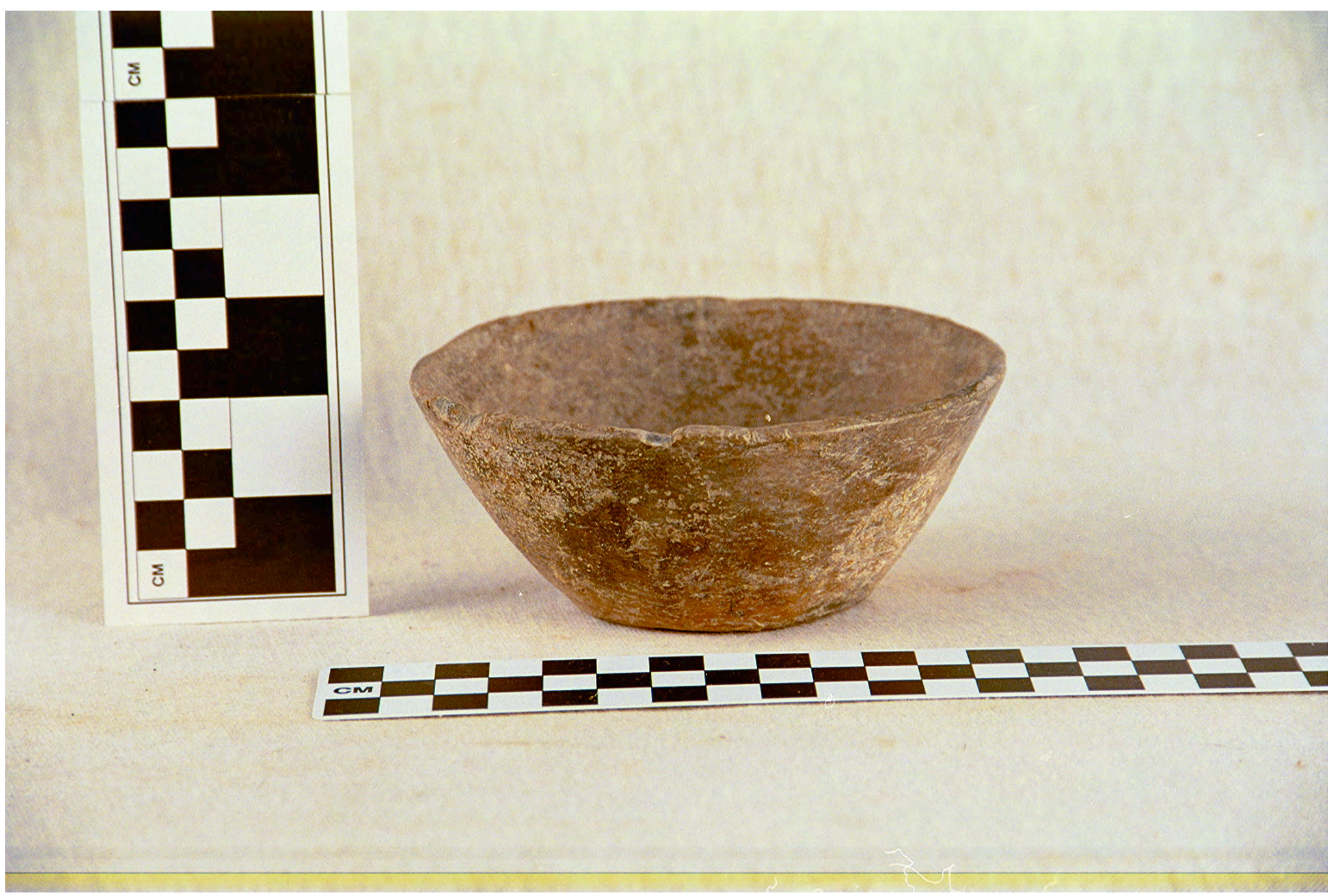

Figure 52 


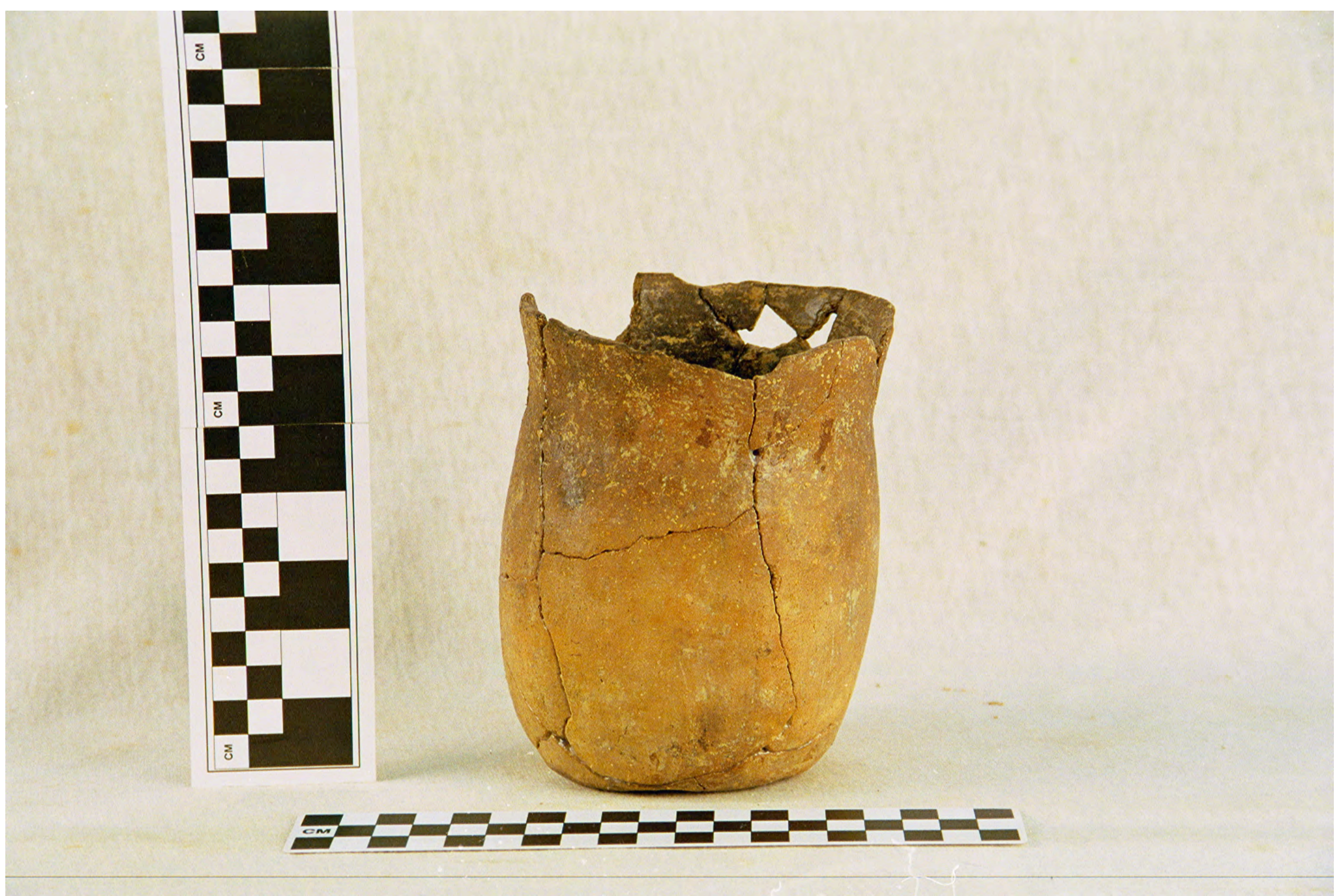

Figure 53 


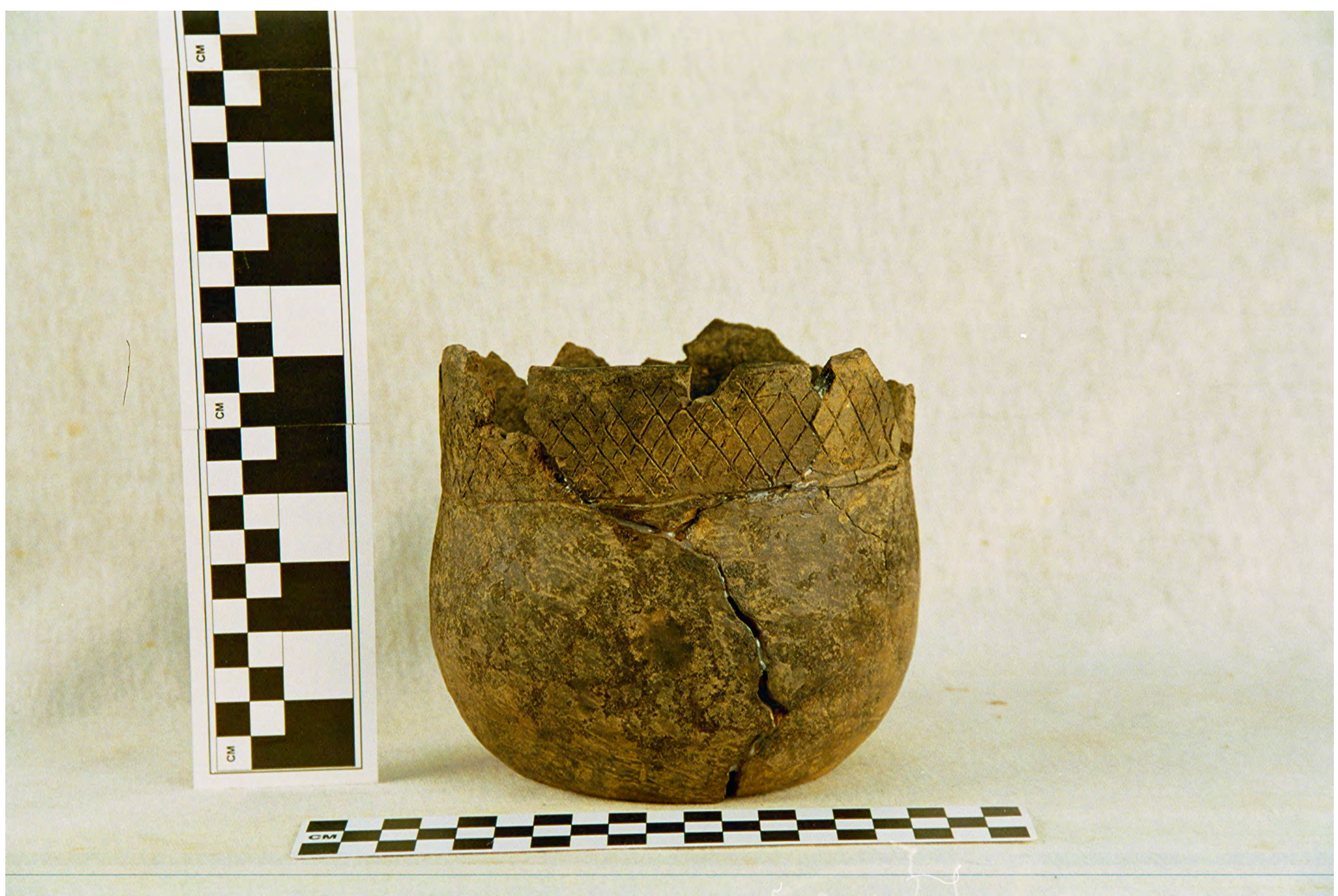

Figure 54 


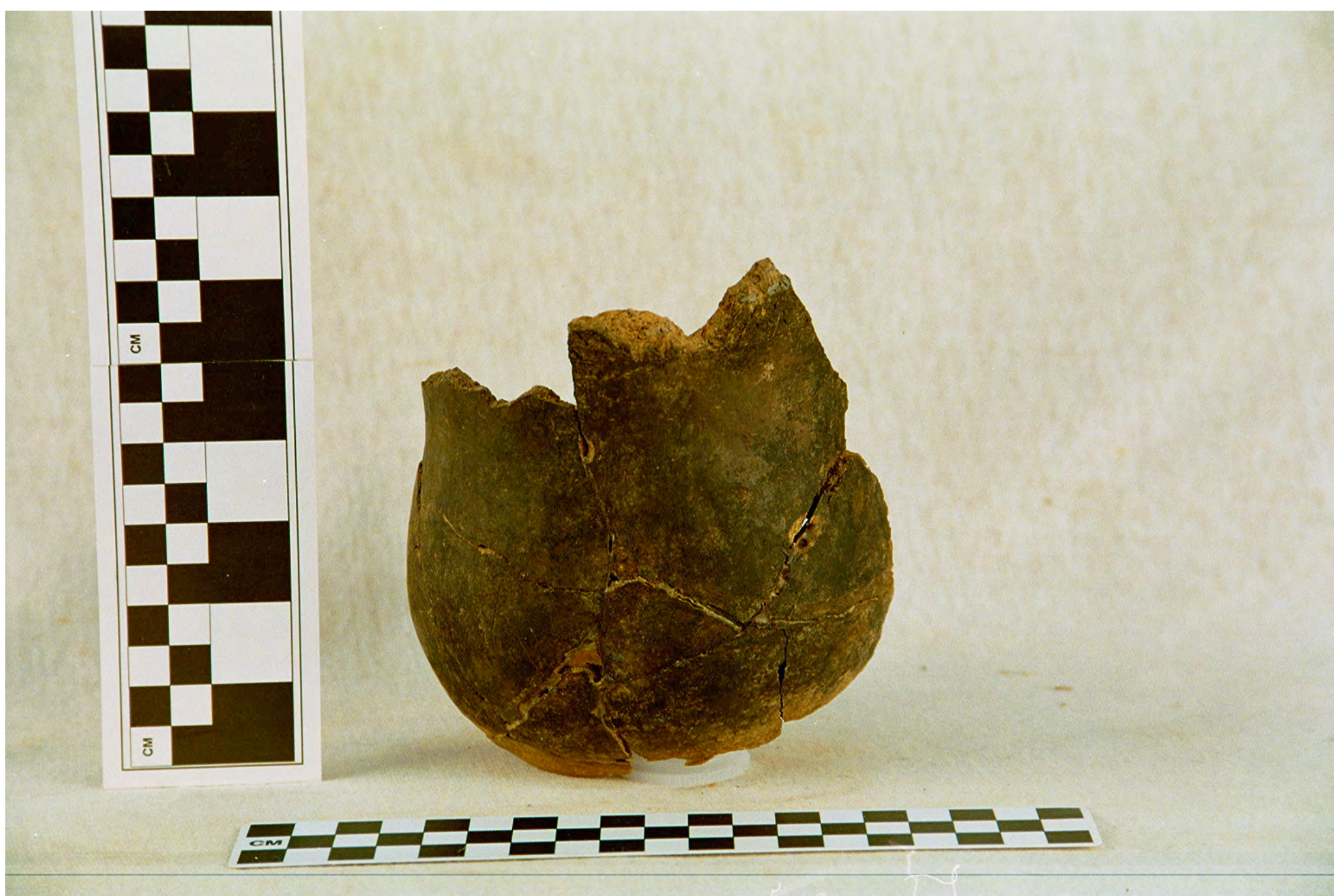

Figure 55 


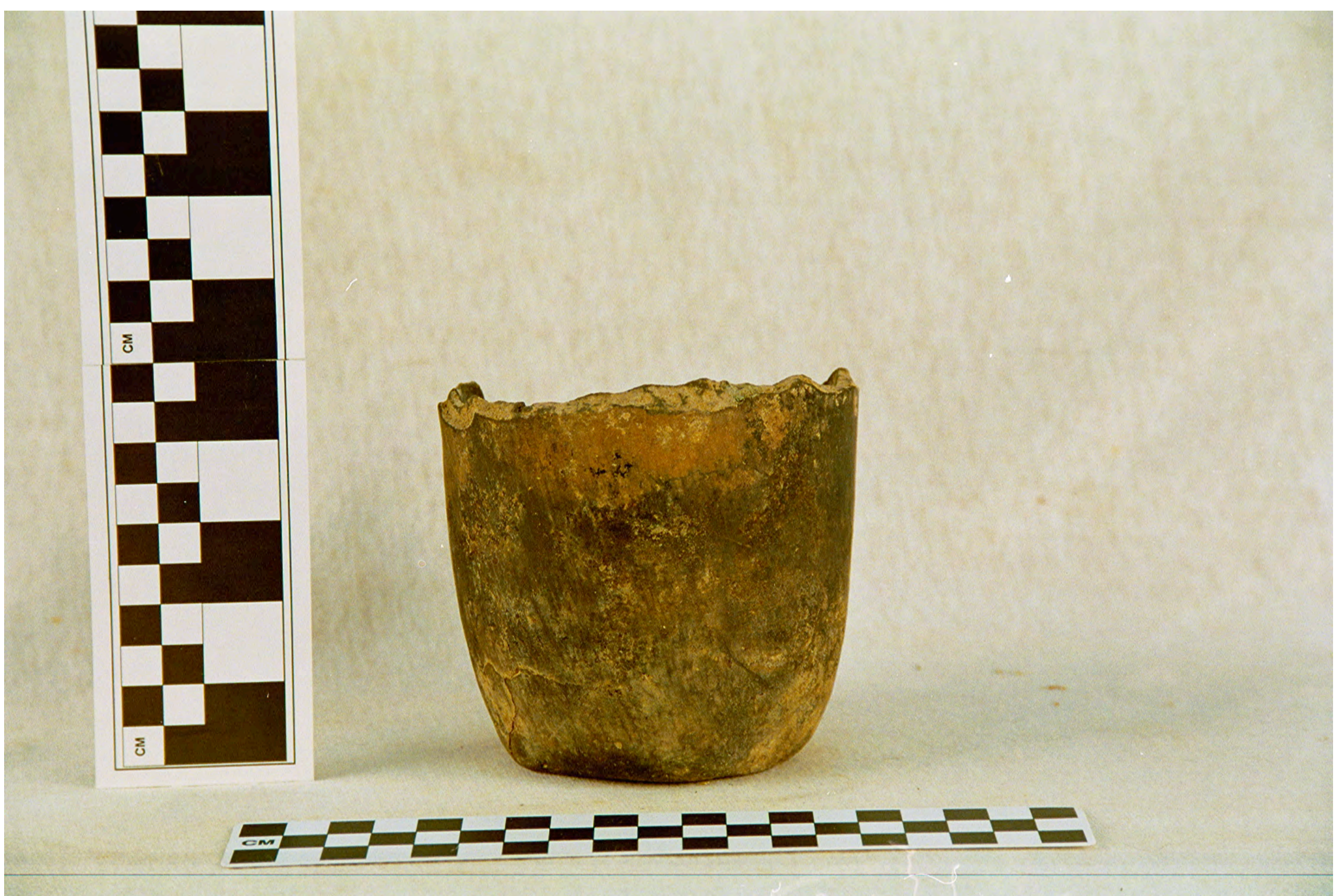

Figure 56 


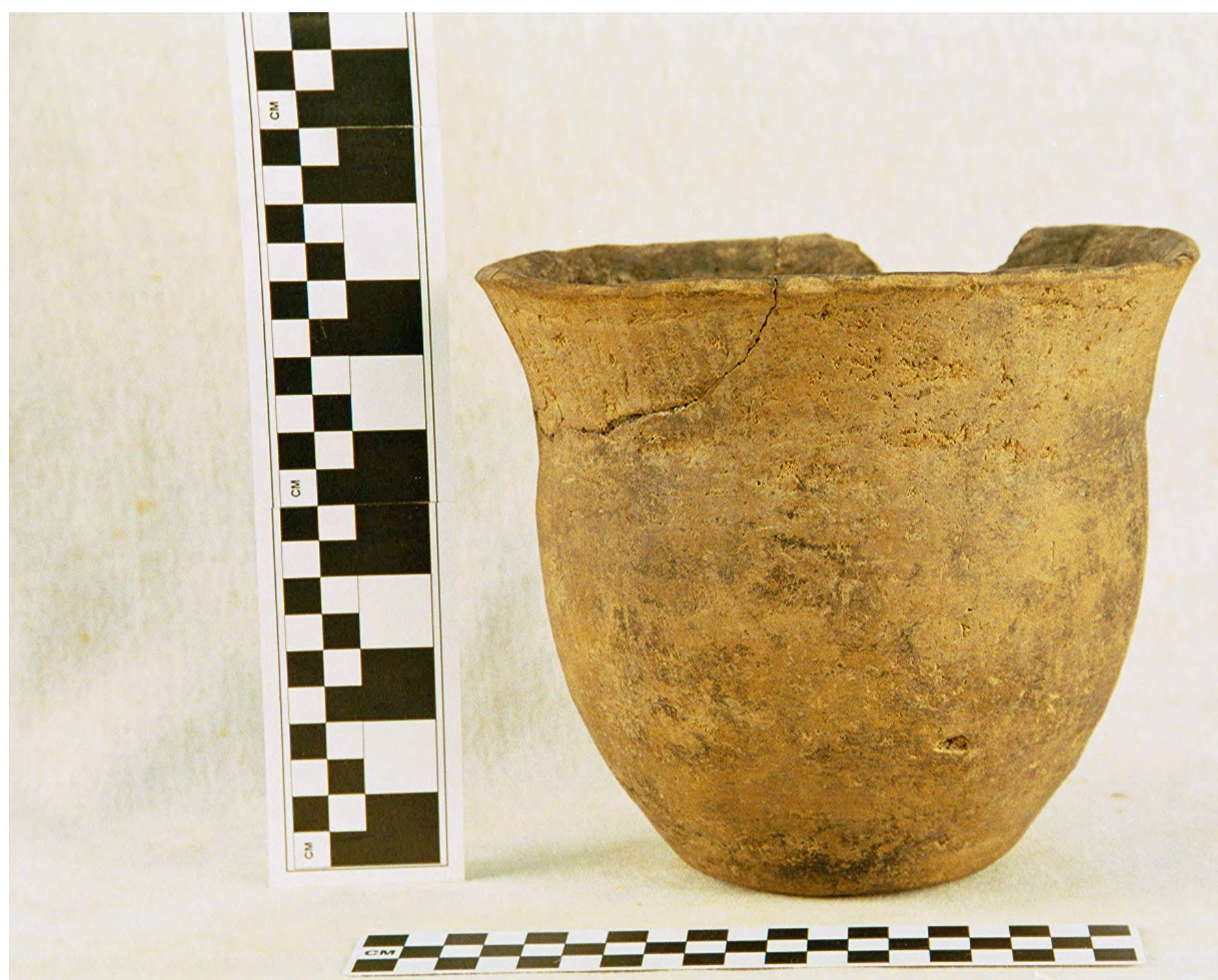

Figure 57 


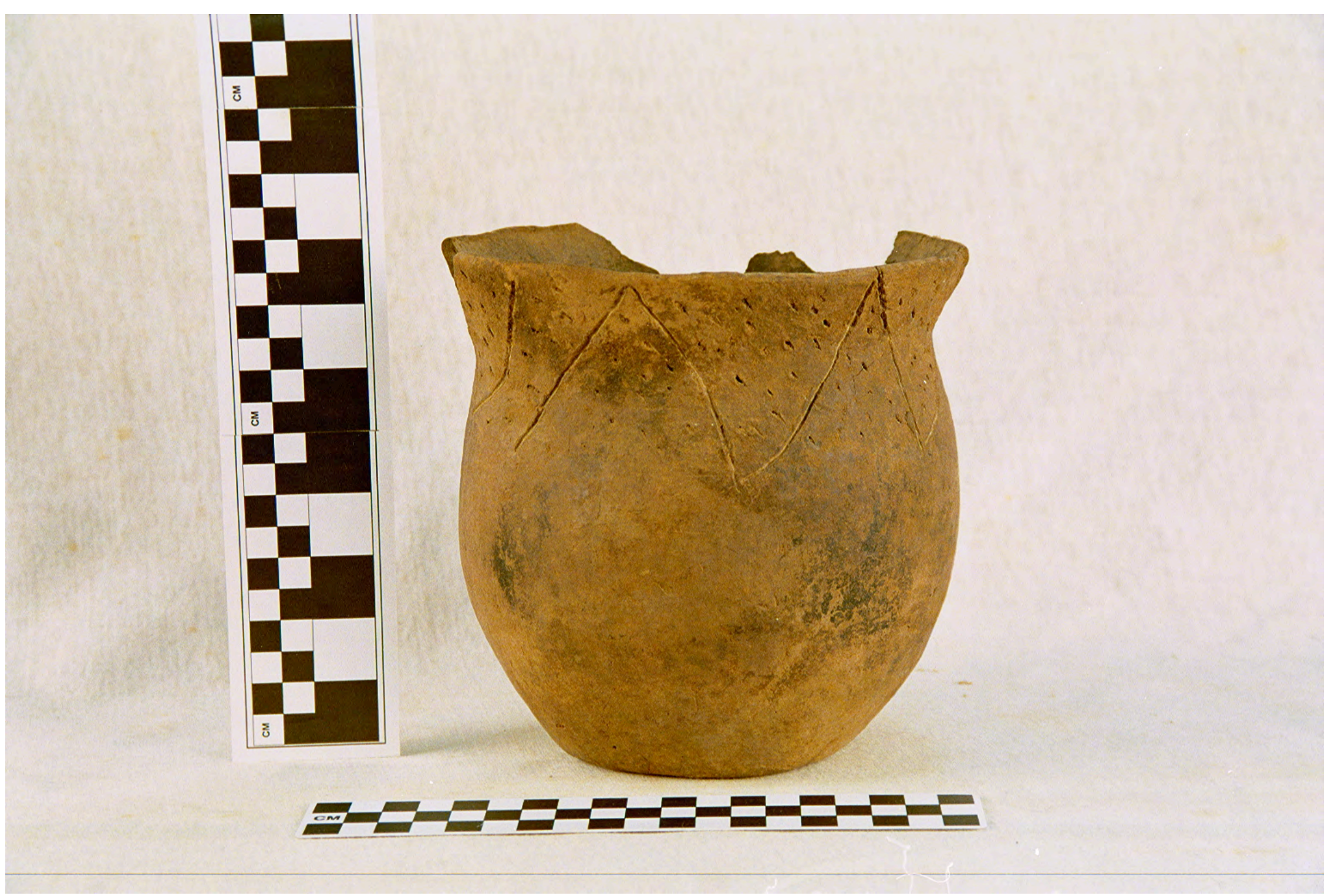

Figure 58 


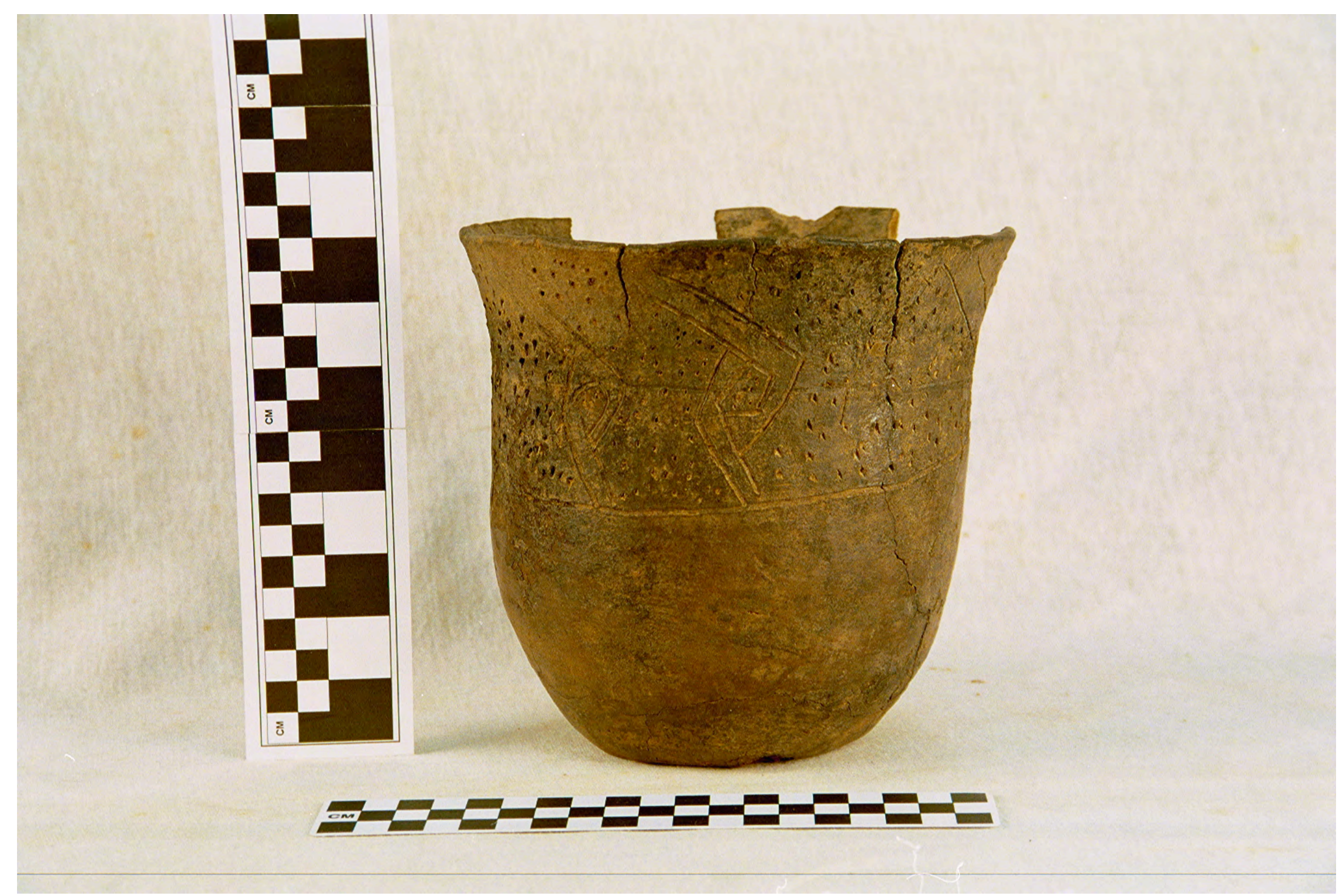

Figure 59 


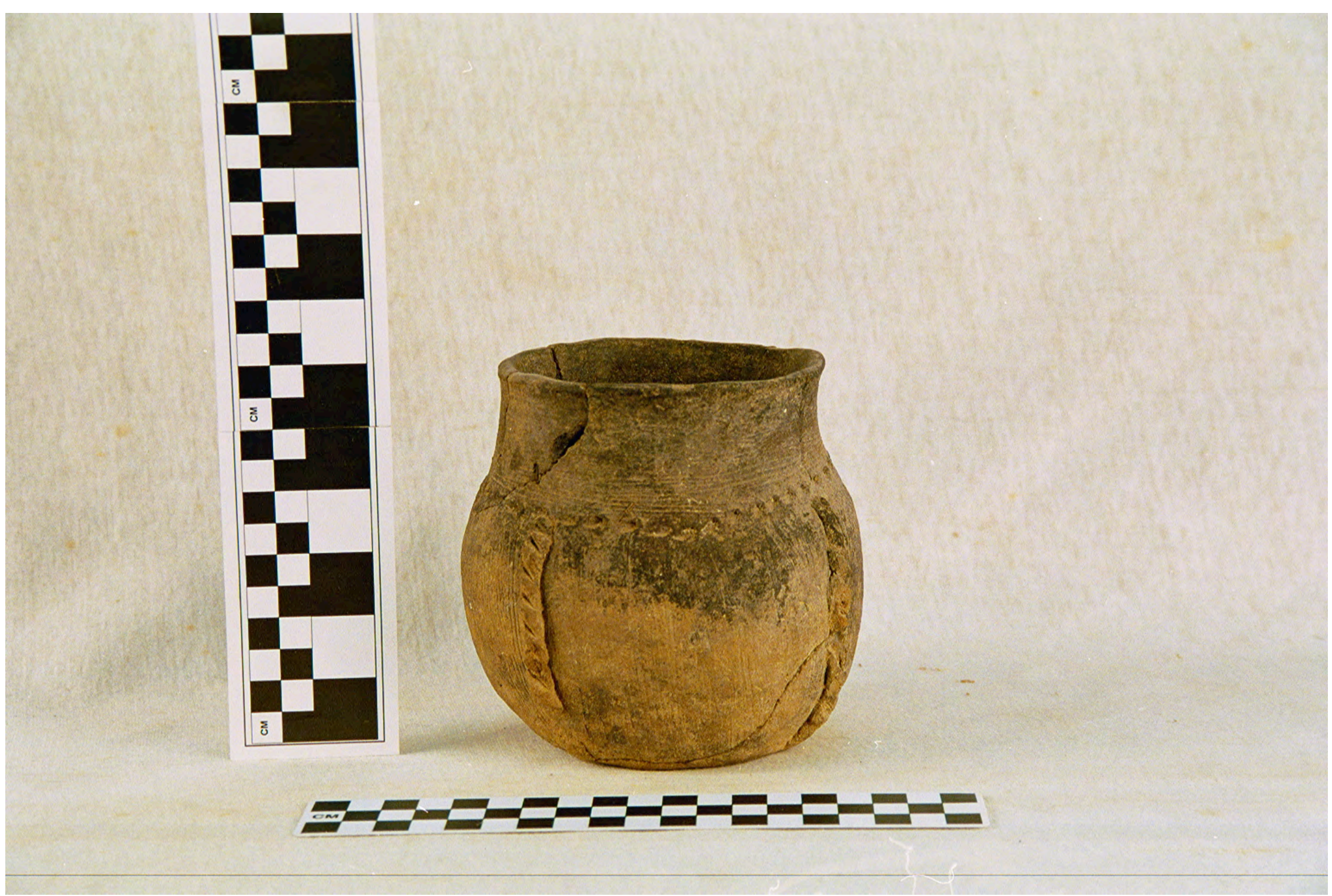

Figure 60 


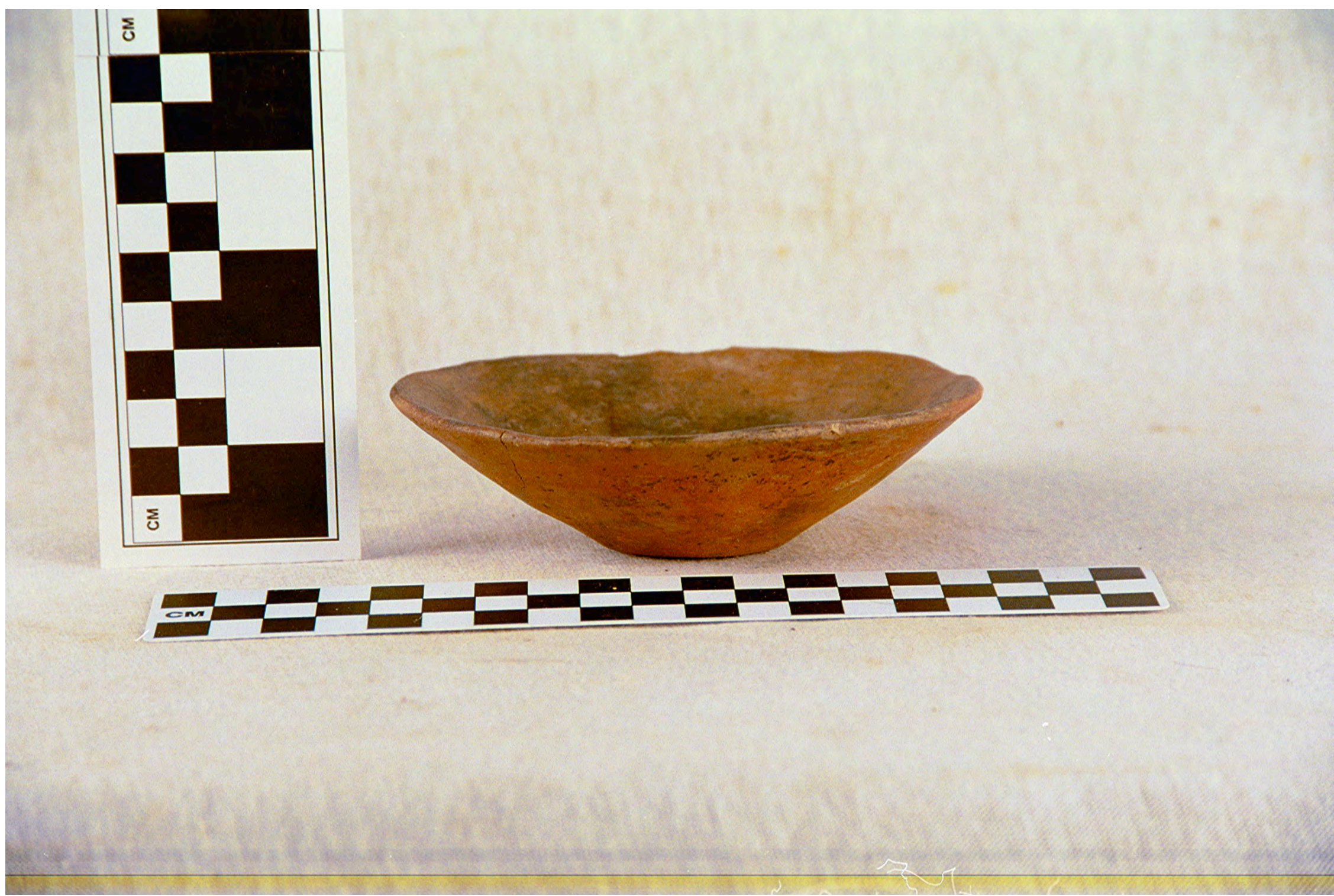

Figure 61 


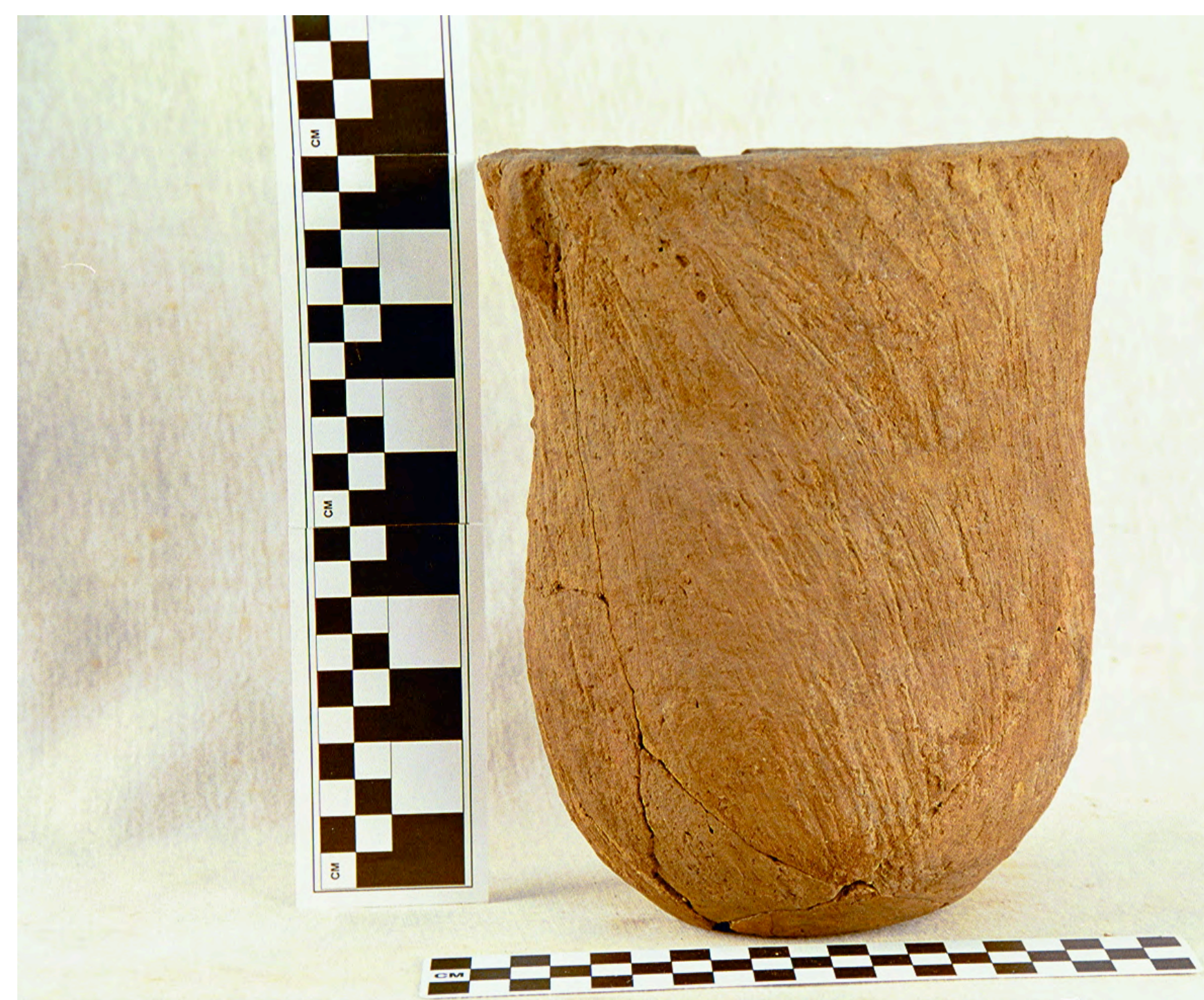

Figure 62 


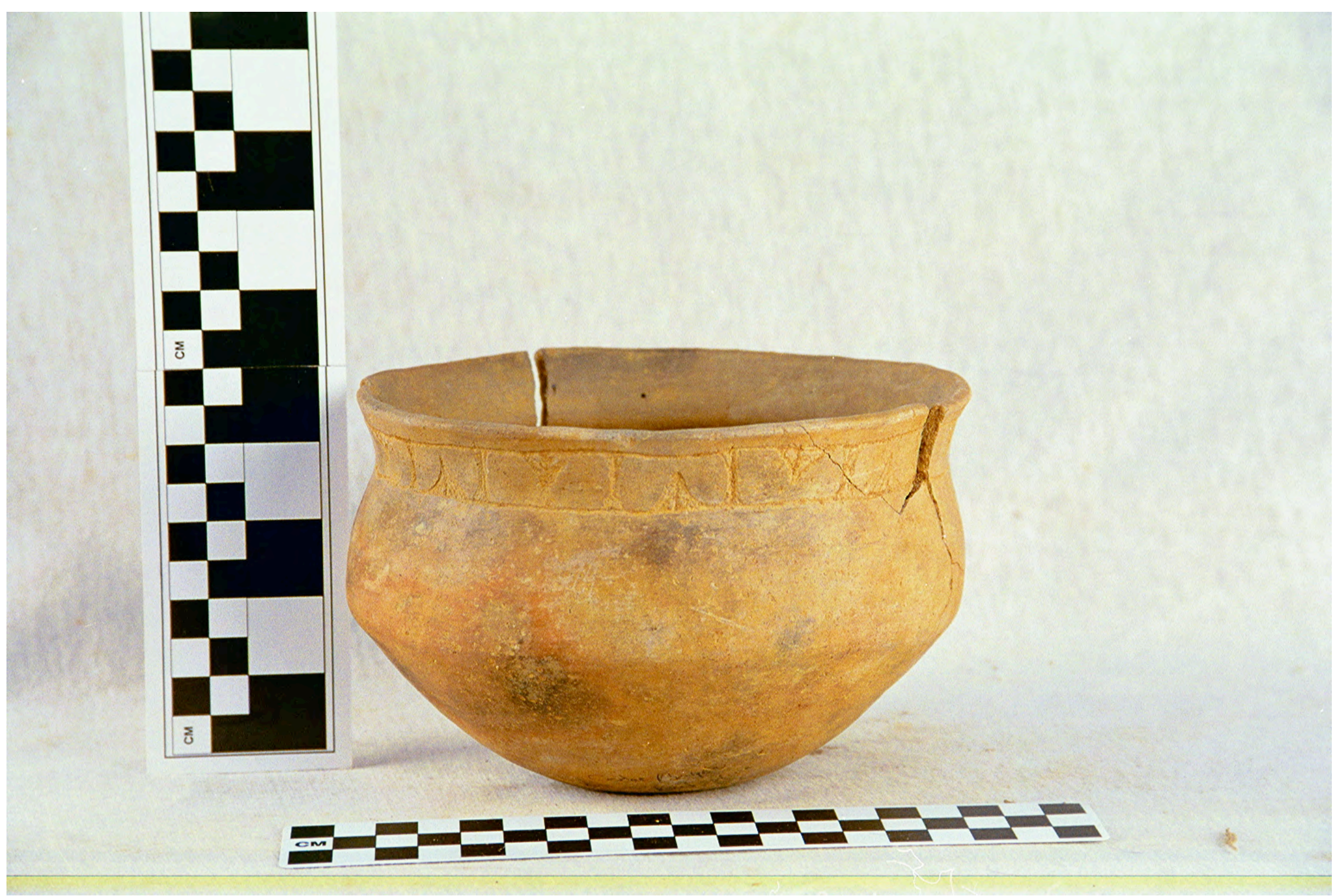

Figure 63 


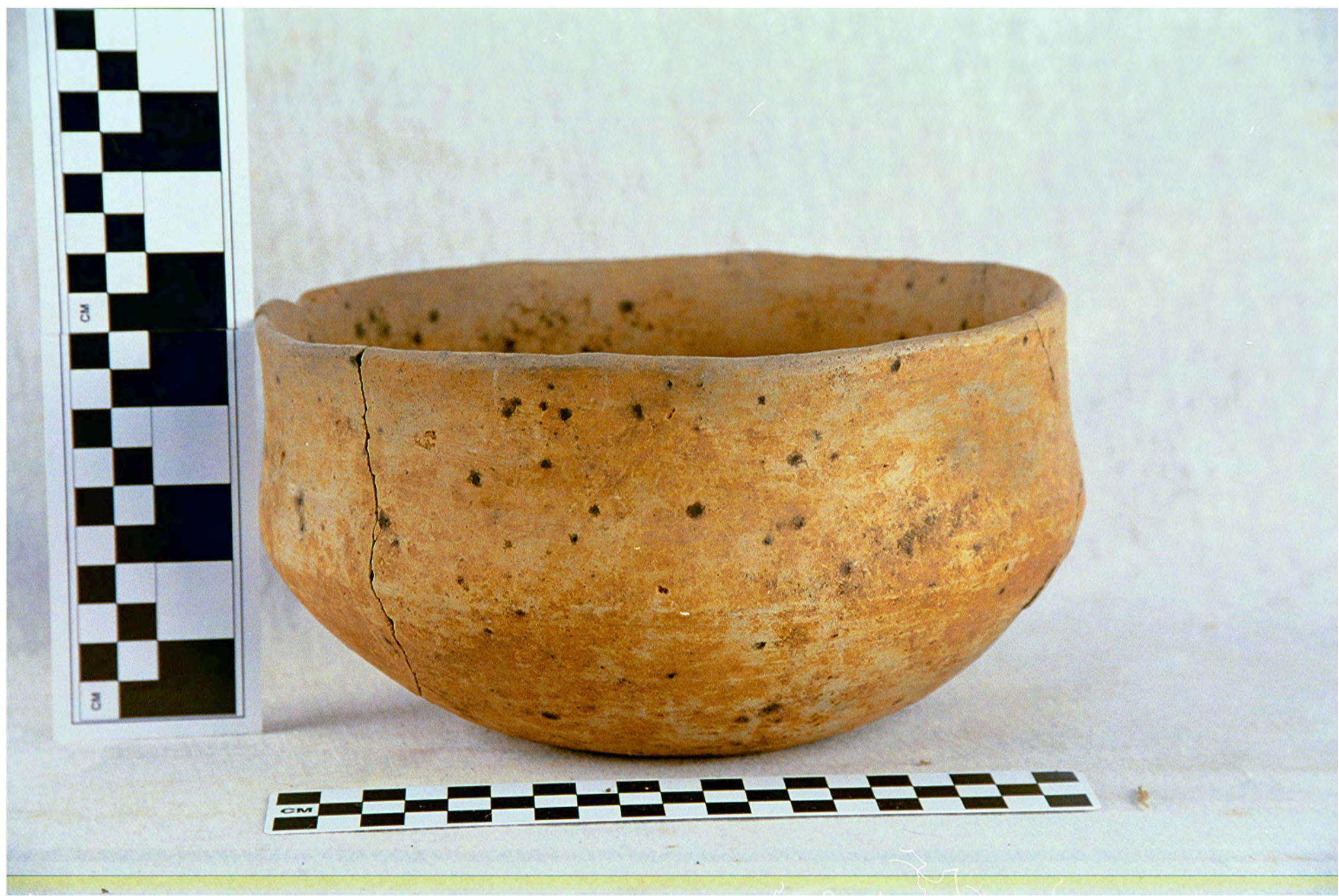

Figure 64 


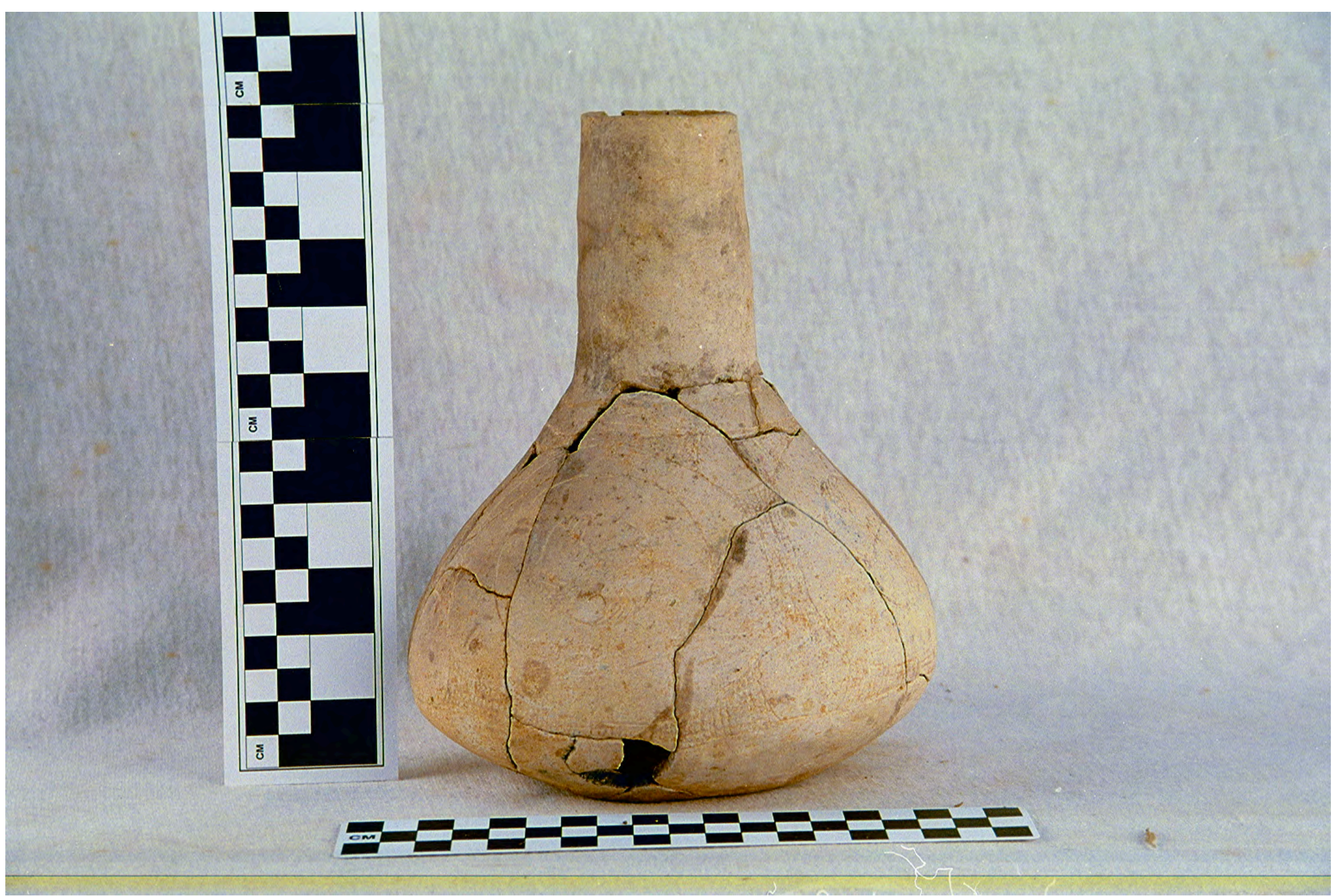

Figure 65 


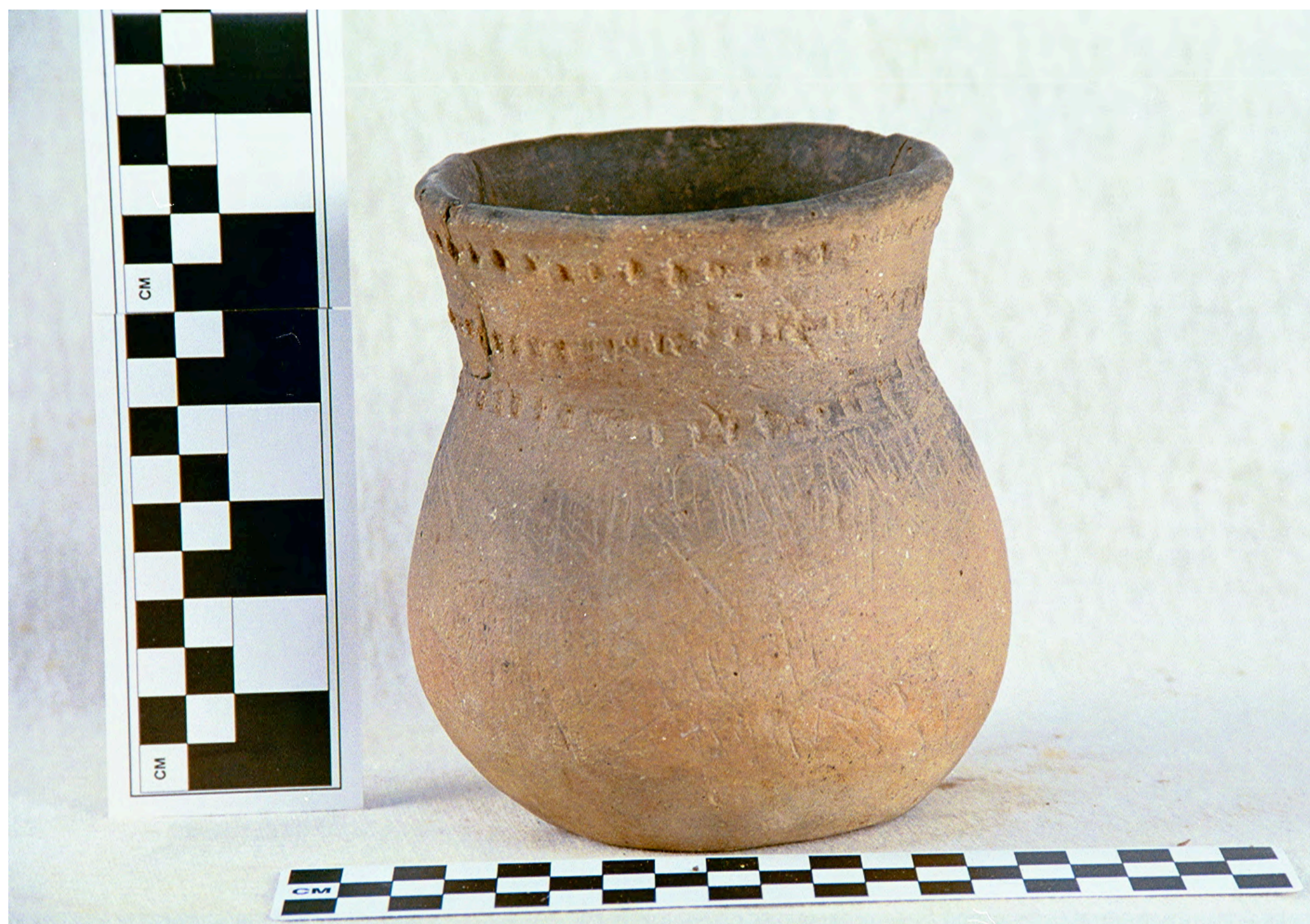

Figure 66 


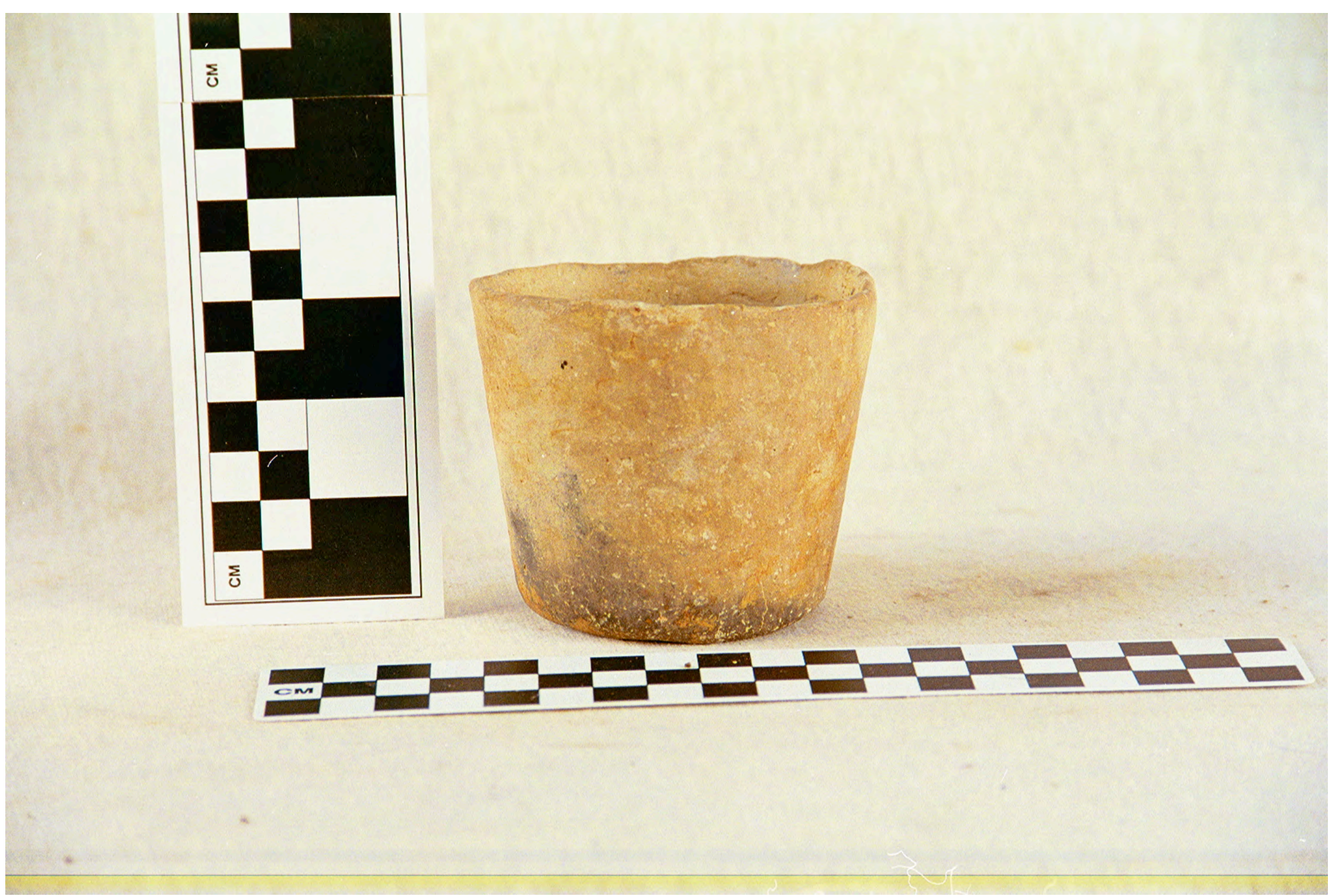

Figure 67 


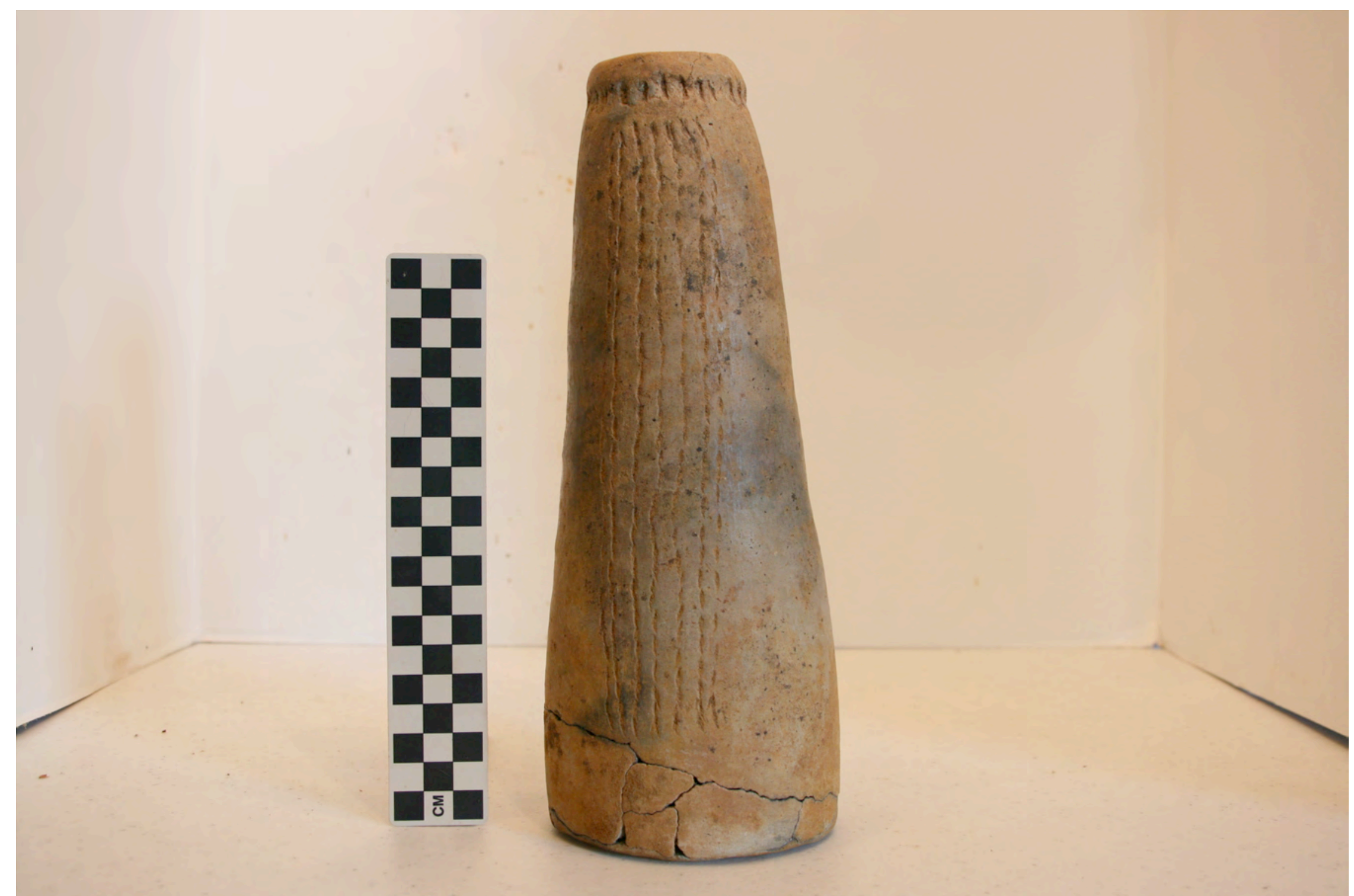

Figure 68 


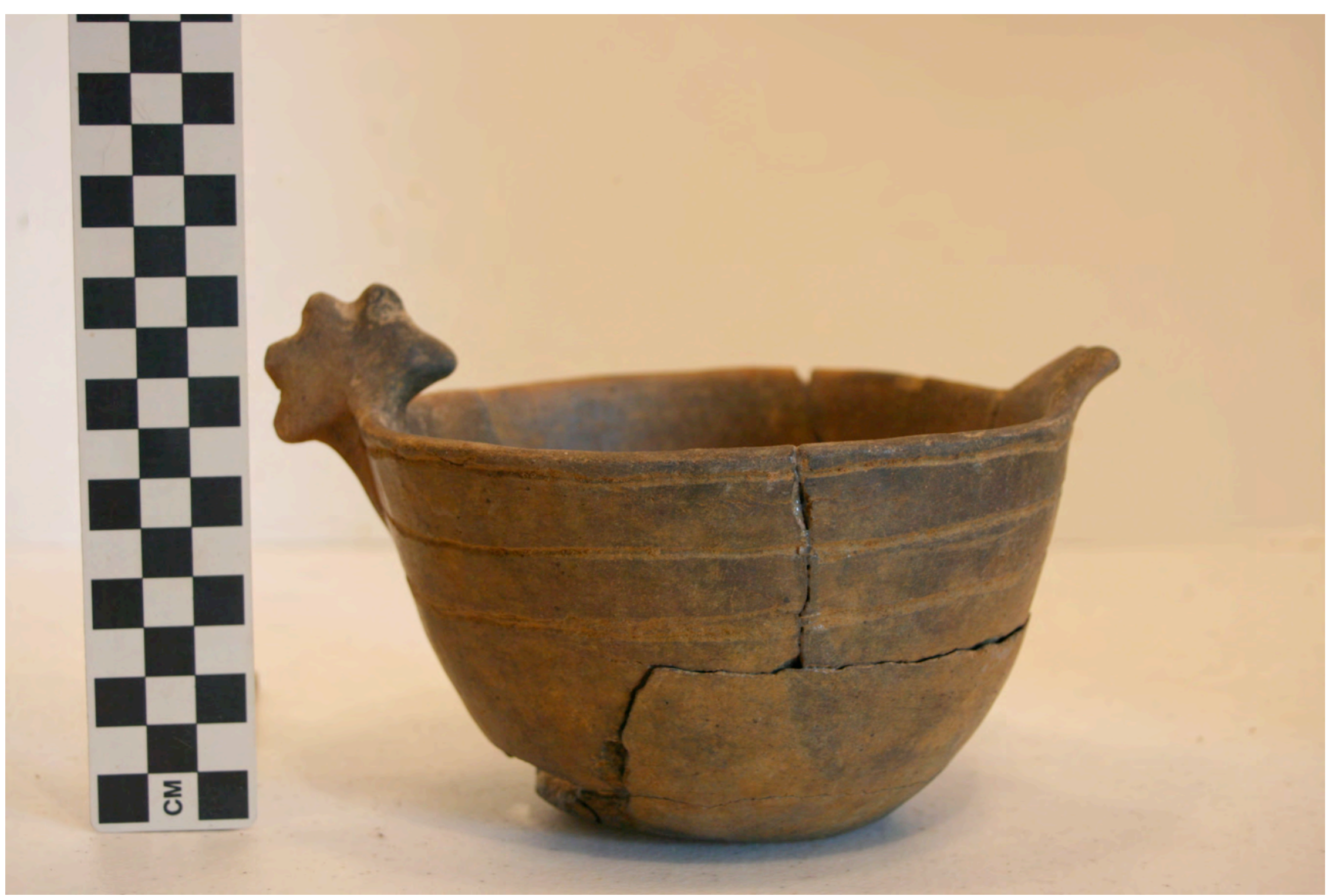

Figure 69 


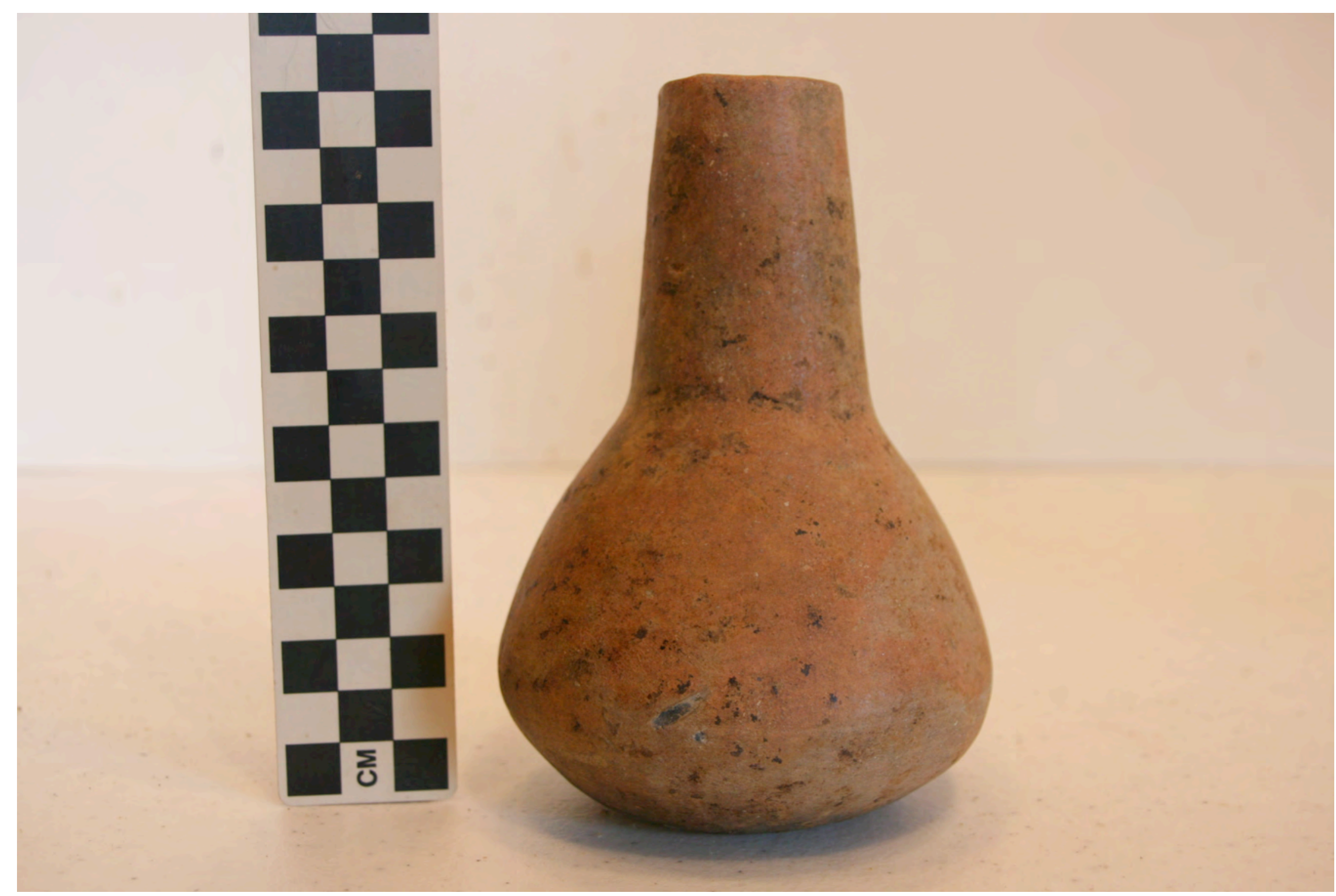

Figure 70 


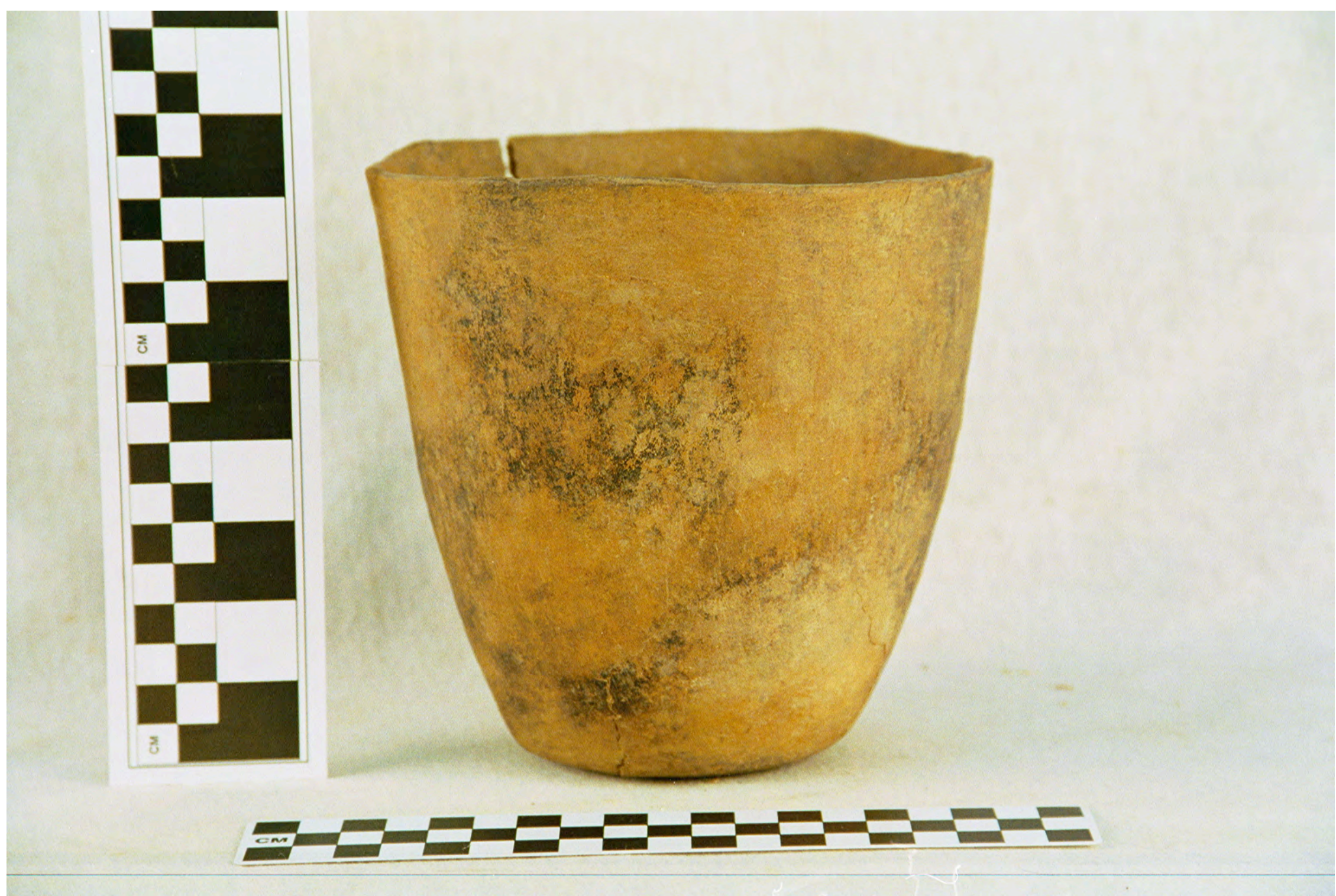

Figure 71 


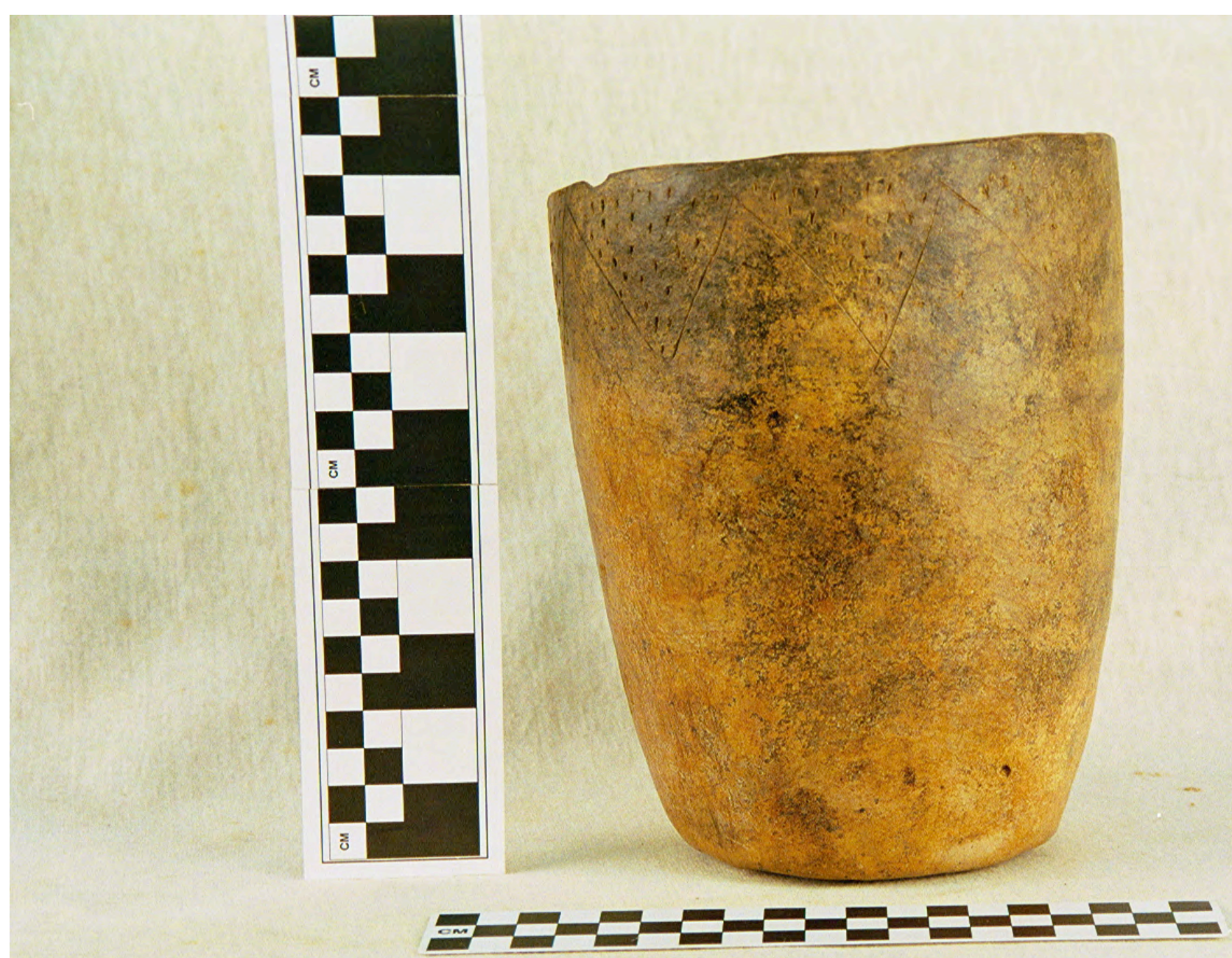

Figure 72 


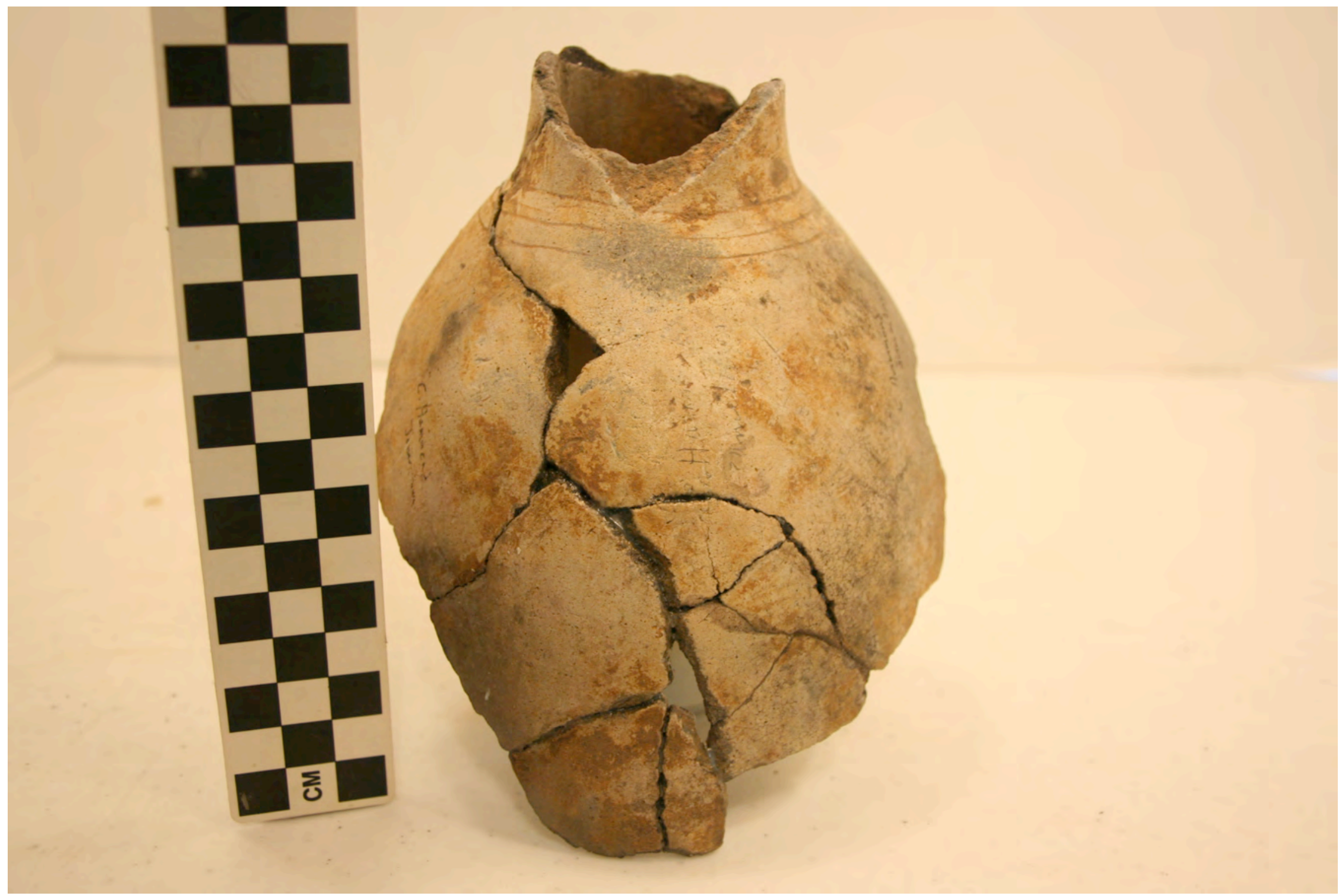

Figure 73 


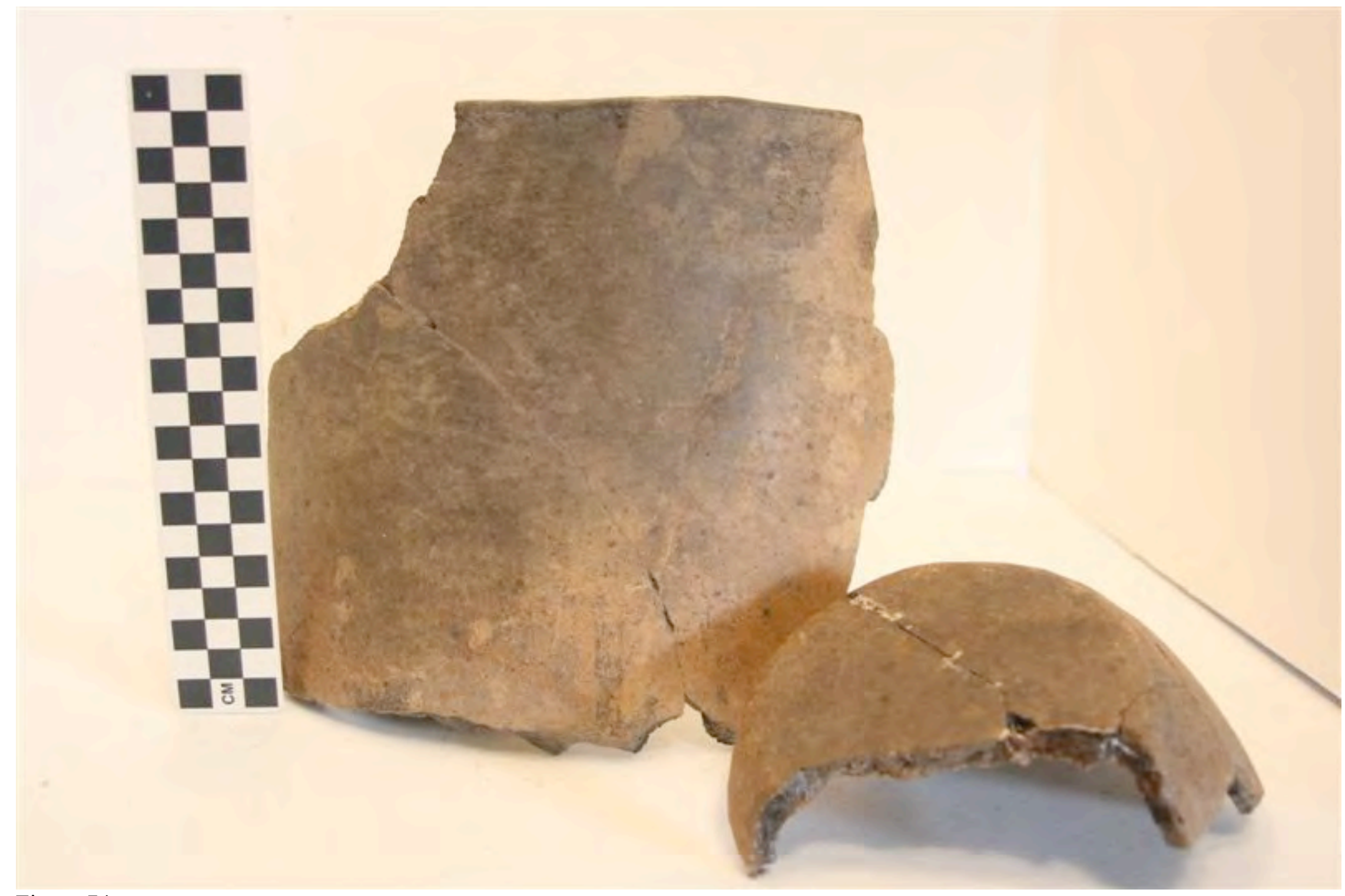

Figure 74 


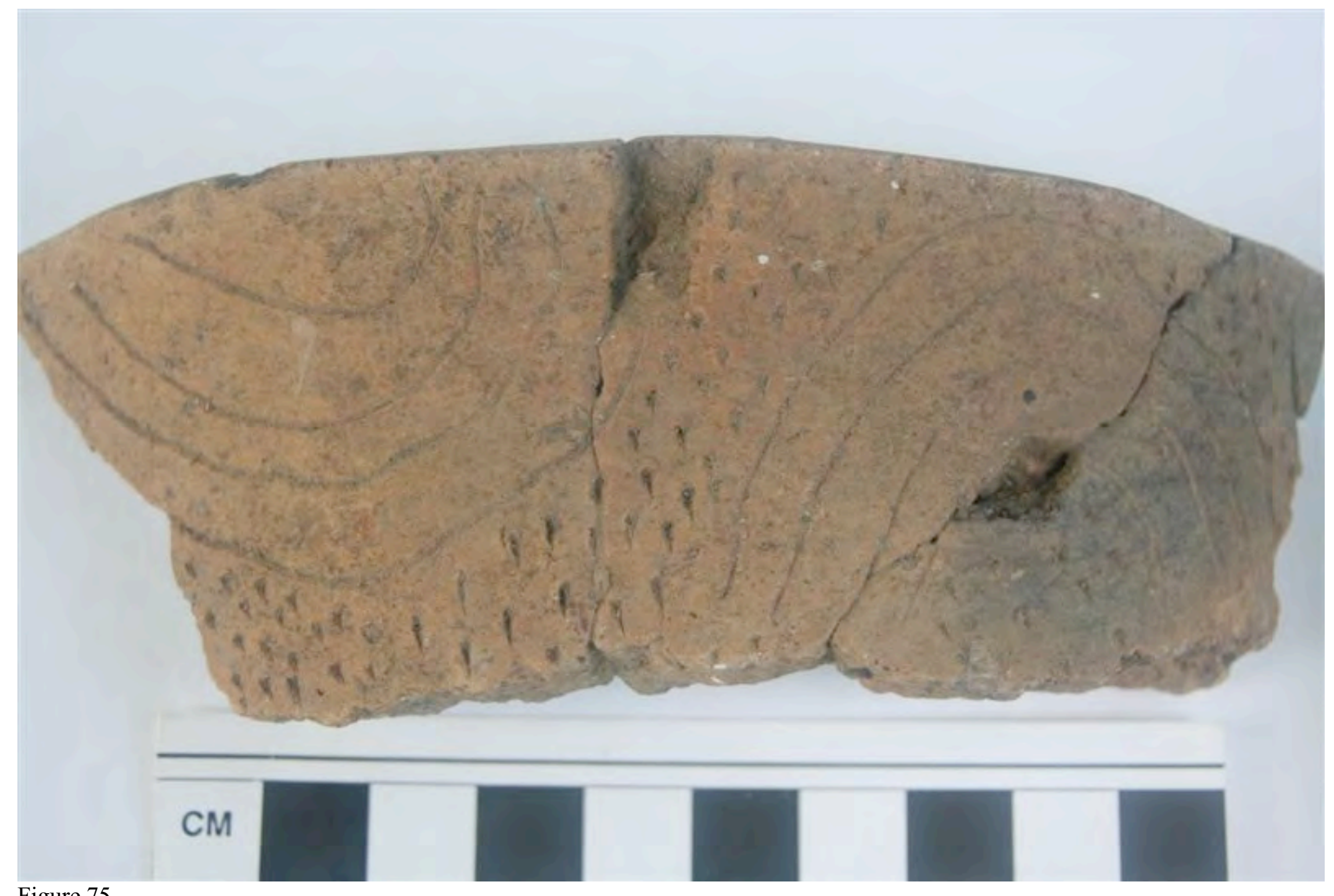

Figure 75 


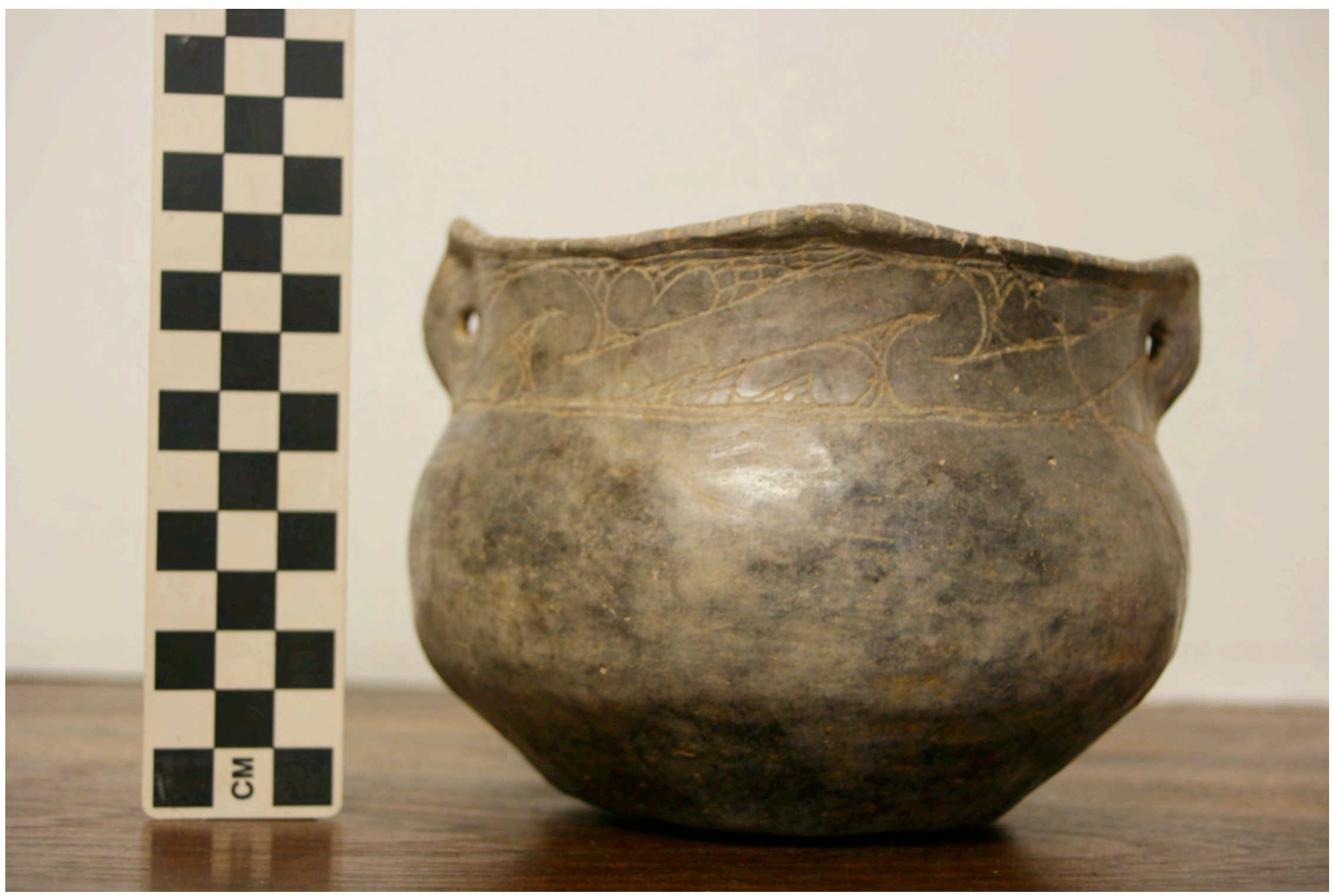

Figure 76 


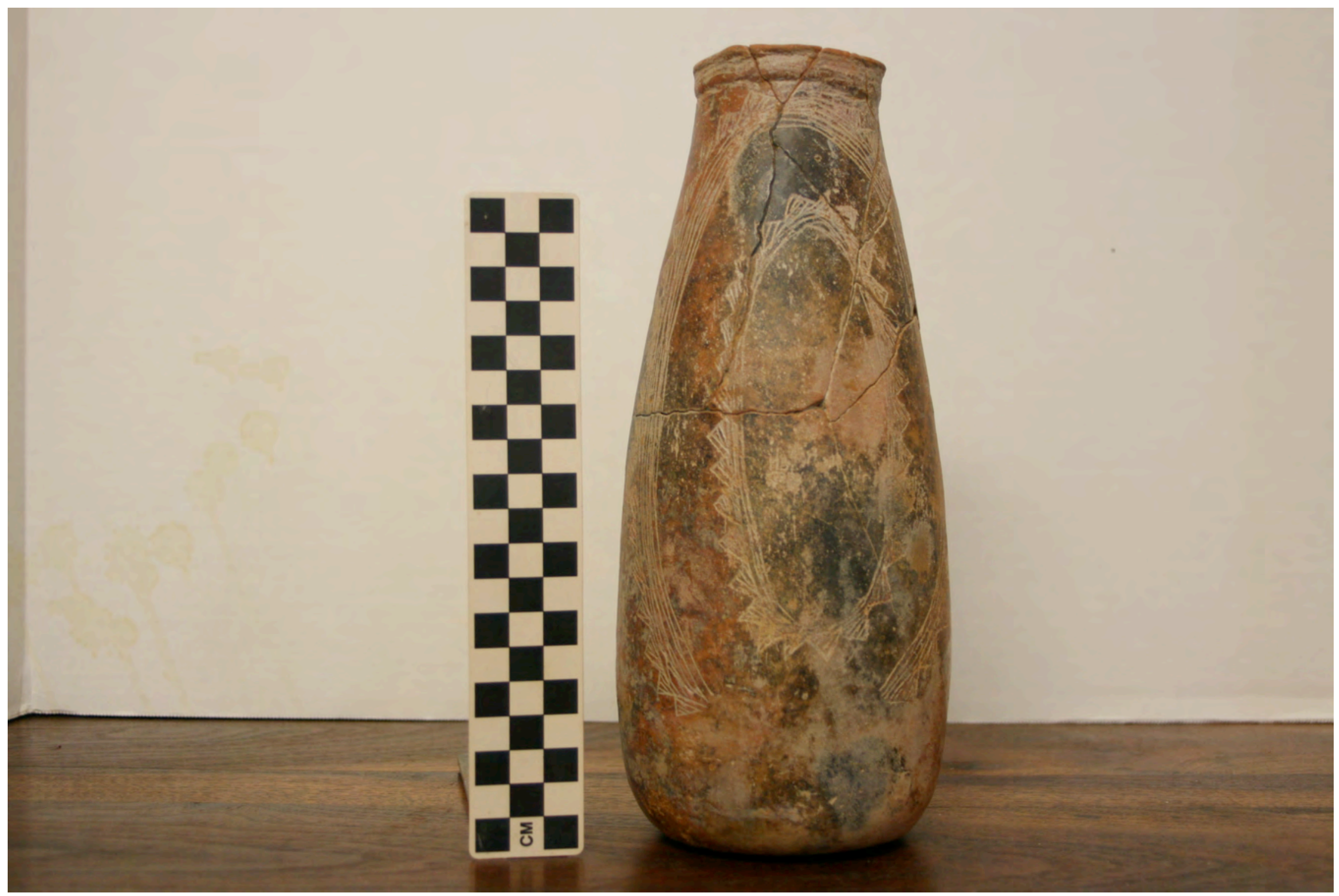

Figure 77 


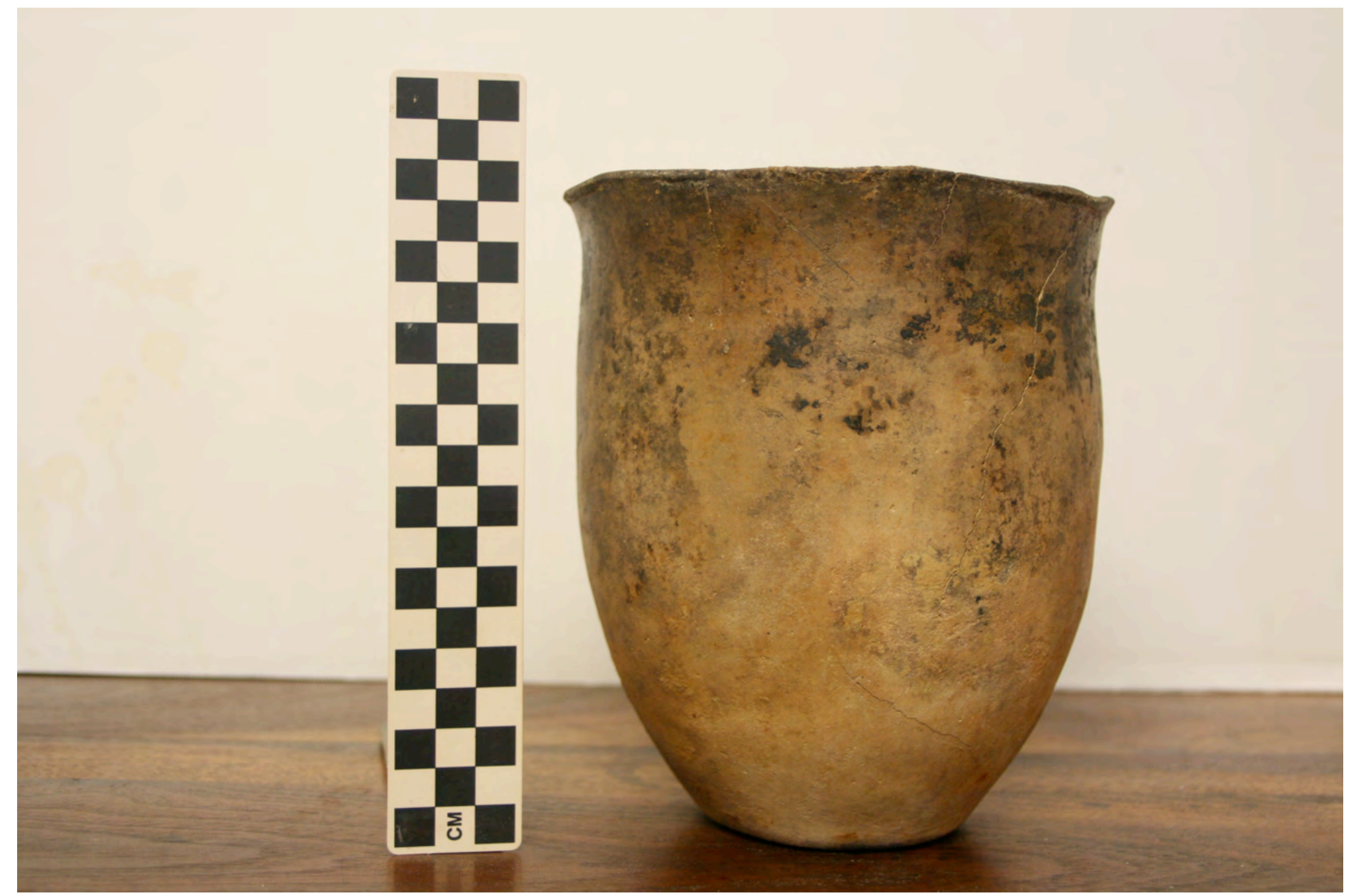

Figure 78 


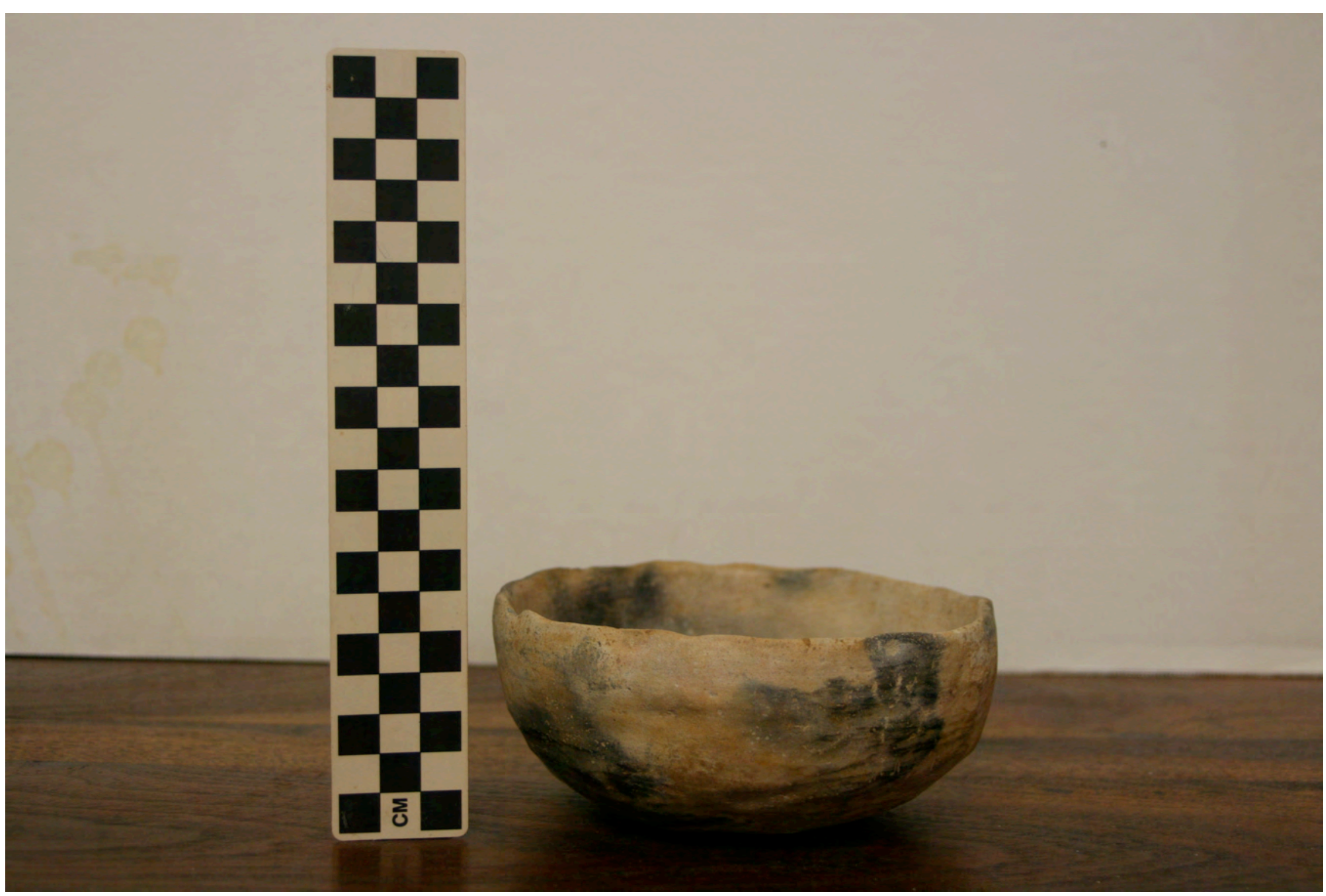

Figure 79 


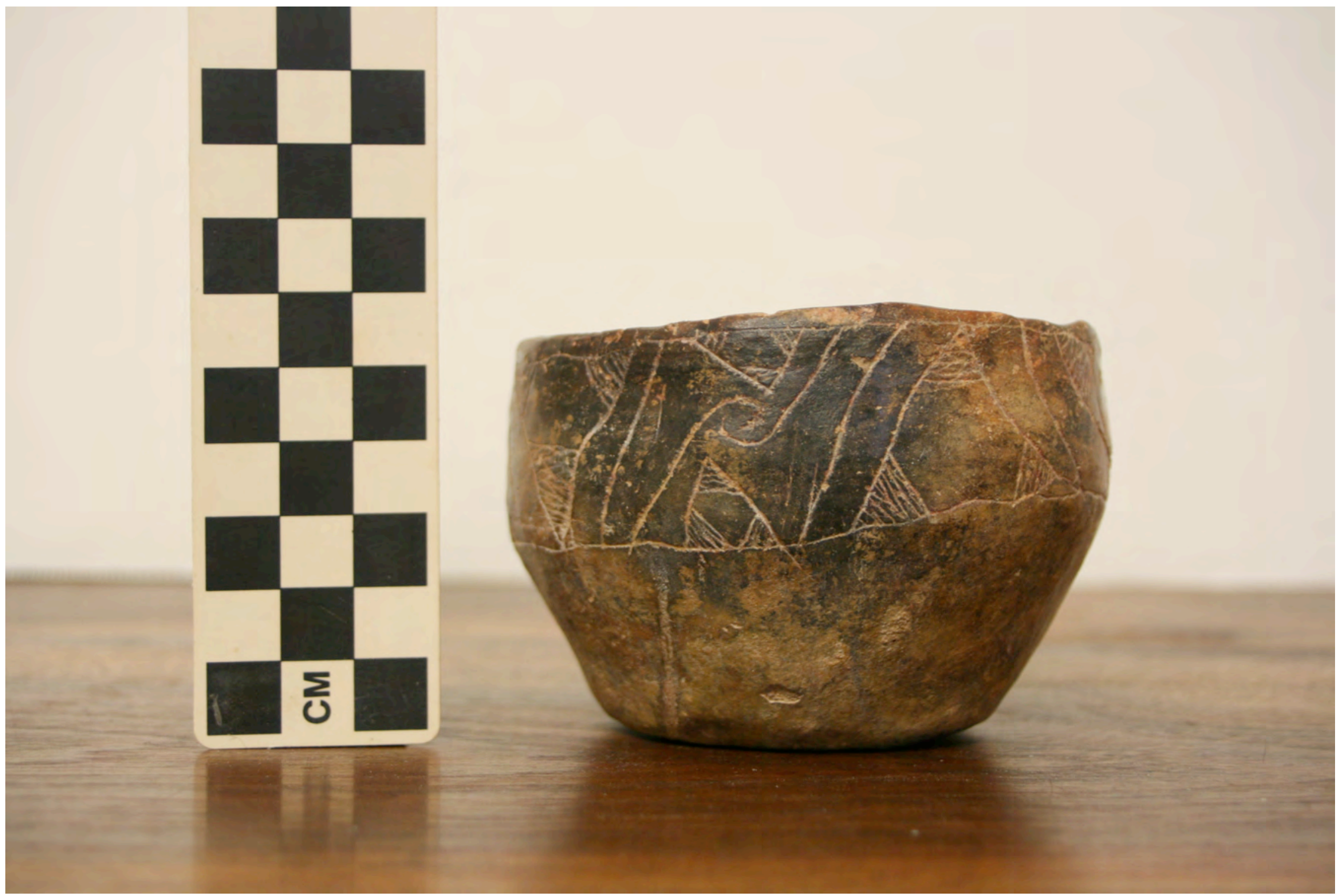

Figure 80 


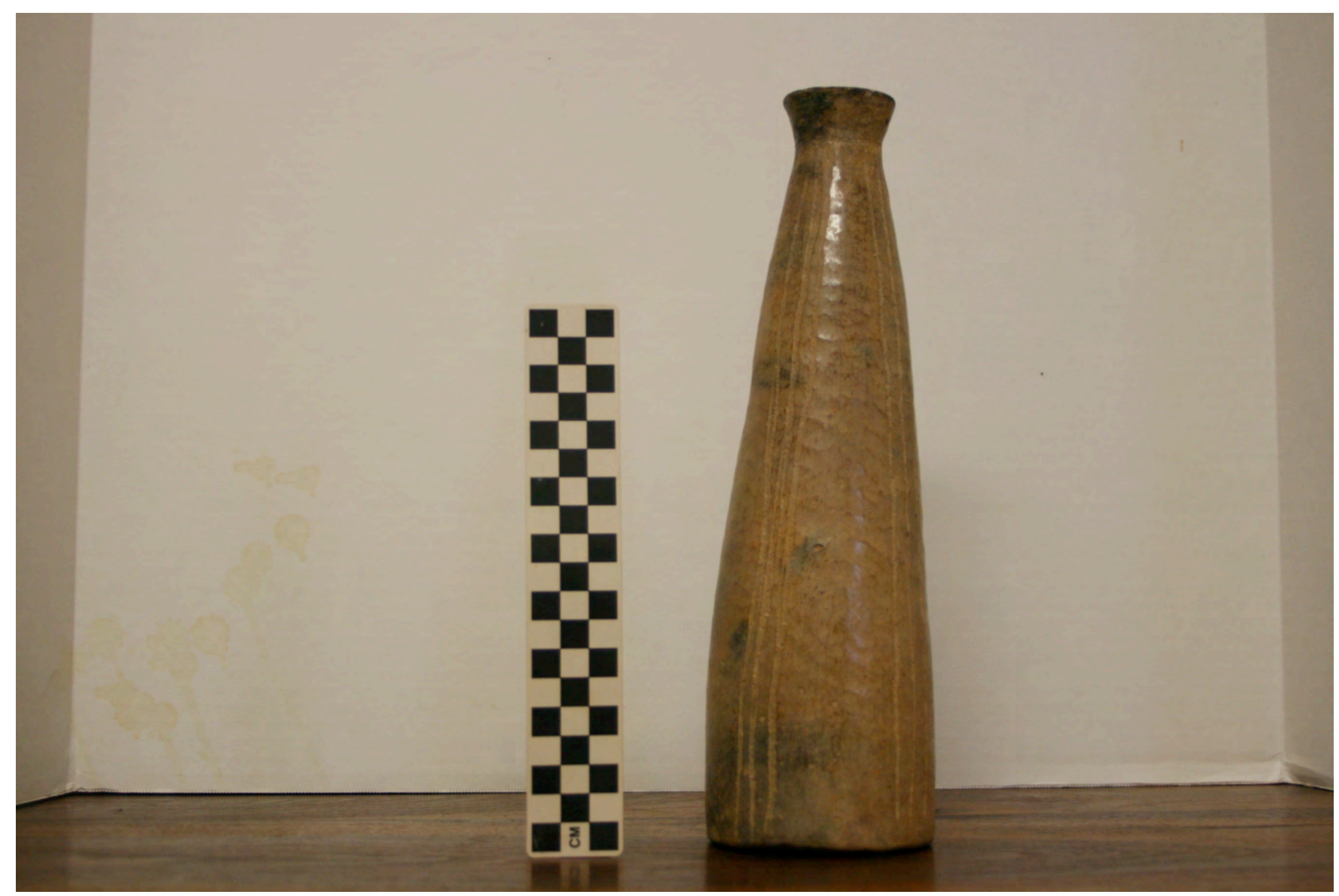

Figure 81 


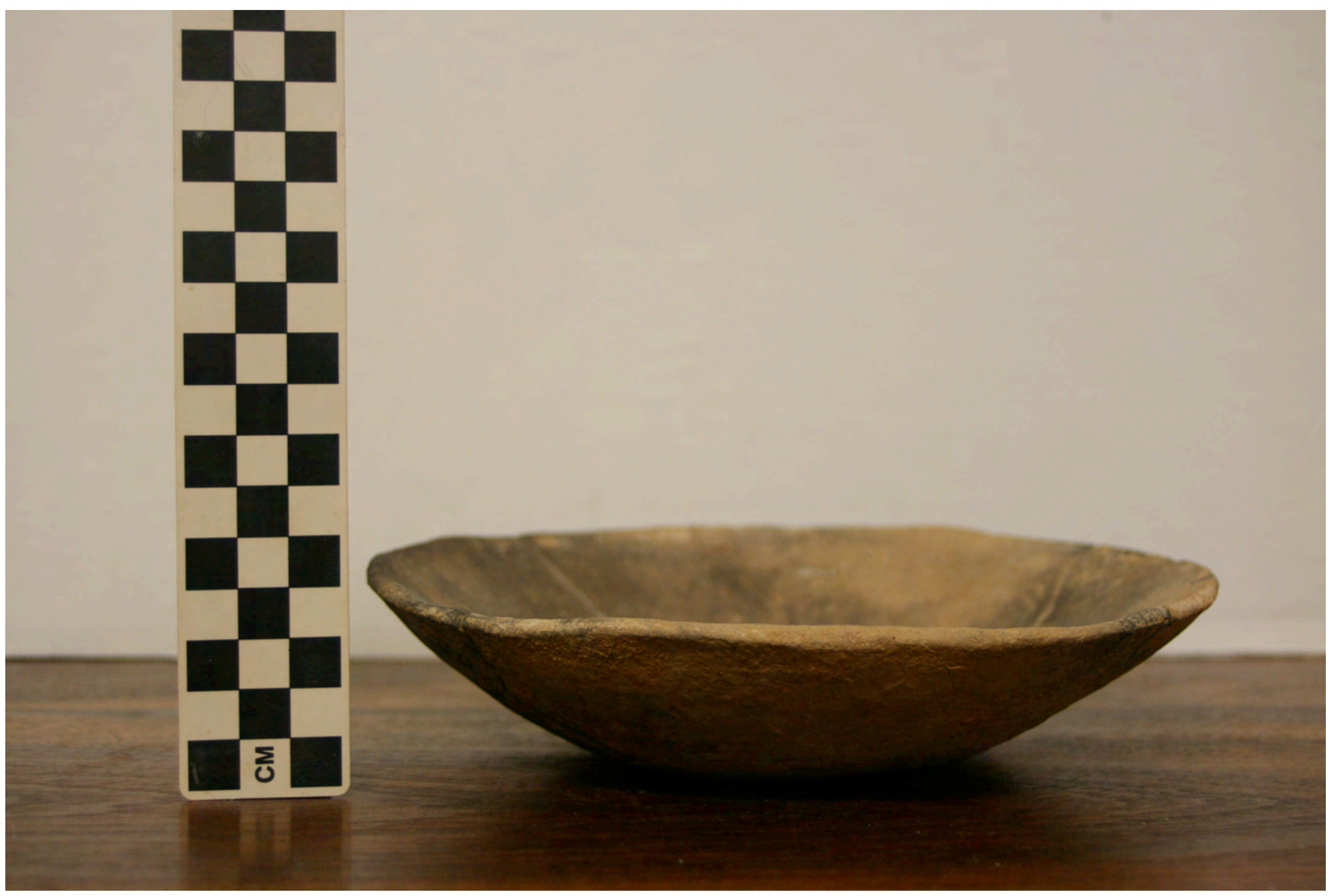

Figure 82 


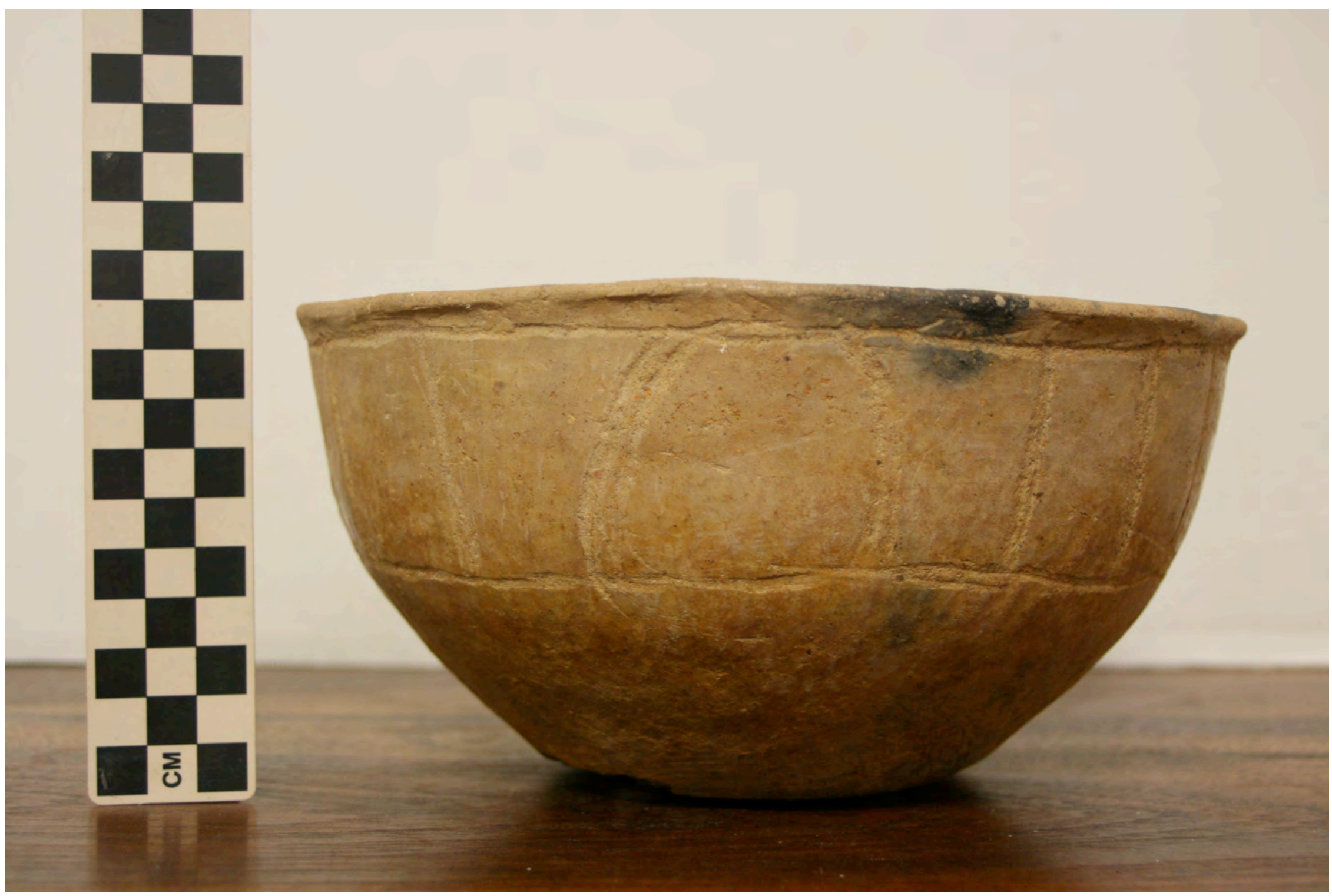

Figure 83 


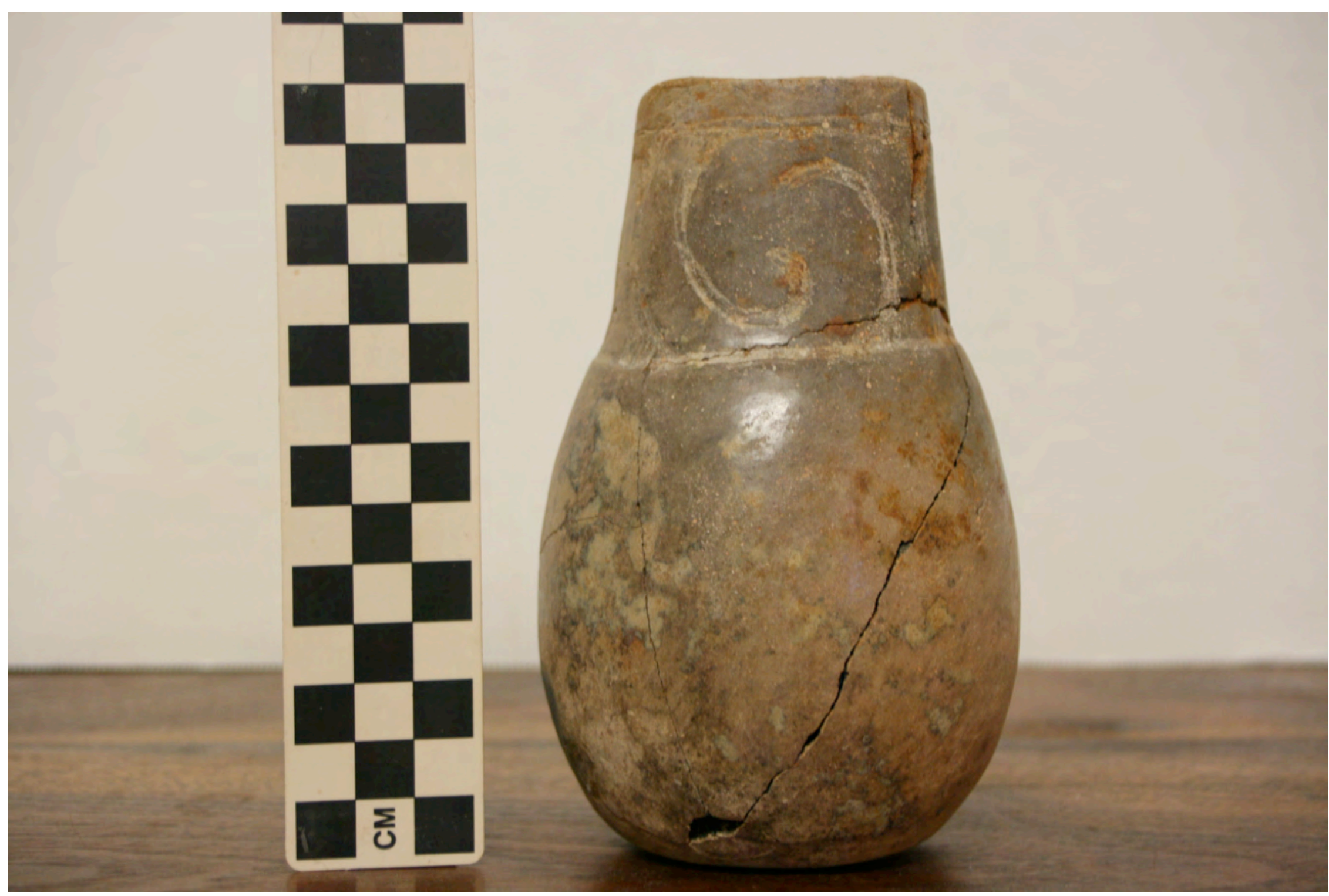

Figure 84 


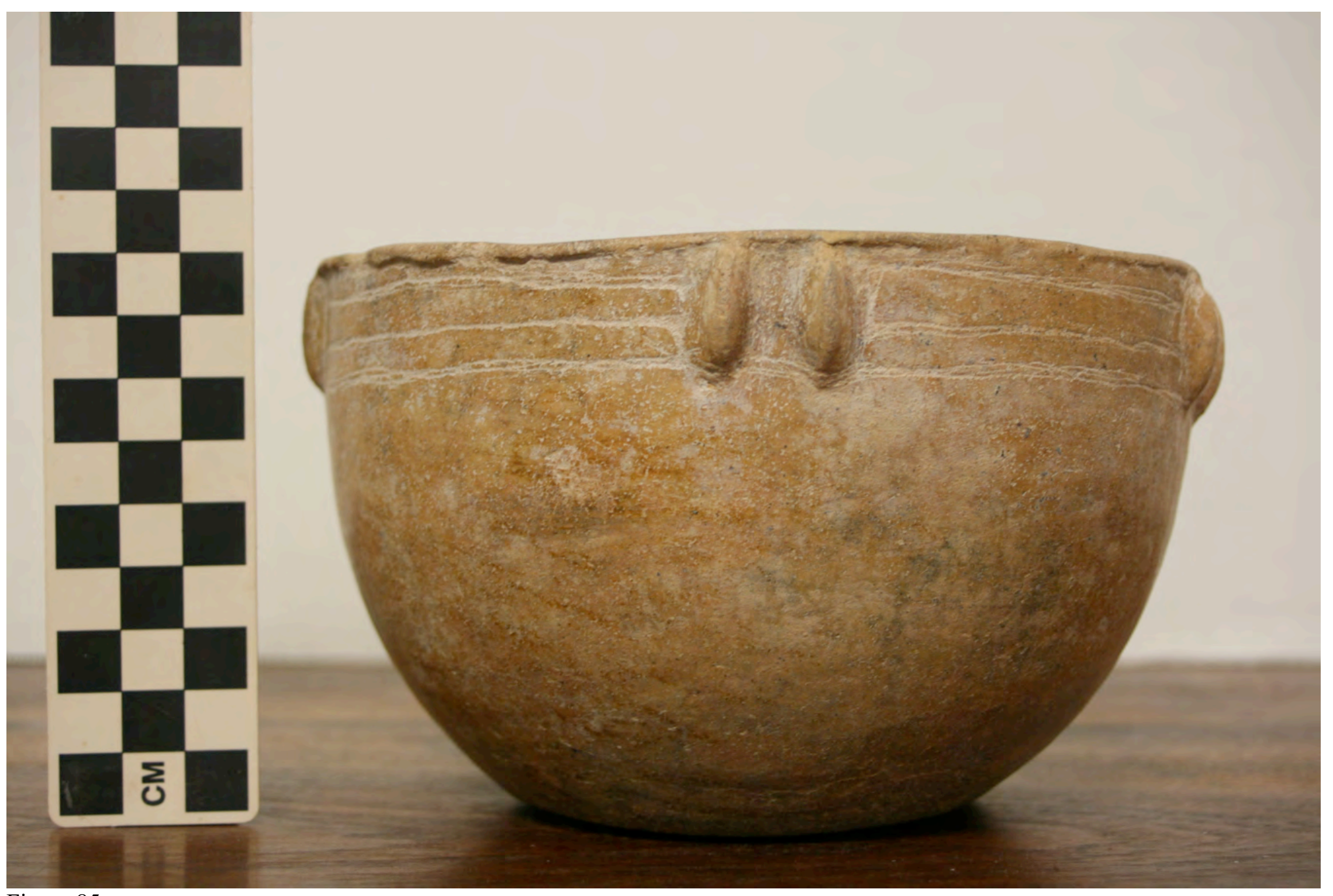

Figure 85 


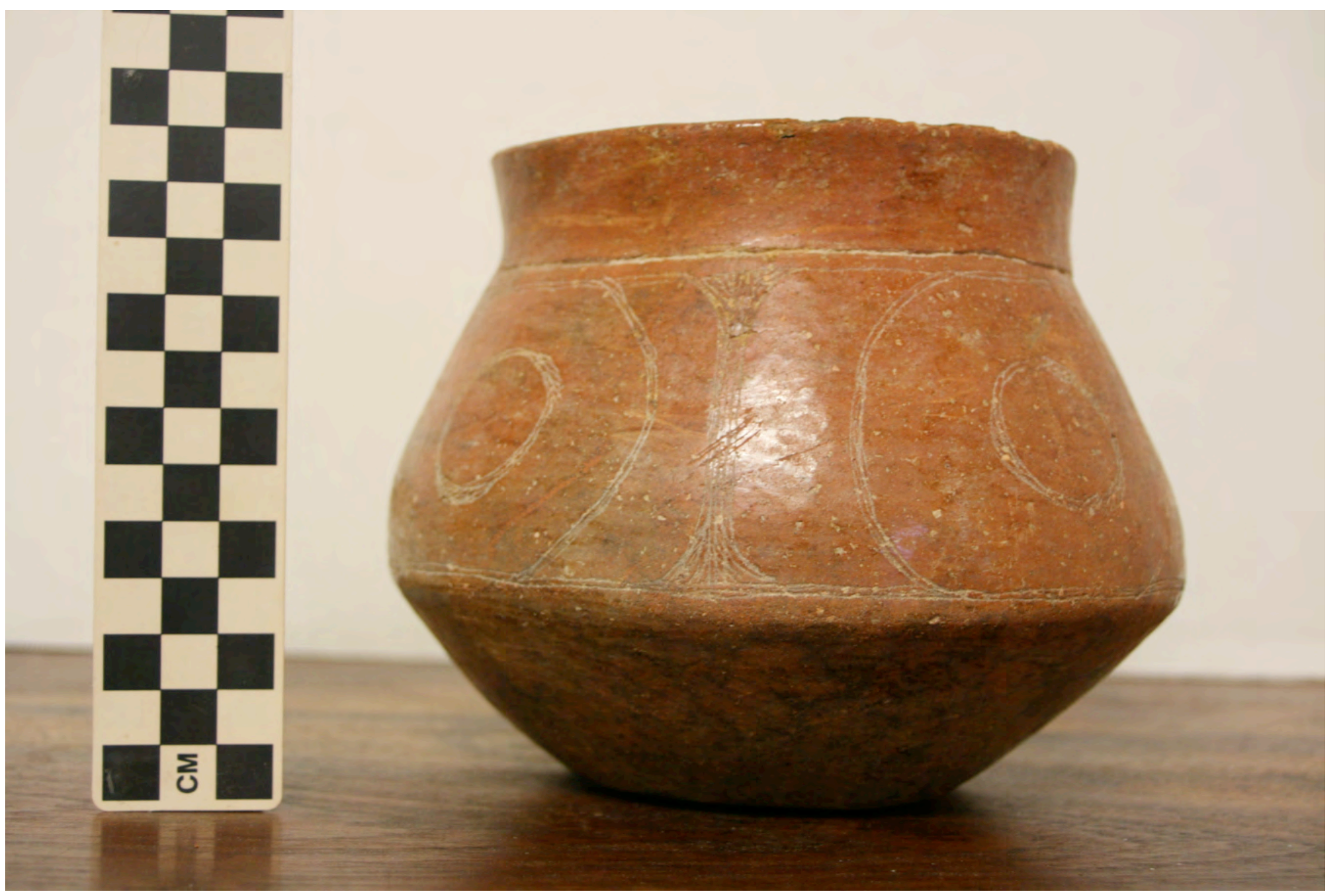

Figure 86 


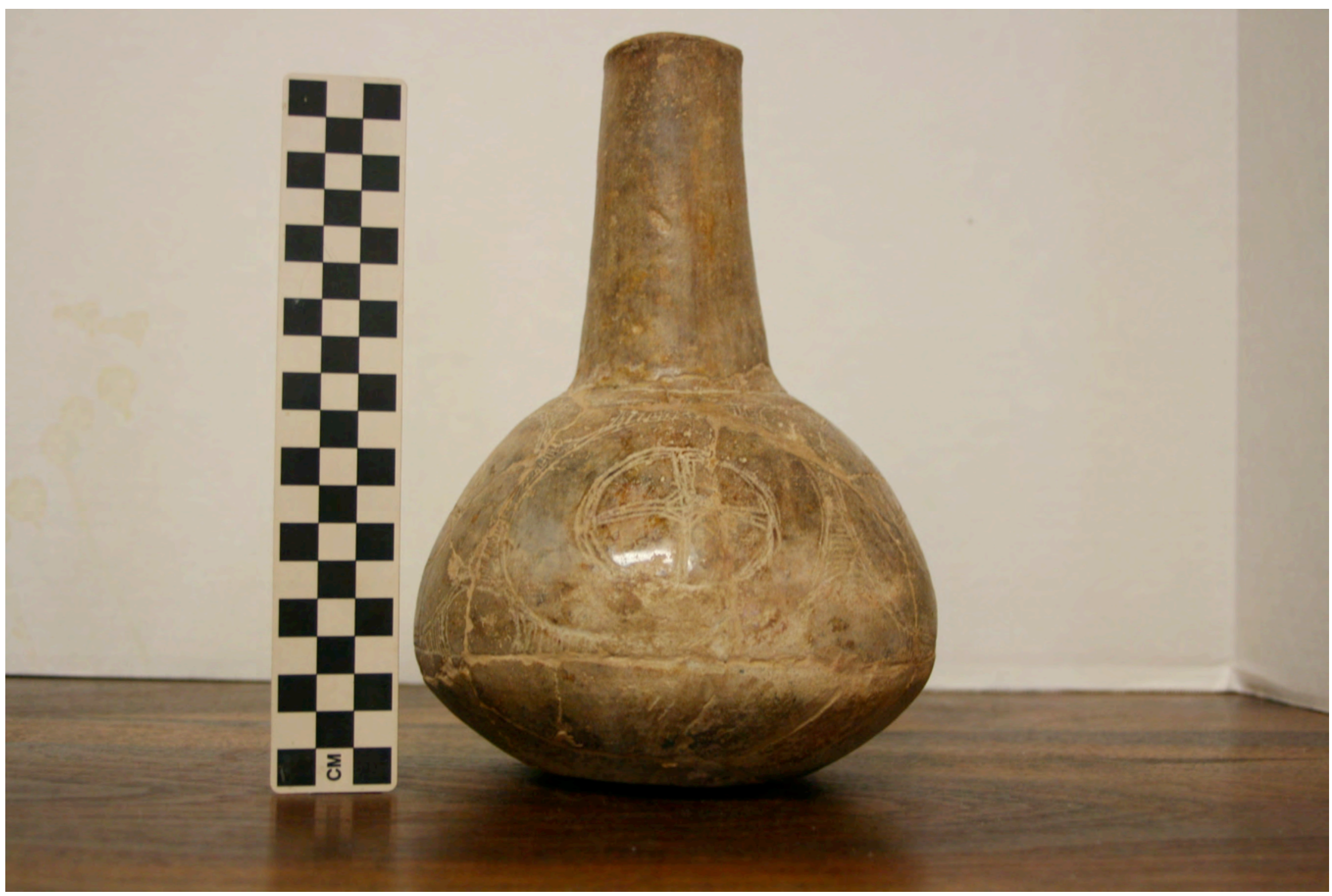

Figure 87 


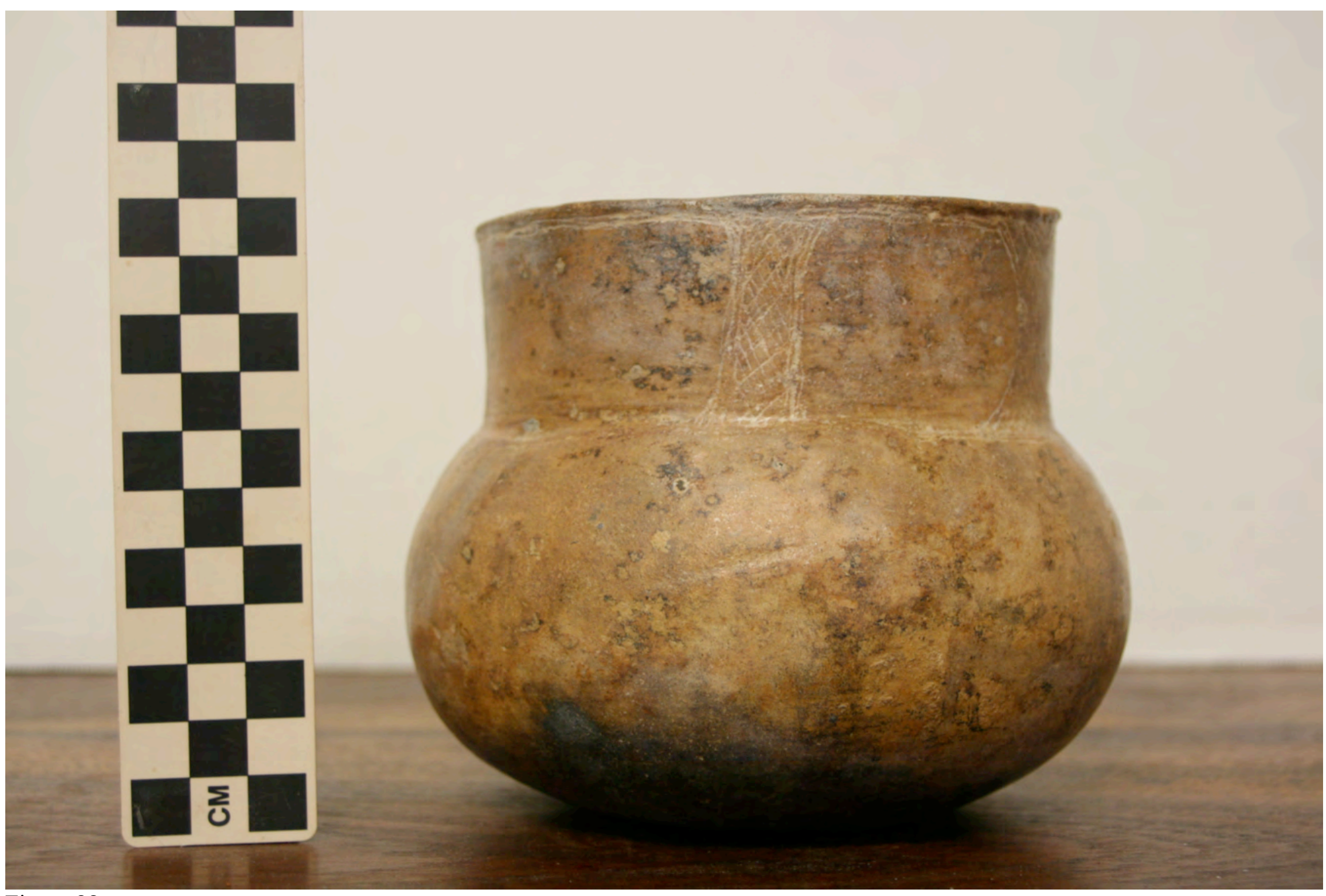

Figure 88 


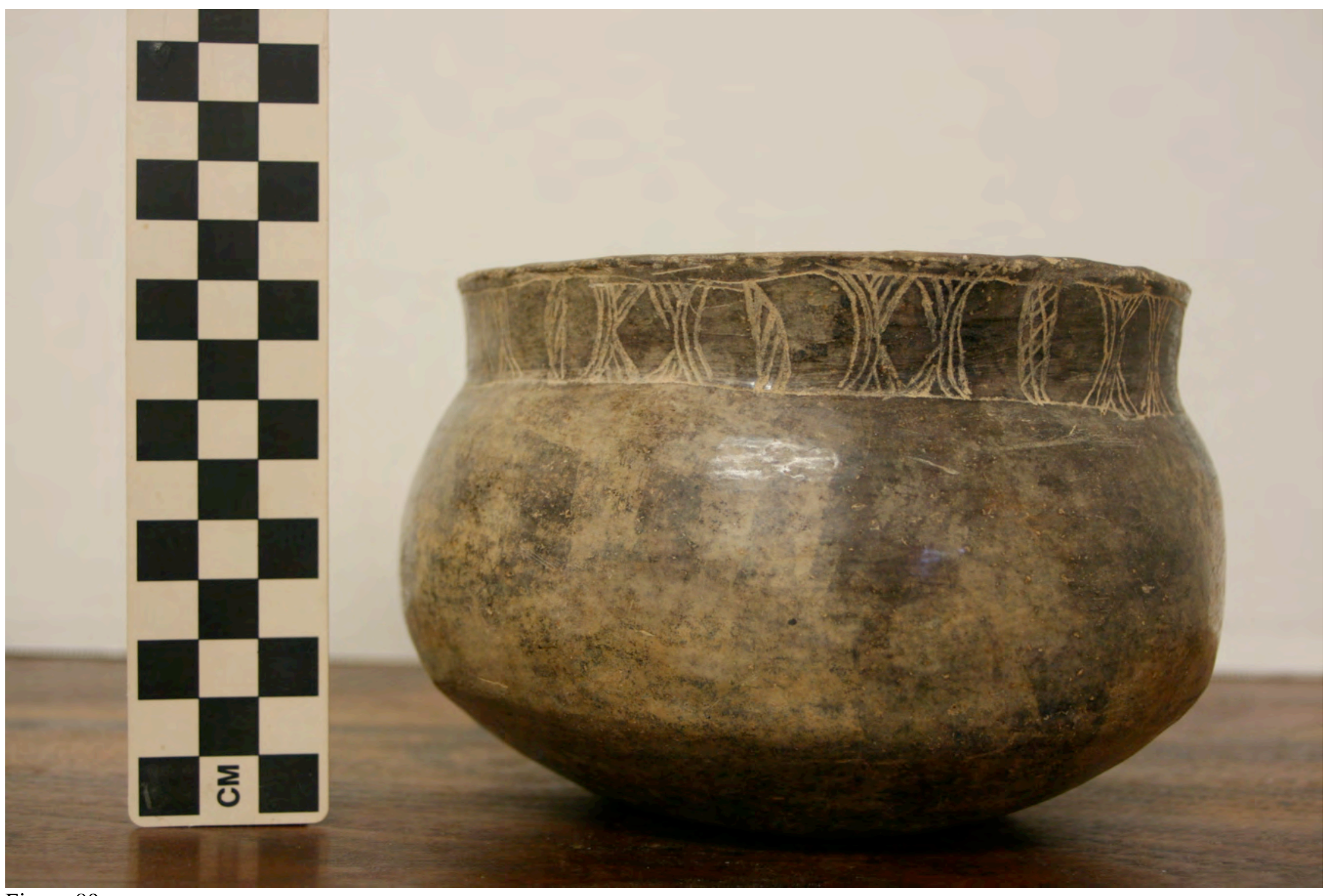

Figure 89 


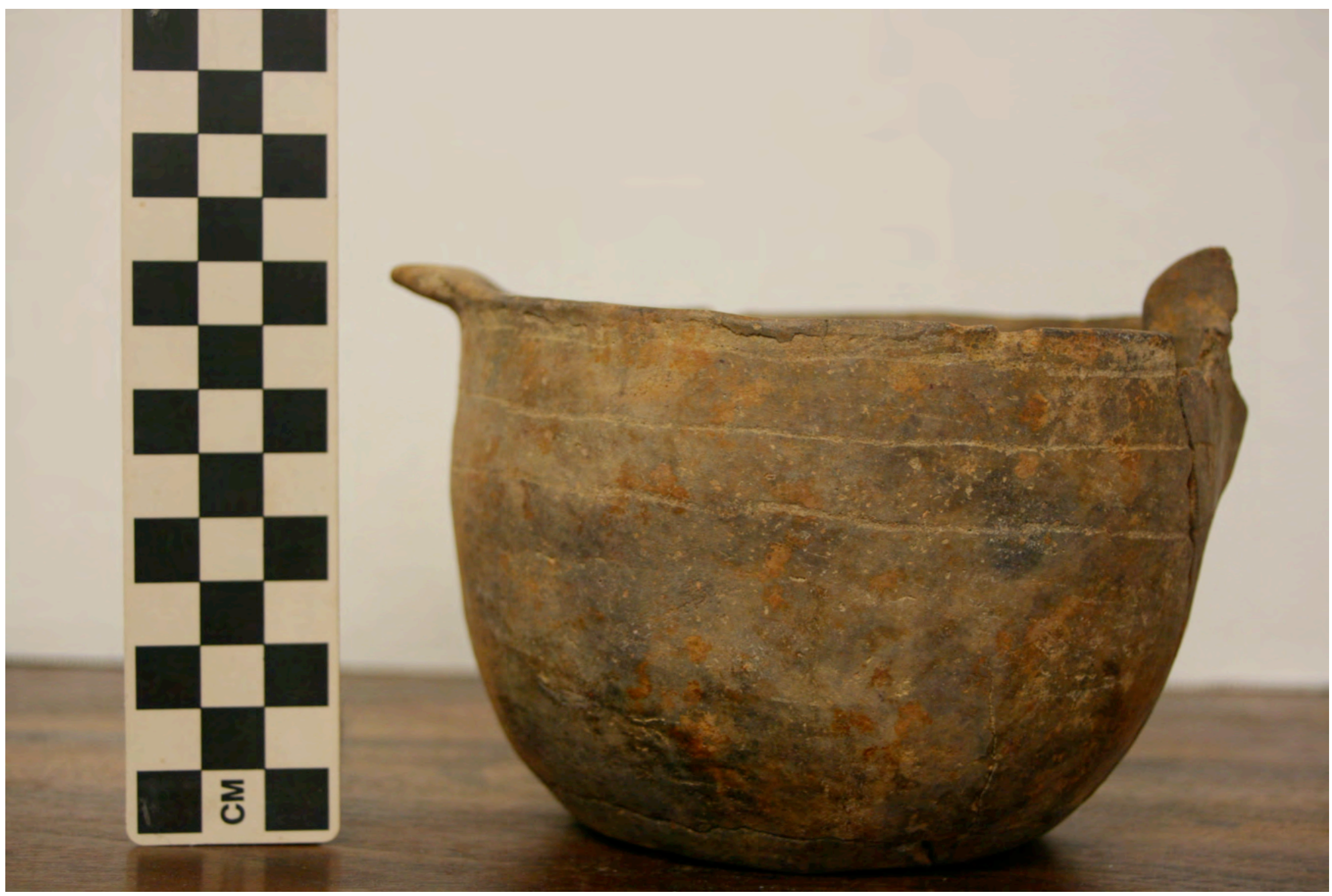

Figure 90 


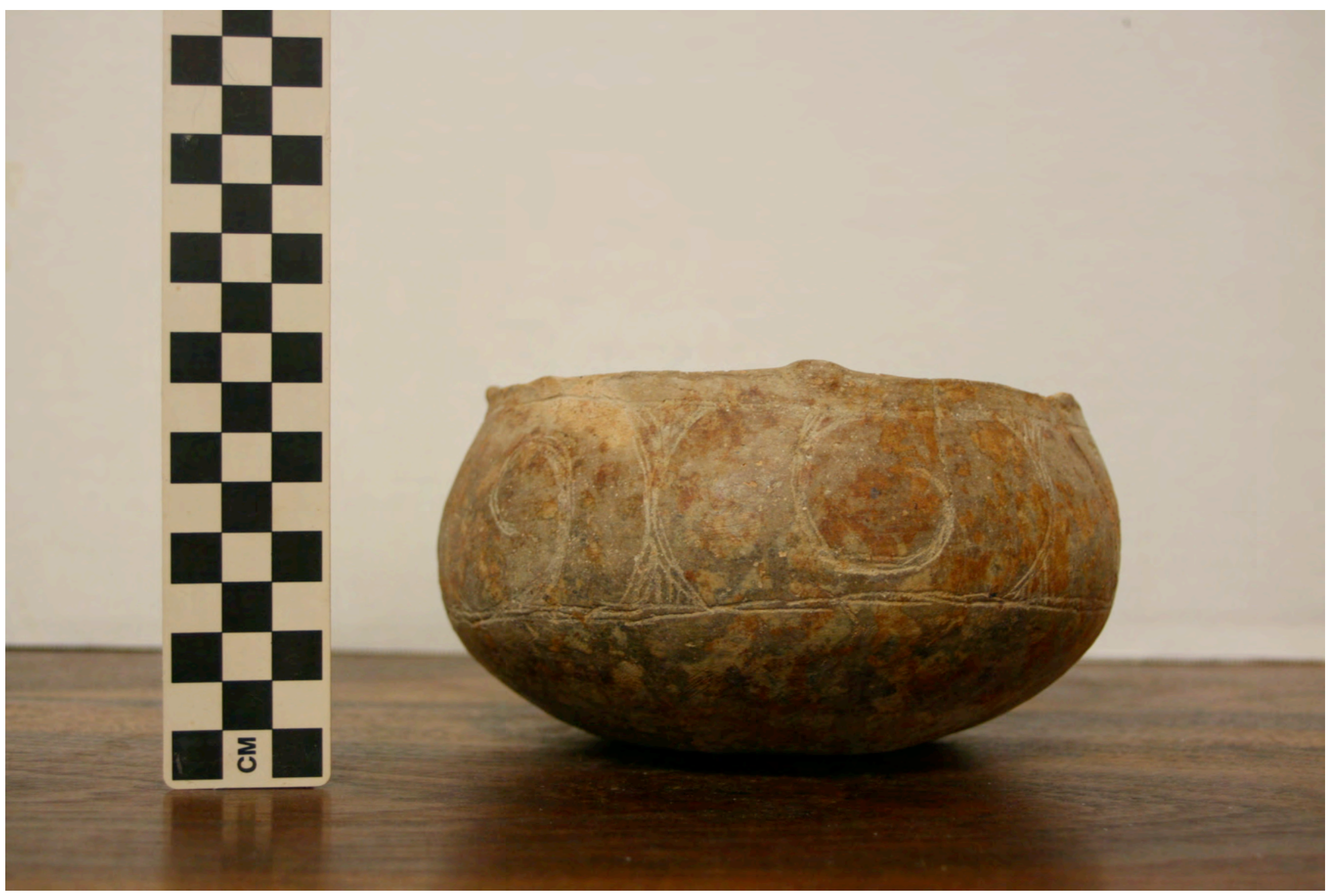

Figure 91 


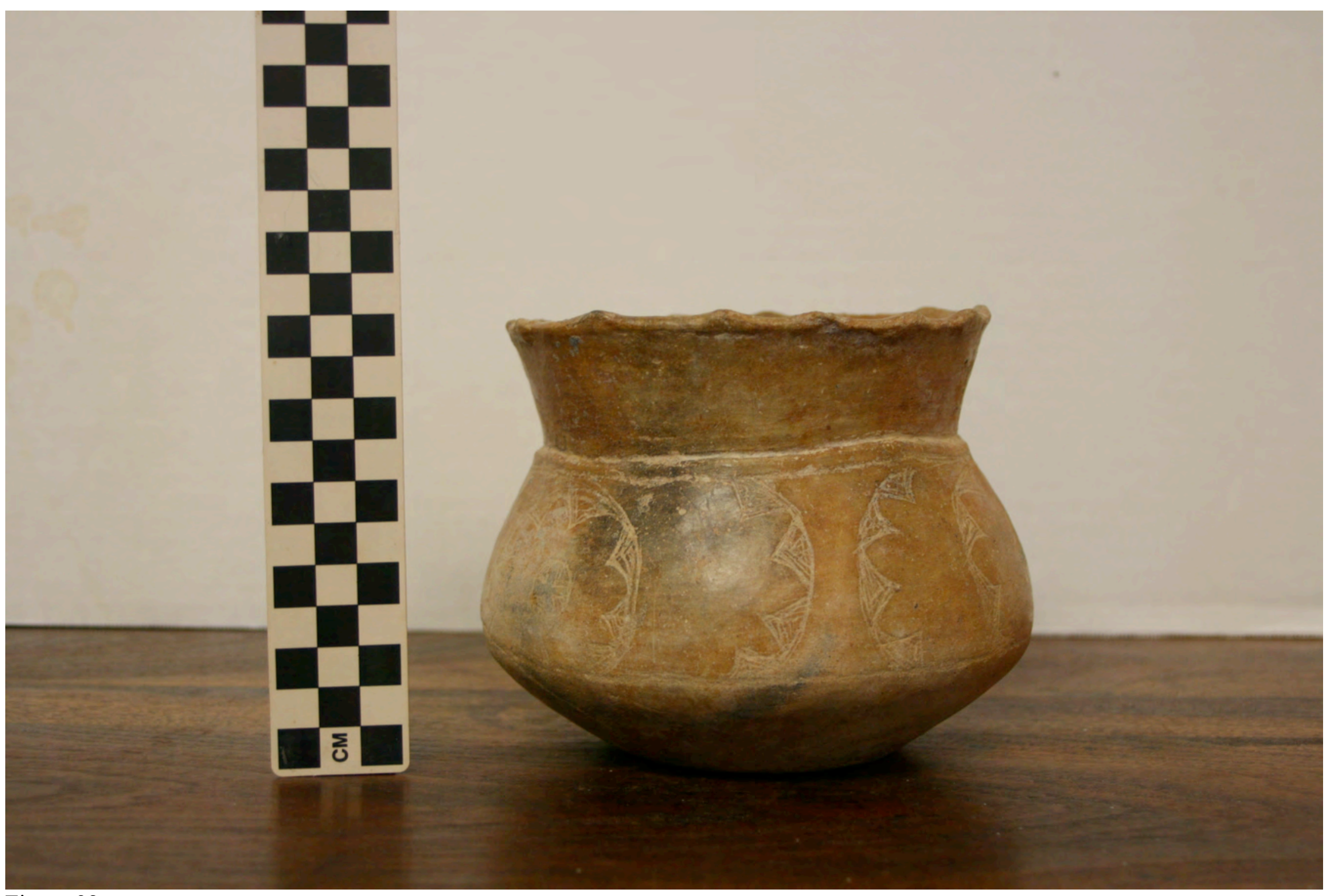

Figure 92 


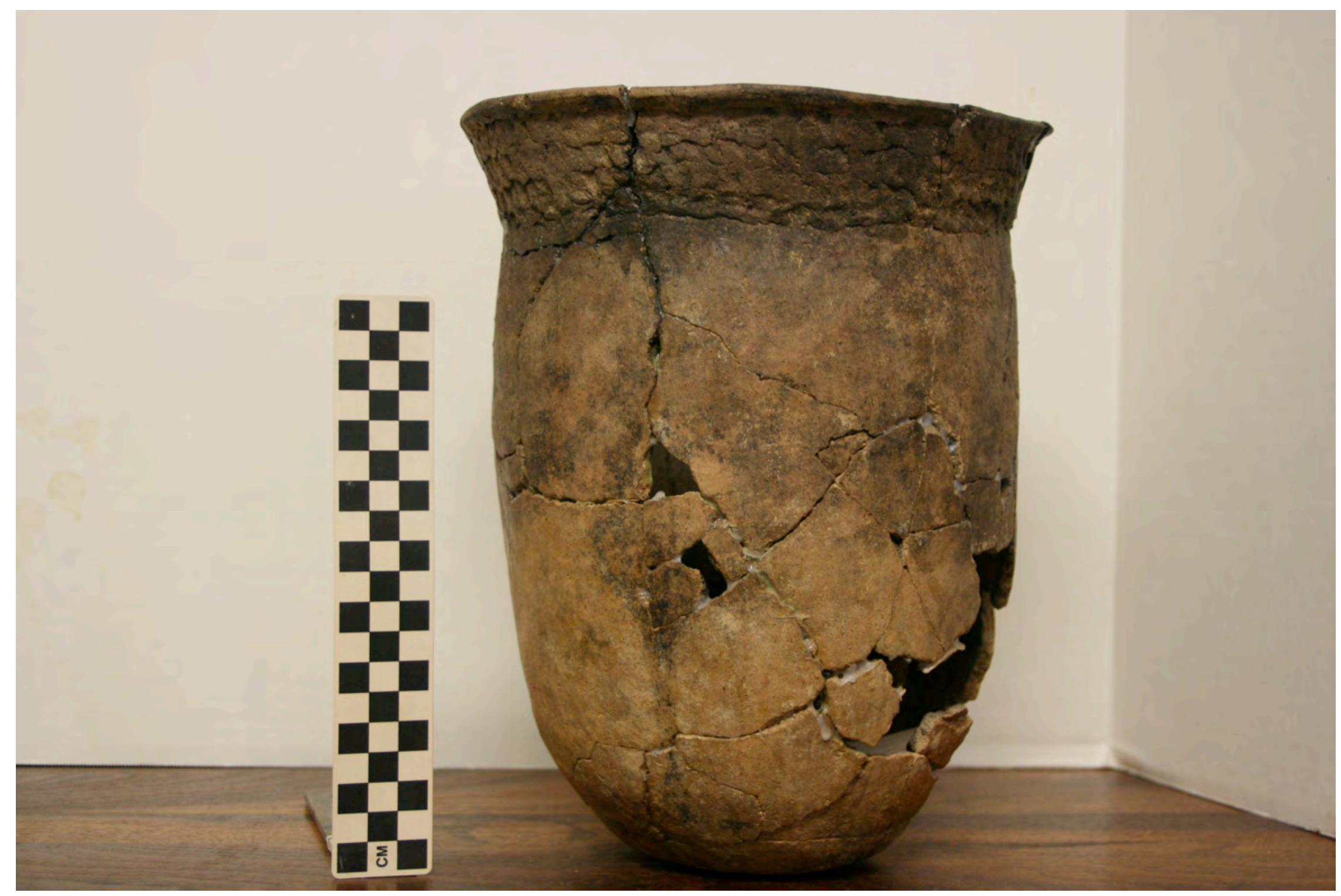

Figure 93 


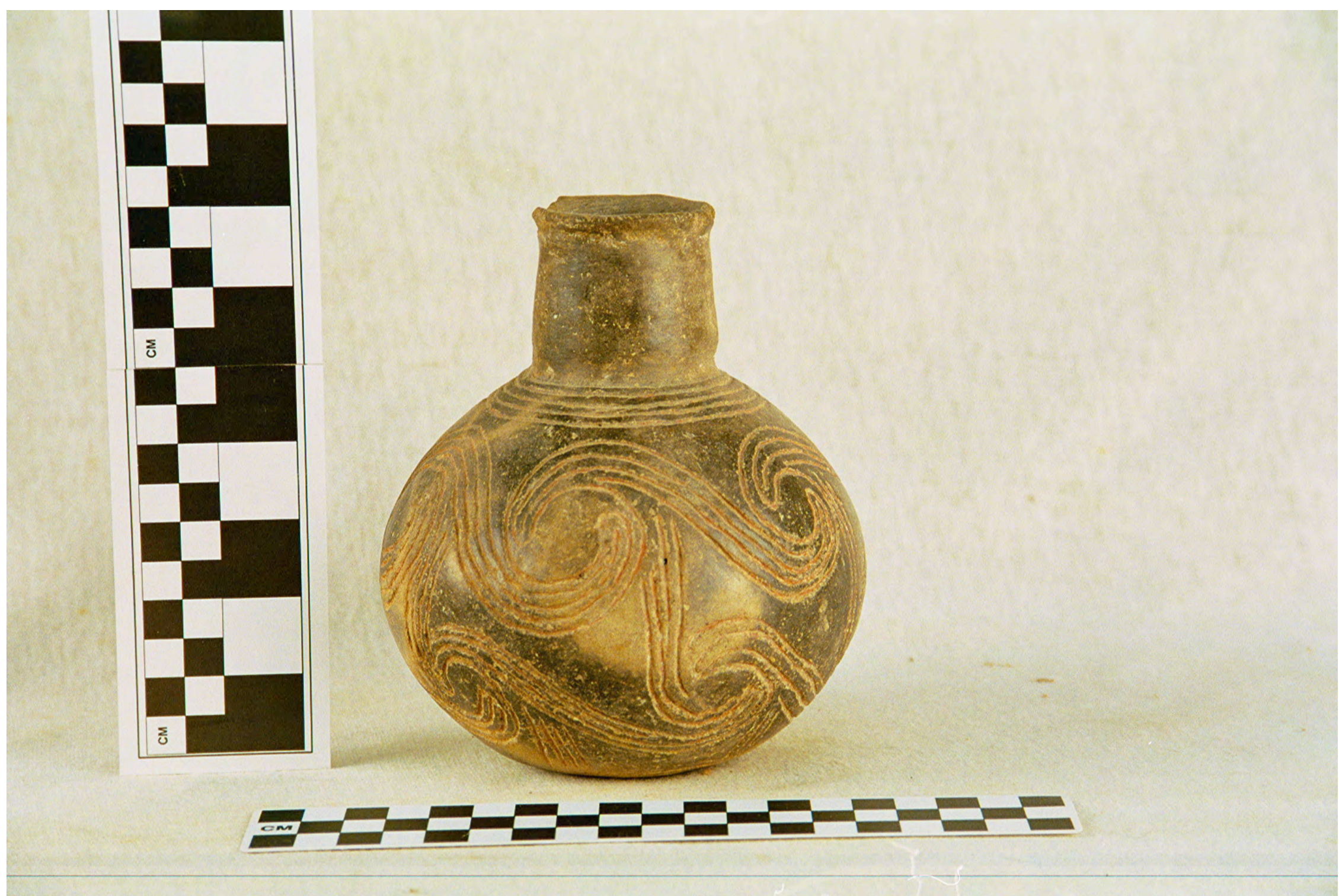

Figure 94 


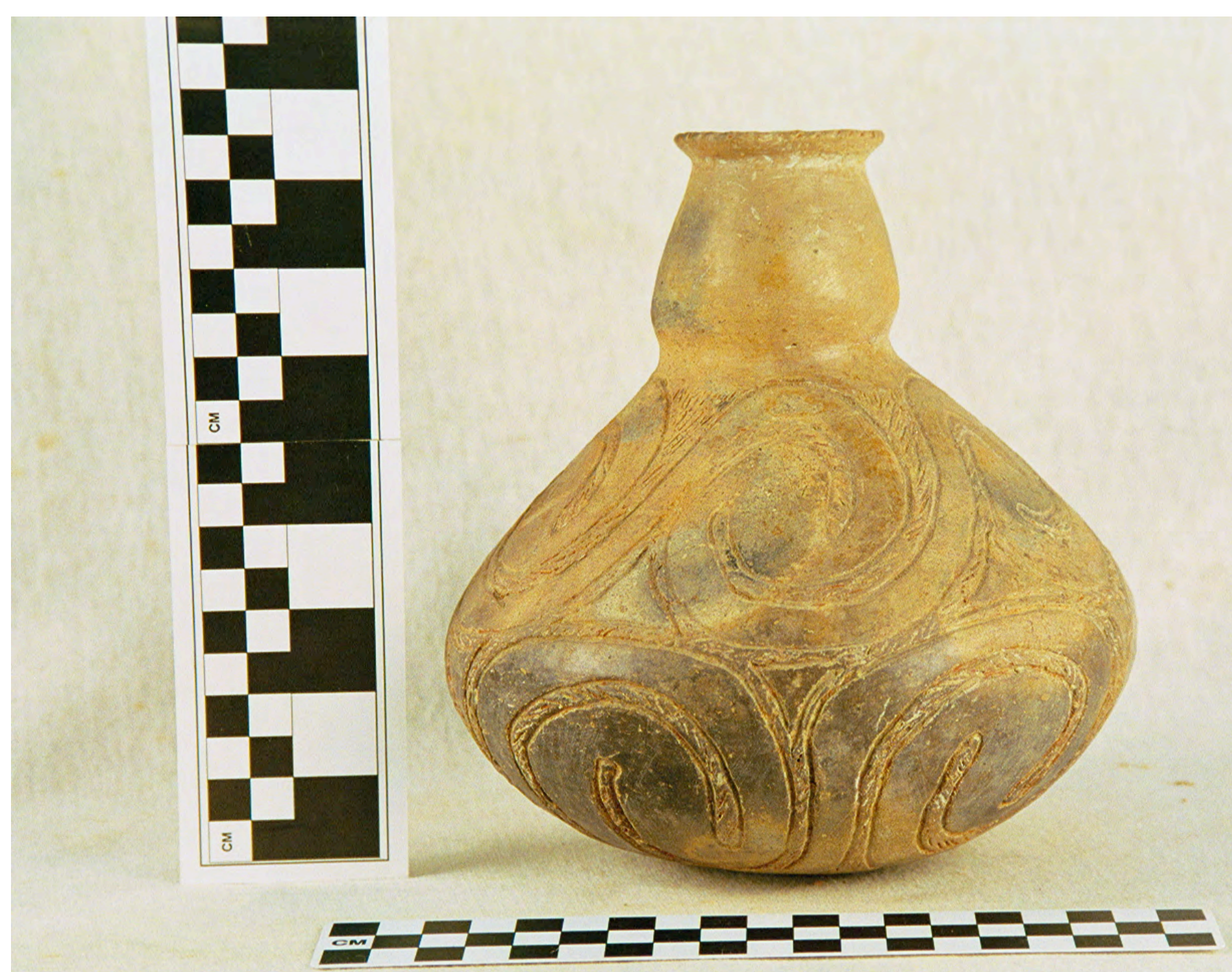

Figure 95 


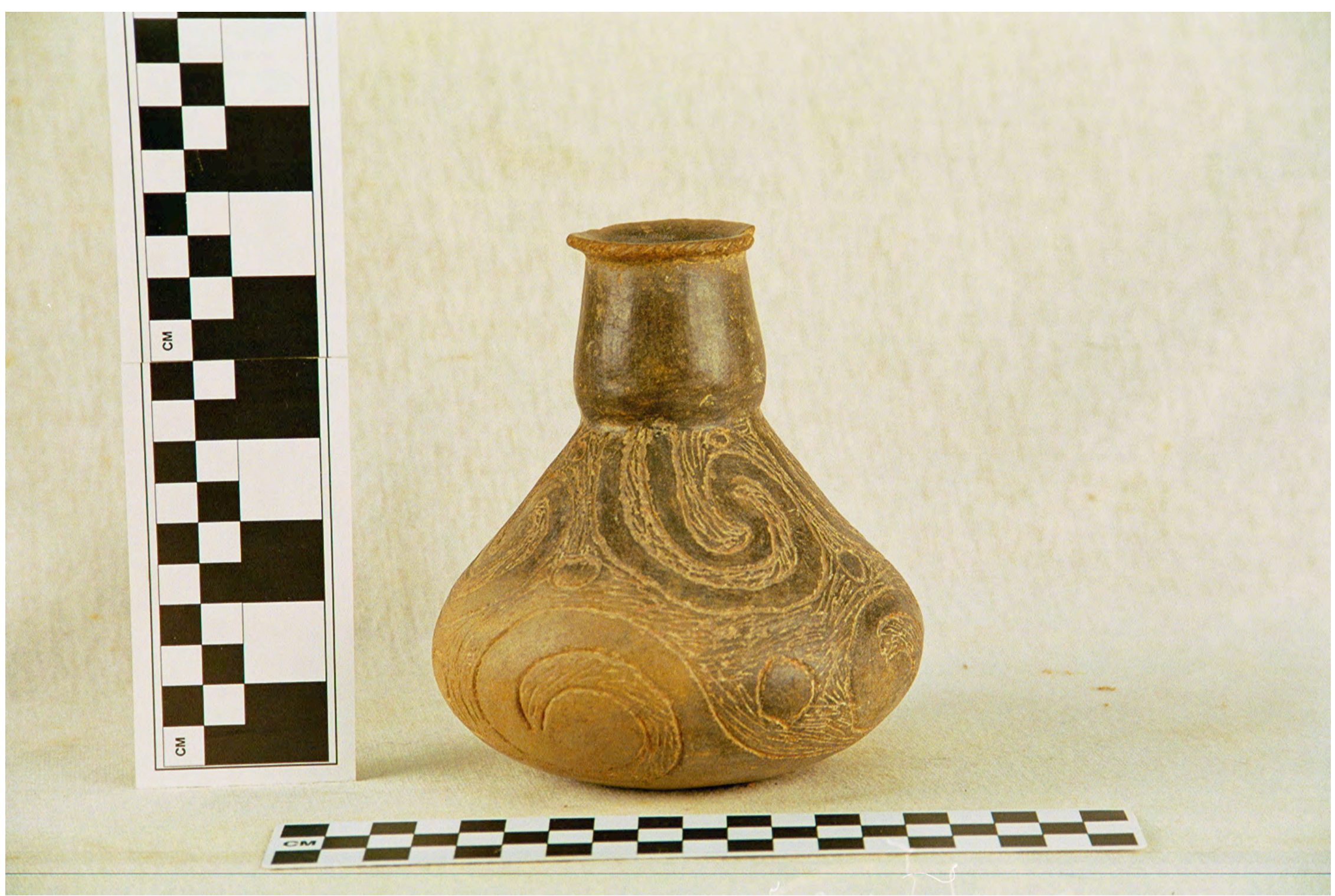

Figure 96 


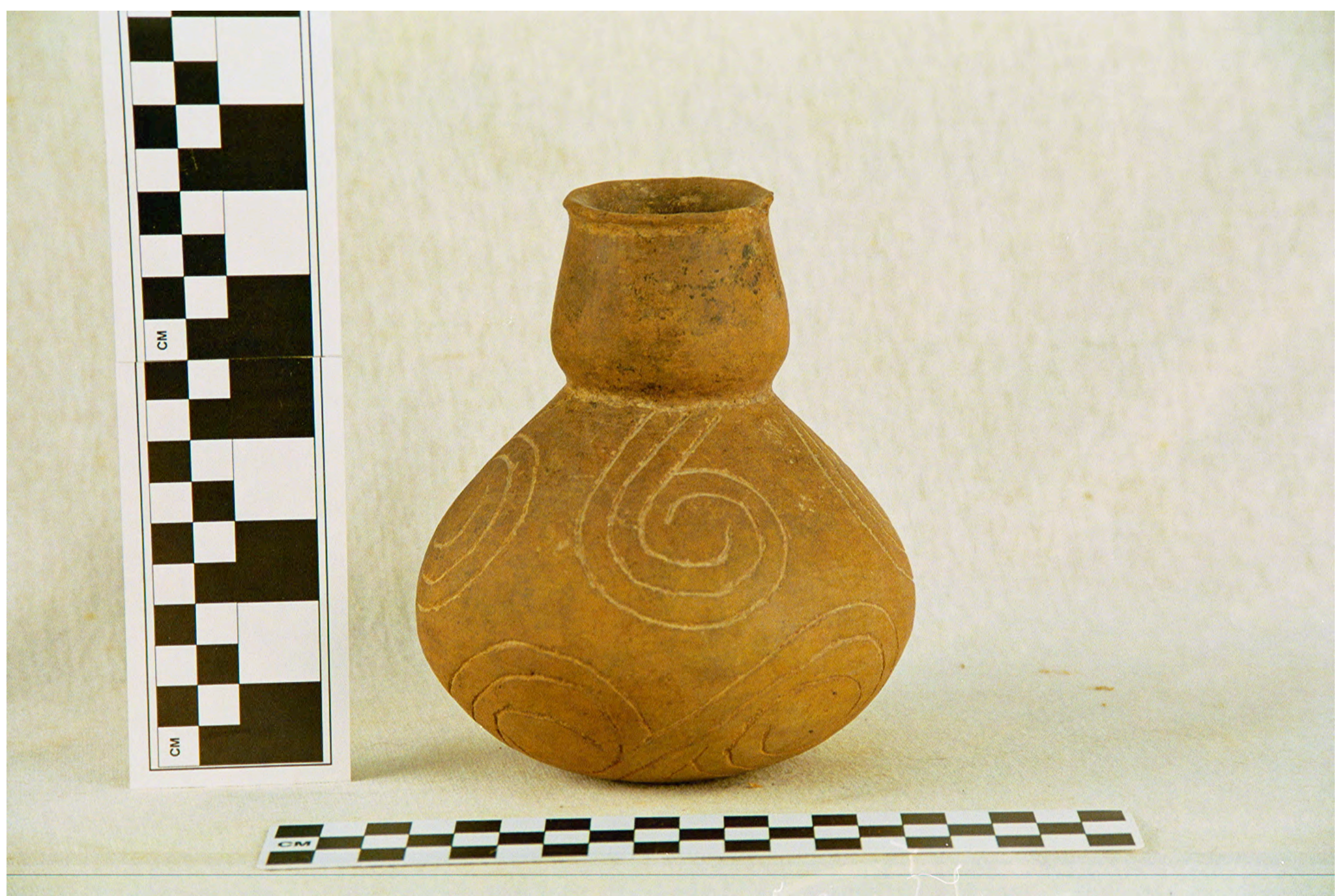

Figure 97 


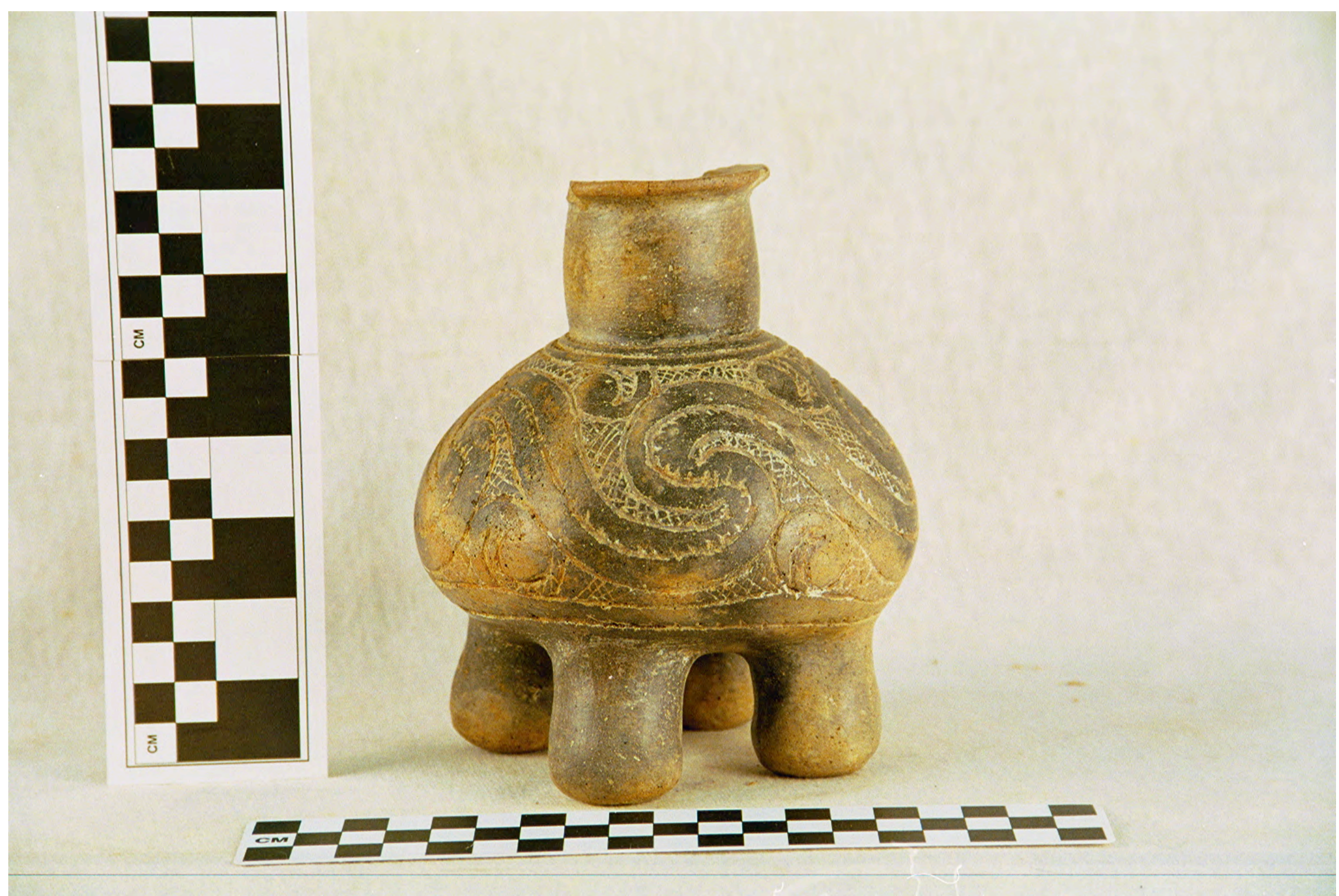

Figure 98 (and cover) 


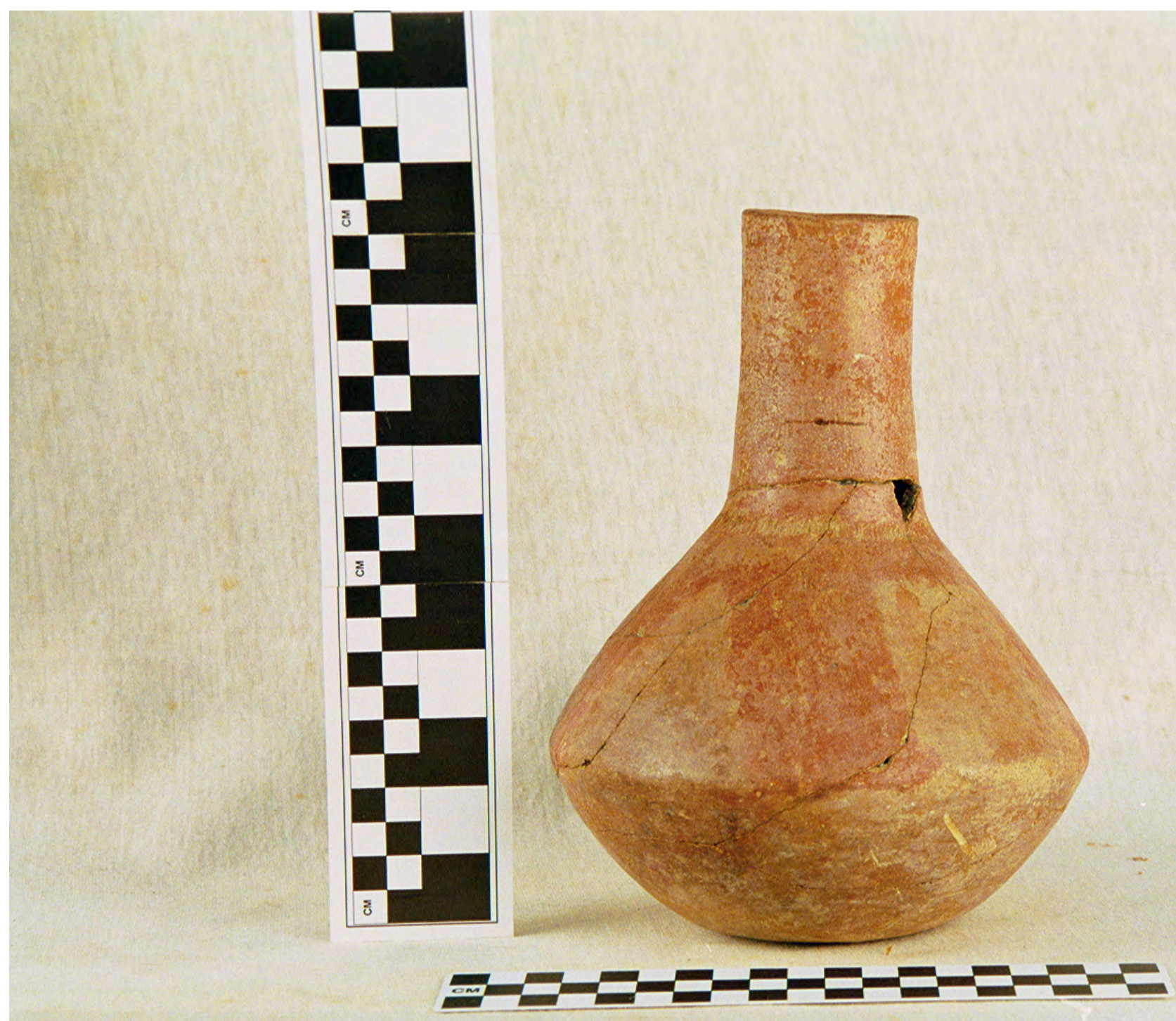

Figure 99 


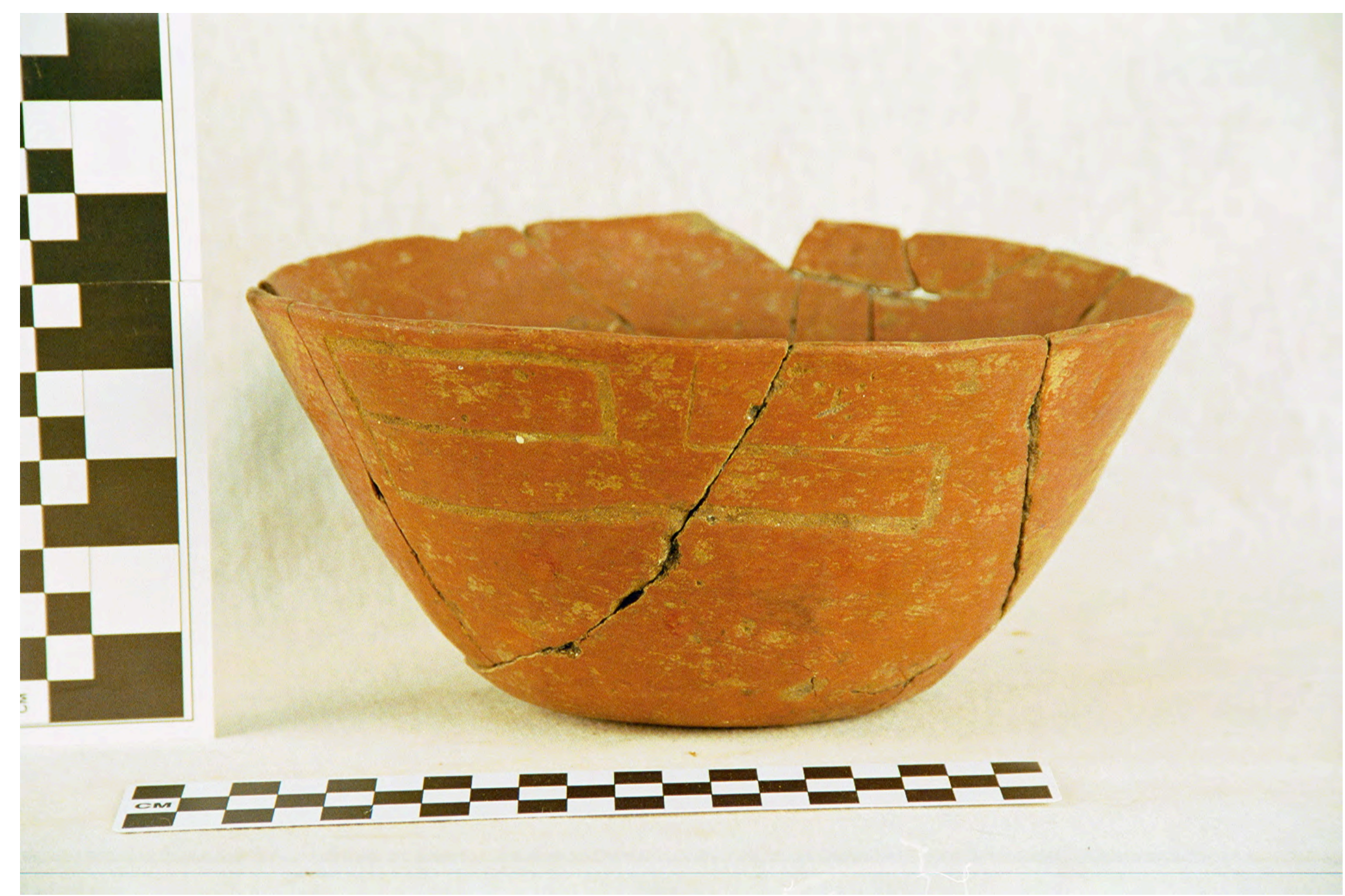

Figure 100 


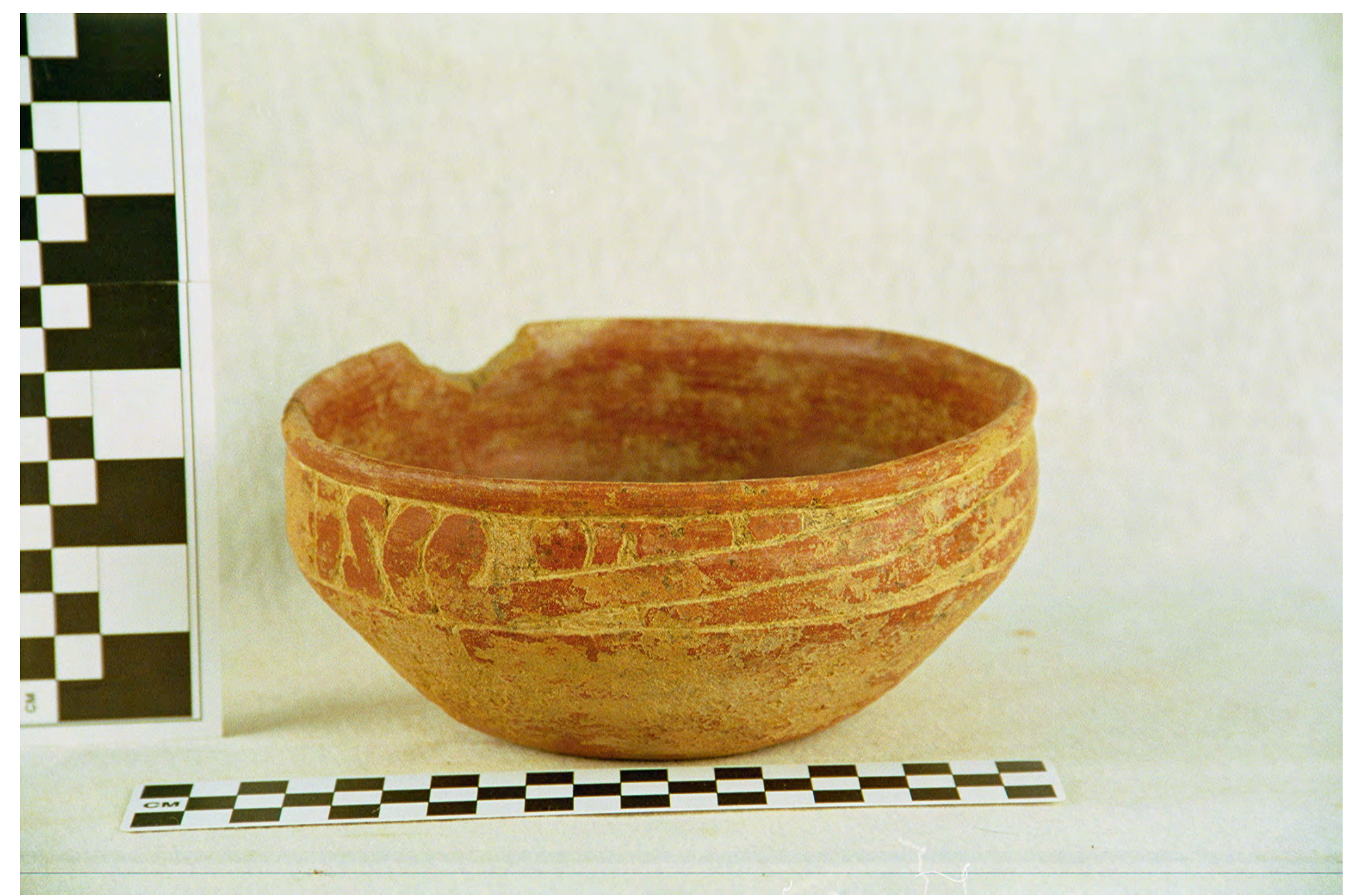

Figure 101 

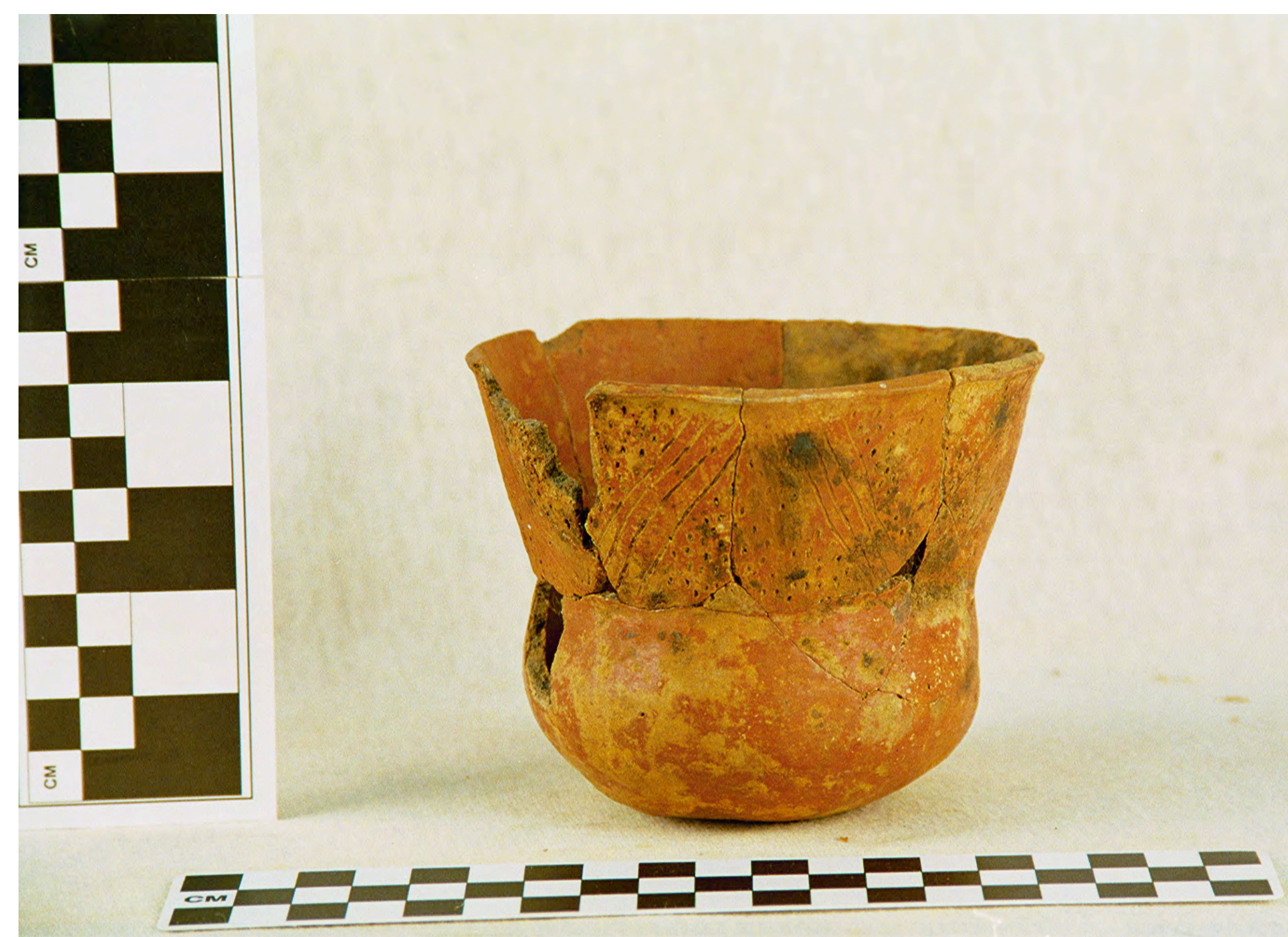

Figure 102 


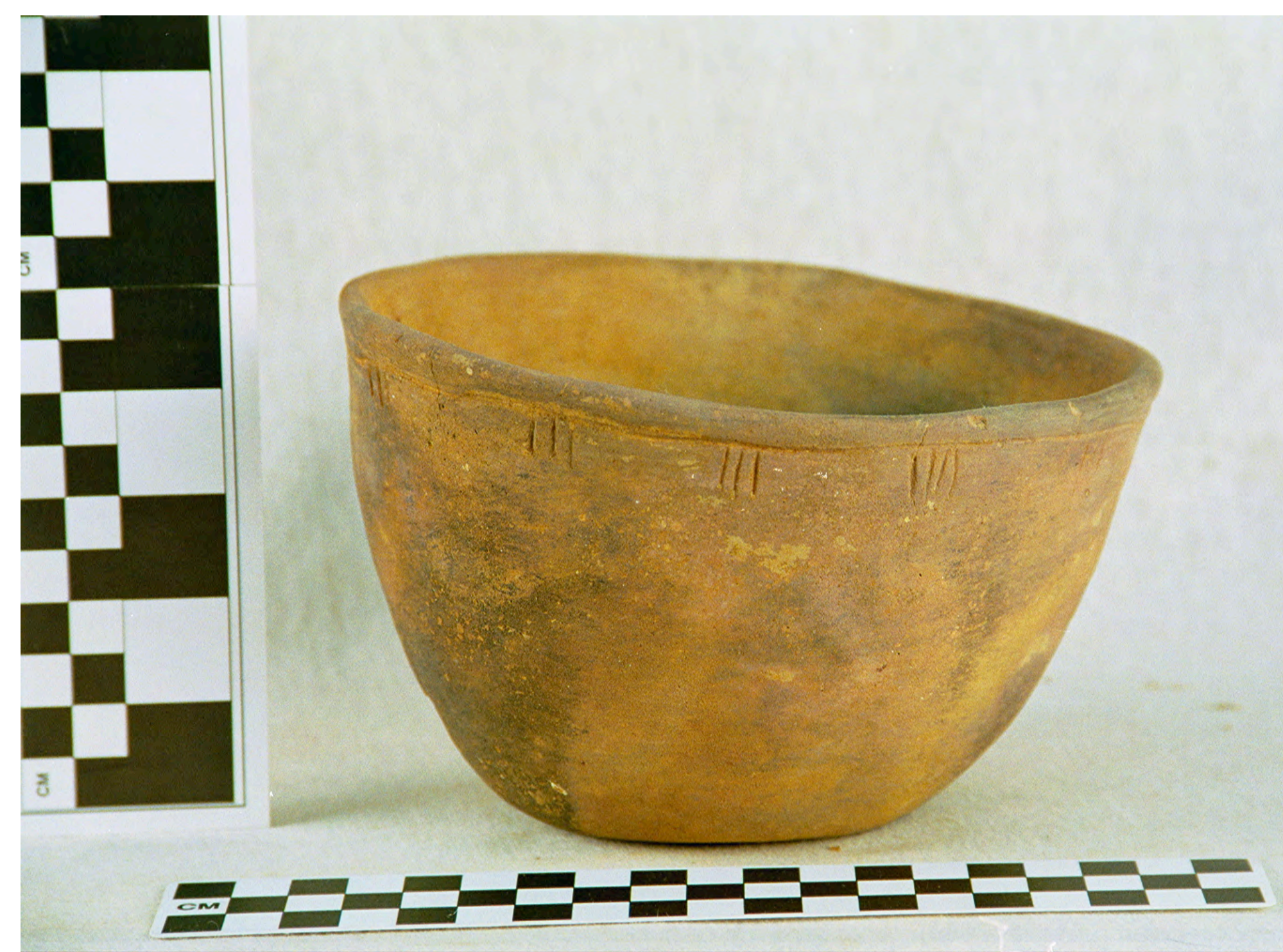

Figure 103 


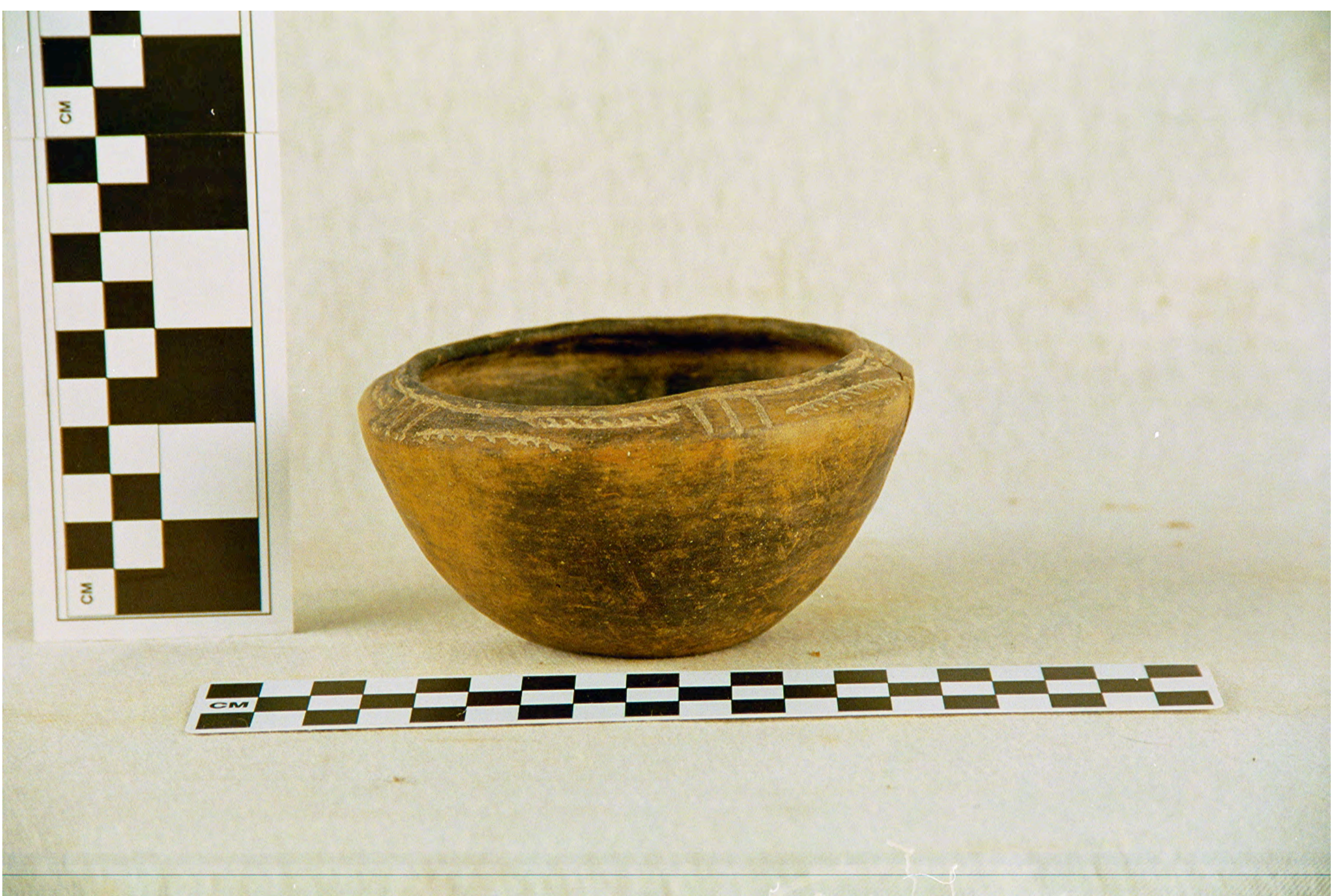

Figure 104 


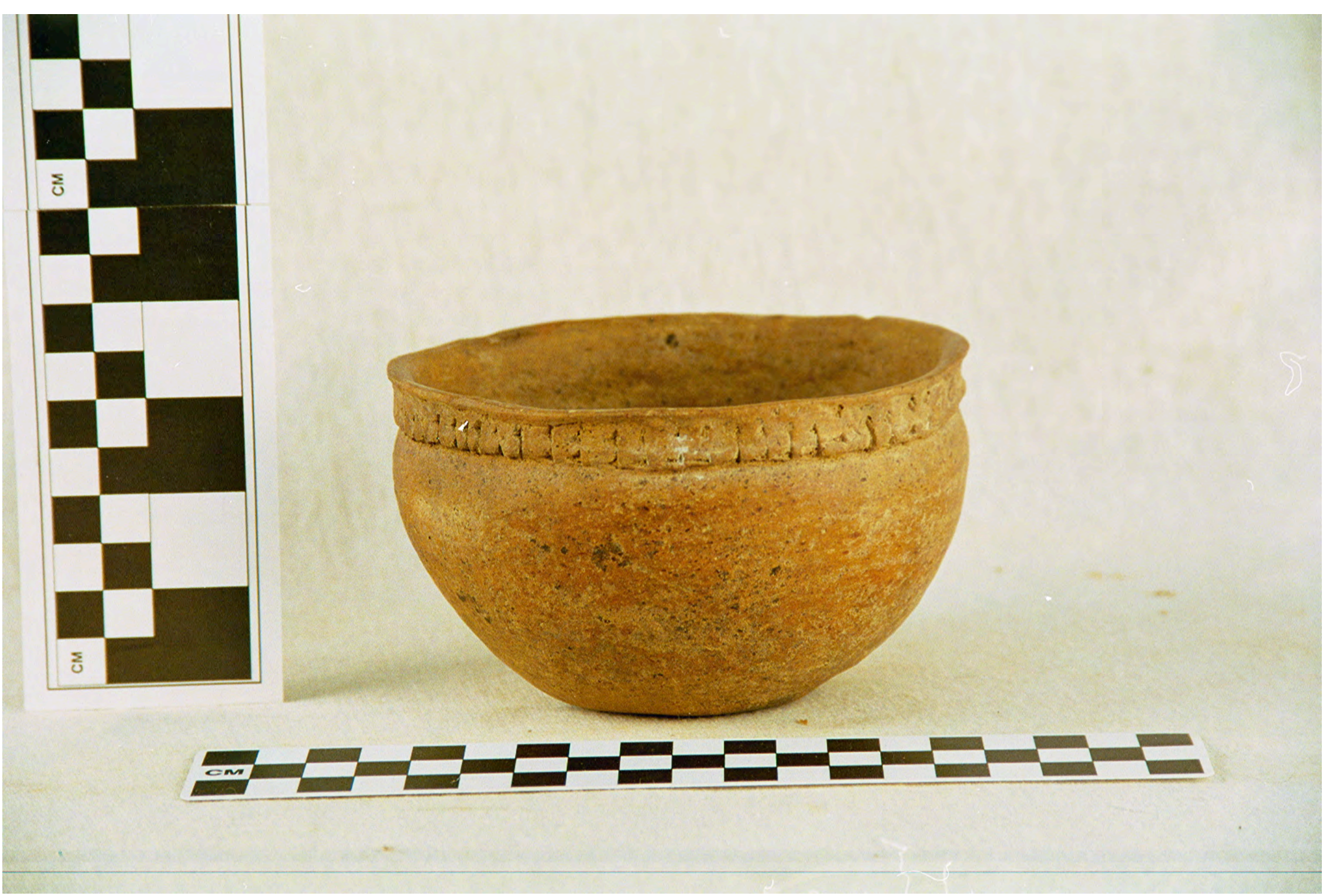

Figure 105 


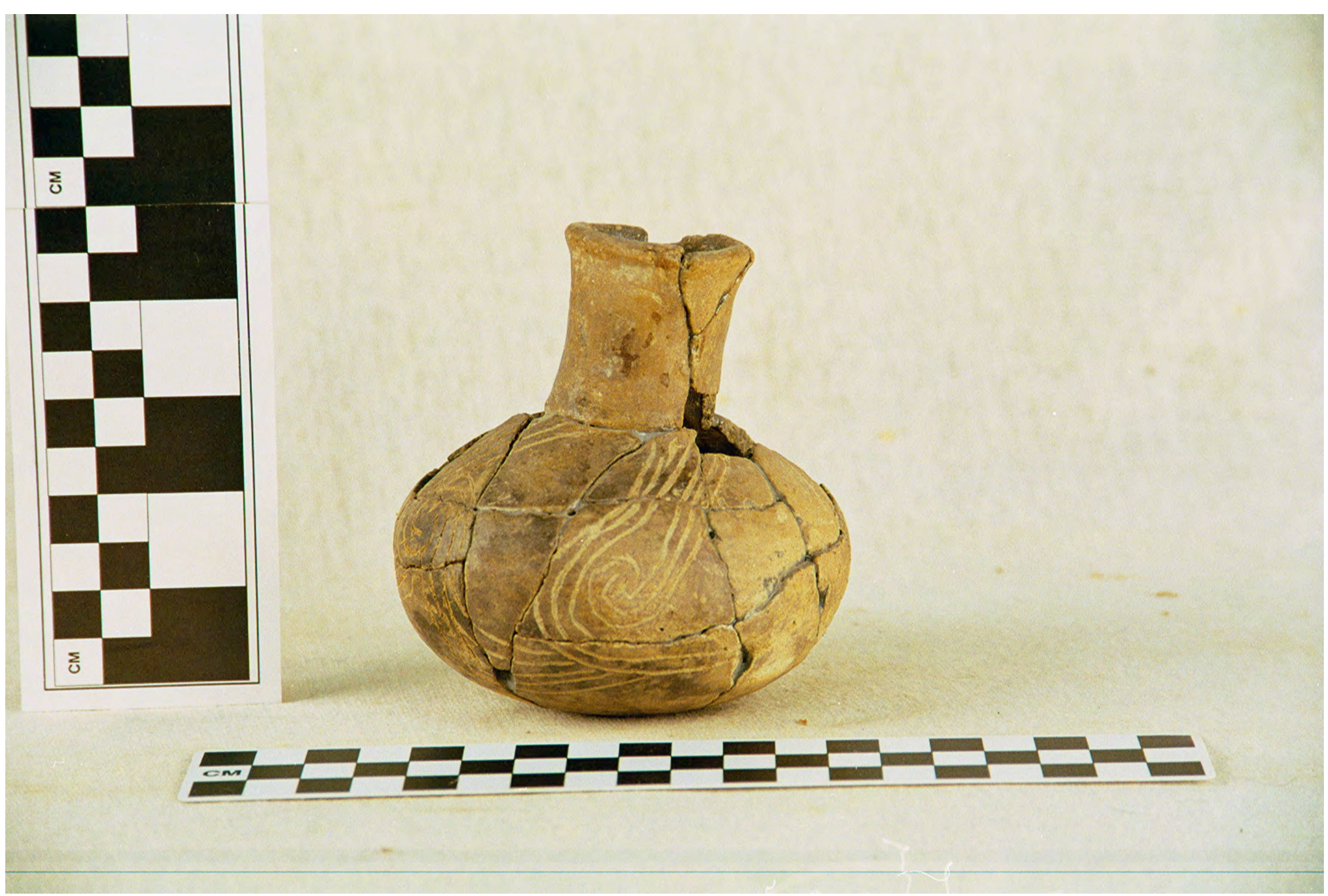

Figure 106 


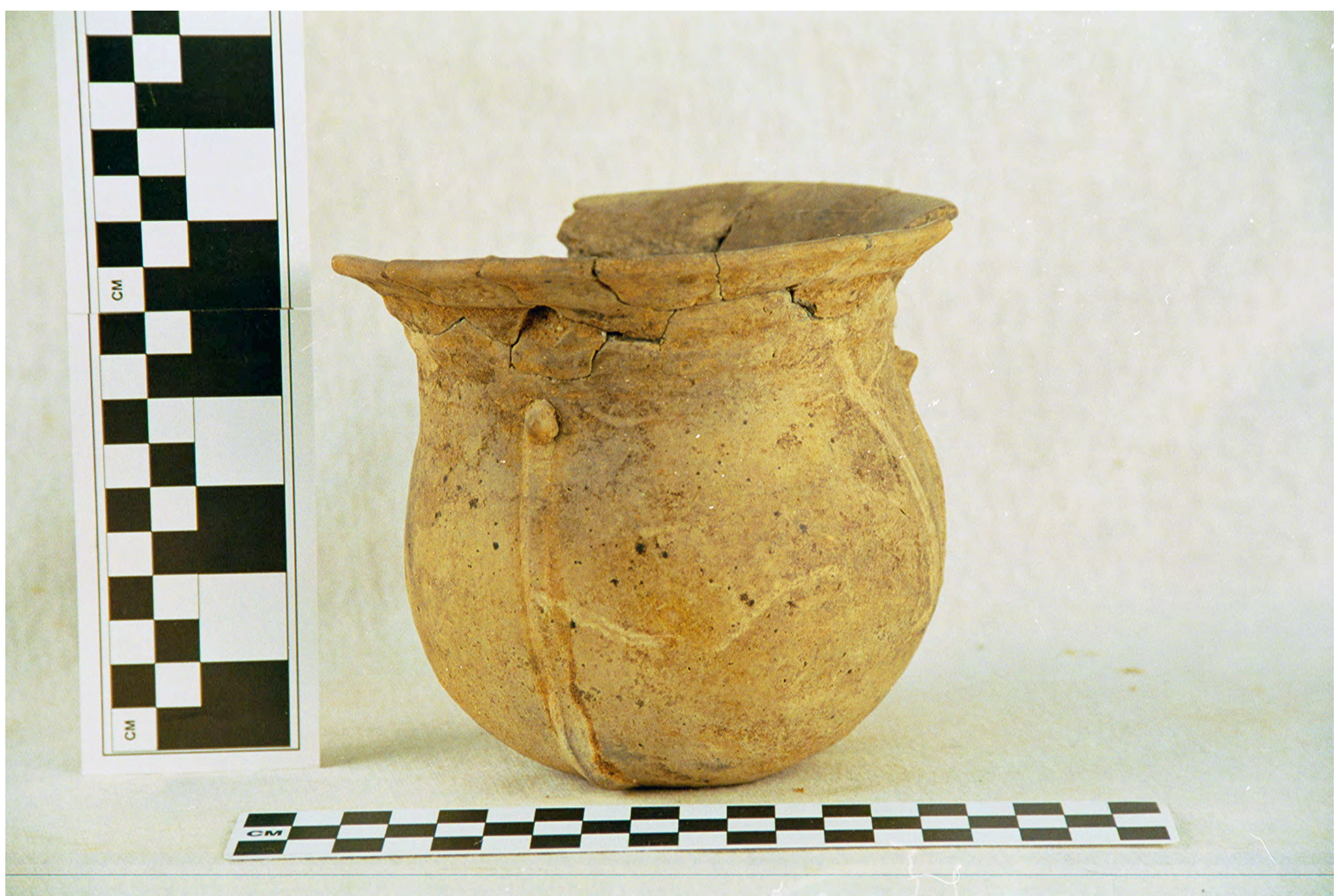

Figure 107 


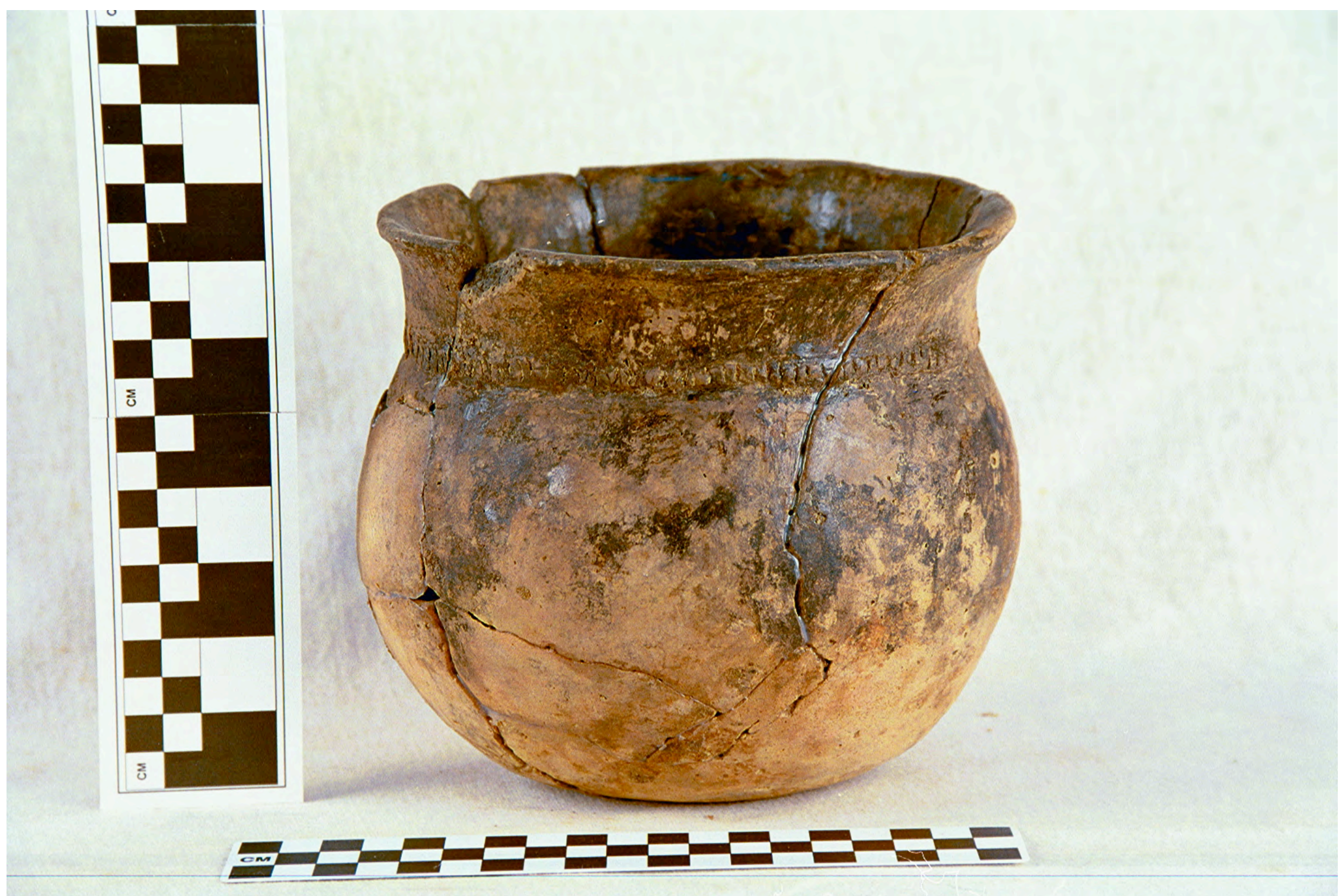

Figure 108 


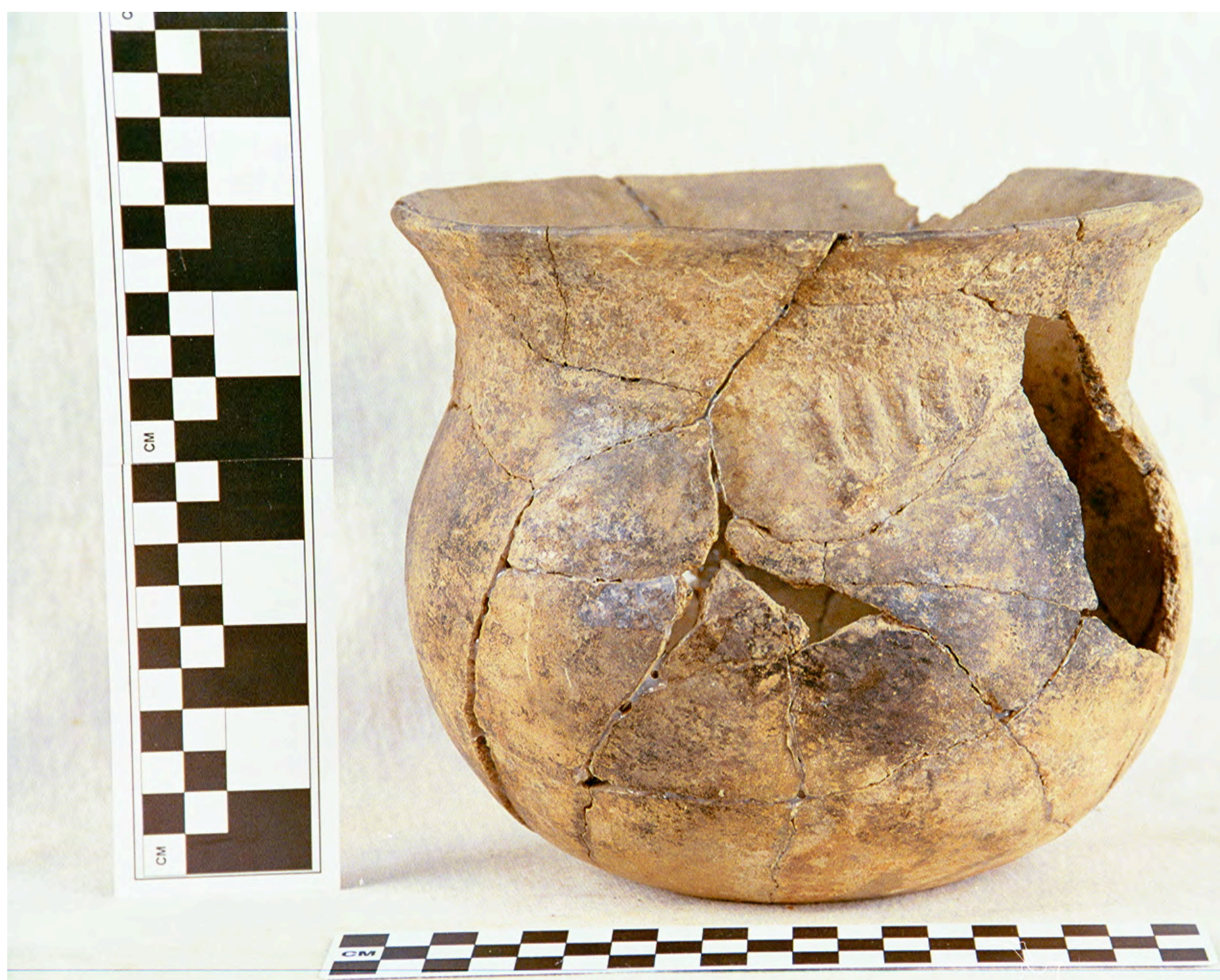

Figure 109 


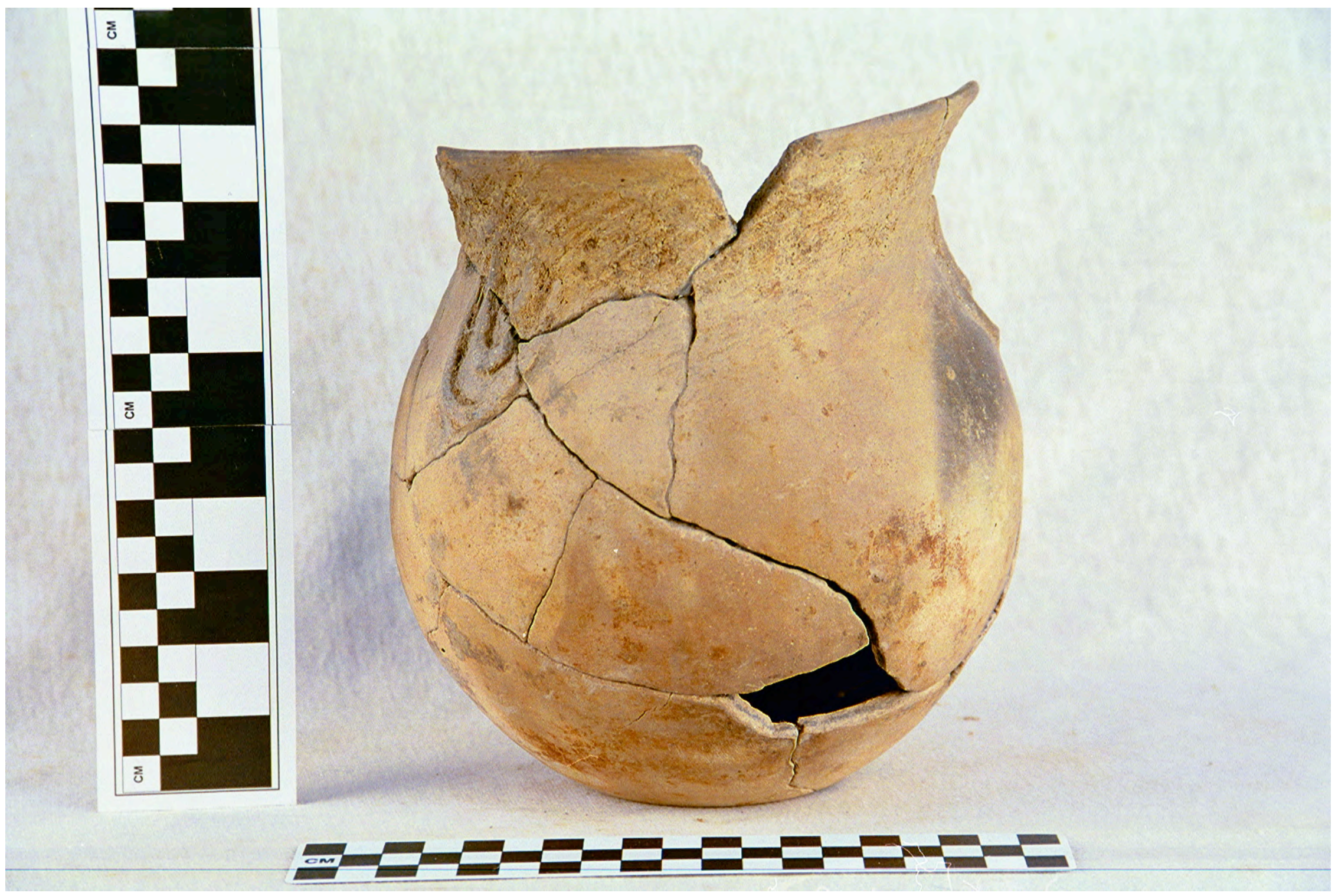

Figure 110 


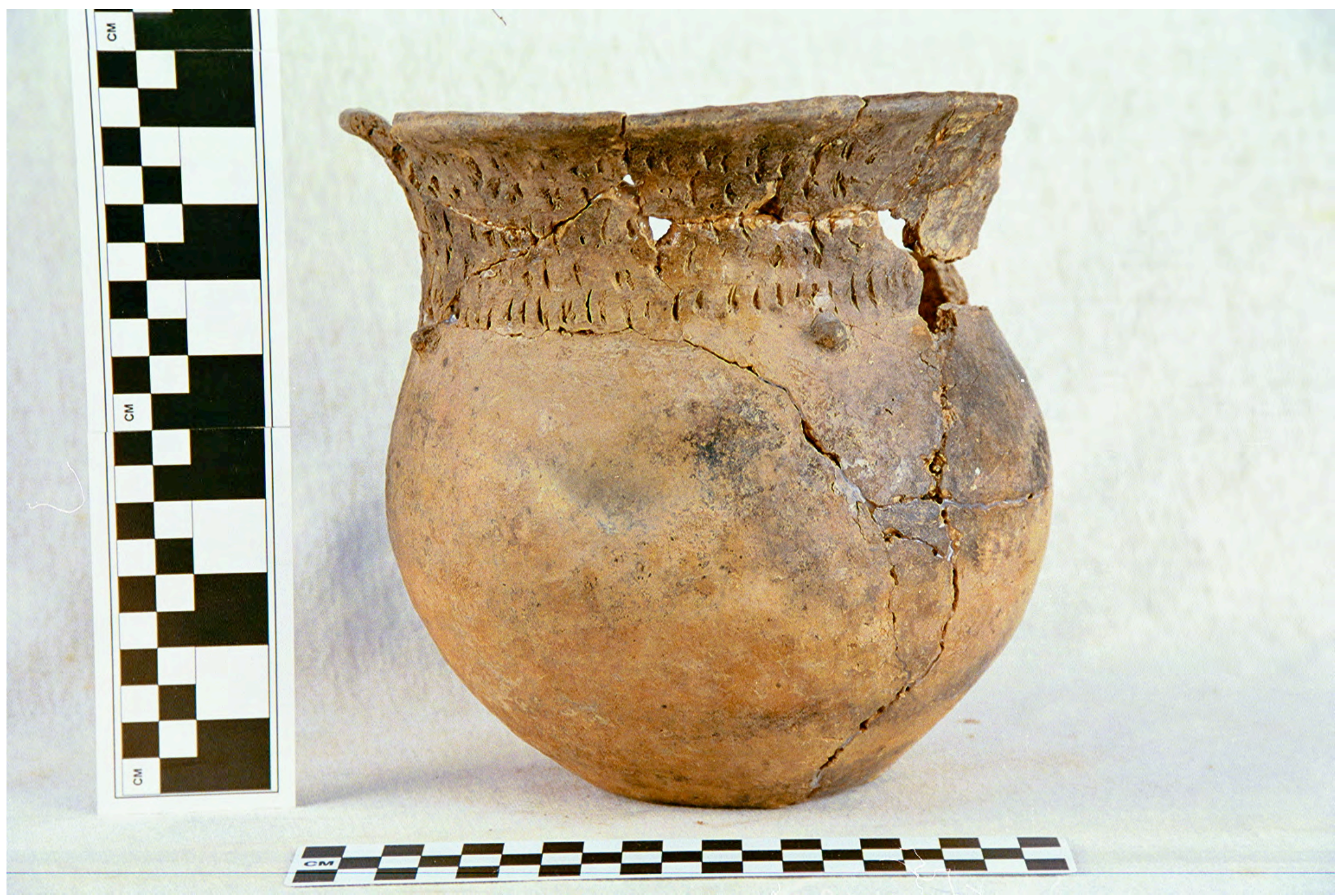

Figure 111 

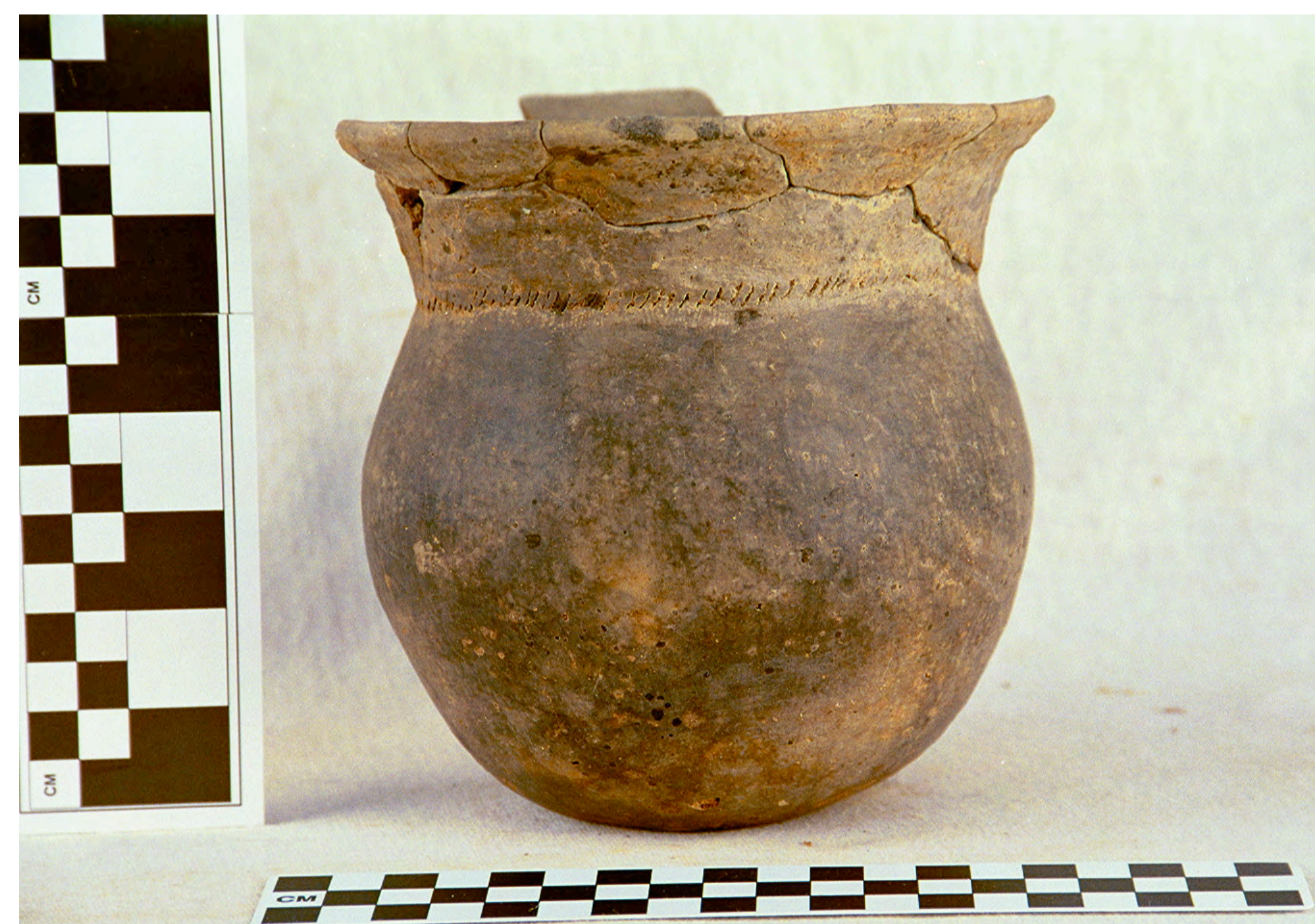

Figure 112 


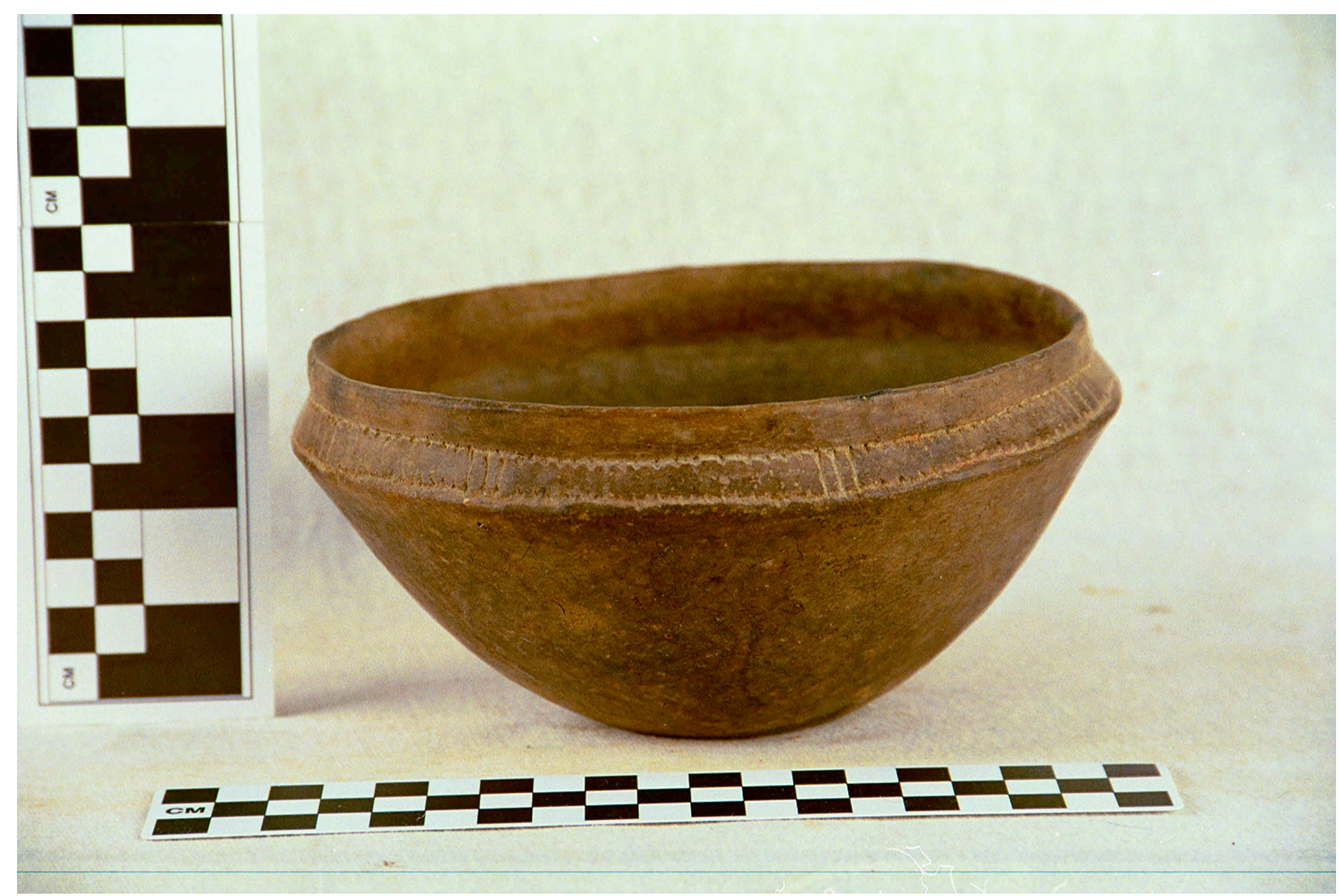

Figure 113 


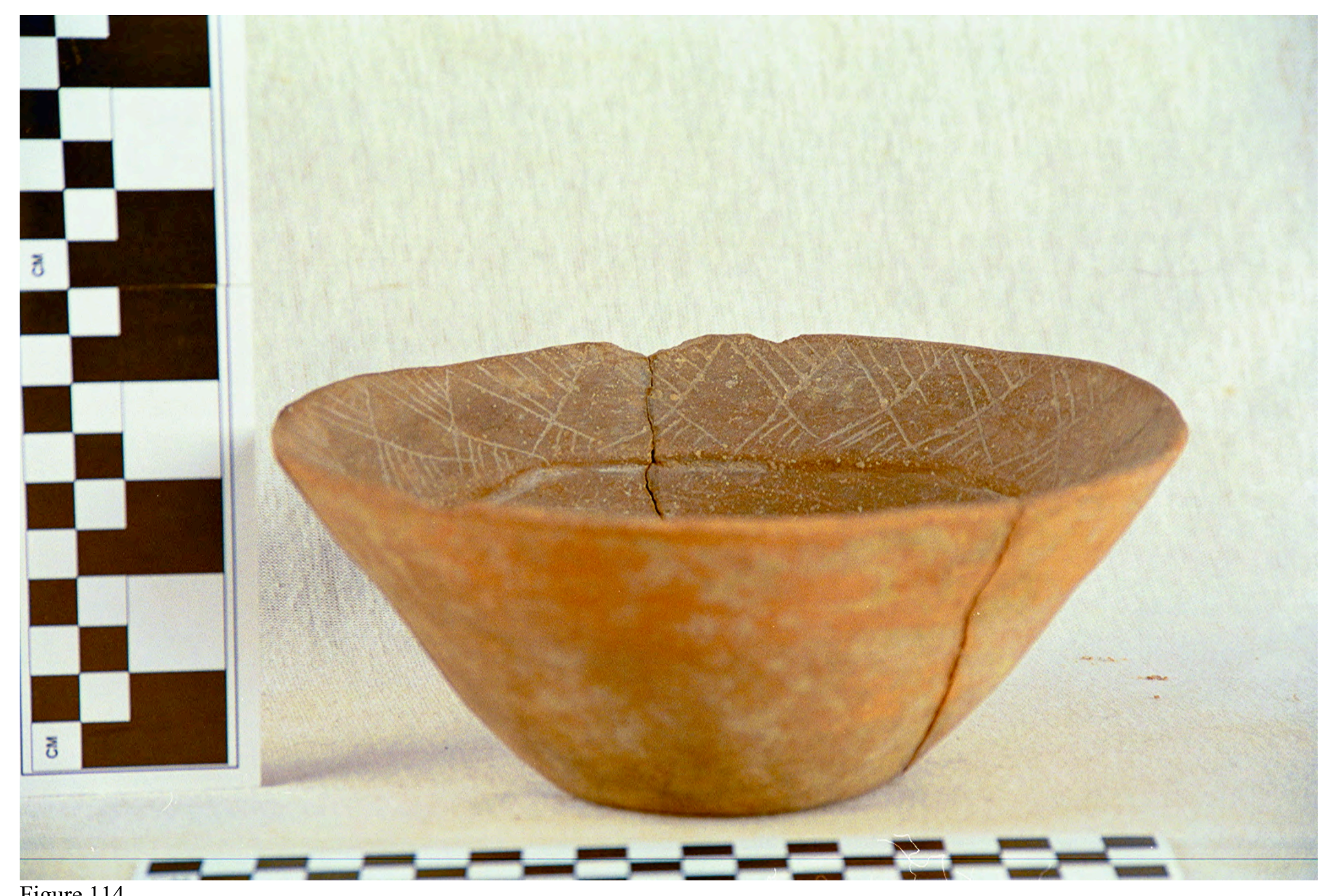

Figure 114 


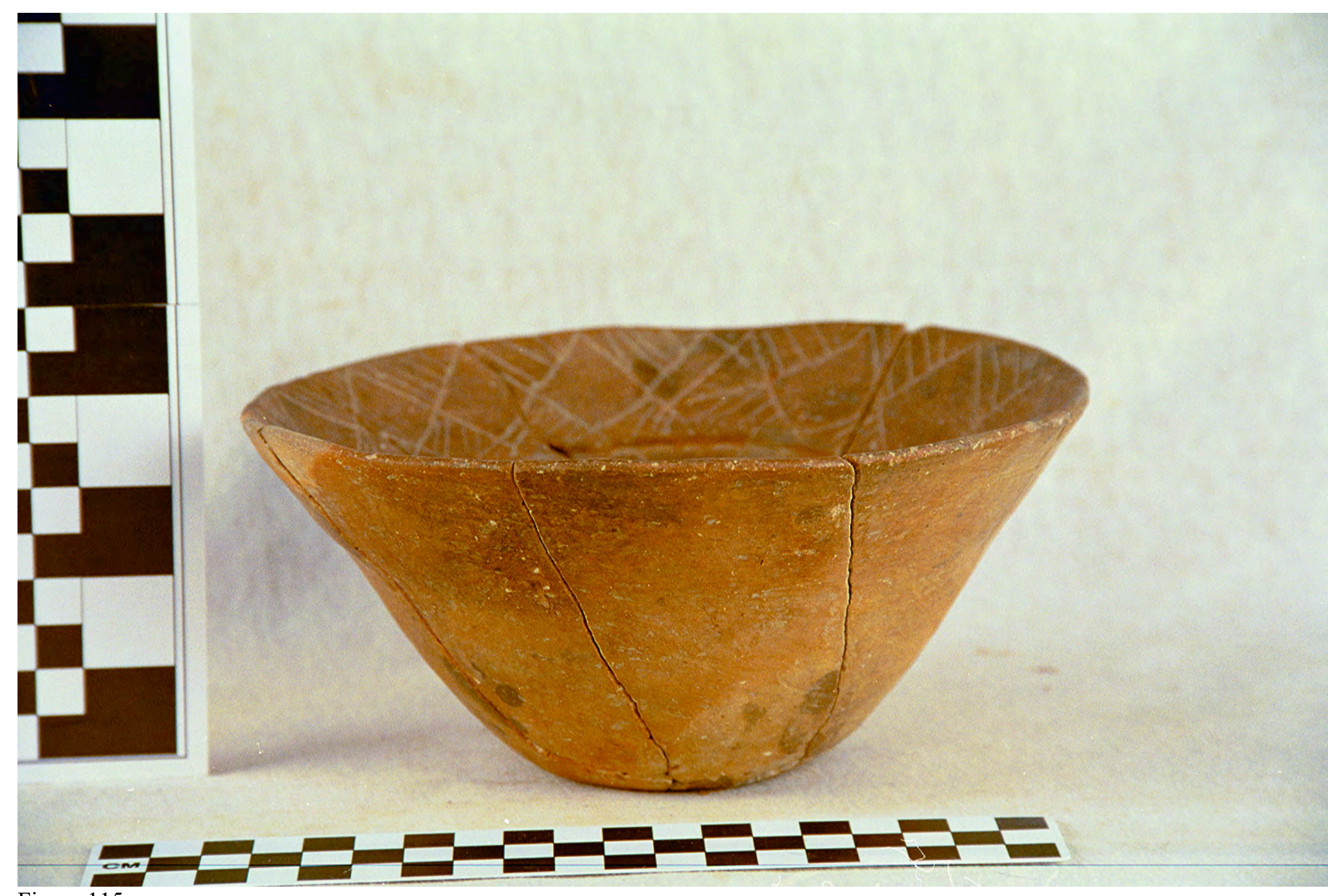

Figure 115 


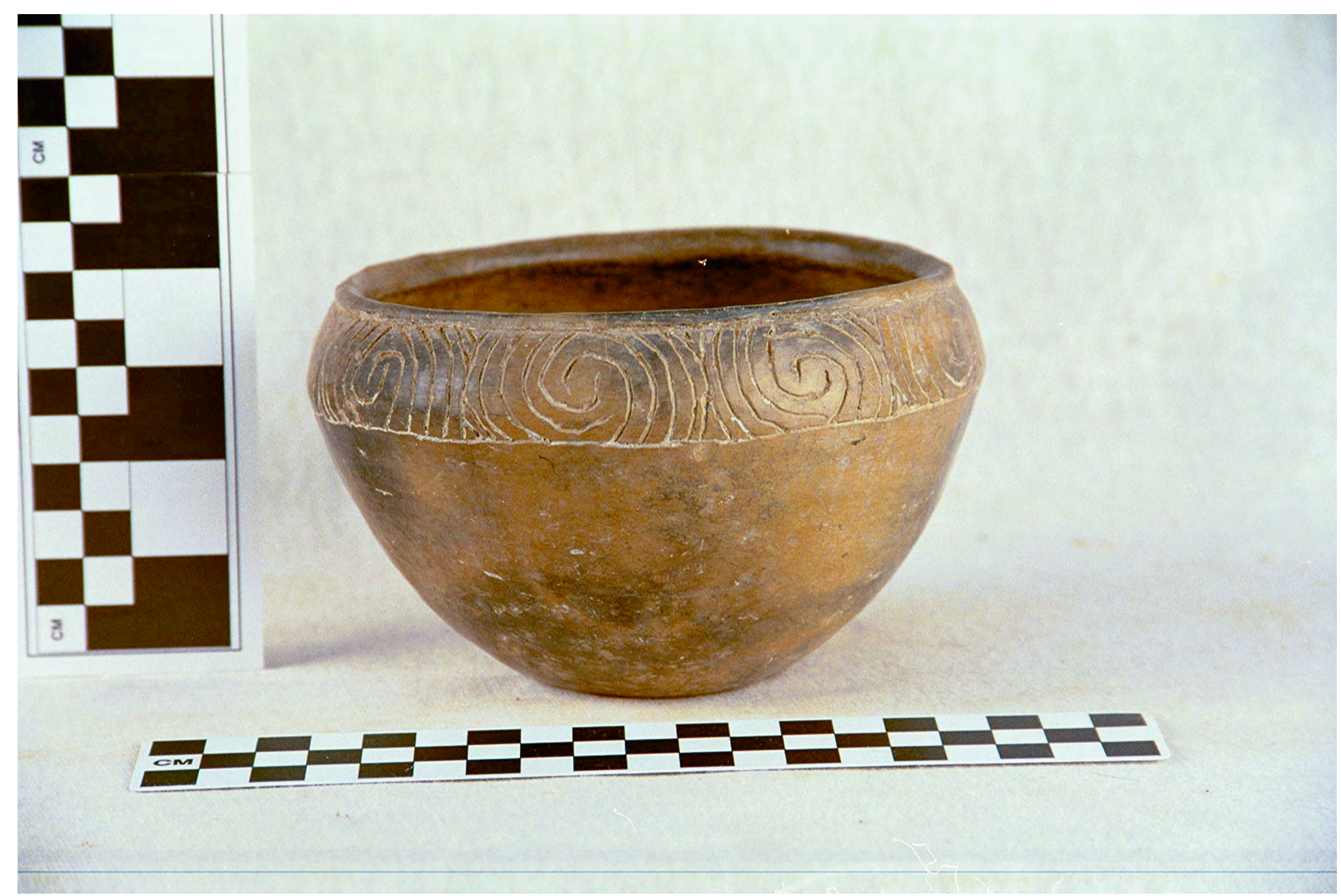

Figure 116 


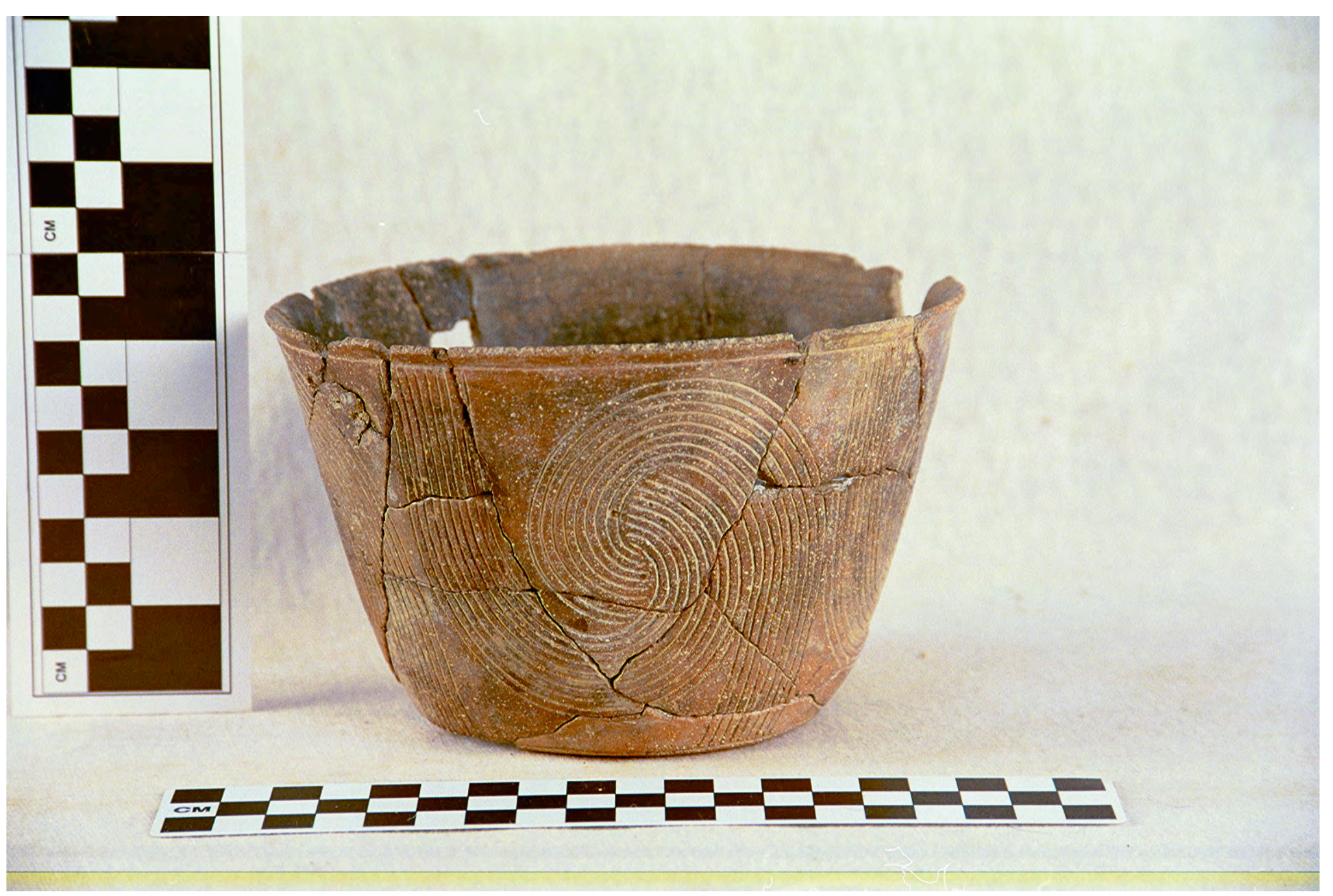

Figure 117 

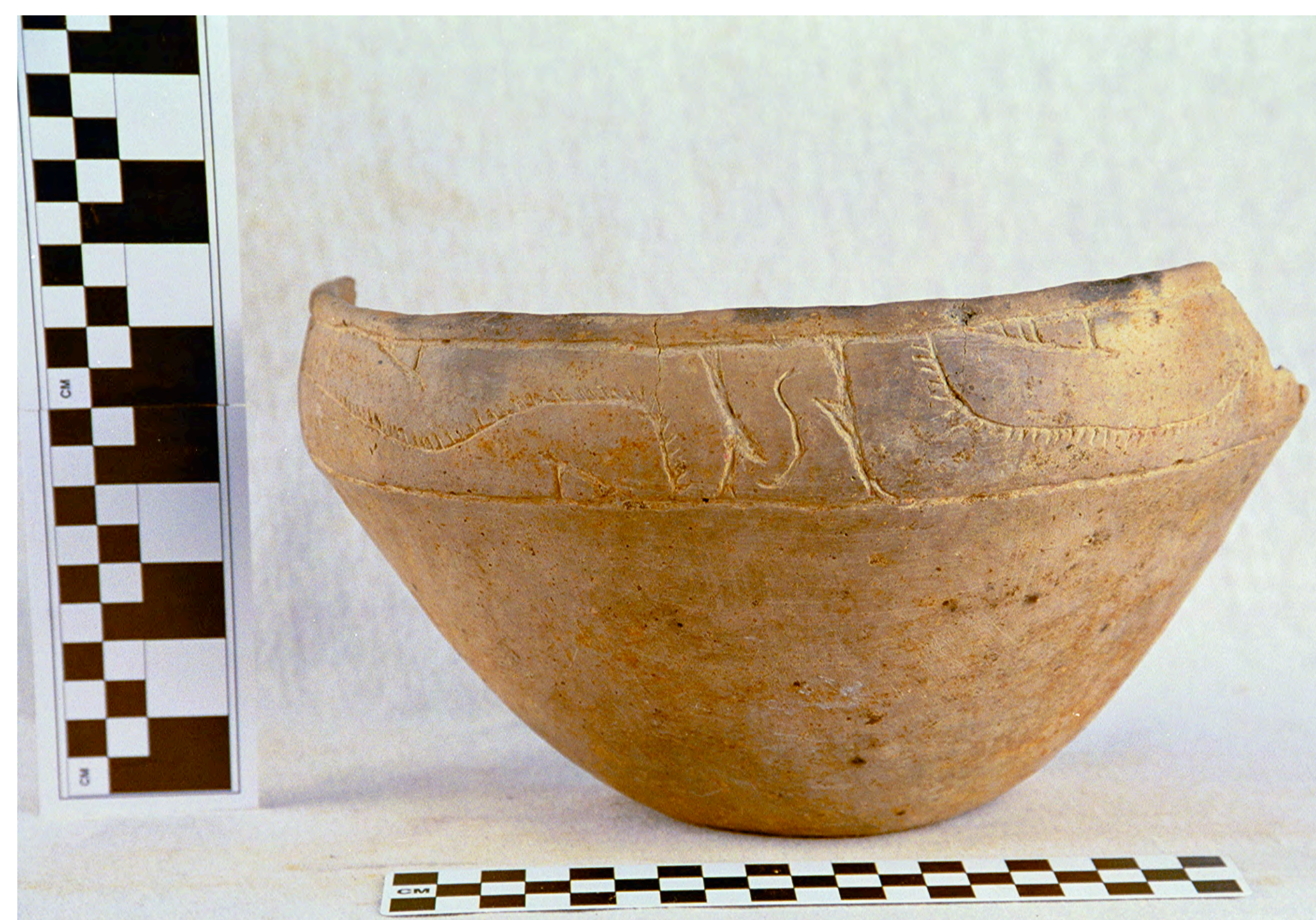

Figure 118 


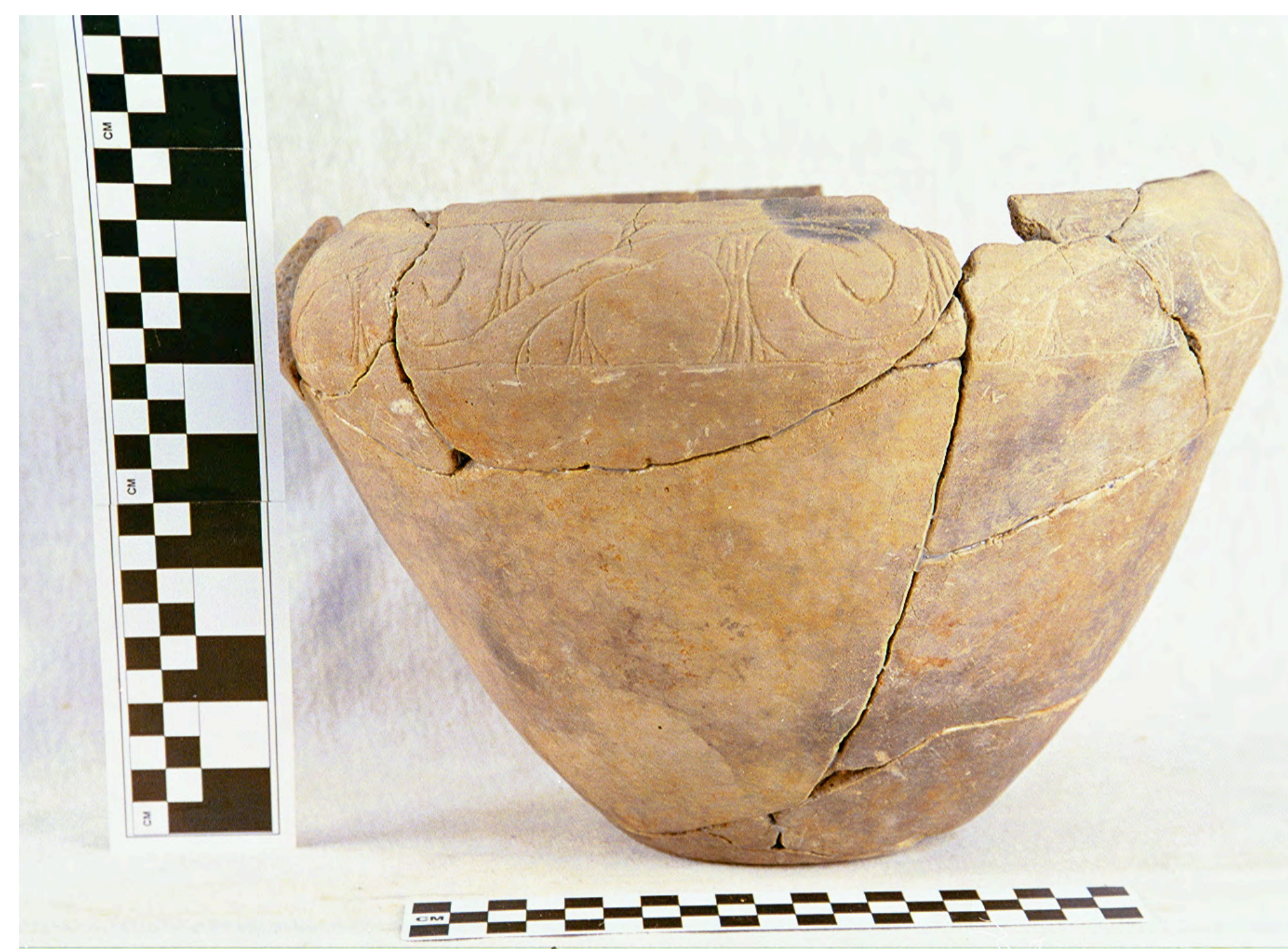

Figure 119 


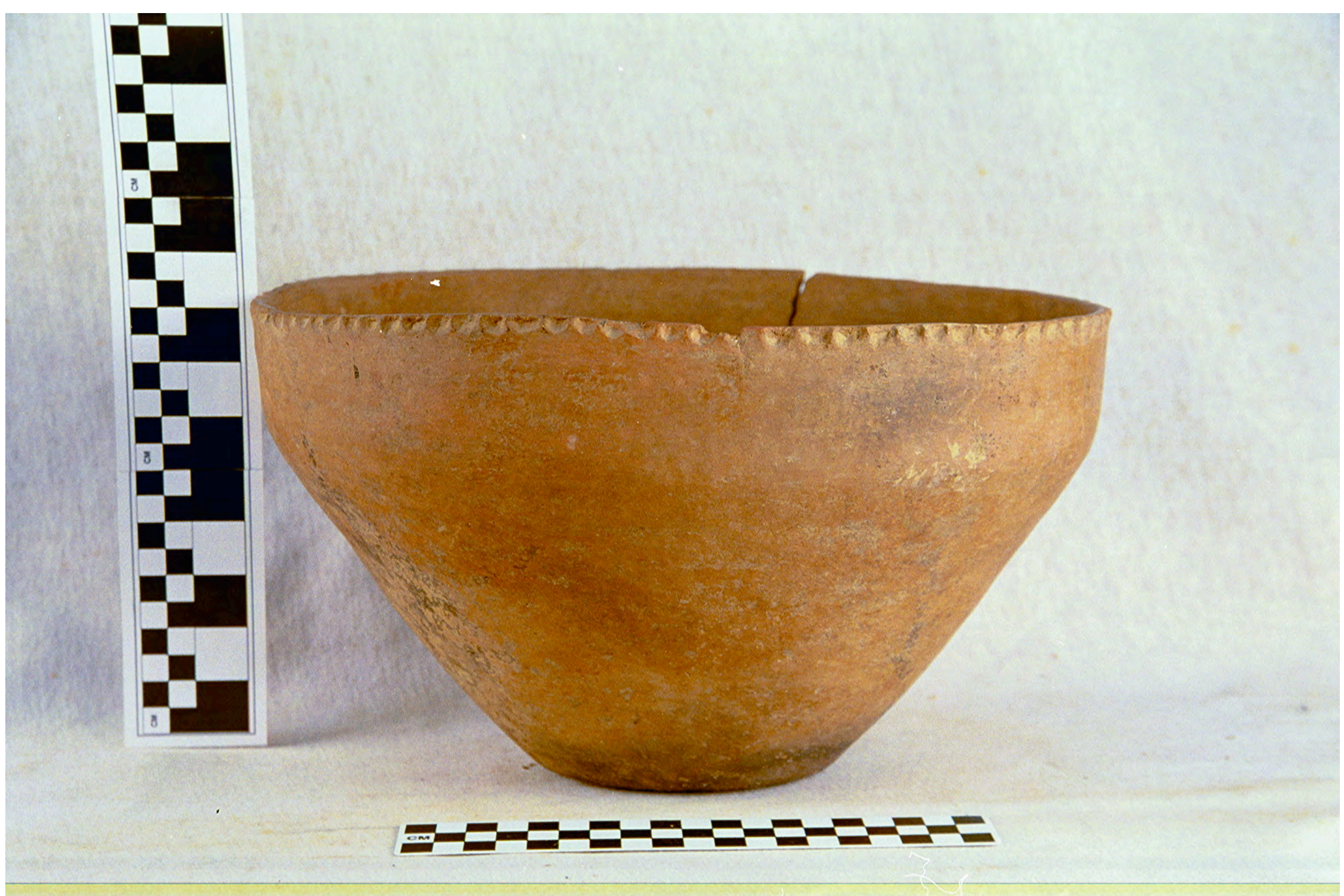

Figure 120 


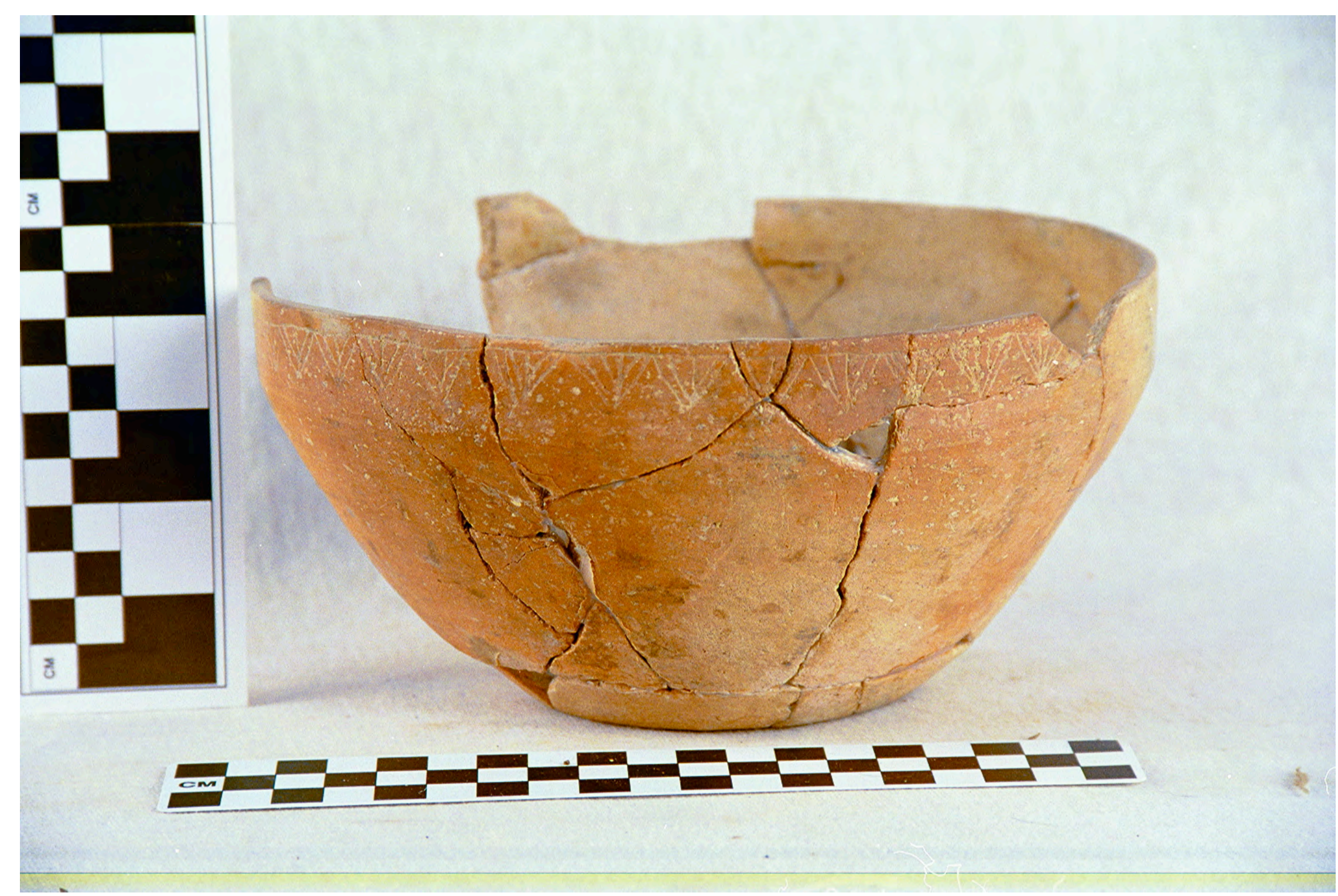

Figure 121 


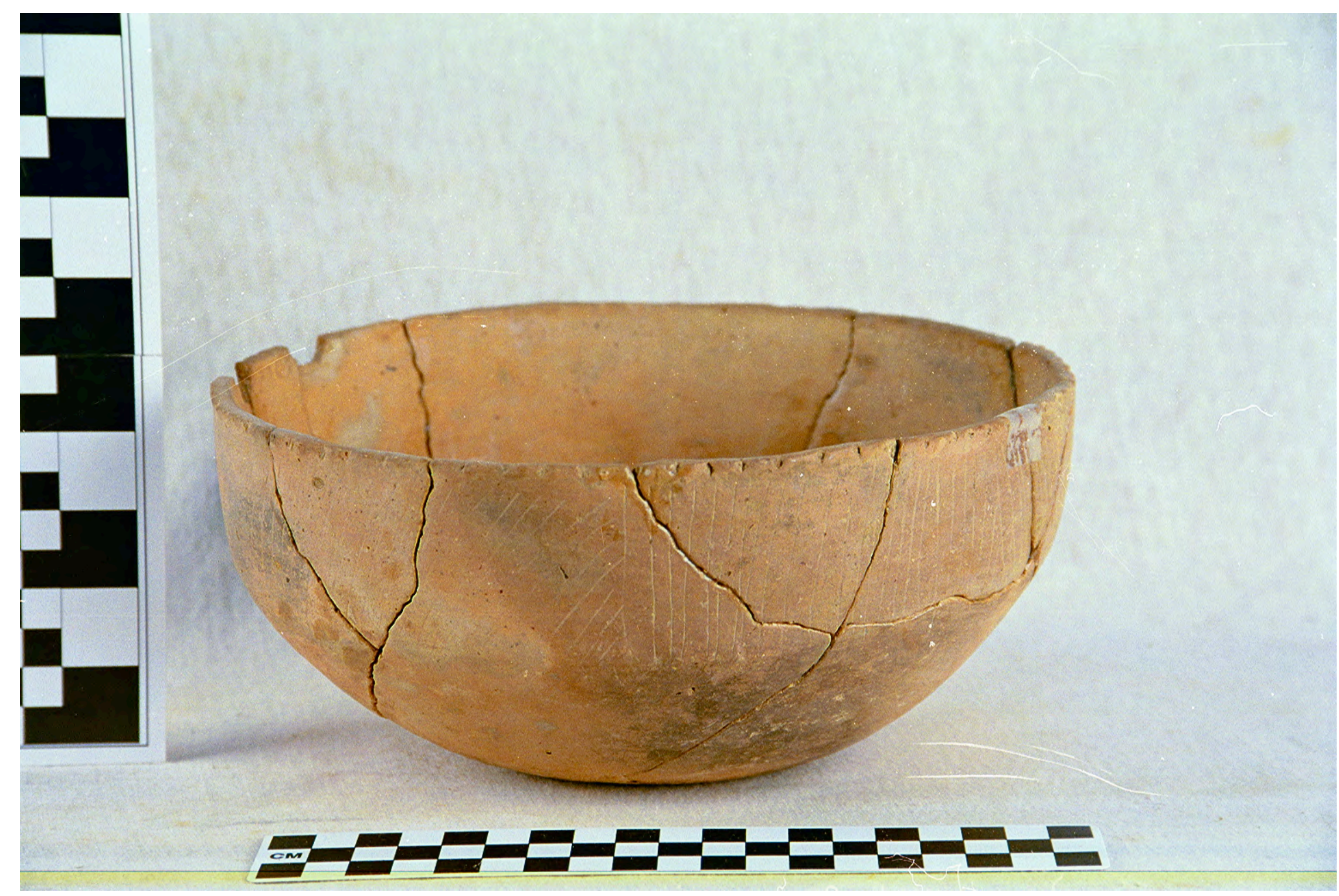

Figure 122 


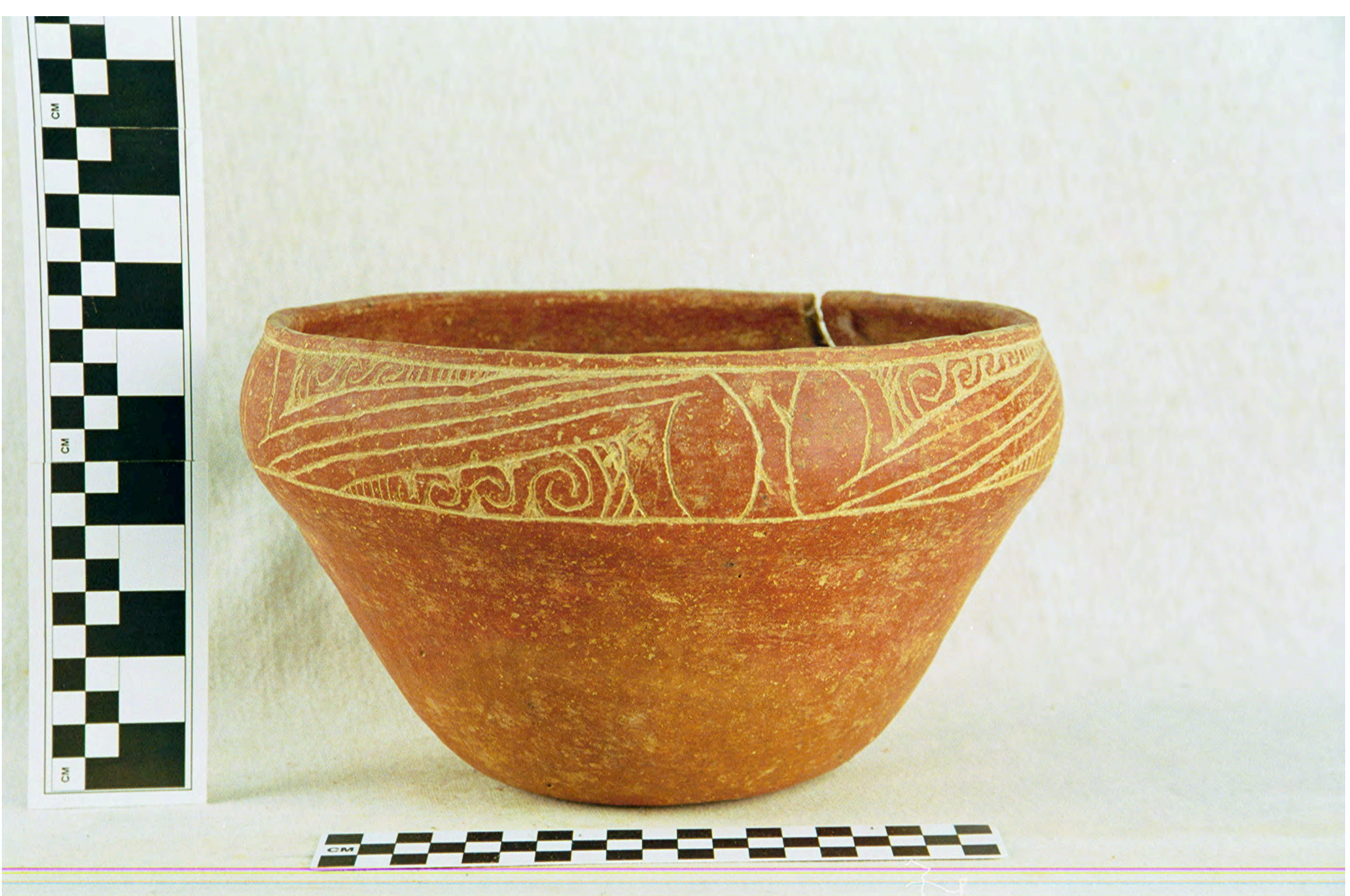

Figure 123 


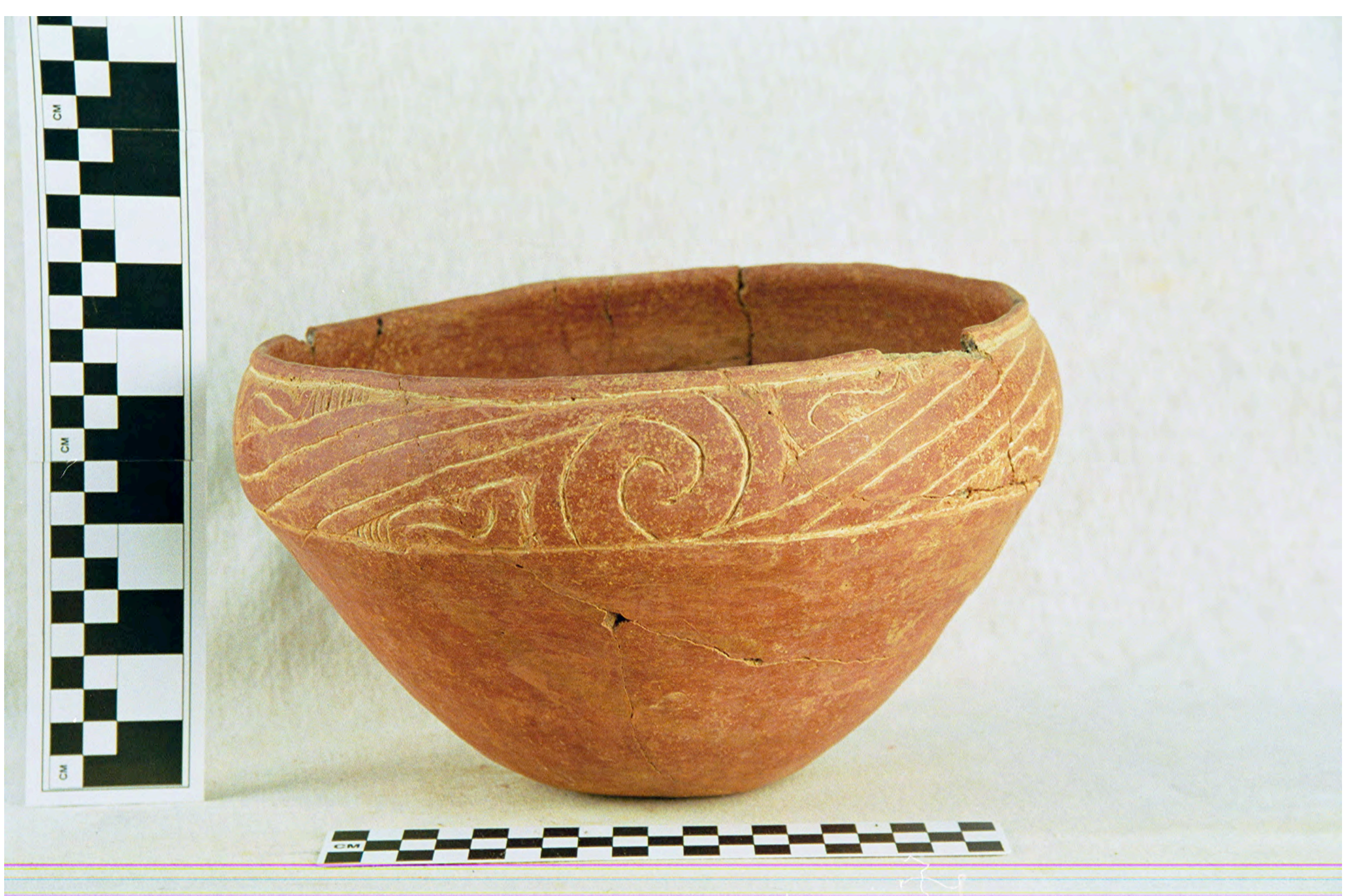

Figure 124 


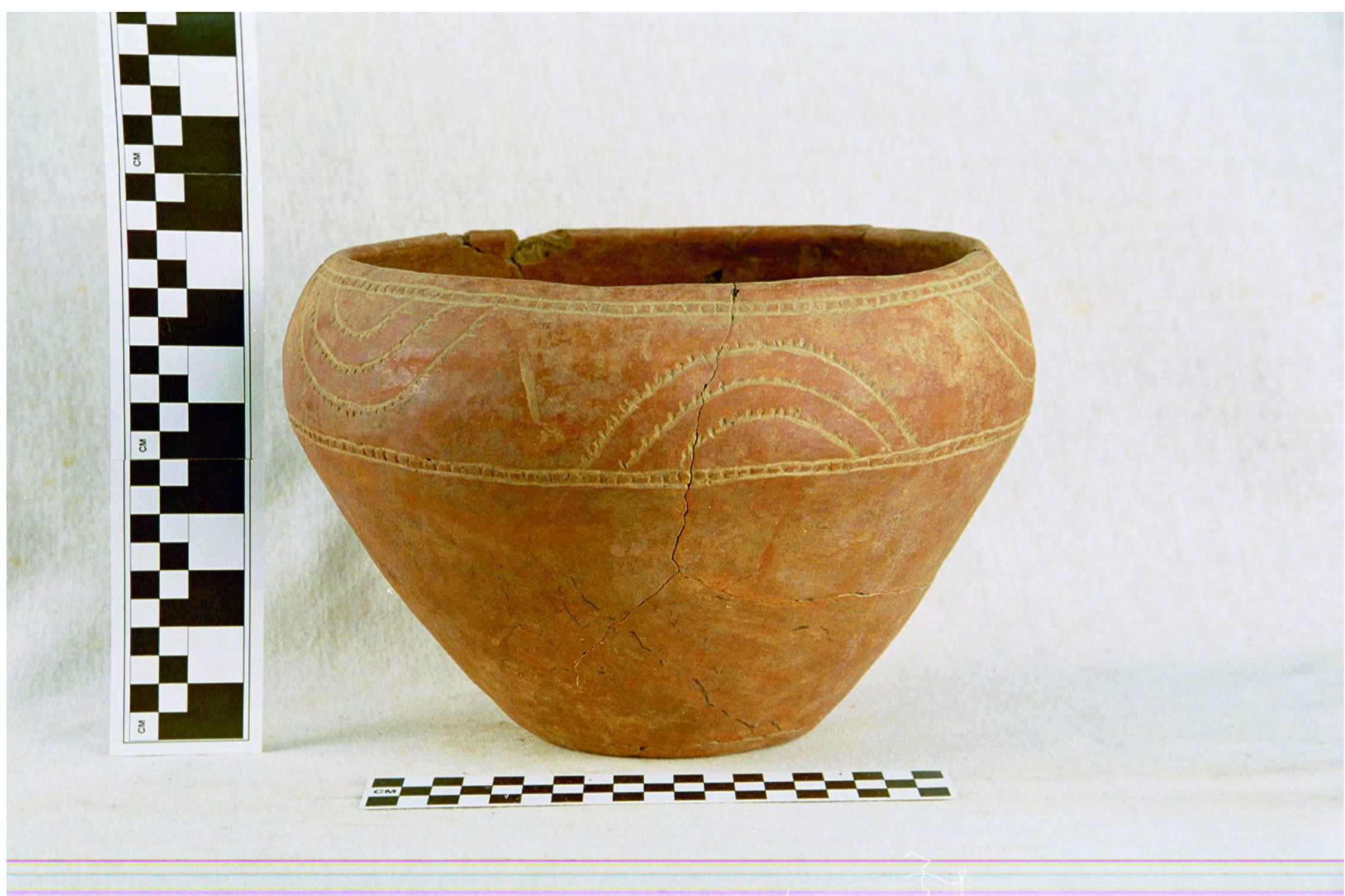

Figure 125 


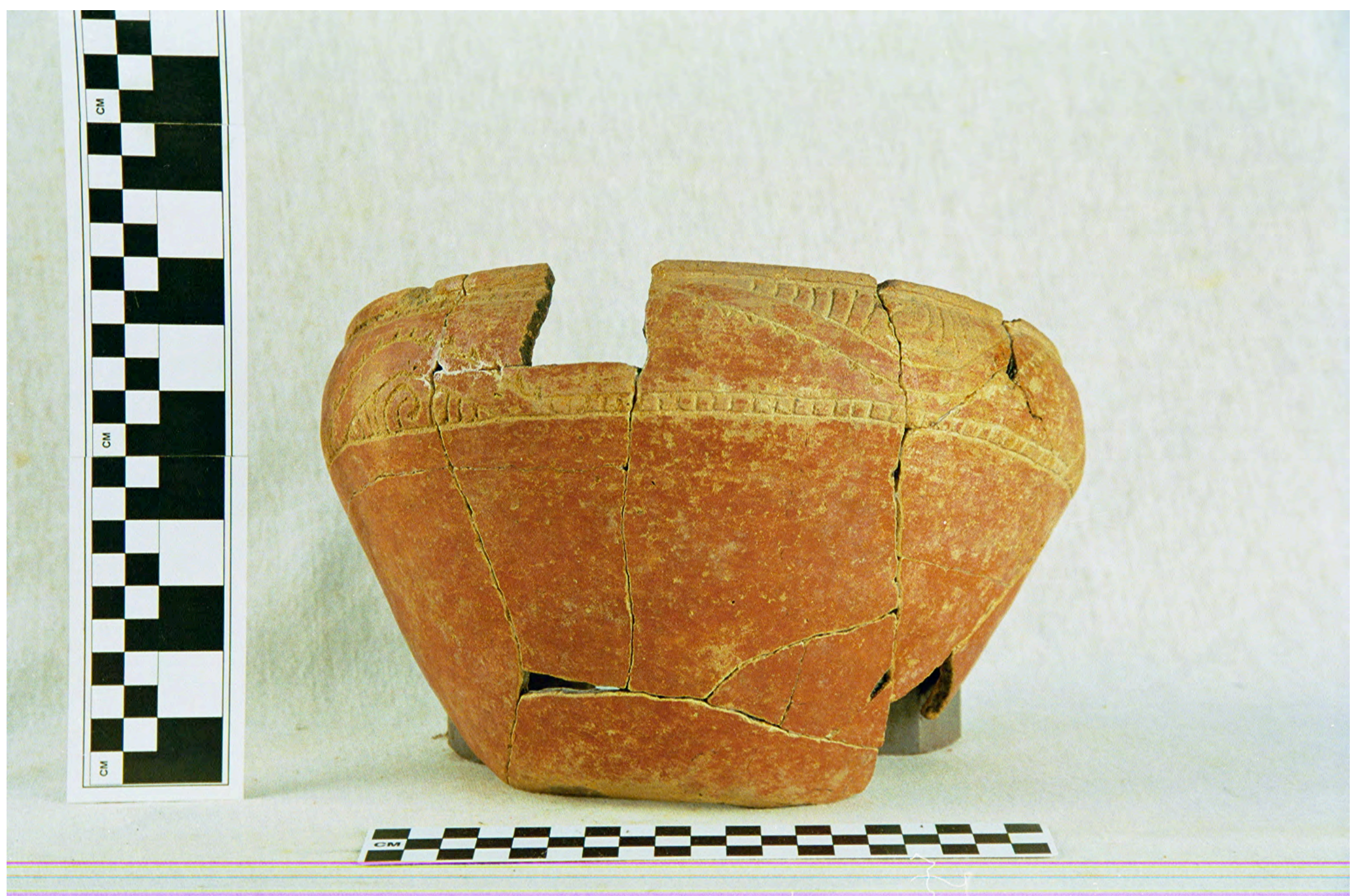

Figure 126 


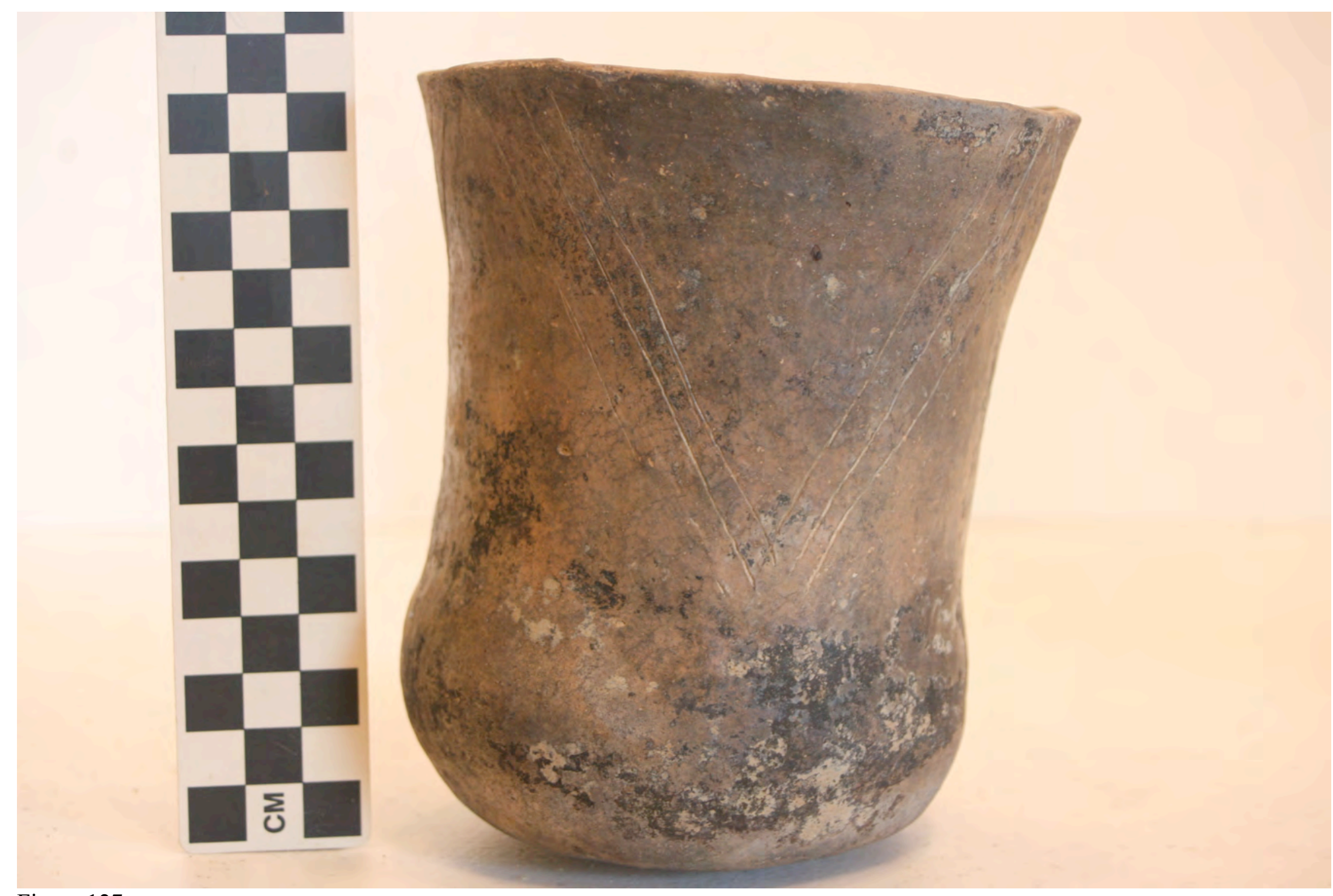

Figure 127 

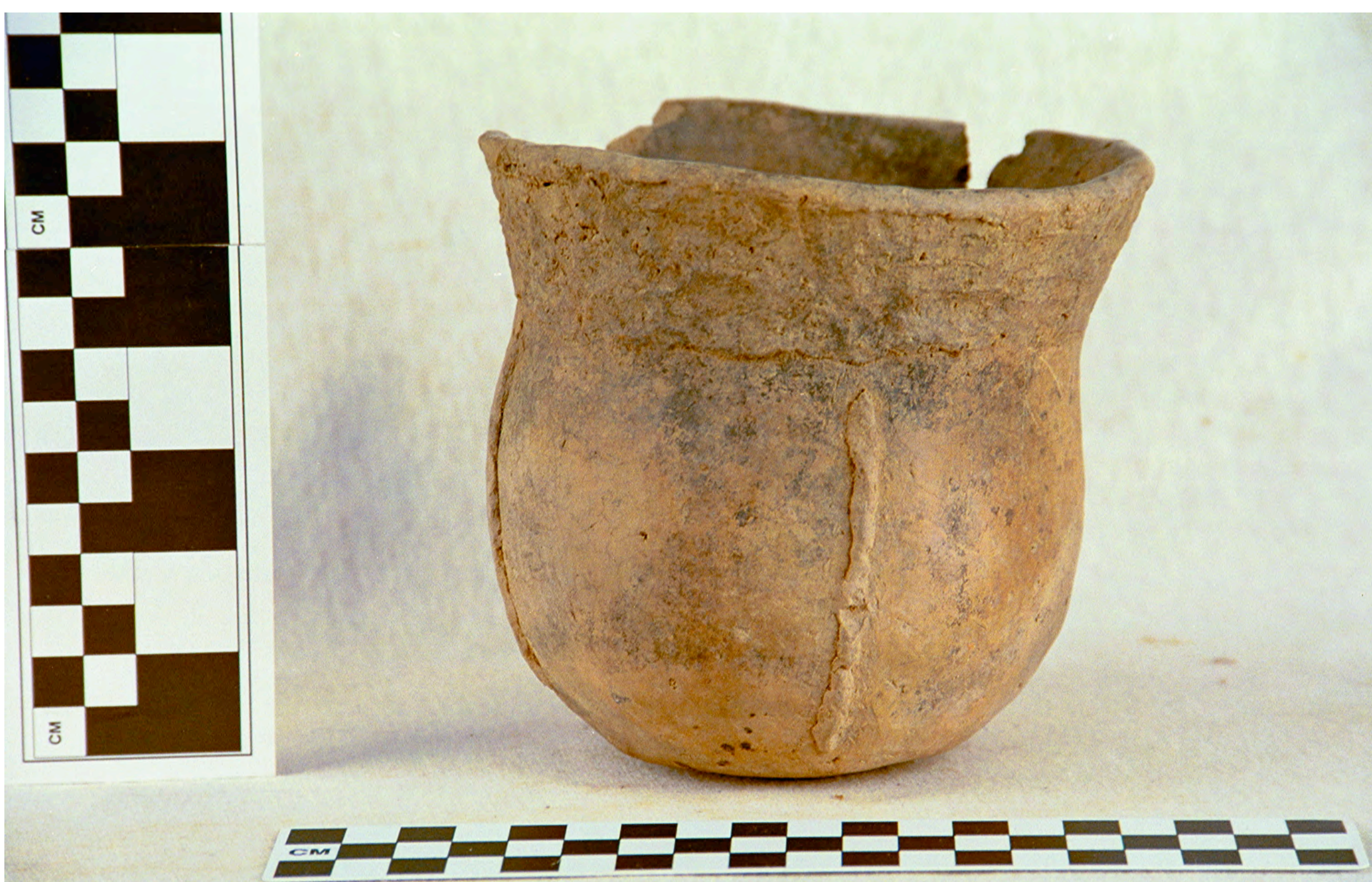

Figure 128 


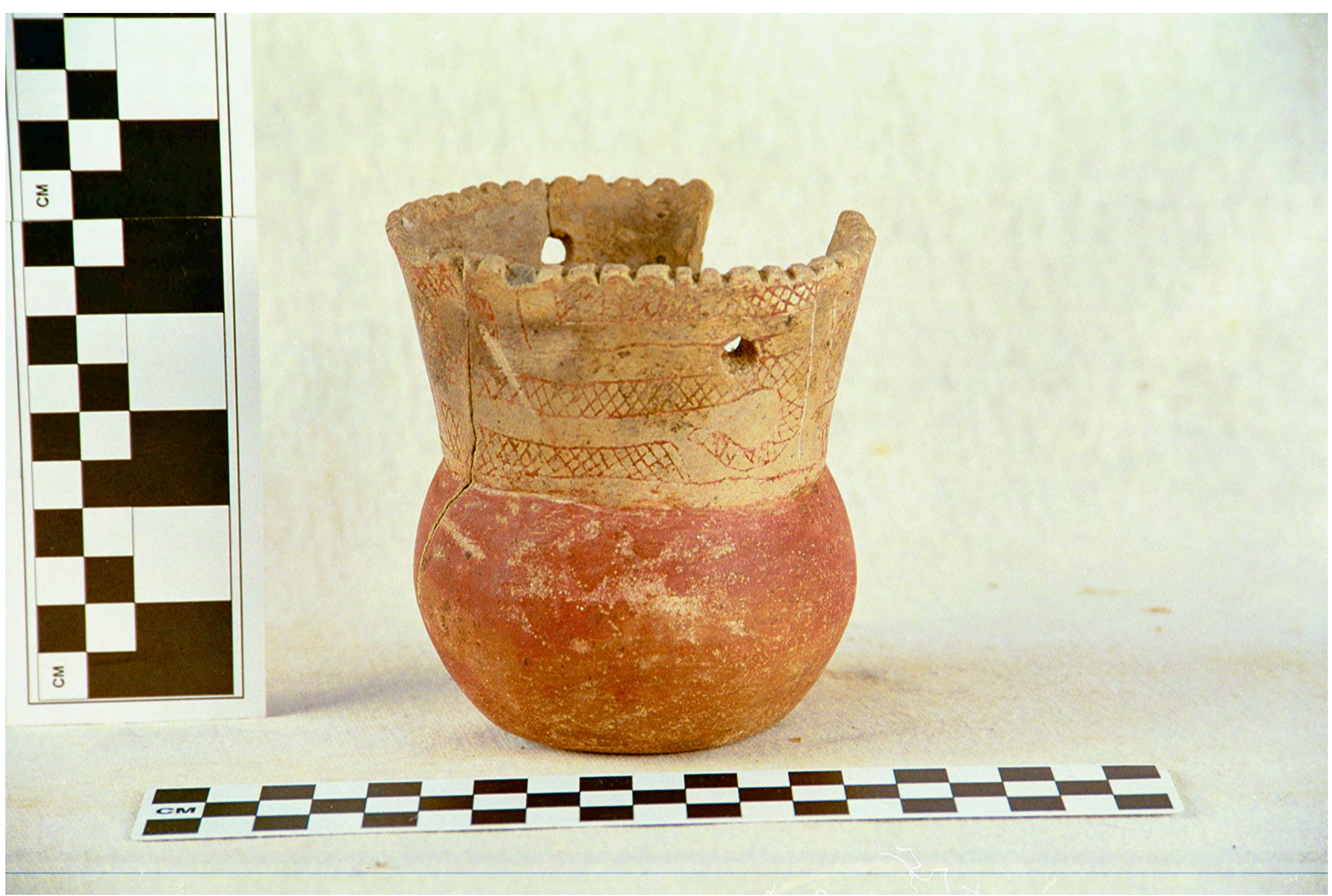

Figure 129 

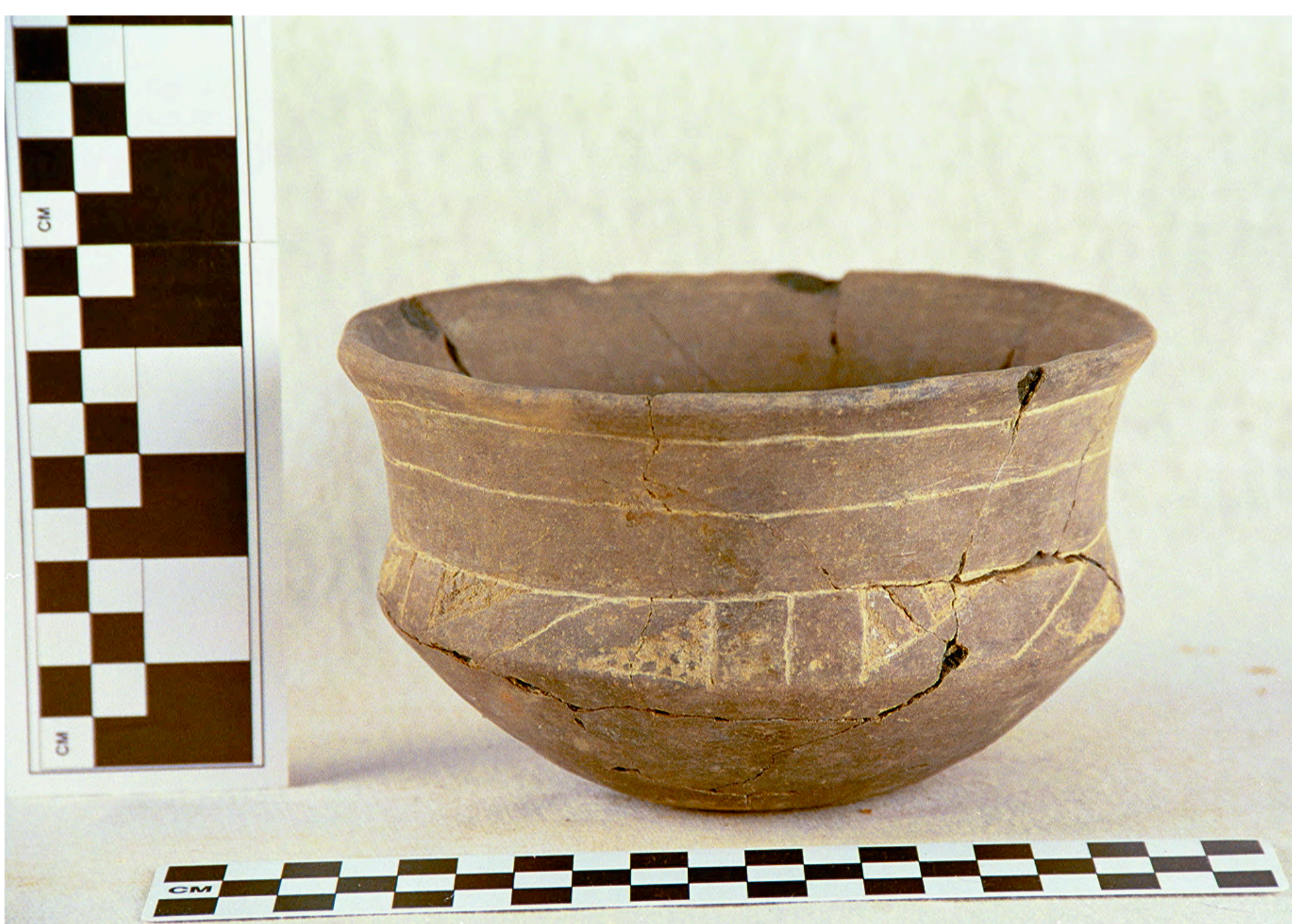

Figure 130 


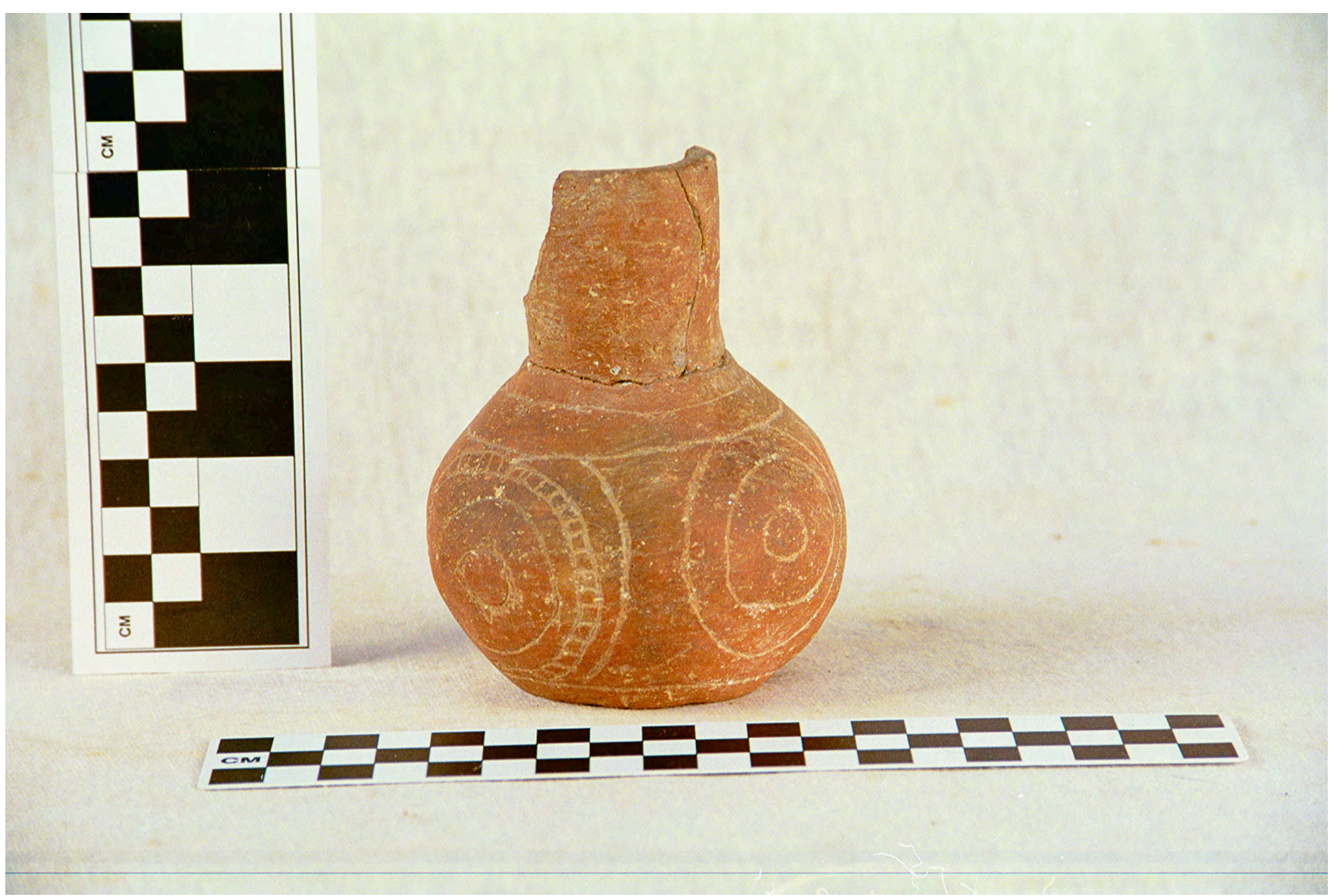

Figure 131 


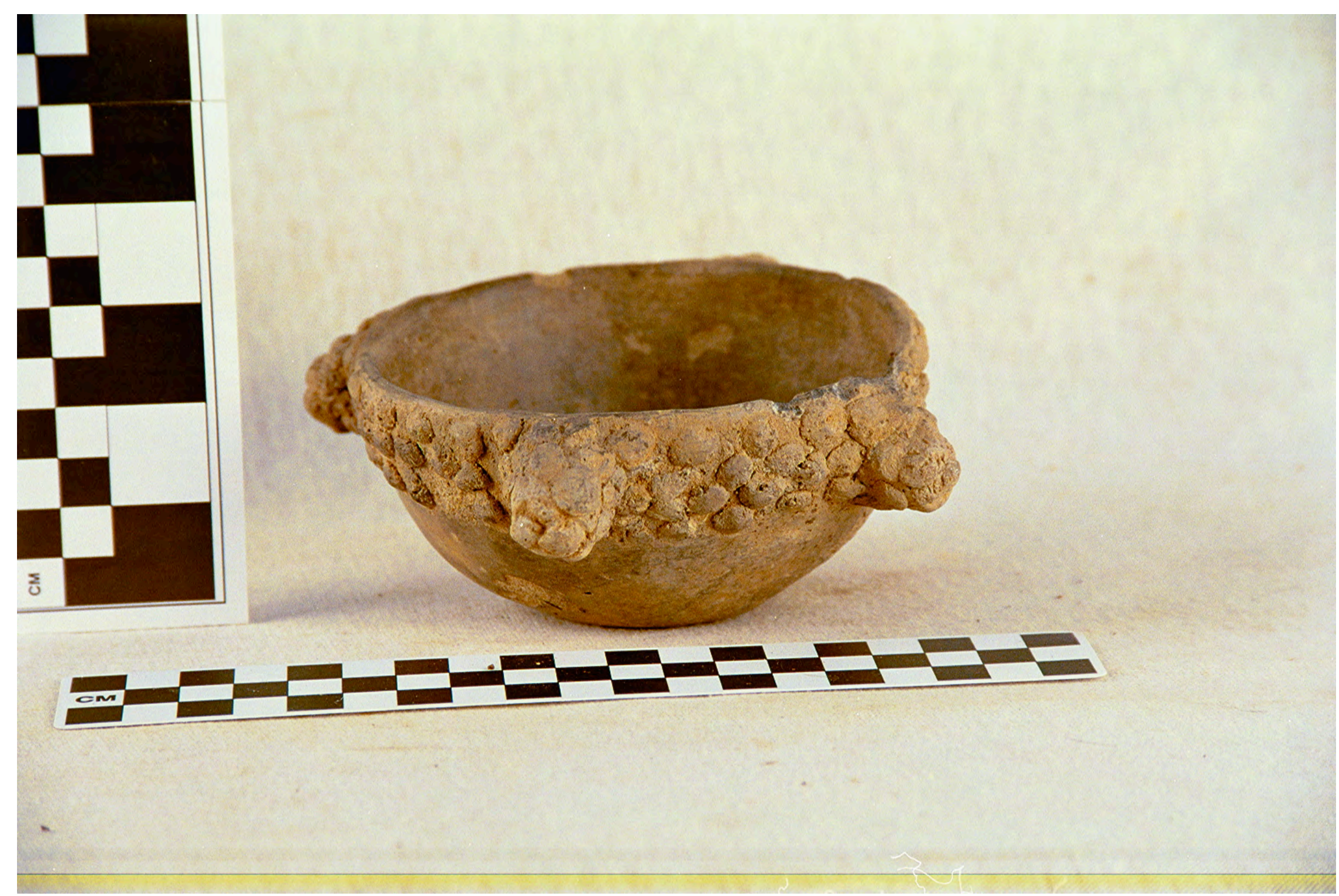

Figure 132 


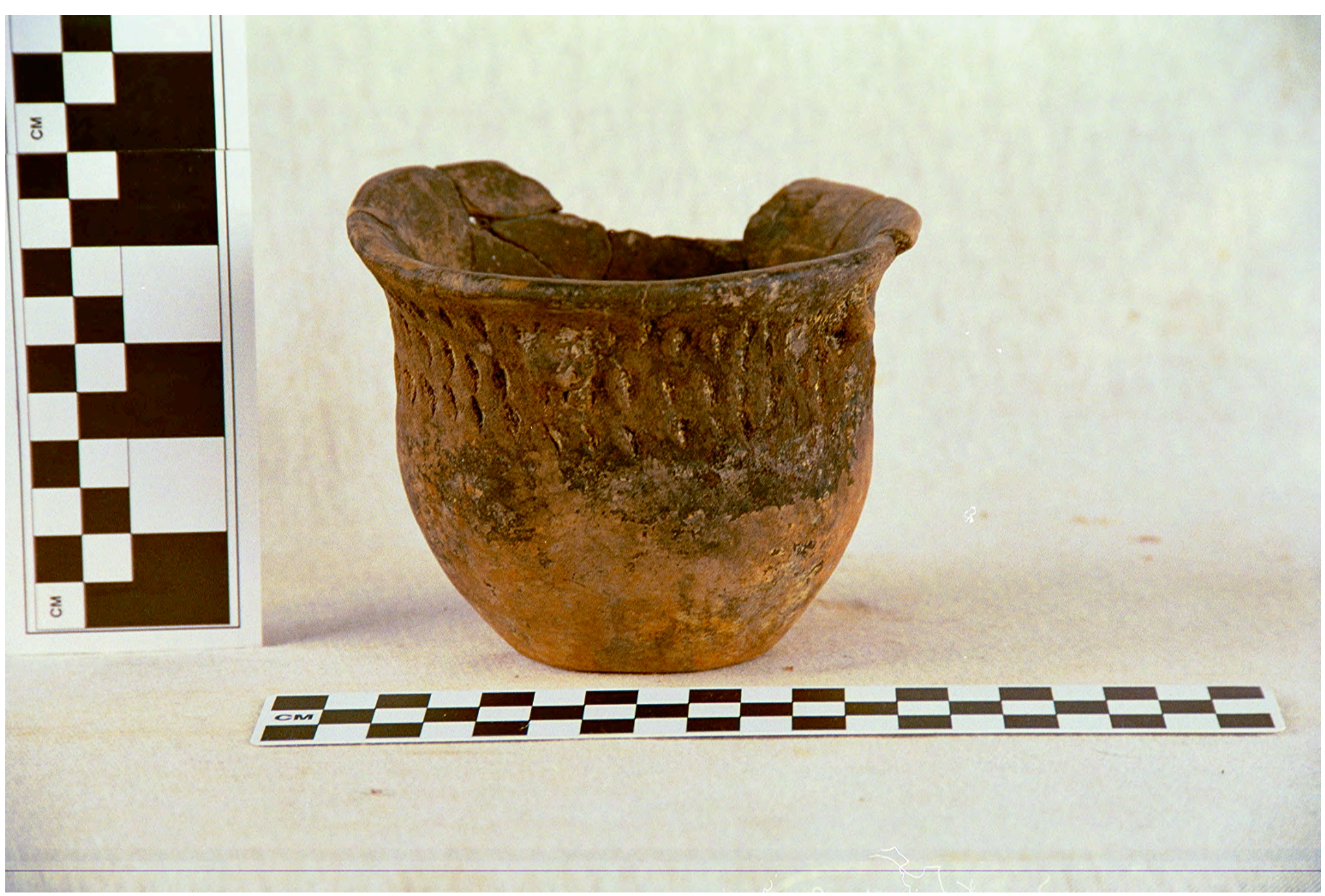

Figure 133 

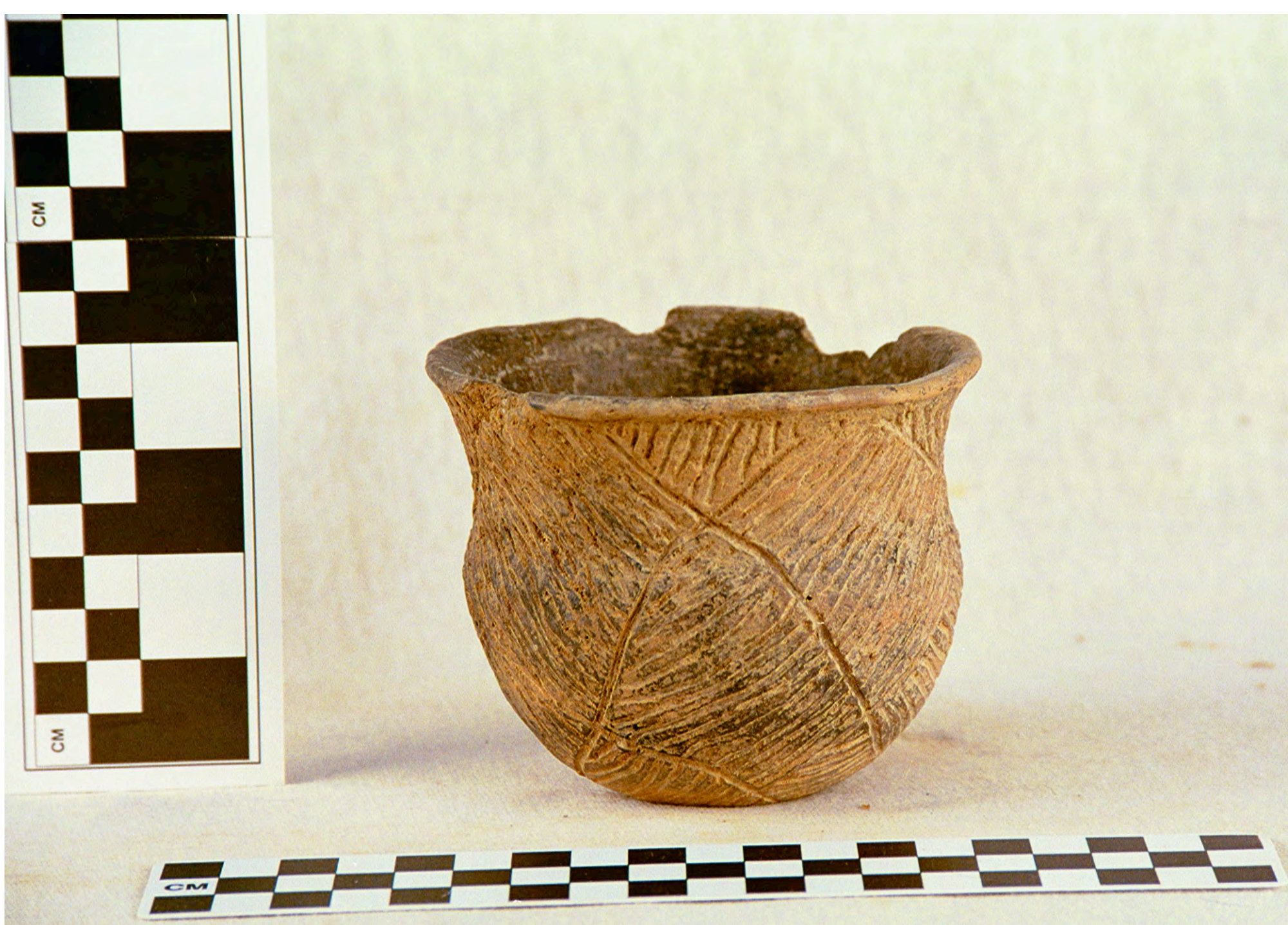

Figure 134 


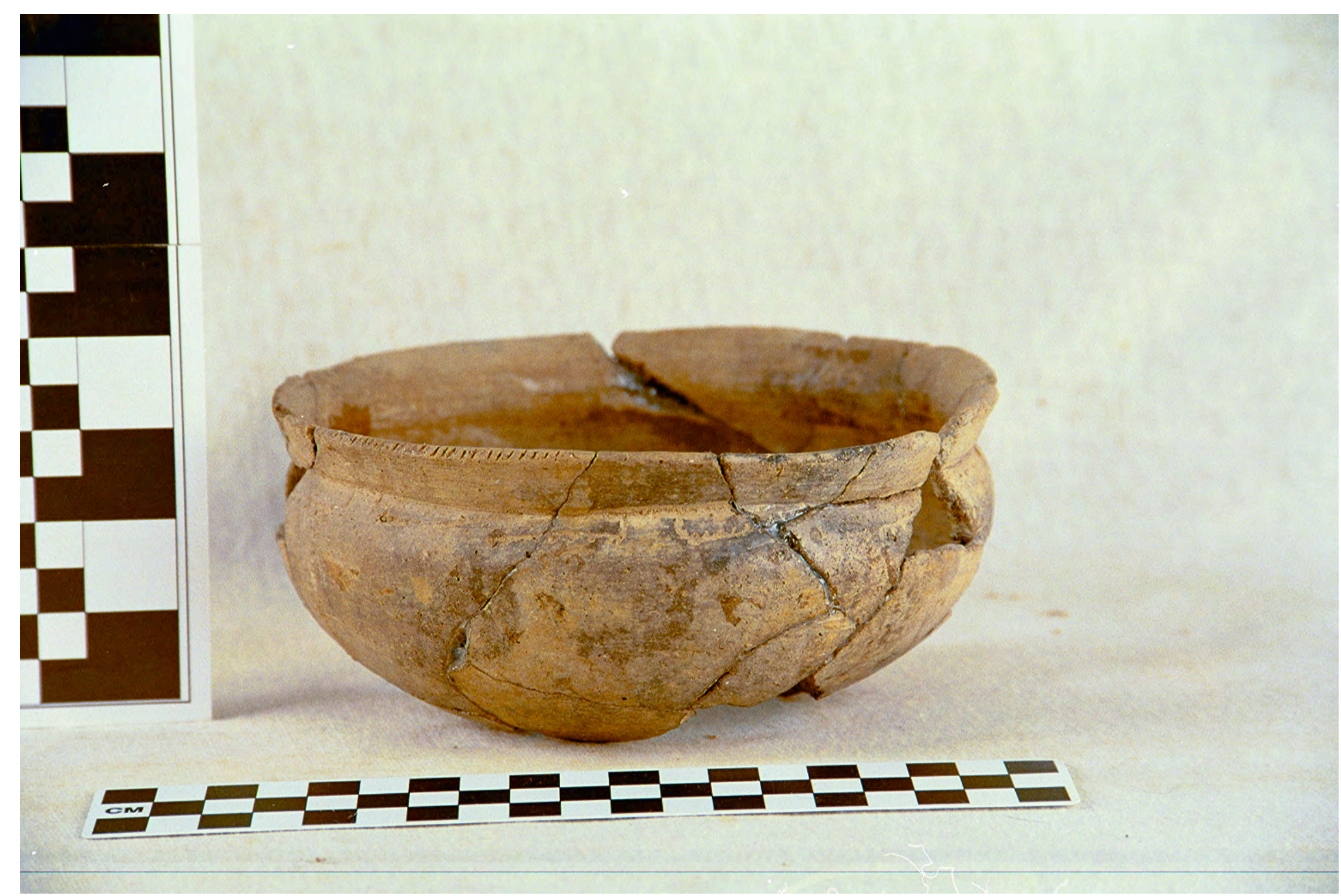

Figure 135 


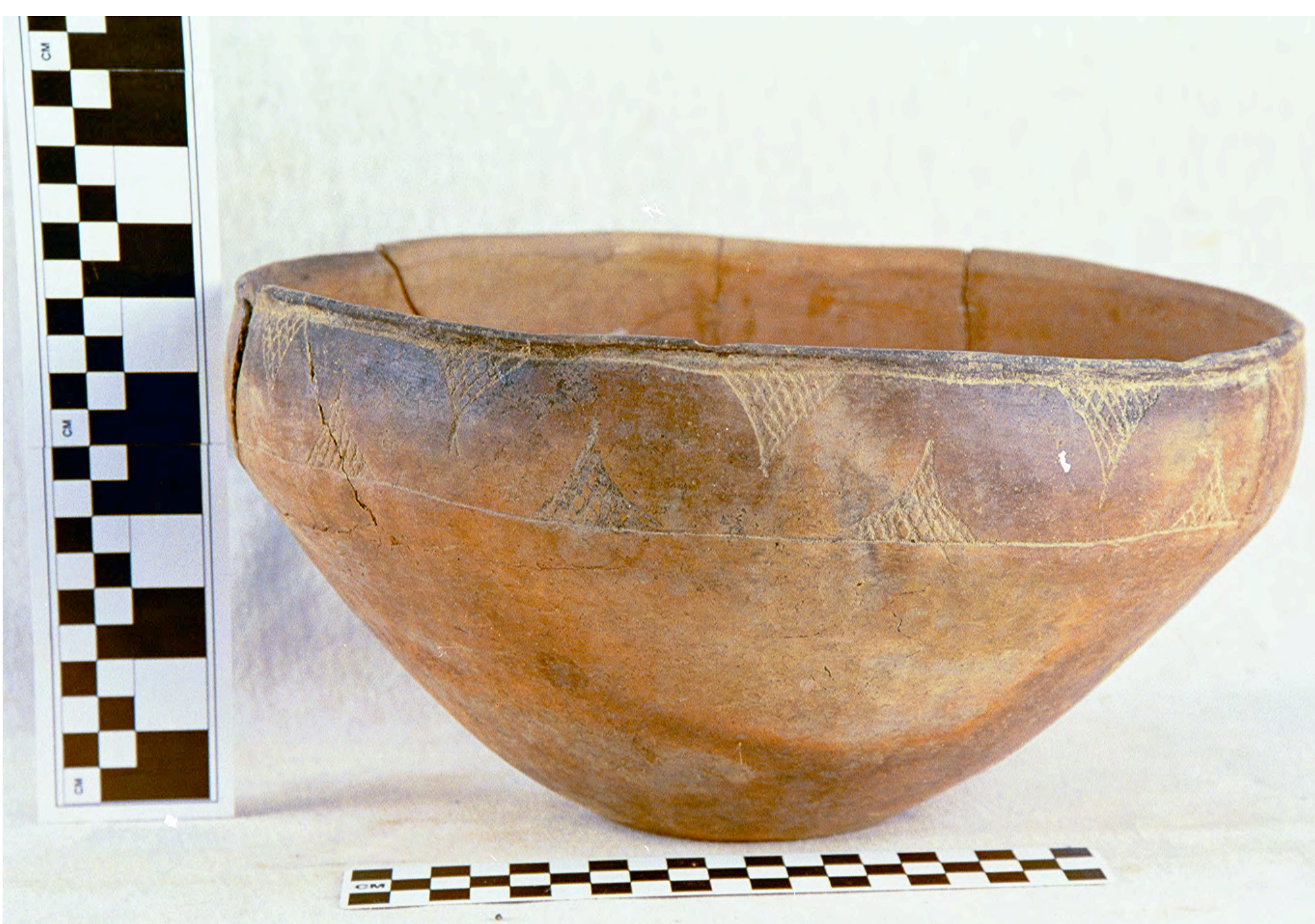

Figure 136 


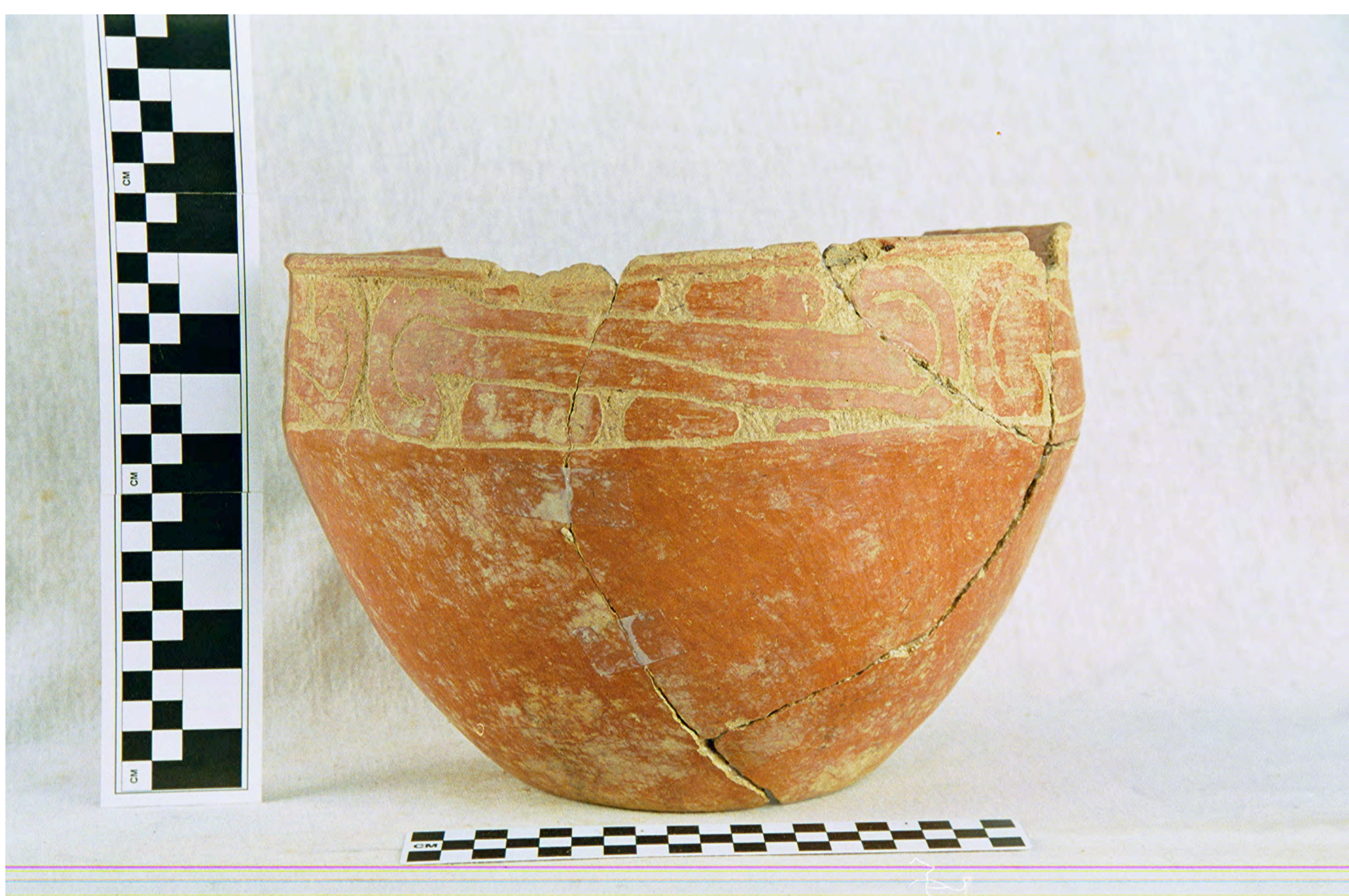

Figure 137 


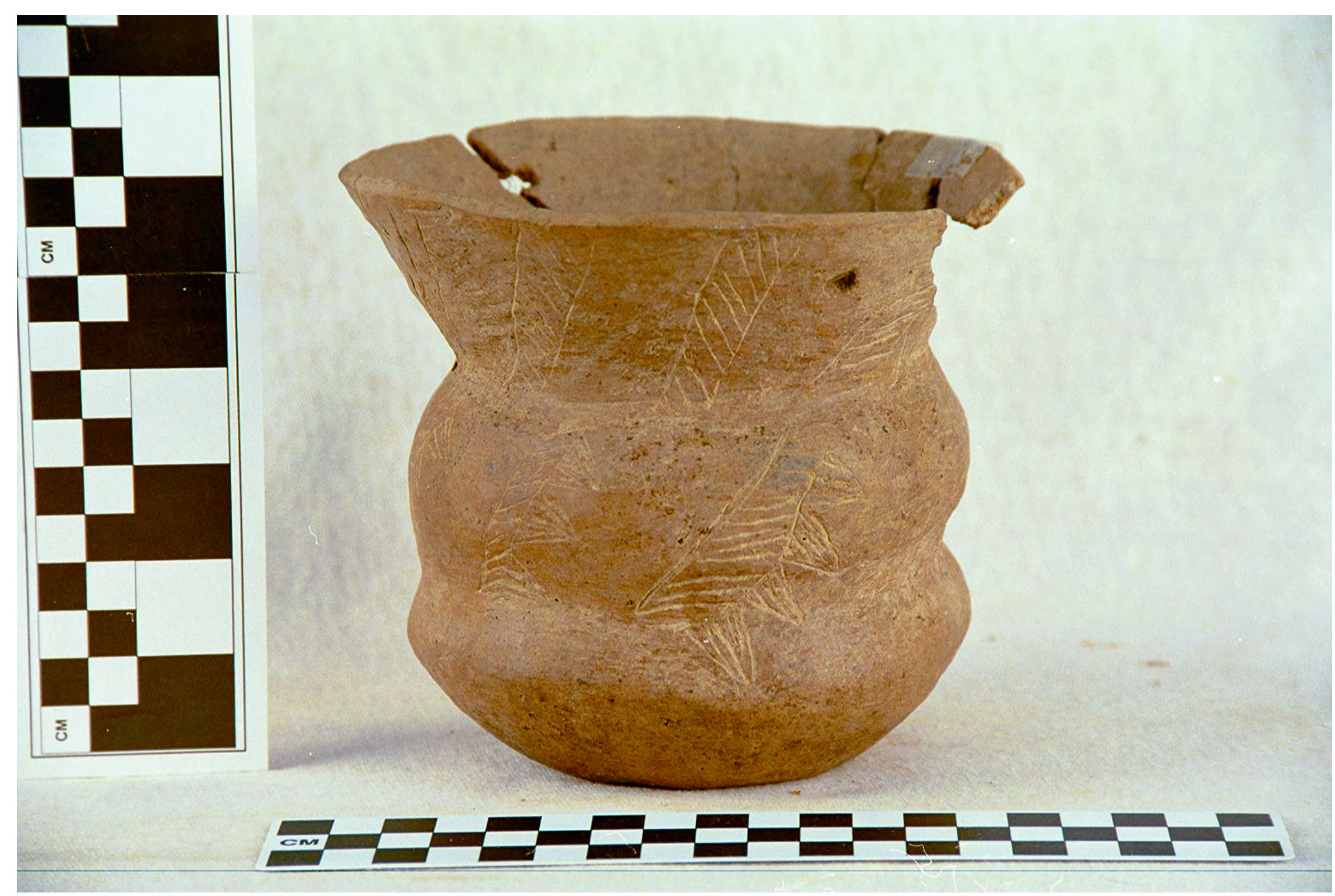

Figure 138 

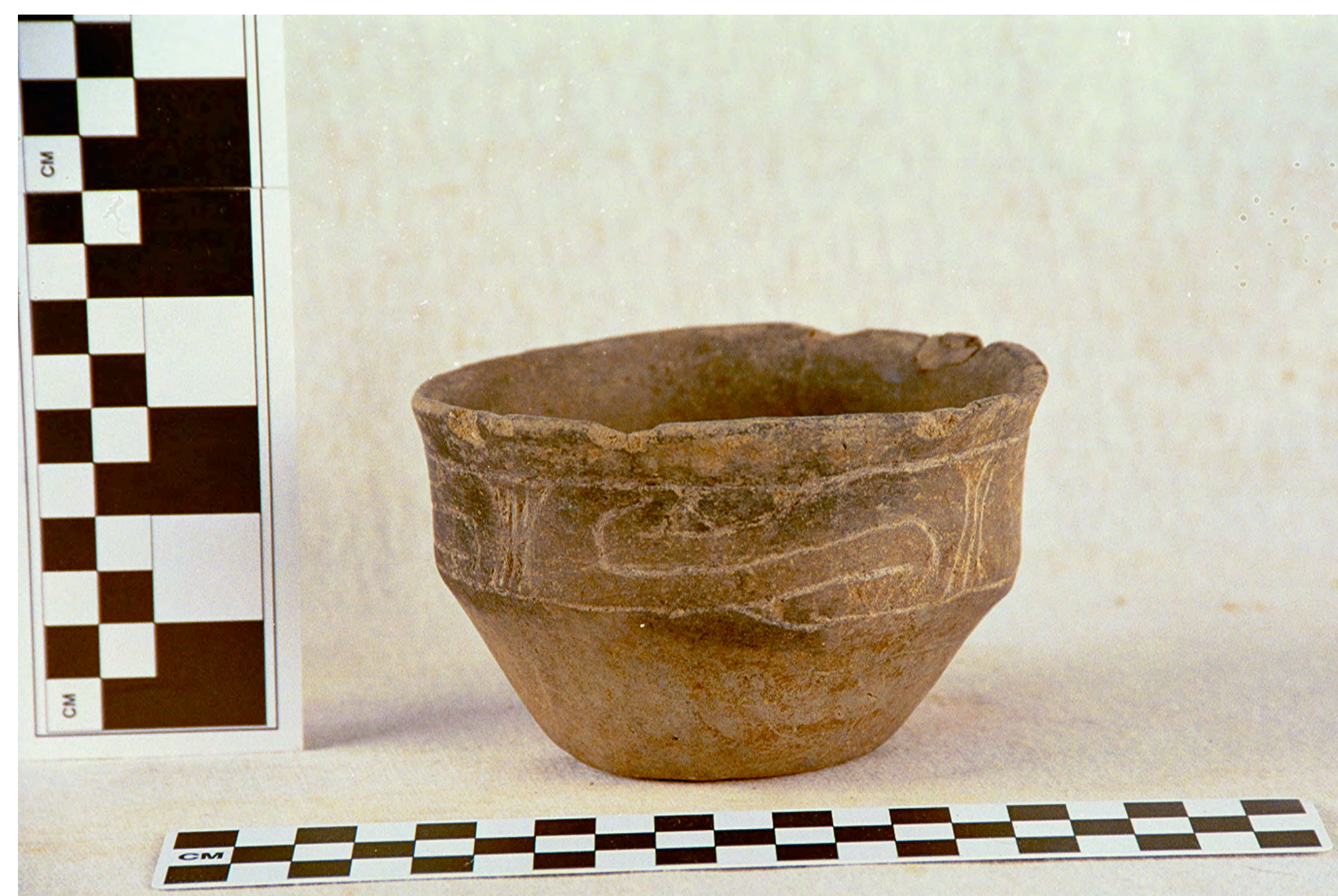

Figure 139 


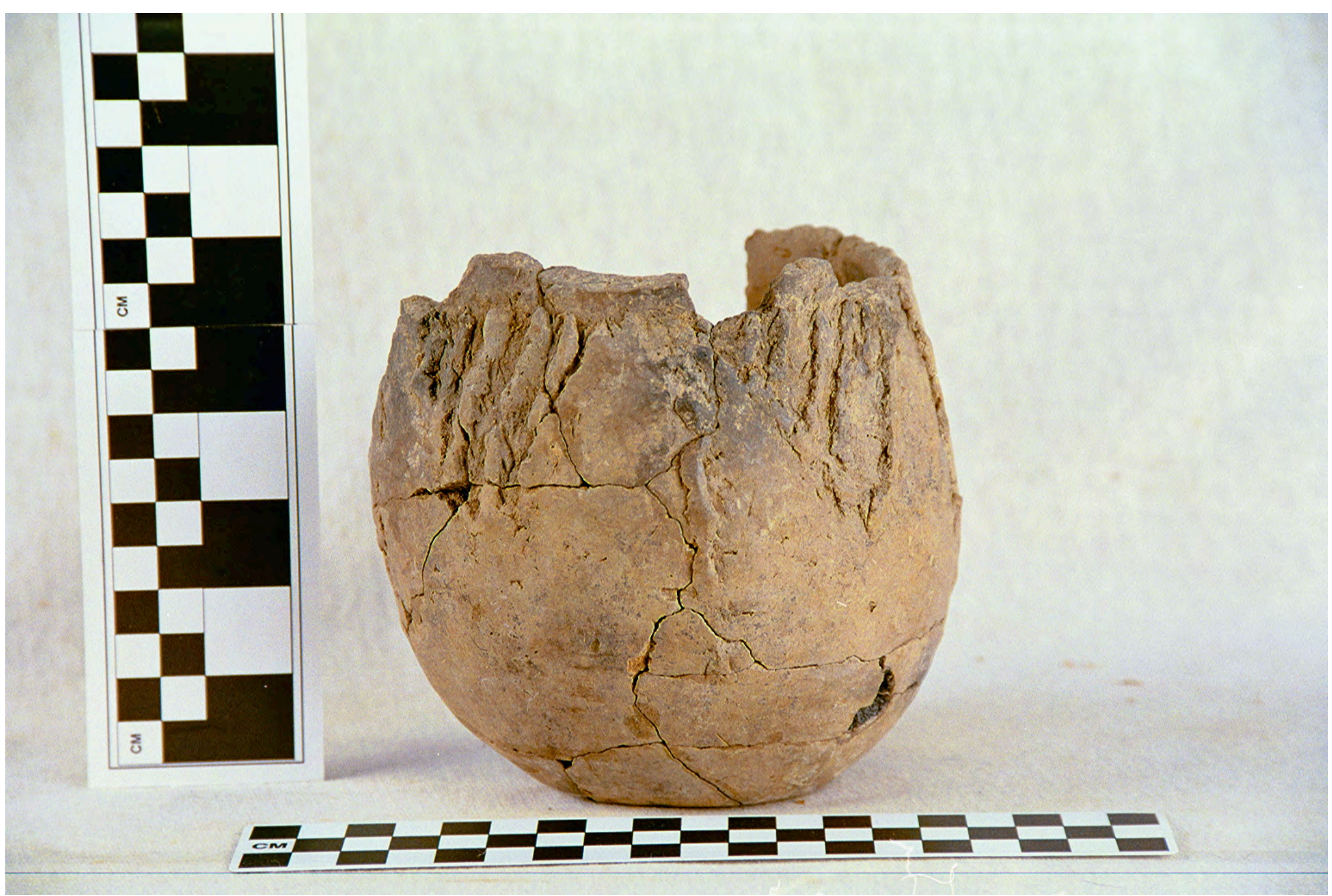

Figure 140 


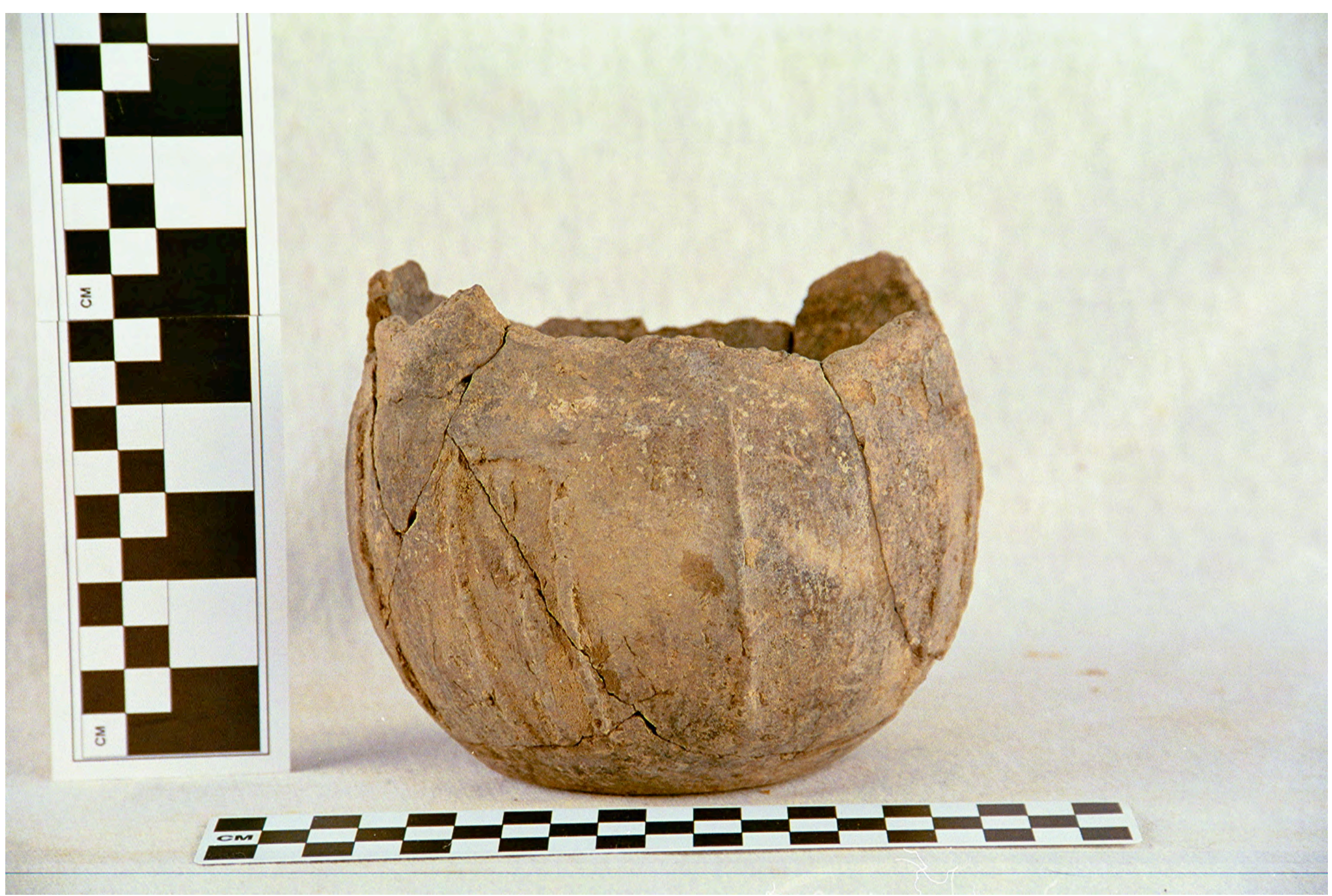

Figure 141 


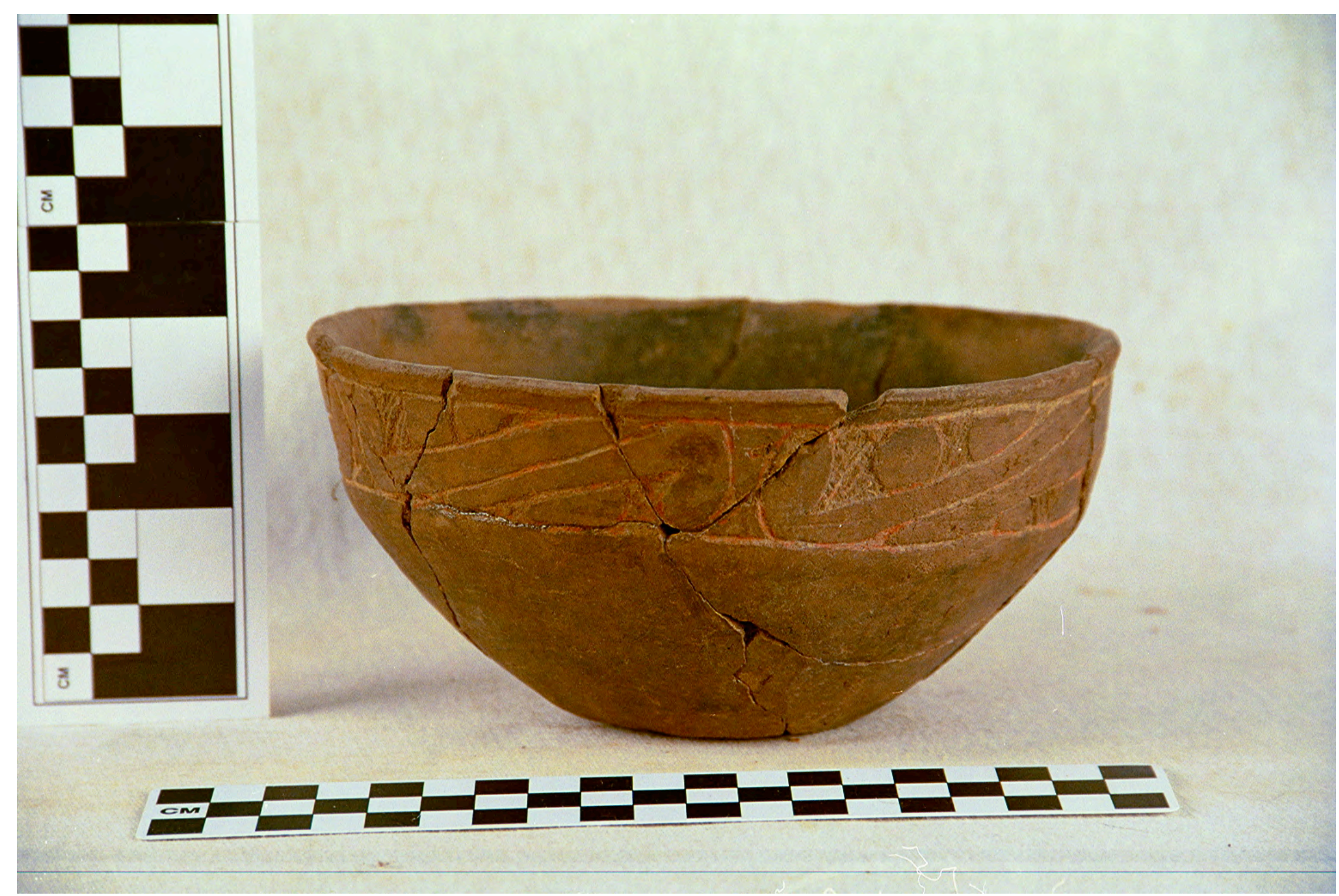

Figure 142 


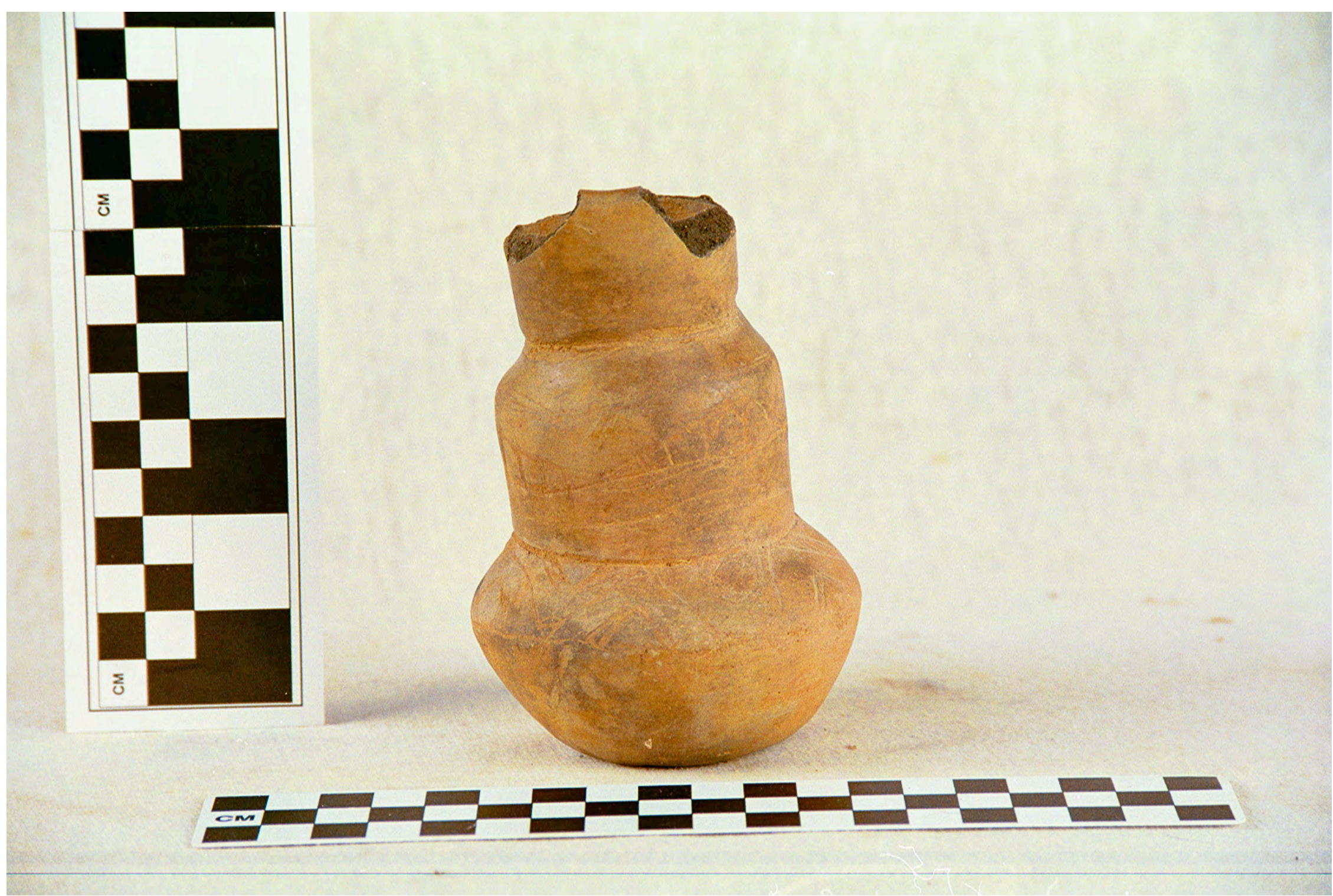

Figure 143 

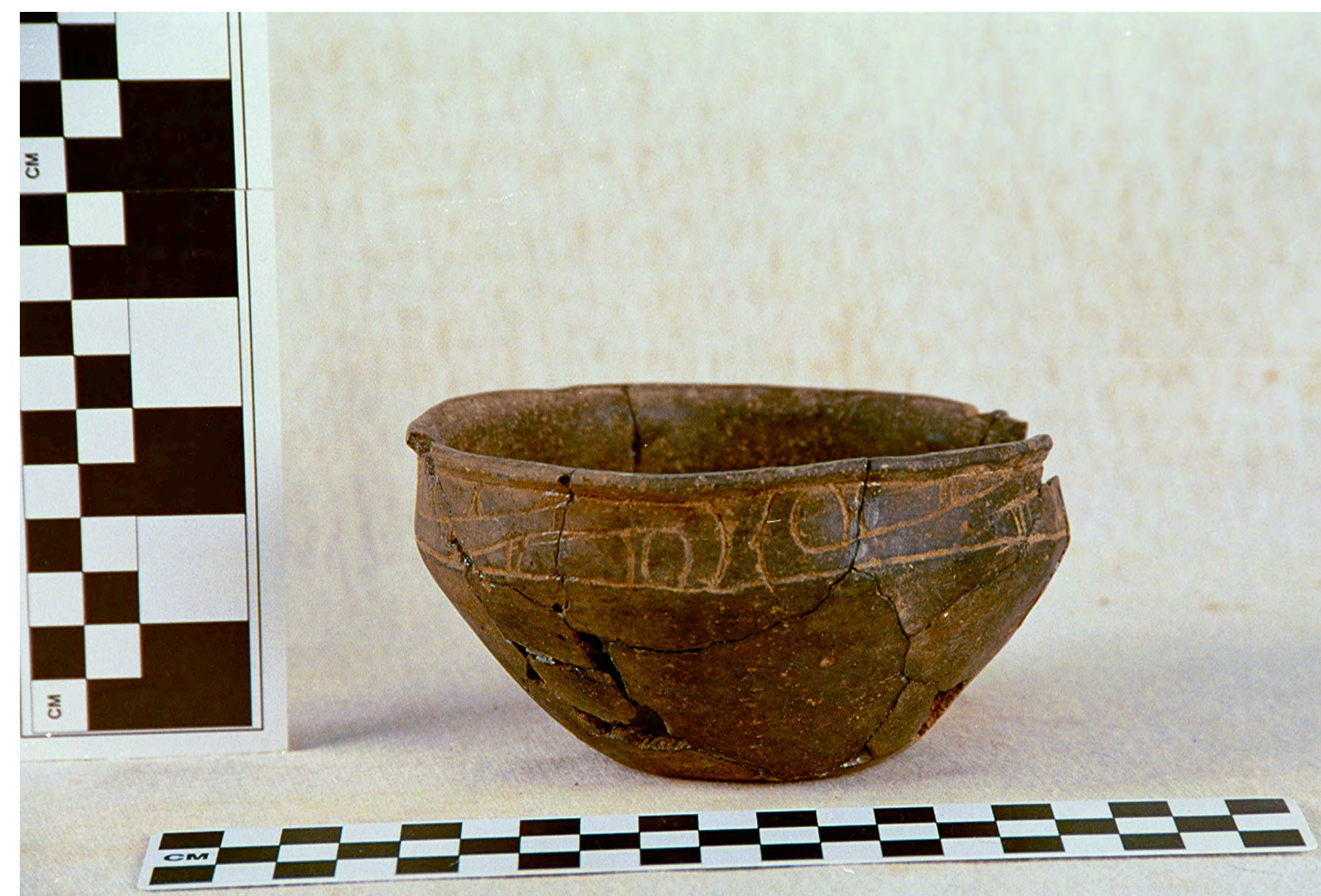

Figure 144 


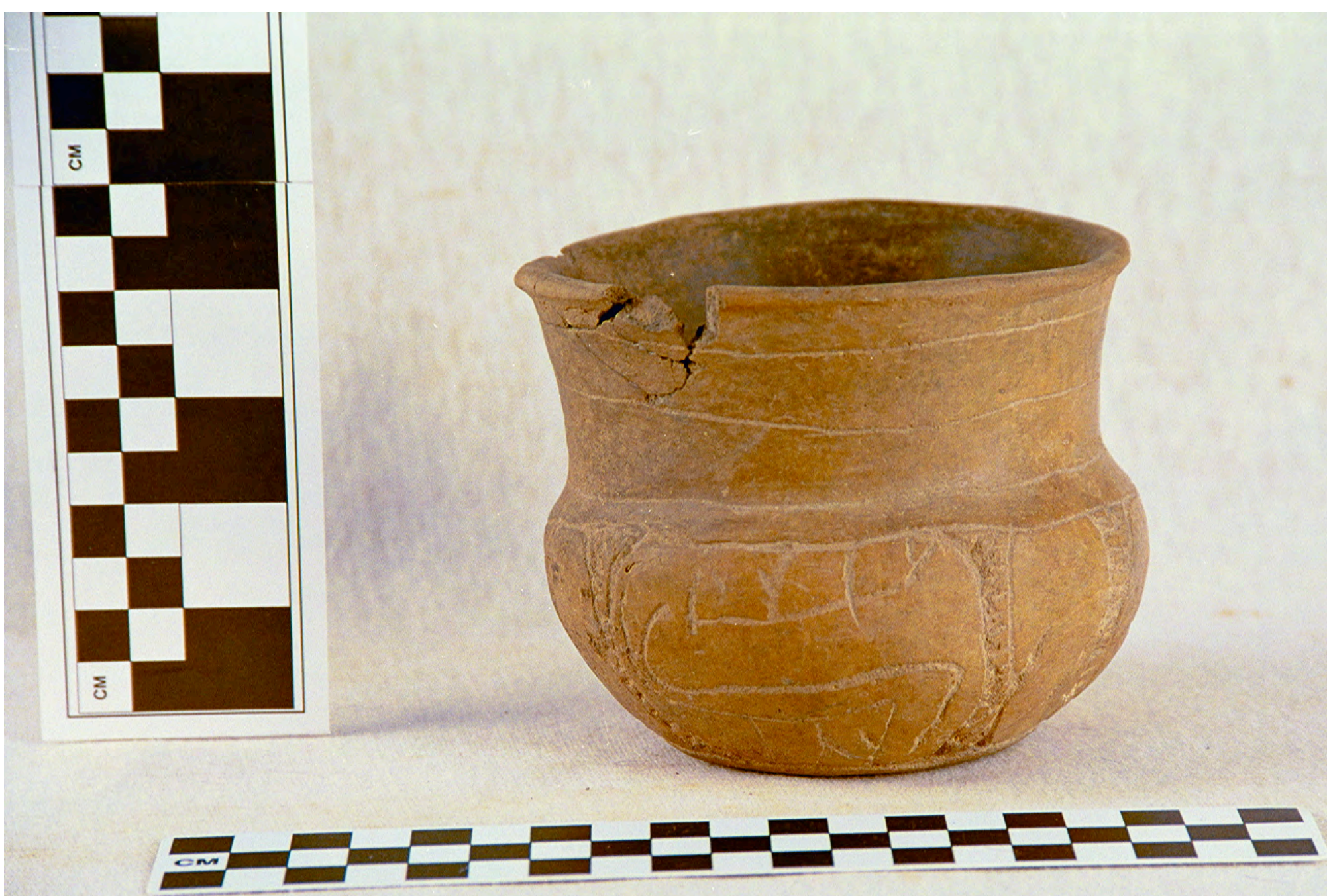

Figure 145 


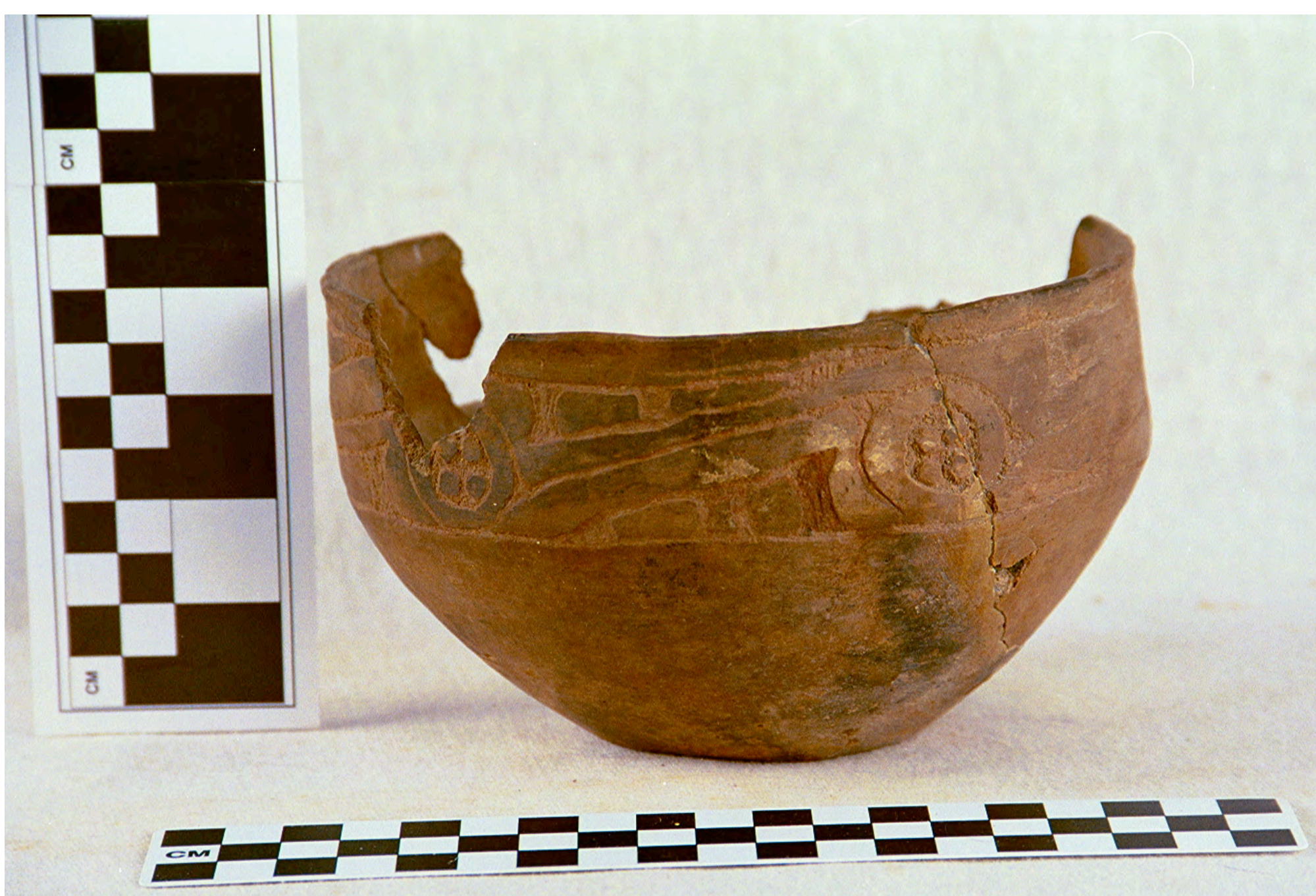

Figure 146 


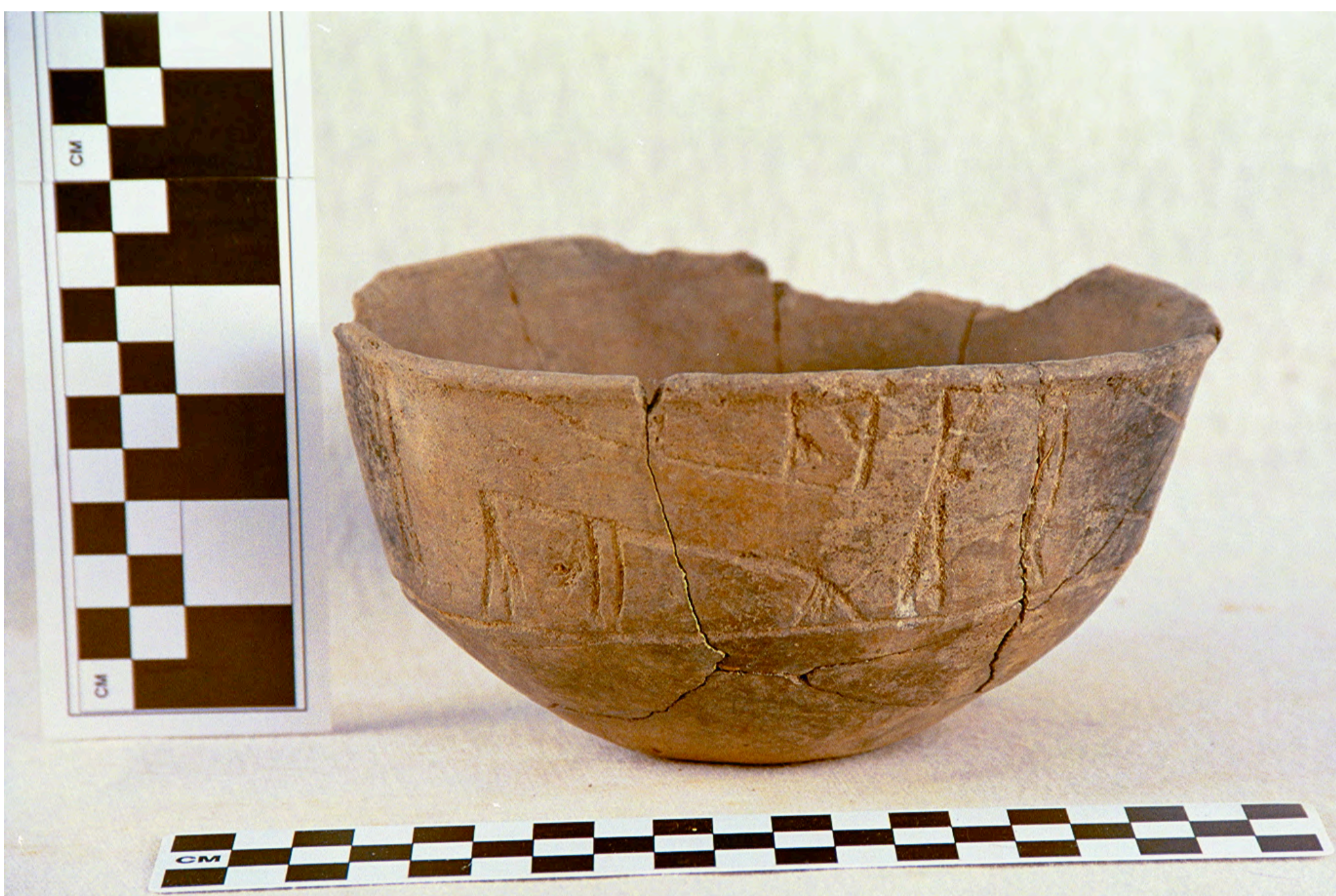

Figure 147 


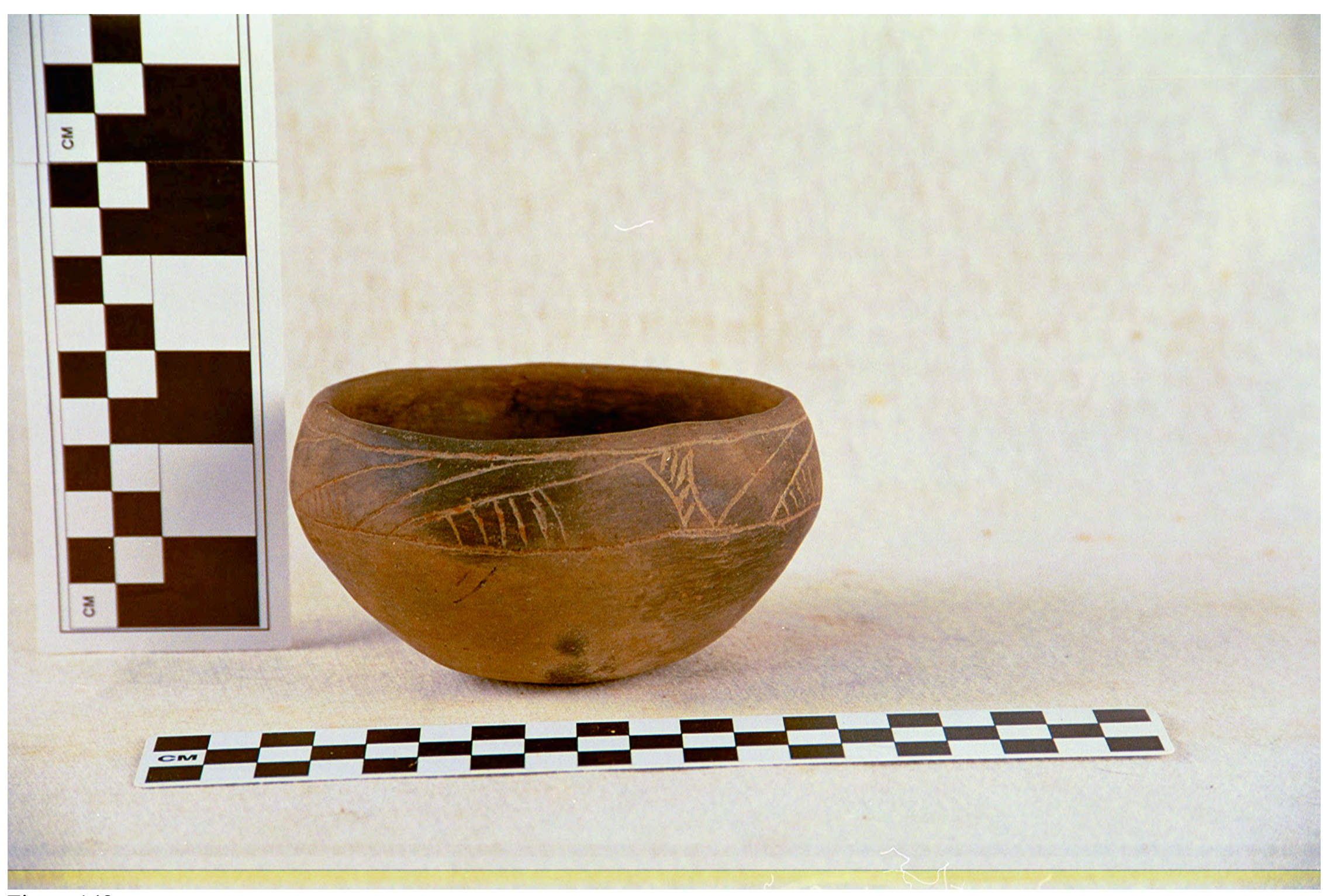

Figure 148 


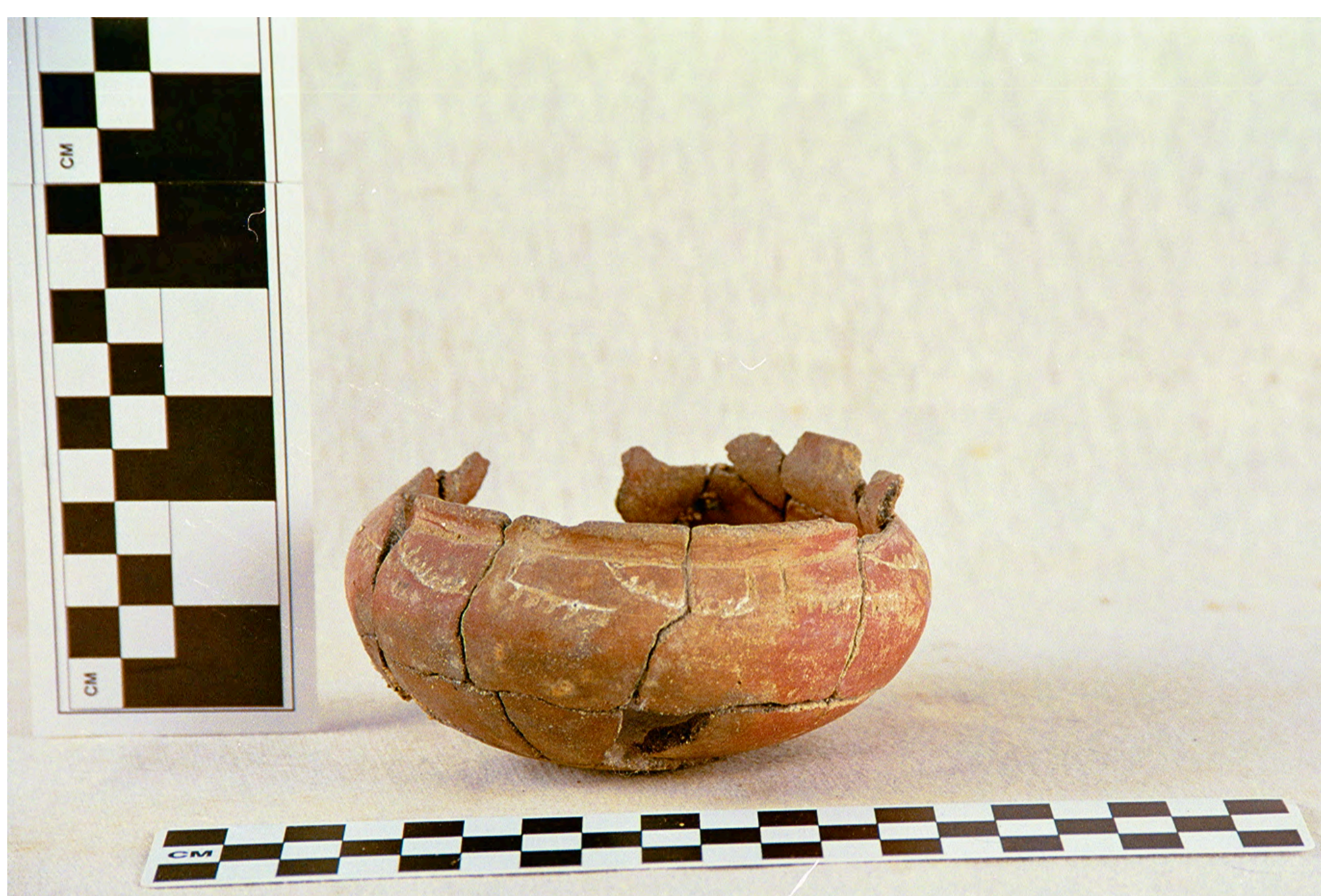

Figure 149 


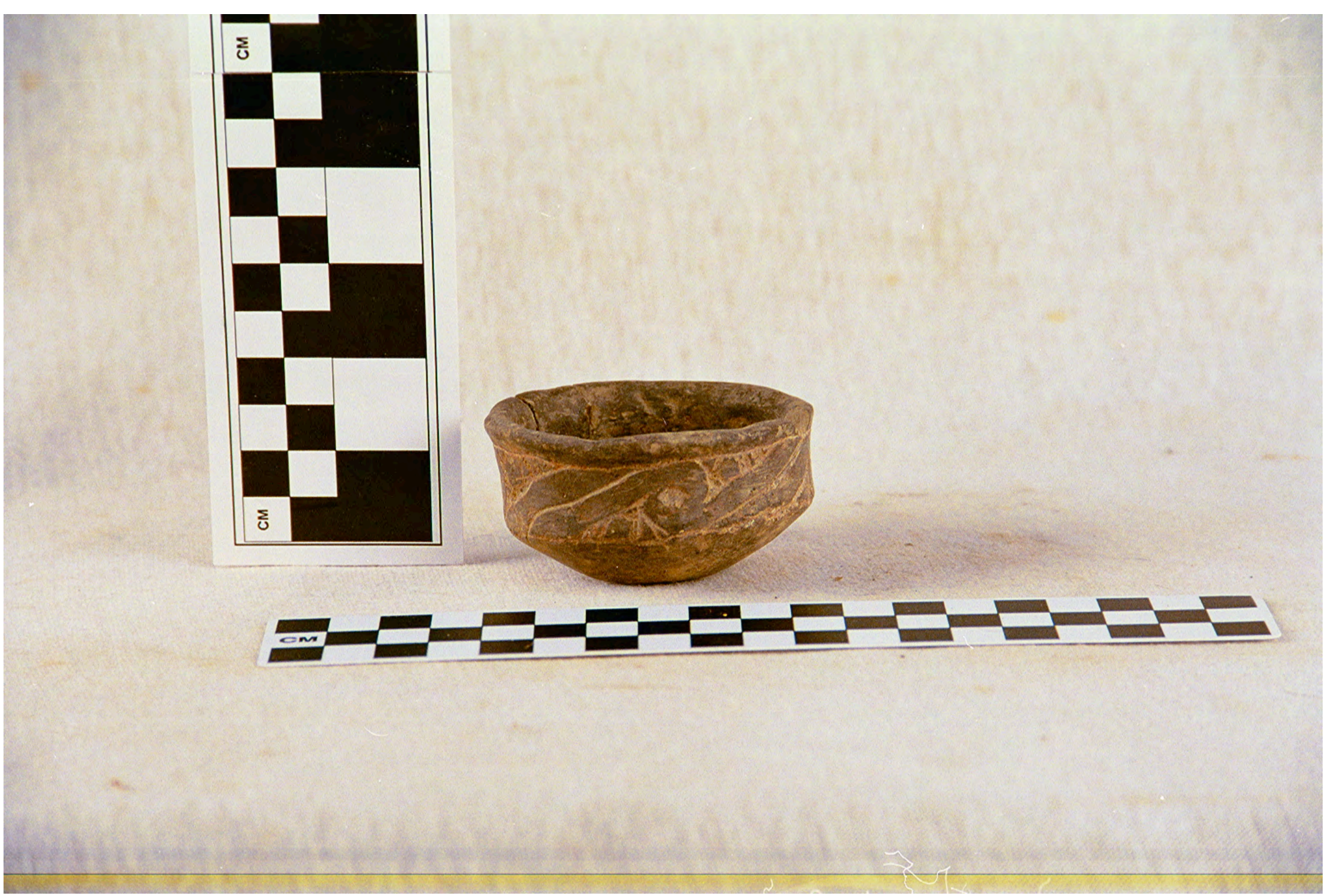

Figure 150 


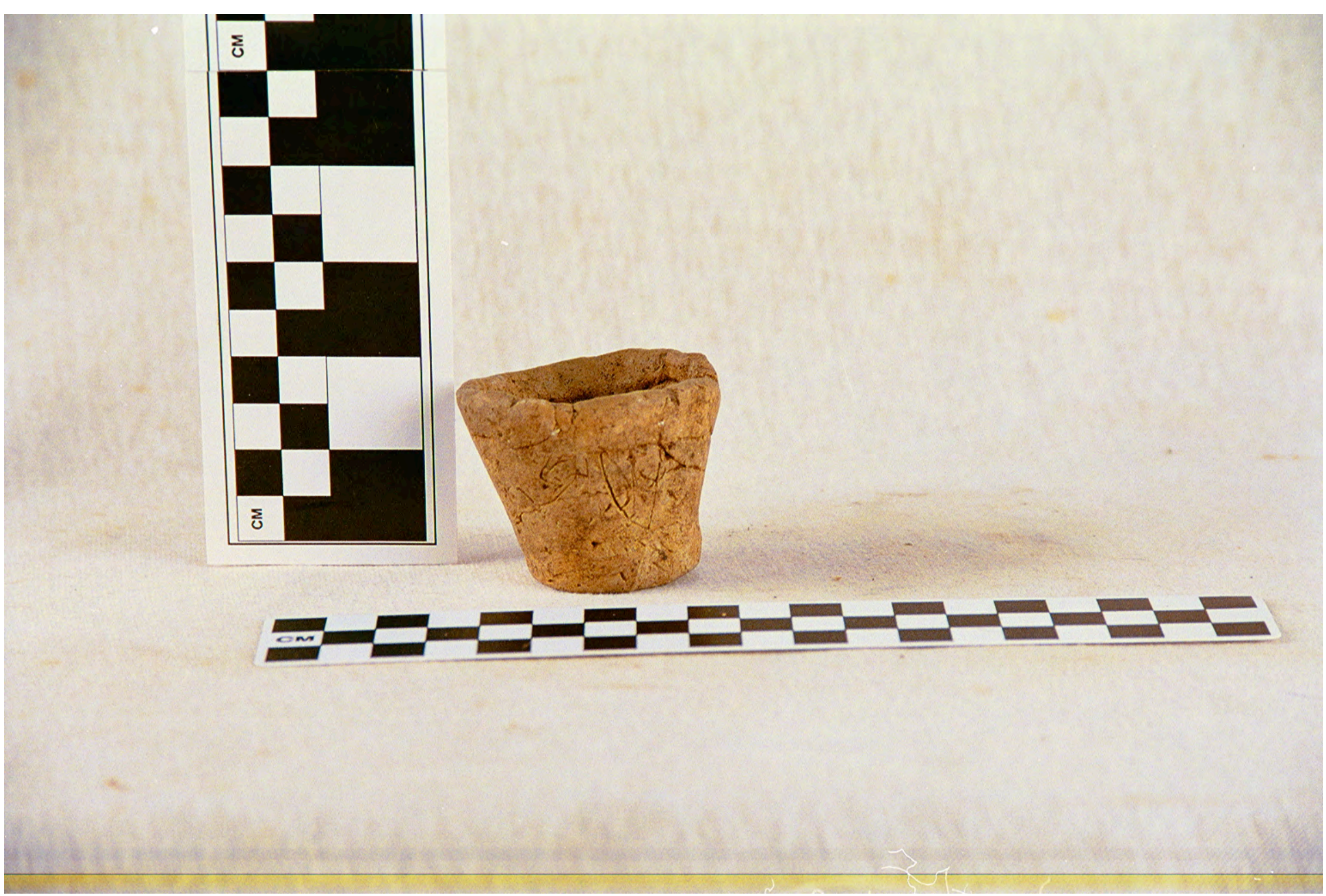

Figure 151 


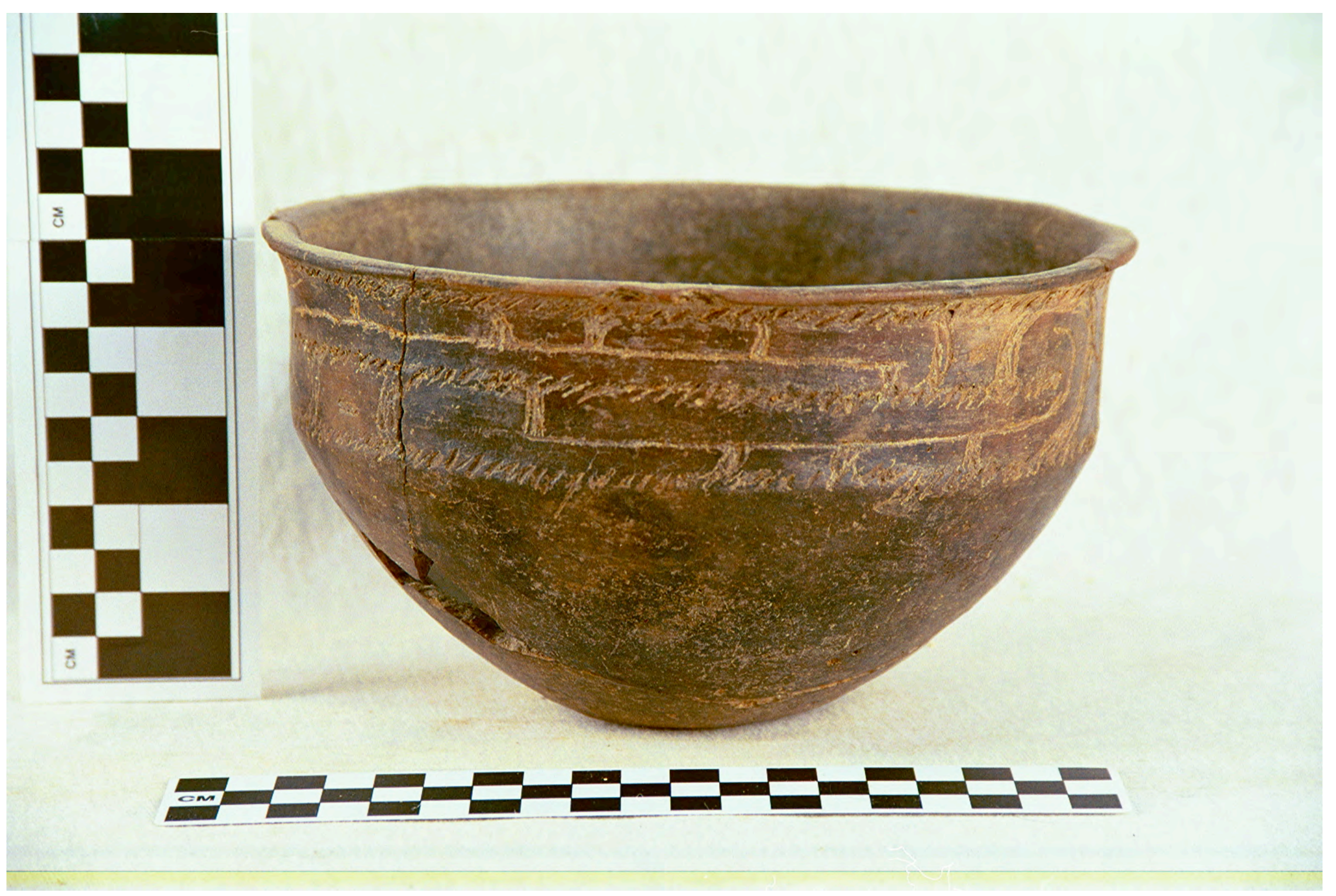

Figure 152 


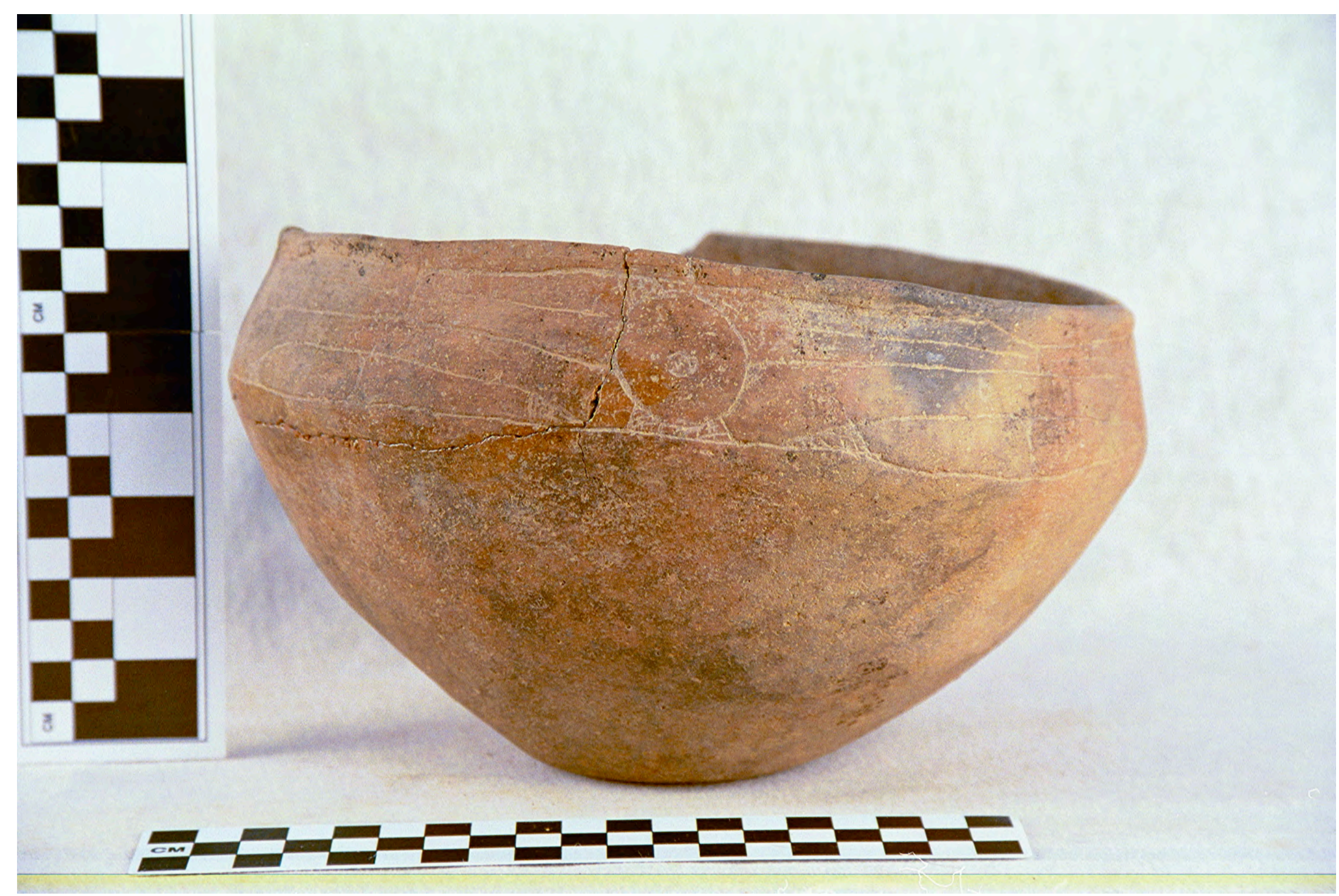

Figure 153 


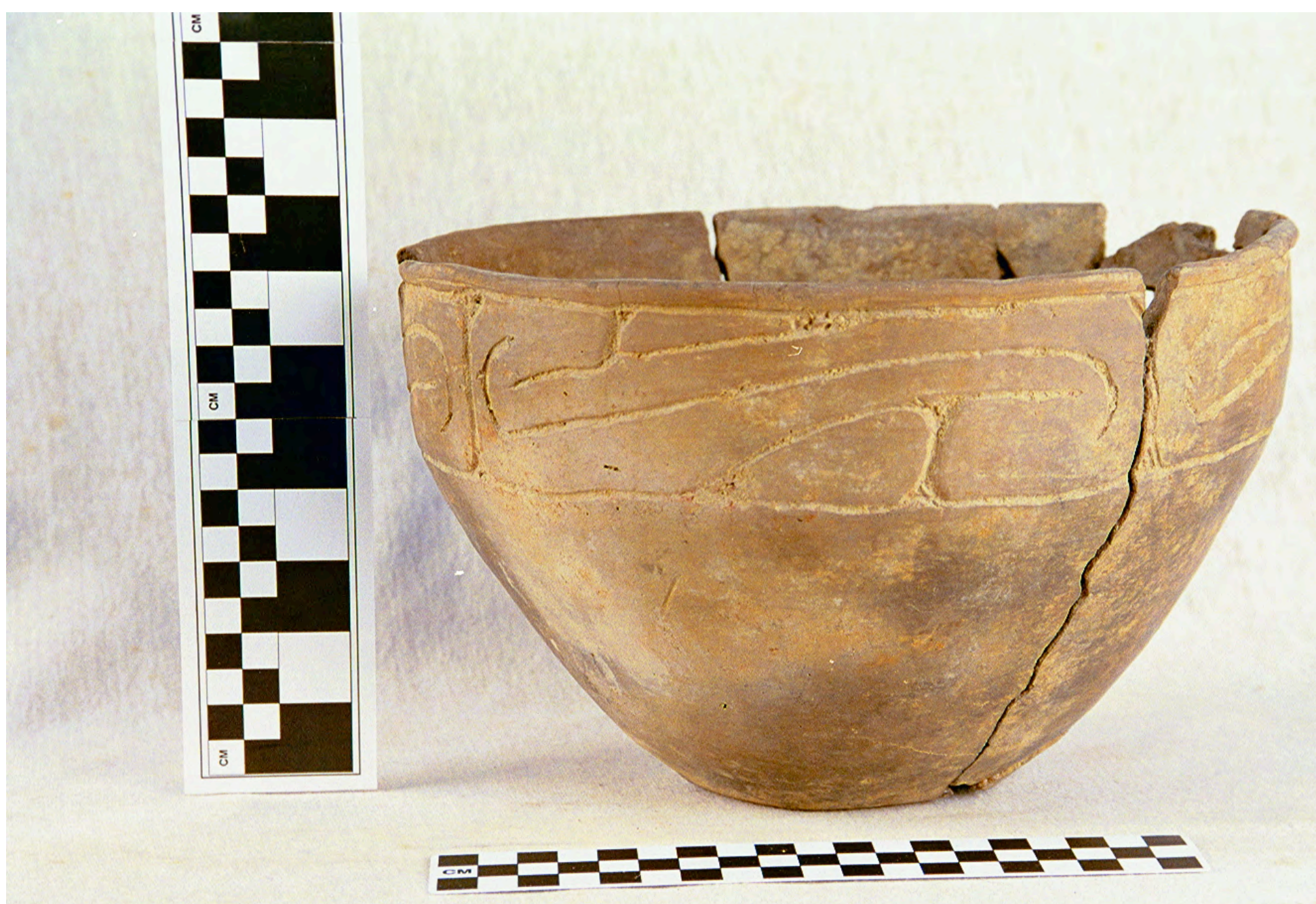

Figure 154 

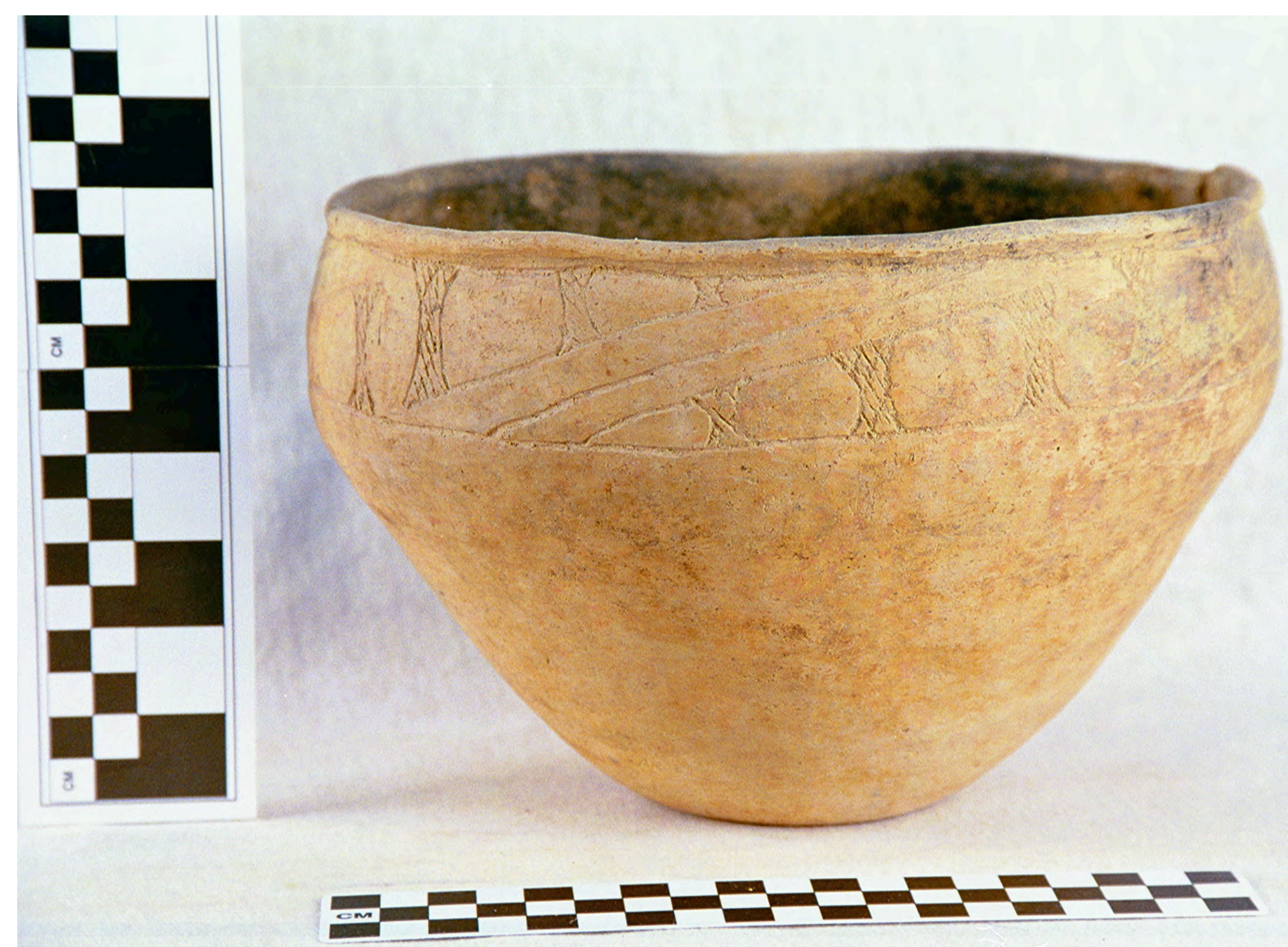

Figure 155 


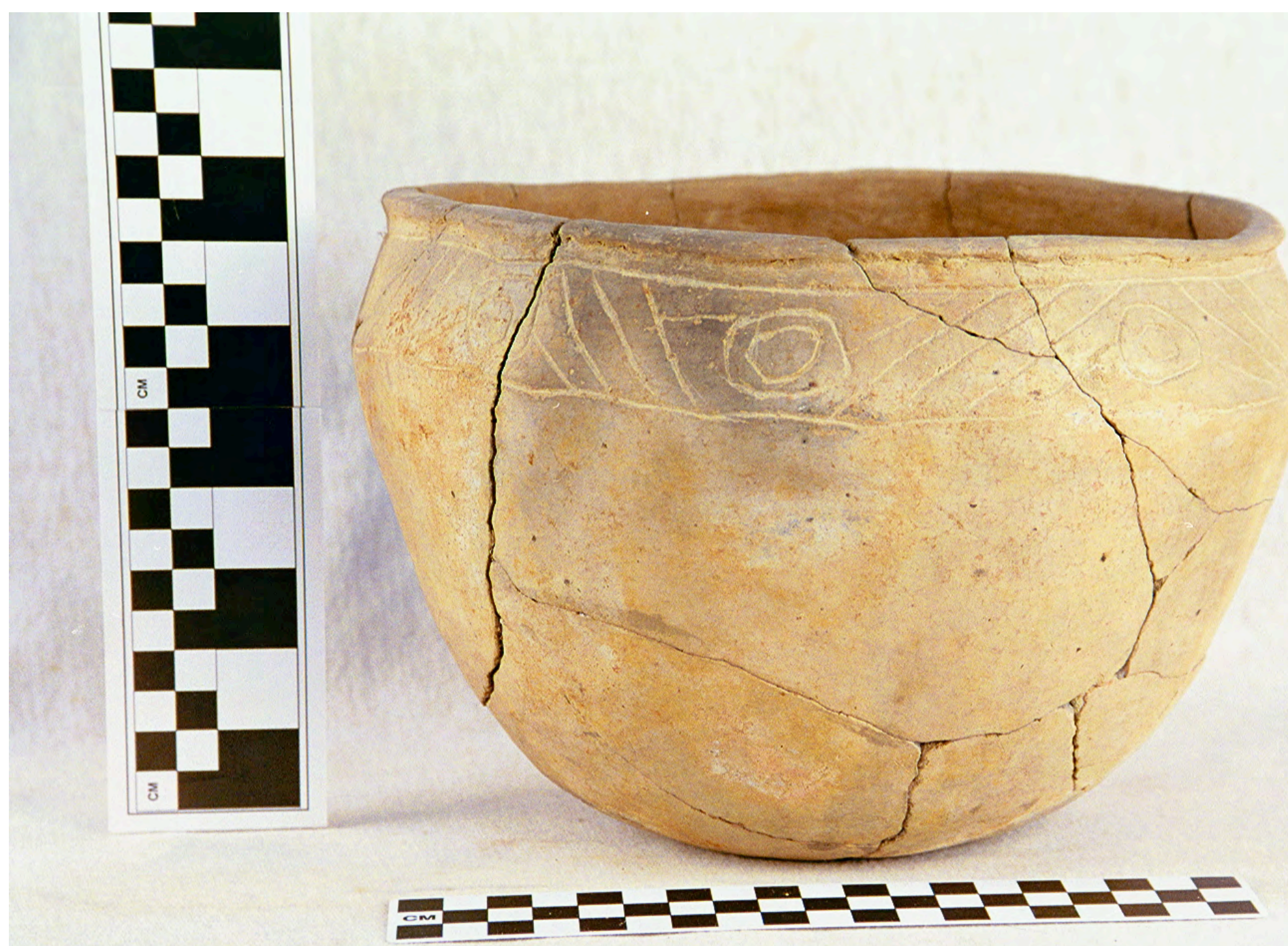

Figure 156 


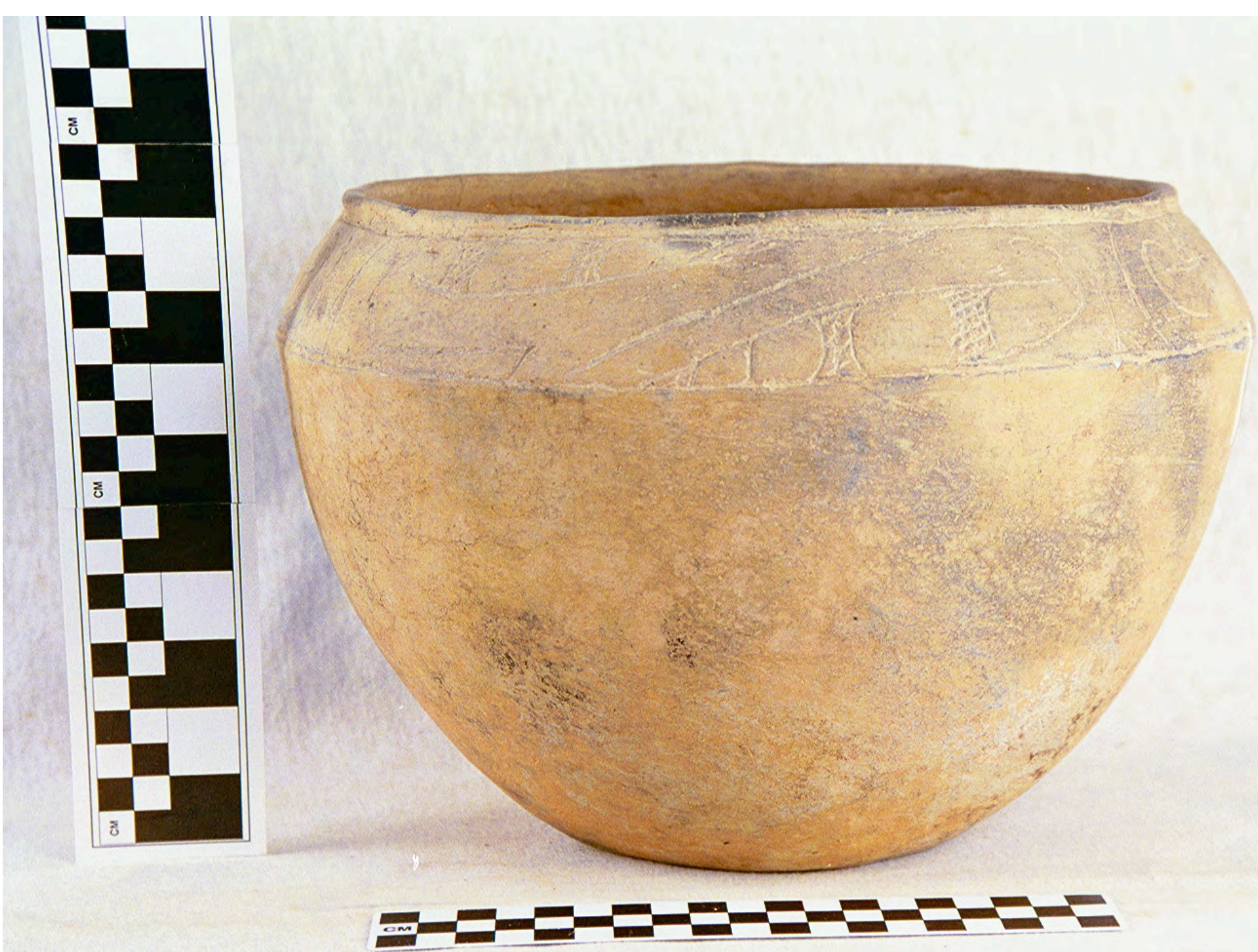

Figure 157 


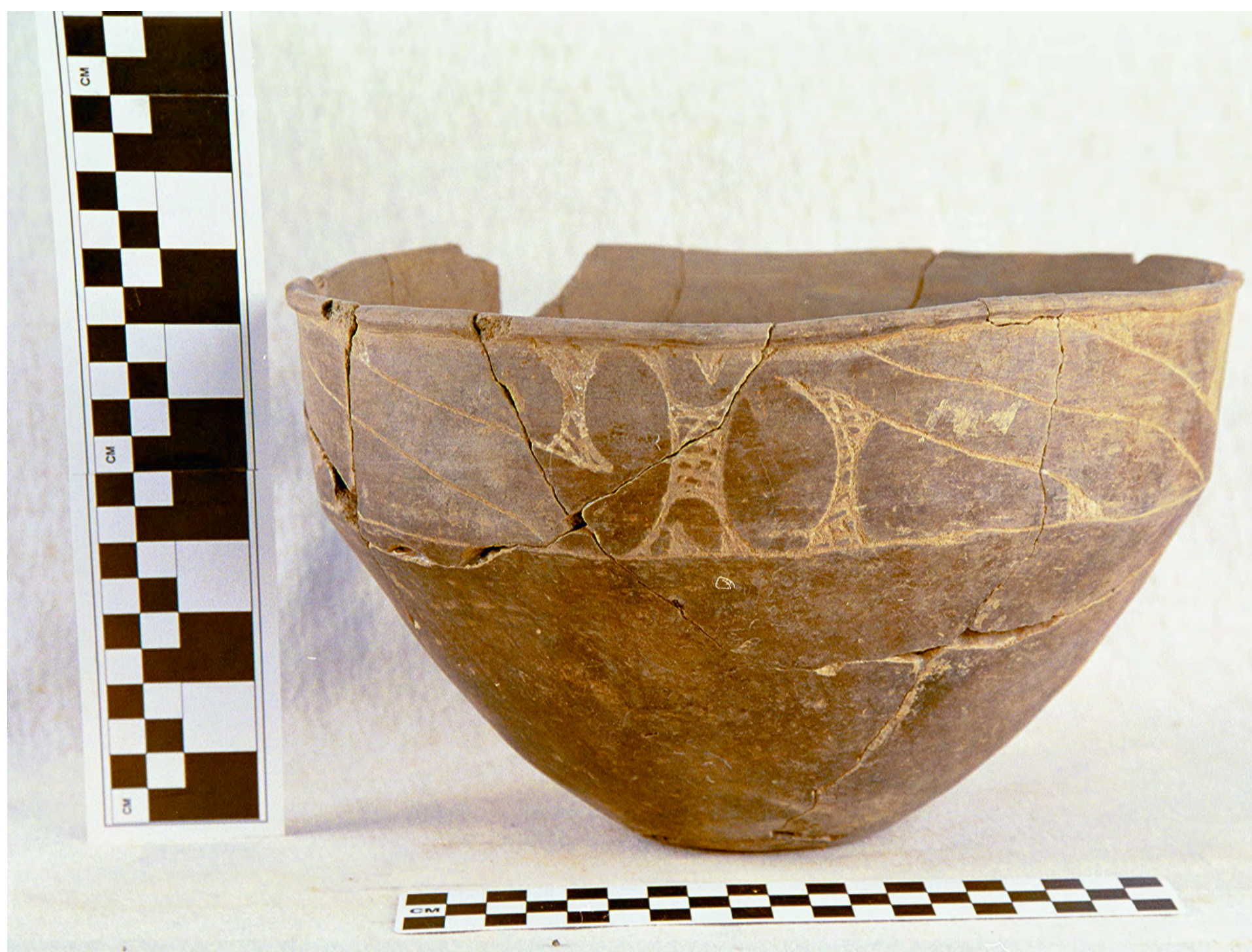

Figure 158 

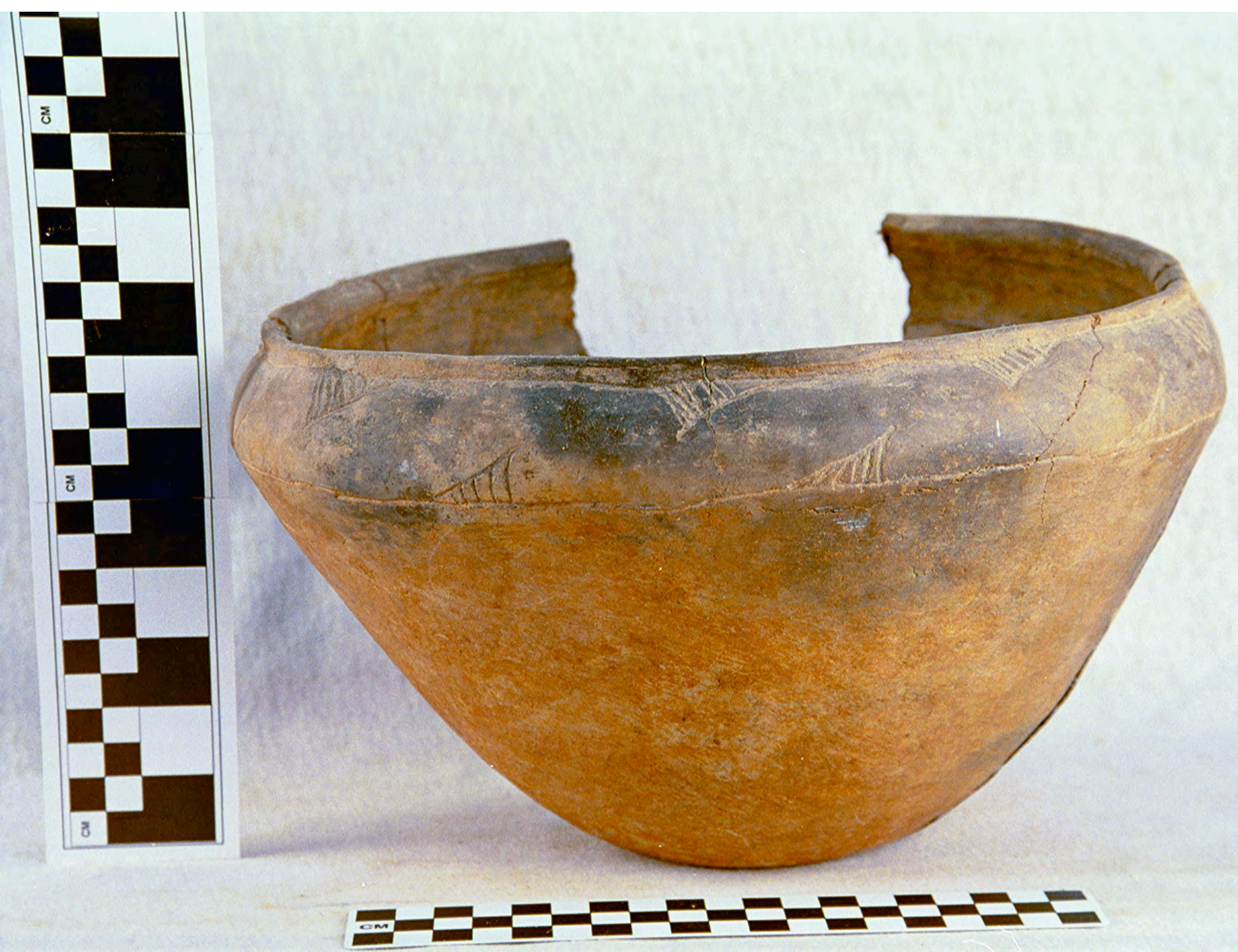

Figure 159 


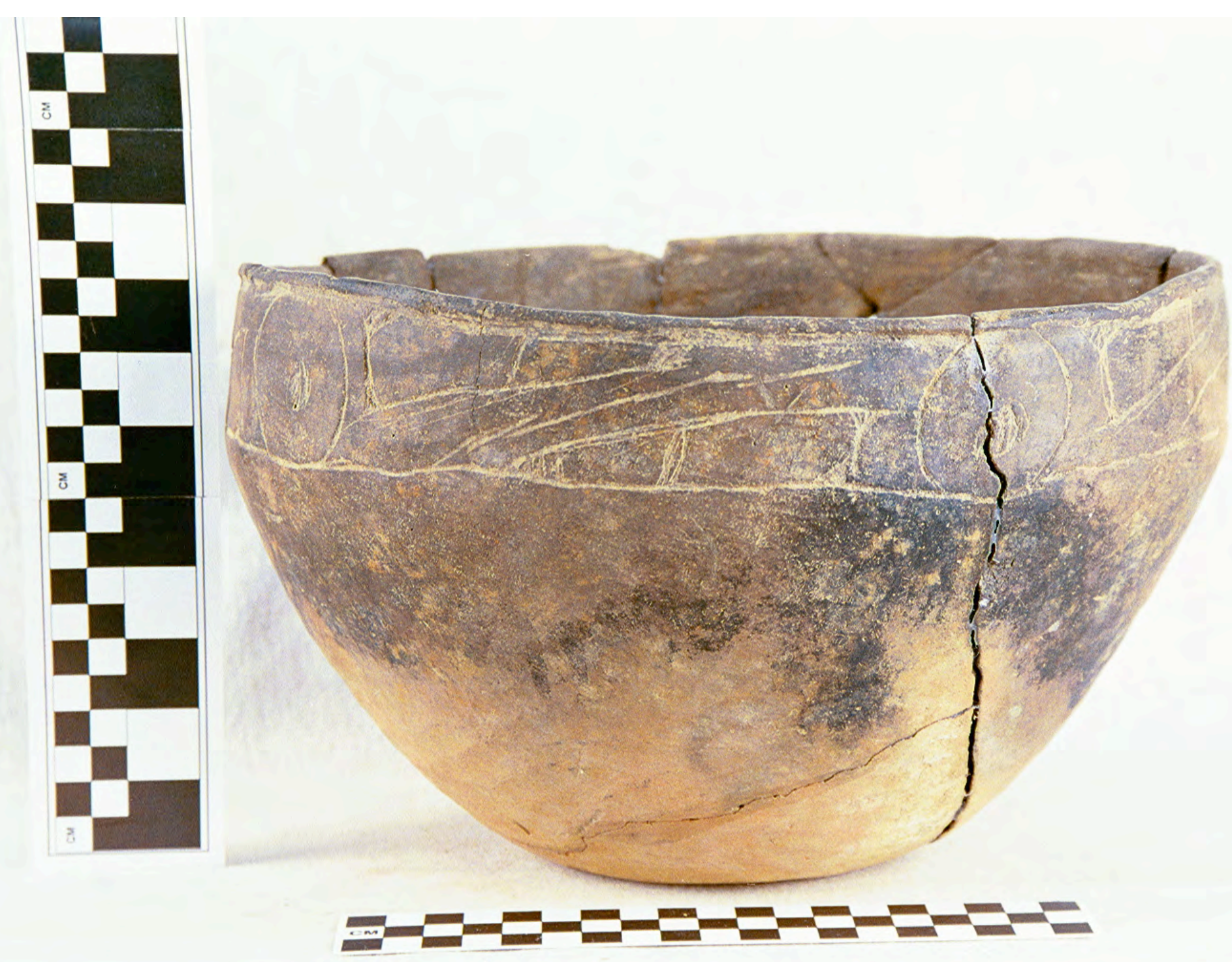

Figure 160 


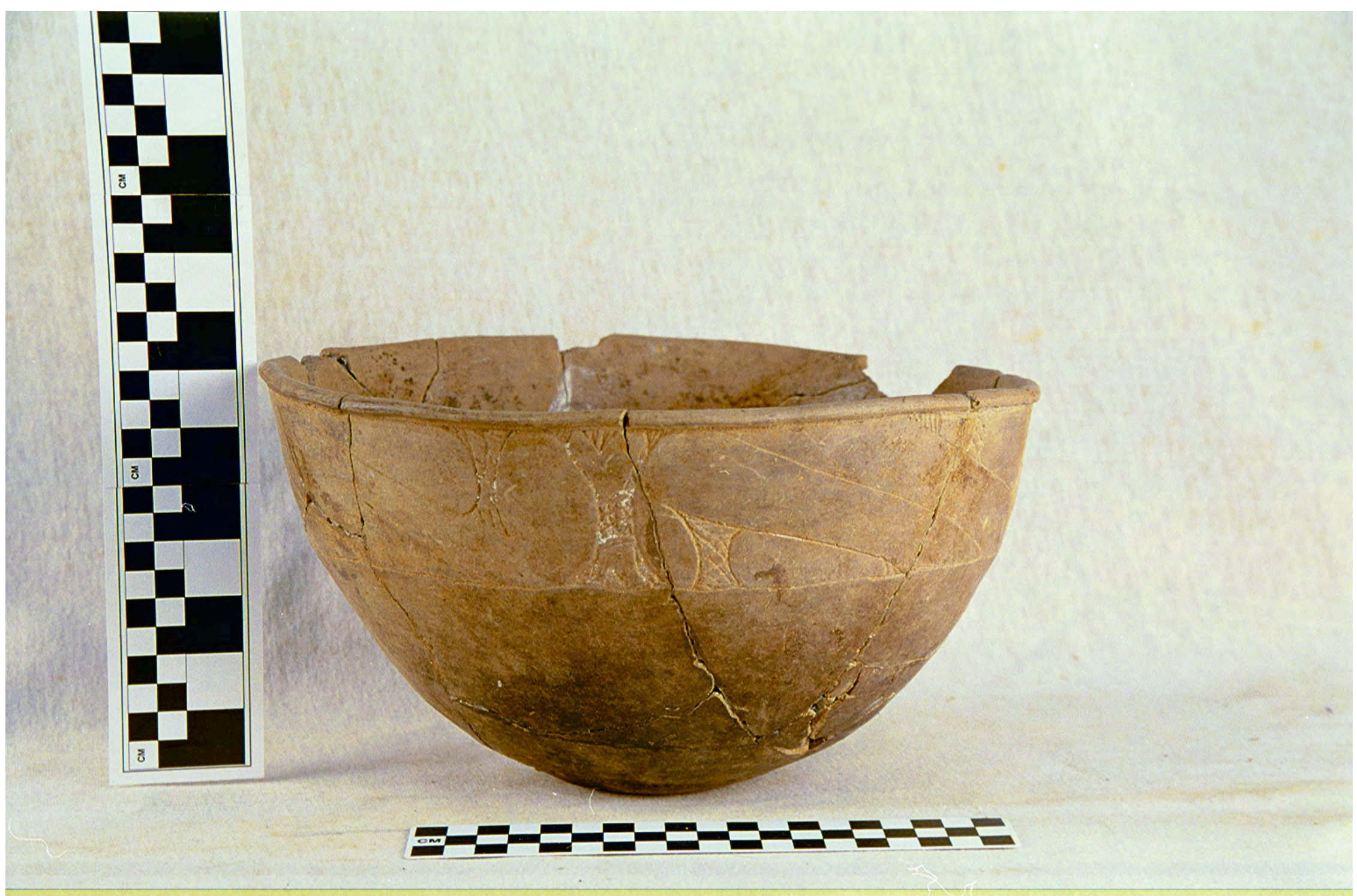

Figure 161 


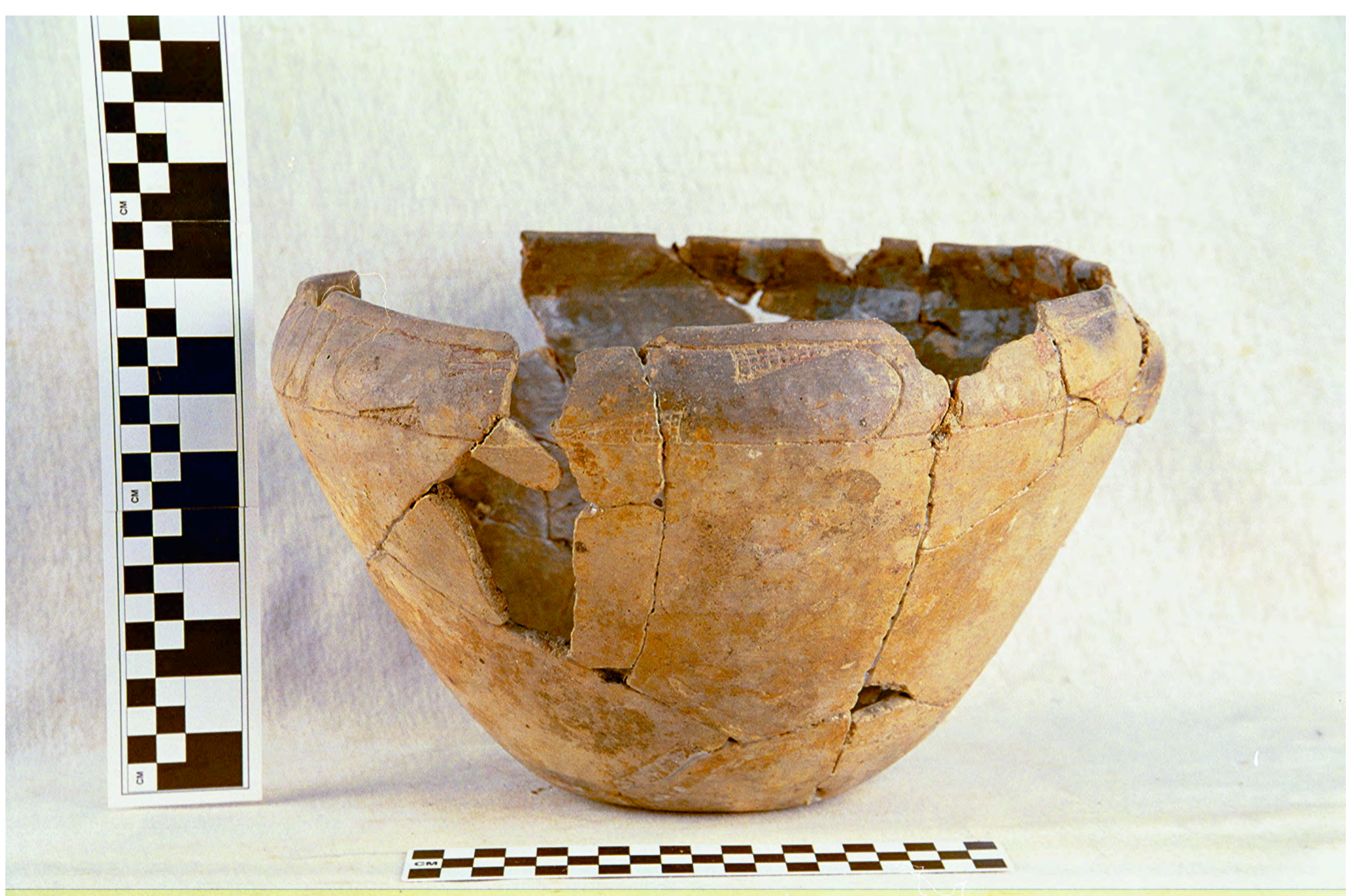

Figure 162 


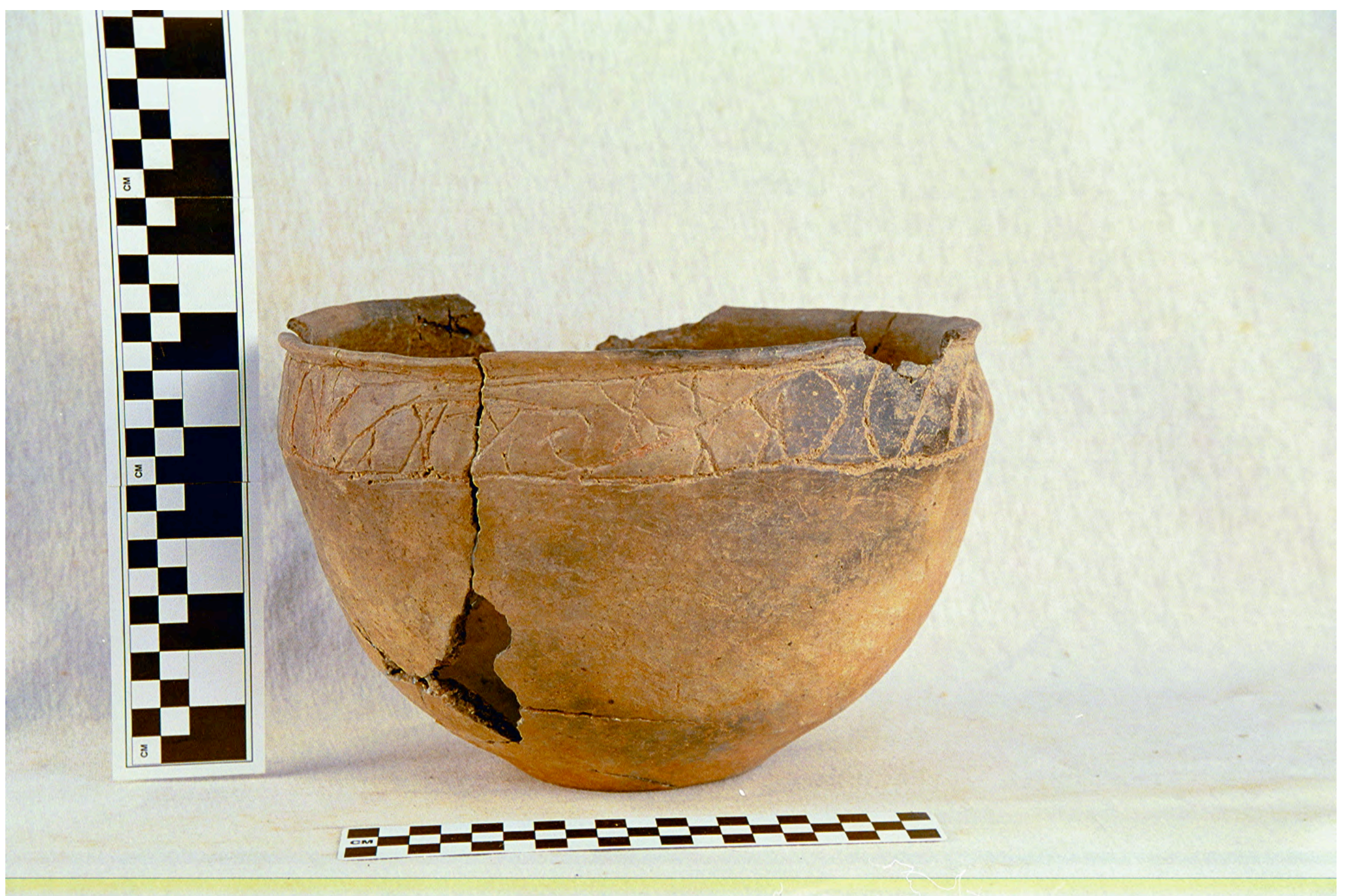

Figure 163 


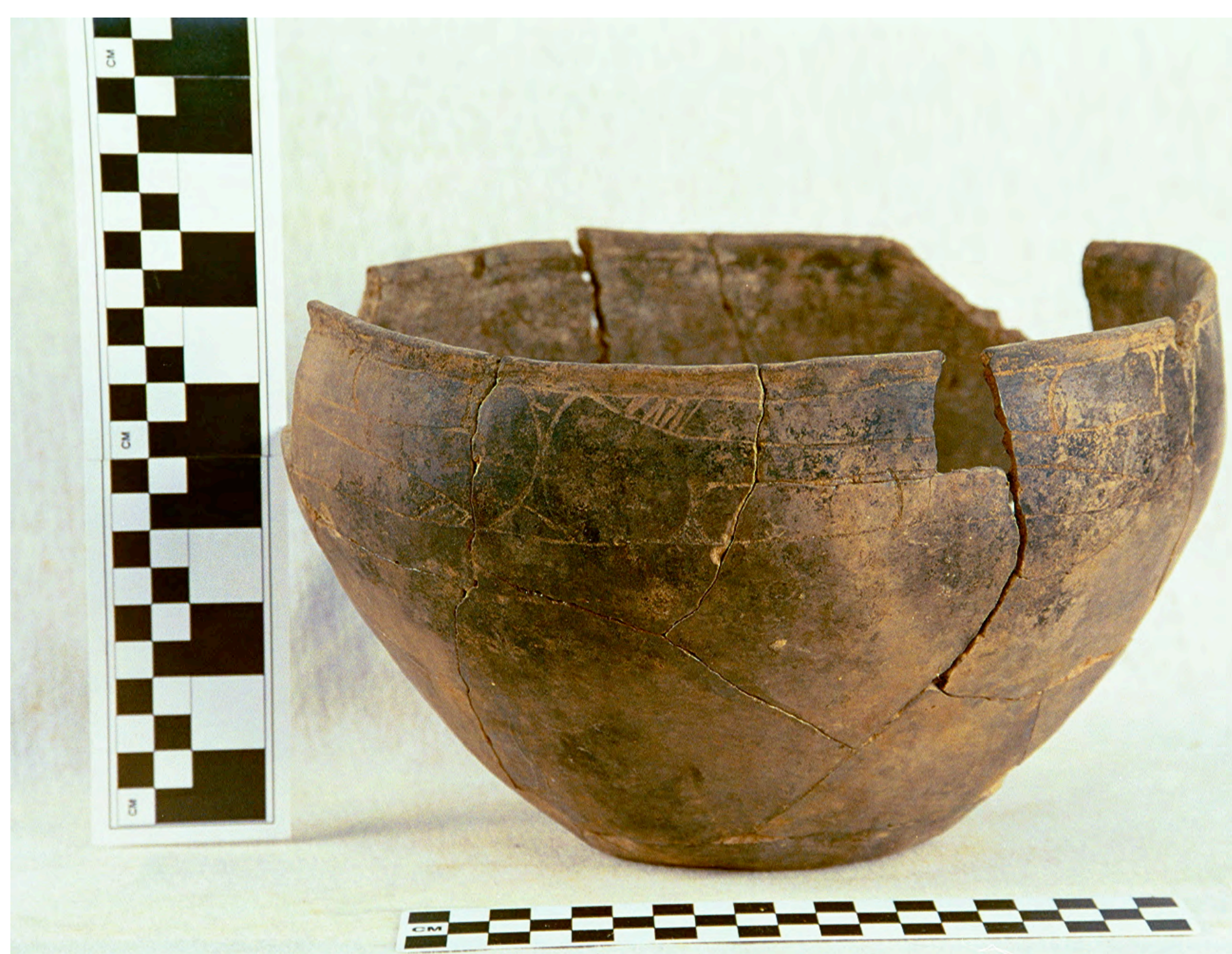

Figure 164 


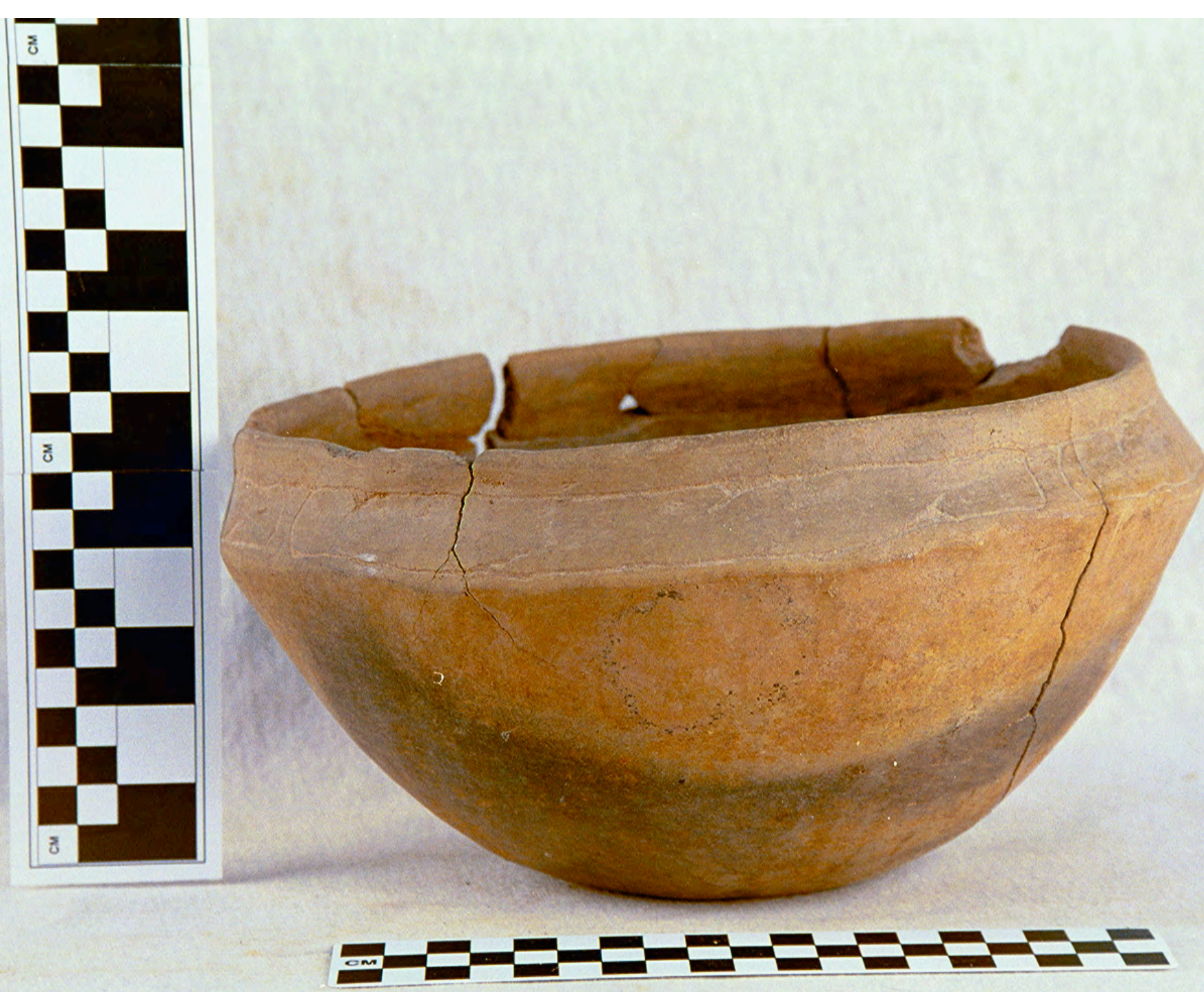

Figure 165 


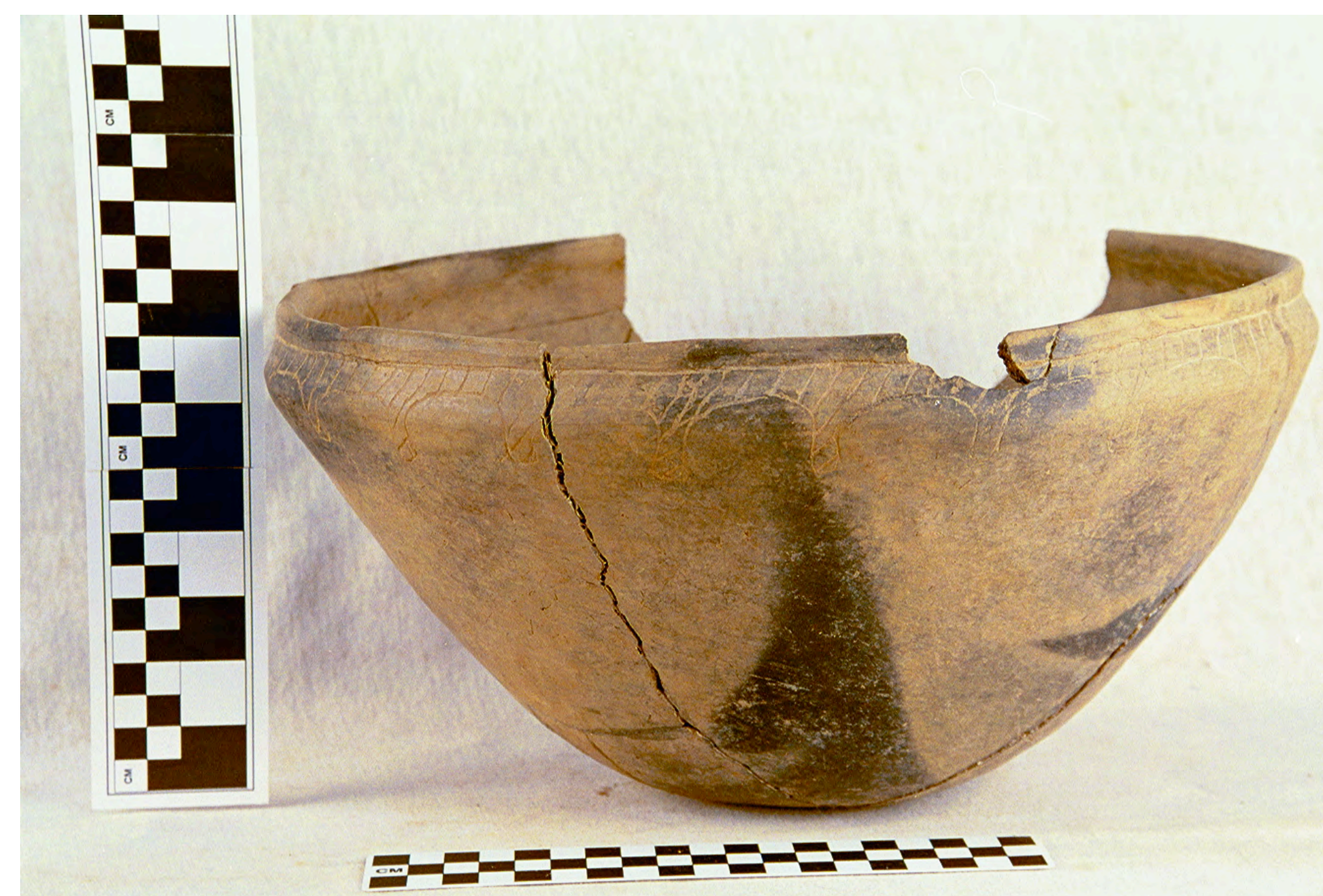

Figure 166 


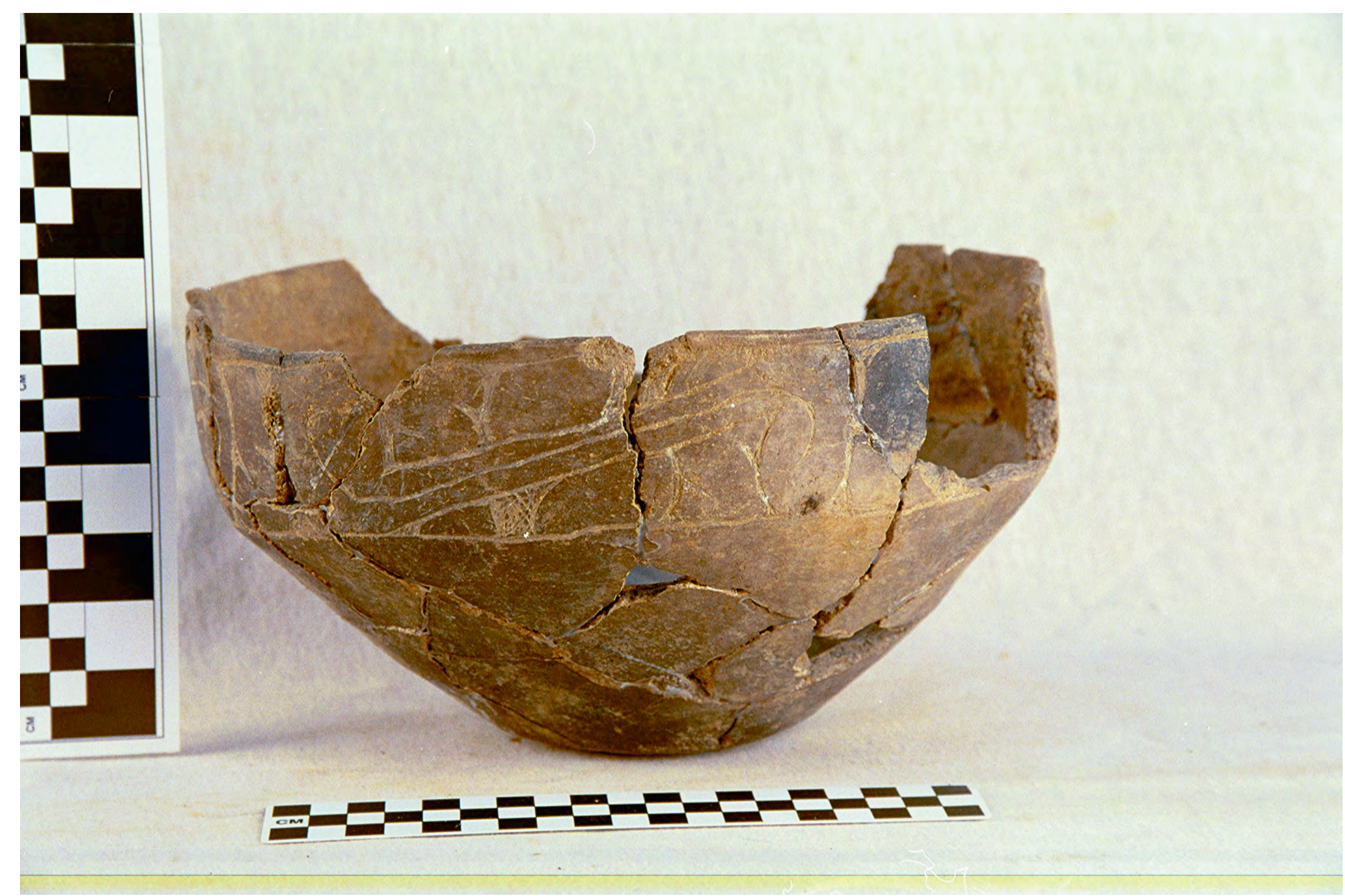

Figure 167 


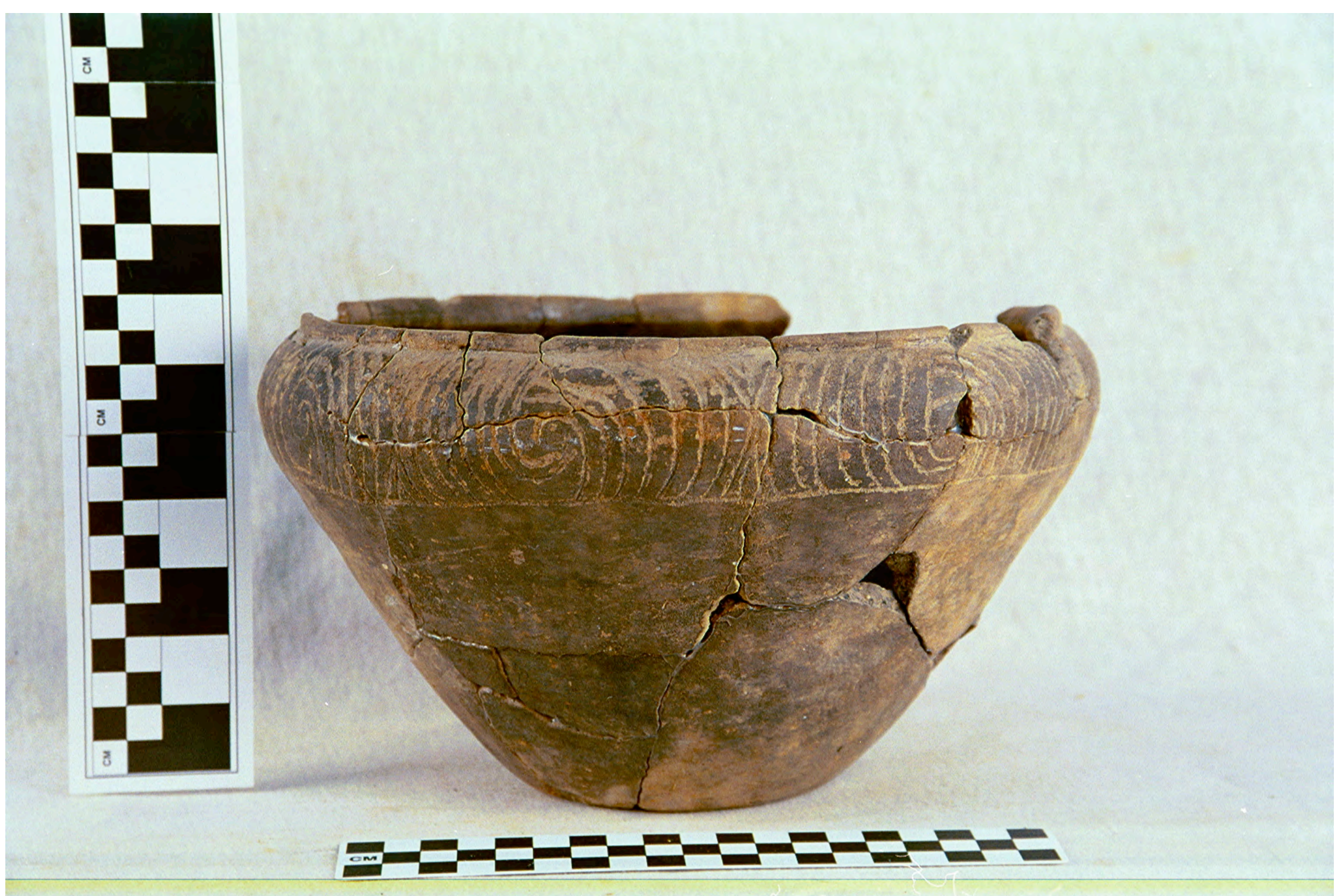

Figure 168 


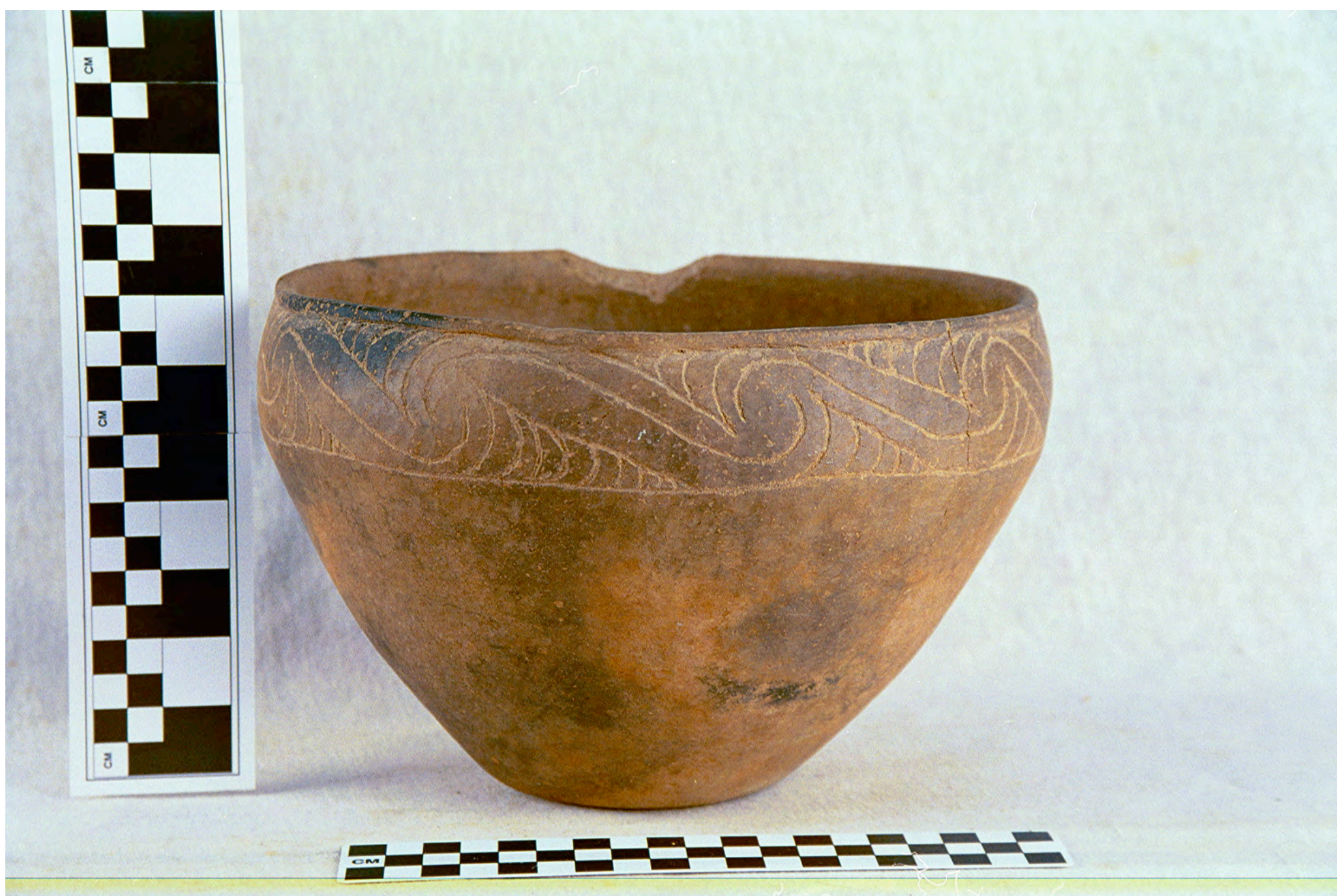

Figure 169 

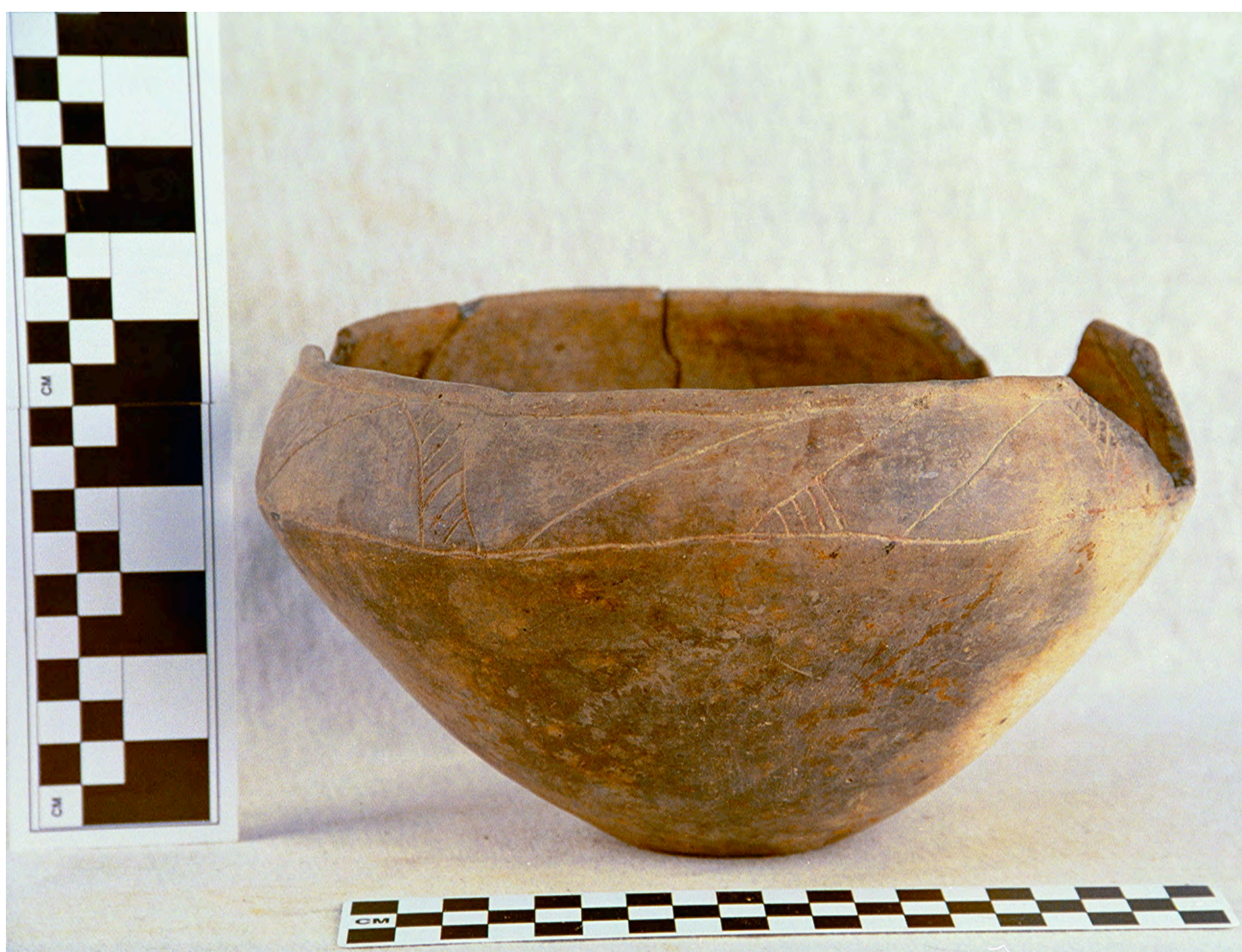

Figure 170 


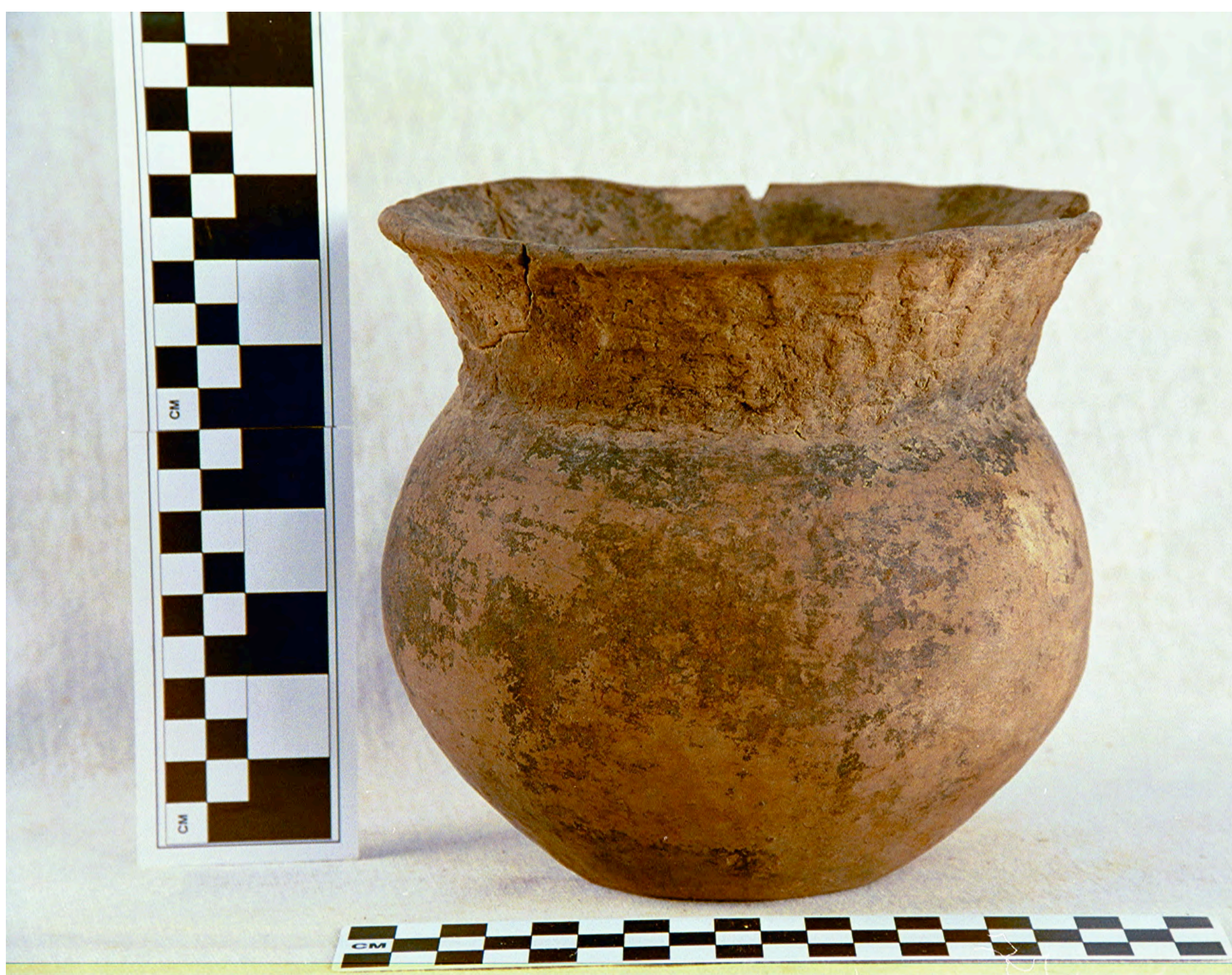

Figure 171 


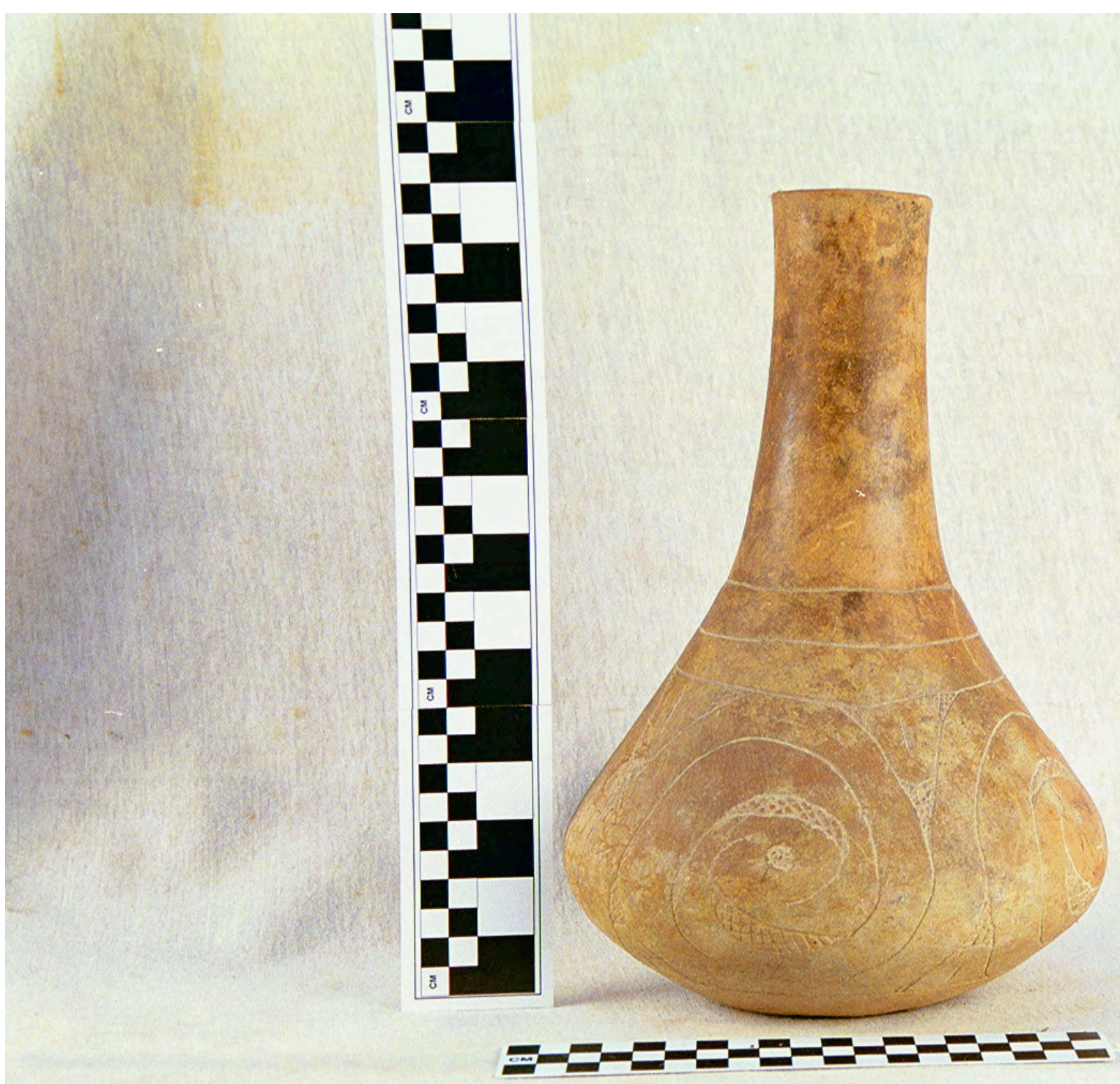

Figure 172 


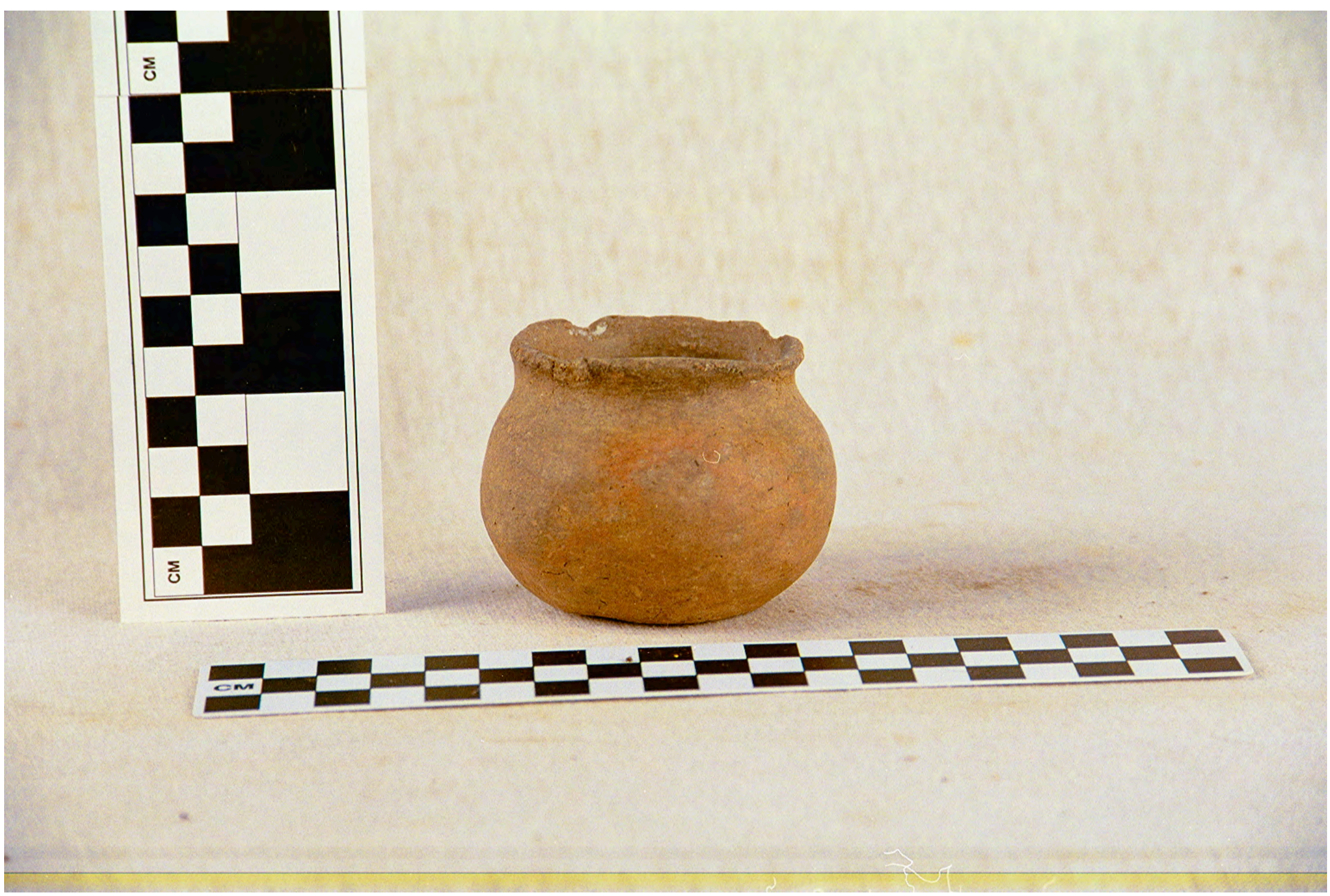

Figure 173 


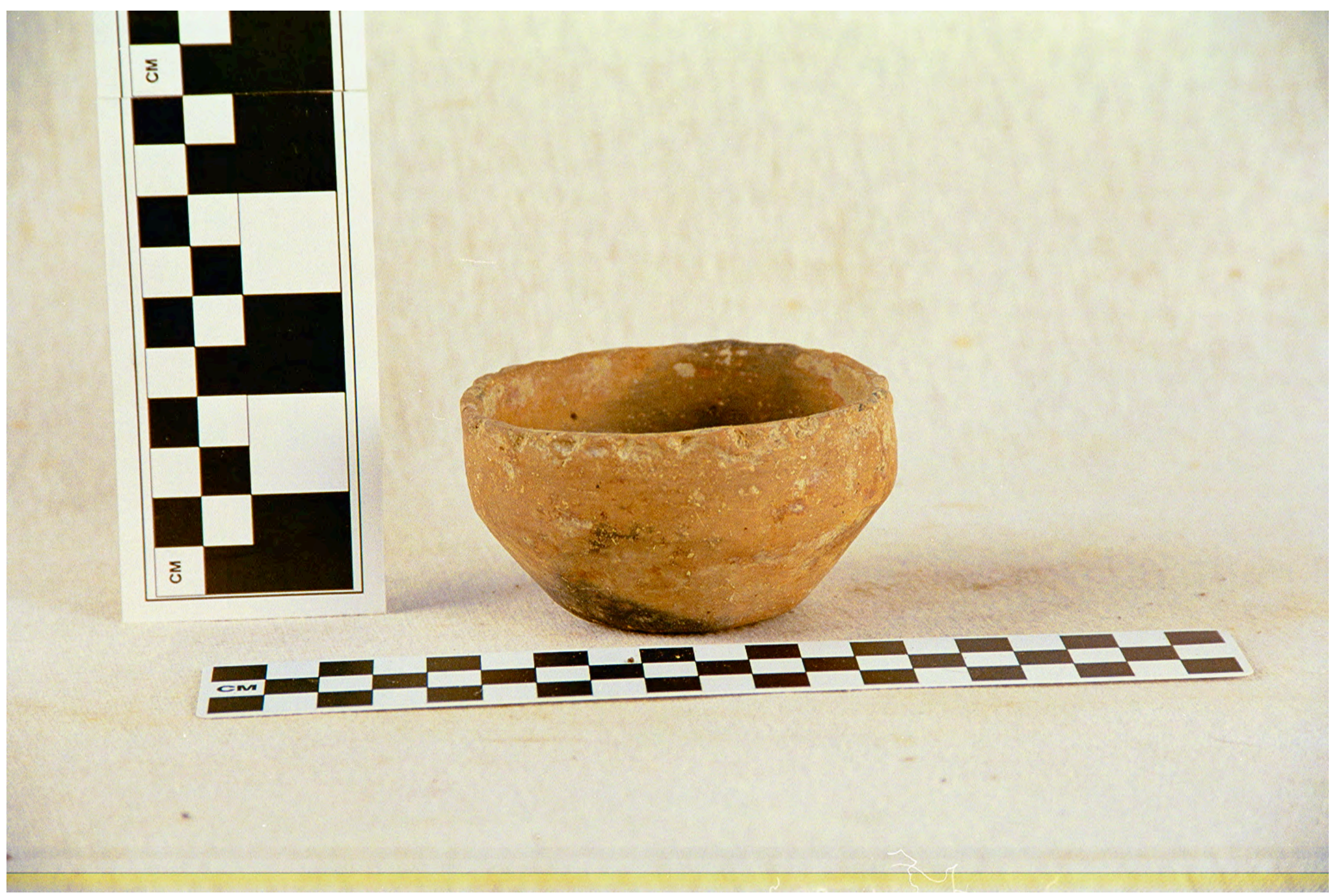

Figure 174 


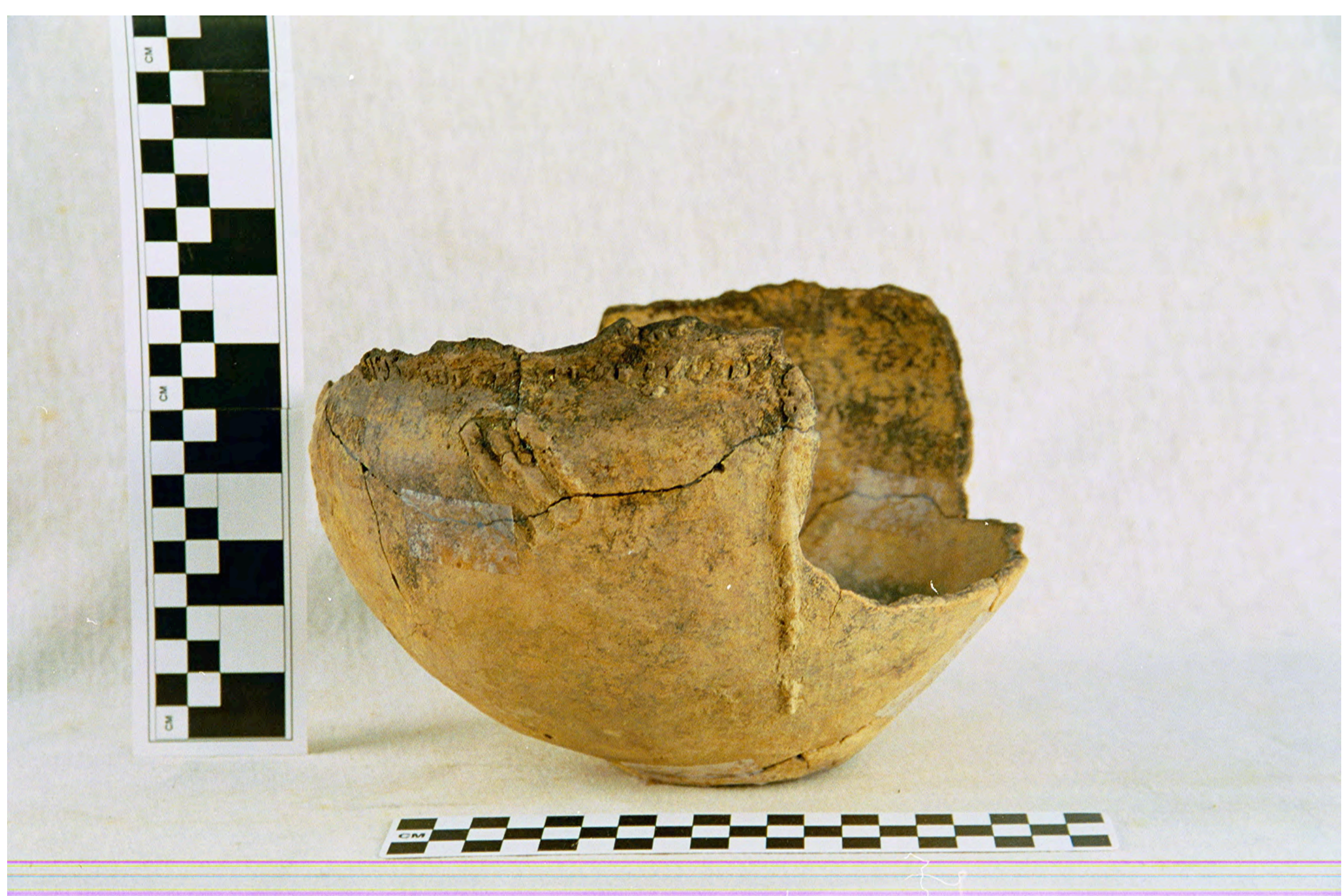

Figure 175 


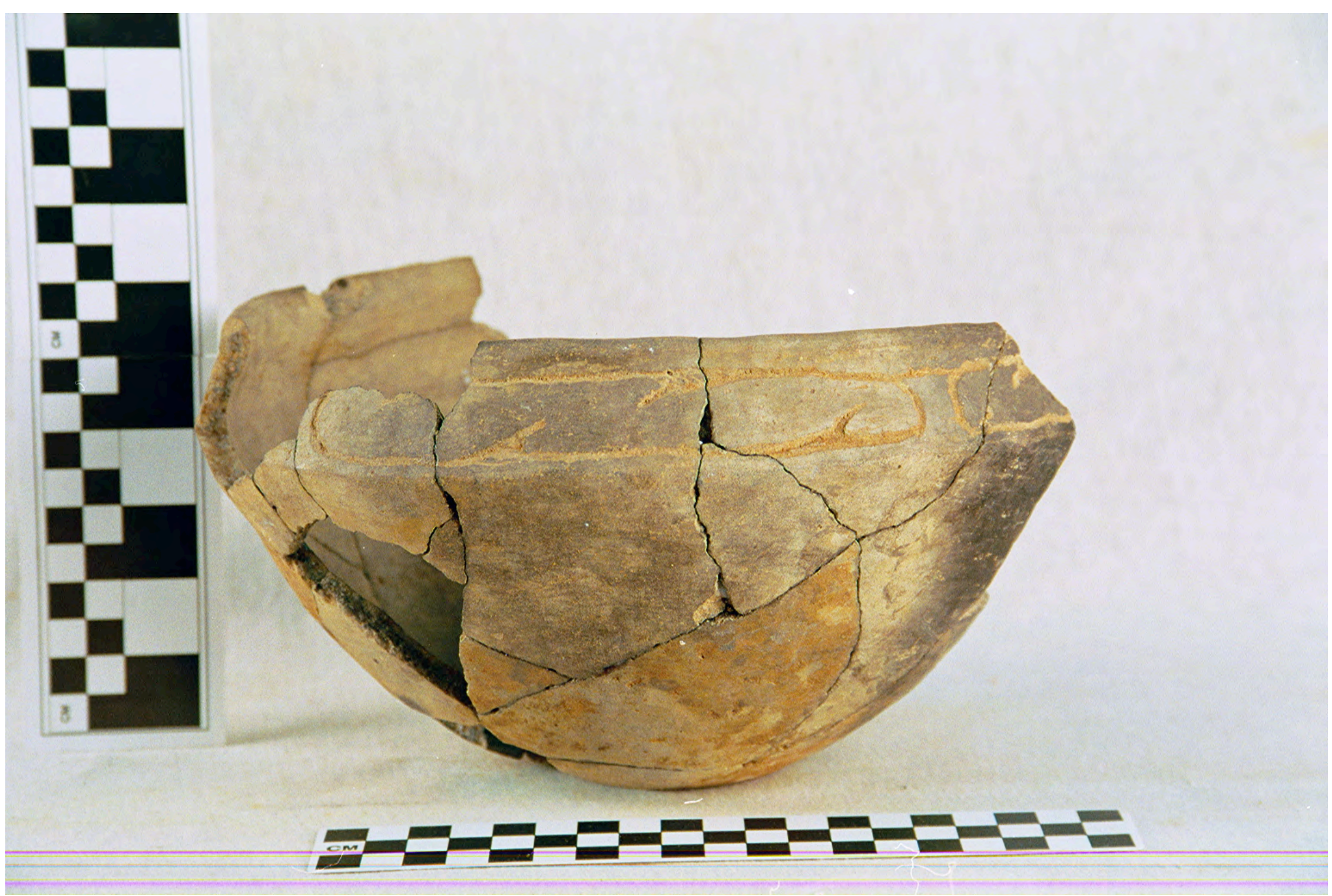

Figure 176 


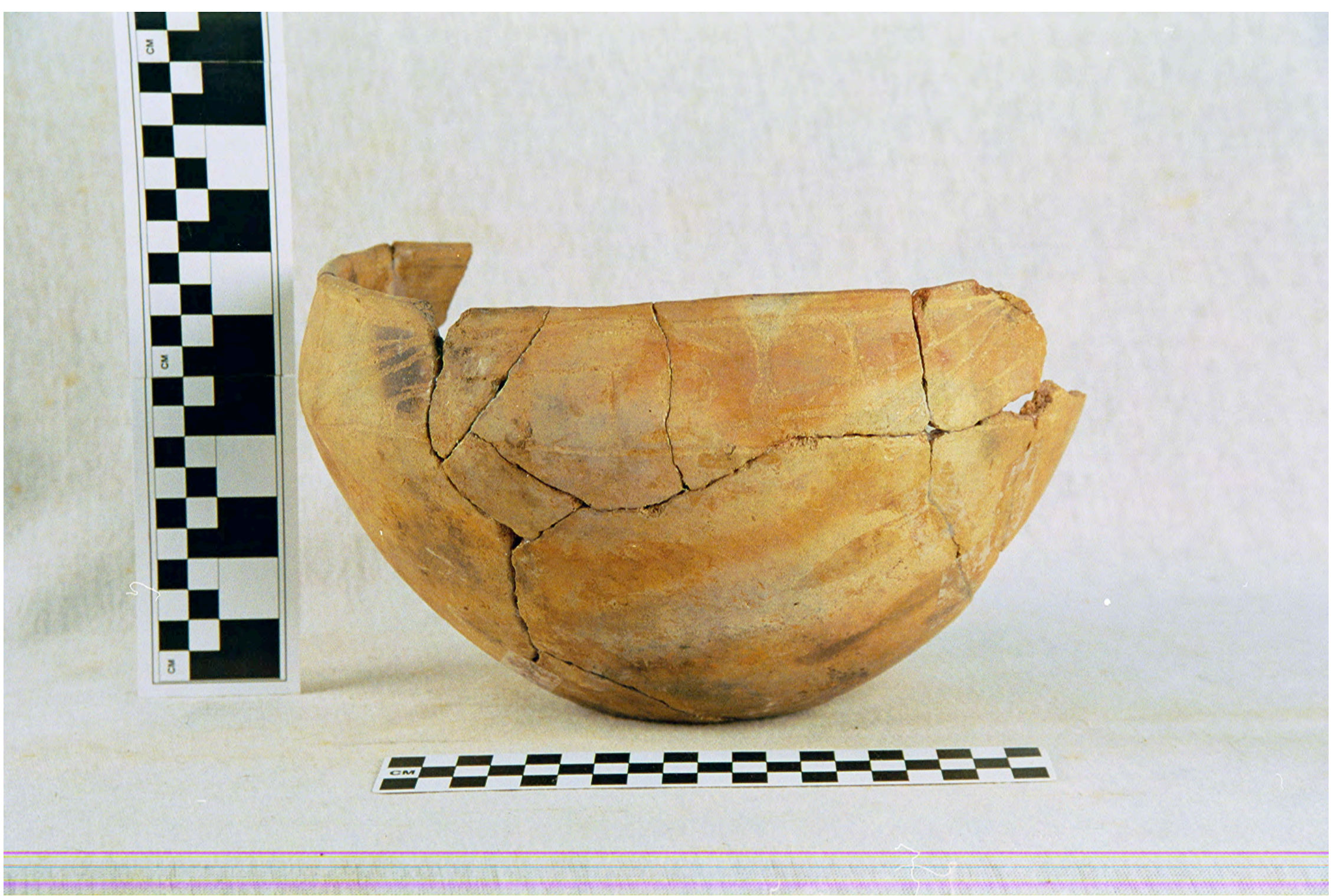

Figure 177 


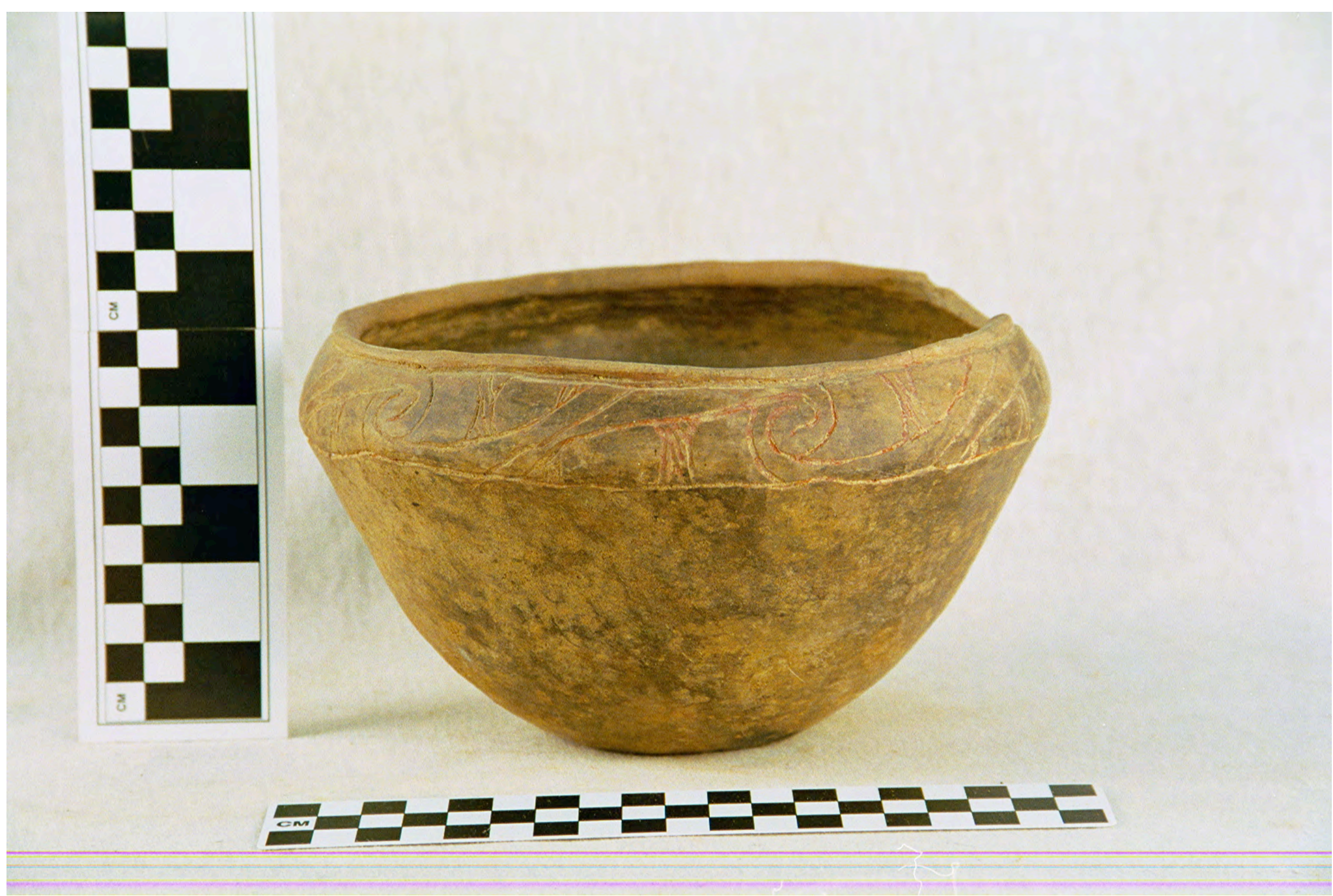

Figure 178 


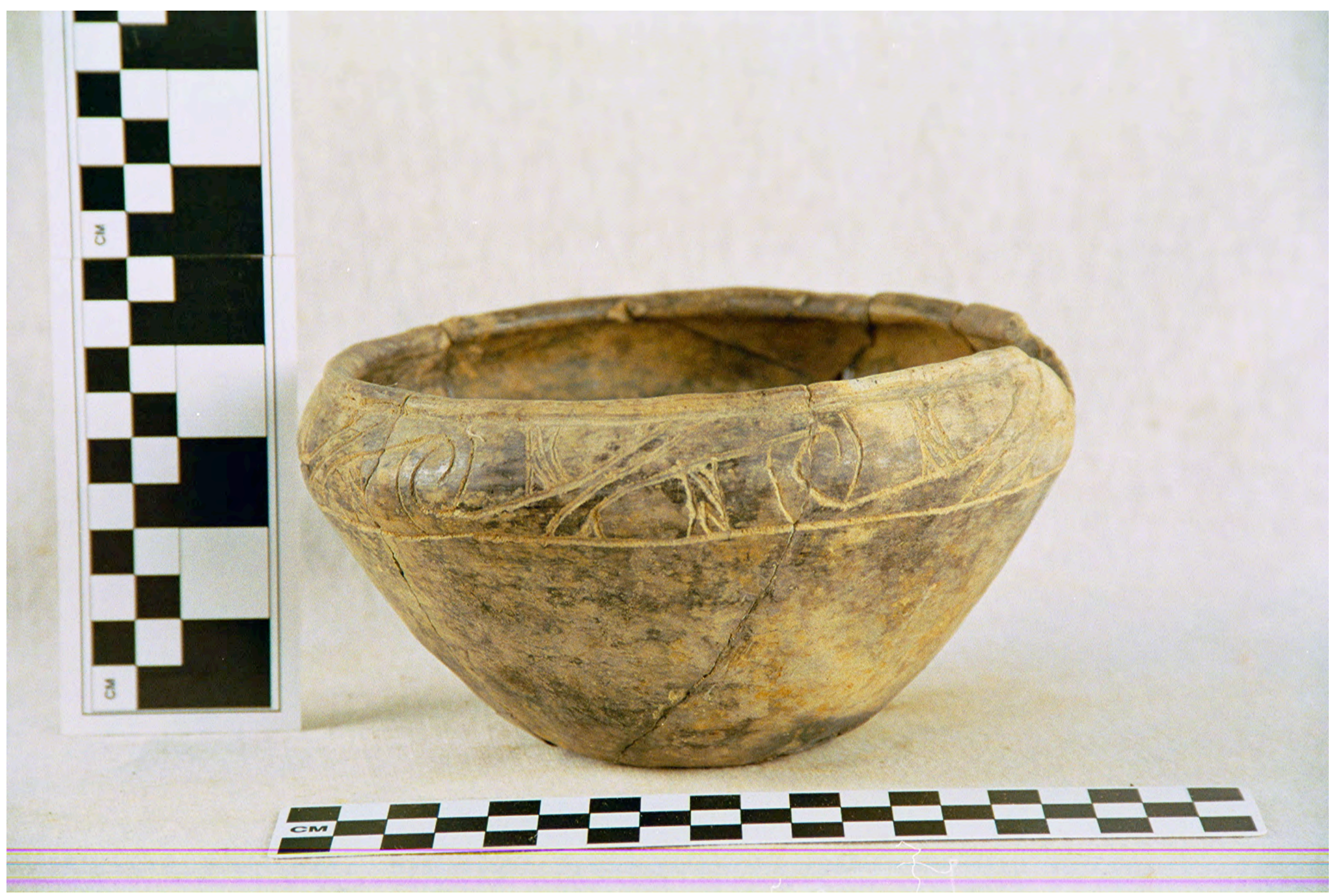

Figure 179 


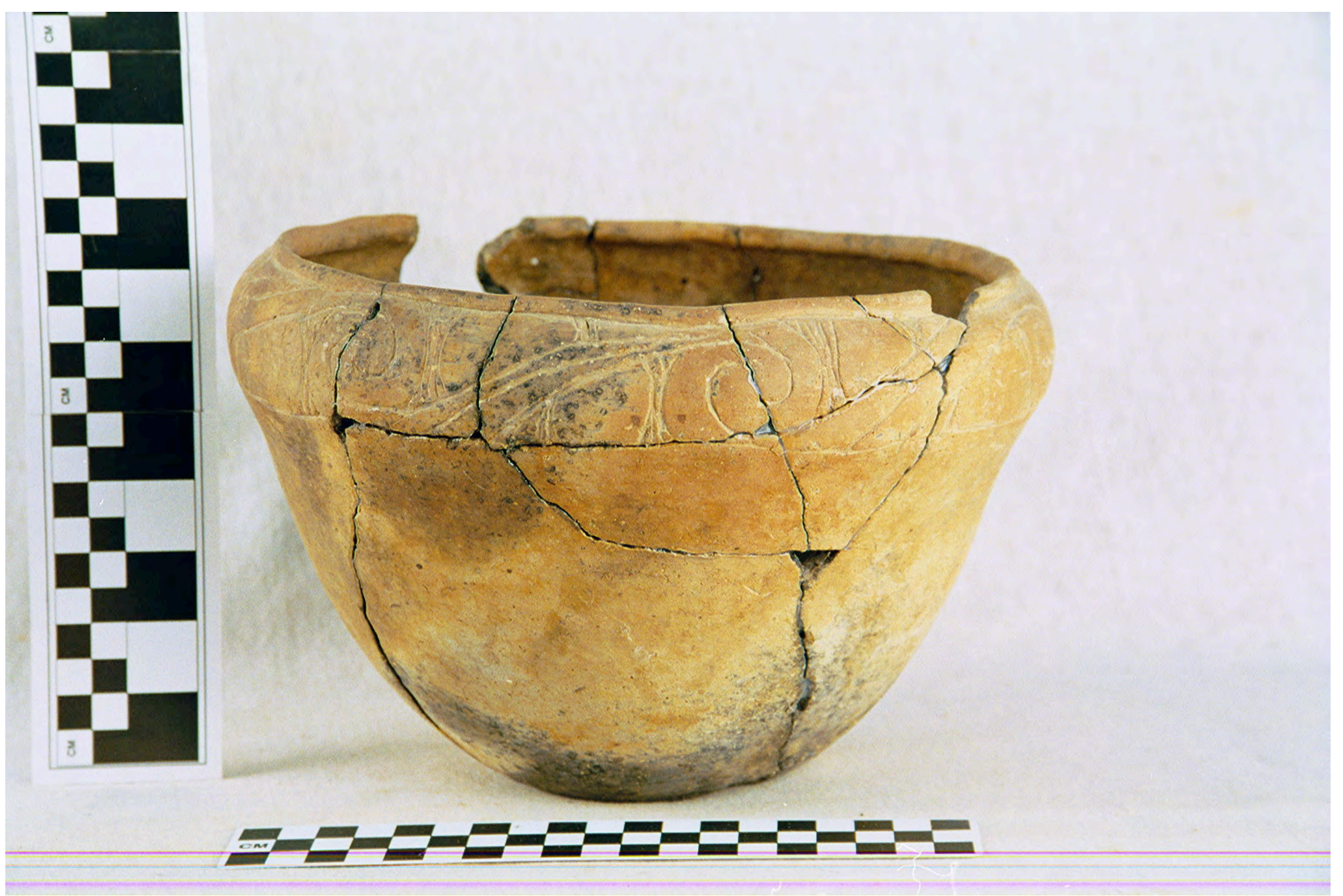

Figure 180 


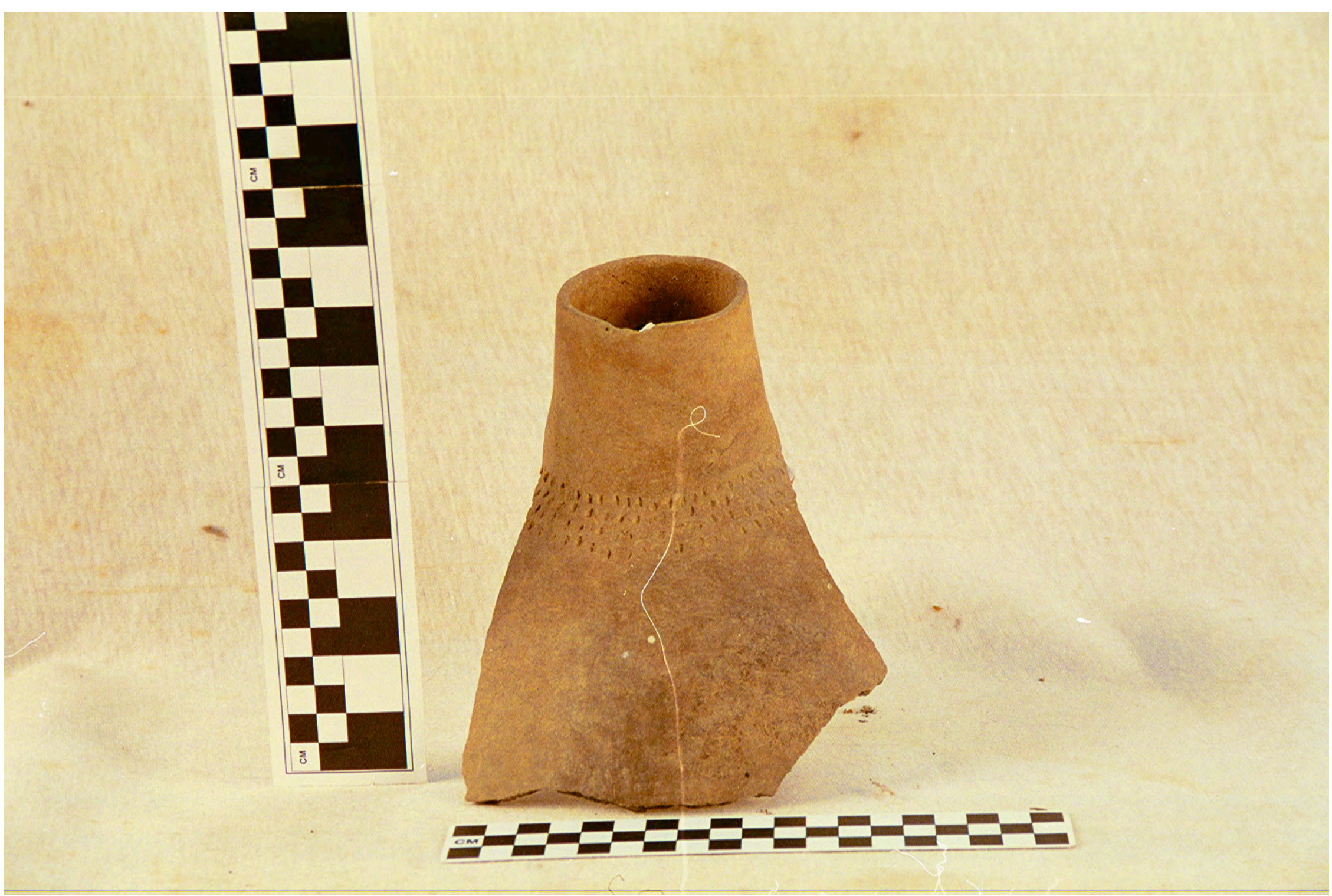

Figure 181 


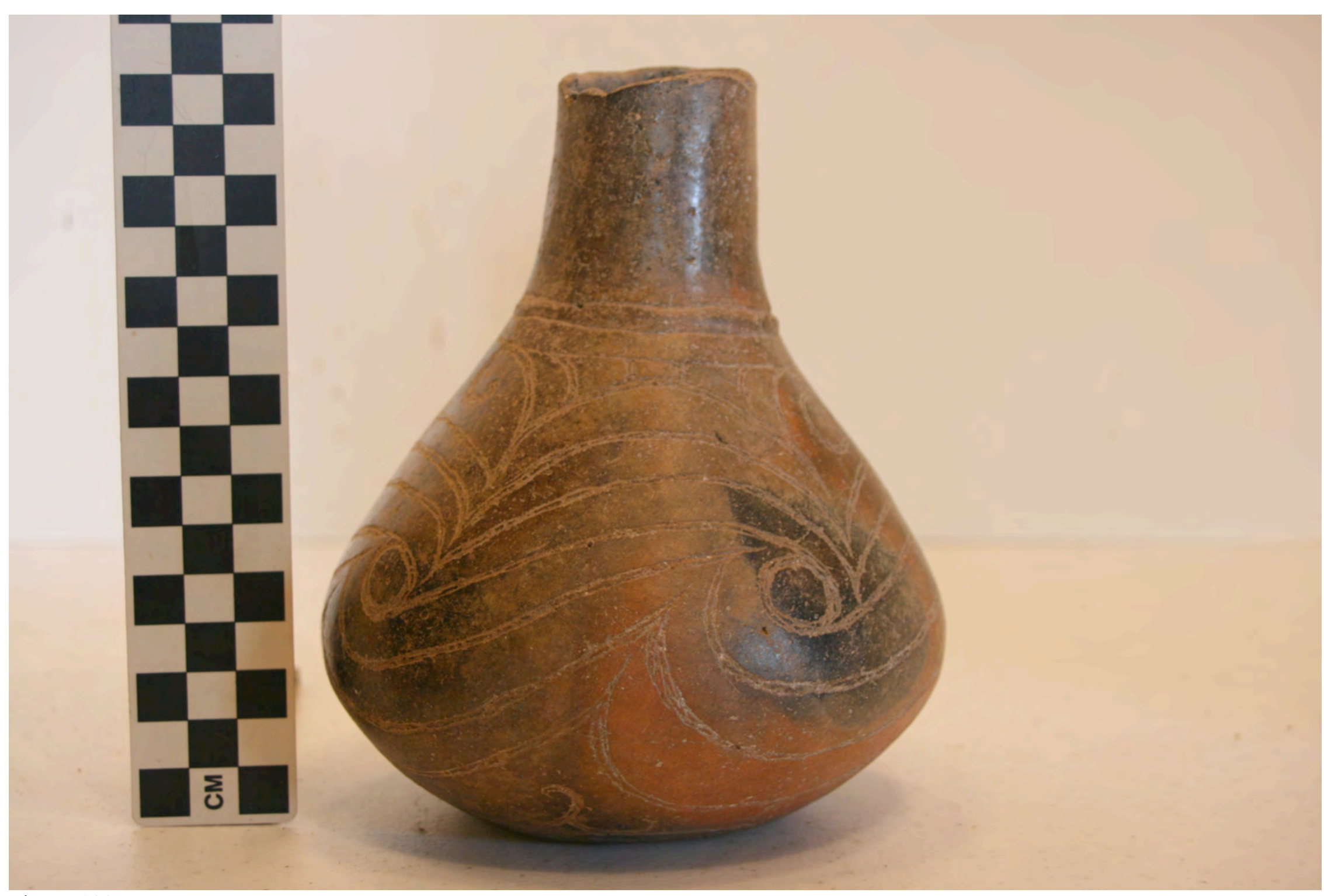

Figure 182 

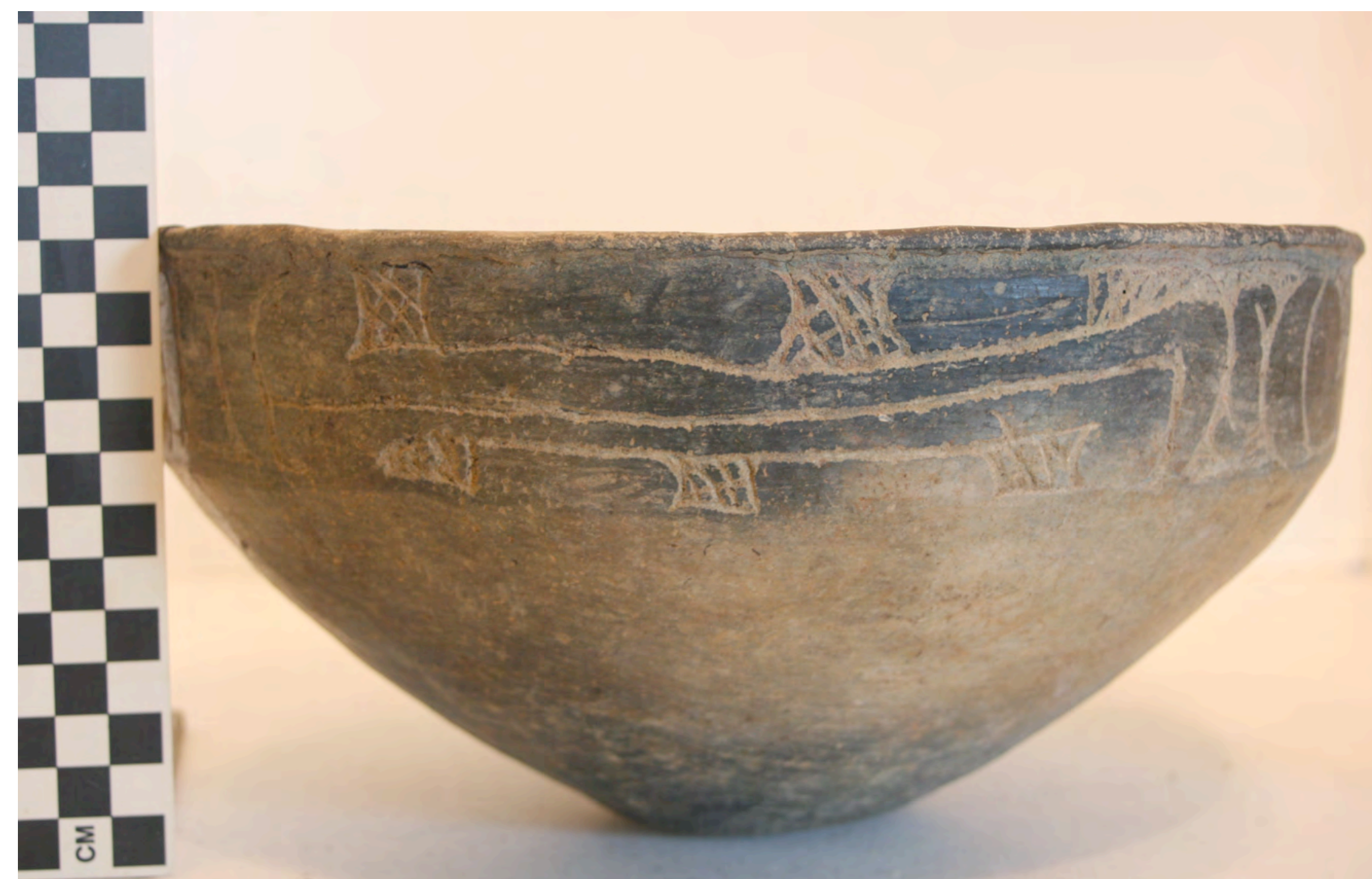

Figure 183 


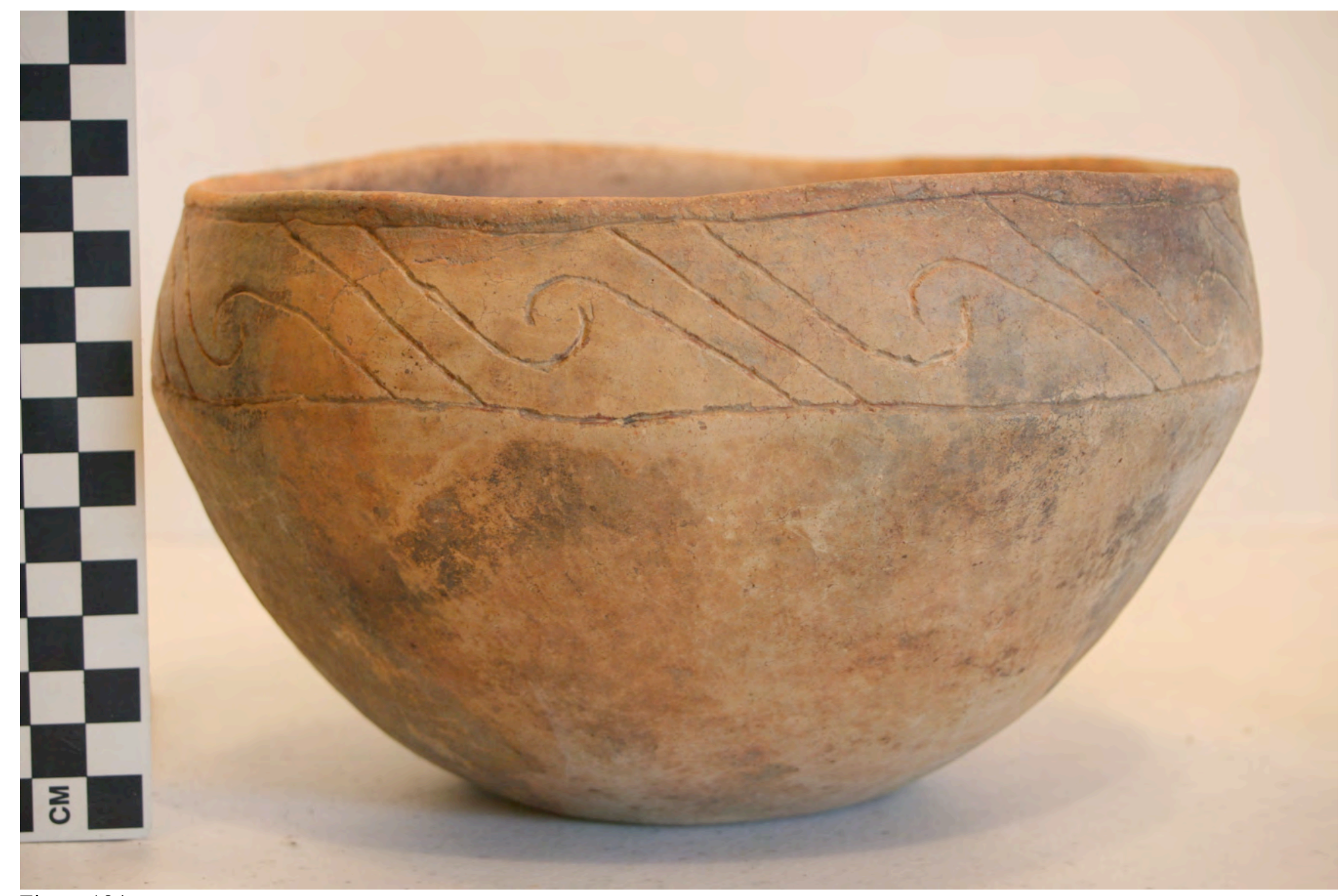

Figure 184 


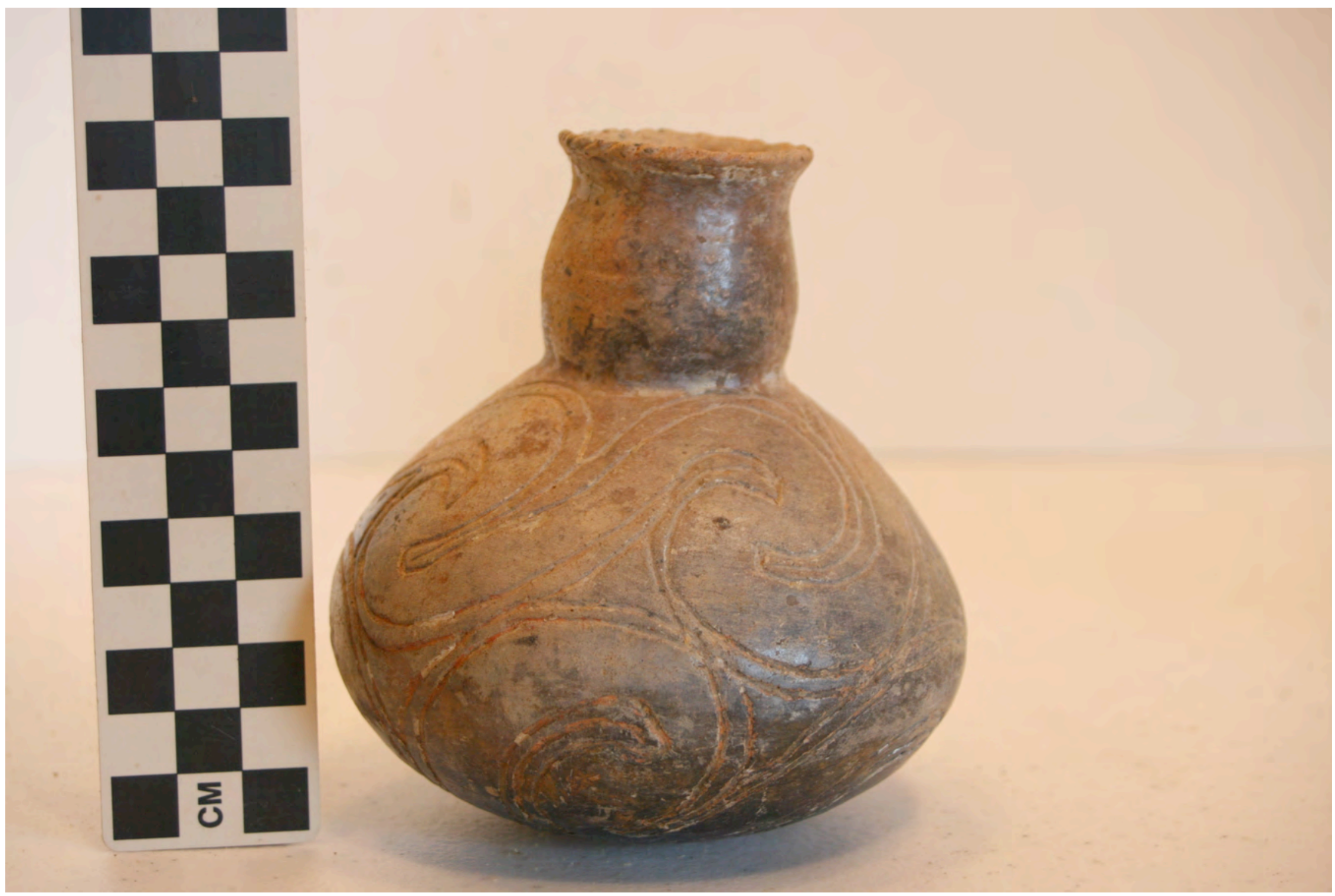

Figure 185 


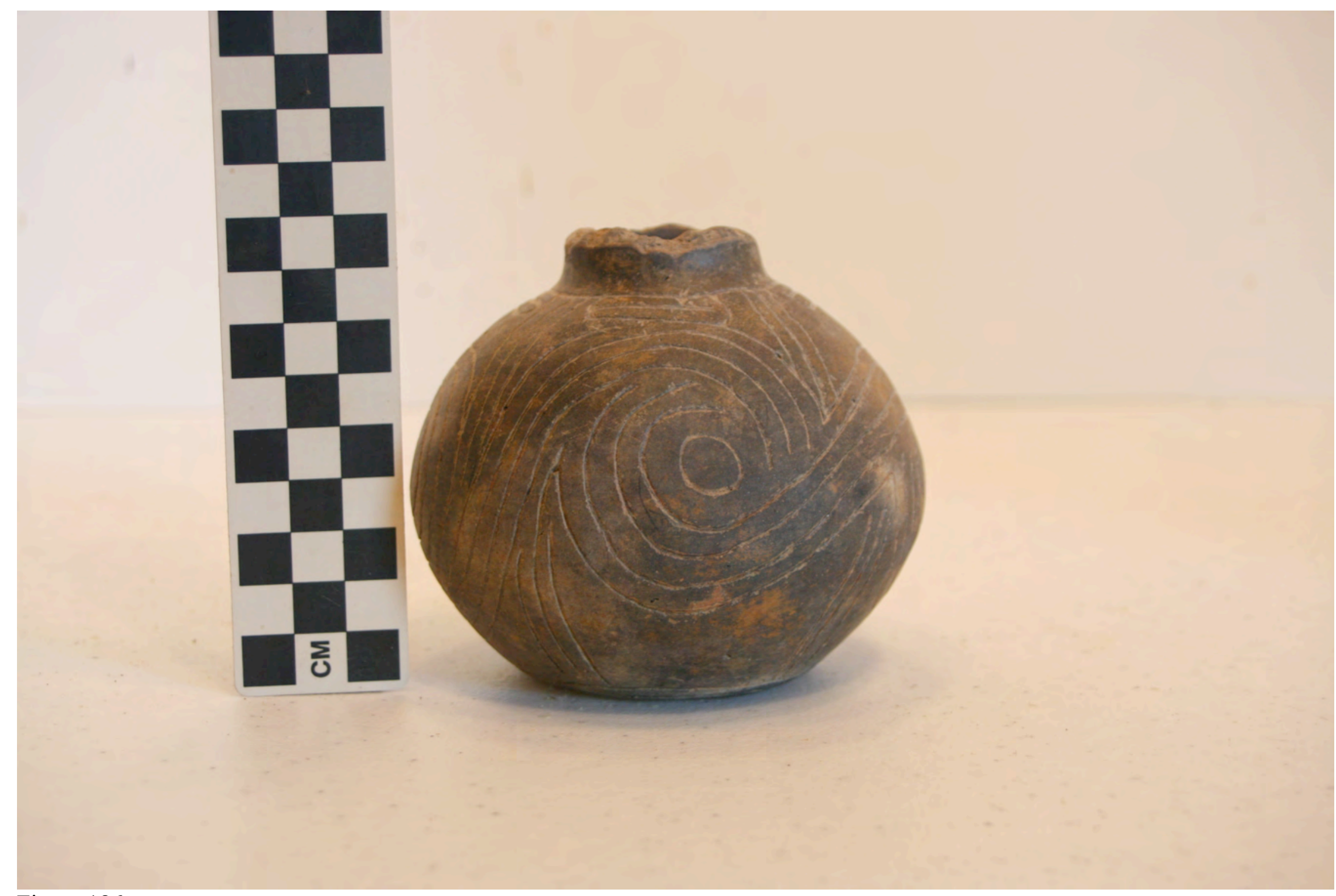

Figure 186 


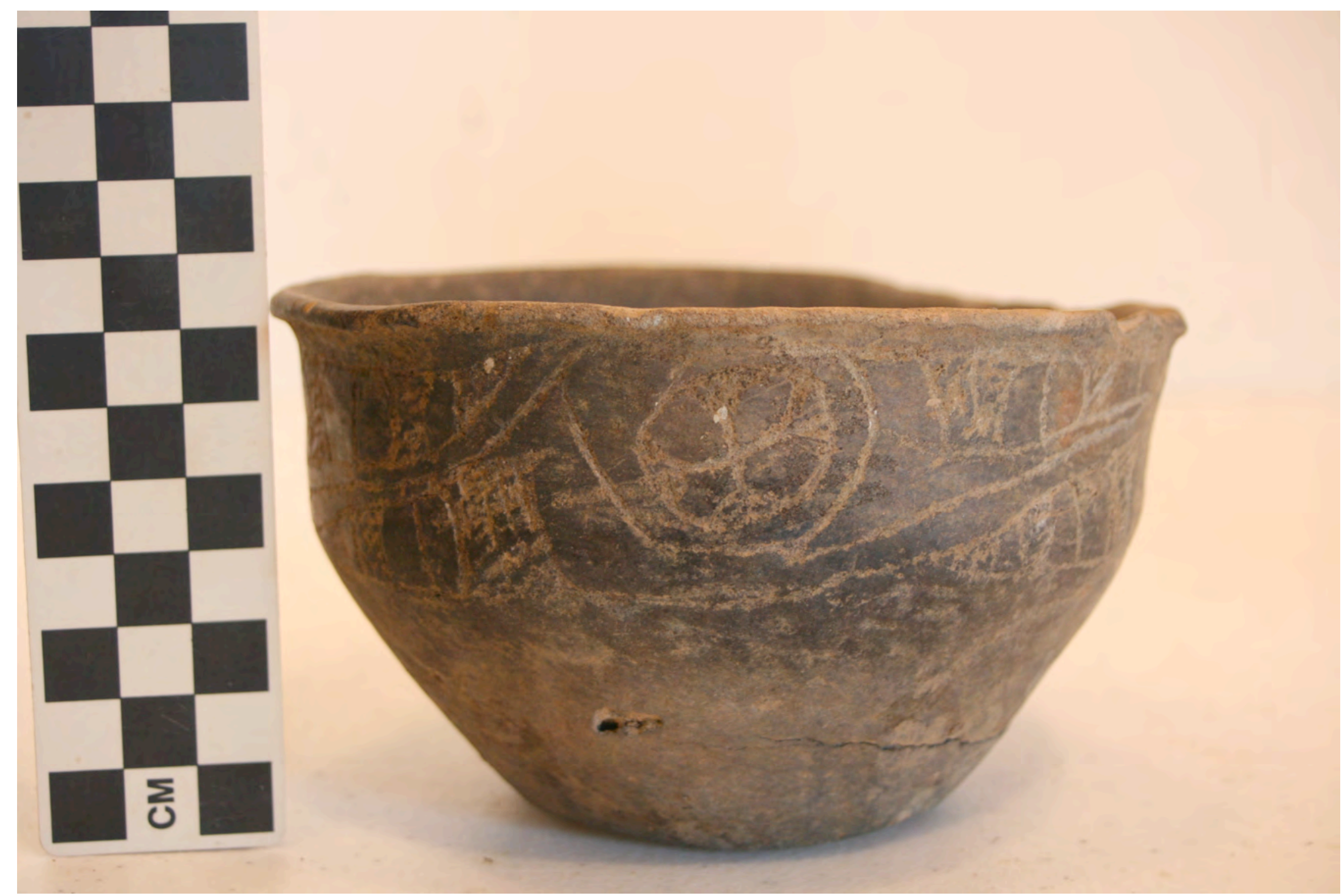

Figure 187 


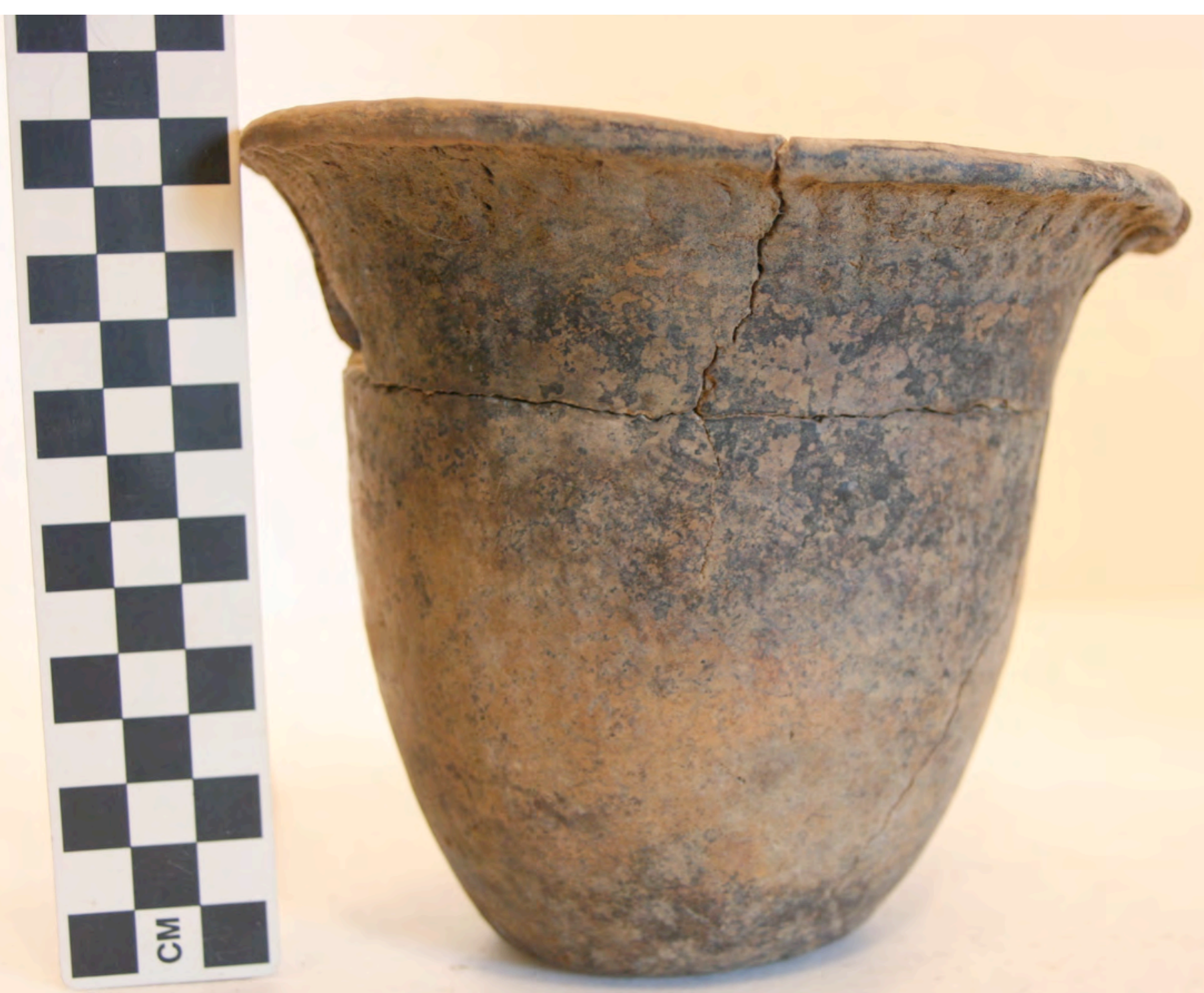

Figure 188 


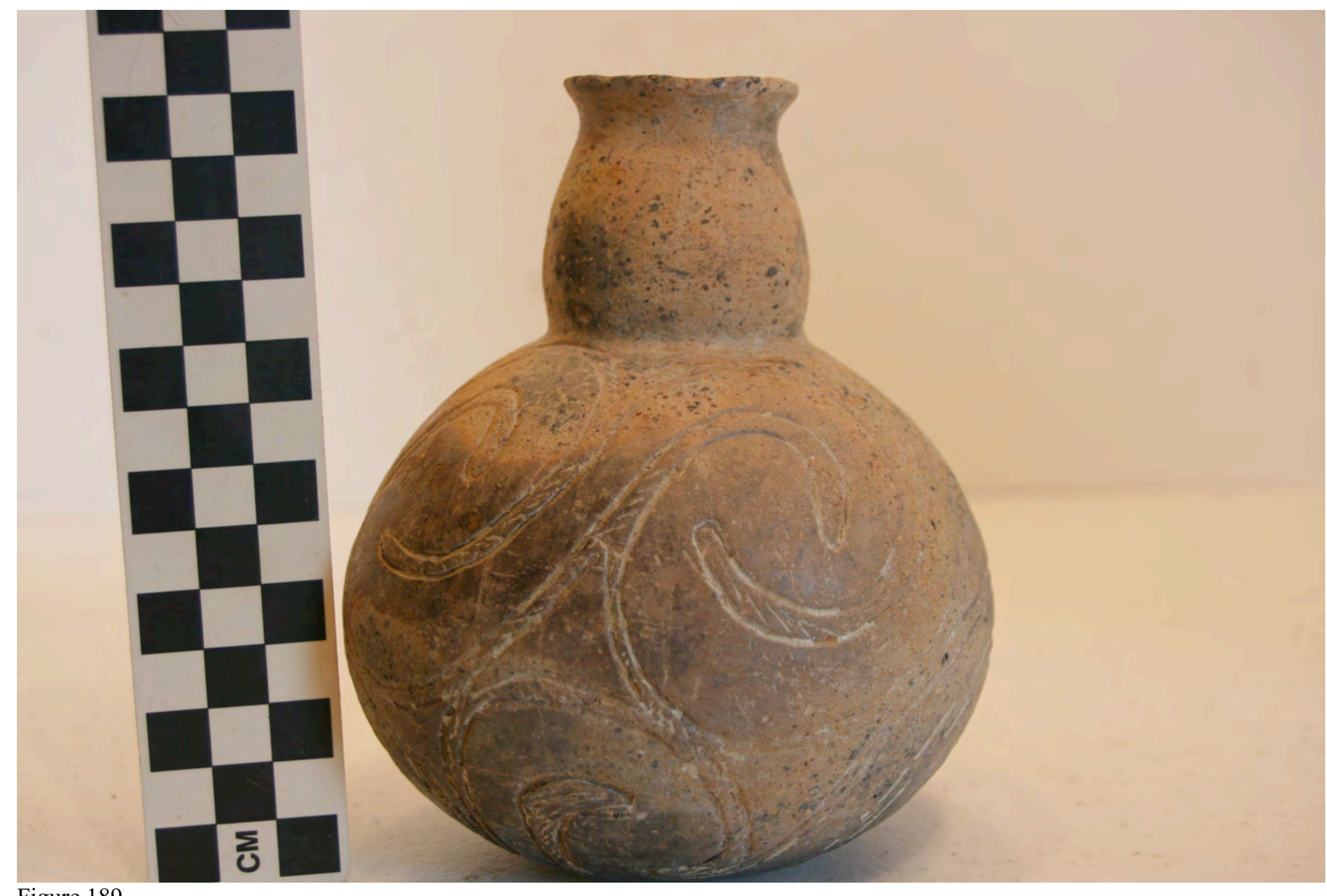

Figure 189 


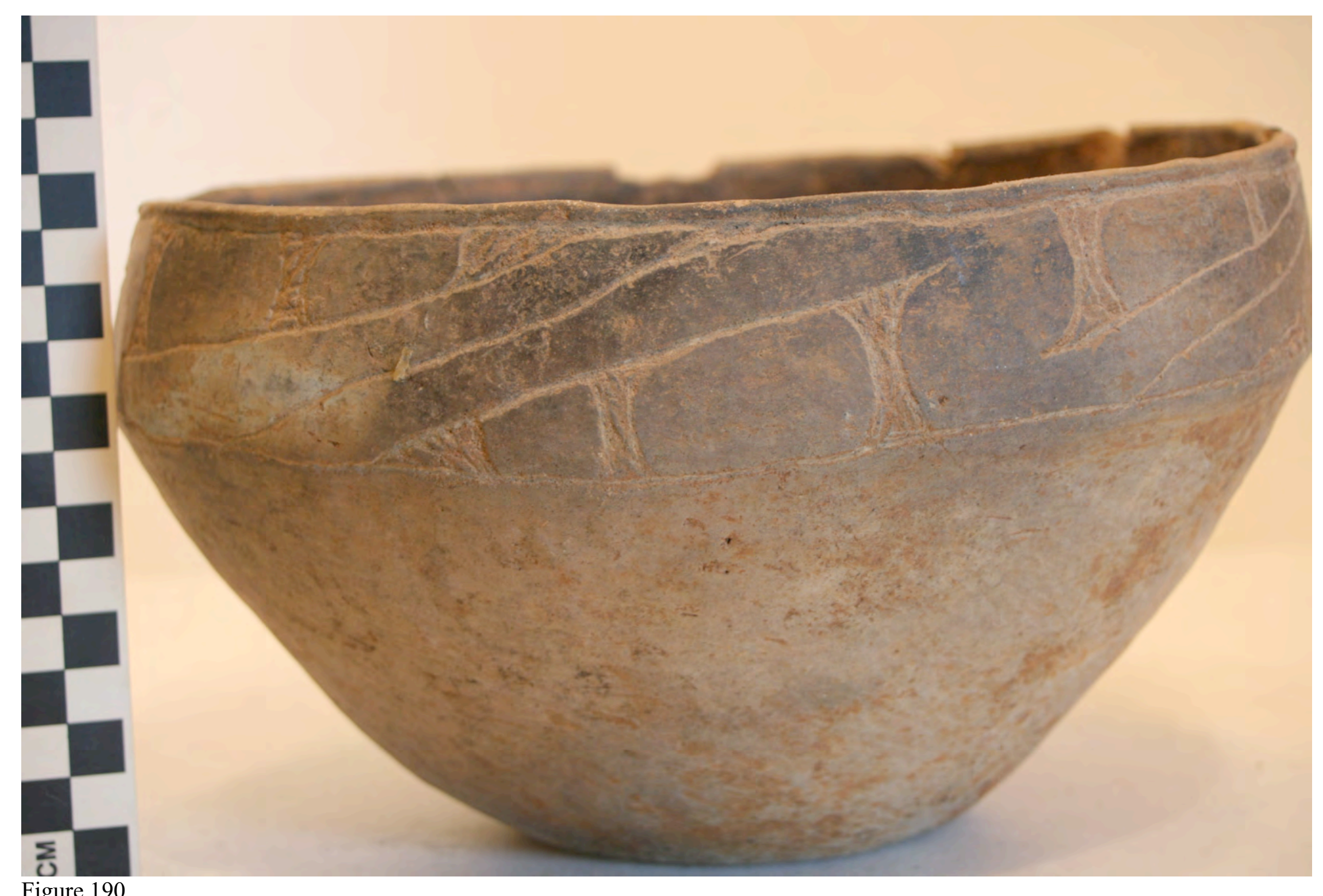

Figure 190 


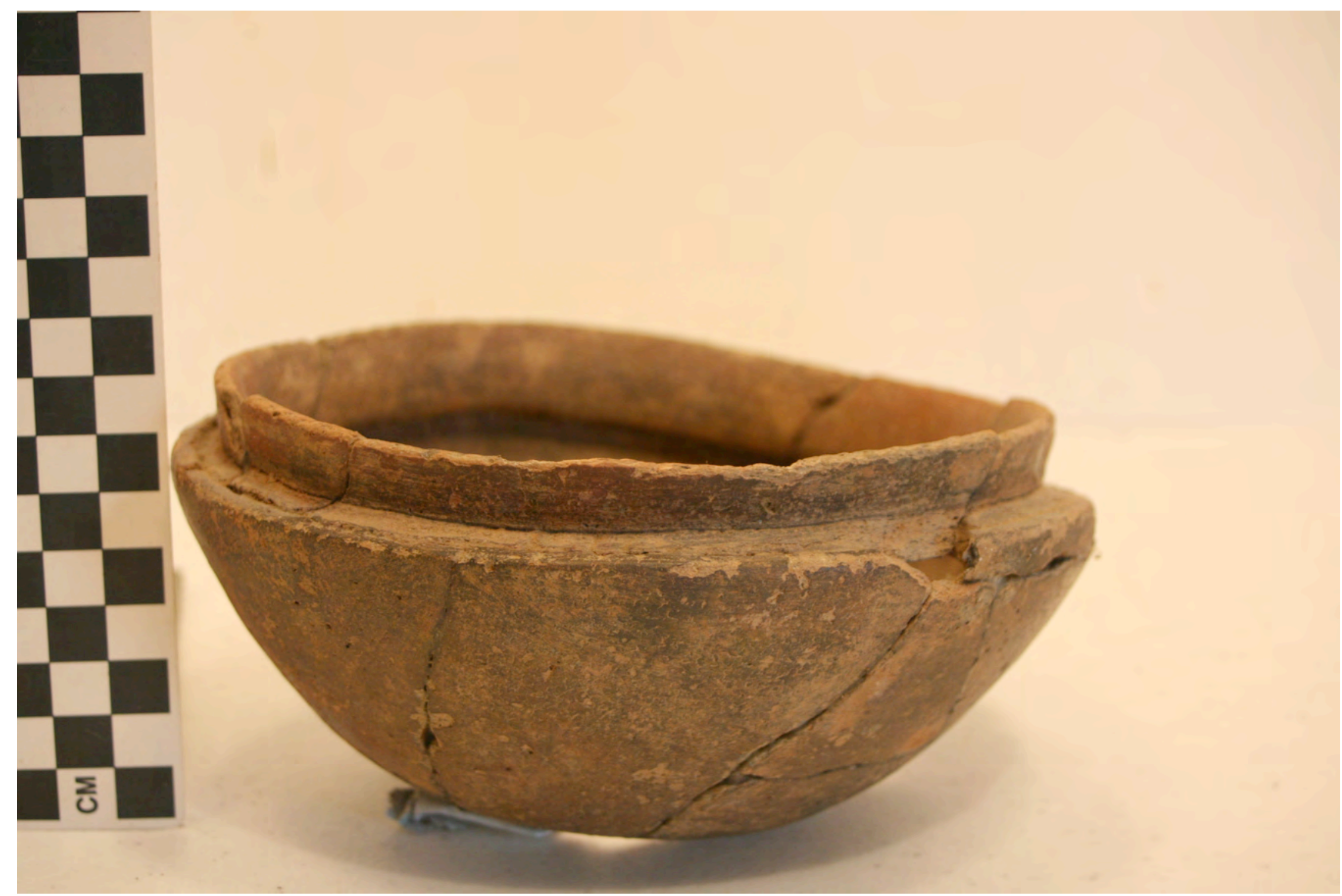

Figure 191 


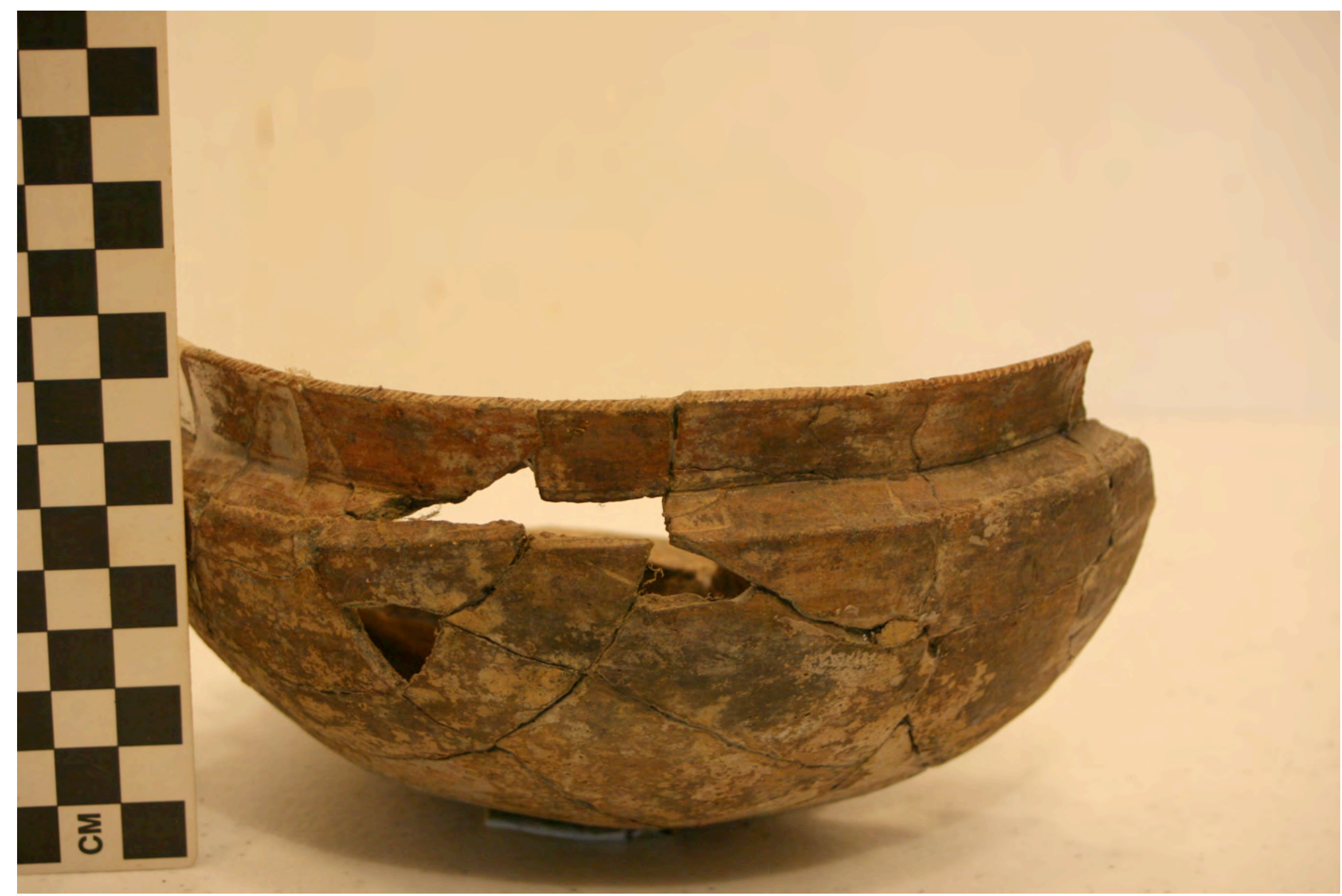

Figure 192 


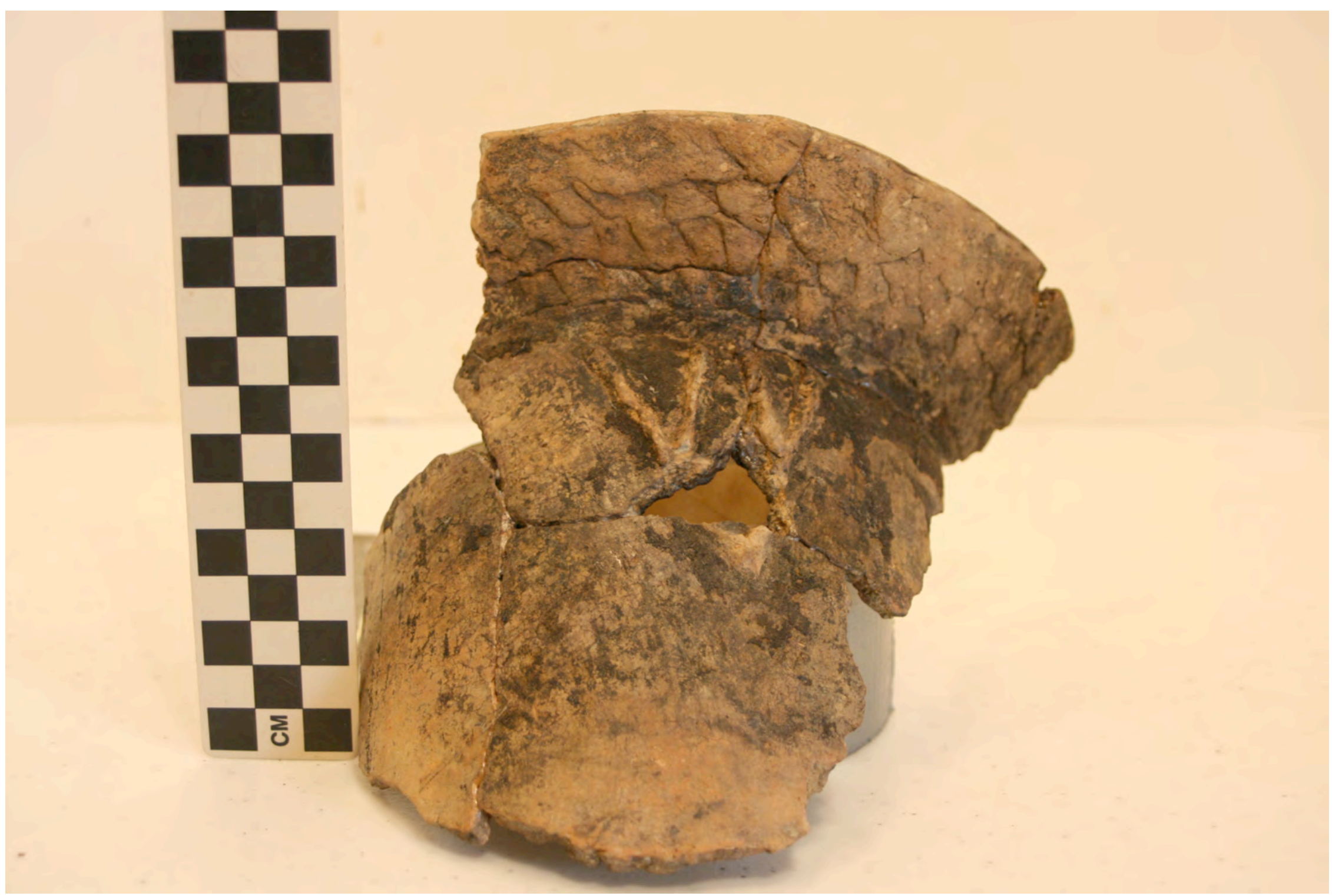

Figure 193 


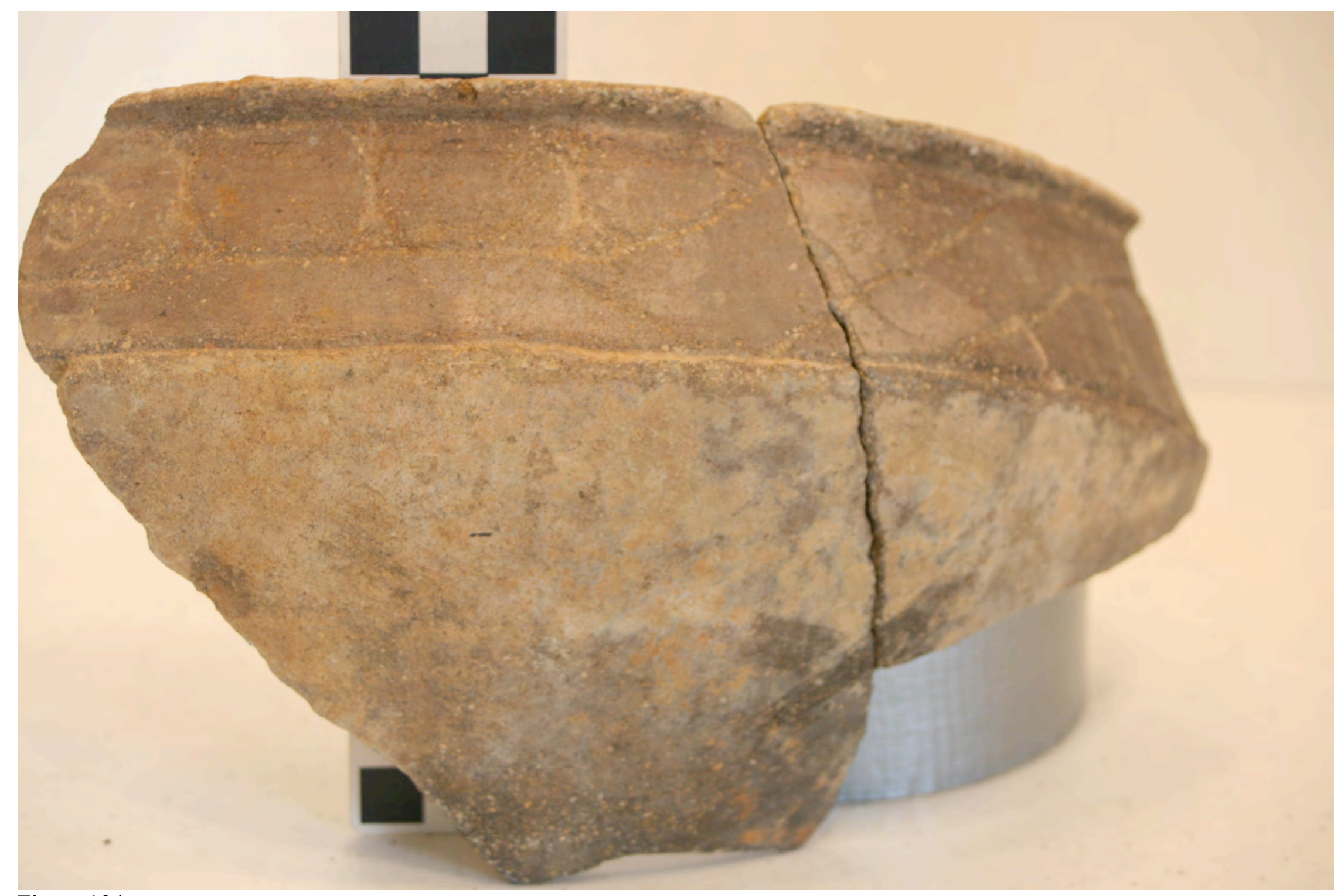

Figure 194 


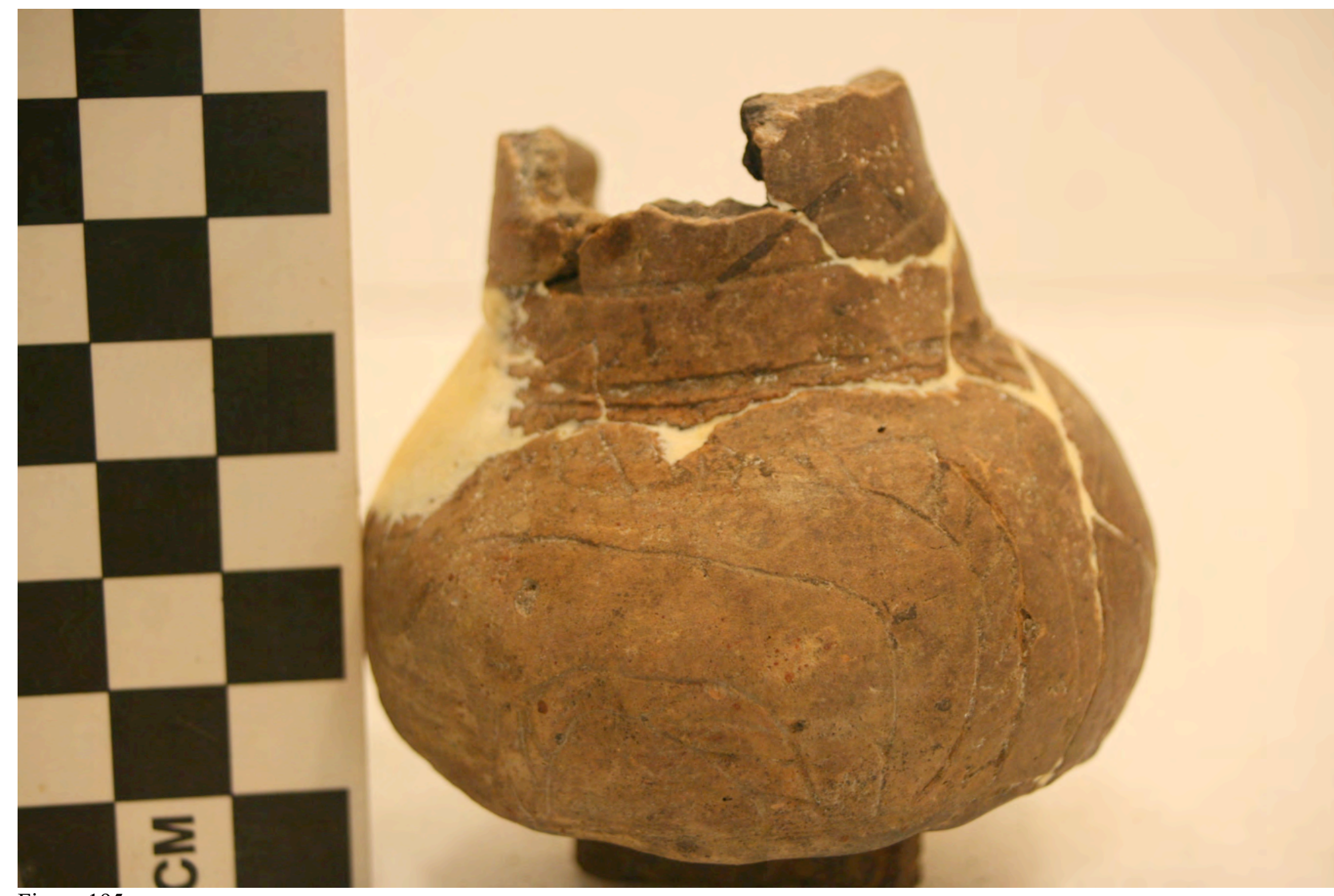

Figure 195 


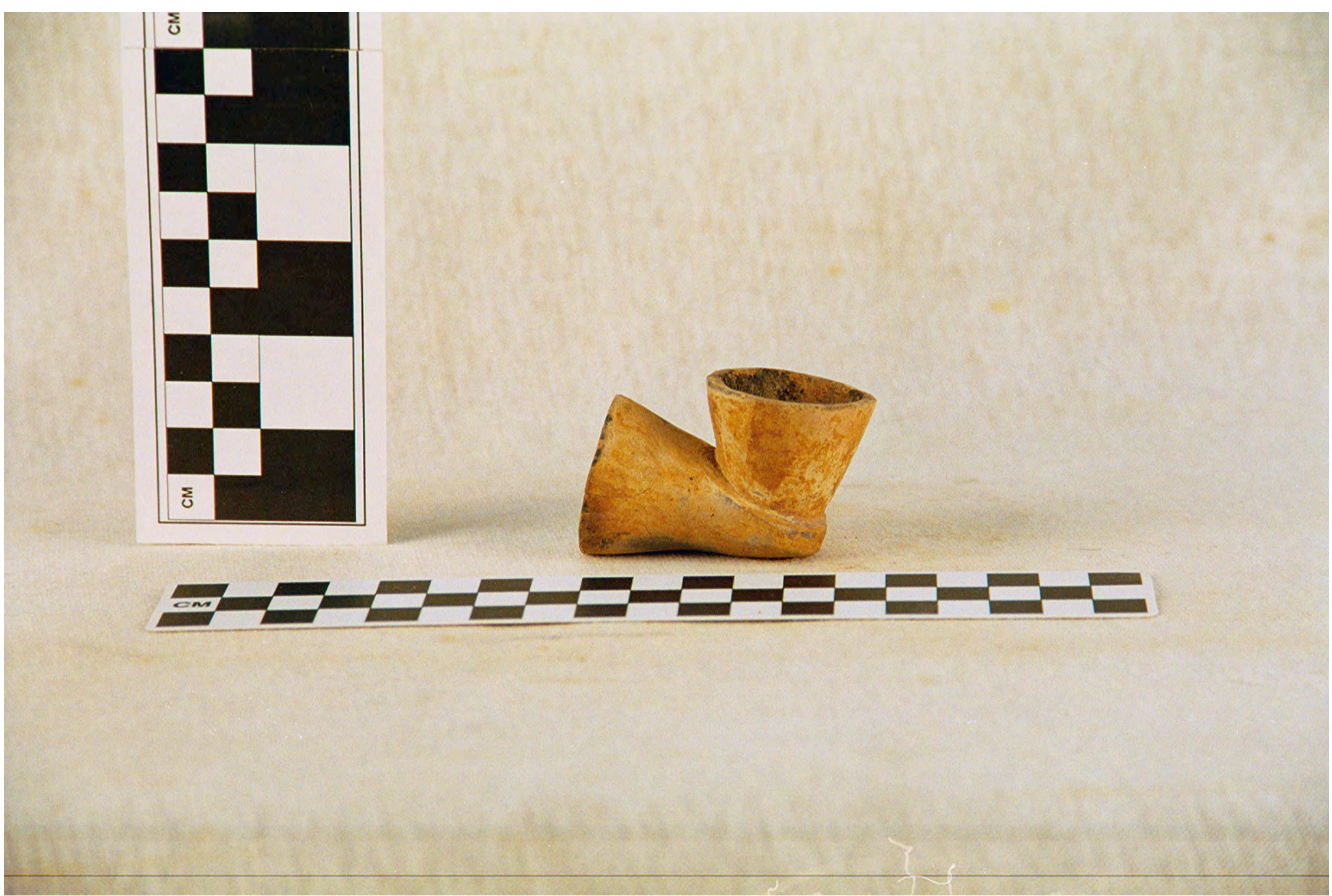

Figure 196 


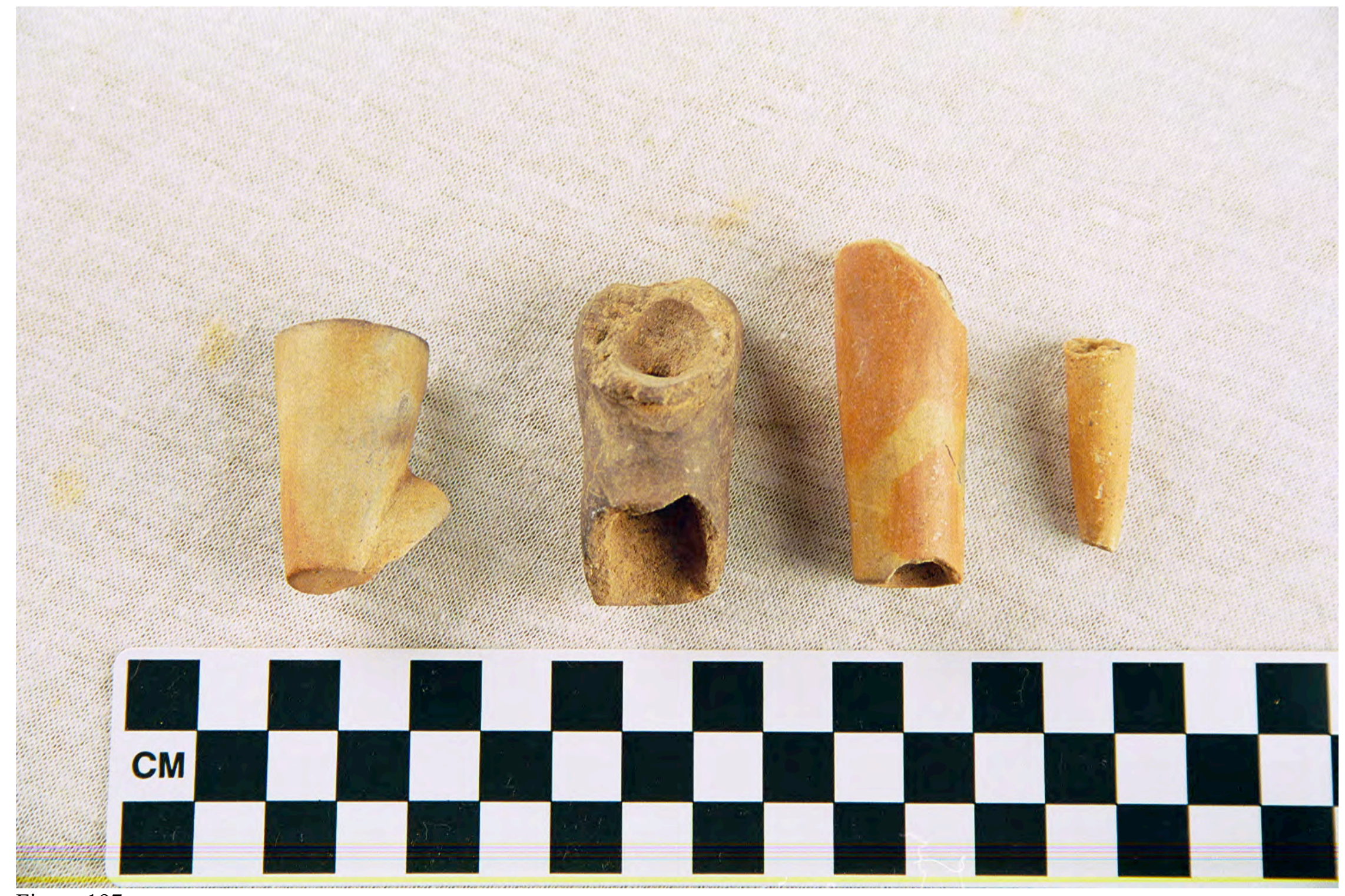

Figure 197 


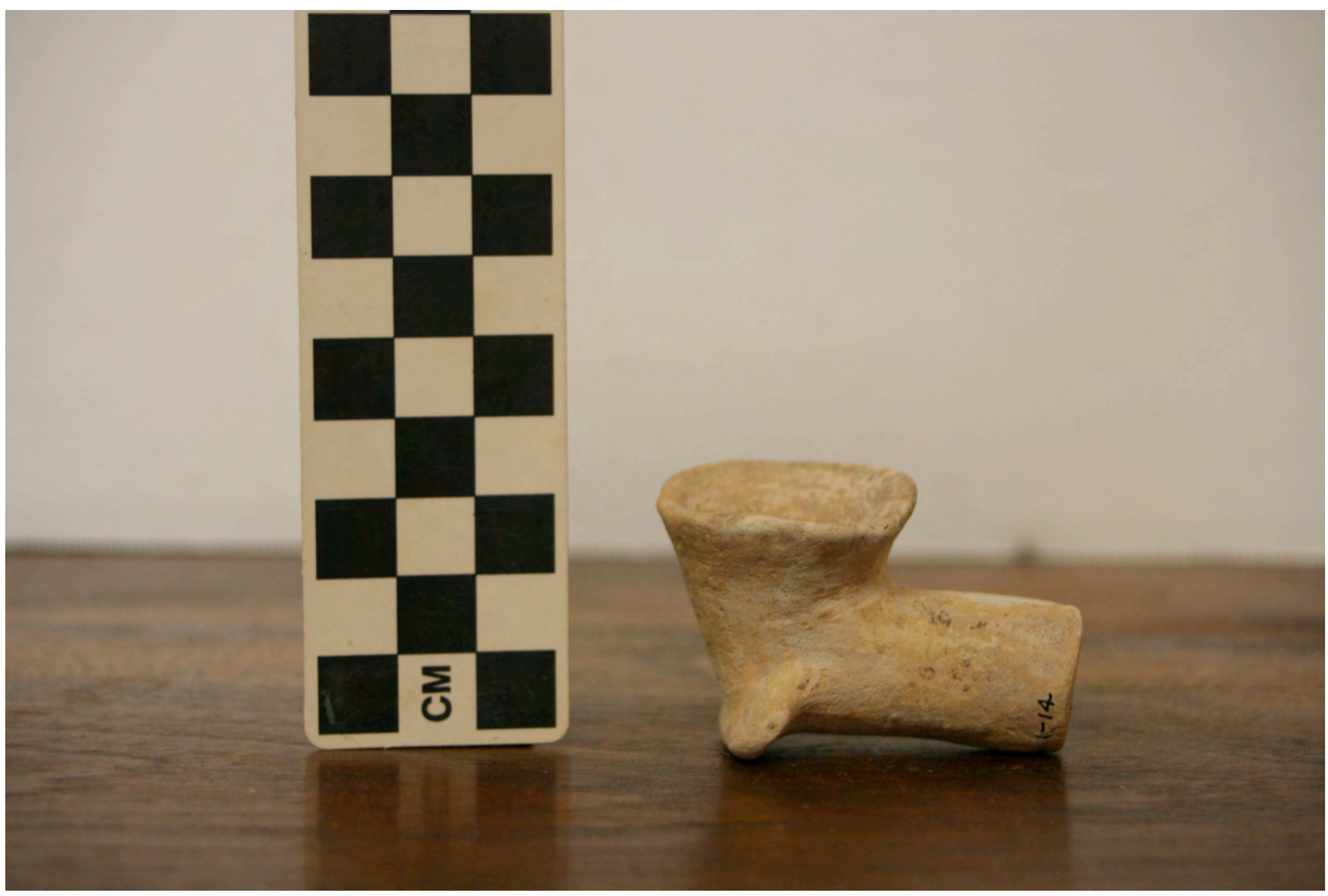

Figure 198a 


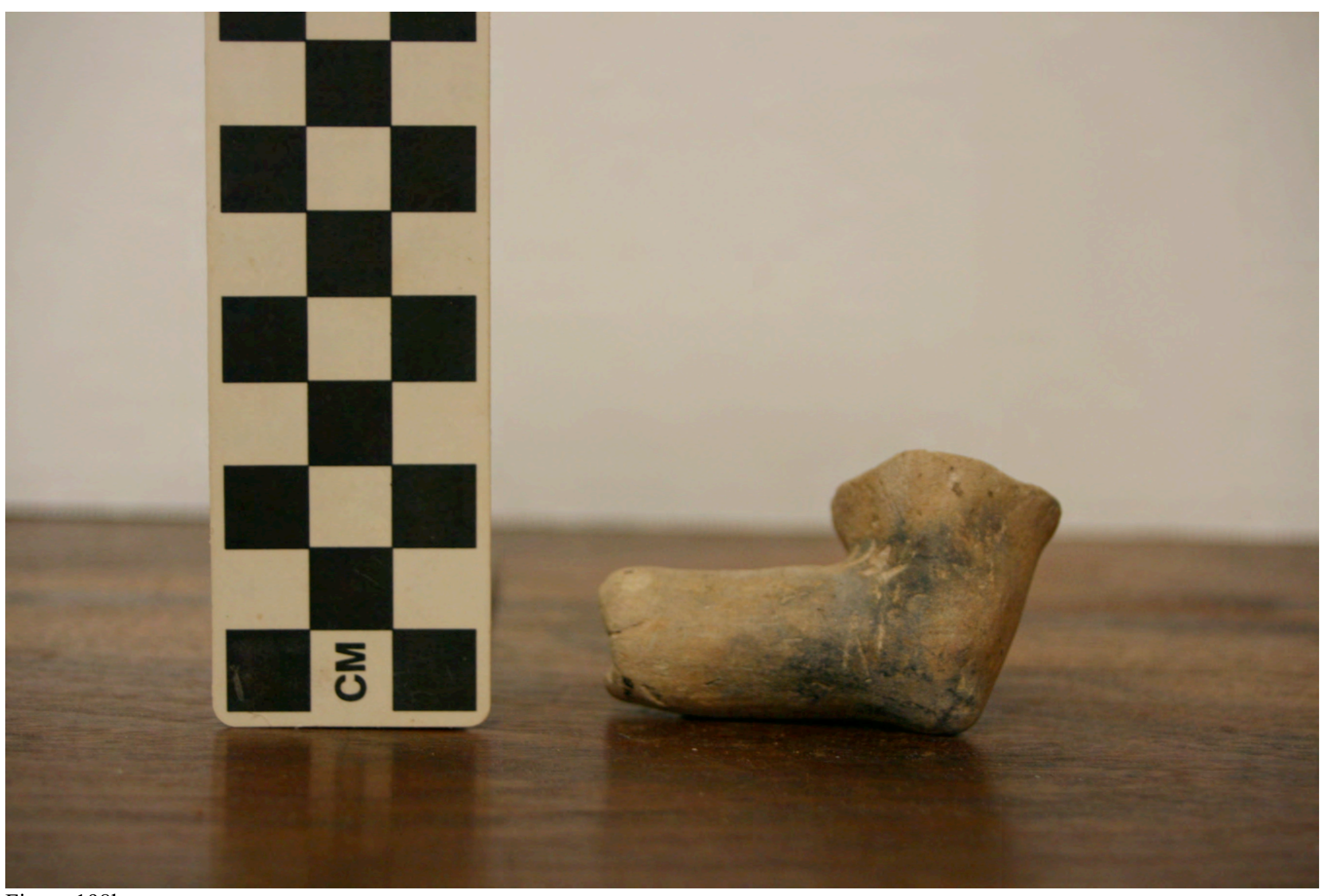

Figure 198b 


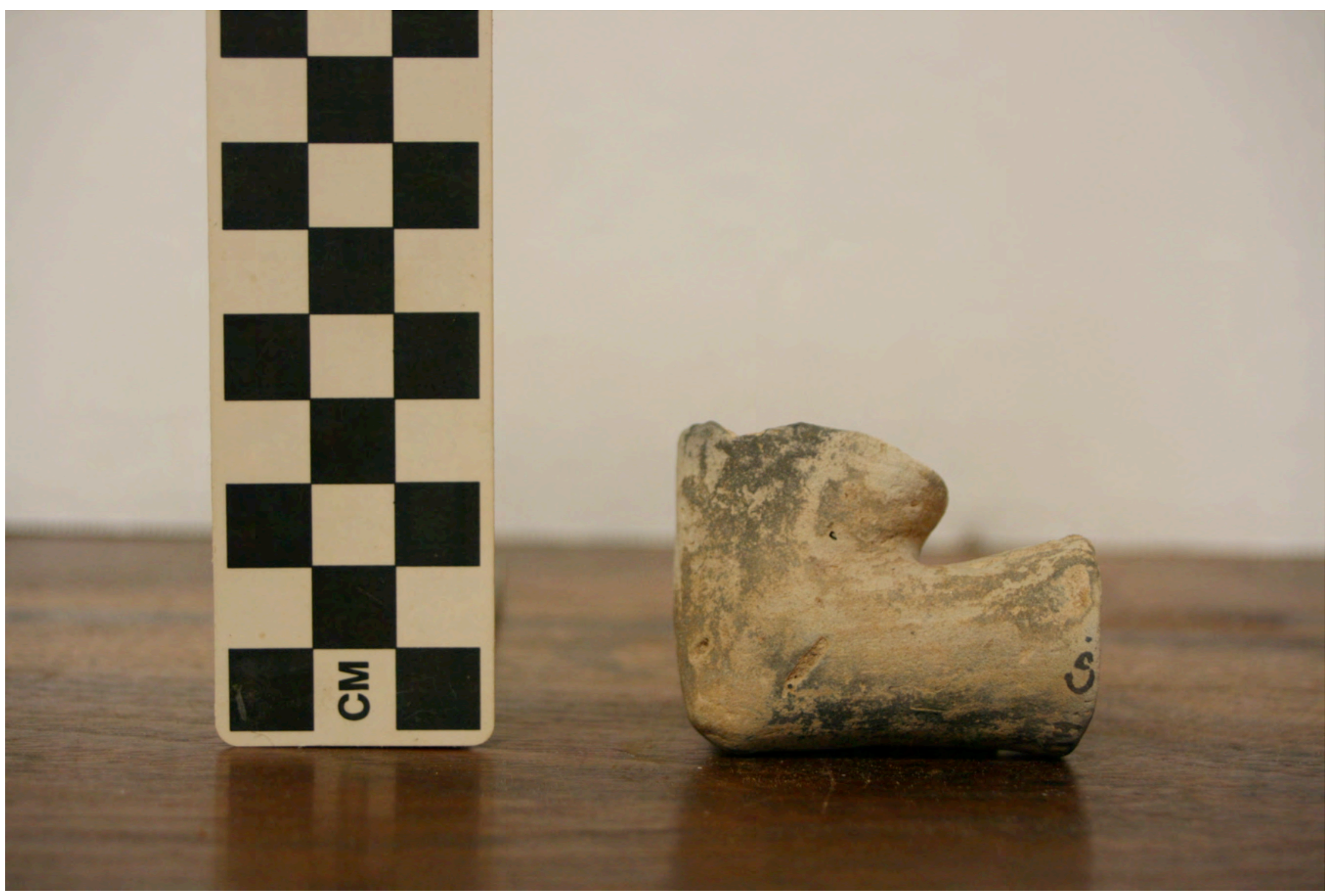

Figure 198c 


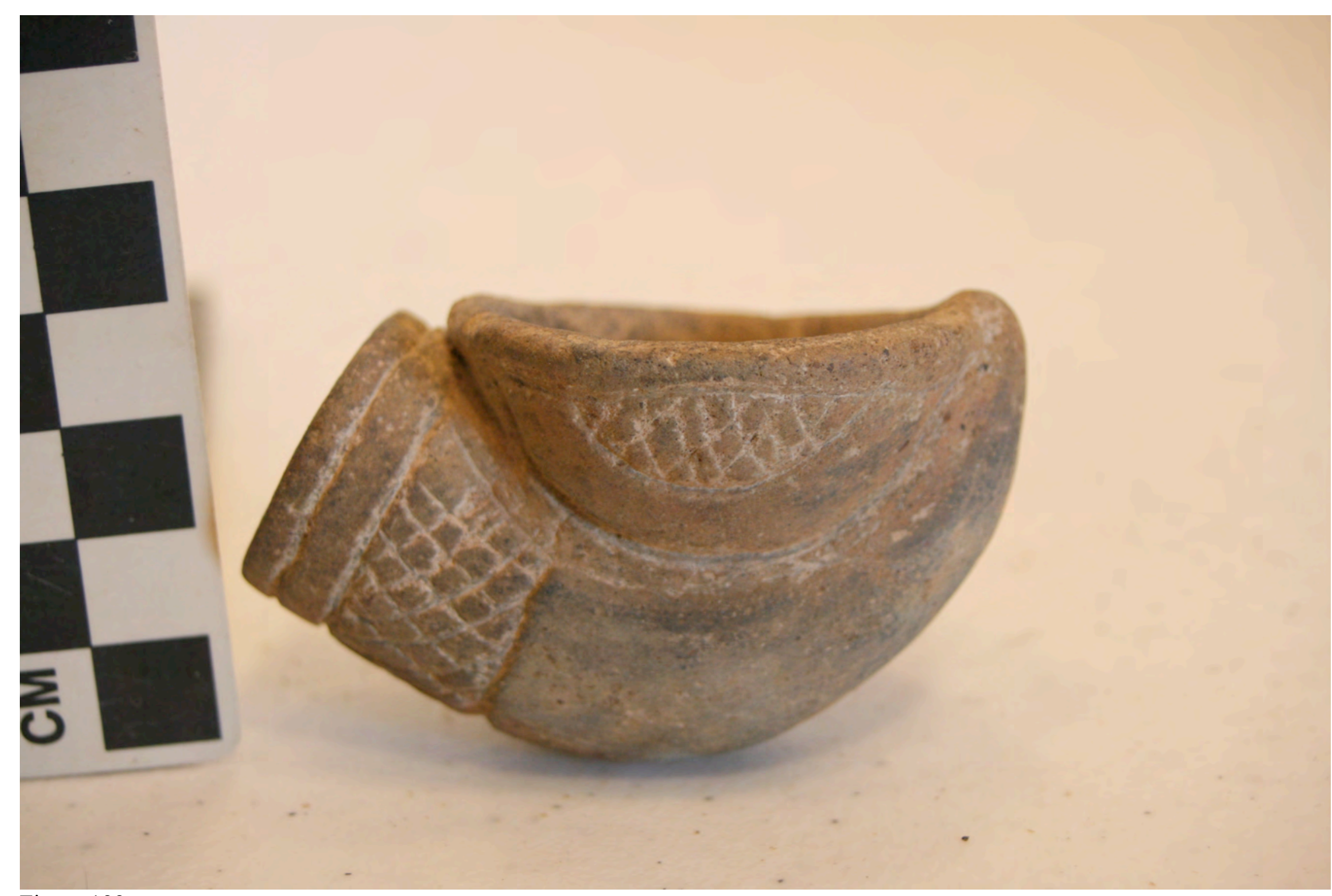

Figure 199 


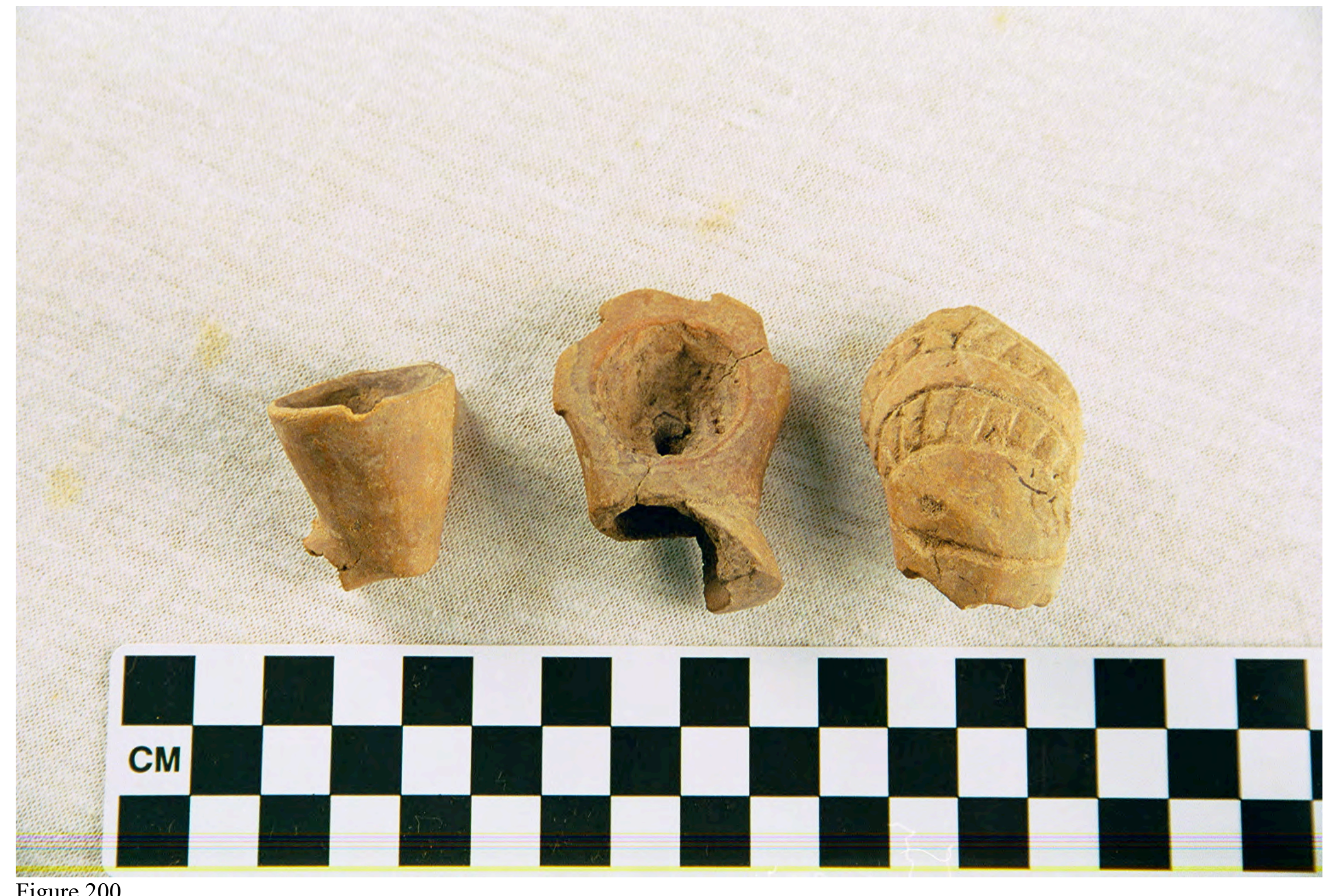

Figure 200 


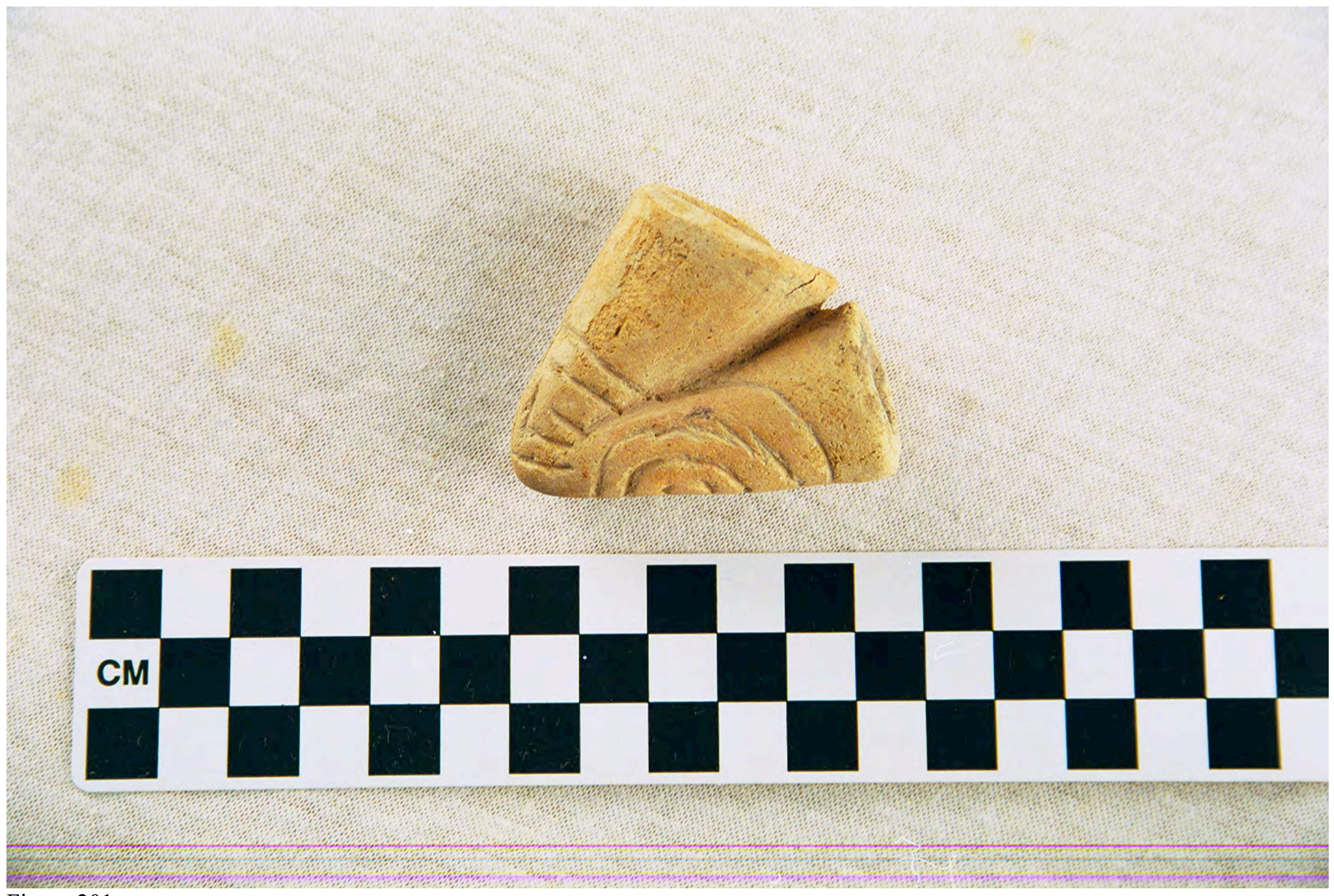

Figure 201 


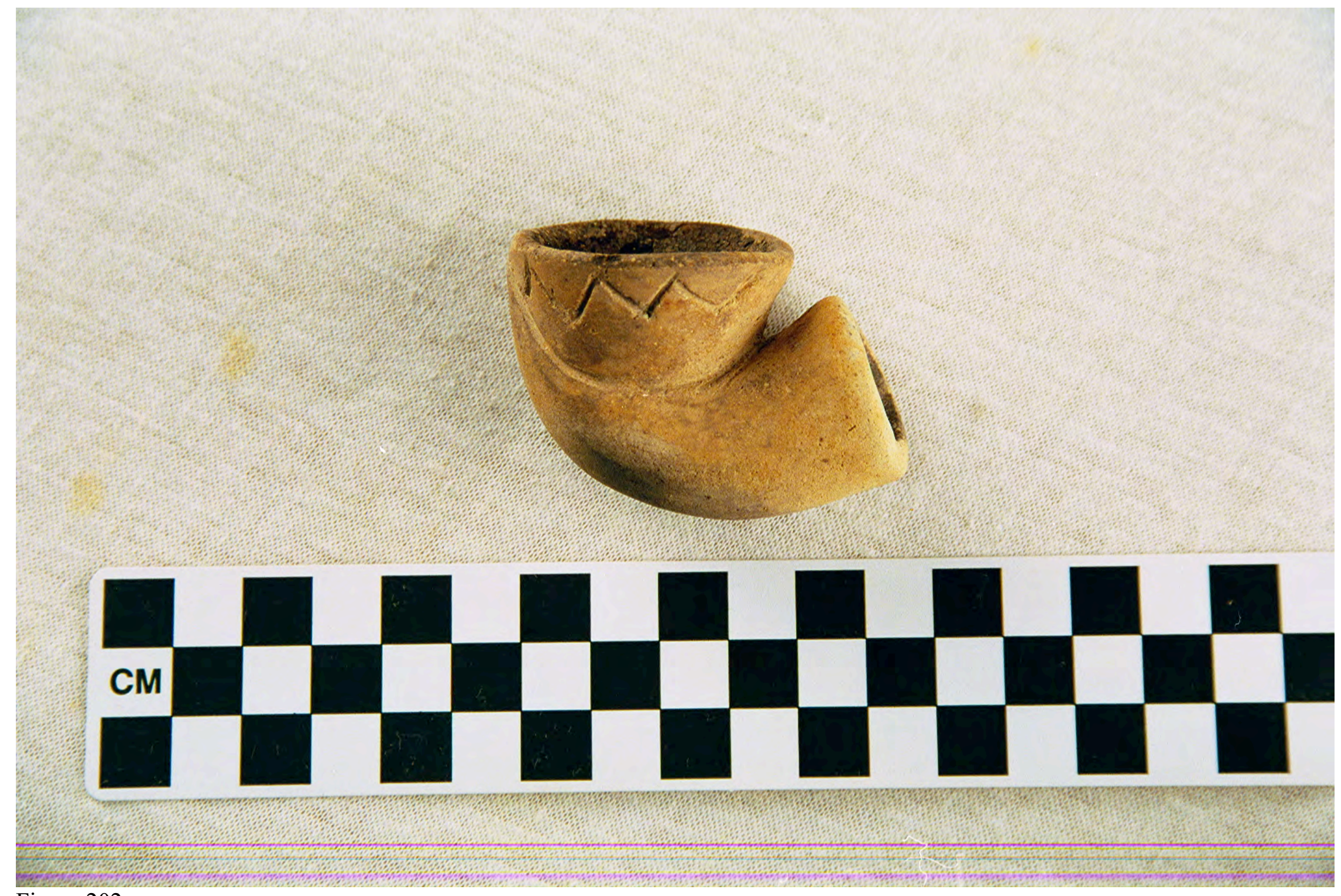

Figure 202a 


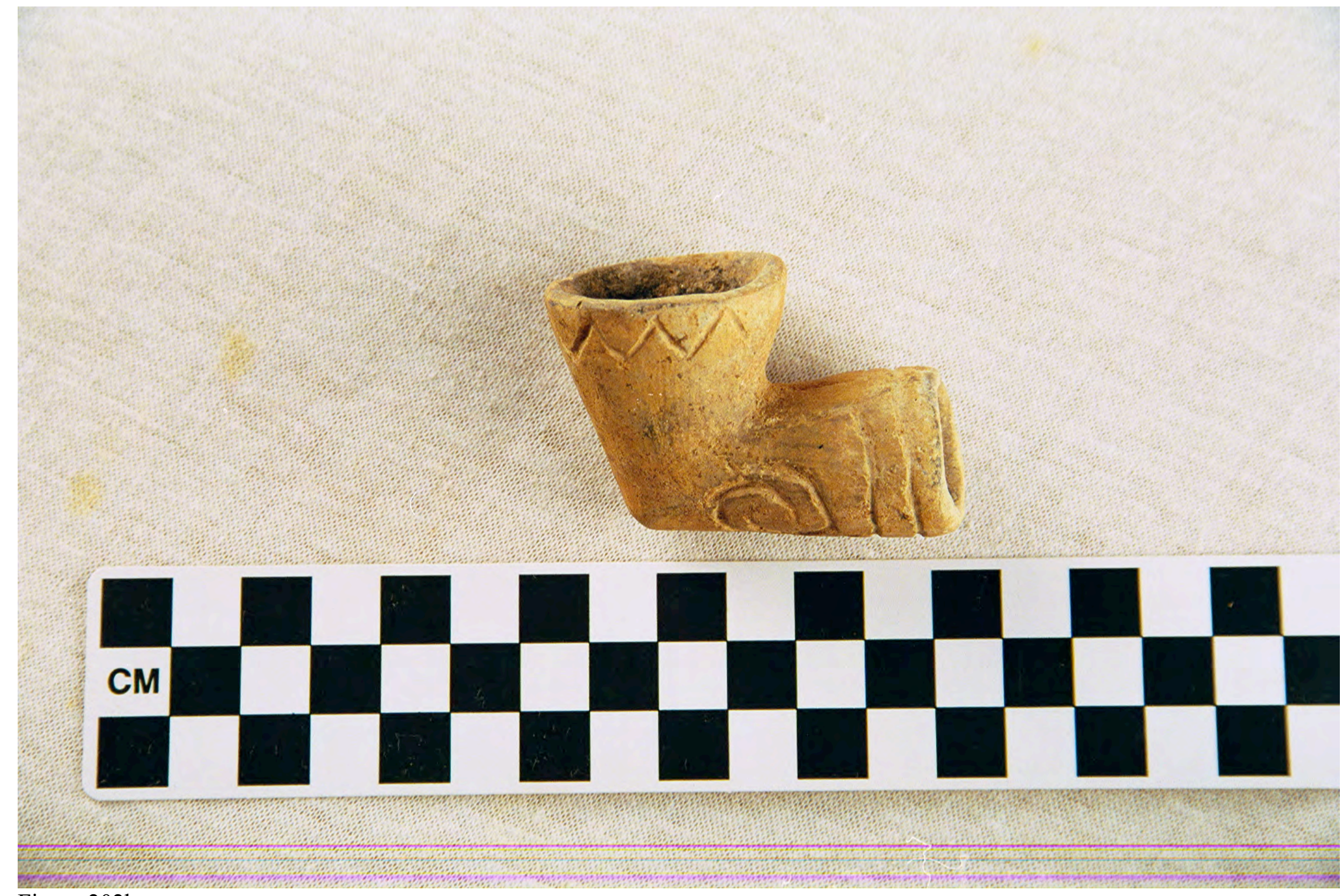

Figure 202b 


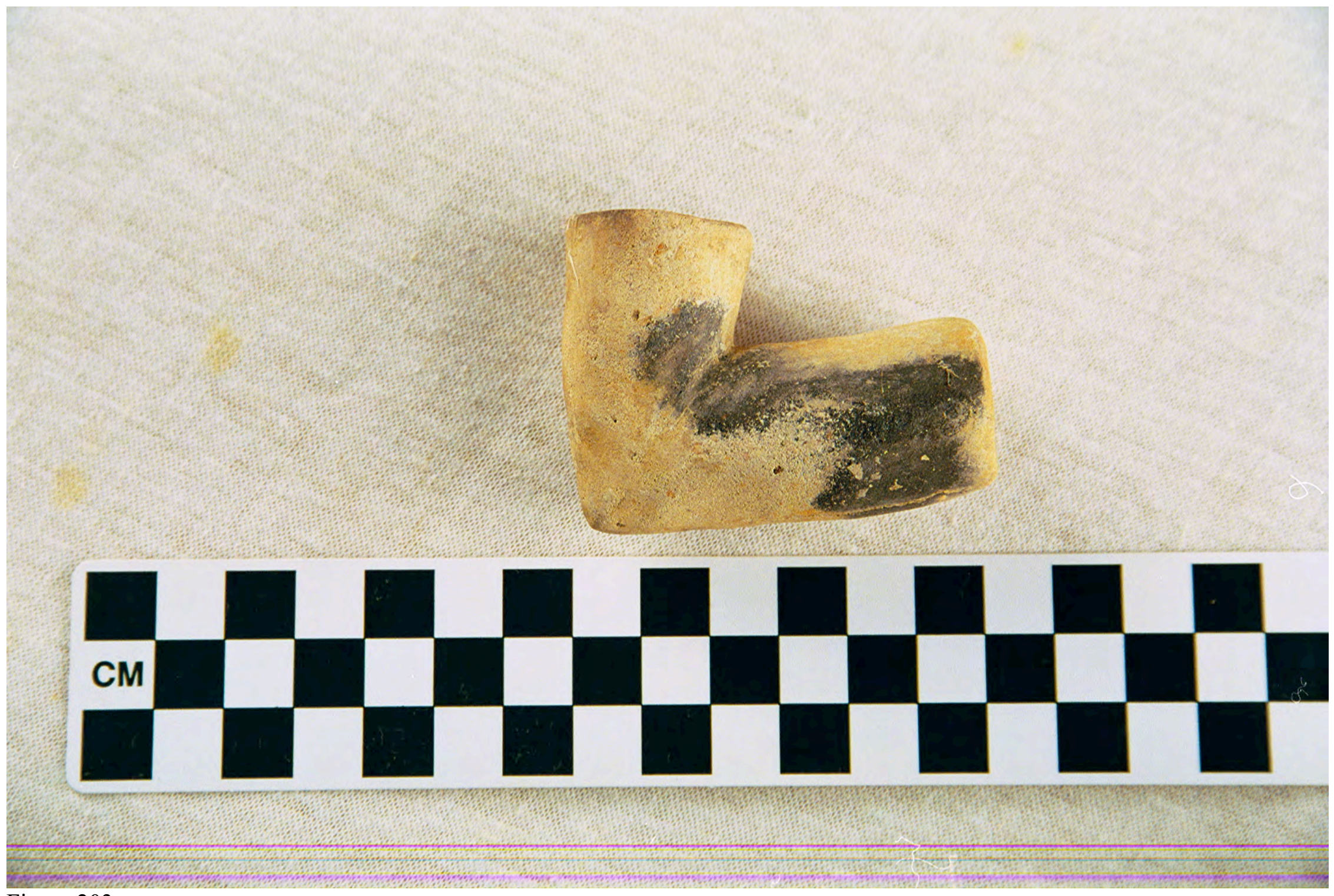

Figure 203a 


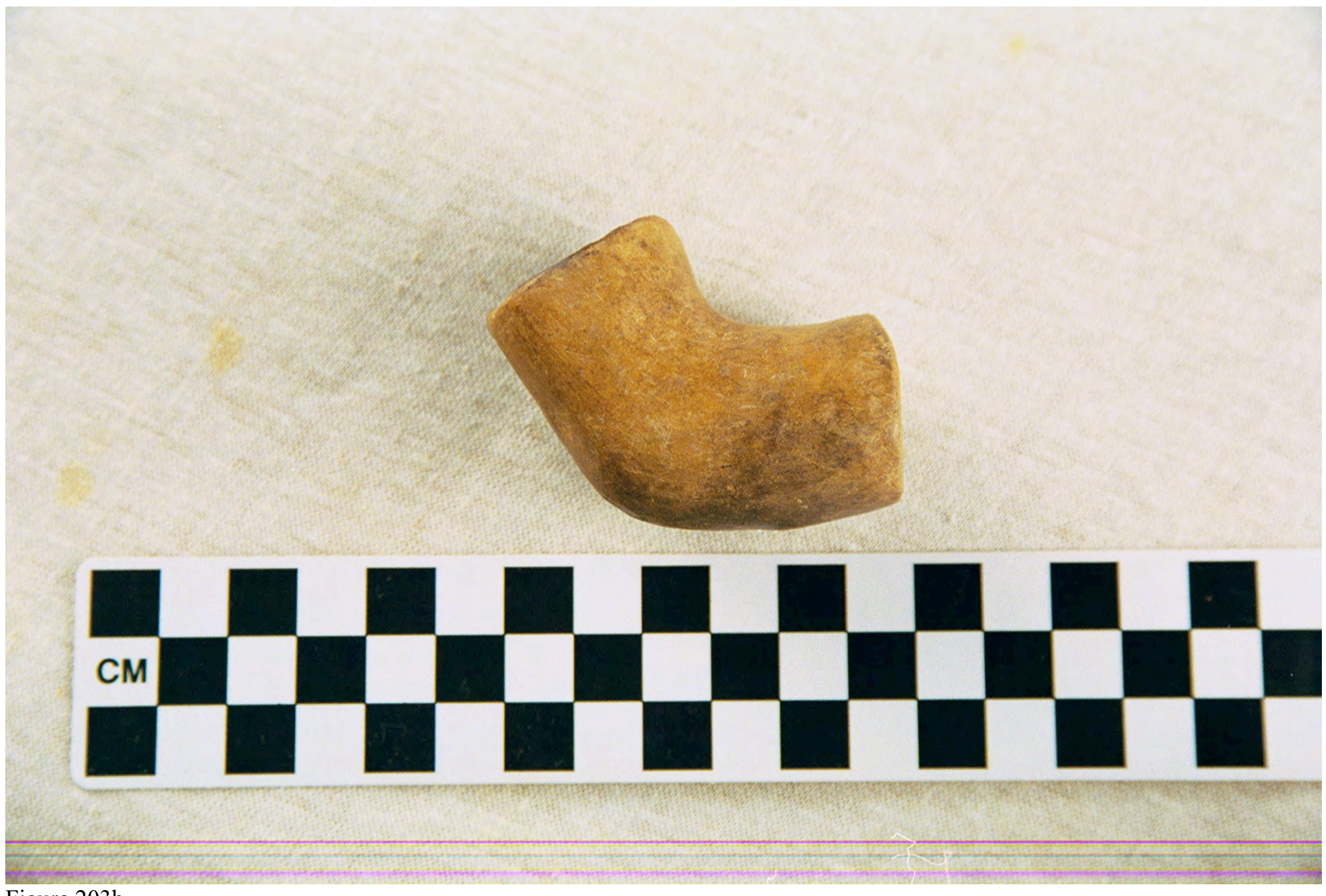

Figure 203b 


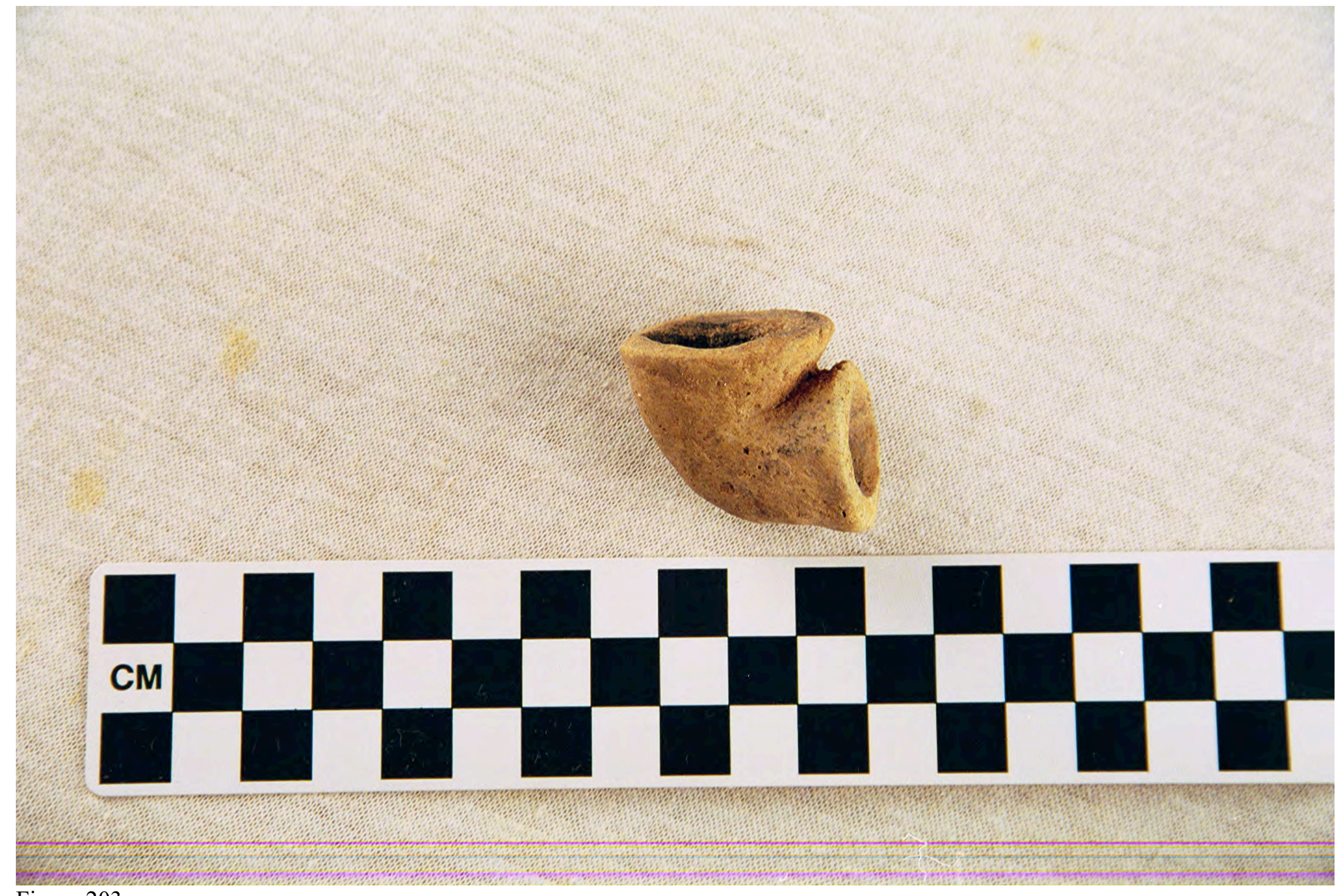

Figure 203c 


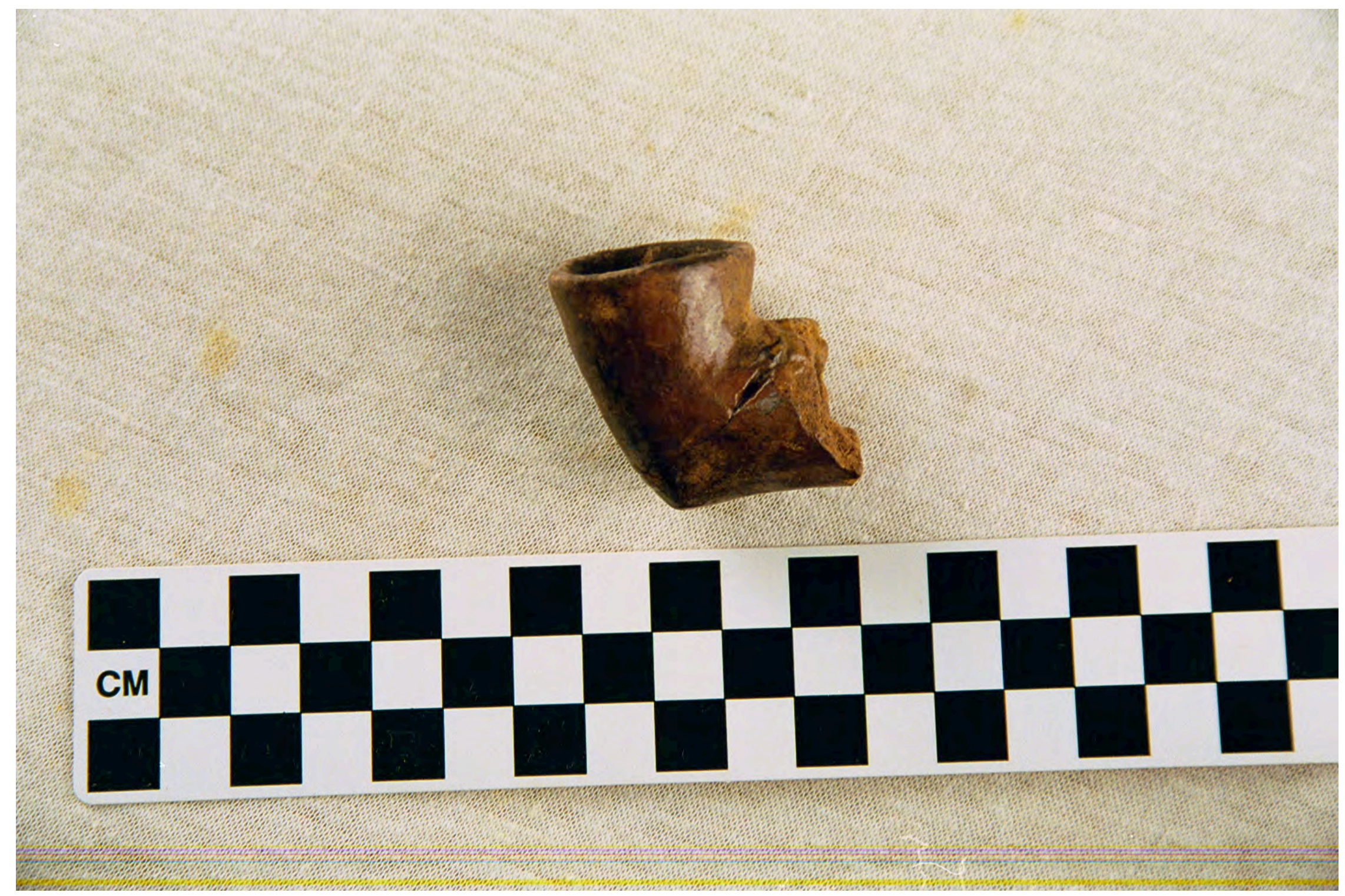

Figure 203d 


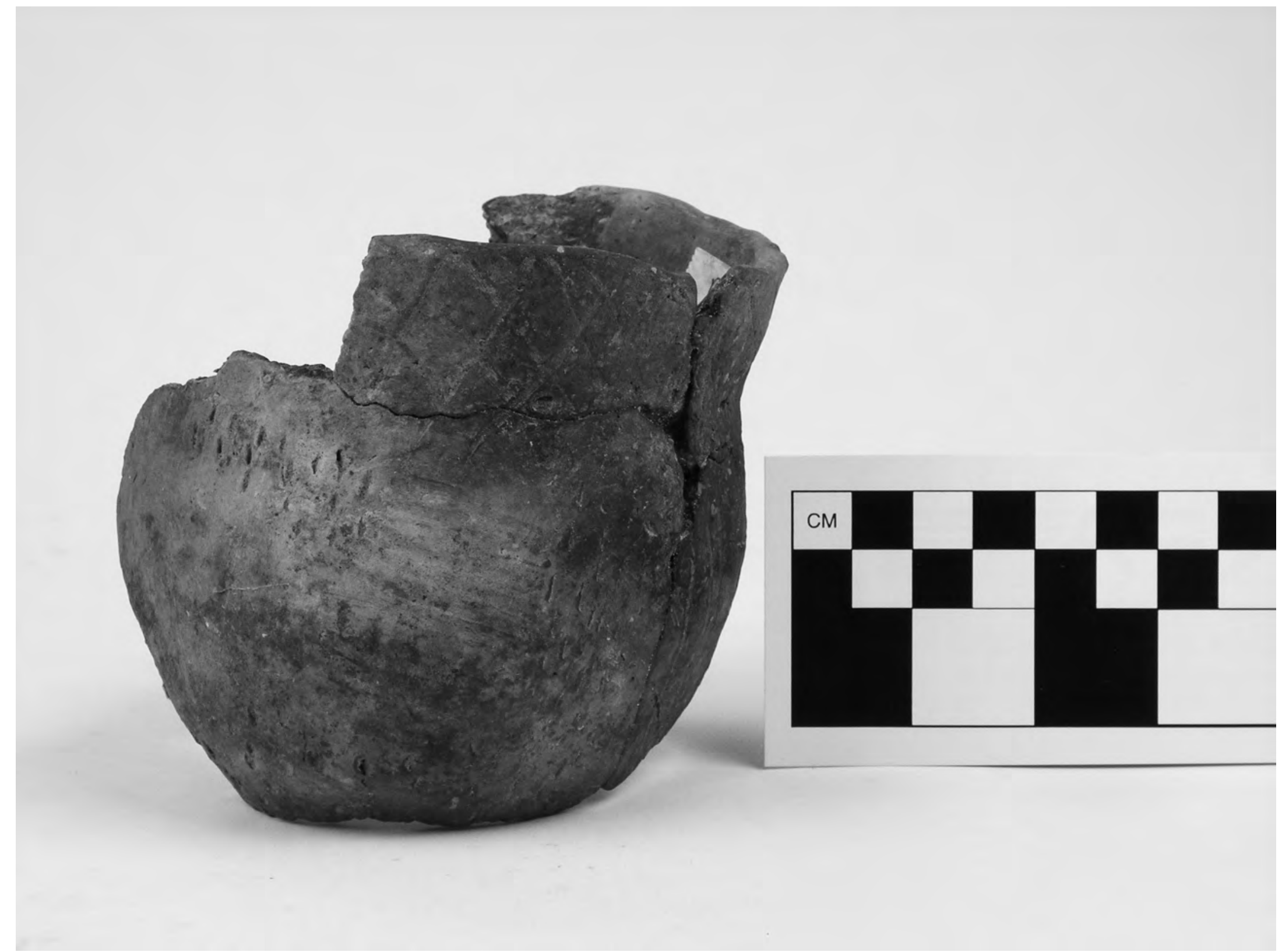

Figure 204 


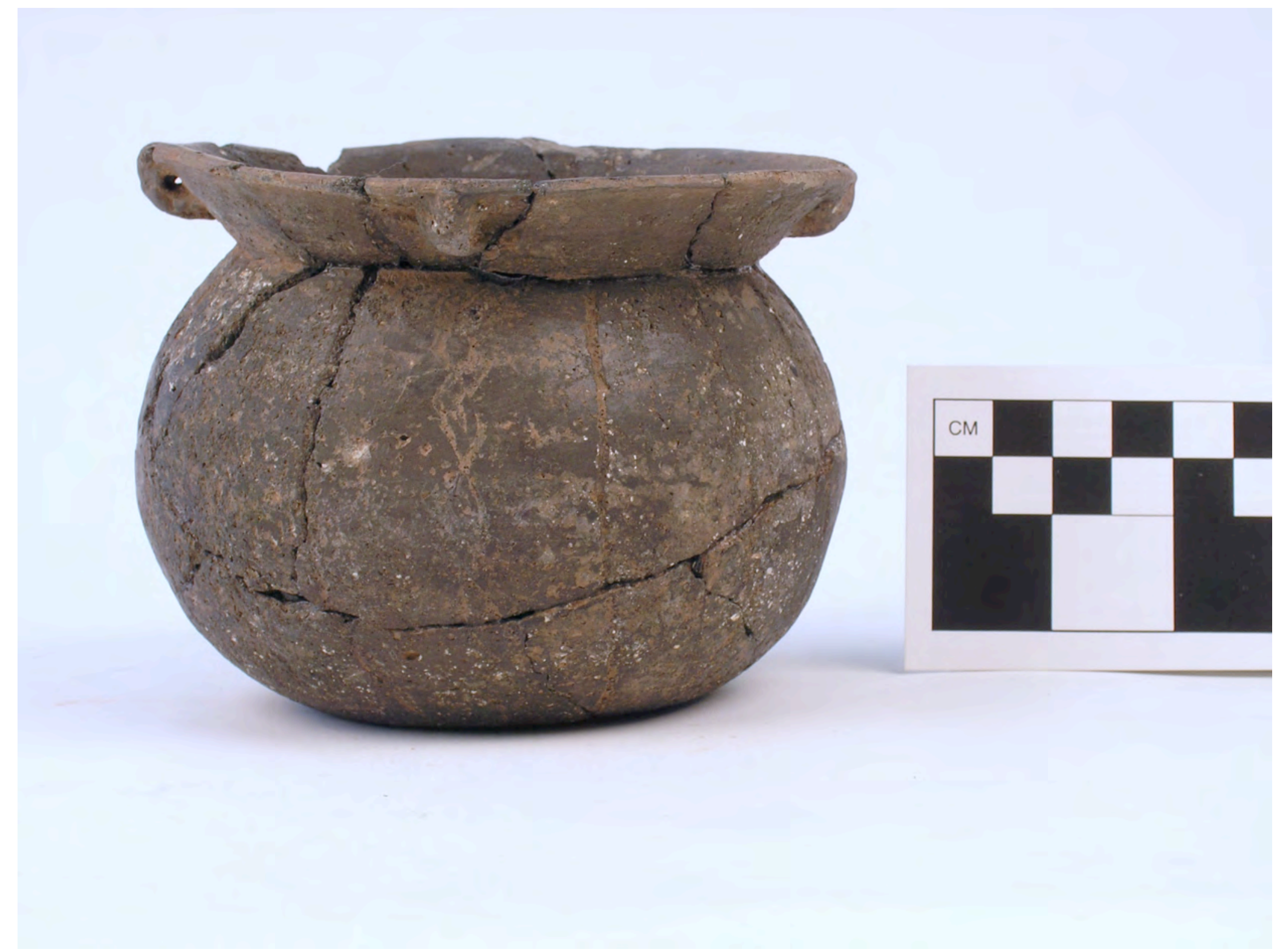

Figure 205 


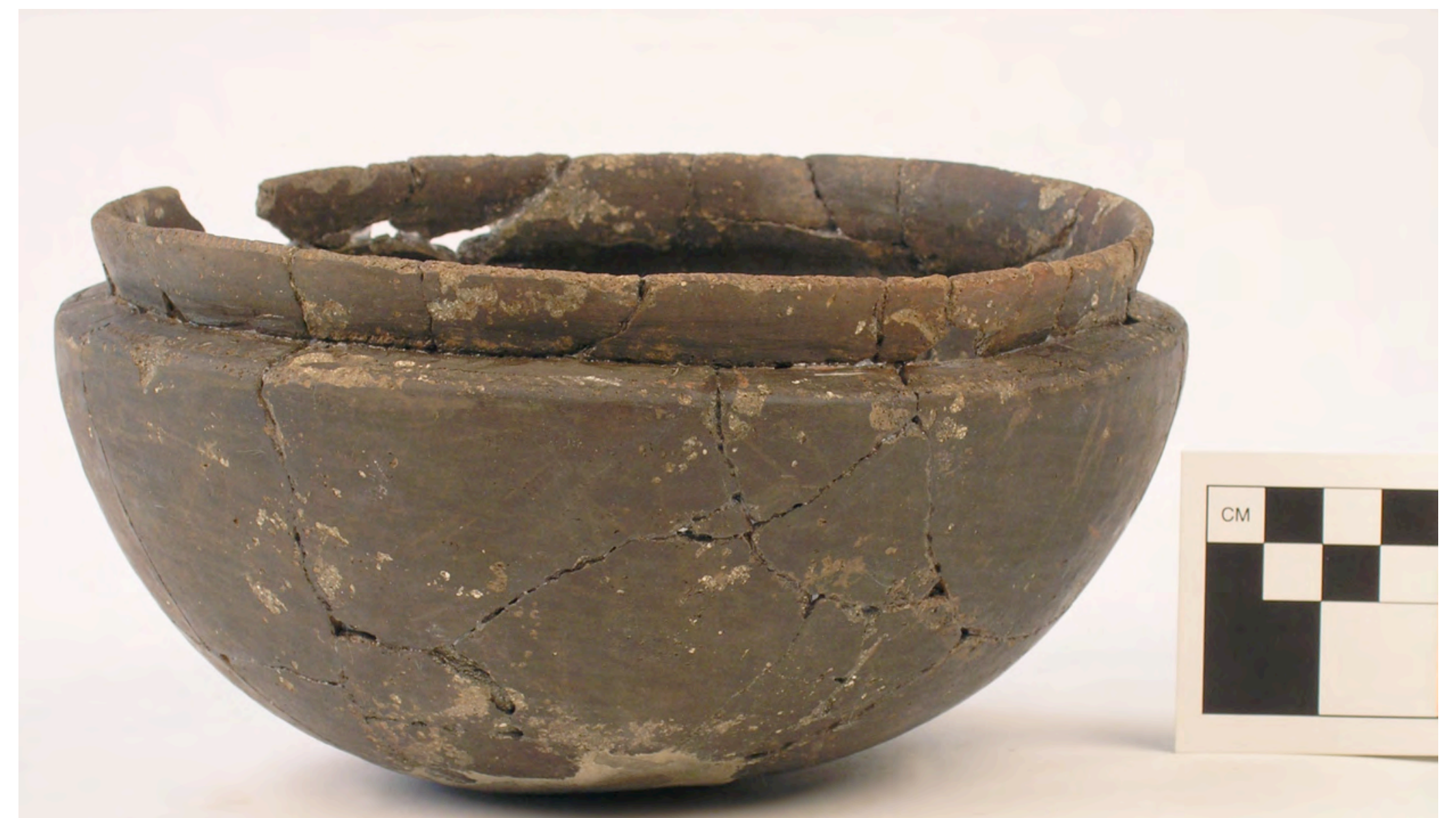

Figure 206 


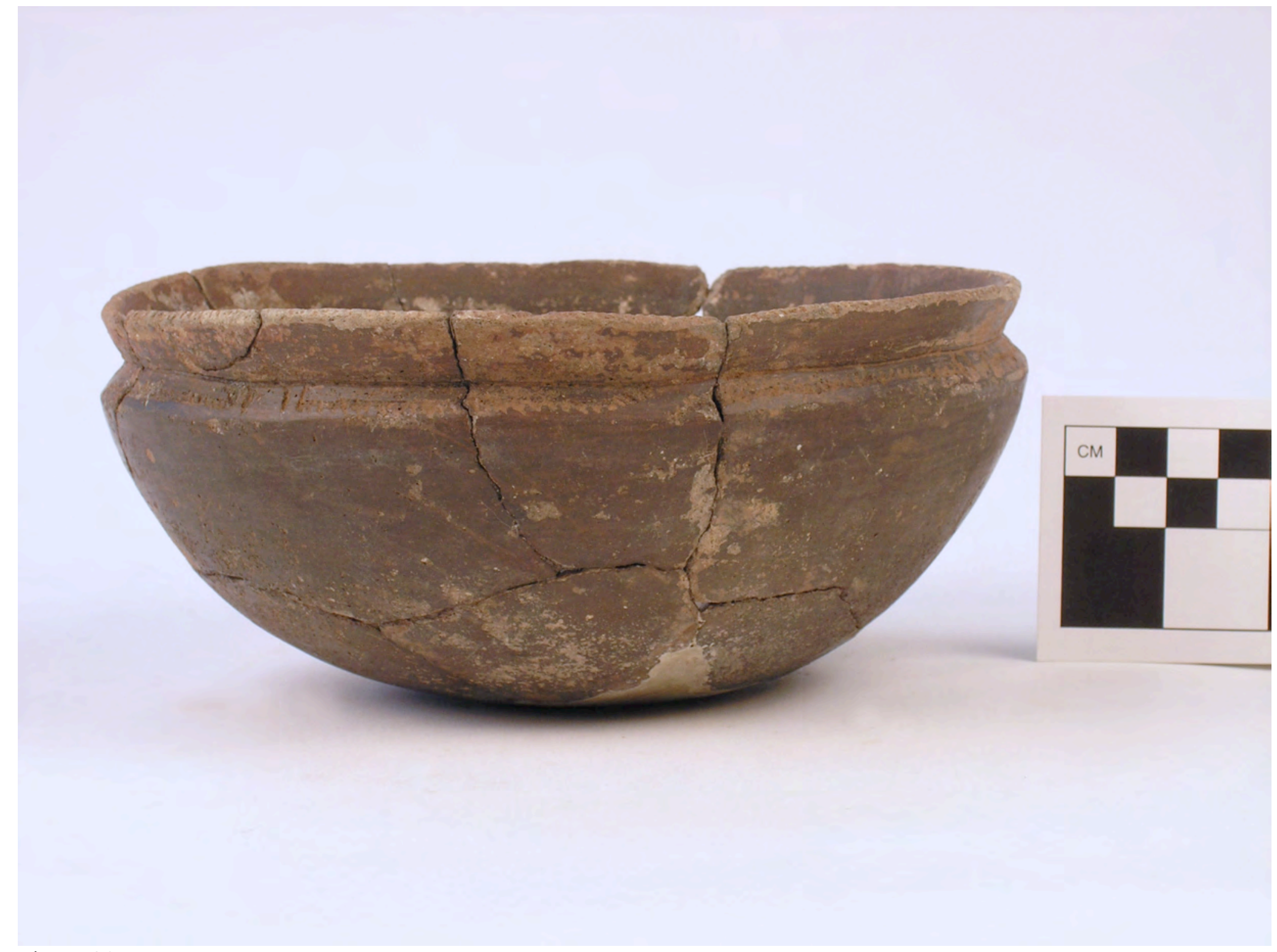

Figure 207 


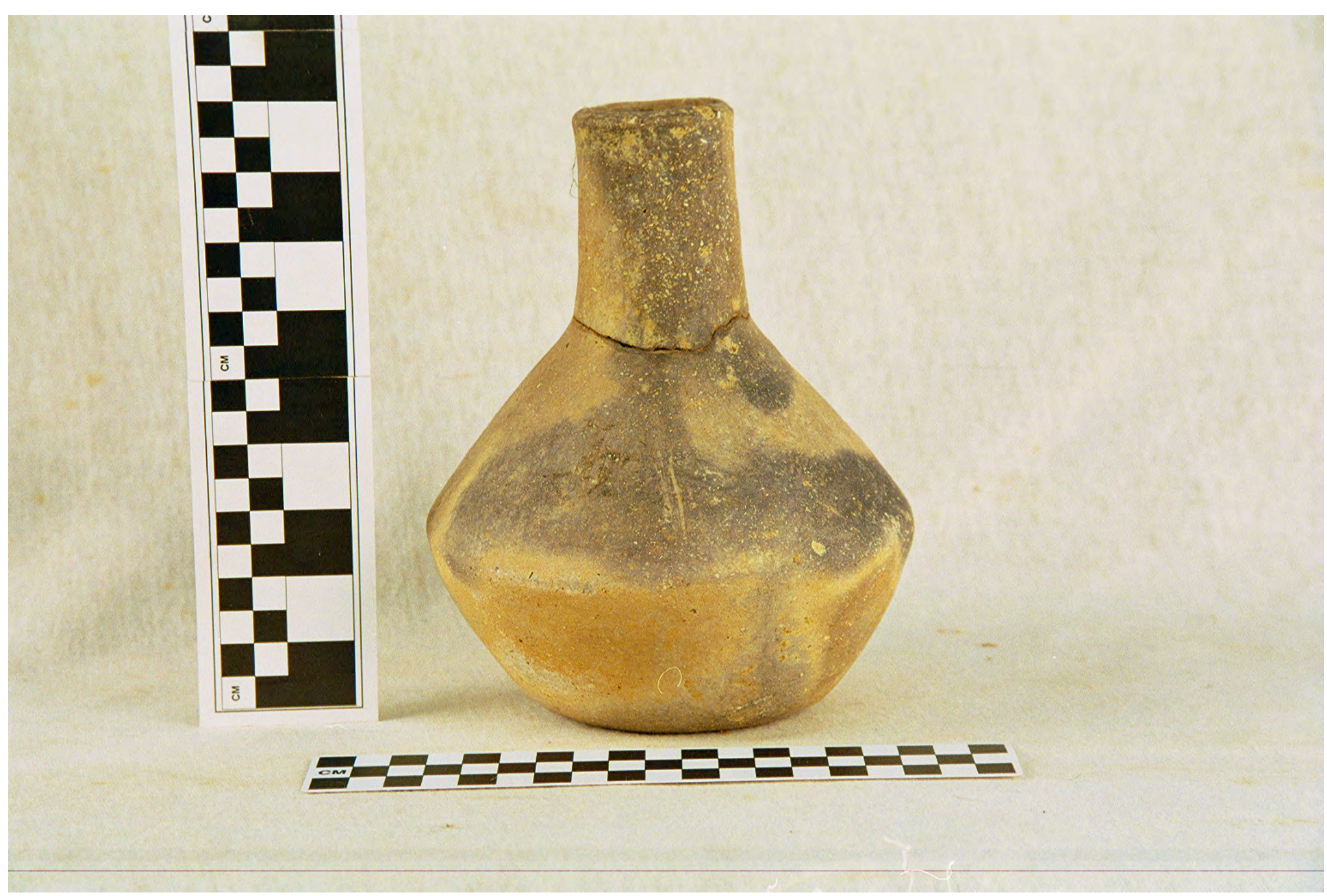

Figure 208 


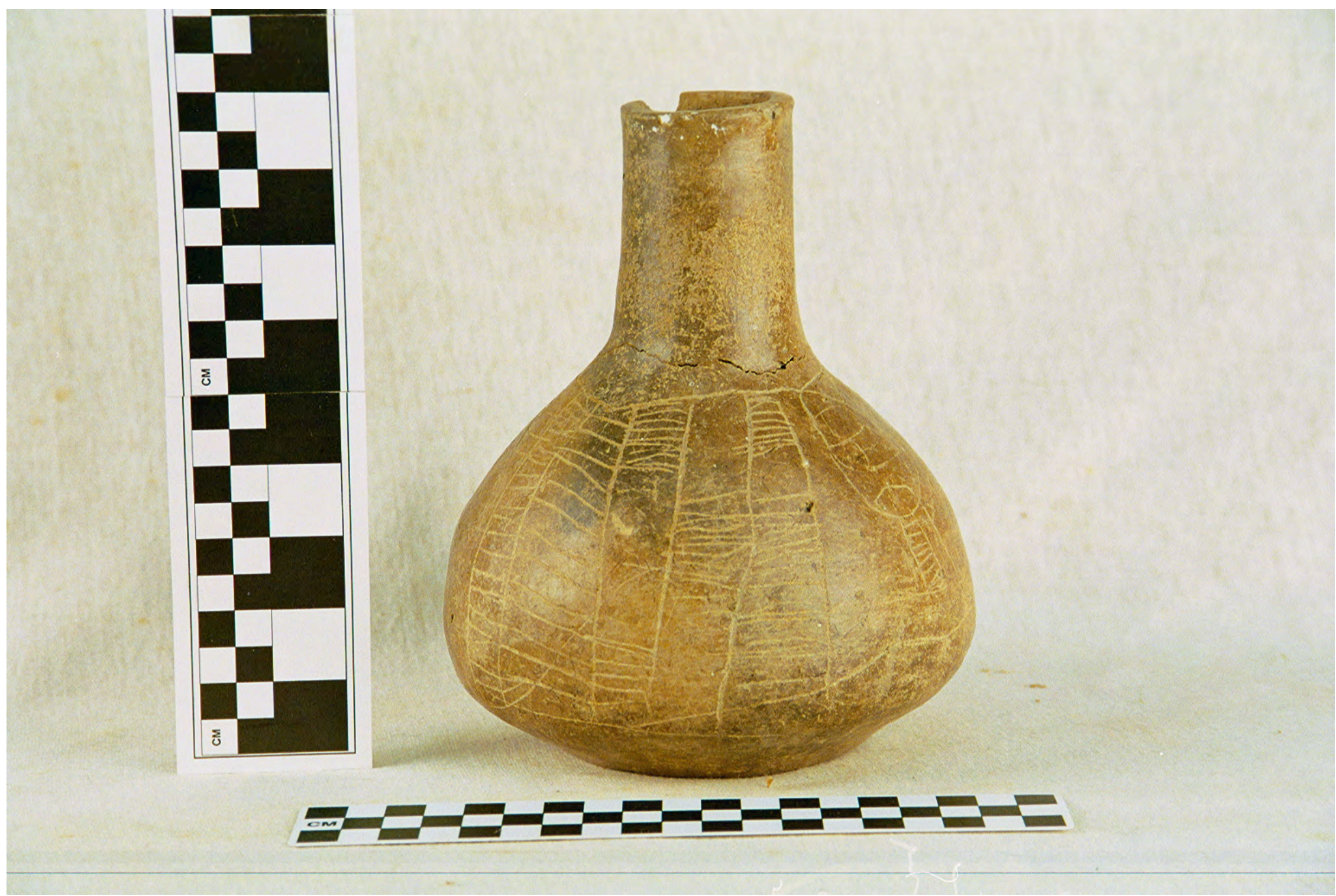

Figure 209a 


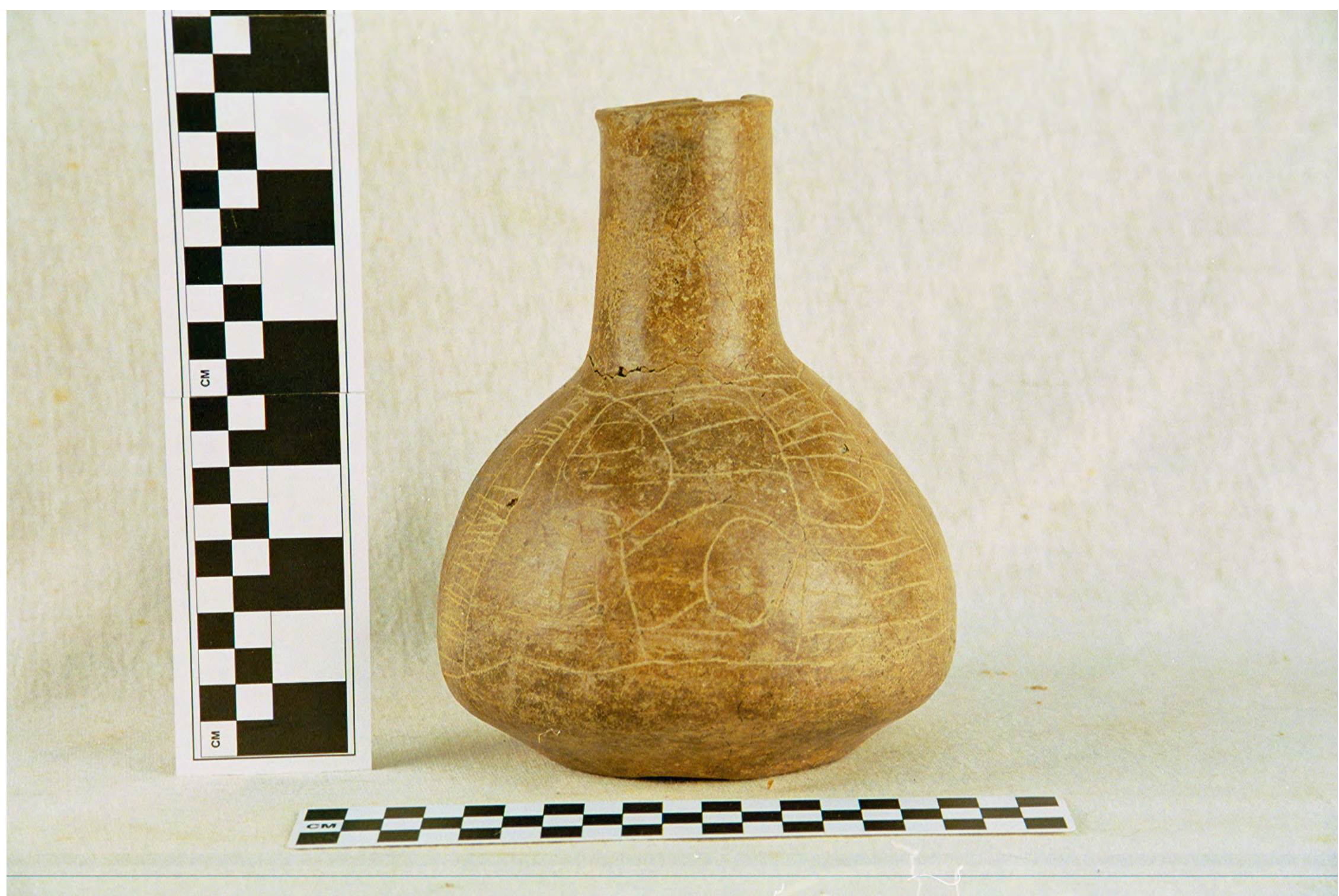

Figure 209b 


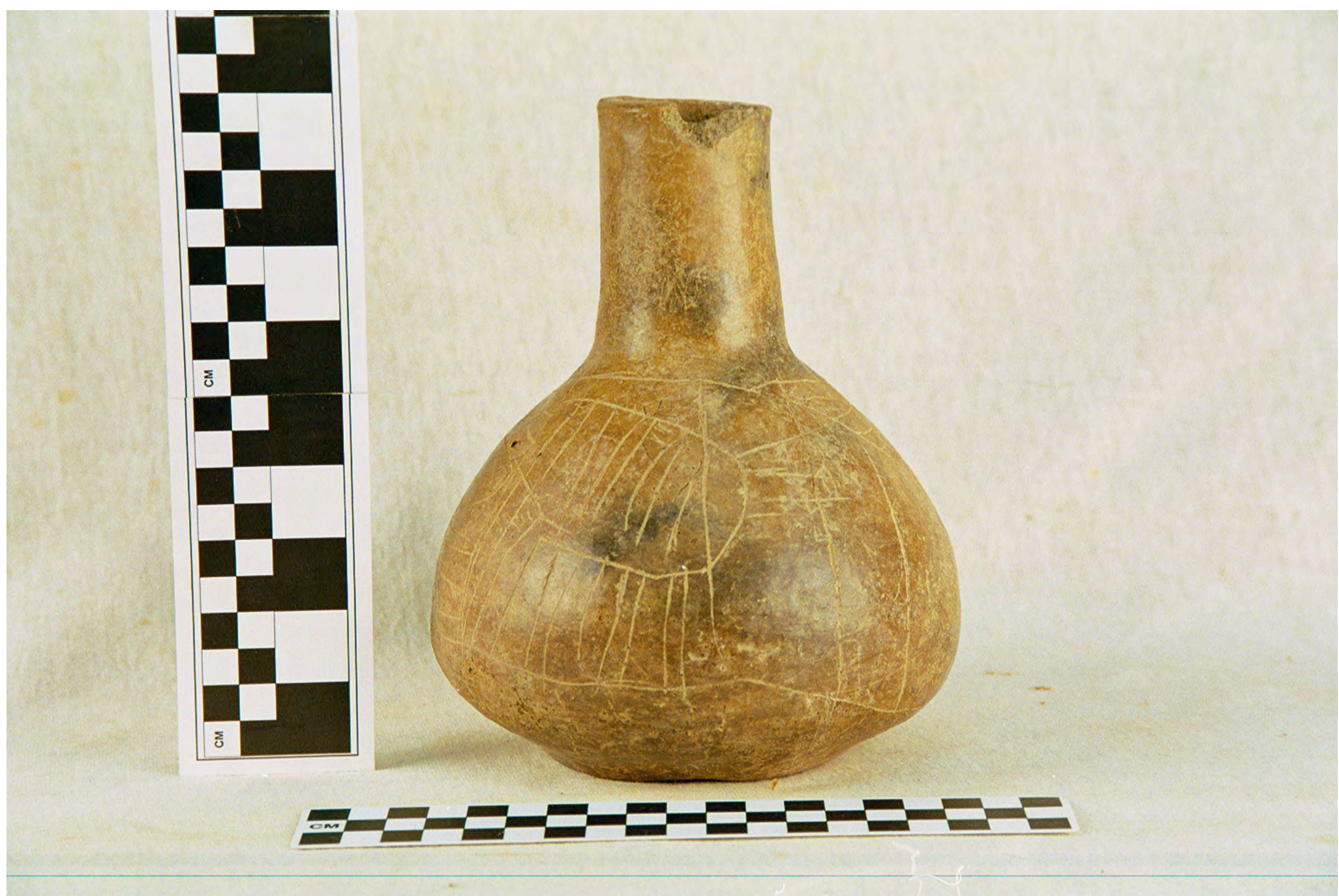

Figure 209c 


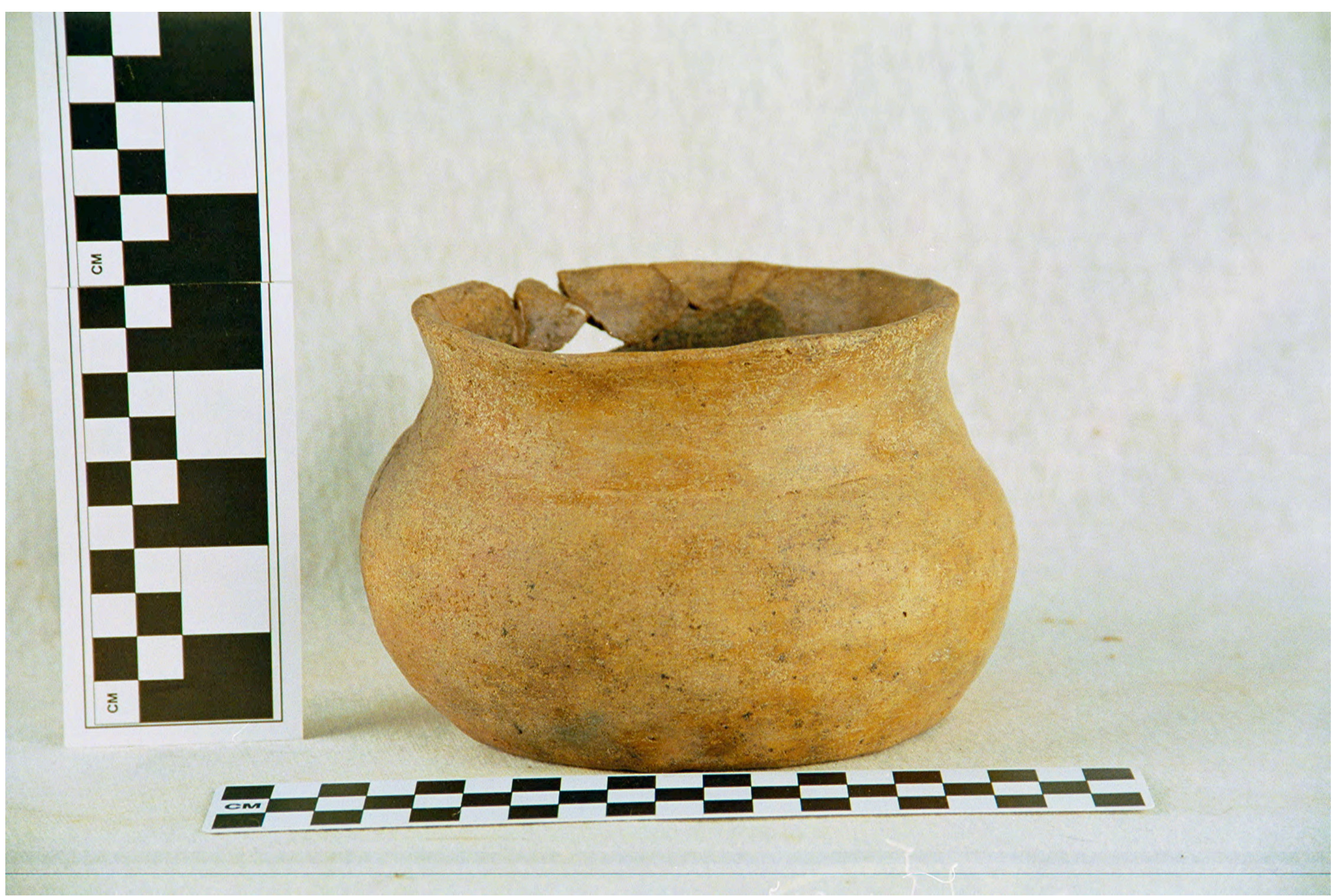

Figure 210 


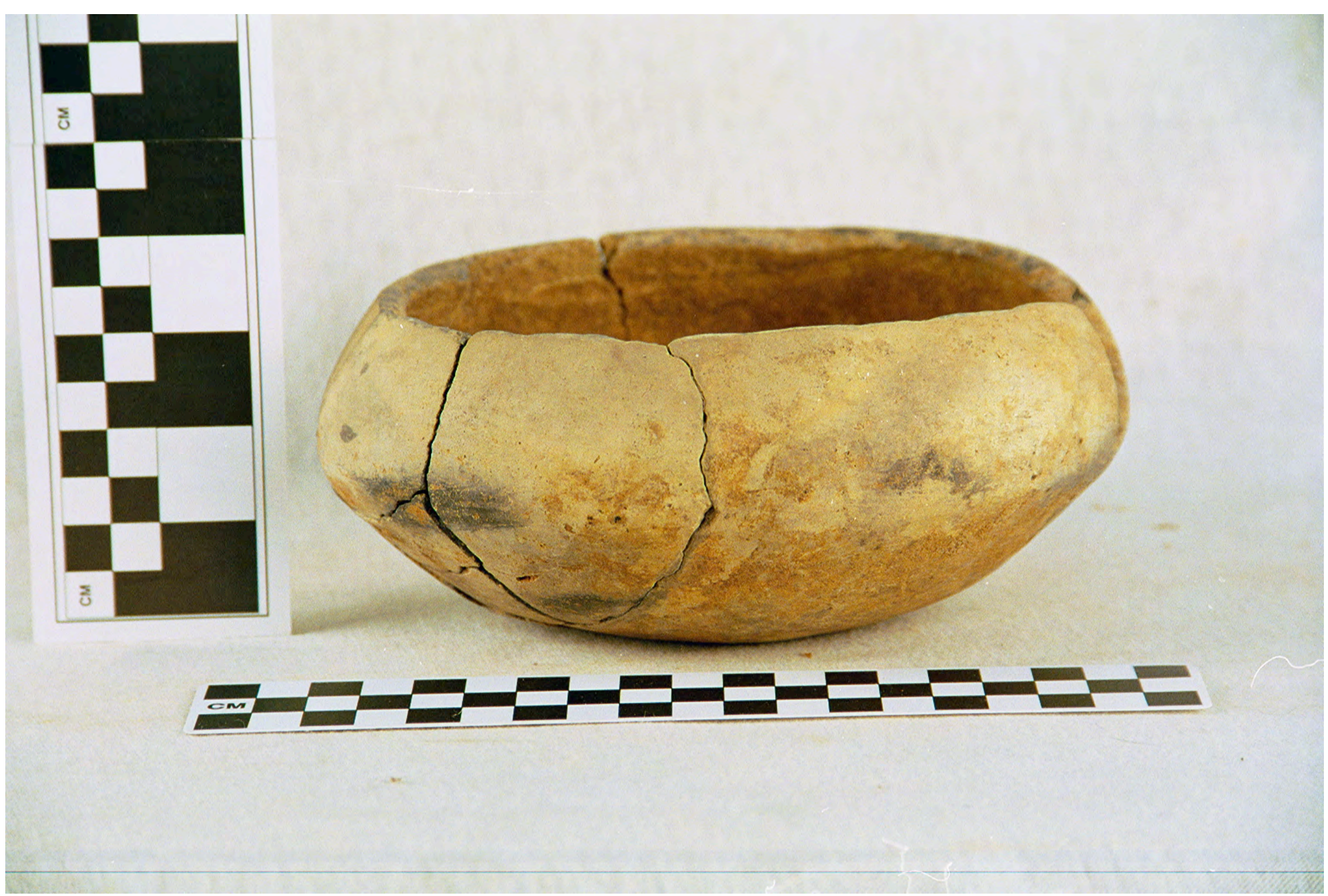

Figure 211 


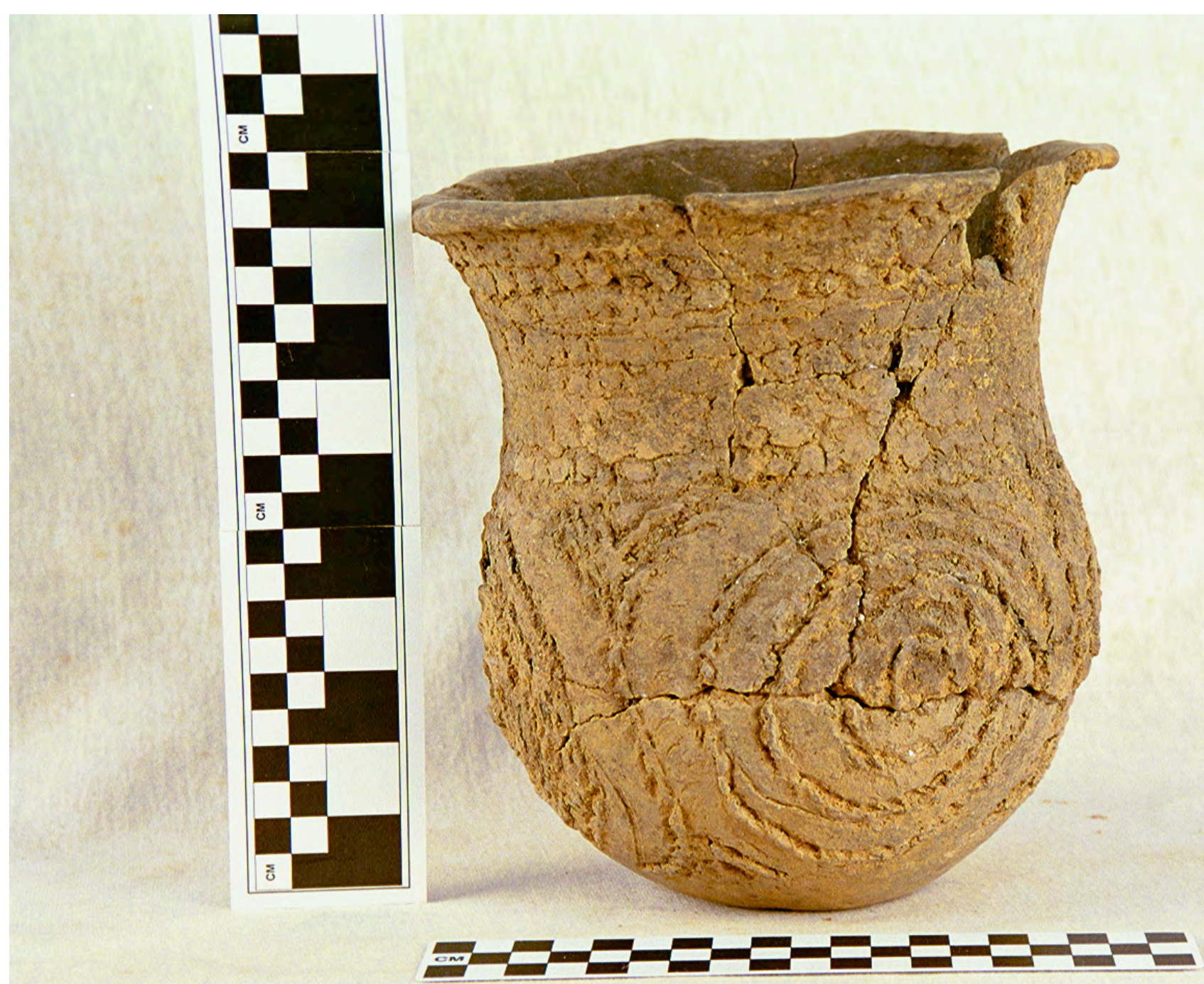

Figure 212 


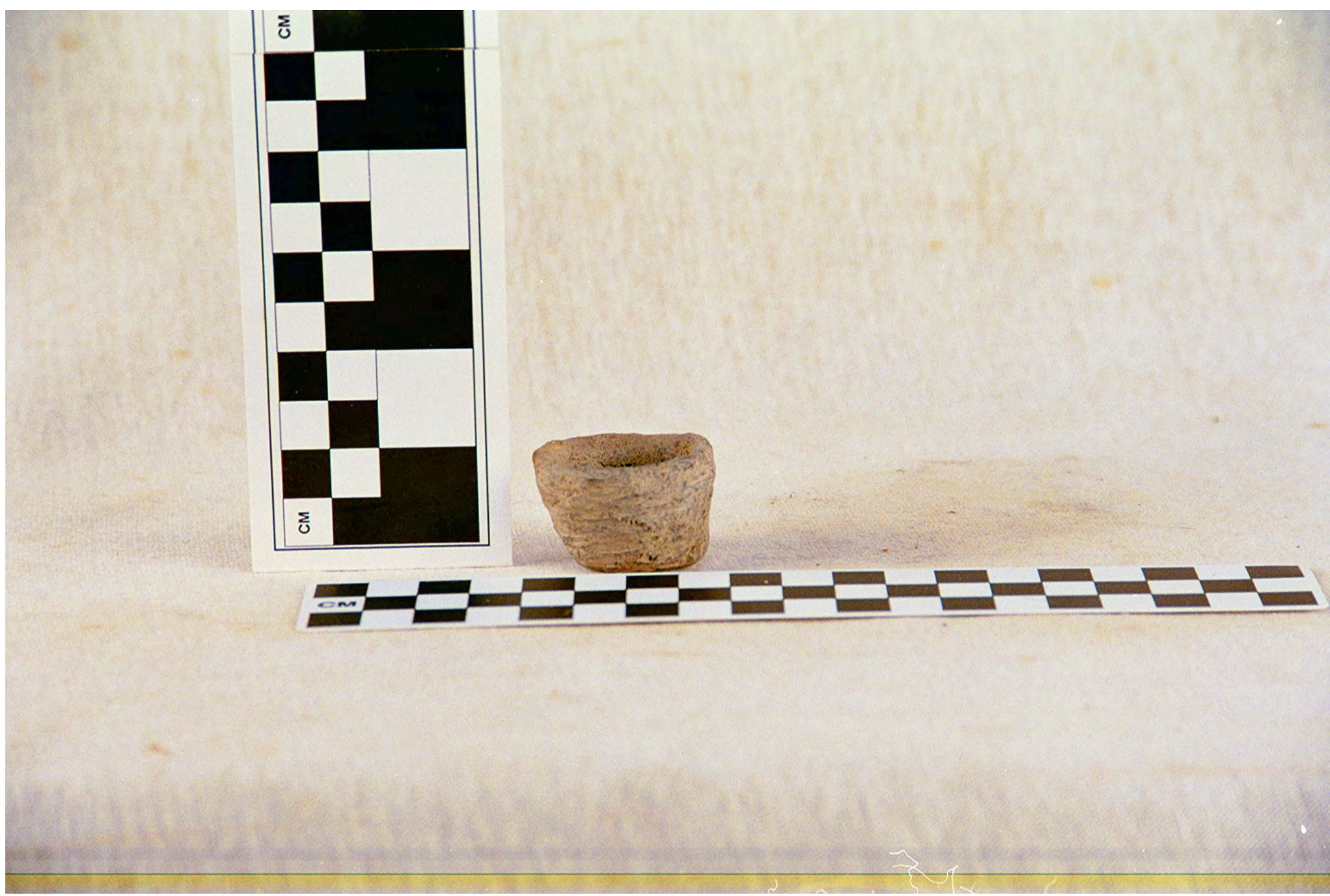

Figure 213 


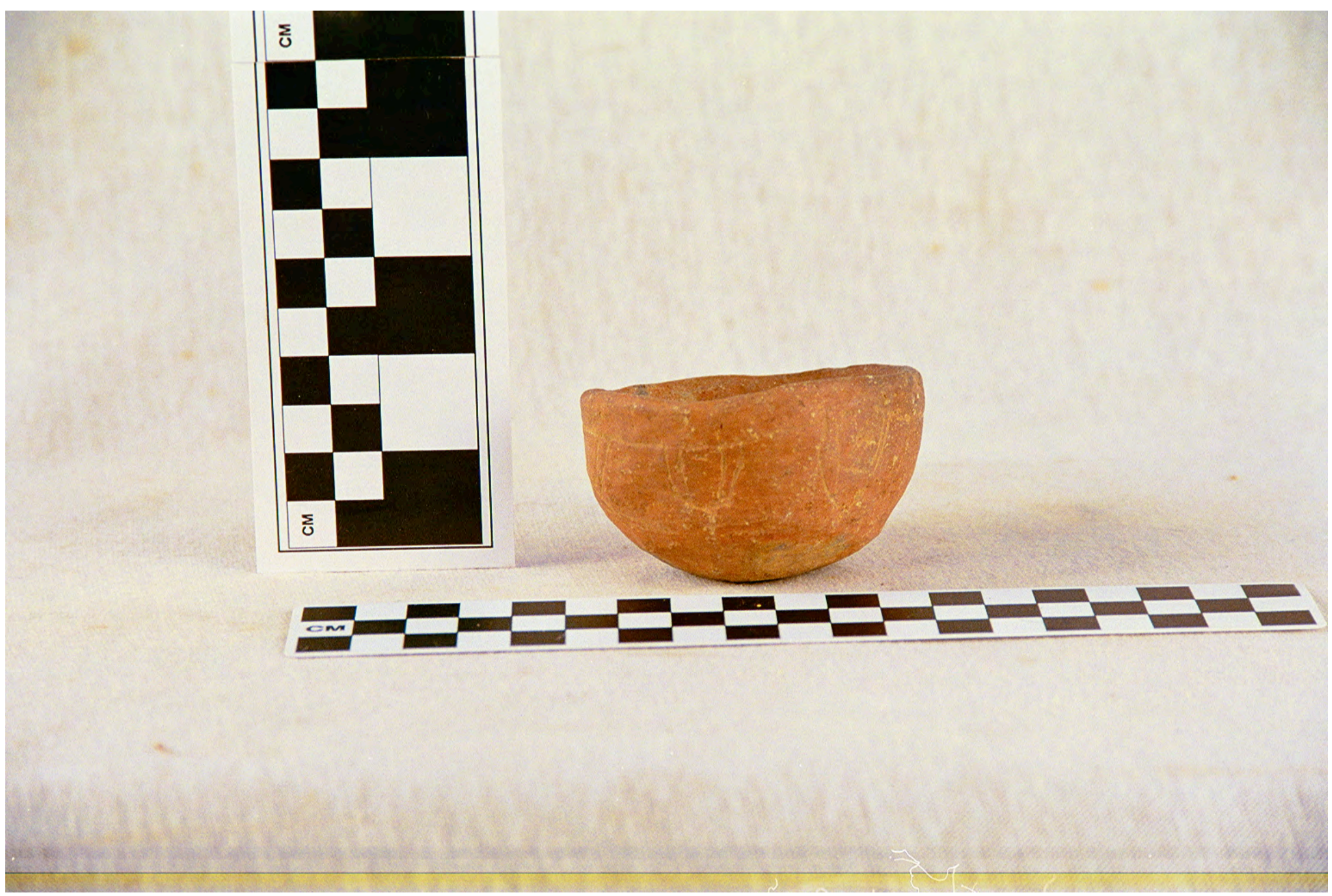

Figure 214 


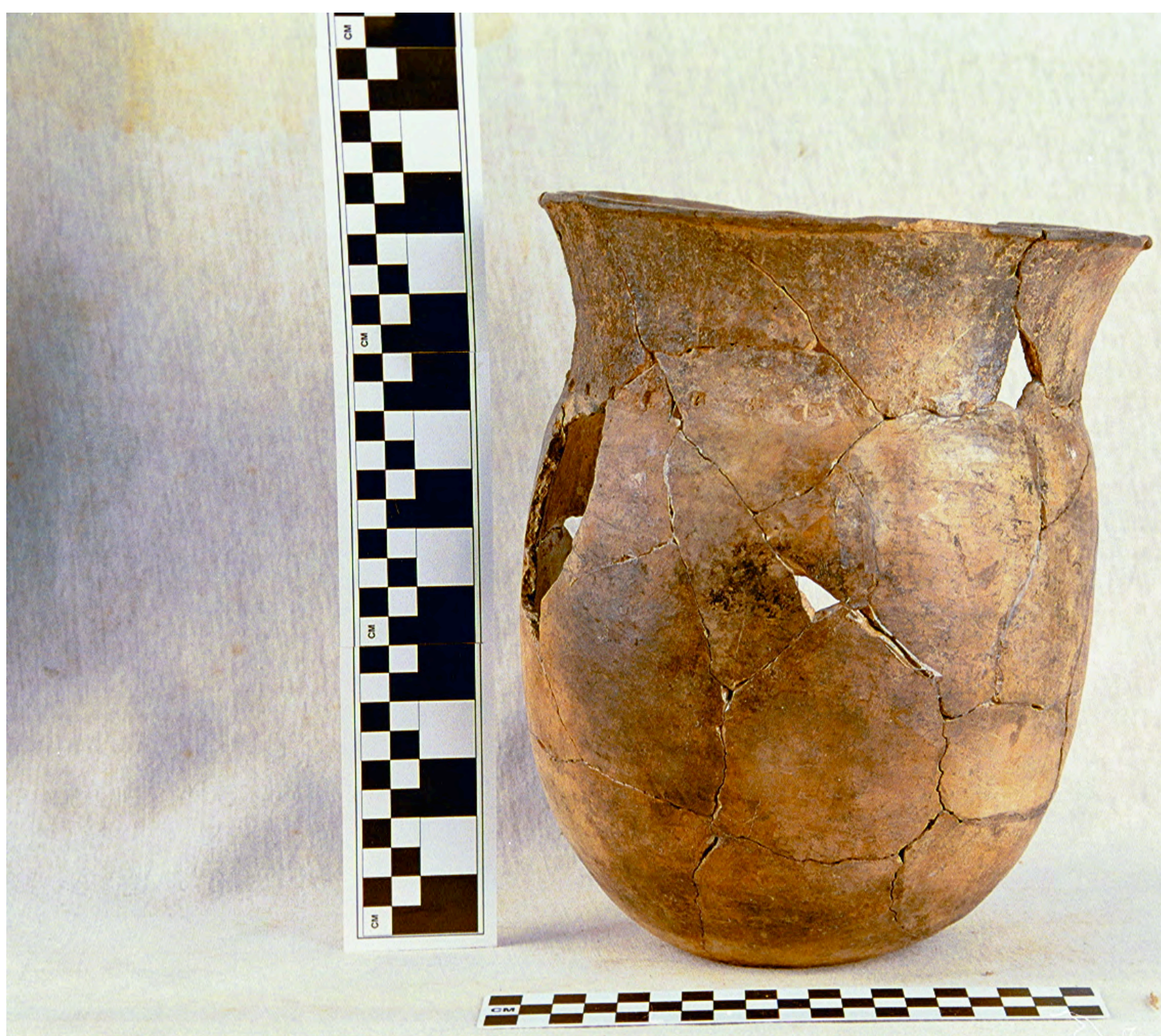

Figure 215 


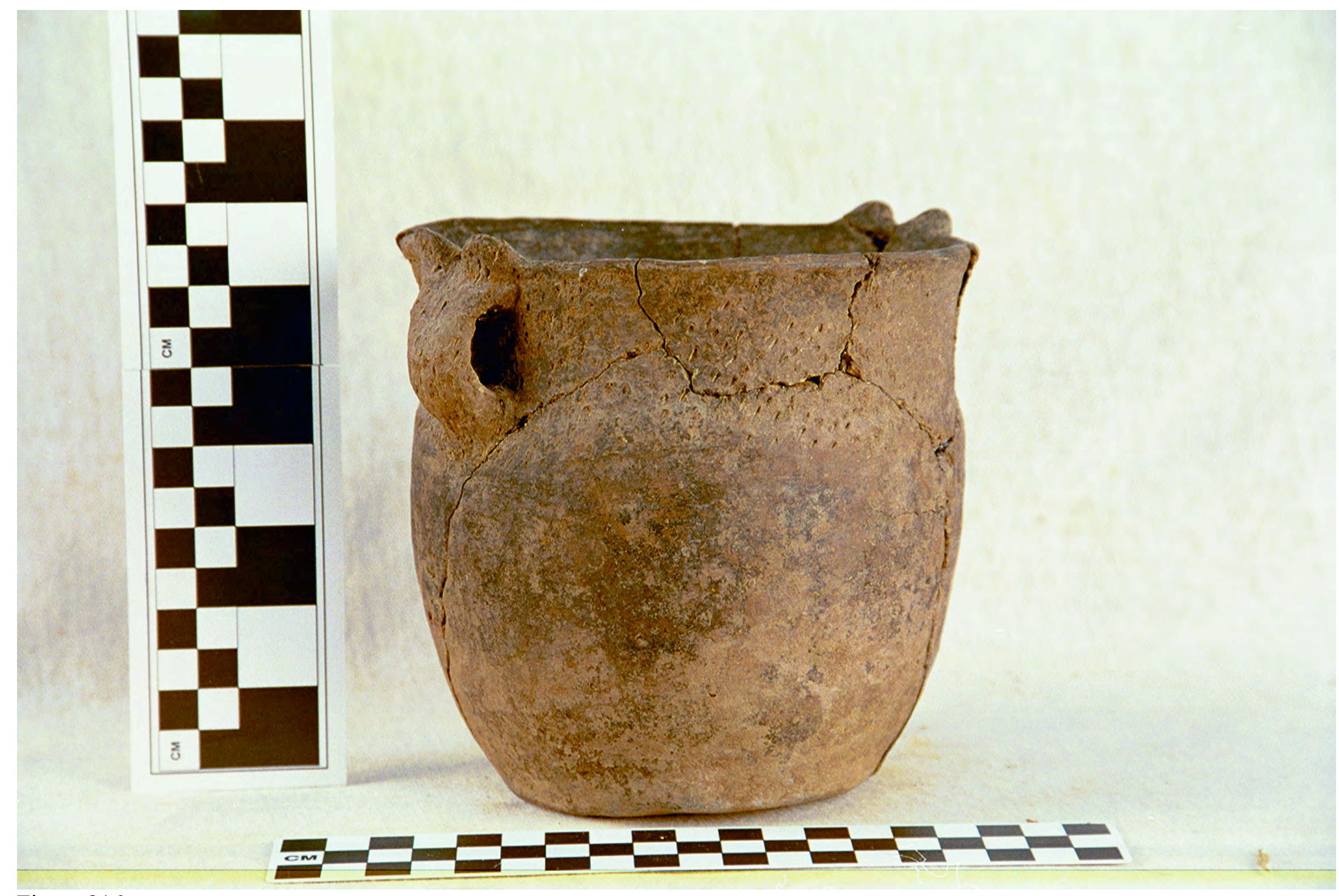

Figure 216 


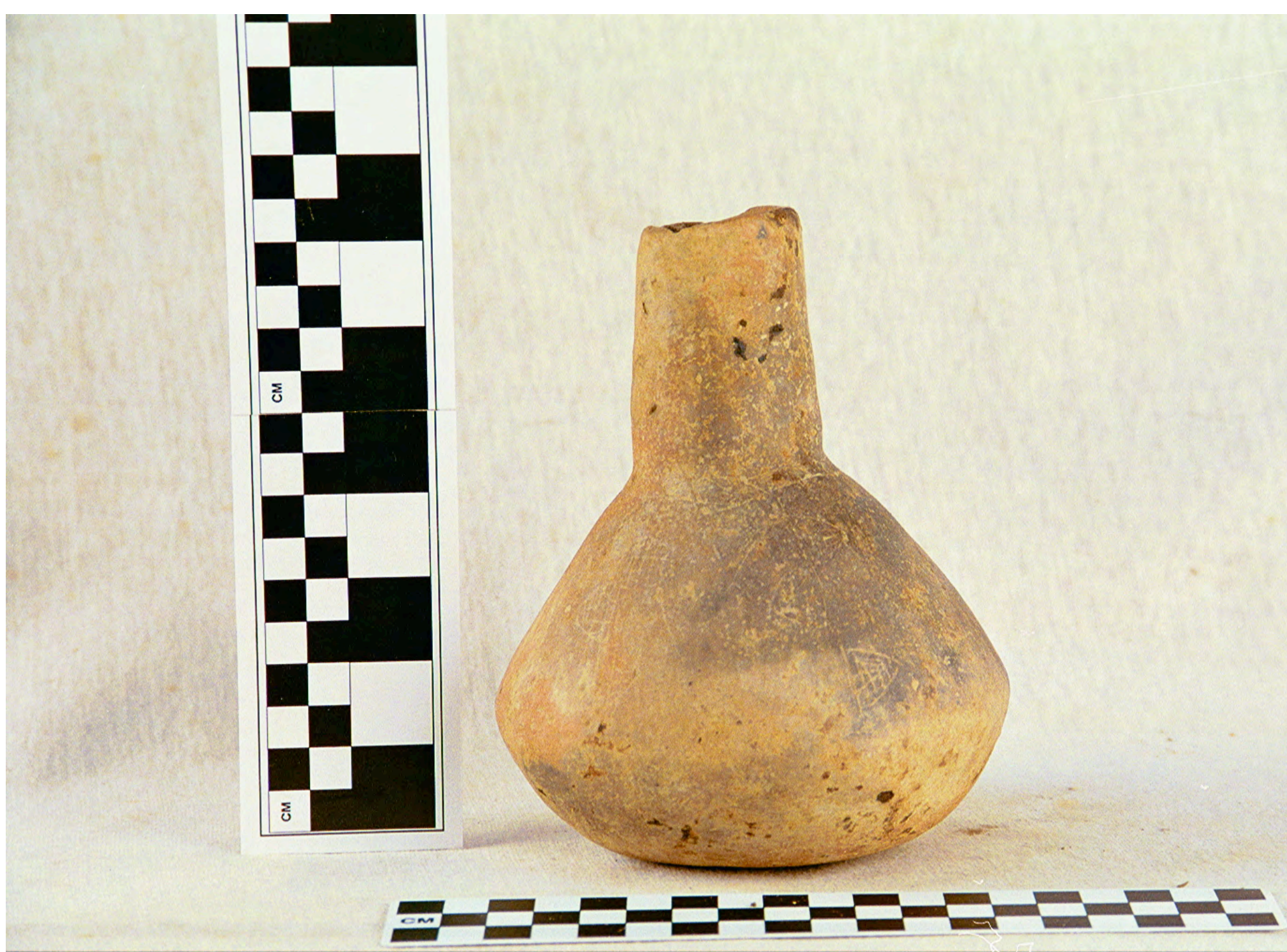

Figure 217 


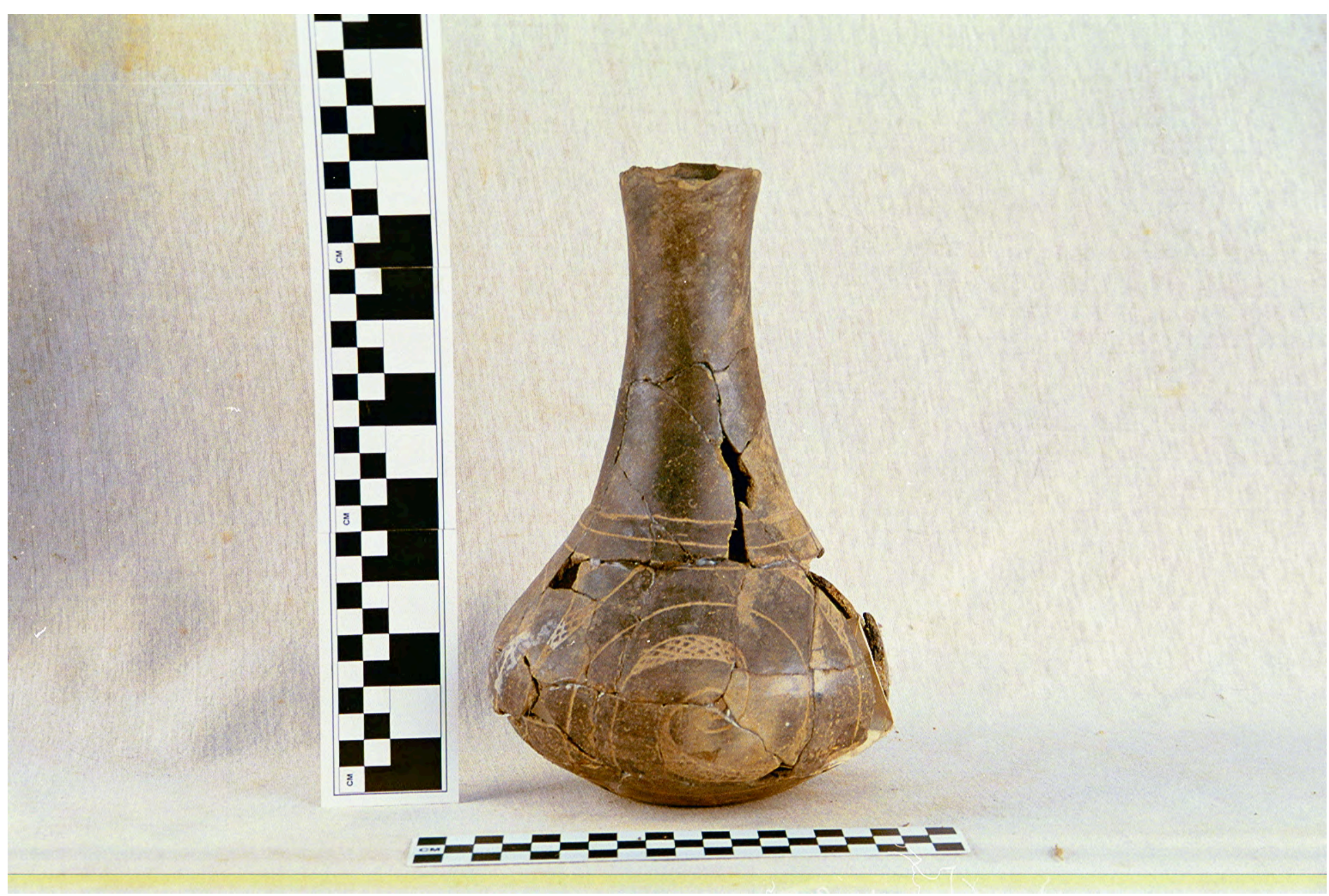

Figure 218 


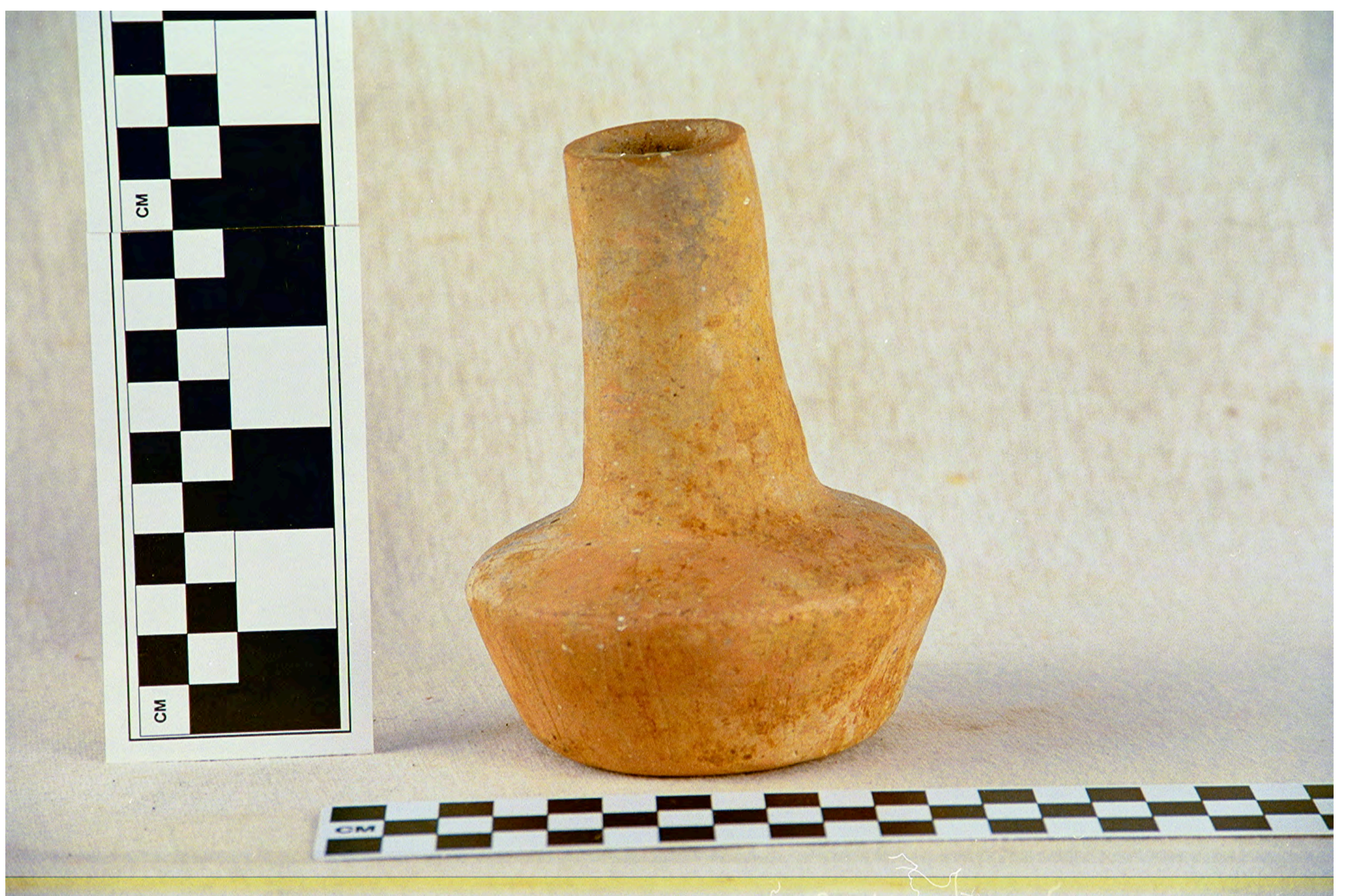

Figure 219 


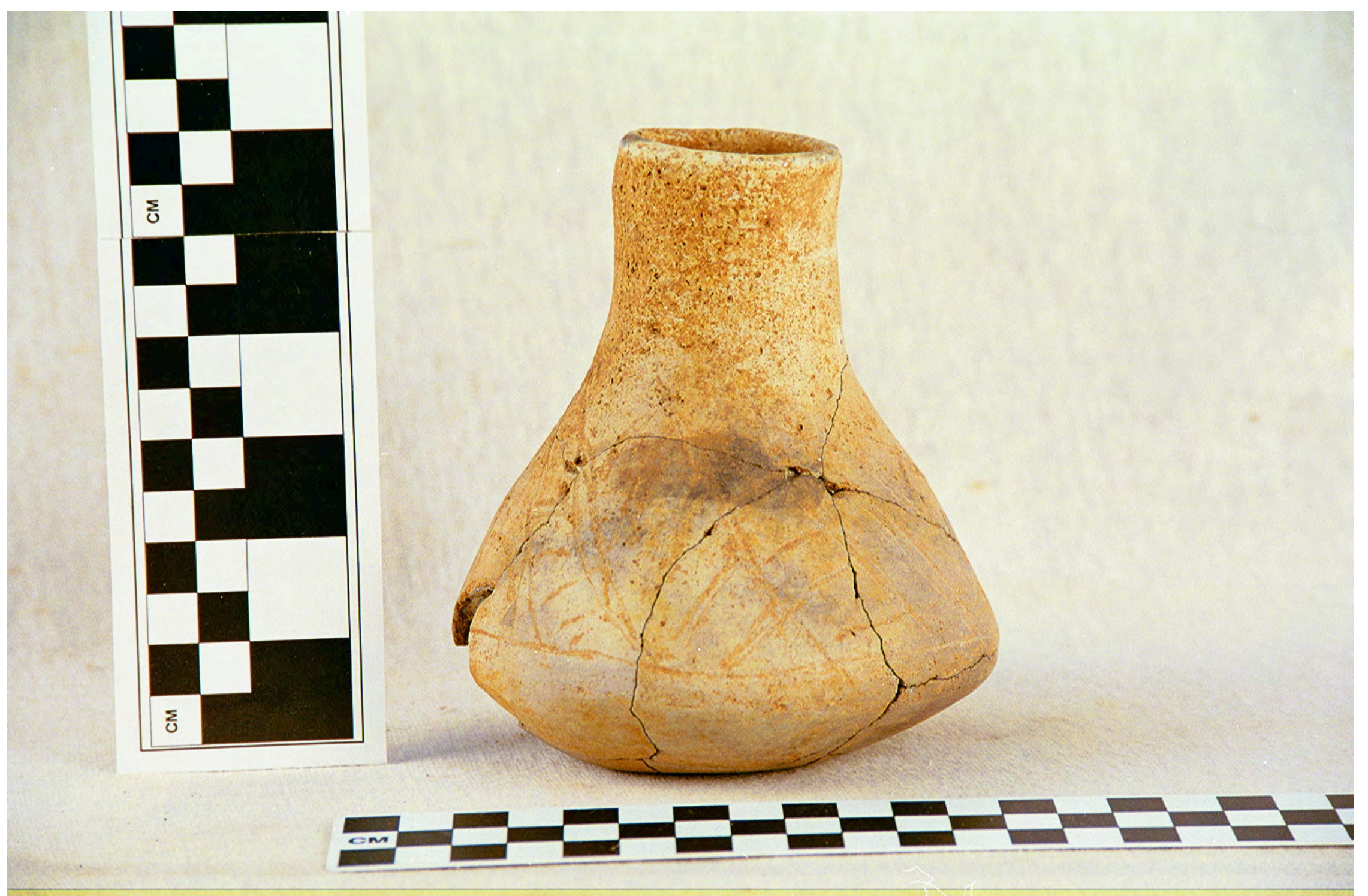

Figure 220 


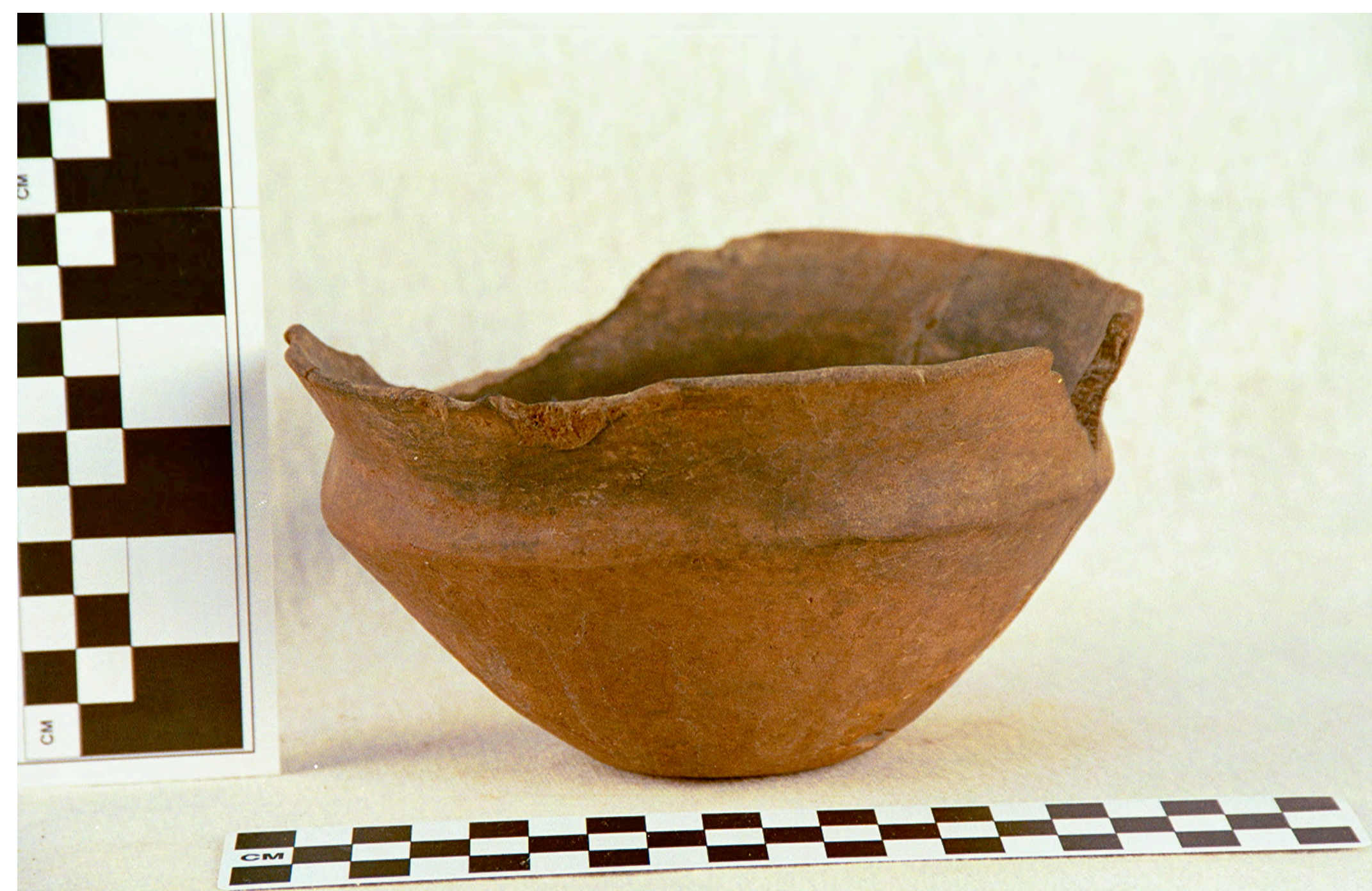

Figure 221 


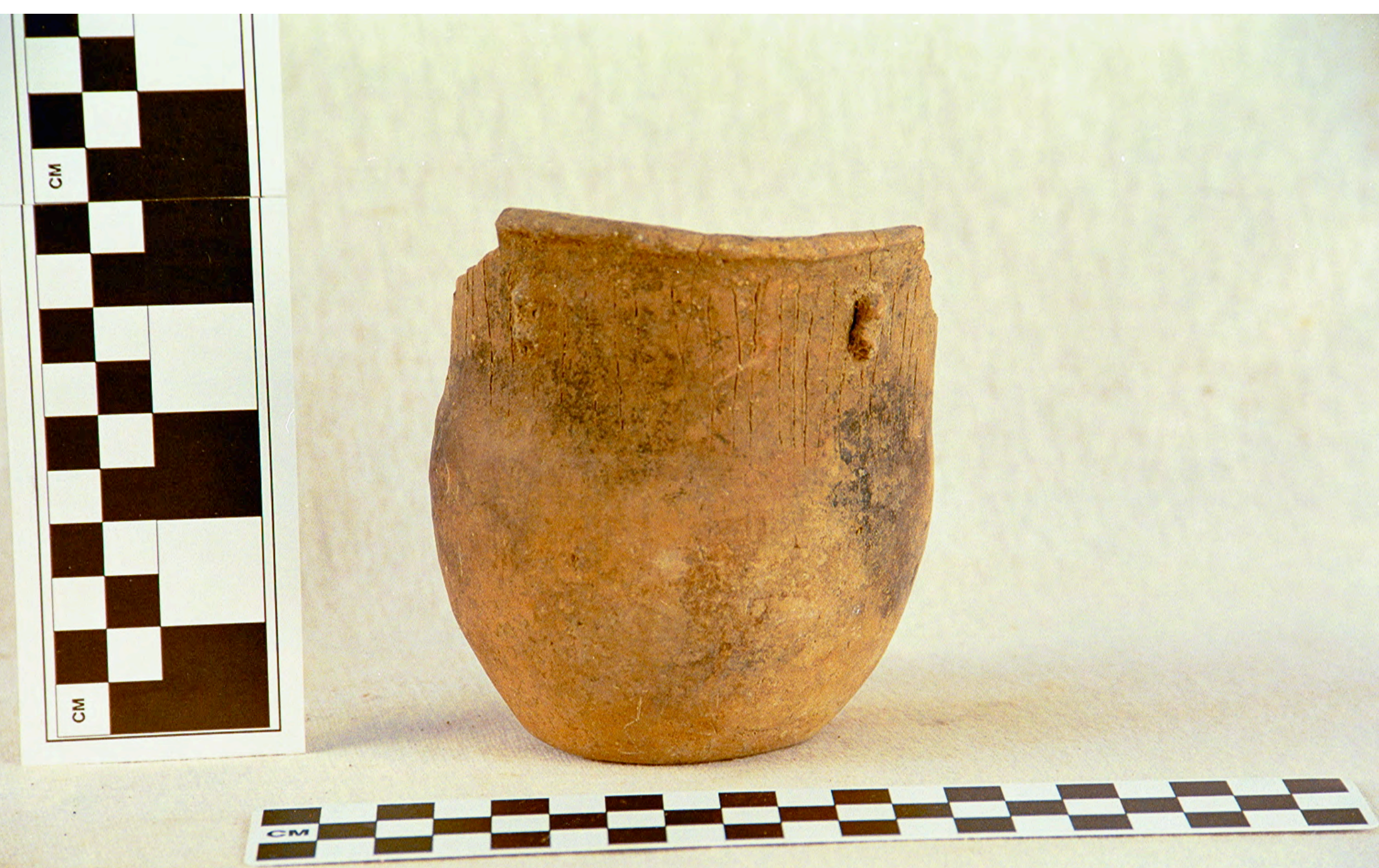

Figure 222 


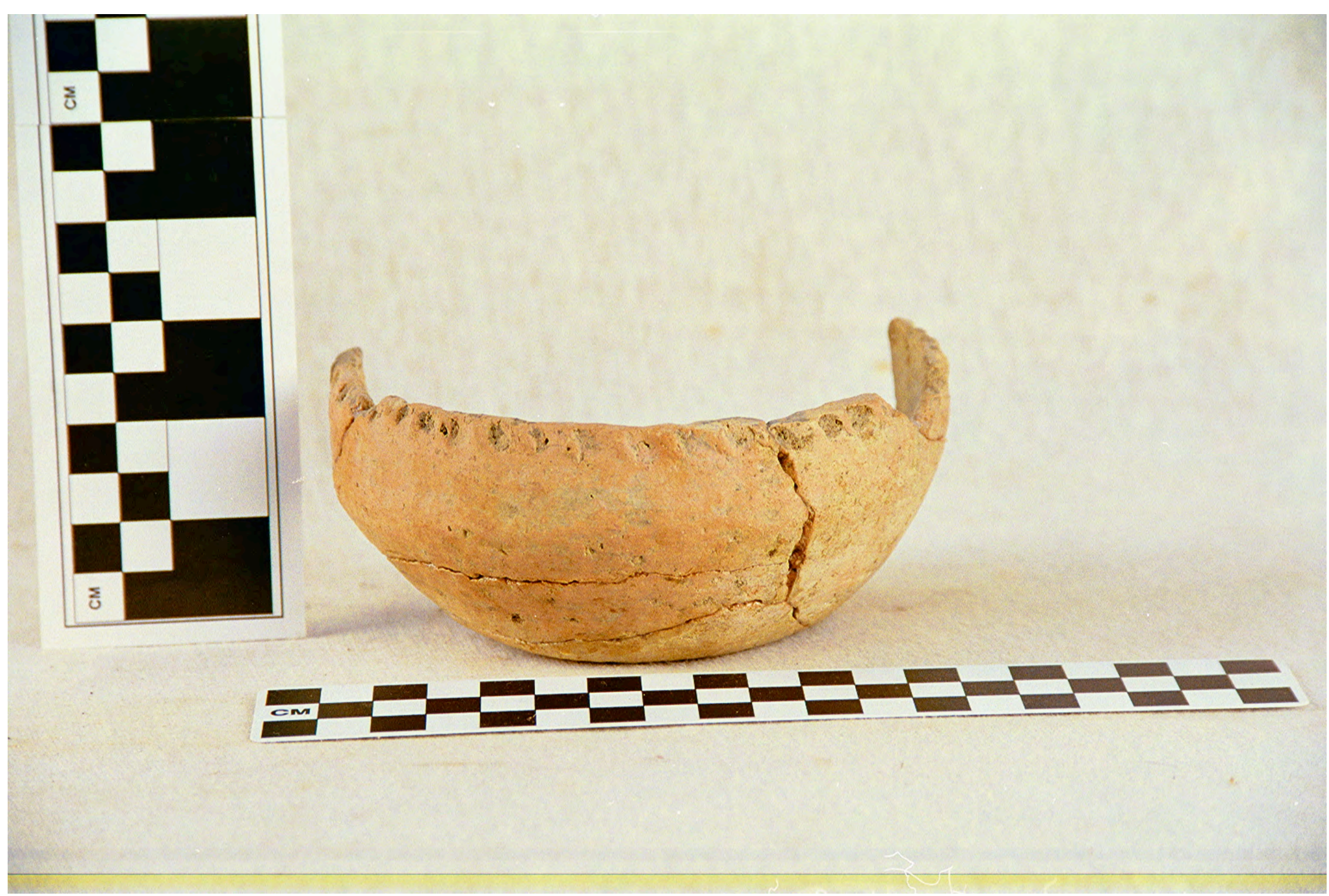

Figure 223 


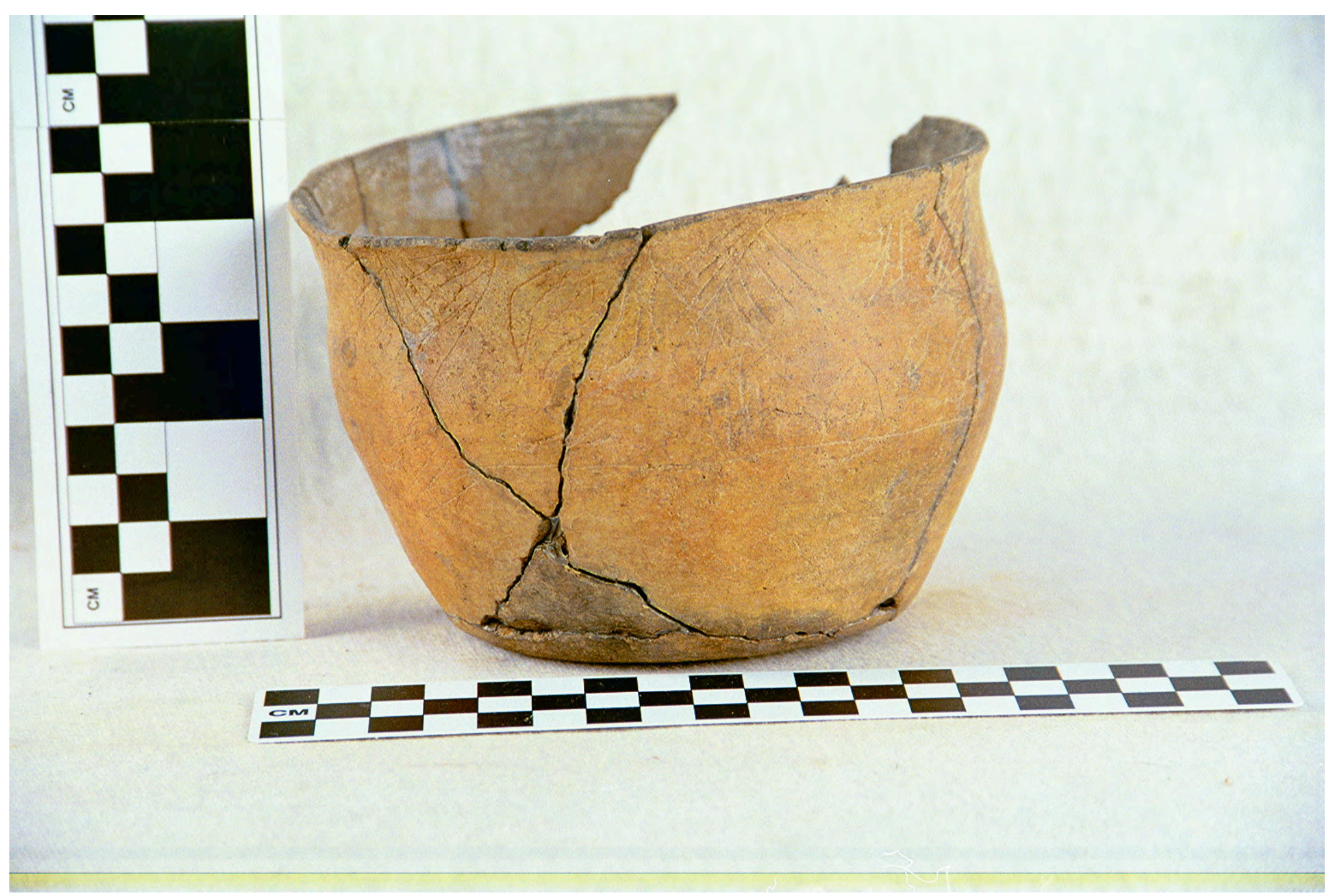

Figure 224 


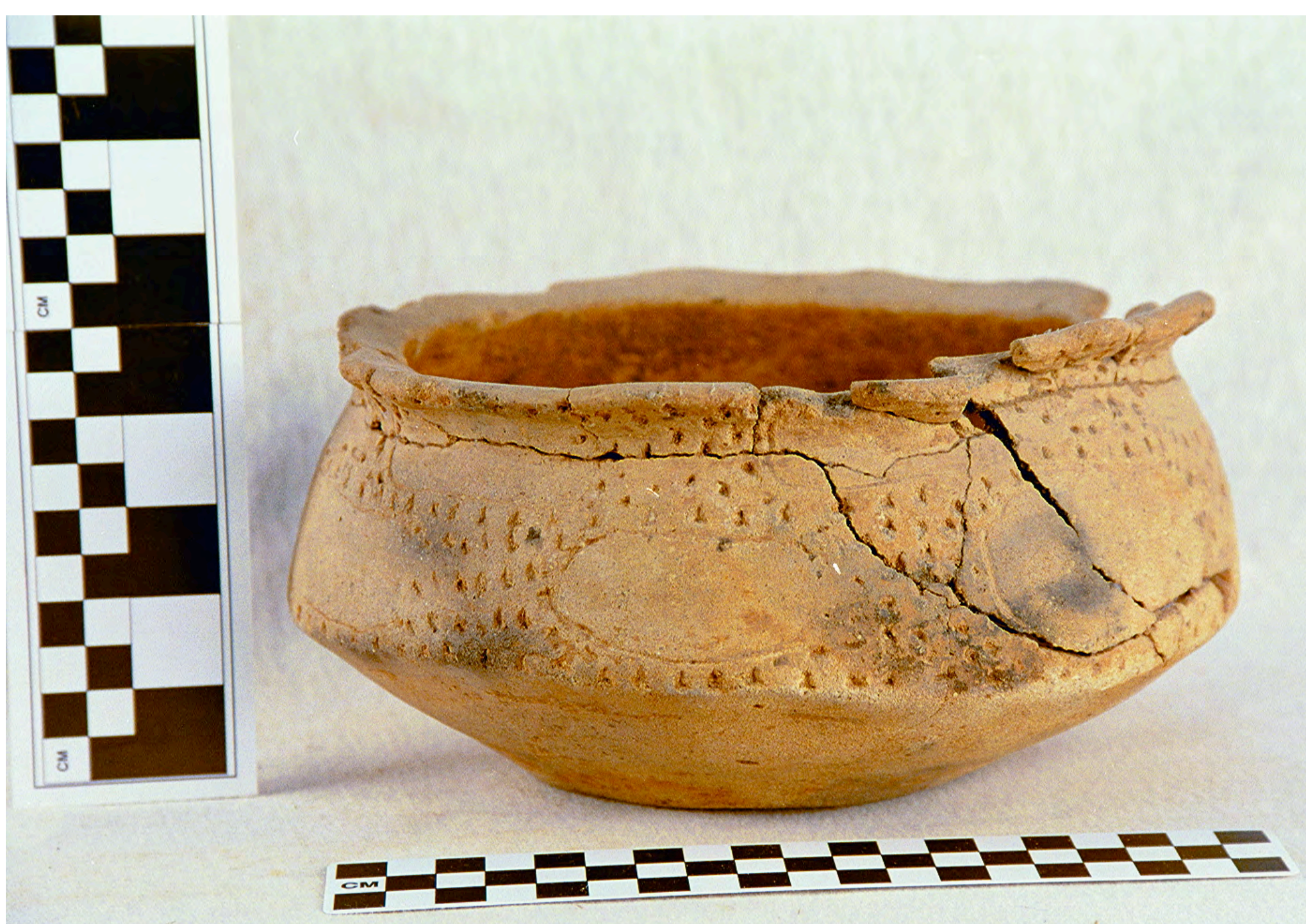

Figure 225 


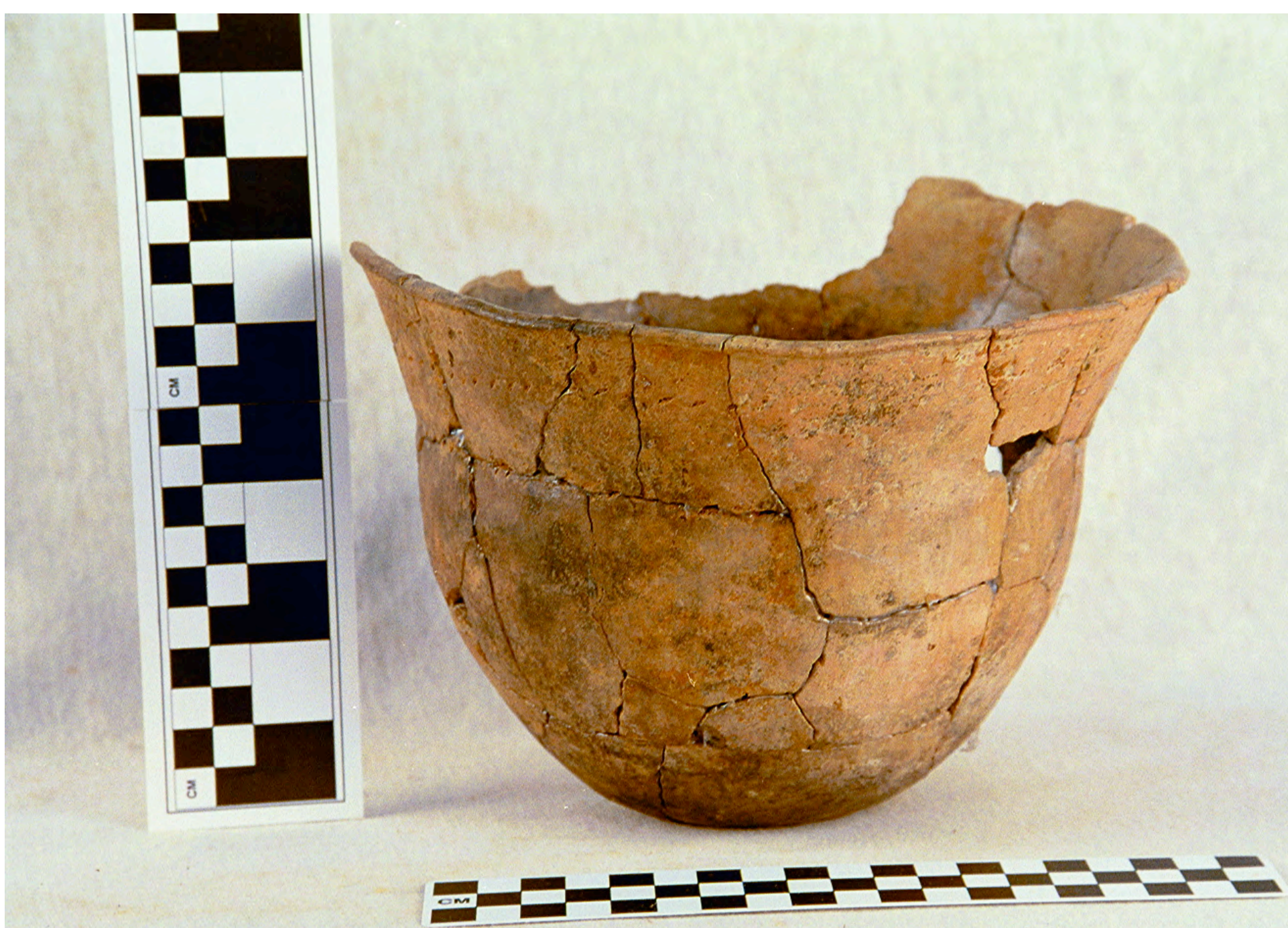

Figure 226 


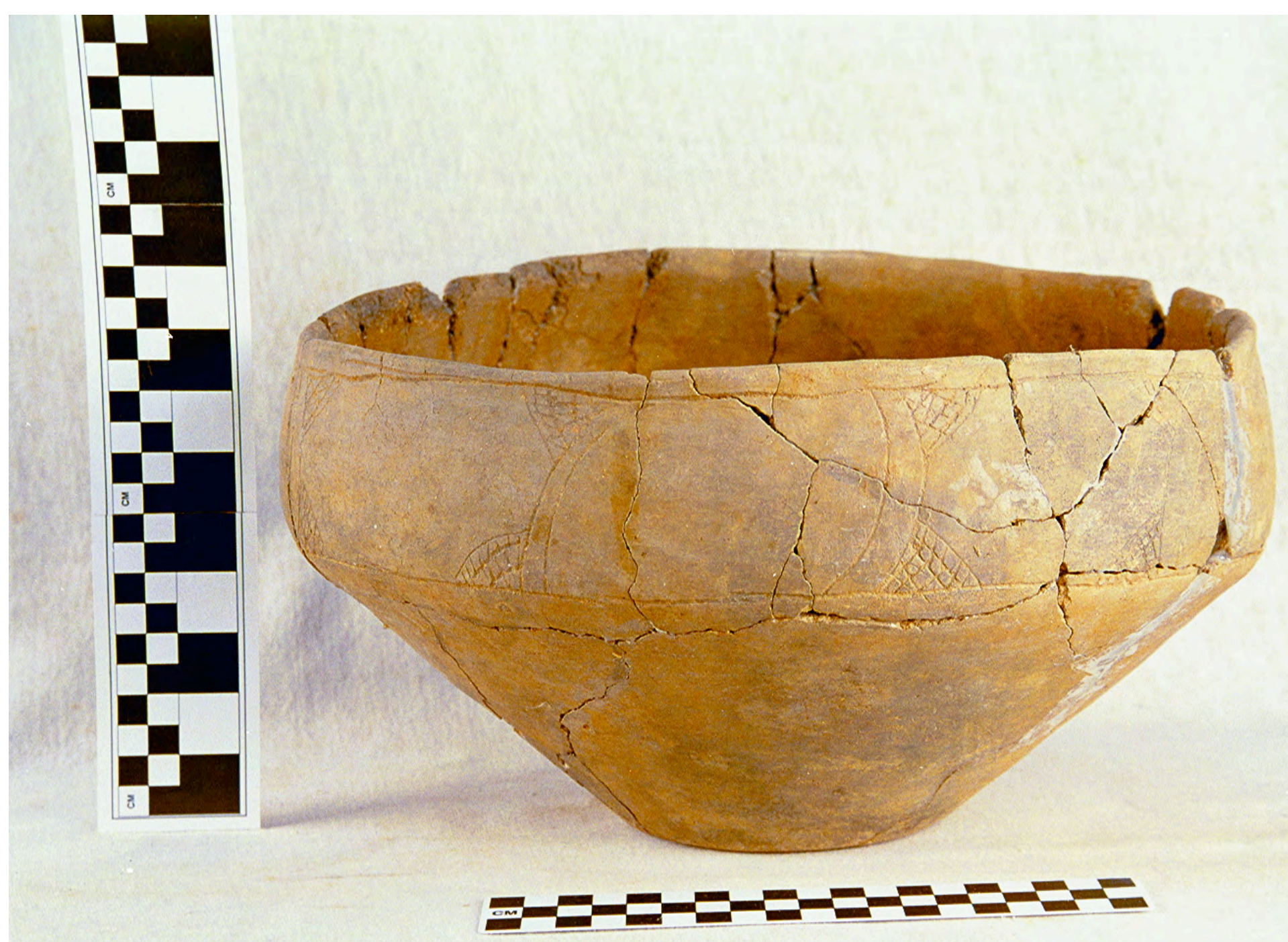

Figure 227 

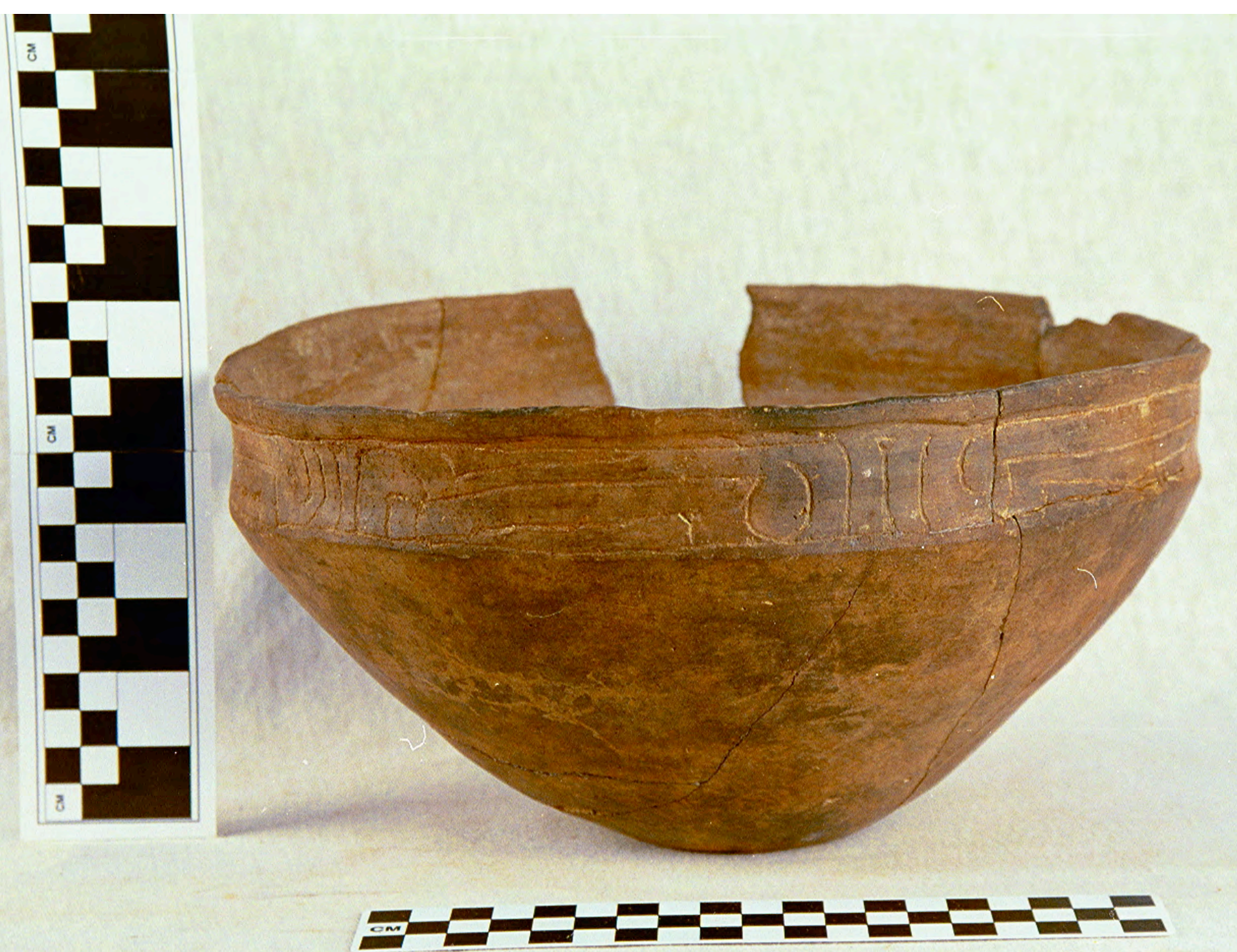

Figure 228 


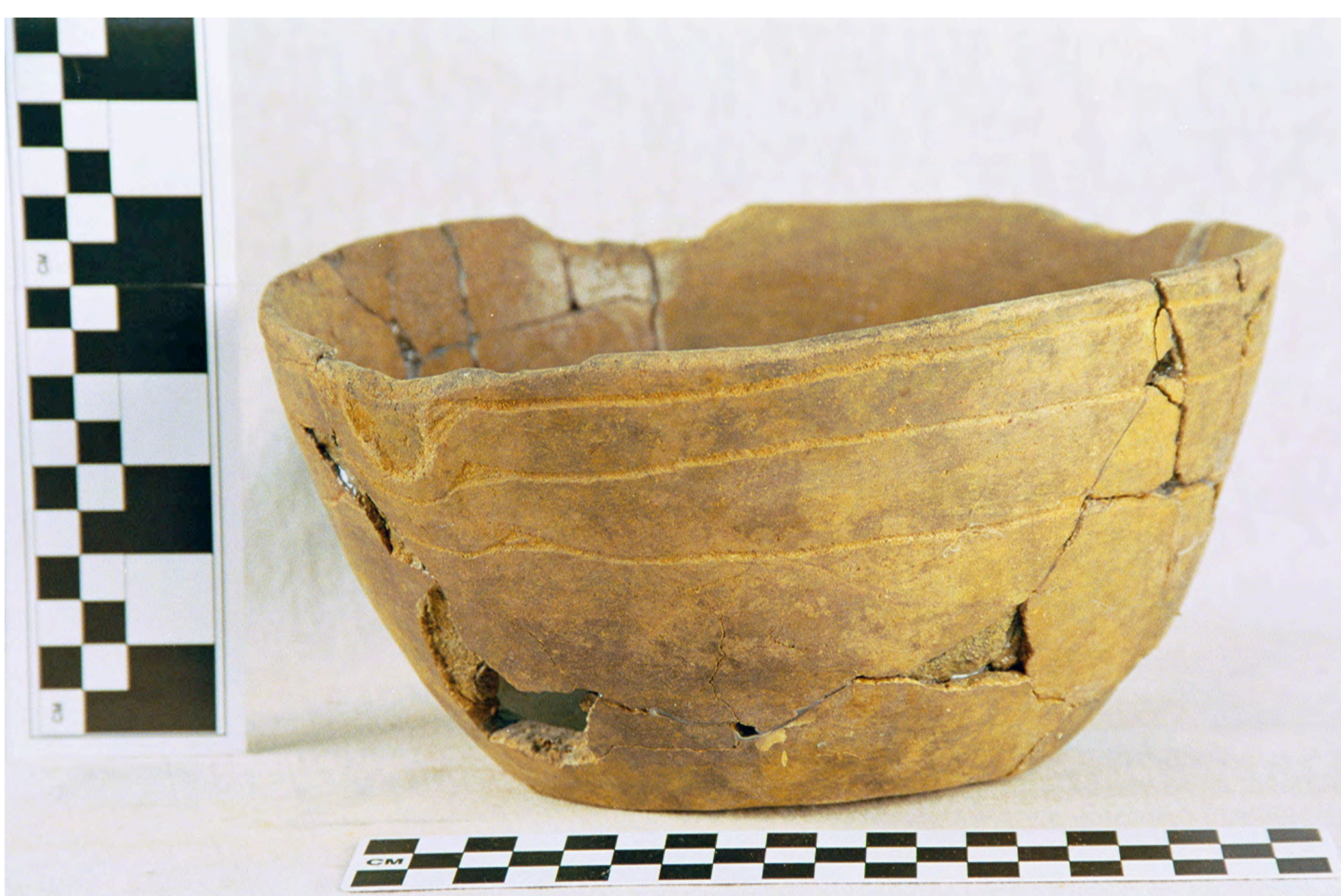

Figure 229 


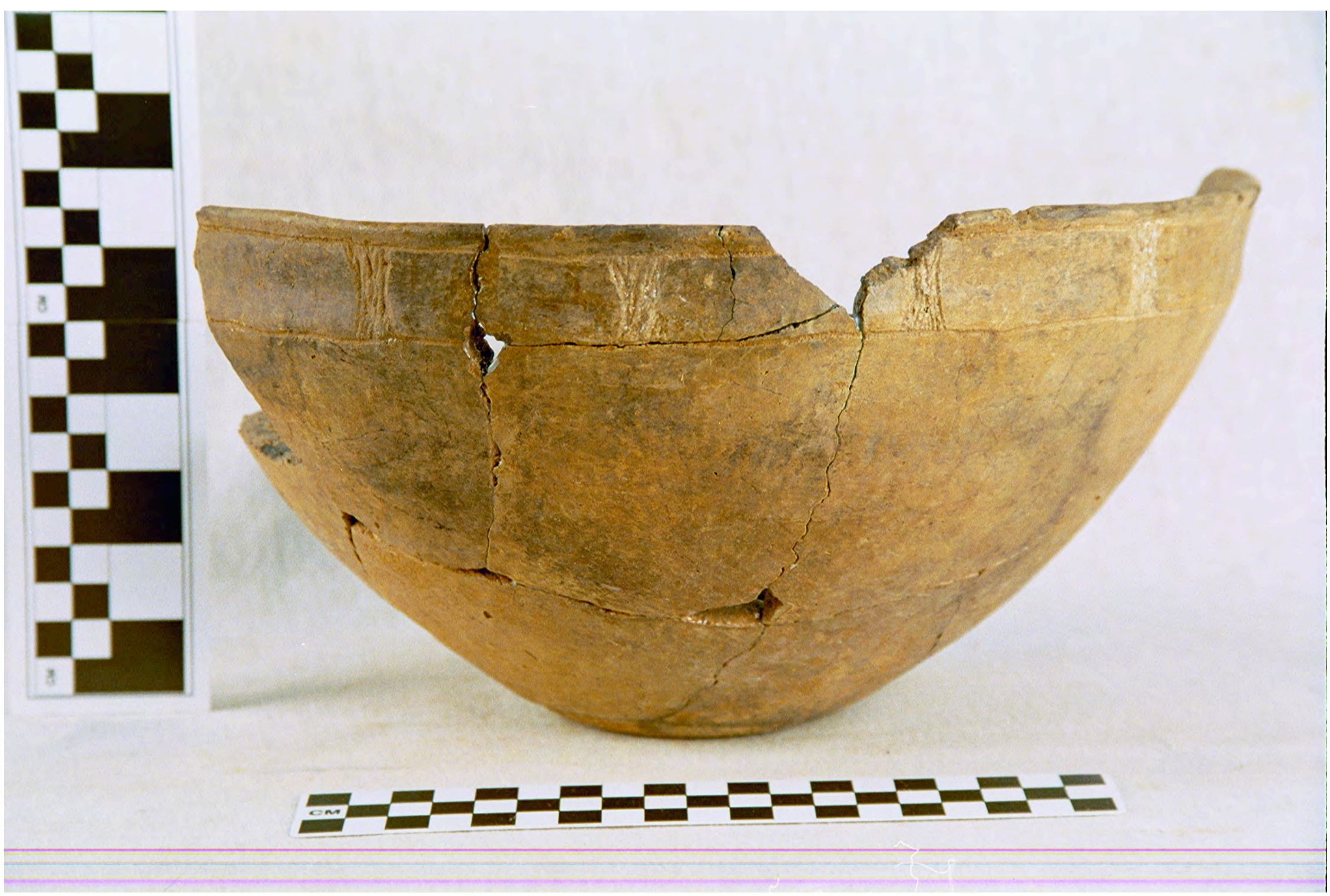

Figure 230 


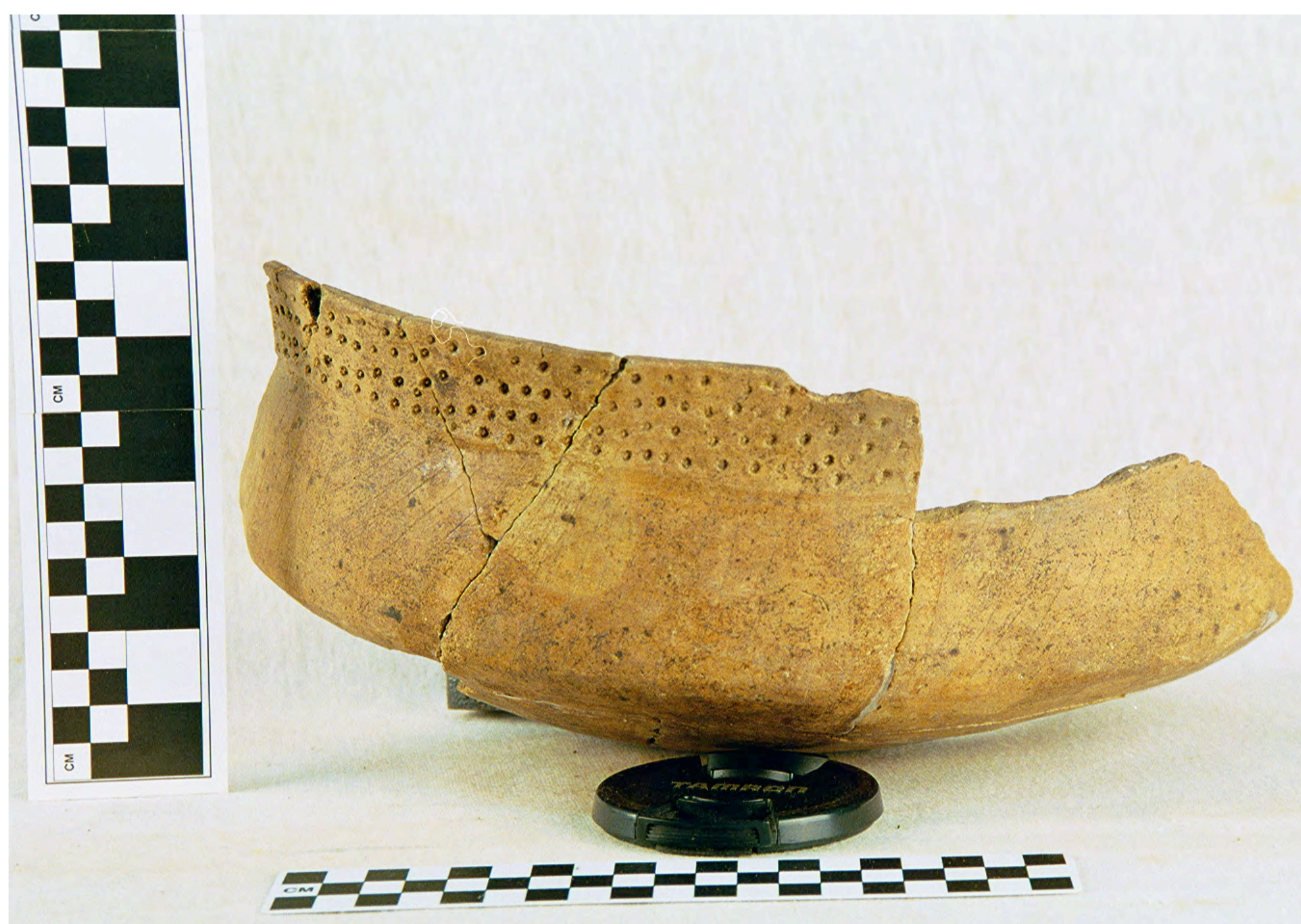

Figure 231 


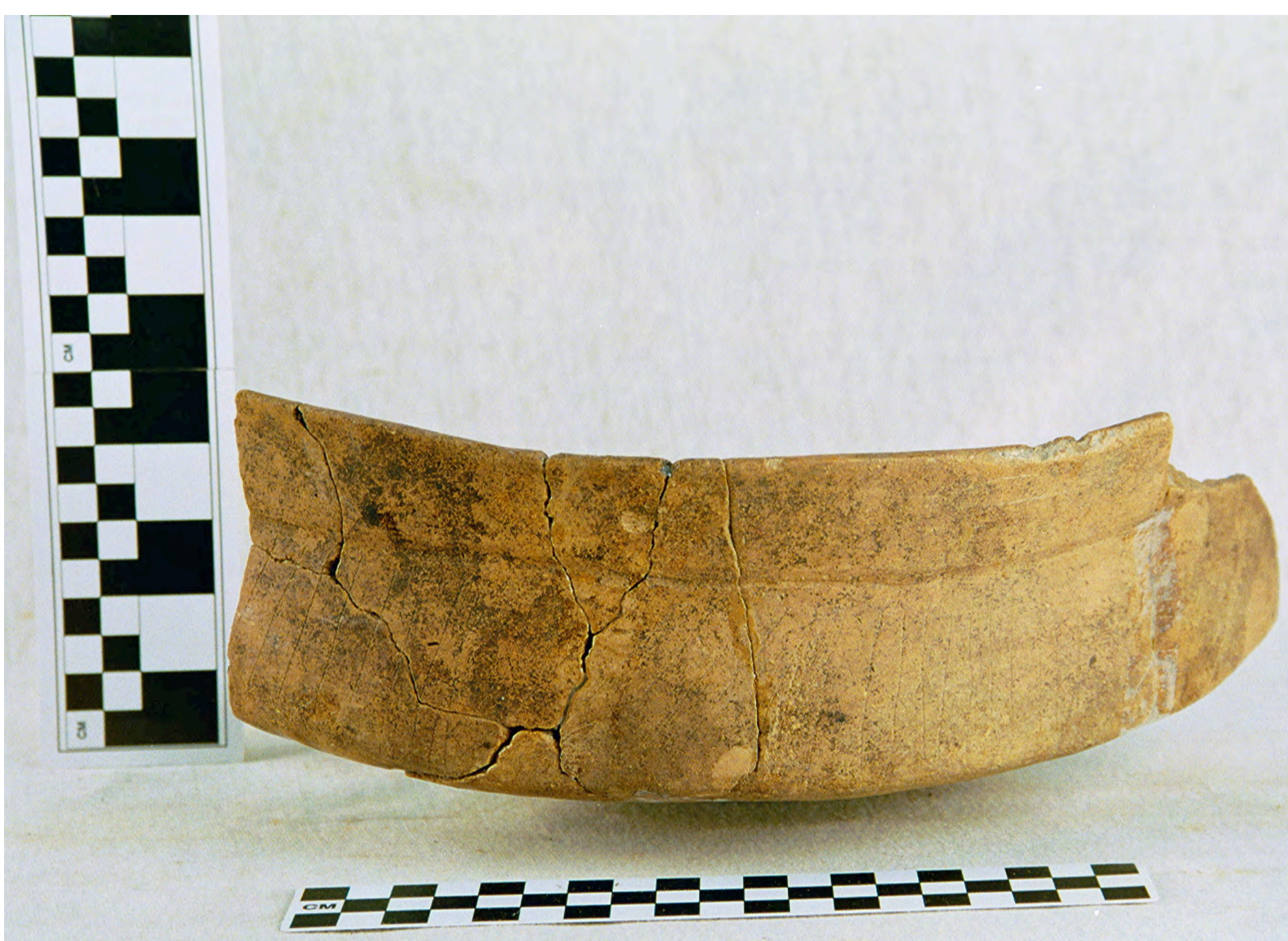

Figure 232 


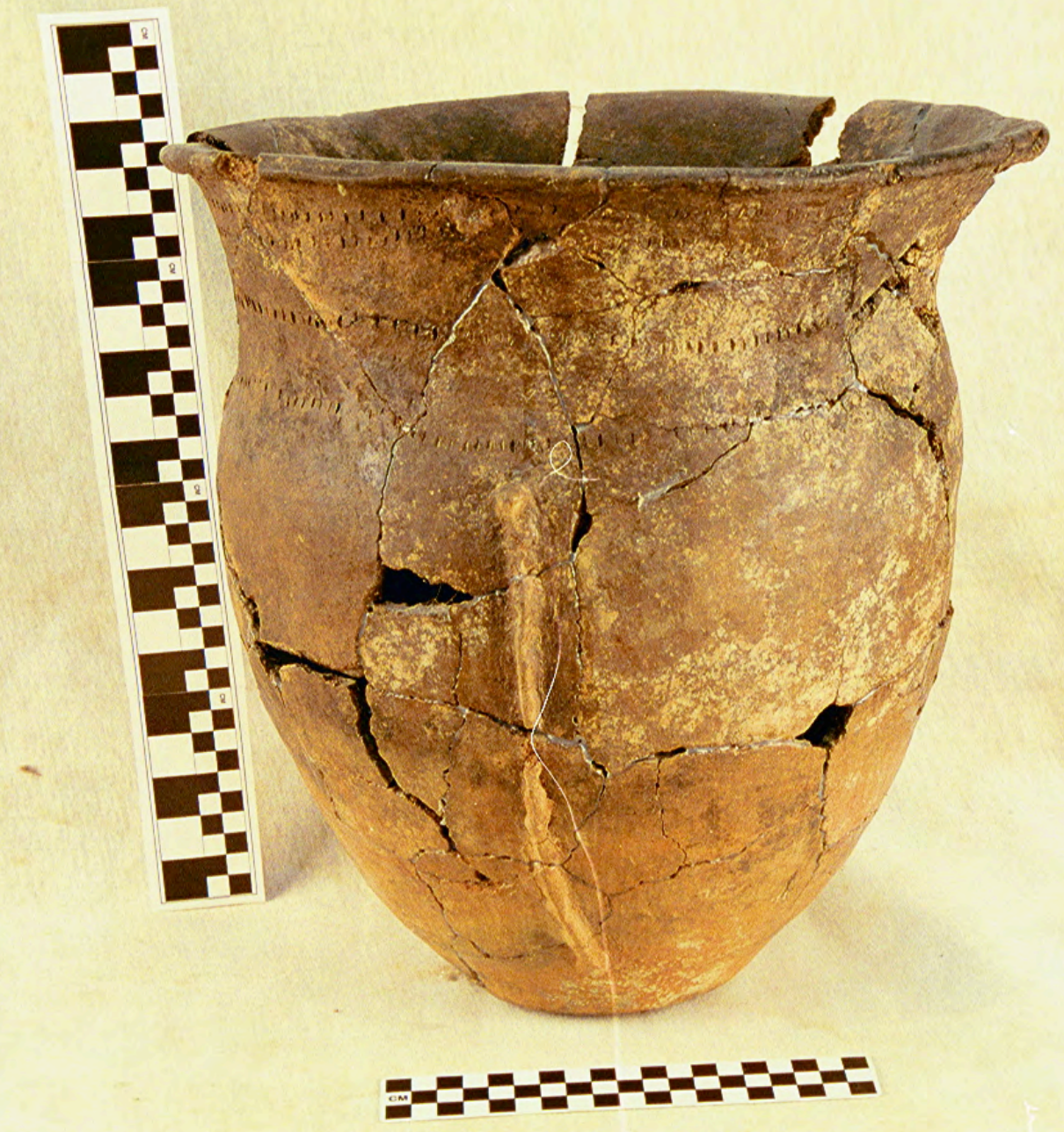

Figure 233 


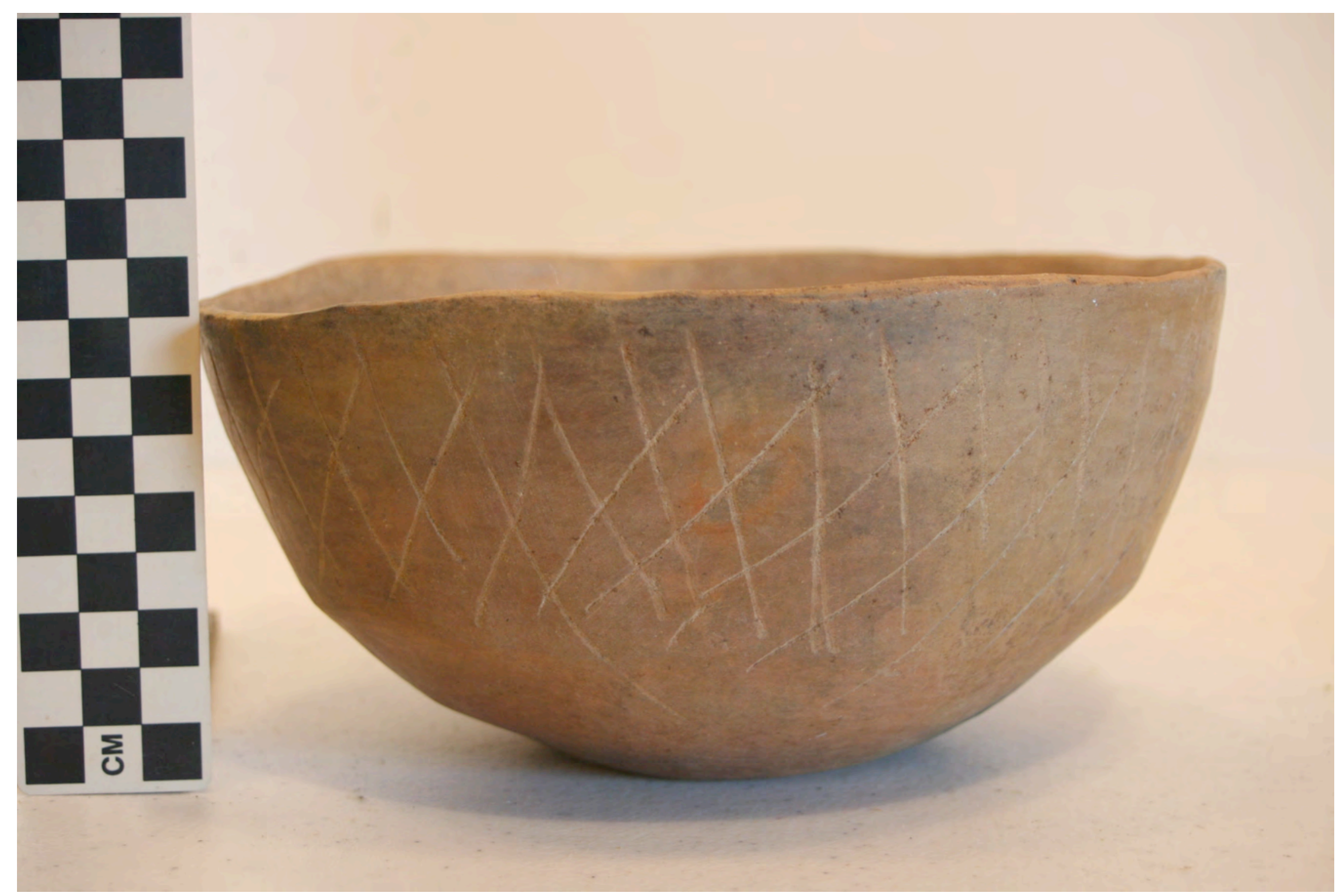

Figure 234 


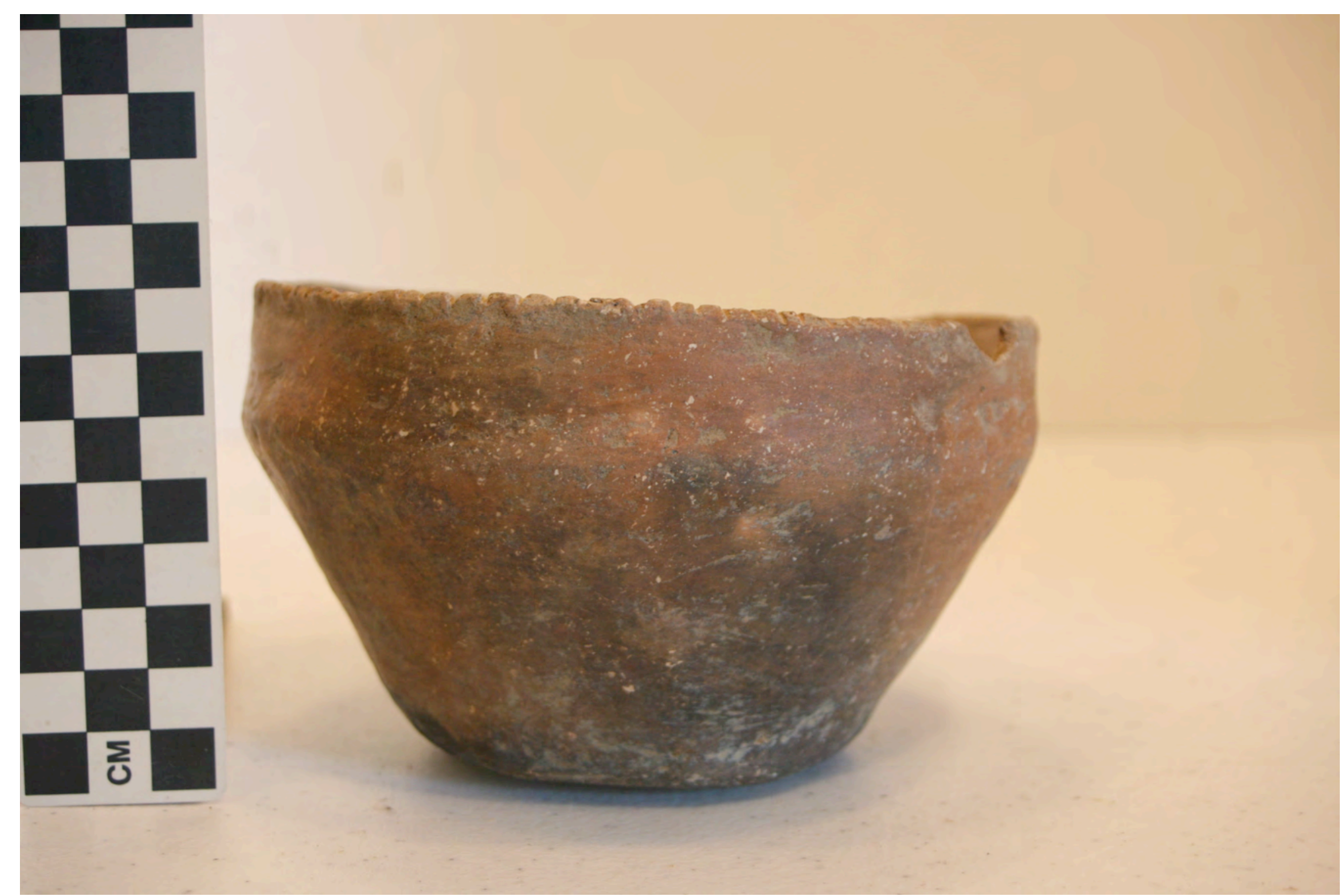

Figure 235 


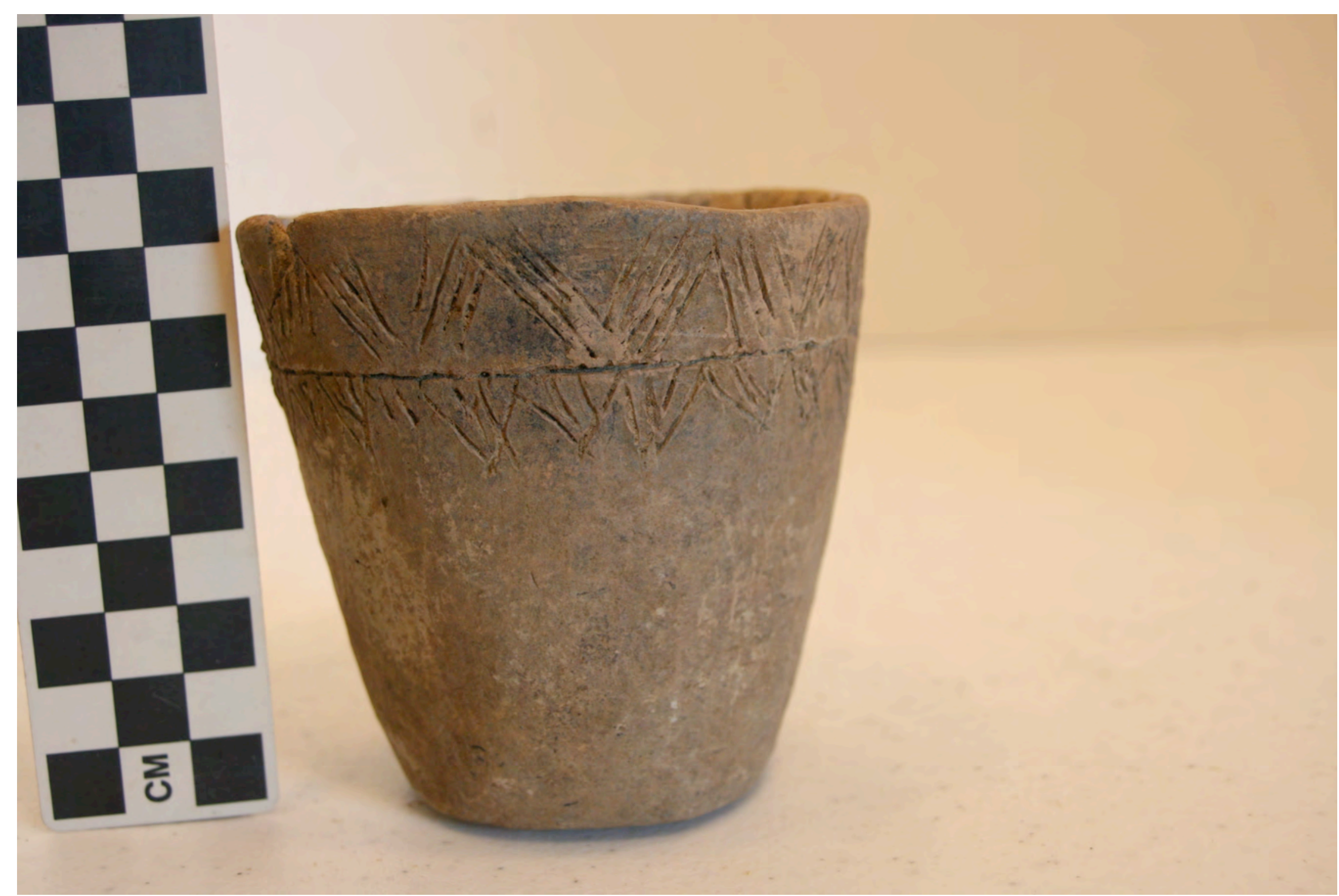

Figure 236 


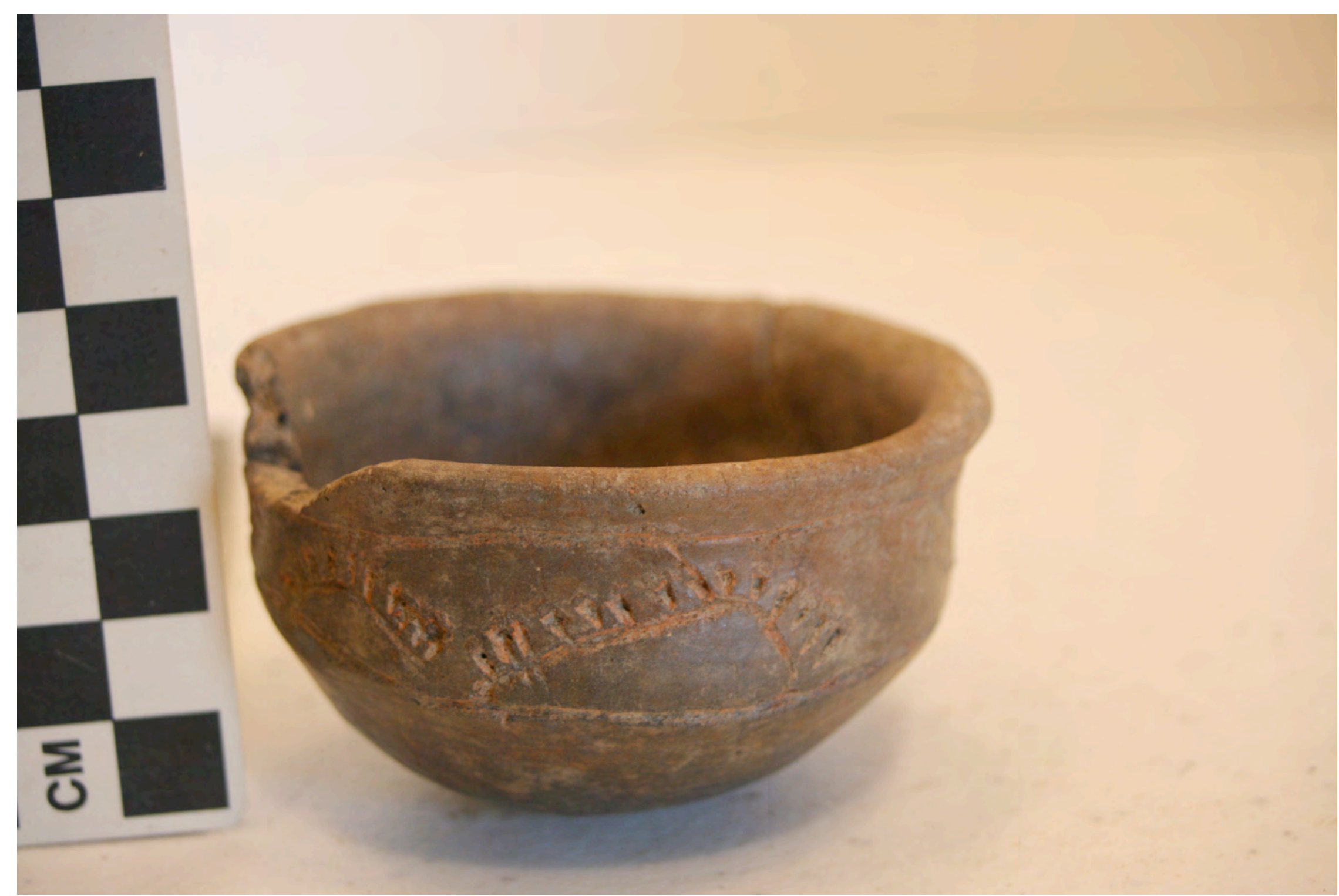

Figure 237 


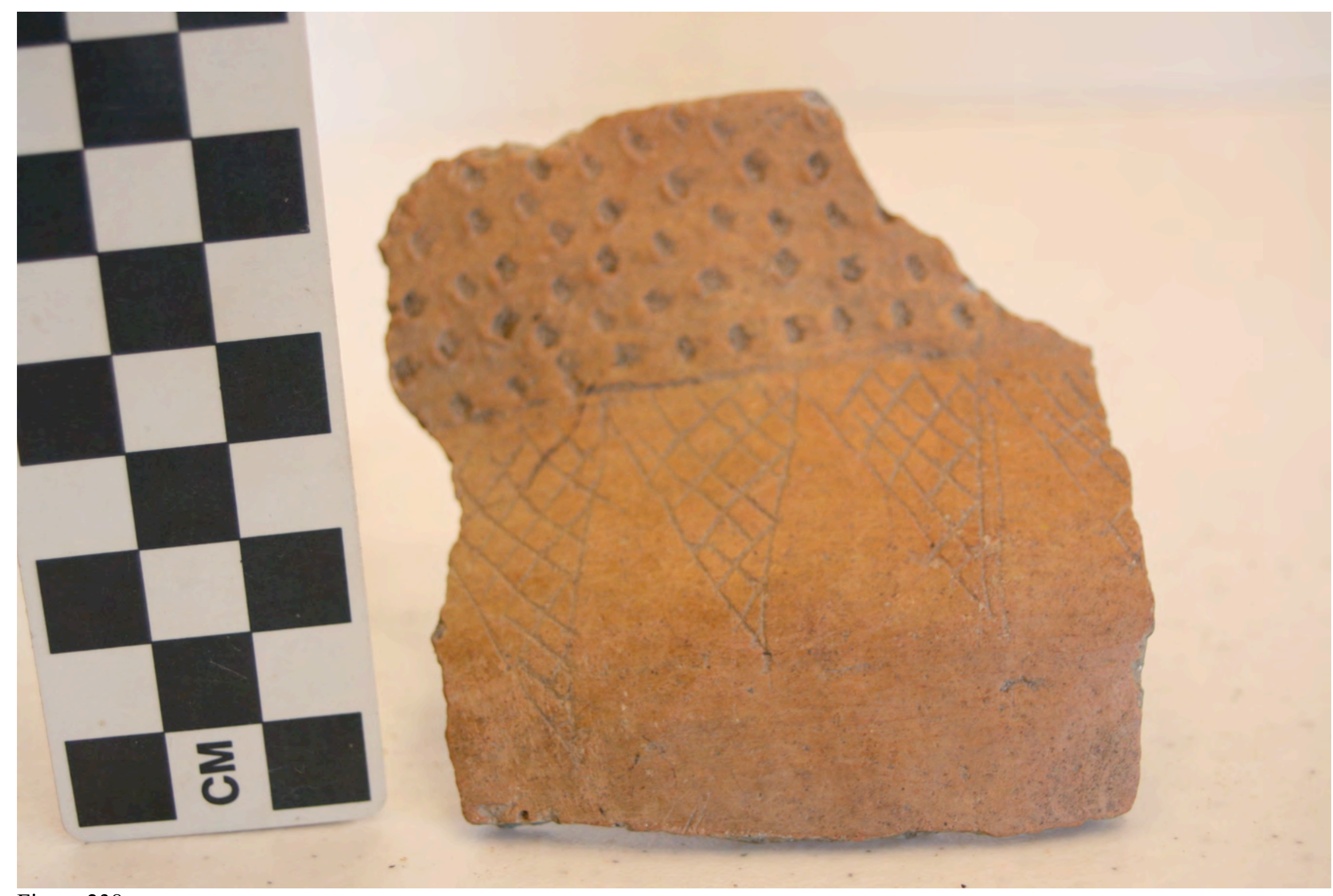

Figure 238 


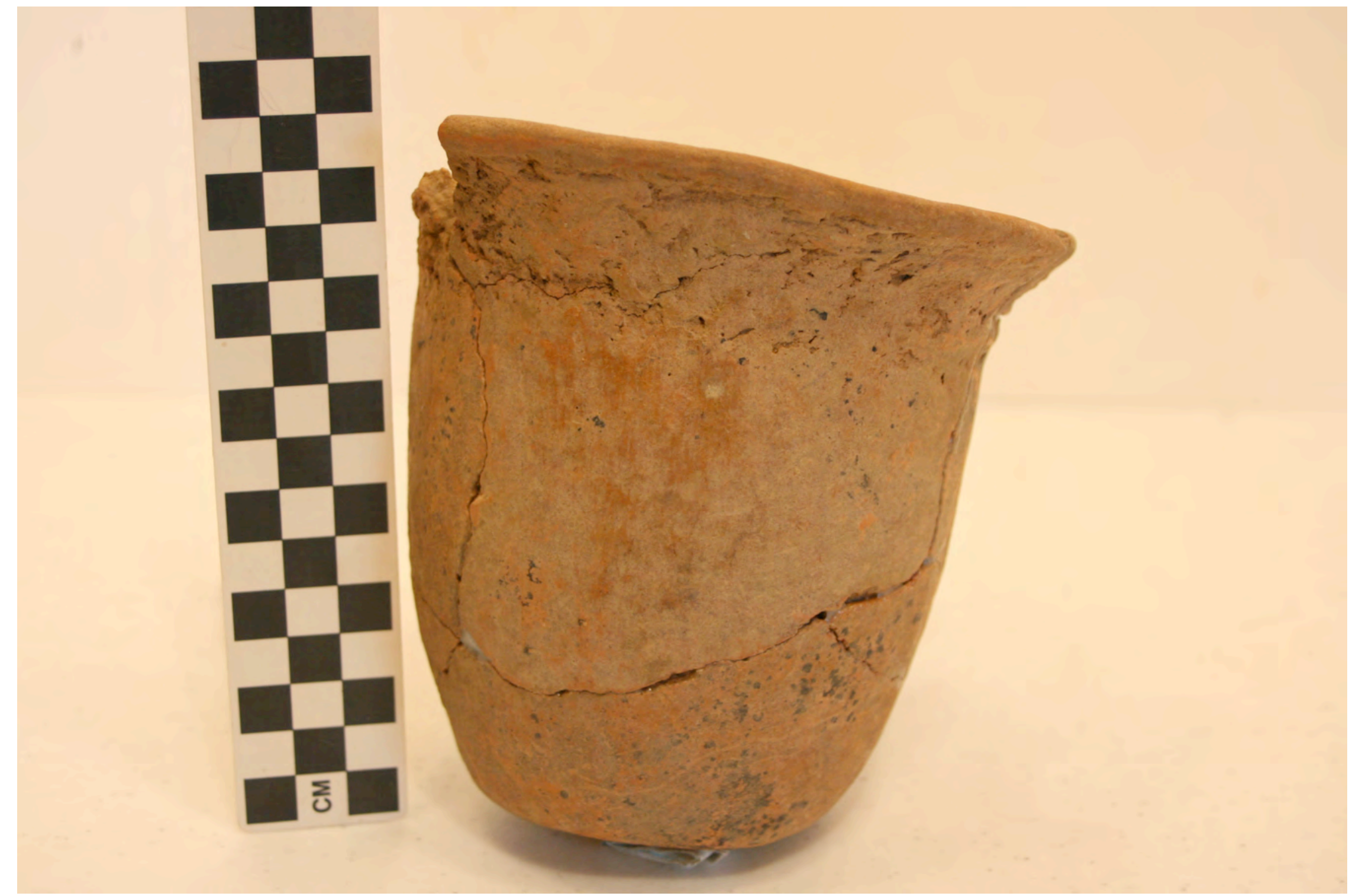

Figure 239 


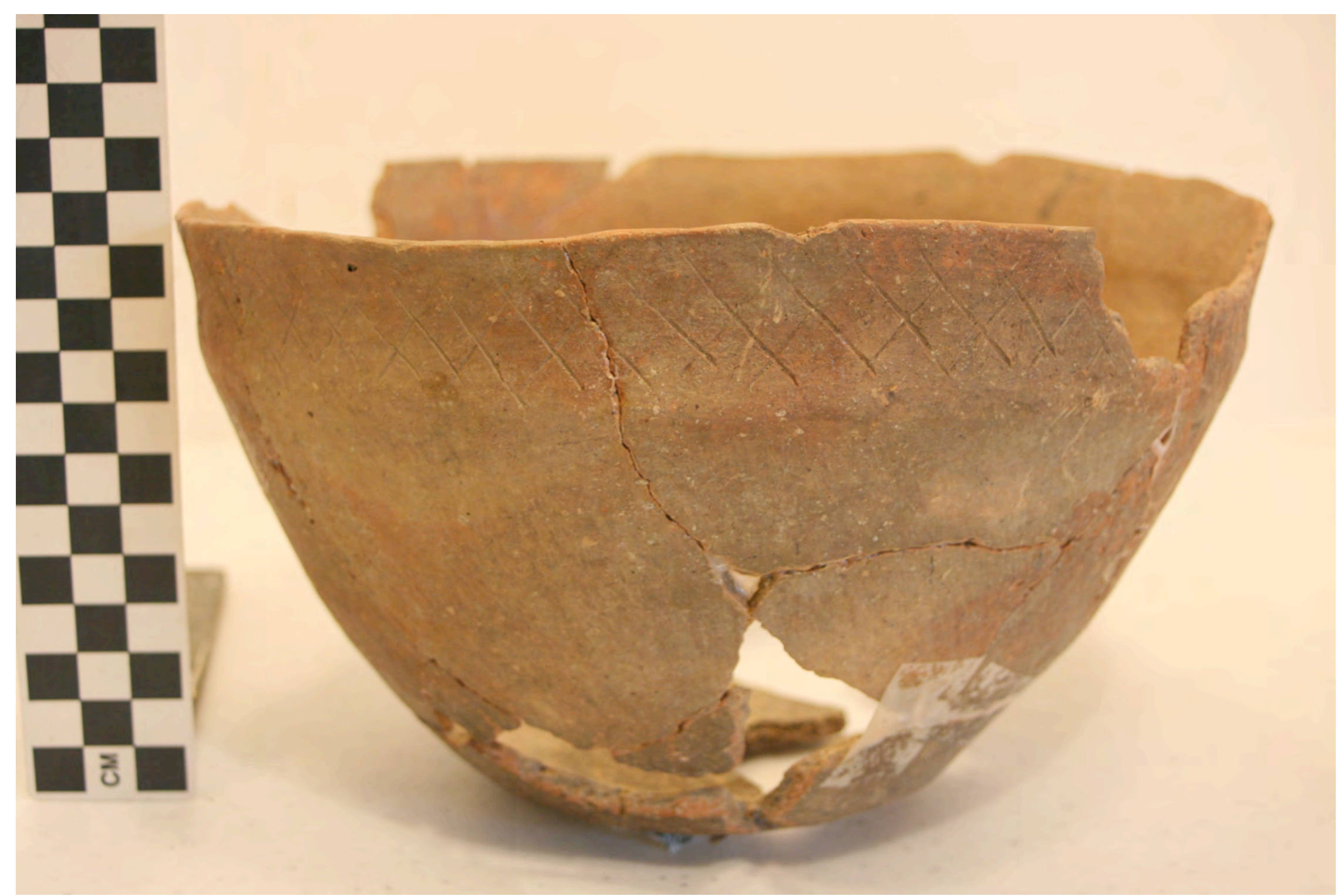

Figure 240 


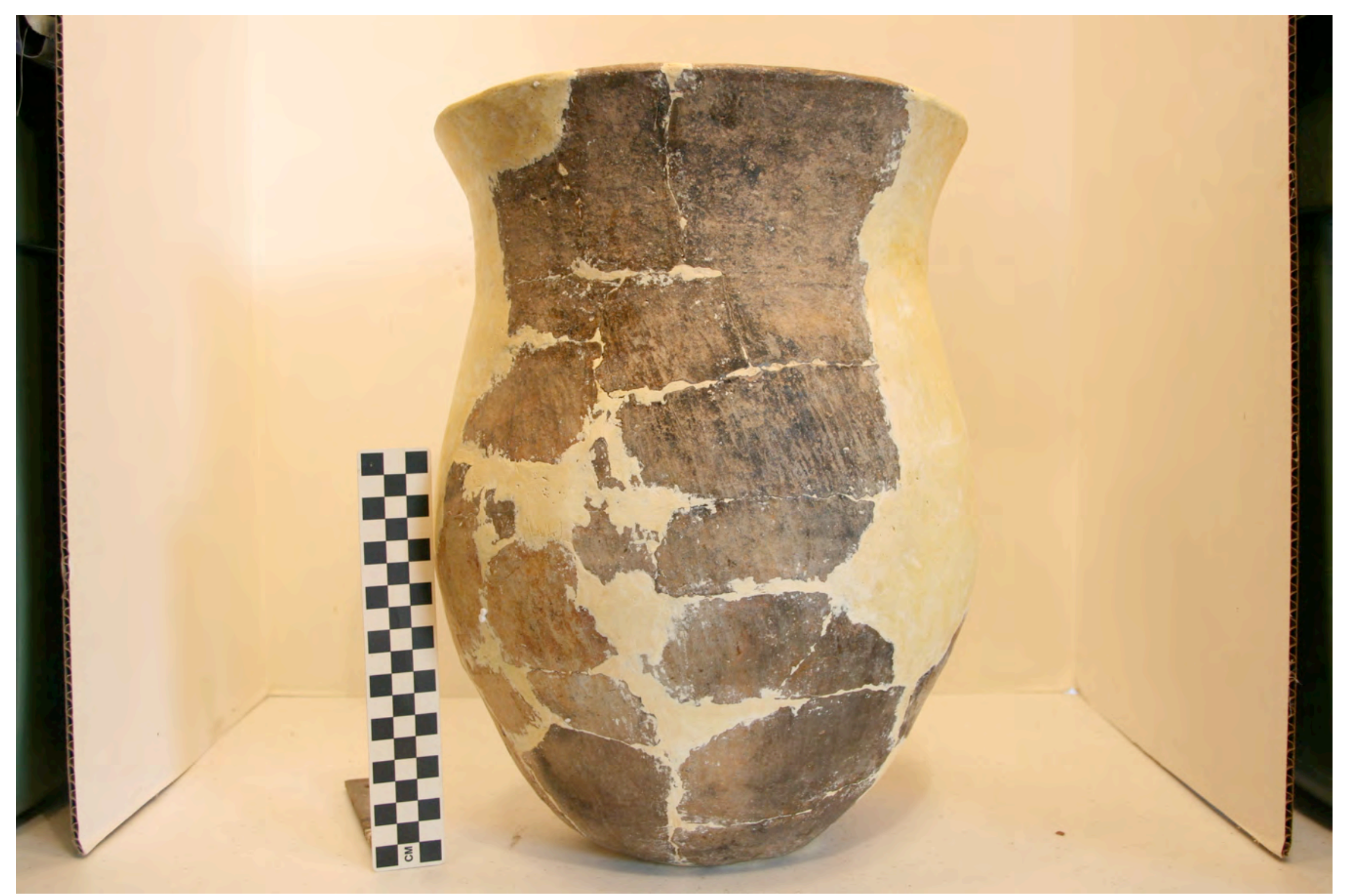

Figure 241 


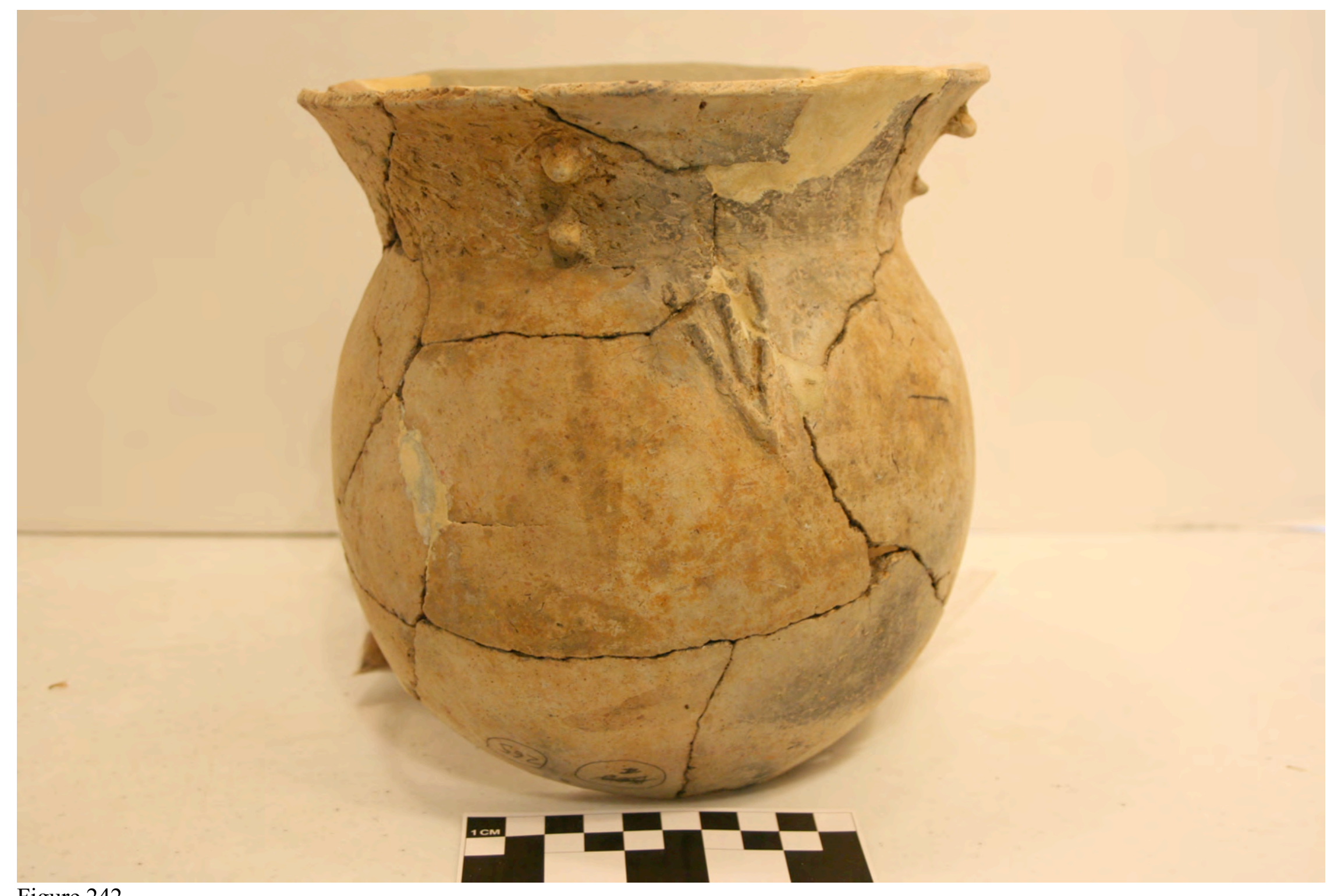

Figure 242 


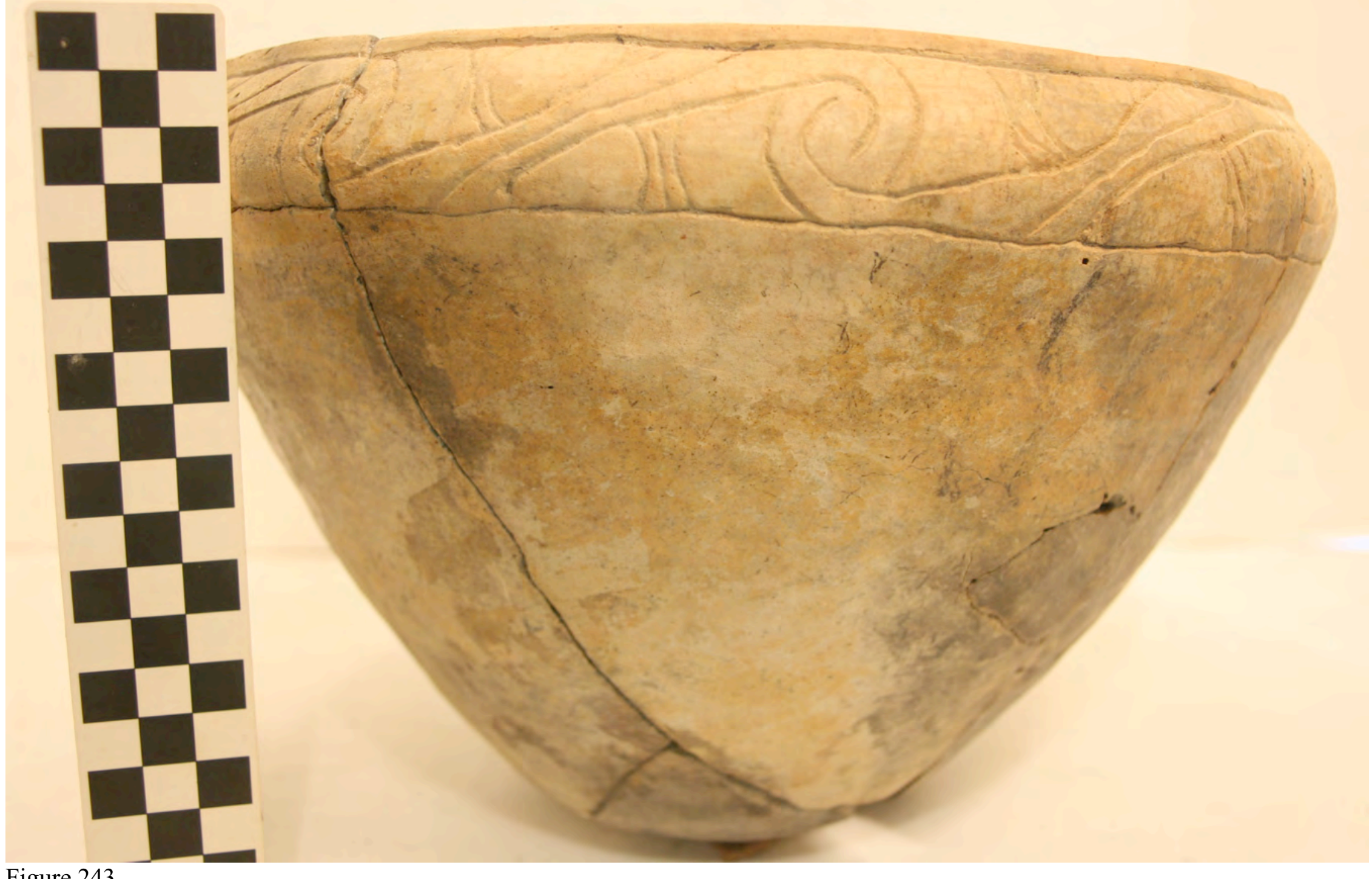

Figure 243 


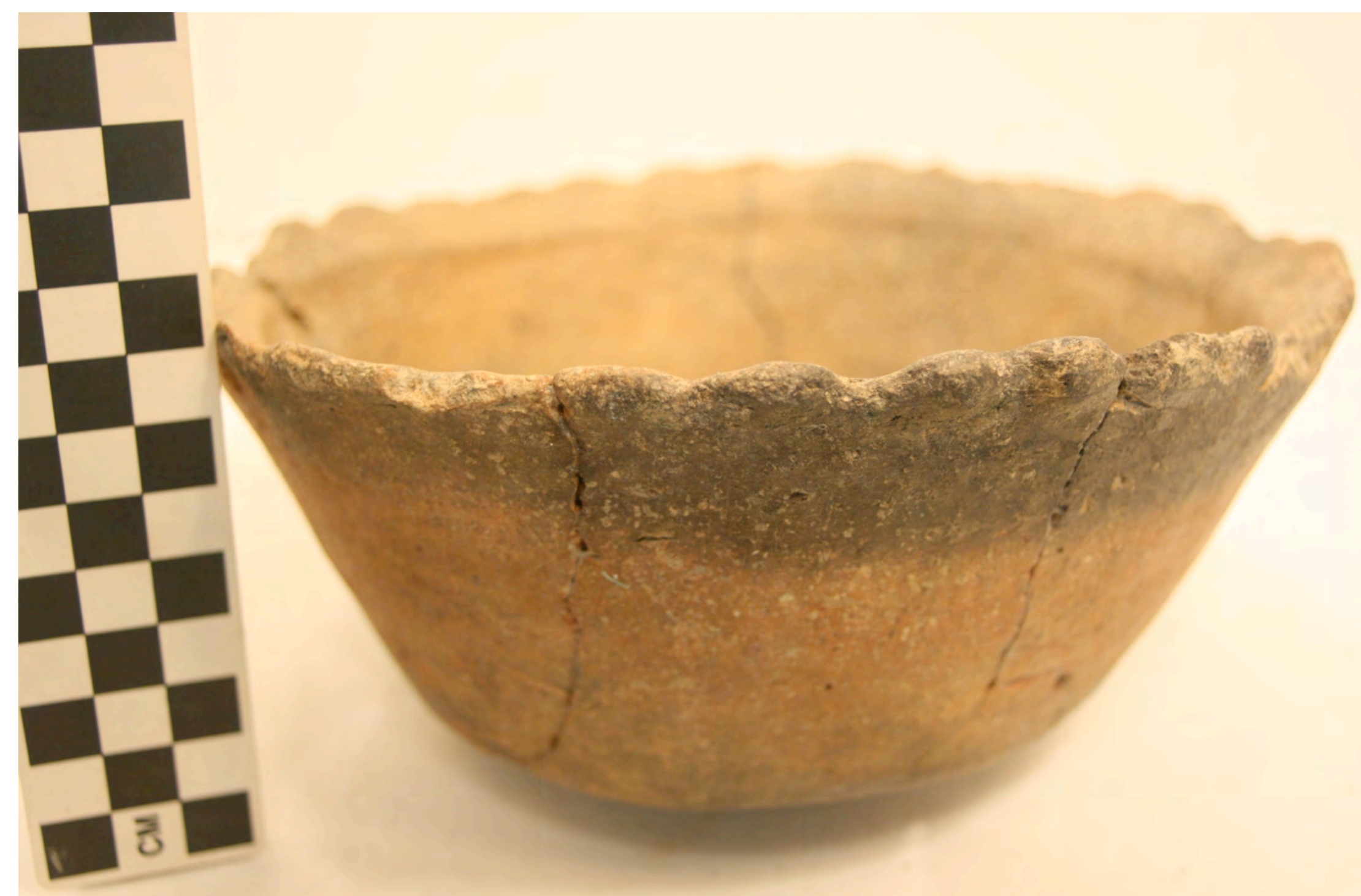

Figure 244 


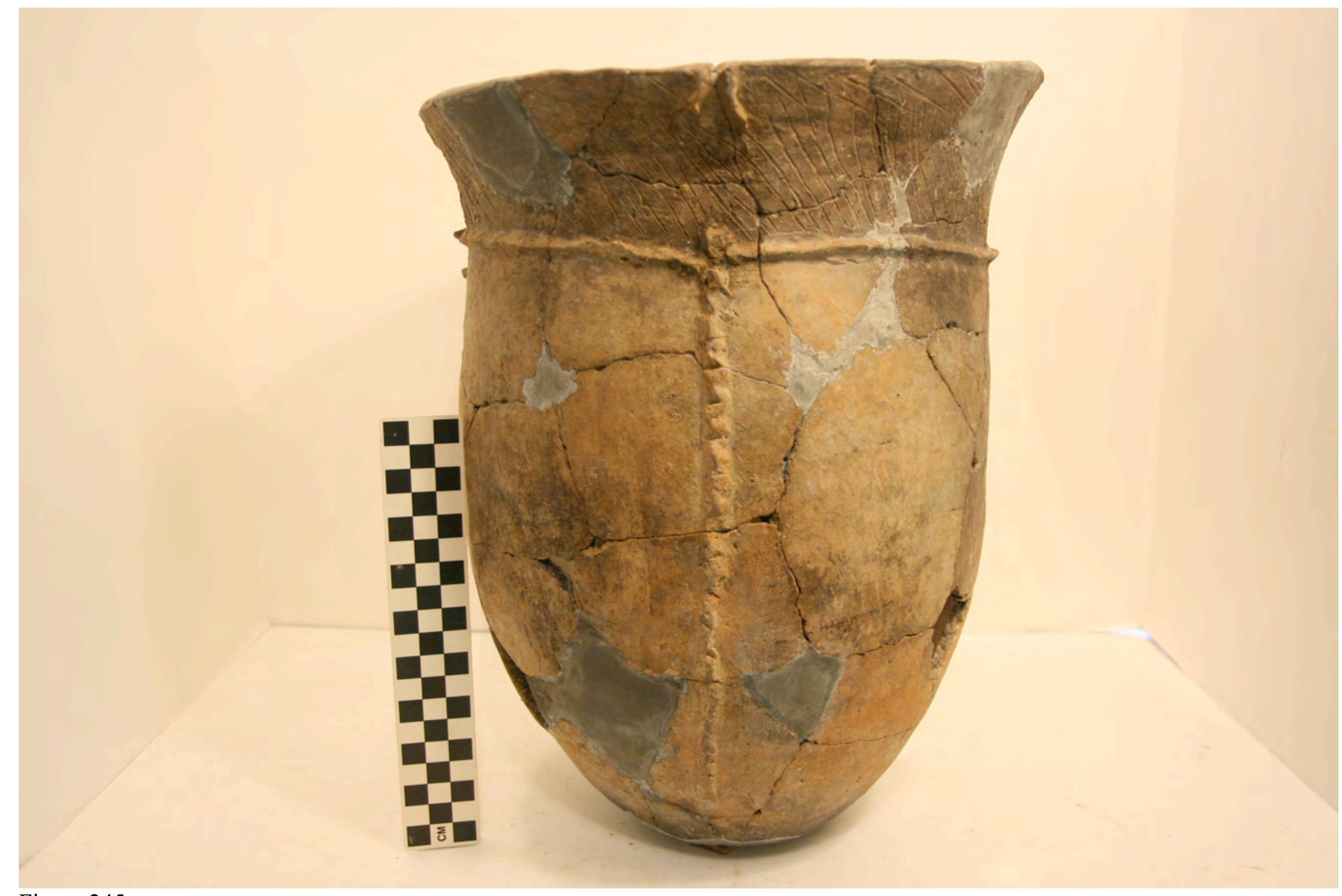

Figure 245 


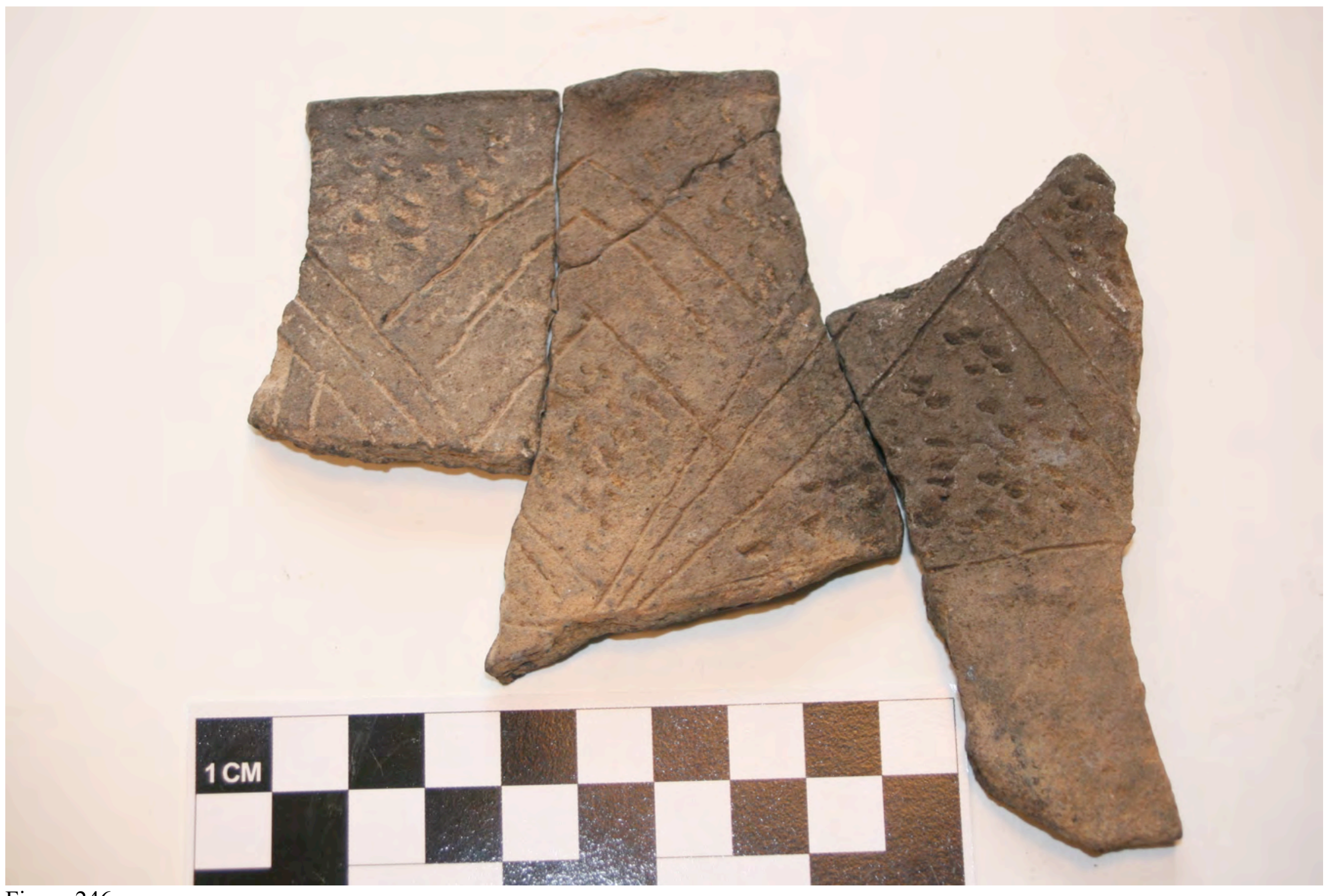

Figure 246 